\title{
"Val Verde on the Sunny Rio Grande" Geoarcheological and Historical Investigations at San Felipe Springs, Val Verde County, Texas
}

Gemma Mehalchick

Prewitt and Associates, Inc.

Terri Myers

Prewitt and Associates, Inc.

Karl W. Kibler

Cross Timbers Geoarcheological Services

Douglas K. Boyd

Prewitt and Associates, Inc.

Follow this and additional works at: https://scholarworks.sfasu.edu/ita

Part of the American Material Culture Commons, Archaeological Anthropology Commons, Environmental Studies Commons, Other American Studies Commons, Other Arts and Humanities Commons, Other History of Art, Architecture, and Archaeology Commons, and the United States History Commons

Tell us how this article helped you.

This Article is brought to you for free and open access by the Center for Regional Heritage Research at SFA ScholarWorks. It has been accepted for inclusion in Index of Texas Archaeology: Open Access Gray Literature from the Lone Star State by an authorized editor of SFA ScholarWorks. For more information, please contact cdsscholarworks@sfasu.edu. 
"Val Verde on the Sunny Rio Grande" Geoarcheological and Historical

Investigations at San Felipe Springs, Val Verde County, Texas

\section{Creative Commons License}

\section{(c) (1) $\Theta$}

This work is licensed under a Creative Commons Attribution-NonCommercial-No Derivative Works 4.0 International License. 


\section{"VAL VERDE ON THE SUNNY RIO GRANDE"}

GEOARCHEOLOGICAL AND HISTORICAL INVESTIGATIONS AT SAN FELIPE SPRINGS, VAL VERDE COUNTY, TEXAS

by

Gemma Mehalchick

Terri Myers

Karl W. Kibler

and

Douglas K. Boyd
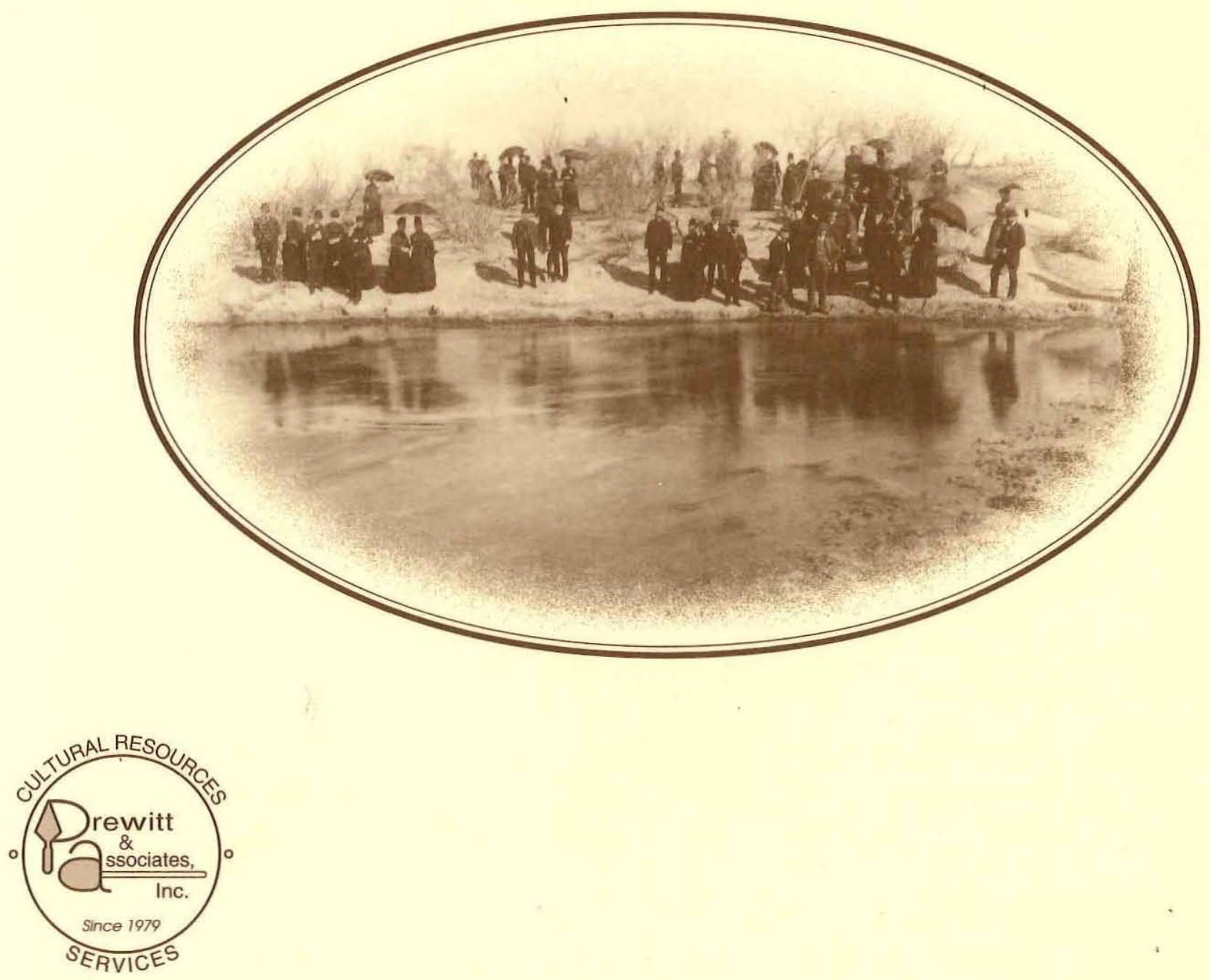
"VAL VERDE ON THE SUNNY RIO GRANDE": GEOARCHEOLOGICAL AND HISTORICAL INVESTIGATIONS AT SAN FELIPE

SPRINGS, VAL VERDE COUNTY, TEXAS

\author{
by \\ Gemma Mehalchick \\ Terri Myers \\ Karl W. Kibler \\ and \\ Douglas K. Boyd \\ with Contributions by \\ David G. Robinson \\ Brian S. Shaffer \\ Jay Barry \\ and \\ J. Phillip Dering
}

Principal Investigator: Douglas K. Boyd

REPORTS OF INVESTIGATIONS, NUMBER 122

Prewitt and Associates, Inc.

Cultural Resources Services

Austin, Texas

March 1999

TEXAS ANTIQUITIES COMIMITEE ARCHEOLOGY PERMITS NOS. 1880 AND 1905 


\section{TABLE OF CONTENTS}

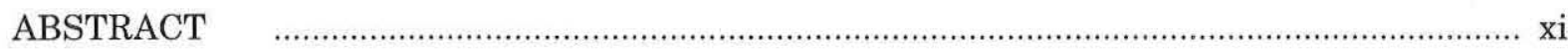

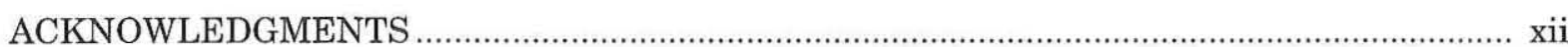

CHAPTER 1: INTRODUCTION

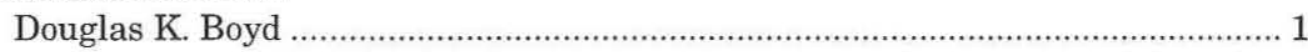

Project History …....................................................................................................... 1

Project Findings and Long-term Management Concerns ............................................... 4

Significant Findings Described in this Report ........................................................... 5

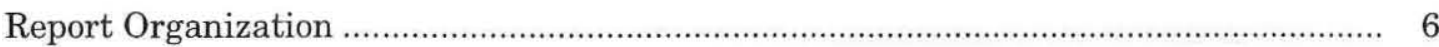

CHAPTER 2: ENVIRONMENTAL AND ARCHEOLOGICAL BACKGROUND OF SAN FELIPE SPRINGS AND VAL VERDE COUNTY

Douglas K. Boyd .......................................................................................... 7

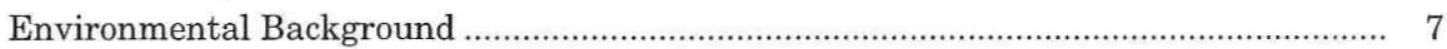

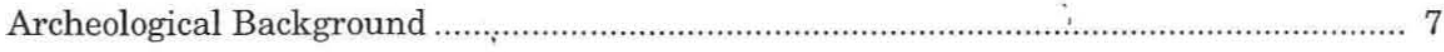

CHAPTER 3: SUMMARY AND METHODS OF INVESTIGATION

Gemma Mehalchick, Terri Myers, Douglas K. Boyd, and Karl W. Kibler ......... 11

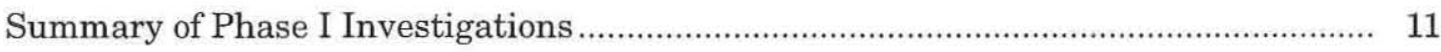

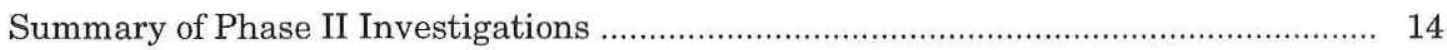

Historic Research Methods ..................................................................................... 14

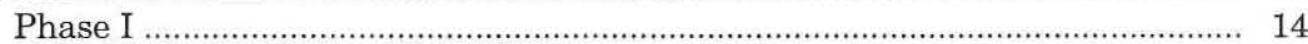

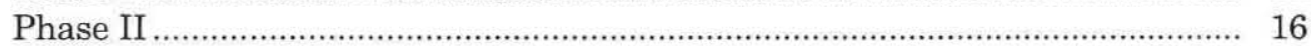

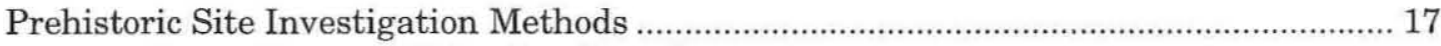

Excavation and Collection Procedures ........................................................... 17

Laboratory and Analysis Procedures ............................................................... 20

Stone Artifacts ................................................................................. 22

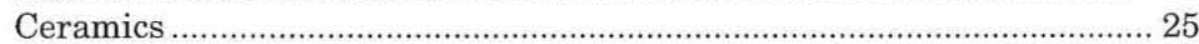

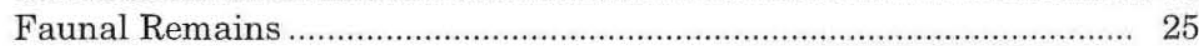

Burned Rocks ......................................................................................... 25

Flotation Samples and Macrobotanical Remains .................................. 26

CHAPTER 4: HISTORIC OVERVIEW OF SAN FELIPE SPRINGS, DEL RIO, AND VAL VERDE COUNTY, TEXAS

Terri Myers ......................................................................................... 27

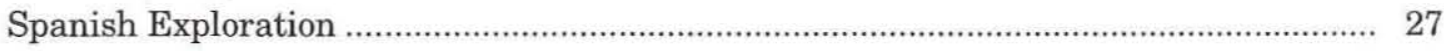

U.S. Military Presence and the Chihuahua Trail …....................................................... 28

Earliest American Settlements at San Felipe Springs: 1859-1862 ….......................... 29

San Felipe Agricultural, Manufacturing and Irrigation Company: 1869-1871 ............ 30

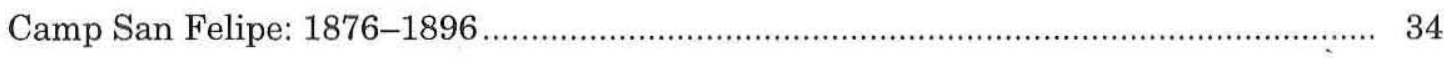

Community of San Felipe Del Rio ............................................................................ 37

Arrival of the Railroad and the Formation of Val Verde County: 1883-1885 ................ 38

Early Community Development: 1885-1896 …........................................................ 38

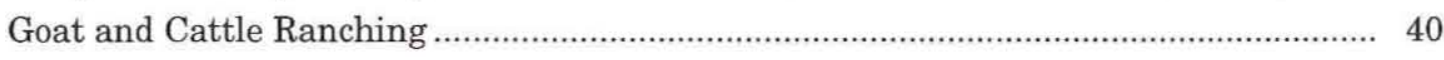

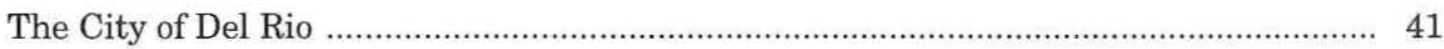




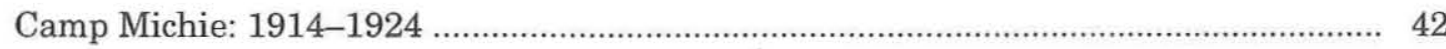

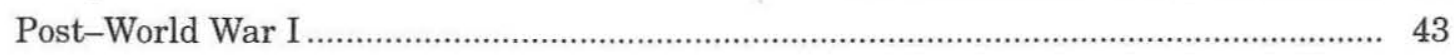

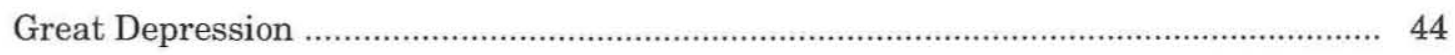

World War II and Recent Developments ...................................................................... 44

CHAPTER 5: DESCRIPTIONS AND ASSESSMENTS OF HISTORIC PROPERTIES

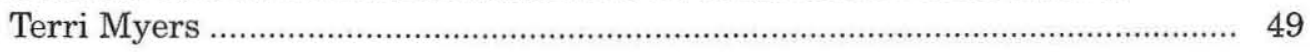

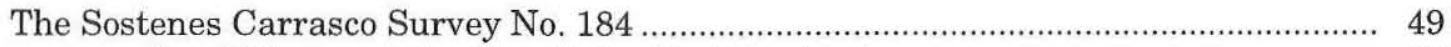

Land History of the San Felipe Springs Area ................................................. 49

San Felipe Country Club and Golf Course .................................................... 49

Lowe Ranch .............................................................................................. 51

San Felipe Country Club and Golf Course ……...................................................... 52

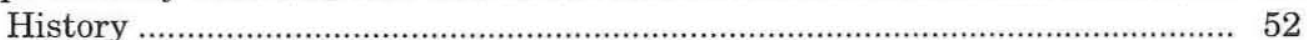

Origins of the San Felipe Country Club .............................................. 52

The Golf Course ...................................................................................... 53

Postwar Developments ....................................................................... 57

Descriptions and National Register Assessments ....................................... 57

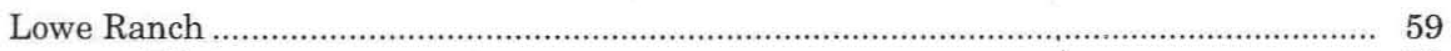

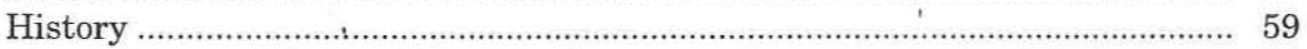

Description and National Register Assessment .............................................. 60

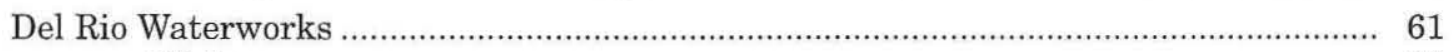

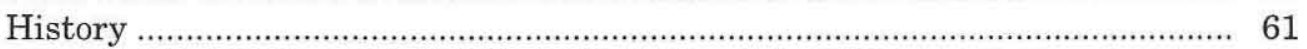

Del Rio Water Company ..................................................................... 62

East Del Rio/East Side Water Company .................................................. 63

City Involvement ........................................................................... 65

Consolidation of the Separate Water Systems ....................................... 67

A New Waterworks: 1935 .................................................................... 70

Post World War II to Present Day ............................................................. 71

Descriptions and National Register Assessments ............................................... 73

Architectural Descriptions of Contributing Features ............................... 73

National Register Assessments ................................................................. 76

CHAPTER 6: GEOARCHEOLOGICAL INVESTIGATIONS AT THE SAN FELIPE

SPRINGS SITE, 41VV444

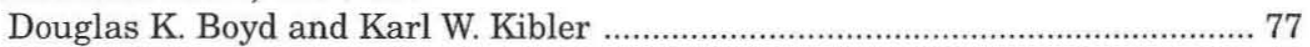

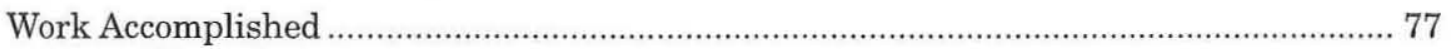

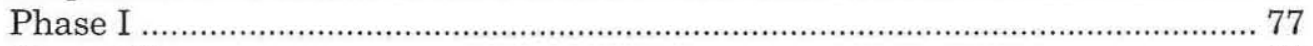

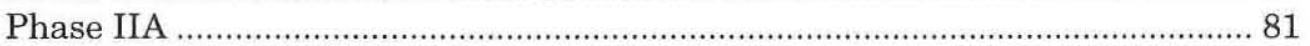

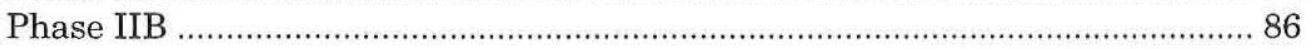

Sediments and Stratigraphy of the San Felipe Creek Valley …....................................... 86

Summary of Depositional History and Prehistoric Occupations ........................................ 92

CHAPTER 7: BLOCK EXCAVATIONS IN AREA 1, 41VV444

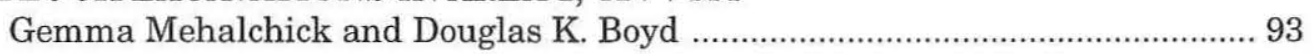

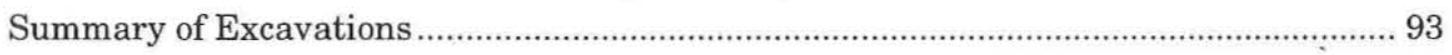

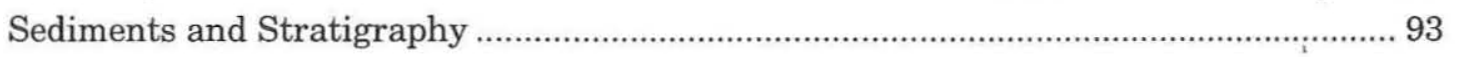

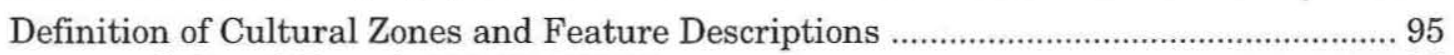

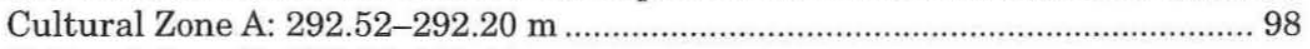

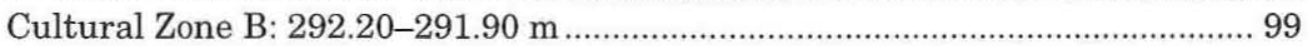

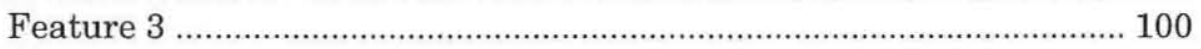

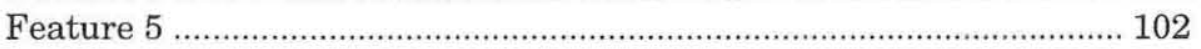




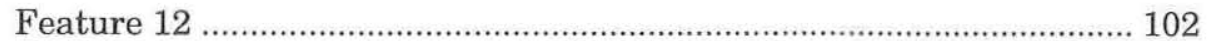

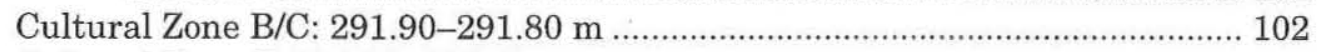

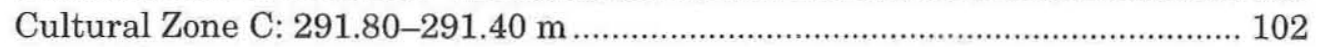

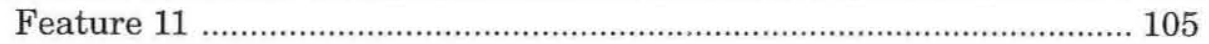

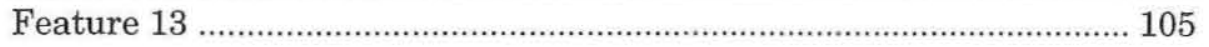

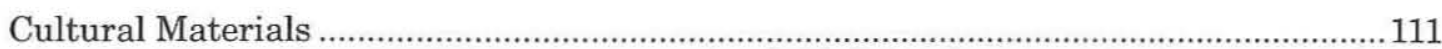

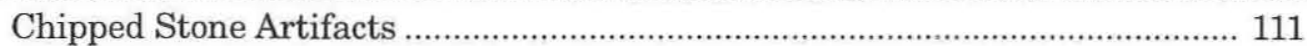

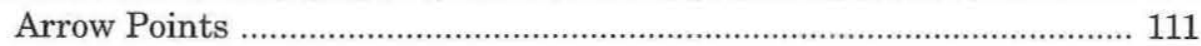

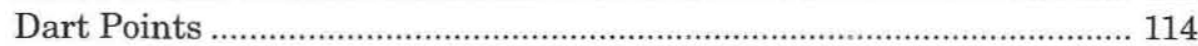

Unidentifiable Projectile Points ............................................................. 118

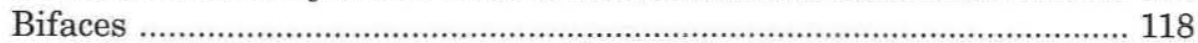

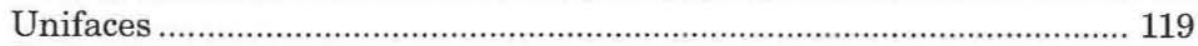

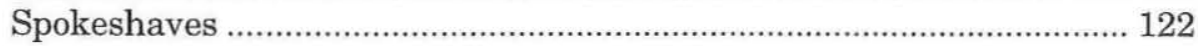

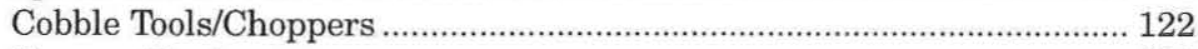

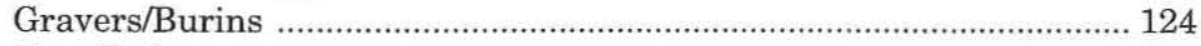

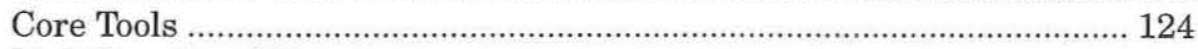

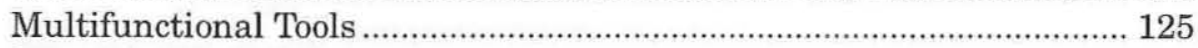

Edge-Modified Flakes ...................................................................... 126

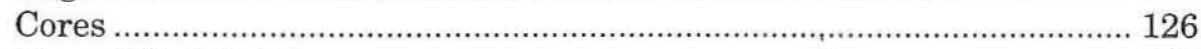

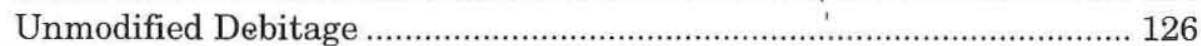

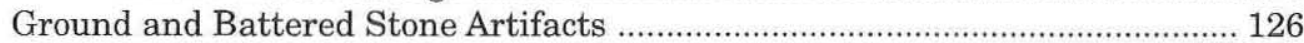

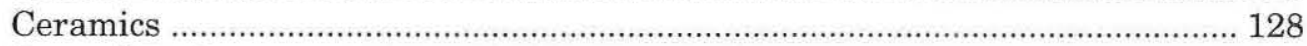

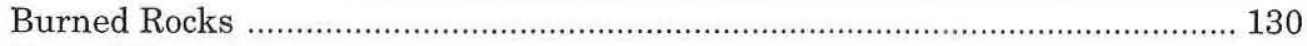

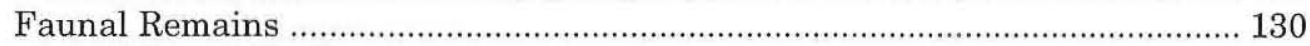

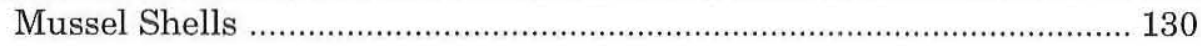

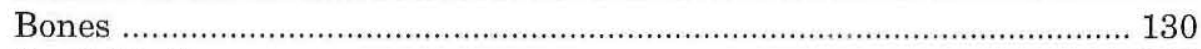

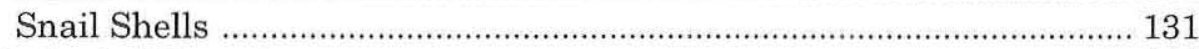

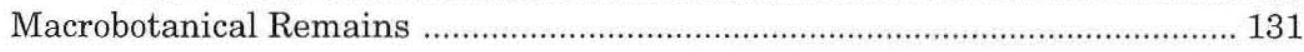

CHAPTER 8: ANALYSIS OF CULTURAL OCCUPATIONS IN AREA 1, 41VV444

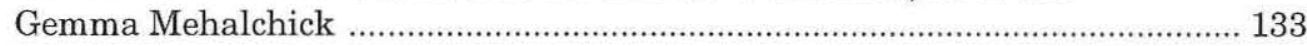

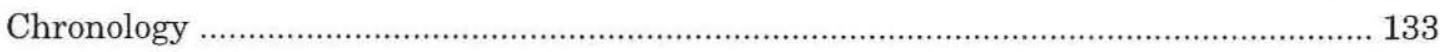

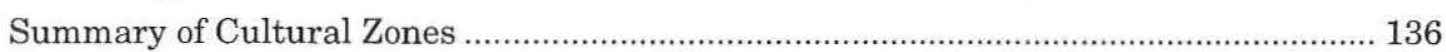

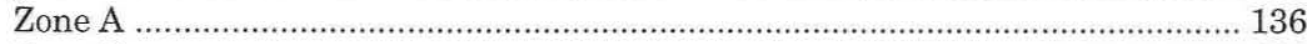

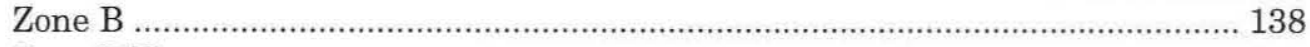

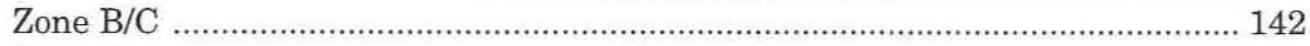

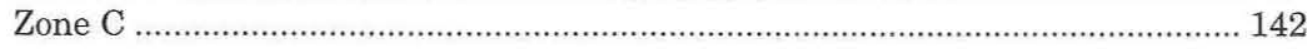

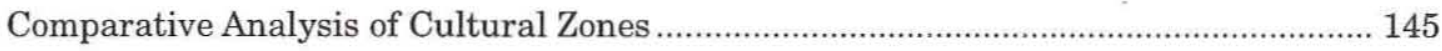

CHAPTER 9: WATER IN THE DESERT: PREHISTORIC OCCUPATIONS AT

SAN FELIPE SPRINGS

Gemma Mehalchick and Douglas K. Boyd …................................................... 149

The Balcones Escarpment Environmental Zone ............................................................. 149

Summary of Prehistoric Occupations at San Felipe Springs ............................................ 151

San Felipe Springs in Regional Perspective ................................................................. 152

Late Prehistoric/Protohistoric Occupations in the Lower Pecos ...................... 152

Late Archaic Occupations in the Lower Pecos ................................................... 157

Middle Archaic Occupations in the Lower Pecos ............................................... 158

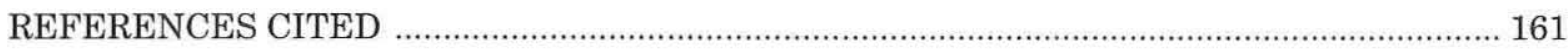

APPENDIX A: Stratigraphic Descriptions for 41VV444

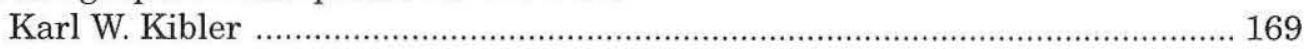


APPENDIX B: Radiocarbon Dating Results from 41VV444

Gemma Mehalchick

APPENDIX C: Petrographic Analysis of Plainware Pottery from 41VV444

David G. Robinson

APPENDIX D: Analysis of Vertebrate Faunal Remains from 41VV444

Brian S. Shaffer and Jay Barry

APPENDIX E: Analysis of Plant Remains from 41VV444

J. Phillip Dering

APPENDIX F: Provenience of Artifacts Recovered from 41VV444 


\section{LIST OF FIGURES}

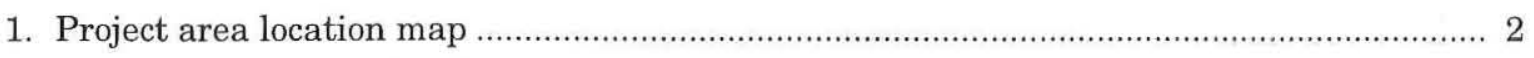

2. Map of project area showing proposed water treatment plant and related facilities ........... 3

3. Upland tract east of San Felipe Springs where proposed water treatment plant

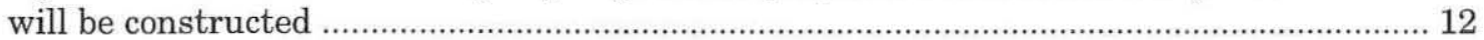

4. Historic 1878 "Sketch of the Reservation of Fort San Felipe Texas" ..................................... 33

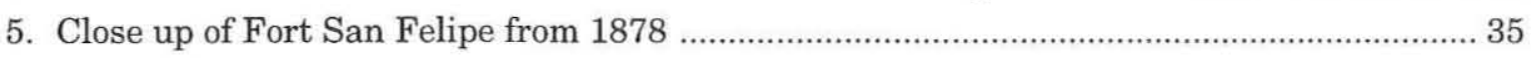

6. Historic "Sketch of Survey on San Felipe Creek, Kinney County, Texas" ............................ 36

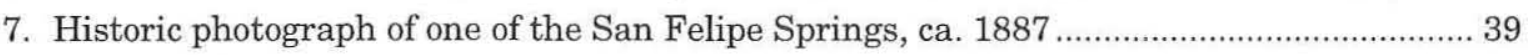

8. "View of 14th Calvary Camp, Del Rio, Texas," ca. 1917-1918 ………................................. 43

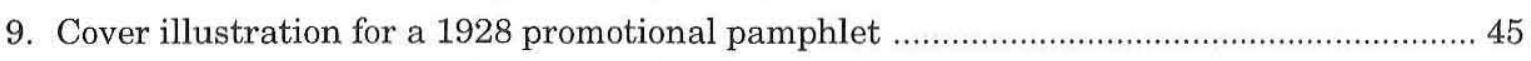

10. Certification survey map from 1852 showing the Sostenes Carrasco Surveys No. 184 and 185 50

11. Former Officer's Club of Camp Del Rio/Camp Michie and first clubhouse for the San Felipe Country Club, ca. 1924 ..................................................................................... 53

12. Caddies in front of the pro shop at the San Felipe golf course, ca. 1920s .......................... 56

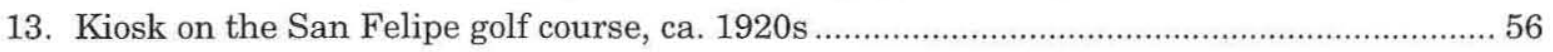

14. San Felipe Country Club golf pro Joe Hendry, ca. 1924-1925 …...................................... 57

15. "Air View of Golf Course, Del Rio, Texas," ca. 1948 ............................................................... 58

16. View north-northwest of the west side of the eastern Bedell tank, 1997 ..........................6 66

17. View northeast of the East Springs pump house and pond, ca. 1938 ................................... 69

18. View north-northwest of the East Springs pump house and pond enclosure, 1997 ........... 74

19. Location of proposed construction areas and Phase I backhoe trenches and shovel tests at 41VV444

20. Modified engineering plan, Phase I excavations, and key archeological areas for

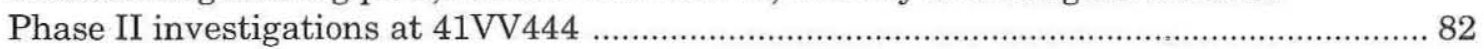

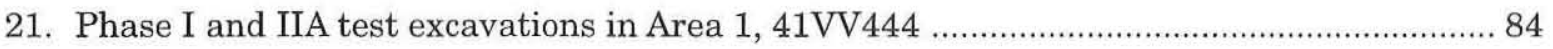

22. Phase I and IIA test excavations in Area 2, 41VV444 …..................................................... 85

23. Phase IIA test excavations in Area 7, 41VV444 ….............................................................. 86

24. Phase I, IIA, and IIB excavations in Area 1, 41VV444 …................................................ 87

25. Map showing locations of selected backhoe trenches, excavation units, and geotechnical bore holes in the vicinity of 41VV444 90

26. San Felipe Creek valley cross section depicting backhoe trench, excavation unit, and goetechnical bore hole profiles . 91

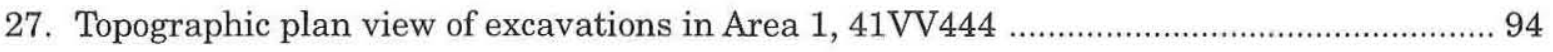

28. Excavated levels in the Area 1 excavation block, 41VV444 …............................................. 96

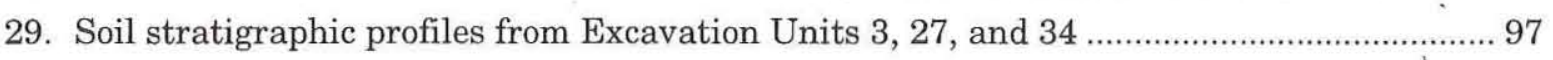

30. Horizontal distribution of burned rocks and artifacts in Cultural Zone A ......................... 98

31. Horizontal distribution of features, burned rocks, and artifacts in Cultural Zone B ......... 99

32. Distribution of burned rocks in Cultural Zone B by level ............................................... 100

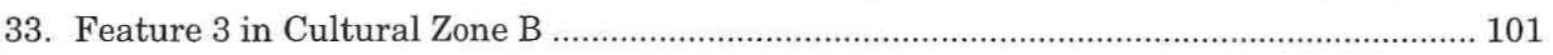


34. Feature 5 in Cultural Zone B

35. Plan view of Feature 12 in Cultural Zone B at $291.50 \mathrm{~m}$ in Excavation Units 7 and 19

36. Horizontal distribution of burned rocks and artifacts in Cultural Zone B/C

37. Horizontal distribution of features, burned rocks, and artifacts in Cultural Zone C ........ 106

38. Photographs of Feature 11 in Cultural Zone $\mathrm{C}$................................................................. 107

39. Plan and profile drawings of Feature 11 in Cultural Zone $\mathrm{C}$............................................. 108

40. Photograph of in situ lithic artifacts in lower portion of Feature 13 in Cultural Zone C

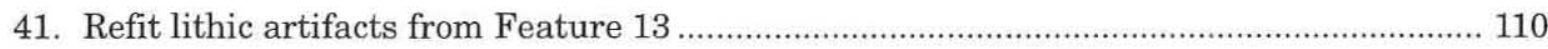

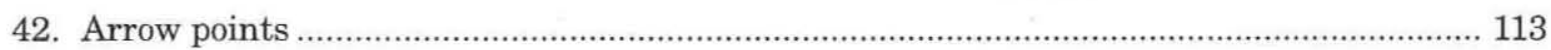

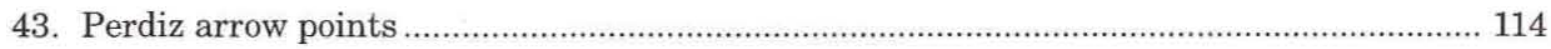

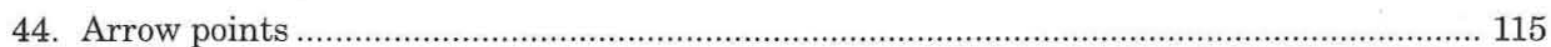

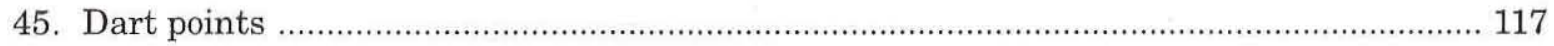

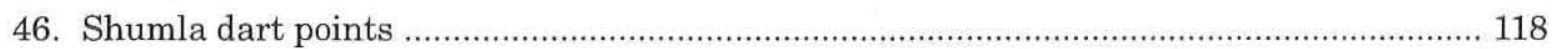

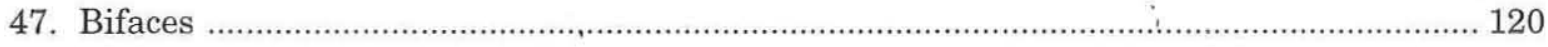

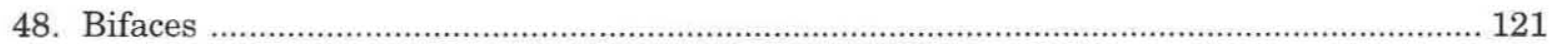

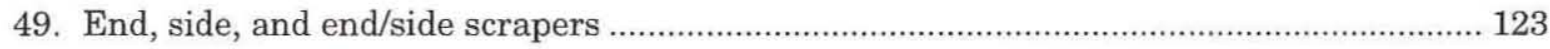

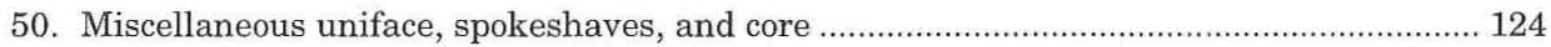

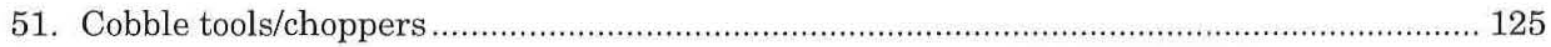

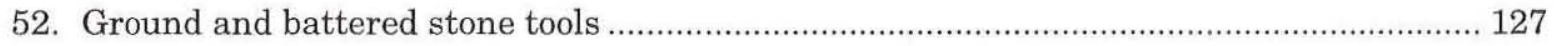

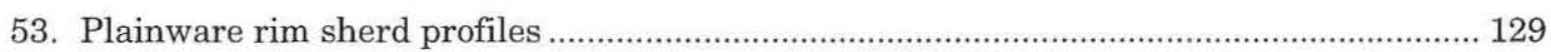

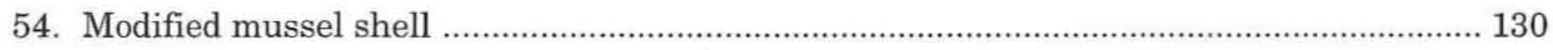

55. Generalized stratigraphic profile of the excavation block in Area 1, 41VV444 …............. 134

56. Horizontal distribution of burned rocks, stone artifacts, ceramics, and

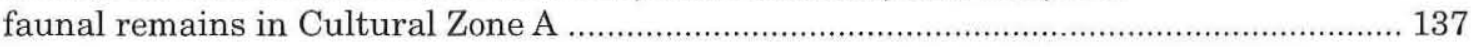

57. Horizontal distribution of various types of chipped stone tools in Cultural Zone A ......... 138

58. Horizontal distribution of features, burned rocks, stone artifacts, ceramics, and faunal remains in Cultural Zone B....

59. Horizontal distribution of various types of chipped stone tools in Cultural Zone B .......... 140

60. Horizontal distribution of cultural materials in Cultural Zone B/C .................................. 143

61. Horizontal distribution of features, burned rocks, stone artifacts, ceramics, ground stones, and faunal remains in Cultural Zone $\mathrm{C}$

62. Horizontal distribution of various types of chipped stone tools in Cultural Zone C .......... 145

63. Comparison of stone artifact densities vs. rates of deposition for the cultural zones in Area 1, 41VV444

64. Map of the Balcones escarpment and fault zone ............................................................... 150

65. Map depicting extent of Classic Toyah and shared Toyah cultures ................................. 156 


\section{LIST OF TABLES}

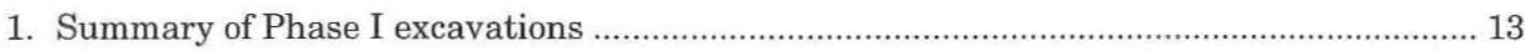

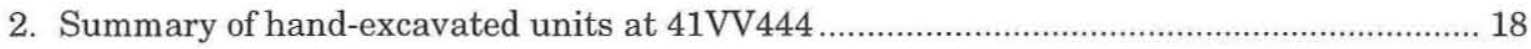

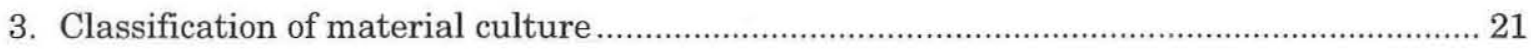

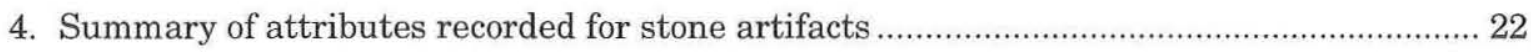

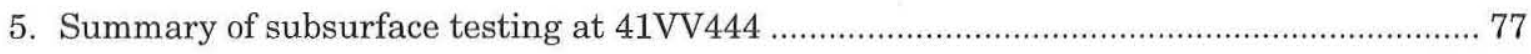

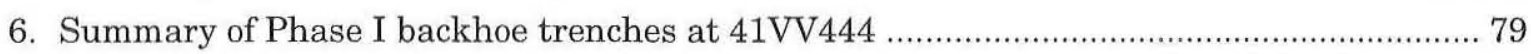

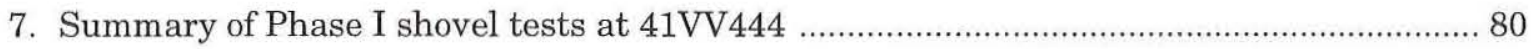

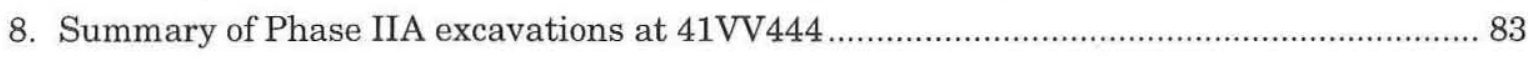

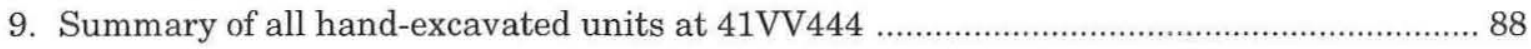

10. Elevation data for excavation block units in Area 1, 41VV444 …..................................... 95

11. Summary of radiocarbon dates and investigated features from Area 1, 41VV444 .............98

12. Summary of lithic artifacts from Feature 13 in Cultural Zone C .................................... 106

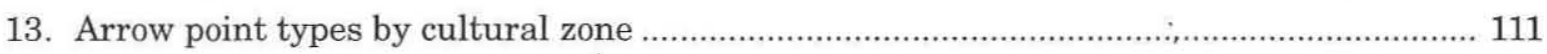

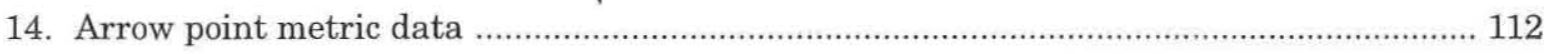

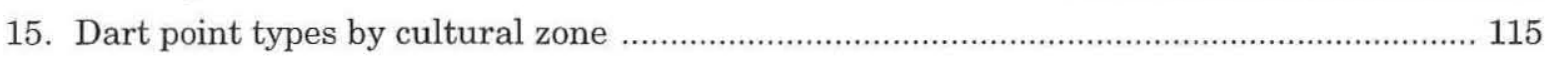

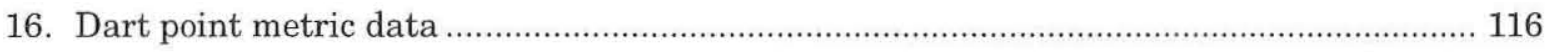

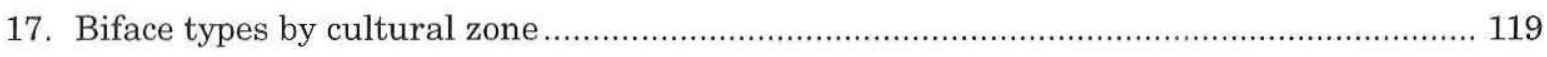

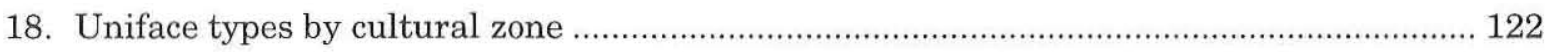

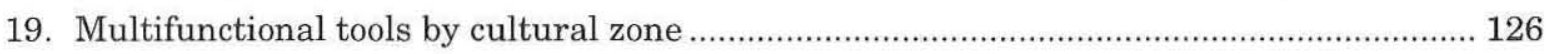

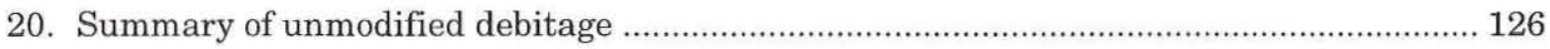

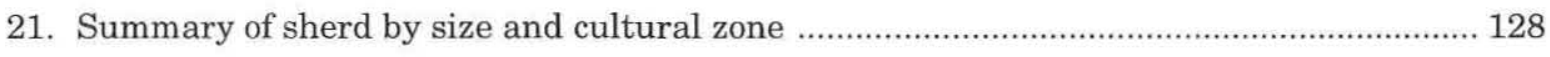

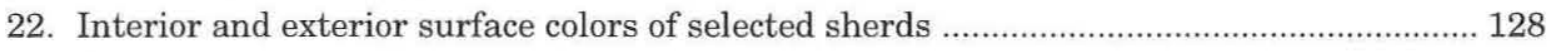

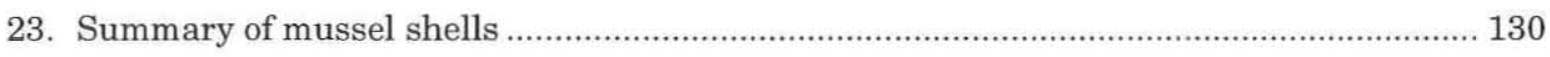

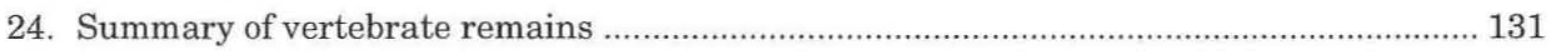

25. Summary of artifact types by cultural zones and features, Area 1, 41VV444 …............... 135

26. Comparisons between the cultural zones in Area 1, 41VV444 ….................................... 146

27. Major and historical springs emerging from the Edwards aquifer along the

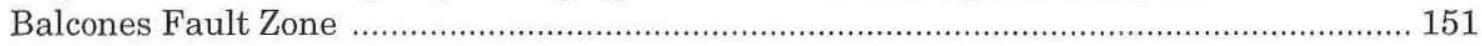

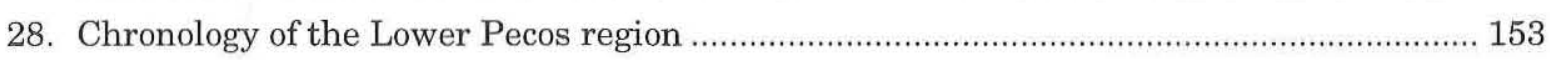

29. Comparison of Val Verde County sites yielding Late Prehistoric/

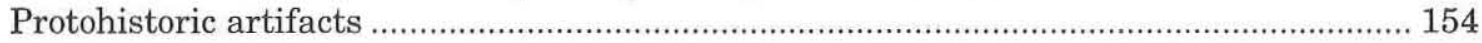

30. Summary of radiocarbon dates, Area 1 excavation block, 41VV444 …............................ 178

31. Provenience data for petrographic sample sherds from Area 1, 41VV444 ….................... 181

32. Summary of ceramic sherds in the 41 VV444 petrographic sample and other Lower Pecos petrographic samples

33. Comparison of ceramic petrographic point count data for 41VV444 and other

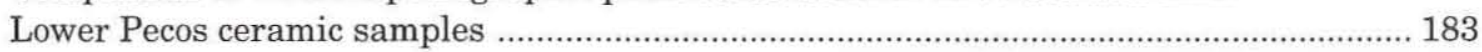

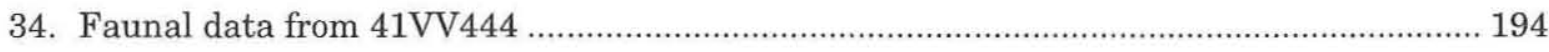

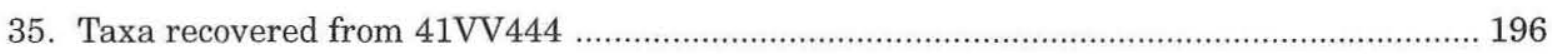


36. Characteristics of mature mesquite xylem compared to mature Acacia Greggii (catclaw acacia) xylem

37. Identification of charcoal samples submitted for radiocarbon dating ................................ 202

38. Counts from flotation samples ........................................................................................... 202

39. EDXA measurements of reference mesquite and archeological mesquite charcoal from 41VV444 and 41ZP364 ........................................................................................ 203

40. Summary of all prehistoric artifacts recovered from 41VV444 …..................................... 209

41. Provenience of Area 1 excavation block artifacts ................................................................ 210

42. Provenience of Area 1 nonexcavation block artifacts ......................................................... 219

43. Provenience of Area 2 artifacts ......................................................................................... 220

44. Provenience of Area 7 artifacts ........................................................................................... 221

45. Provenience of artifacts from shovel tests, backhoe trenches, and surface contexts ......... 221 


\begin{abstract}
In the fall of 1997, Prewitt and Associates, Inc. conducted archival and oral history research, an archeological survey, and National Register testing of a prehistoric site in the vicinity of the San Felipe Springs in southeastern Val Verde County, Texas. The work was done in preparation for construction of a water treatment plant and related facilities for the City of Del Rio. The survey resulted in the recording of one historic site (41VV1820) and further documentation of historic and prehistoric components at a previously known site, 41VV444. The latter site also was the focus of intensive geoarcheological investigations.

National Register testing of 41VV444, called the San Felipe Springs site, was restricted to portions of the alluvial terraces of San Felipe Creek near the East and West San Felipe Springs. A 40-m ${ }^{2}$ block excavation near the East Springs revealed three stratified prehistoric components in the upper ca. $100 \mathrm{~cm}$ of alluvium. These sediments represent continual deposition over the last 3,000-4,000 years, and archeological materials denoting Late Prehistoric/Protohistoric, Late Archaic, and Middle Archaic occupations were recovered.
\end{abstract}

The upper component post-dates A.D. 1300 and produced plain bone-tempered potsherds, Cliffton and Perdiz arrow points, and steeply beveled scrapers. This component represents a Toyah phase occupation on the western periphery of the Toyah culture area, but it shares many attributes with Protohistoric Infierno phase occupations of the Lower Pecos.

The middle component is characterized by Shumla dart points and three pit features originating near the base of a dense burned rock layer. It represents utilization of the area during the Flanders Subperiod of the Late Archaic. Although recovered from many sites (particularly rockshelters), the chronology of Shumla points is not well established in the region. Radiocarbon assays place the age of the San Felipe Springs Shumla component at ca. 800-200 B.C.

Geomorphic evidence suggests that a major flood episode (or episodes) occurred along San Felipe Creek between ca. 1300 and 800 B.C. This gravelly deposit separates the middle component from the lower component and is indicative of a high volume flood event, possibly similar to the August 1998 flooding along San Felipe Creek resulting from Hurricane Charley. Underlying this zone is a discrete Middle Archaic occupation containing a dense burned rock layer and an internal pit feature. Radiocarbon dates, along with associated Bulverde and Langtry variant dart points, correlate to the San Felipe Subperiod. Also associated with this occupation is a small concentration of artifacts representing a dump or cache of usable lithic materials.

Historic components at 41VV1820 and 41VV444 contain structures related to the City of Del Rio's water pumping and distribution system. These resources, particularly the East Springs pump house and pond enclosure at 41VV444, are historically significant; however, they will be removed during construction of new water pumping facilities. Site 41VV444 encompasses most of what is now the San Felipe Country Club golf course. Built by Texas' first golf course architect, John Bredemus, in 1922, the San Felipe course is now recognized as an important historic landscape. 


\section{ACKNOWLEDGMENTS}

The archeological and historical investigations at San Felipe Springs were sponsored and funded by the City of Del Rio, Texas under supervision of City Manager Beth Eby. Our work was directly supervised by Malcolm Pirnie, Inc. (MPI) of San Antonio, Texas. Mark Roetzel, Senior Project Engineer, and John Avolio, Senior Program Leader, did much of the coordination and planning of our work and were extremely helpful. Other involved MPI personnel included Judd Warren, Greg Gomez, and O. J. Valdez. Robert Hernandez, a hydrologist/geologist with MPI, supervised our daily field activities. He assisted us in many ways and on occasion became an important part of our field crew. The dedicated professionals on the MPI team made our job easier and we are grateful for their efforts.

The City of Del Rio also assisted in many ways. They supplied a backhoe and competent operators as needed, coordinated by Rudy Delgado. Mitch Lomas (Del Rio Water Department) allowed us to use his office at the springs when needed, stored our equipment in buildings at the East Springs, and arranged for the city to provide barricades and pallets to comply with safety regulations and protect the site.

The San Felipe Country Club folks were helpful and cooperative. Golf Pro Clint Baack and Club Manager Betty Hollingsworth were gracious hosts, despite our digging up the 6th fairway of their golf course.

Many Prewitt and Associates personnel and several consultants were involved in the project. I directed field work on occasion, but Project Archeologist Gemma Mehalchick did most of the supervision. The Project Geomorphologist was Karl Kibler and the Project Historical Archeologist was Marie Blake. The archeological field crew included Karl Kleinbach, Mike Wilder (and his dog JoJo), Cullom, Paul Maslyk, Mark Holderby, and Don Badon. Archival and oral history research was done by consulting historian Terri Myers, of Hardy $\downarrow$ Heck $\downarrow$ Moore \& Myers, assisted by Ann Malanka. Elton Prewitt, who had worked in the San Felipe Springs area some 23 years earlier, provided sage advice and was involved in planning all phases of work. Karen Gardner and Audra Pineda assisted with the laboratory work, data analysis and database management, and curation. Report editing and production were done by Melissa Hennigan. Figures and illustrations were prepared by Brian Wootan and Sandy Hannum, and artifact photographs were taken by Jack Rehm and Jim Cazares. Special analyses were conducted by consultants David Robinson (Texas Archeological Research Laboratory, University of Texas at Austin), Phil Dering (Center for Ecological Archeology, Texas A\&M University), and Brian Shaffer and Jay Barry (Institute of Applied Sciences, University of North Texas).

Several people at the Texas Historical Commission (THC) were involved in the review of this project. In the Department of Antiquities Protection, Bill Martin and Debra Beene were extremely helpful and attentive to our concerns about keeping the project schedule on track. They, along with Greg Smith of the National Register Department, participated in meetings to discuss critical details and make quick decisions so that the archeological work would not delay the overall project schedule. Ms. Beene also came for an on-site visit to see the excavations in progress. Sharon Fleming, with THC's Architecture Department, reviewed the standing architectural remains.

Last, but not least, thanks to the many fine people of Del Rio who made our work there pleasurable as well as productive. Special thanks to Mitch Lomas and Tony Ojeda for cooking us some hot meals when the weather became chilly. Del Rio police officer and Texas Archeological Steward James Boyd visited our excavations on several occasions and provided us with information on local sites. Joe Labadie, archeologist with Amistad National Reservoir Area, also 
visited the site and gave us insights into the local lithic materials. Chris Durrett, a Del Rio High School student, volunteered for a few days during our excavations. Knowledgeable local informants who provided our historian with important information and insights included Ruth Coleman, Roebuck Daughtrey, Bill Hahn, Richard Hernandez, James Hester, Betty Hollingsworth, Lee Lincoln, Douglas and Lillian Newton, Jim Palmer, Harry Parsi, Thomas Qualia, Julian Sanchez, and Jesse Valdez.

Douglas K. Boyd

Principal Investigator 



\section{INTRODUCTION}

Douglas K. Boyd

1

The San Felipe Springs are an important geological feature, providing a dependable source of water in the arid northern Chihuahuan desert. The City of Del Rio owes its existence to this water source, and the importance of the springs is noted in Spanish, Mexican, and American documents spanning three centuries. Archeological evidence indicates that the springs were also an important attraction for prehistoric peoples. Archeological and historical investigations conducted at San Felipe Springs in 1997-1998 add new evidence to the story of human occupations tethered to major spring localities along the Balcones escarpment of Texas (Figure 1).

\section{PROJECT HISTORY}

Archeological and historical investigations at San Felipe Springs, in the southeastern corner of Val Verde County, Texas, were required by various state and federal laws when the City of Del Rio planned to upgrade its water distribution system and install a new water treatment plant at the springs (Figure 2). Del Rio currently pumps water out of the two major San Felipe Spring vents, known as the East and West Springs. The new system will continue to pump water from these springs but will tap into them below the surface to avoid water contaminated by agricultural, industrial, and municipal runoff. The existing East and West Springs pumping facilities will be removed and replaced. A series of buried pipelines will be installed to pump the water from the springs uphill ca. $0.4 \mathrm{~km}$ to the east, where the new treatment plant will be built on the level upland overlooking the creek valley. Treated water will then flow west across San Felipe Creek to the opposite side of the valley in buried pipelines. From there, water will flow to a series of water storage tanks on a prominent hill ca. $1.5 \mathrm{~km}$ northwest of the springs. Since the existing storage tanks (known locally as the Bedell tanks) leak thousands of gallons of water a day, they will be torn down and replaced with new ones. The new storage tanks will tie into the existing distribution system to pipe water to various parts of the city.

In 1997, Del Rio was mandated by an administrative order from the Texas Natural Resource Conservation Commission to install a new water treatment plant by 31 May 1999. Water quality problems caused by using untreated surface water from the springs necessitated the treatment plant for bringing the city's water supply into compliance with provisions of the federal Safe Drinking Water Act. The City of Del Rio contracted with Malcolm Pirnie, Inc. (MPI), consulting engineers, scientists, and planners from San Antonio to plan and construct the water treatment plant and related facilities. MPI was also responsible for ensuring compliance with various state and federal environmental and cultural resource laws. The project is on lands owned by the city, is mandated by an administrative order of the Texas Natural Resource Conservation Commission, and is funded in part by the Border Environmental Infrastructure Fund of the Environmental Protection Agency; thus, it was subject to the rules and regulations of the Texas Antiquities Code (Texas Natural Resource Code of 1977, Title 9, Chapter 191, VTCS 6145-9) and Section 106 of the National Historic Preservation Act of 1966, as amended. In August 1997, MPI contracted with Prewitt and Associates, Inc. 


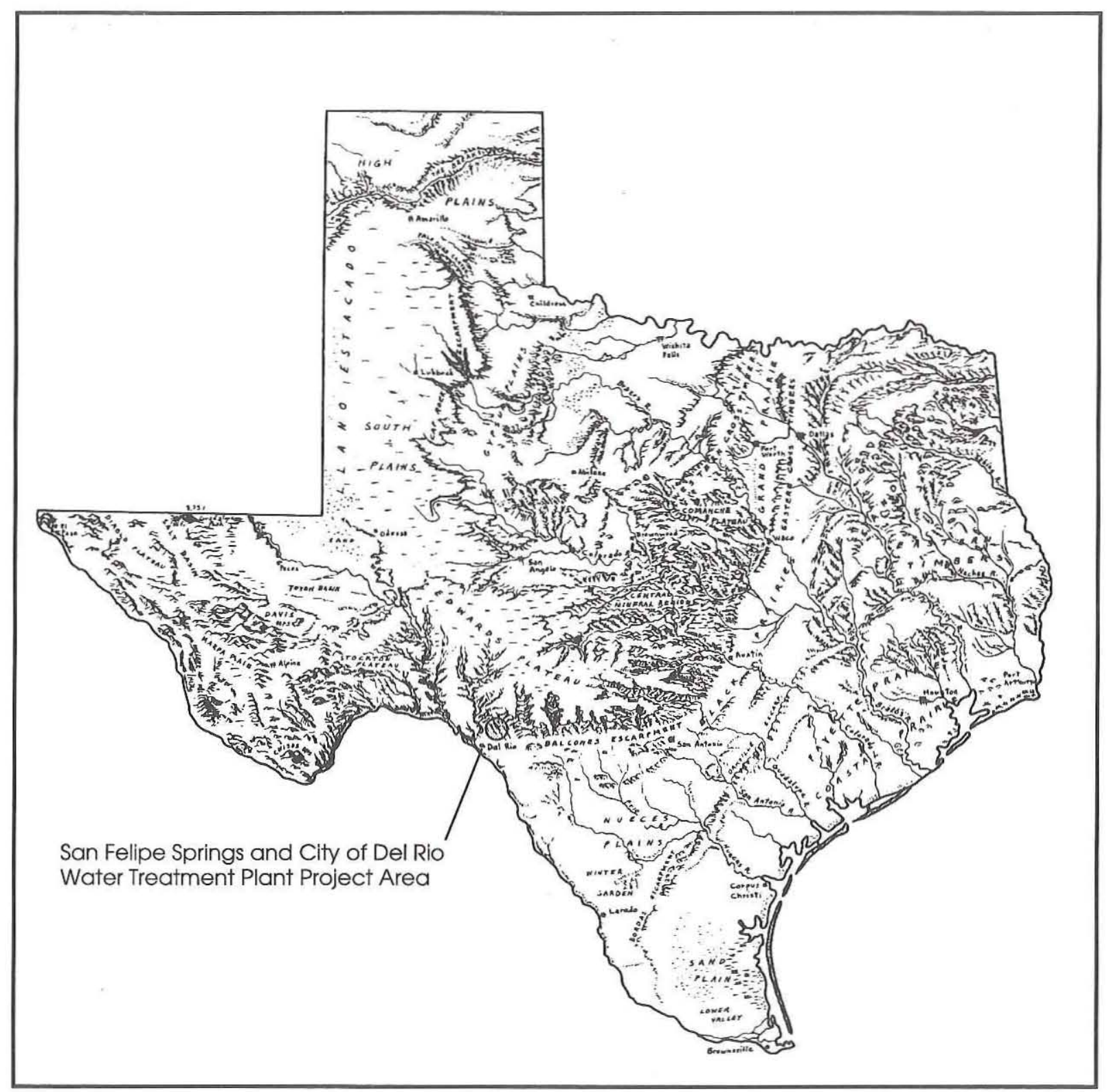

Figure 1. Project area location map.

(PAI) of Austin to conduct cultural resources investigations. The archeological work reported herein was conducted by PAI under the direction of the Principal Investigator, Doug Boyd, and Project Archeologist, Gemma Mehalchick, while the historic resources investigations were conducted by Terri Myers of Hardy $\diamond$ Heck $\diamond$ Moore \& Myers of Austin.

Project planning and construction schedules were tight, so the cultural resources studies had to be done quickly. Phase I field investigations, conducted on 8-11 September 1997 under authority of Texas Antiquities Permit No. 1880, consisted of limited archival research, a 100 percent pedestrian survey of proposed construction areas, and subsurface testing in selected construction areas. Site 41VV1820 was recorded as consisting of two historic components, and historic and prehistoric components were documented at previously recorded site $41 \mathrm{VV} 444$. The latter site is large, encompassing the entire valley 


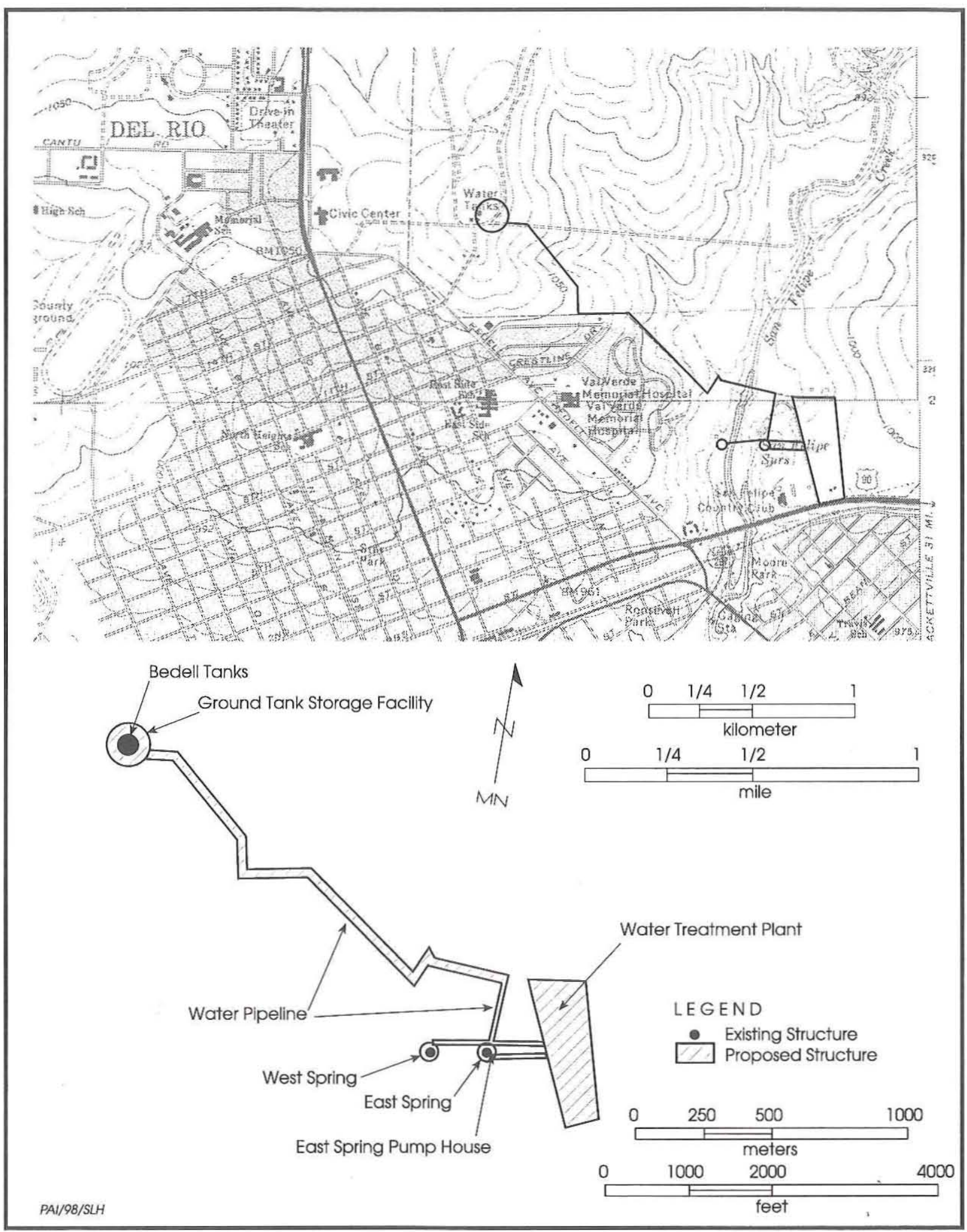

Figure 2. Map of project area showing proposed water treatment plant and related facilities; area is located on the Del Rio NW (top) and Del Rio SW (bottom) USGS 7.5-minute quadrangle maps. 
bottom of San Felipe Creek in the vicinity of the two main spring vents (East and West Springs) and virtually all of the San Felipe Country Club golf course. Backhoe trenches and shovel tests were used to sample and examine prehistoric deposits in the area of potential effect within 41VV444.

During Phase I investigations, prehistoric and historic resources that were potentially eligible for listing in the National Register of Historic Places (NRHP) were identified. The project then entered into a two-part testing/ assessment phase conducted under authority of Texas Antiquities Archeology Permit No. 1905. Phase IIA included additional subsurface testing (backhoe trenches and hand-excavated 1x1-m test units) of prehistoric deposits in several areas at 41VV444 on 3-14 November 1997. Additional archival and oral history research was undertaken for 41VV.444 and $41 \mathrm{VV} 1820$, and standing historic structures at these sites were recorded. Initial testing revealed that potentially significant prehistoric archeological deposits were present at 41VV444. To avoid delaying the construction schedule, a more-intensive level of testingPhase IIB-began after consultation with the Department of Antiquities Protection of the Texas Historical Commission (THC). It was determined that a ca. $30-\mathrm{m}^{3}$ block excavation near the East Springs would constitute an interpretable sample of the intact prehistoric deposits in the area of potential effect. This Phase IIB excavation, completed between 19 November and 11 December 1997, would serve to mitigate the adverse effects of project construction.

This report documents the results of the archival, oral history, and archeological field investigations completed for San Felipe Springs as part of the City of Del Rio's water treatment plant project. Work accomplished and reported herein consists of:

- re-recording of prehistoric and historic components and limited testing of prehistoric deposits in four main areas at 41VV444;

- intensive testing of stratified prehistoric deposits threatened by pipeline construction in Area 1 near the East Springs at 41VV444;
- recording of remains of the twentiethcentury Lowe Ranch and historic Bedell water storage tanks as site 41VV1820;

- historic archival and oral history research to define contexts for various historic resources;

- NRHP evaluation of Del Rio's earlytwentieth-century water works, including architectural evaluation of pumping facilities at East and West Springs (41VV444) and the Bedell water storage tanks (41VV1820); and

- NRHP evaluation of the historic landscape of the San Felipe Country Club golf course (encompassing virtually the same area as site 41VV444).

\section{PROJECT FINDINGS AND LONG-TERM MANAGEMENT CONCERNS}

All NRHP assessments and decisions regarding appropriate treatment of the cultural resources were made in consultation with the Department of Antiquities Protection and the National Register and Architecture Divisions of the THC. The following determinations were made:

- the twentieth-century Lowe Ranch is not eligible for listing in the NRHP and will not be impacted by this project;

- the twentieth-century City of Del Rio water works system is eligible for listing in the NRHP, and two of the Bedell water tanks and the East Springs pump house and pond are contributing historic features of this system;

- the historic Bedell tanks and East Springs pump house facility will be removed during construction of the treatment plant and new storage and pumping facilities, but architectural documentation from this investigation constitutes mitigation of adverse effects;

- the twentieth-century golf course is eligible for listing in the NRHP as a 
historic landscape, but there will be no permanent adverse effects due to project construction;

- all new facilities constructed in the country club area during this project are visually sensitive to the historic golf course landscape and do not constitute an adverse effect; and

- stratified prehistoric deposits are present at 41VV444 and are eligible for listing in the NRHP.

Based on these findings, Del Rio is responsible for continued protection and management of two NRHP-eligible resourcesburied prehistoric remains at 41VV444 and the twentieth-century golf course landscape. These resources overlap in space within the country club area and all future projects must take them into account. The city must consult with the $\mathrm{THC}$ for any projects requiring subsurface excavation or the removal, addition, or modification of any surface structure, feature, or landscape associated with the San Felipe Springs or the San Felipe Country Club (Texas Natural Resource Code of 1977, Title 9, Chapter 191, Subchapter A, Section 191.0525). Only a small portion of the extensive buried prehistoric deposits at 41VV444 was sampled during this investigation. Intact remains may be present throughout the country club.

\section{SIGNIFICANT FINDINGS DESCRIBED IN THIS REPORT}

Archival and oral history research revealed that the San Felipe Springs were critical to settlement, development, and prosperity in Del Rio. Prior to the mid-nineteenth century settlement in the San Felipe area, primarily by Hispanic people, was sporadic. In the late nineteenth century Euro-American entrepreneurs began looking at the economic potential of the area. Recognizing that the springs were important, a group of men began acquiring land in the San Felipe Creek valley in 1869 and formed the San Felipe Agricultural Company in 1871. Later reorganized as the San Felipe Agricultural, Manufacturing and Irrigation Company, this firm is the oldest continually operating irrigation company in Texas. Promoters in the early twentieth century touted the springs as an important part of life in this desert community. By capitalizing on the abundant water, an influx of speculators and settlers turned a sleepy desert town into the modern community of Del Rio. While the earliest inhabitants channeled the waters of San Felipe Creek into acequias to irrigate lands and serve their needs, the City of Del Rio tapped directly into the San Felipe Springs. As early as 1929, water was stored on the highest hill and gravity was used to pipe water to various parts of the town. The current water works system was essentially in place by the 1950 s, with only minor modifications and additions occurring after that time. Construction of the new water treatment plant, intake structures at the springs, and storage tanks in 1998-1999 is the first major renovation of the city's water system since the 1930s.

As Del Rio was growing in the early part of the twentieth century, some far-sighted residents saw the potential for the springs to support a golf course. Then relatively new to America, golf was growing in popularity and was seen as a means of boosting the local economy and attracting wealthier immigrants. The San Felipe Country Club was formed in 1921, and architect John Bredemus was hired to build a golf course at the springs. Completed in 1922, the San Felipe course is one of the earliest golf courses built in Texas and was the first in Texas to be designed by an architect. Bredemus became one of the premier golf course architects in Texas and was a prominent figure in the history of the sport. The San Felipe golf course is recognized as a nationally significant man-made landscape, and has changed very little since its construction in 1922.

Archeological testing of prehistoric remains at 41VV444, the San Felipe Springs site, involved mechanical excavation of 37 backhoe trenches and hand excavation of 11 shovel tests and $531 \mathrm{x} 1-\mathrm{m}$ test units. The most intensive work was concentrated in Area 1, where a block excavation of 40 test units (39 contiguous) revealed intact cultural zones and features in the upper ca. $120 \mathrm{~cm}$ of alluvial deposits in the late Holocene terrace between San Felipe Creek and the East Springs. This excavation, located on the 6th fairway of the golf course, removed a total of $36.4 \mathrm{~m}^{3}$ of fill and revealed three buried occupation zones. An upper Toyah phase 
occupation is characterized by bone-tempered pottery and Bonham, Cliffton, and Perdiz arrow points, but no features are associated. A middle occupation zone, Late Archaic in age, is characterized primarily by Shumla dart points. A massive accumulation of burned limestone rocks and a probable baking pit are evidence of subsistence activities. A thin, relatively sterile zone overlies the lowest occupation zone. This lowest zone is Middle Archaic in age and produced a Bulverde dart point. A large rocklined baking pit, a lithic dump or cache (i.e., cores and flakes dumped as a tight cluster or contained in a perishable container), and other amorphous features are associated with this occupation. These components yielded important archeological data for interpreting prehistoric activities along the eastern edge of the Lower Pecos region.

\section{REPORT ORGANIZATION}

Nine chapters and six appendixes constitute this report. Environmental and cultural background information are presented in Chapter 2 and geoarcheological and historical investigations conducted at the springs are summarized in Chapter 3.

Historic resources and investigations are considered in Chapters 4 and 5. Chapter 4 is a detailed historical overview describing use of the San Felipe Springs through the centuries and the settlement and development of Del Rio and Val Verde County. Descriptions and National Register assessments of historic properties documented in conjunction with this project are presented in Chapter 5.

The rest of the report relates to prehistoric resources. Chapters 6-8 relate to the prehistoric archeological remains found at 41VV444.
Chapter 6 summarizes geoarcheological investigations at the site and presents results of testing in most areas (except for Area 1). Geomorphology of the San Felipe Creek valley is described and the depositional history of the culture-bearing sediments is interpreted. The intensive archeological work undertaken in Area 1 of 41 VV444 is described in Chapter 7. Cultural stratigraphy is reviewed and features and material culture are described. In Chapter 8, archeological data for Area 1 of 41VV444 are analyzed and interpreted. Finally, Chapter 9 compares prehistoric occupational evidence from Area 1 with other archeological site data to understand the regional perspectives. The intensive late Holocene activities at the San Felipe Springs site are viewed relative to intensive human utilization of other major springs localities along the Balcones escarpment.

Results of special 'studies are presented in five appendixes, with the final appendix providing provenience data. Geological profile descriptions for nine backhoe trenches and four excavation units are presented in Appendix A. Nine radiocarbon assays by Beta Analytic, Inc., which help define the chronology of the prehistoric occupations at 41VV444, are presented in Appendix B. The results of a petrographic analysis of seven thin-sectioned bone-tempered potsherds, conducted by David Robinson, are presented in Appendix C. The next two appendixes present analyses of animal and plant remains recovered from 41VV444; Brian Shaffer and Jay Barry (University of North Texas) conducted the vertebrate faunal analysis in Appendix D and Phil Dering (Paleobotany Laboratory, Texas A\&M University) did the macrobotanical analysis in Appendix E. Finally, tables in Appendix F list proveniences of artifacts recovered from 41VV444. 


\title{
ENVIRONMENTAL AND ARCHEOLOGICAL BACKGROUND OF SAN FELIPE SPRINGS AND VAL VERDE COUNTY
}

\author{
Douglas K. Boyd
}

\section{ENVIRONIENTAL BACKGROUND}

The project area is located at the northeast edge of the City of Del Rio in Val Verde County, Texas. It is situated along San Felipe Creek ca. $6 \mathrm{~km}$ (3.7 miles) north-northeast of its confluence with the Rio Grande and in the immediate vicinity of the 2 largest spring vents of the 10 historic San Felipe Springs (Brune 1981:452-453). Located at the southern end of the Balcones escarpment, the San Felipe Springs exist because this ancient fault zone provides a conduit for the waters of the Edwards and Trinity aquifers to reach the surface. Like many other large springs located along this escarpment zone (e.g., Las Moras, San Antonio, Comal, San Marcos, and Waco Springs), the San Felipe Springs and springfed creek valley are an enticing locality, providing abundant water, trees, and a variety of plant and animal resources.

Geologically, the area is underlain by Cretaceous limestone of the Salmon Peak Formation (Bureau of Economic Geology 1977; Fugro-McClelland 1997:i). Within the project area, upland soils assigned to the Coahuila, Zapata, and/or Vinegarroon series are ancient (i.e., Pleistocene and earlier), while soils along San Felipe Creek are assigned to the Reynosa series and are Holocene in age (Golden et al. 1982).

The project area is located at the junction between two major physiographic regions - the Edwards Plateau and the South Texas Plains (also called the Rio Grande Plains), and three major vegetation zones-the desert shrub savanna, mesquite savanna, and mesquitechaparral savanna (Arbingast et al. 1973). Del Rio is also located at the junction of three major biotic provinces defined by Blair (1950) as the Balconian, Chihuahuan, and Tamaulipan. Each of these is characterized by a different set of flora and fauna that can be found within a short distance of the San Felipe Springs.

The climate of Val Verde County is arid; the region is characterized by mild winters and hot summers and generally year-round dry conditions (Bomar 1983:Tables B-7, B-9, C-2). At Del Rio, the average annual precipitation is 17 inches. The average daily high temperature is above $90^{\circ} \mathrm{F}$ from June through September, and temperatures reach $100^{\circ} \mathrm{F}$ or more an average of 27 days per year. The hottest year on record is 1953, when Del Rio's daily highs reached temperatures of $100^{\circ} \mathrm{F}$ or more on 78 days. This occurred during the 7-year-long statewide drought (1950-1957) that was Texas's worst in the twentieth century (Paulson et al. 1991: 518-520).

\section{ARCHEOLOGICAL BACKGROUND}

The San Felipe Springs are located at the junction of three major cultural areas-the Lower Pecos (part of the greater Trans Pecos region), the Edwards Plateau, and the South Texas Plains. Due to limited archeological research in the immediate vicinity, precise cultural placement for the San Felipe Springs area is controversial. However, most archeological evidence and the proximity of Del Rio to the Devils River suggest that the strongest cultural connections are with the Lower Pecos (Elton Prewitt, personal communication 1997).

The Lower Pecos River region of Texas has been occupied by humans for at least the last 12,000 years. The prehistoric archeological evidence from this area, summarized by Turpin 
(1995), documents a continuous sequence of cultures and encompasses a wide range of resources. Types of prehistoric archeological sites recognized in the region include campsites in a variety of environmental settings, villages with structural remains, specialized activity sites (e.g., hearth fields and burned rock middens), rockshelters, and rock art.

The springs along San Felipe Creek played an extremely important role in the historic development of the area. For several centuries, the springs served primarily as an oasis campsite for Spanish, Mexican, and American explorers and military. The springs began to be utilized more intensively with the formation of the San Felipe Agricultural, Manufacturing and Irrigation Company in 1875 and increasing populations brought by the coming of the railroad in 1883 (Jones 1976:109-113, 466-479). The San Felipe Springs have served as Del Rio's primary water source since its founding as San Felipe del Rio in 1834, and their importance is well documented in historic times (Brune: 1981:453). The springs were an important resource in prehistoric times as well; Brune (1981:452) notes the presence of burned rock middens and Indian campsites around the San Felipe Springs and points out that since they are the fourth largest springs in Texas, it is not surprising that they were utilized so intensively in the past.

The earliest archeological investigation in the immediate project area was by William A. Boggess of Del Rio in the 1920s and 1930s. He collected prehistoric artifacts from a large campsite located between and north of the east and west spring vents (41VV444 Site File, Texas Archeological Research Laboratory). This site was revisited in 1973 and assigned site number 41VV444 (Prewitt and Dibble 1974); it is within the water treatment plant project area described in this report.

A 1973 archeological survey upstream from the current project recorded 14 sites (41VV43141VV443 and 41VV445) along the middle portion of San Felipe Creek (Prewitt and Dibble 1974). This study was done in conjunction with a proposed Soil Conservation Service (SCS) reservoir that was never built. Thirteen of these sites were listed in the National Register of Historic Places in 1974 as the San Felipe Creek Archeological District (Steely 1984:176). Among these resources are burned rock middens, hearths, and terrace sites with stratified occupations spanning from late Paleoindian to historic times.

Other archeological work in the vicinity of Del Rio includes a survey of a water pipeline from San Felipe Springs to Laughlin Air Force Base reported by Labadie (1986); a survey near the Del Rio airport reported by McDonald and Hester (1975); survey and testing associated with a city landfill expansion reported by Burkett (1990) and Eaton et al. (1991); and a survey of Laughlin Air Force Base reported by Tennis et al. (1996). Of particular interest is the geomorphological study by Jim Abbott (see Appendix II in Eaton et al. [1991]) that defines the geomorphology and archeological potential of the proposed landfill area at the southeastern edge of Del Rio. Abbott examined the sediments in the uplands, valley, slope, and upper drainages of a small tributary to Calaveras Creek and defined the archeological potential of these deposits as being relatively poor. Most of the study area was located between the 1,010 and $1,060 \mathrm{ft}$ elevation contours in a setting comparable to much of the San Felipe Springs water treatment plant area, located $3 \mathrm{~km}$ to the northwest.

More recently, Texas A\&M University completed subsurface testing of 11 sites at Laughlin Air Force Base. This work, reported by Dering (1998), provides insight into prehistoric cultural activities that occurred in an upland setting away from the Rio Grande, the Pecos River, and major streams. The report also contains good environmental and cultural background information, characterizes the geomorphology and archeological potential of the uplands, and discusses hunter-gatherer mobility and land-use intensity in this low productivity environment.

Although many intensive archeological investigations have been done in Val Verde County, they are confined primarily to the Lower Pecos region proper, on both sides of the border. Most of these studies involved dry caves and shelters along major drainages, but several open sites and even sinkhole sites have been investigated. Archeological investigations have been done at Arenosa Shelter, Baker Cave, Bonfire Shelter, Castle Canyon site, Centipede Cave, Conejo Shelter, Coontail Spin, Cueva de la Zona, Cueva Quebrada, Damp Cave, Devil's Mouth site, Eagle Cave, Fate Bell Shelter, Hinds 
Cave, La Calsada site, Moorhead Cave, Nopal Terrace site, Perry Calk site, Piedra del Diablo site, Seminole Sink, and Skyline Shelter (see Turpin [1991, ed. 1991, 1995] for references to these investigations). Much of this work was done at sites in and around Amistad Reservoir and Seminole Canyon. Despite the intensity of work upstream, no major testing or data recovery was done at prehistoric sites in the immediate vicinity of Del Rio until the current project. The PAI archeological investigations reported herein reveal evidence of substantial buried components of Late Archaic and Late Prehistoric age in the alluvial deposits along San Felipe Creek in the vicinity of the two main spring vents. 



\section{SUMMARY AND METHODS OF INVESTIGATION}

Gemma Mehalchick, Terri Myers, Douglas K. Boyd, and Karl W. Kibler

\section{SUMMARY OF PHASE I INVESTIGATIONS}

Initial investigation of the water treatment plant project area began with a 100 percent pedestrian survey of all proposed construction areas (see Figure 2), excavation of backhoe trenches and shovel tests to search for and sample buried cultural deposits, and archival and oral history research. Detailed project area maps (scale at 1 inch $=60 \mathrm{ft}$ ) provided by Malcolm Pirnie (MPI) engineers allowed for accurate plotting of survey areas, exposed cultural materials, and excavations.

The 23.3-acre trapezoidal upland tract proposed as the location for the water treatment plant was surveyed using $30-\mathrm{m}$ transects. This tract is bordered by San Felipe Springs Road on the west, U.S. Highway 90 on the south, and Jap Lowe Road on the east (Figure 3). The northern one-third of this tract slopes sharply to the north, but the remainder is relatively level.

Four areas are present within this tract. The three largest areas, encompassing 19.8 acres, are enclosed by 6 -ft-tall chain link fences. These are extensively disturbed and were used by the Texas Department of Transportation as an equipment storage facility at the time of the survey. Several structures (such as a vehicle maintenance barn, office building, gas tanks, etc.) were present, and some areas were covered with asphalt or gravel. All areas not paved were examined, but no surface cultural materials were observed (excluding modern debris).

Prior to the current investigation, several geologic bore holes drilled in this tract provided basic information on the depth of fine-grained deposits and suggested that the soil mantle was very ancient (Fugro-McClelland 1997). Seventeen backhoe trenches were excavated in this tract, but no cultural materials were observed (Table 1). The northernmost trenches exposed only heavily weathered colluvial soils on slopes, but those in the southern portion of the tract exposed deeper upland soils corresponding to the ancient Coahuila series described in the Val Verde County Soil Survey (Golden et al. 1982).

No backhoe trenches were excavated in the 3.5-acre strip of land along Jap Lowe Road, but this section was carefully surveyed with transects spaced $10 \mathrm{~m}$ apart. This area was undisturbed, with sparse to moderate native vegetation; ground surface visibility was very good. Numerous shovel probes were excavated to check the sediments, which were the same as those observed in backhoe trenches to the west. Other than modern debris, no cultural materials were observed.

The pedestrian survey in the vicinity of 41VV444 concentrated on the proposed pipelines and the areas immediately adjacent to the springs. Areas around the East and West Springs were intensively examined, and all proposed pipeline corridors were surveyed by archeologists walking $15-\mathrm{m}$-wide transects. Ground surface visibility was good in a few areas where vegetation was removed by heavy foot or golf cart traffic, but many proposed construction areas were golf course fairways covered by thick grasses. Due to limited visibility and the necessity of sampling deep sediments, intensive backhoe testing was done across the lower portion of the San Felipe Creek valley in areas where colluvial and alluvial deposits were expected. When cultural materials were observed in situ in backhoe trenches or in 


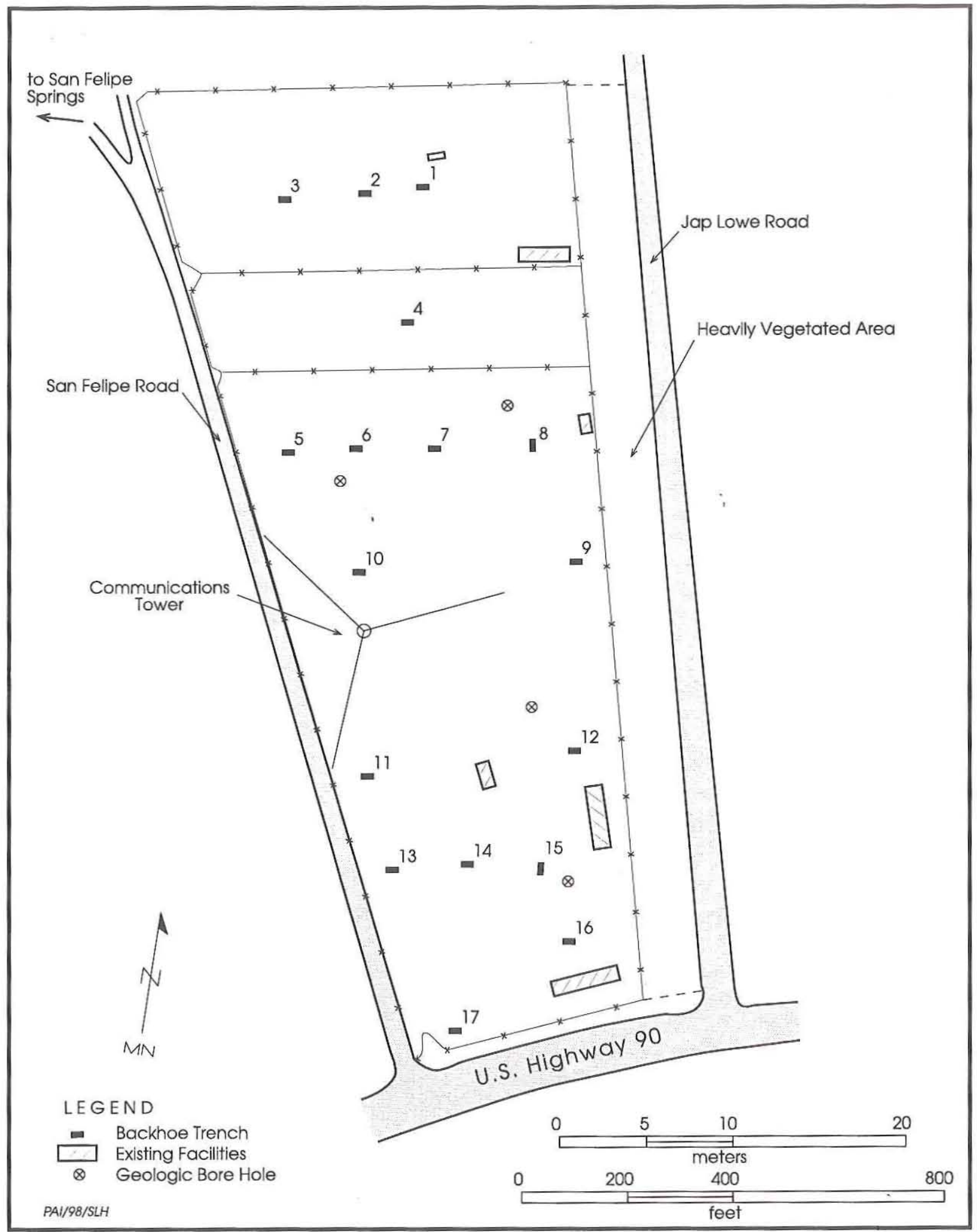

Figure 3. Upland tract east of San Felipe Springs where proposed water treatment plant will be constructed. Locations of backhoe trenches and geologic bore holes are shown. 
Table 1. Summary of Phase I backhoe trenches excavated in the upland water treatment plant tract

\begin{tabular}{|c|c|c|}
\hline $\begin{array}{l}\text { Backhoe } \\
\text { Trench }\end{array}$ & $\begin{array}{c}\text { Dimensions } \\
\text { (length } \mathrm{x} \text { width } \mathrm{x} \text { depth) }\end{array}$ & Observations* \\
\hline 1 & $2.1 \times 0.7 \times 0.87 \mathrm{~m}$ & $\begin{array}{l}\text { caliche encountered at } 10 \mathrm{~cm} \text {, weathered bedrock encountered at } \\
87 \mathrm{~cm}\end{array}$ \\
\hline 2 & $2.3 \times 0.7 \times 1.25 \mathrm{~m}$ & caliche encountered at $87 \mathrm{~cm}$ \\
\hline 3 & $2.6 \times 0.7 \times 0.94 \mathrm{~m}$ & - \\
\hline 4 & $2.1 \times 0.7 \times 1.06 \mathrm{~m}$ & disturbed to $20 \mathrm{~cm}$, caliche encountered at $40 \mathrm{~cm}$ \\
\hline 5 & $2.1 \times 0.7 \times 0.70 \mathrm{~m}$ & - \\
\hline 6 & $2.3 \times 0.7 \times 0.82 \mathrm{~m}$ & - \\
\hline 7 & $2.5 \times 0.7 \times 1.20 \mathrm{~m}$ & - \\
\hline 8 & $2.4 \times 0.7 \times 1.25 \mathrm{~m}$ & - \\
\hline 9 & $2.9 \times 0.7 \times 1.14 \mathrm{~m}$ & - \\
\hline 10 & $2.4 \times 0.7 \times 1.17 \mathrm{~m}$ & - \\
\hline 11 & $2.3 \times 0.7 \times 1.12 \mathrm{~m}$ & disturbed fill at $0-25 \mathrm{~cm}$ \\
\hline 12 & $2.1 \times 0.7 \times 1.35 \mathrm{~m}$ & disturbed fill at $0-10 \mathrm{~cm}$ \\
\hline 13 & $2.1 \times 0.7 \times 1.42 \mathrm{~m}$ & asphalt cap and artificial fill at $0-41 \mathrm{~cm}$ \\
\hline 14 & $1.6 \times 0.7 \times 1.05 \mathrm{~m}$ & asphalt cap to $13 \mathrm{~cm}$ \\
\hline 15 & $2.0 \times 0.7 \times 1.00 \mathrm{~m}$ & asphalt/gravel cap to $14 \mathrm{~cm}$ \\
\hline 16 & $2.0 \times 0.7 \times 0.95 \mathrm{~m}$ & asphalt cap to $3 \mathrm{~cm}$ \\
\hline 17 & $1.7 \times 0.7 \times 0.75 \mathrm{~m}$ & asphalt cap to $4 \mathrm{~cm}$ \\
\hline
\end{tabular}

backhoe trench fill, shovel tests were excavated nearby. In all, 26 backhoe trenches and 11 shovel tests were excavated at 41VV444 during Phase I. Results of these investigations are discussed in detail in Chapter 6.

The engineering plan includes buried water pipelines to pump water from the springs ca. 1.5 miles northwest to a prominent hill where new storage tanks will be built. Archeologists surveyed this 30 -ft-wide pipeline corridor by walking $10-\mathrm{m}$-wide transects. Many sections along this line are extensively disturbed, and all areas were either exposed bedrock or were covered by thin gravelly upland colluvial soils like those observed in the northern end of the water treatment plant tract; numerous shovel probes confirmed the depth and nature of the soils. Other than modern debris, no cultural materials were observed.

The new water storage tanks will be constructed next to the three existing tanks, known locally as Bedell tanks. The Bedell tanks are within a $225 \times 225-\mathrm{m}$ chain link fence enclosure on a hilltop characterized by a thin $(<20 \mathrm{~cm})$ soil mantle on bedrock. This hill was surveyed by archeologists walking 15-m-wide transects, but no prehistoric evidence was observed. Historic and modern debris is scattered around the area, primarily to the south of the fenced enclosure, where ruins of woodframe structures were found. This area was recorded as historic site 41VV1820, and archival and informant research revealed it to be the remains of the twentieth-century Lowe Ranch.

Historic research and oral history interviews conducted during Phase I were of a general nature, concentrating primarily on the role that the San Felipe Springs played in the settlement and development of Del Rio and Val Verde County. Research also focused on highly visible historic resources in and around the springs and on the standing structures at the San Felipe Country Club, the City of Del Rio water works (including the East and West Springs pumping facilities and the Bedell tanks), and the Lowe Ranch.

Following the Phase I survey, MPI engineers, Prewitt and Associates (PAI) archeologists, and Department of Antiquities Protection (Texas Historical Commission [THC]) staff met and developed a plan for a second phase of investigations to assess the National Register of Historic Places (NRHP) eligibility of the identified prehistoric and historic resources. Because the golf course was constructed in the 1920 s, the potential historical 
significance of this artificial landscape also had to be considered.

\section{SUMMARY OF PHASE II INVESTIGATIONS}

National Register testing and assessment studies were undertaken in two parts, Phases IIA and IIB. Phase IIA consisted of archival and oral history research and NRHP testing of prehistoric deposits in the proposed construction areas at 41VV444. Historic research concentrated specifically on identifying the NRHP eligibility of three properties - the Lowe Ranch (a component of 41VV1820), the City of Del Rio water works (including parts of 41VV444 and 41VV1820), and the San Felipe Country Club golf course. Additional photographic documentation of standing historic structures was also completed. After research was complete, the historic resources were reviewed in consultation with the National Register Division and Department of Architecture at the THC. The Lowe Ranch was found to be ineligible for listing in the NRHP, while the City of Del Rio water works and the San Felipe golf course were found to be eligible (see Project Findings and Long-Term Management Concerns in Chapter 1).

Eleven additional backhoe trenches and 18 test units were excavated in areas of potential effect at 41 VV 444 for Phase IIA. Due to engineering design changes, the proposed construction areas had changed from the original design of Phase I. Phase IIA testing concentrated in three areas defined as Area 1, between the East Springs and San Felipe Creek; Area 2, between San Felipe Creek and the West Springs; and Area 3, west of the West Springs. Buried cultural deposits were found in all three areas, but they were ephemeral in Area 3 and extensively disturbed in Area 2. Except for the uppermost ca. $20 \mathrm{~cm}$, however, cultural deposits in Area 1 were found to be intact. Although natural stratigraphy was limited and subtle, the vertical distribution of artifacts revealed that two or three cultural zones were present and stratigraphically separable. Diagnostic artifacts recovered during initial testing included a Shumla dart point, Perdiz and bulbar-stemmed arrow points, and potsherds. The latter are exceptionally rare in the area. Following this initial testing, the Department of Antiquities Protection was consulted and the project proceeded directly into intensive testing.

Phase IIB investigations were limited to intensive testing of Area 1 at 41VV444. Thirtyfive additional hand-excavated test units were dug in Area 1 (for a total of 42 when combined with the 7 previously excavated units). Forty of these units (39 contiguous units in a single excavation block and 1 isolated unit near the block) were renumbered as excavation units for analysis purposes. The depth of units in the excavation block ranged from 66 to $130 \mathrm{~cm}$; average depth was $85 \mathrm{~cm}$. A total of $34.9 \mathrm{~m}^{3}$ of fill was excavated in these 40 units, yielding an interpretable sample of features and artifacts associated with three separate components. Chapters 6,7 , and 8 cover the investigations in Area 1.

\section{HISTORIC RESEARCH METHODS}

\section{Phase I}

Phase I research and field investigations were conducted primarily to identify extant cultural resources within the project area, note their type and condition, and assess their significance and potential for listing in the NRHP. A secondary goal was to obtain a general understanding of the area's history and develop a context within which resources could be adequately evaluated. Two key components of Phase I were historic and archival research to determine historic use of the land and a reconnaissance-level architectural survey to minimally document the extant cultural resources.

Known historic activity in the Del Rio area includes Spanish colonial exploration, U.S. military occupation following the Mexican War and again after the Civil War, early Hispanic and Anglo settlement efforts, the formation of an irrigation system in 1871, and the arrival of the railroad in 1883. Early-twentieth-century developments potentially affecting the project area include the reestablishment of military presence during the Mexican Revolution and continuing through World War I, ranching activities, the development of the city water works plant and water storage tanks, and the creation of a country club and golf course on land containing the largest of the springs.

Several historic features had been previously identified and documented in the 
vicinity of the project area, including portions of an acequia (irrigation canal) system dating to the early 1870 s, the early-twentieth-century Lowe Ranch house complex, the clubhouse of the San Felipe Country Club, and archeological remains of late-nineteenth/early-twentiethcentury military posts known variously as Camp Del Rio, Camp San Felipe, and Camp Michie.

An important research goal was to determine, prior to archeological investigations, whether any part of the various military camps or irrigation system overlaid the project area. The Project Historian and a research assistant conducted a literature search at the various archives in Austin, with initial efforts concentrating on a general historic overview, including the contributions of the springs, the acequia system, ranching, and the military presence to the area's growth and development. National Register, Recorded Texas Historic Landmark, and Subject Marker files for Del Rio and Val Verde County were reviewed at the Texas Historical Commission. The Office of the State Archeologist provided documentation regarding a proposed National Register nomination of Fort San Felipe (later known as Camp Del Rio and Camp Michie) and the nomination of the San Felipe Creek Archeological District (41VV43141VV443, 1974), both under Criterion D. Also checked were vertical files, photographic collections, newspaper references, Sanborn Fire Insurance maps, and the Val Verde County scrapbook at the Center for American History at the University of Texas at Austin.

Researchers examined original land patents at the General Land Office and obtained photocopies of the original San Felipe Agricultural, Manufacturing and Irrigation Company's incorporation papers at the Secretary of State Office. The Historian consulted census records on file in the Genealogy Section of the State Library for primary information about the Lowe family and their ranch holdings in Val Verde County. Locally published county histories, including $L a$ Hacienda (Jones 1976) and The Spirit of Val Verde (Zertuche 1985), were also examined at the State Library. In addition, local informants were identified and contacted to arrange interviews during the site visit.

The Project Historian and a research assistant traveled to Del Rio on 1-5 September 1997. Deed research was conducted at the Val Verde County Courthouse to develop a chain of title and identify property owners and historic uses of the areas potentially affected by the proposed water treatment plant. Specific deed and map information was gathered for the Lowe Ranch, the Bedell tanks site, and the San Felipe Country Club, which includes the East and West Springs water pumping stations. Transcripts of Kinney County and Uvalde County deed records containing references to the project area were also reviewed.

Records of the city's purchase of the pump house property and its relationship to the country club were obtained at the City Clerk's office. The research team reviewed vertical files and collections of the Whitehead Museum and the archives and photographic collections of the Val Verde Historical Society, also housed at the Whitehead Museum. Interviews were conducted with local historian Roebuck Daughtrey, former Val Verde Historical Society chairman Ruth Coleman, and local military buff and resident of Fort Clark, Bill Hahn. The team visited the San Felipe Agricultural, Manufacturing and Irrigation Company office where board members Thomas Qualia and James Hester provided information about the historic irrigation corporation. The Historian also consulted the collections and records of old Fort Clark, of which Camp Del Rio was an outpost, at the Fort Clark Museum.

Initial field investigations consisted of visits to the San Felipe Country Club, both the East Springs and West Springs pumping stations within the golf course, the Jasper and Braddie Lowe Ranch, and the Bedell water tanks, which lay on a one-acre parcel within the ranch. In addition, the Project Historian traveled the numerous dirt roads throughout the Lowe Ranch with Roebuck Daughtrey, former employee of Jasper Lowe and part of the construction crew that built the Bedell tanks in 1928, to search for previously unidentified built features such as a cistern, sheds, etc. Other than fencing, none were found. The Historian identified and minimally documented the surviving built resources on the Jasper and Braddie Lowe Ranch, the San Felipe Country Club facility and golf course, and the water works system, including the pump house and water tanks.

Historic maps, deed records, and previous archeological examinations, as well as research on file with the Val Verde Historical Society, indicate that none of the 
various military reservations lie within the project area boundaries, although the World War I-era Camp Michie is immediately adjacent to it on the west. A visit to Lowe Ranch revealed that the historic ranch house built by the Lowes in the 1920s had been demolished and replaced by a new house built in 1997. Several deteriorated outbuildings-including a small barn and privyalong with several sheds, animal pens, wood fencing, and old construction materials are all that remain of the Lowe Ranch. Lee Lincoln, director of the Whitehead Museum, informed the Historian that she used materials from the old Lowe House to build exhibits on the museum grounds.

Based on this initial research and reconnaissance, it was concluded that no evidence of historic military-related construction is present within the project area, the Lowe Ranch retains insufficient architectural integrity and historic significance to warrant further investigation, and the country club facility (built in 1947) has undergone such extensive alterations that it is no longer recognizable to its period of construction. Neither the Lowe Ranch nor the country club facility are eligible for listing in the NRHP.

However, the research and site visit did indicate that, because of its significant role in the establishment and development of the City of Del Rio, the water works system, including the 1935 pump house and the 1928 Bedell tanks, might be eligible for listing in the National Register under Criterion A for historic associations. The West Springs pump facility was built in 1964 and does not meet the age criterion for National Register consideration. Evidence gathered during Phase I led to the conclusion that, while the country club facility is not eligible for National Register listing, the San Felipe golf course, built in 1921 by pioneer Texas golf course architect, John Bredemus, might be eligible as a historic landscape; further research was needed.

\section{Phase II}

Results of initial field investigations determined subsequent archival and oral history research. For instance, no further research was planned for the Lowe Ranch in Phase II because Phase I had shown that the historic ranch house had been replaced by a modern dwelling and that significant outbuildings had been removed or had deteriorated to an almost unrecognizable condition. Phase II historic investigations included more in-depth recording of the existing historic properties, including photographic documentation and architectural descriptions. Additional research efforts focused on resources that showed the greatest potential for NRHP eligibility: the water works system - particularly the East Springs pump house and pond enclosure and the Bedell water storage tanksand the San Felipe golf course. The objective was to assemble sufficient information about these historic properties to evaluate their National Register eligibility.

Field investigations were conducted on 511 December 1997. The Project Historian documented the type, design, materials, landscape, and other pertinent physical attributes of both the West and East Springs pump stations, the Bedell water storage tanks, and the San Felipe golf course. Cultural resources at each site were photographed with black-and-white print and color slide film. Contributing and noncontributing elements of each site were documented.

Oral interviews were conducted with Del Rio citizens familiar with these resources. Douglas and Lillian Newton were interviewed in two sessions about the San Felipe golf course. They loaned several historic photographs of the golf course for duplication. Julian Sanchez, a former employee of the City Water and Wastewater Department, was interviewed for information about construction of the later facilities at the pumping plant. Betty Hollingsworth, manager of the San Felipe Country Club, allowed the Historian to copy negatives of historic photographs of the club and provided access to architectural renderings of more-recent modifications and additions to the clubhouse. The Historian met with city engineer Harry Parsi, engineering technician Jesse Valdez, water/wastewater superintendent Jim Palmer, and water utilities engineer Richard Hernandez to obtain relevant information about the water works system. Neither the city engineer's office nor the water/ wastewater utilities office had historic maps, files, or other site-specific records pertaining to construction of the system.

Further research was conducted at the Whitehead Museum where vertical files, city directories, old newspapers, and photographic files yielded previously unknown information about the water works system, military presence, country club, and golf course. 
City Commission minutes regarding the construction, maintenance, and extension of the city's water works from Del Rio's incorporation in 1906 through the establishment of a separate Water Utilities Commission in the late 1940s were examined. Water Utilities Commission minutes dating from the late 1940s through 1964 also were researched. City clerk Jane Douglas gave access to old city files containing a record of the negotiations with G. Bedell Moore for the purchase of the springs site.

In addition, the Project Historian contacted Chad Ritterbusch of the American Society of Golf Course Architects for information about the San Felipe golf course and its builder, John Bredemus. Ritterbusch contributed several articles and reference materials that enabled evaluation of the significance of the San Felipe course relative to other Texas courses of the period. Del Rio resident and lifelong golfer Douglas, Newton provided correspondence and articles about John Bredemus and the San Felipe golf course by golf historian Frances Trimble.

From the information collected in the Phase II investigations, the Project Historian recommended that the Del Rio water works, including the East Springs pumping plant and the two Bedell water storage tanks, are potentially eligible for listing in the NRHP under Criterion A for their historic associations with the development of Del Rio. The West Springs pumping plant and the most recent of the Bedell tanks are more recent additions and do not meet the age requirements for National Register listing, but are still considered noncontributing elements of the system. The Historian also concluded that the San Felipe golf course is potentially eligible for $\mathrm{Na}$ tional Register listing under Criterion $\mathrm{A}$ and Criterion C, as a historic landscape. Due to successive alterations and/or age, the country club complex, including the clubhouse, swimming pool, tennis courts, and cart sheds, is ineligible for National Register listing. The National Register Division of the State Historic Preservation Office concurred with these findings.

\section{PREHIISTORIC SITE INVESTIGATION MIETHODS}

\section{Excavation and Collection Procedures}

Twenty-six backhoe trenches (Backhoe Trenches 1-26) and 11 shovel tests (Shovel Tests
1-11) were excavated at 41VV444 during the Phase I investigations. The trenches were located in high-potential areas. They ranged from 1 to $5 \mathrm{~m}$ long, averaged $0.7 \mathrm{~m}$ wide, and were 0.1-1.7 m deep. Most trenches were terminated at basal gravels or weathered bedrock. Each trench was thoroughly inspected for cultural materials. Trench dimensions and profiles were described on general data forms, and sketch maps depicting trench locations were drawn. Shovel tests were excavated in arbitrary $20-\mathrm{cm}$ levels in areas where cultural materials were observed in situ in trench walls or in backdirt piles. When introduced fill was encountered, it was considered overburden and was not screened. Shovel test depths ranged from 40 to $95 \mathrm{~cm}$, but most were $40-50 \mathrm{~cm}$ deep. All cultural materials and land snail shells were collected. Shovel test results were recorded on general data forms.

Site 41VV444 was divided into Areas 1-3 prior to Phase IIA excavations. The length of each area was defined by the landform and the results of the Phase I investigations. Widths were pre-determined by the pipeline right-ofway, which varied according to the number of pipelines transecting each area.

Phase IIA investigations included excavation of 11 backhoe trenches and 18 hand-excavated test units within Areas 1-3, while Phase IIB investigations included excavation of 35 additional excavation units in Area 1 (Table 2). The long axis of each trench was primarily parallel to a proposed pipeline's orientation. Trenches varied from 0.6 to $0.8 \mathrm{~m}$ in width and 0.9 to $1.5 \mathrm{~m}$ in depth; basal gravels or weathered bedrock were encountered in several trenches. Trench numbers continued in consecutive order from the numbers assigned in Phase I.

Dimensions (length, width, and depth), stratigraphic observations, and observations regarding cultural materials were recorded for each trench. The Geomorphologist profiled selected backhoe trench and excavation unit walls and described the strata on geologic profile forms. In cases where stratigraphic profiles were similar, only one or two trench profiles were recorded. Geologic profile descriptions were completed for nine trenches and four excavation units (see Appendix A).

All trenches were inspected for cultural remains. When appropriate, diagnostic artifacts 
Geoarcheological and Historical Investigations at San Felipe Springs

Table 2. Summary of hand-excavated units at $41 \mathrm{VV} 444$

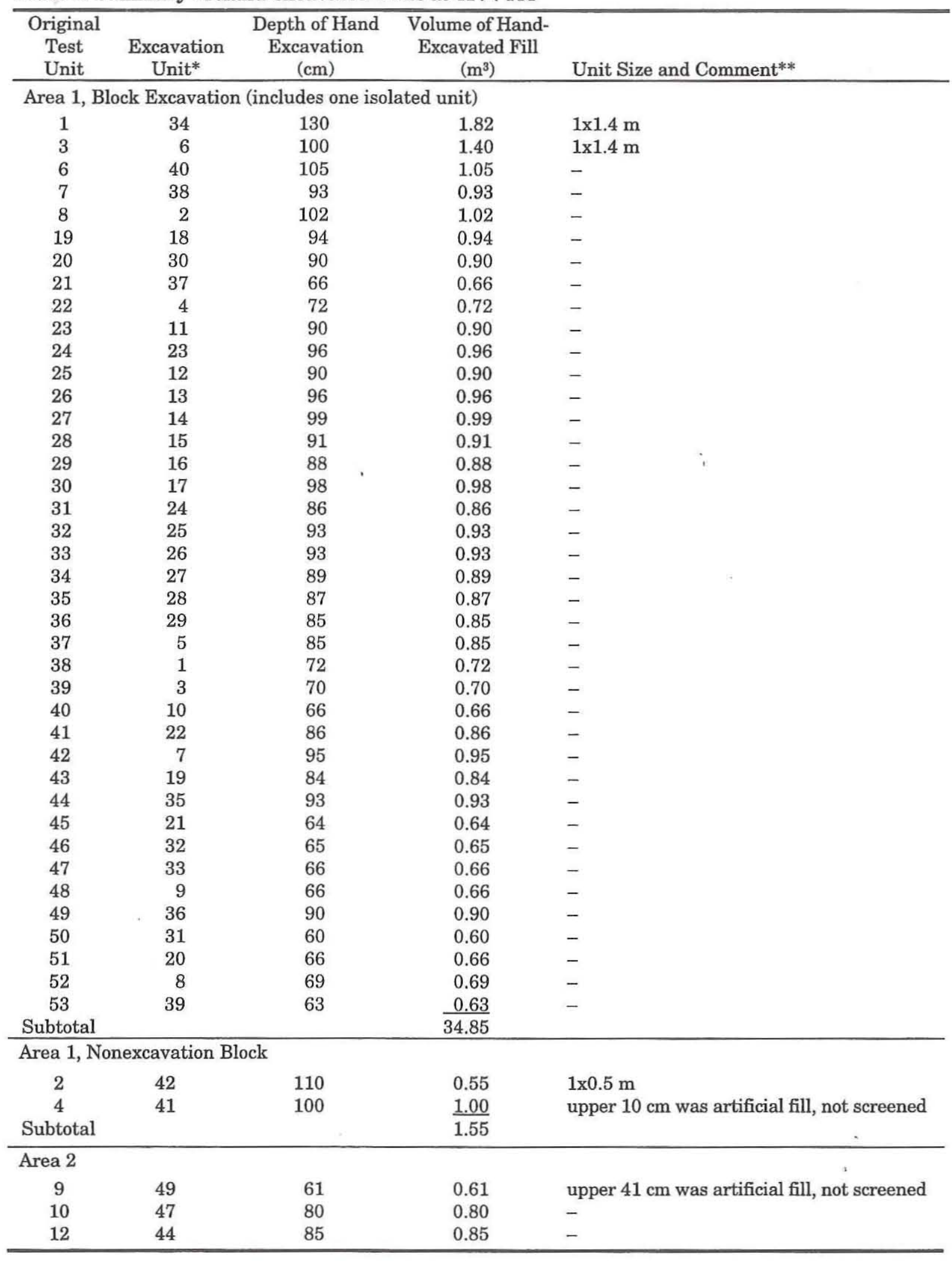


Table 2 continued

\begin{tabular}{|c|c|c|c|c|}
\hline $\begin{array}{c}\text { Original } \\
\text { Test } \\
\text { Unit } \\
\end{array}$ & $\begin{array}{c}\text { Excavation } \\
\text { Unit* }\end{array}$ & $\begin{array}{l}\text { Depth of Hand } \\
\text { Excavation } \\
\text { (cm) }\end{array}$ & $\begin{array}{c}\text { Volume of Hand- } \\
\text { Excavated Fill } \\
\left(\mathrm{m}^{3}\right)\end{array}$ & Unit Size and Comment** \\
\hline \multicolumn{5}{|c|}{ Area 2, continued } \\
\hline 13 & 48 & 43 & 0.43 & upper $43 \mathrm{~cm}$ was artificial fill, not screened \\
\hline 14 & 51 & 50 & 0.50 & - \\
\hline 15 & 46 & 45 & 0.45 & upper $15 \mathrm{~cm}$ was artificial fill, not screened \\
\hline 16 & 50 & 38 & 0.38 & upper $23 \mathrm{~cm}$ was artificial fill, not screened \\
\hline 17 & 45 & 49 & 0.49 & upper $33 \mathrm{~cm}$ was artificial fill, not screened \\
\hline 18 & 43 & 46 & 0.46 & upper $30 \mathrm{~cm}$ was artificial fill, not screened \\
\hline Subtotal & & & $\overline{4.97}$ & \\
\hline \multicolumn{5}{|l|}{ Area 3} \\
\hline 5 & 52 & 130 & 1.30 & - \\
\hline \multirow[t]{2}{*}{11} & 53 & 95 & $\underline{0.35}$ & $\begin{array}{l}1 \times 0.5 \mathrm{~m} \text {, upper } 60 \mathrm{~cm} \text { was removed by } \\
\text { backhoe }\end{array}$ \\
\hline & & & 1.65 & \\
\hline \multicolumn{2}{|c|}{ Total Excavated Volume } & & 43.02 & \\
\hline \multicolumn{4}{|c|}{$\begin{array}{l}\text { * Excavation unit numbers assigned in the laboratory. } \\
\text { ** Unless noted otherwise, units were } 1 \times 1 \mathrm{~m} \text {. }\end{array}$} & ; \\
\hline
\end{tabular}

either in situ or from the backdirt piles were collected. The center of the concrete star in front of the Texas State Historical Survey Committee Marker at San Felipe Springs was established as the primary site datum, and all elevations correspond to actual elevations above mean sea level (msl). Vertical elevation control was maintained by an electronic (Sokkia) total station, and a water level was used to help with elevation control in the Area 1 block excavations. All test units in Areas 1 and 2 are on exact grid points (i.e., at even meter intervals); although the test units in Area 3 were placed along the center line of the proposed pipeline, they do not occur at even meter intervals.

Test units were placed both adjacent to backhoe trench walls and away from trenches. Generally, test units measured 1x1 m. Deviations from the standard size ranged from a minimum of $1 \times 0.5 \mathrm{~m}$ to a maximum of $1.4 \mathrm{x} 1 \mathrm{~m}$. Excavation levels were set at even $10-\mathrm{cm}$ increments. Some test units were excavated to basal gravels, while others were terminated at arbitrary depths.

Test units were numbered consecutively as they were begun. Any obvious recent or introduced fill was removed as overburden and not screened; otherwise, all matrix was dry screened through 1/4-inch-mesh hardware cloth. All cultural materials, excluding unmodified mussel shell fragments lacking hinges (presence noted), burned rocks (sorted by size, counted, and weighed), and intrusive historic and modern items (noted), were collected. When found in situ, diagnostic artifacts and large pieces of charred wood were point provenienced and then collected. If present, a maximum of 20 land snail shells was collected from general level contexts and features. An excavation record form was completed for each level, and artifact frequency distribution summary and inventory of field bags forms were filled out for every unit. Selected test unit profiles, particularly those revealing features or cultural lenses in cross section, were drawn. General data forms were used for additional excavation information and daily notes.

All cultural features were numbered consecutively as they were encountered. Small distinct features, such as pits or stains, were removed as discrete units. The nonfeature matrix surrounding the feature was removed according to arbitrary levels and screened separately. Large features (e.g., dense layers of burned rocks) were excavated in $10 \mathrm{~cm}$ increments. A feature data form was completed for each feature, and a plan view and profile were drawn. Whenever possible, point-provenienced charcoal samples were taken. In many cases, all of the feature's matrix was removed as a flotation 
sample. Contingent on the size of the feature and type of fill, the size of flotation samples varied. If only a portion of the feature fill was sampled for flotation, the remaining matrix was screened through 1/4-inch-mesh hardware cloth.

Special samples included charcoal, flotation, pollen/phytolith, and sediment from feature and general level contexts. Samples in each of the four categories were given an individual sample number consisting of the first letter of the sample type followed by a number (e.g., C1 for a charcoal sample). Within each sample type, samples were numbered sequentially as they were collected. All samples were recorded on a sample inventory form specific to sample category.

The site and its excavations were photographed and videotaped. Black-and-white print and color slide photographs were taken to document all phases of the investigations. Photographic subjects included site and area overviews, backhoe trench and test unit profiles, cultural features, other unusual archeological remains, and general excavation progress.

Completed excavations were backfilled to ensure public safety. The perimeters of all areas with open excavation pits were marked with laths connected with caution flagging. During intervals between archeological work sessions, pallets were placed over open excavations requiring future work. At the conclusion of the Phase IIB fieldwork, a total of $43 \mathrm{~m}^{3}$ of fill had been hand excavated from 53 test units (see Table 2) Most of this effort was expended in Area 1 , where a large block was excavated. To facilitate data analysis and presentation, all test units were renumbered as excavation units once the analysis phase began. The original field records correspond to test units, but discussions throughout the remainder of this report use the excavation unit numbers. Excavation Units 140 constitute the Area 1 excavation block (all but Excavation Unit 39 are contiguous), which is analyzed in detail in Chapters 6-9.

\section{Laboratory and Analysis Procedures}

All artifact and material collections were processed and curated according to federal curation guidelines, the Council of Texas Archeologists' standards, and current curation and conservation standards. Materials were organized by provenience as they were brought to the lab. They were checked against the field bag inventory form or the sample inventory form (completed by excavators in the field) for problems or inconsistencies with the provenience information. If a problem was noted, it was corrected by referring to other excavation records or by consulting with the Project Archeologist. Collection bags were also checked for special information/instructions (e.g., notations of fragile materials), and these materials were handled accordingly.

Materials were then taken to the wet lab for cleaning. Artifacts were removed from bags, sorted by artifact types, and subjected to appropriate cleaning methods. Some artifact categories, such as bone, charcoal, and vegetal matter, were either not cleaned or were dry-brushed rather than cleaned with water. Other artifacts were cleaned using tap water and a soft toothbrush. After cleaning, artifacts were placed on a drying rack and allowed to air dry thoroughly before being catalogued; artifacts were then bagged by material type within each provenience.

Each group of artifacts was assigned a unique provenience-specific lot number. A specimen inventory in lot number order was compiled; all artifacts were listed under their respective lot numbers. Information recorded on the specimen inventory includes the lot number, associated provenience data, the name of the excavator(s), the date of excavation, any other information recorded on the field bag, and the type and quantity of artifacts recovered. For some material categories, such as charcoal, a weight (usually in grams) was recorded rather than a count.

All artifacts were catalogued with the site and lot number. Diagnostic artifacts also were assigned unique specimen numbers within each lot number. When assigned, a specimen number was added after the lot number on the artifact. Artifacts received a base coat of PVA (a 10 percent solution of Polyvinyl Acetate ResinAYAT in acetone), and the site, lot, and specimen numbers were recorded using a rapidograph pen. This catalogue number was then covered with a top coat of PVA.

Each artifact type was placed into a 4-mil polyethylene ziplock bag. Archival curation tags documenting the name of the project, project number and date, site number, provenience 
data, lct number, artifact type, and the number of specimens (or weight) were placed into 1.5mil polyethylene bags and placed within each artifact bag. Artifacts were grouped by classes or subgroups if appropriate. For example, projectile points were bagged by separate type names rather than as one unit.

Flotation samples were processed using the Flote-Tech flotation system, which provides a multimodal method of separating materials in a soil sample. The flotation process resulted in a light fraction, utilized for macrobotanical analysis, and a heavy fraction that was checked for artifacts. Any artifacts found in flotation samples were processed following the procedures outlined above.

Black-and-white photographs and negatives were checked against the photo logs to ensure that frame numbers and captions correlated and that the recorded information was accurate. Contact sheets were organized by site, and each negative was marked on the back with project number, site number, and photo number. Color slides were checked against the photo log to ensure that the frame numbers and captions correlated and that the recorded information was accurate. Each slide was labeled with project name and number, site number, slide number, and caption. All photographic materials were placed into appropriate archival holders.

All forms and records used in the field and the lab were printed on archival paper and filled out in pencil. Records were grouped by categories such as daily journal notes, testing forms, feature forms, specimen inventories, etc. The only exception is that all photographs were curated as a unit, with all of the blackand-white photographs together and all of the color slides together. All written and photographic materials were placed in archival folders and archival curation boxes. An inventory detailing the contents was included with each curation box. Curated photographic records also contain a computer-generated copy of the photo log and a disk copy of the computerized photo logs.

The material culture classification scheme employed during this analysis is outlined in Table 3 . Artifacts were grouped first by type of material, such as stone, ceramic, bone, shell, etc. Within each material group, artifacts were further classified into morphological/functional classes and subclasses. Systematic observations of selected attributes were defined for different classes of artifacts. Each specimen was analyzed individually, and its specific attribute data were recorded on a coding form and entered into a computer database. The detailed attributes recorded for stone artifacts, the most abundant artifact type recovered, are summarized in Table 4. For smaller artifact classes, such as modified shell, specimens are described individually but detailed attributes were not recorded in the

Table 3. Classification of material culture

\begin{tabular}{|c|c|}
\hline \multirow{2}{*}{$\begin{array}{l}\text { CHIPPED STONES } \\
\text { - Unidentifiable projectile points } \\
\text { - Arrow points } \\
\text { named types } \\
\text { untypeable fragments } \\
\text { - Dart points } \\
\text { named types } \\
\text { untypeable fragments }\end{array}$} & $\begin{array}{l}\text { - Core tools } \\
\text { - Multifunctional tools } \\
\text { - Edge-modified flakes } \\
\text { - Cores } \\
\text { - Unmodified debitage }\end{array}$ \\
\hline \\
\hline & $\begin{array}{l}\text { GROUND AND BATTERED STONES } \\
\text { - Manos }\end{array}$ \\
\hline - Perforators & \multirow{2}{*}{$\begin{array}{l}\text { - Metates } \\
\text { - Mano/Hammerstones }\end{array}$} \\
\hline - Gouges & \\
\hline - Bifaces & - Hammerstones \\
\hline early stage & - Other ground stones \\
\hline $\begin{array}{l}\text { middle stage } \\
\text { late stage }\end{array}$ & \\
\hline $\begin{array}{l}\text { finished } \\
\text { beveled knife }\end{array}$ & CERAMICS \\
\hline miscellaneous bifaces & FAUNAL REMAINS \\
\hline $\begin{array}{l}\text { - Unifaces } \\
\text { end scrapers }\end{array}$ & - Vertebrate \\
\hline side scrapers & unmodified bones \\
\hline $\begin{array}{l}\text { end/side scrapers } \\
\text { other scrapers } \\
\text { miscellaneous unifaces }\end{array}$ & $\begin{array}{l}\text { modified shells } \\
\text { unmodified shells }\end{array}$ \\
\hline spokeshaves & \multirow[t]{2}{*}{ BURNED ROCKS } \\
\hline - Cobble tools/choppers & \\
\hline - Gravers/burins & MACROBOTANICAL REMAINS \\
\hline
\end{tabular}


Table 4. Summary of attributes recorded for stone artifacts

\begin{tabular}{|c|c|c|c|c|}
\hline Attributes Recorded & $\begin{array}{l}\text { Arrow and } \\
\text { Dart Points }\end{array}$ & $\begin{array}{c}\text { Unmodified } \\
\text { Debitage }\end{array}$ & $\begin{array}{c}\text { Chipped Stone } \\
\text { Tools }\end{array}$ & $\begin{array}{c}\text { Ground Stone } \\
\text { Tools }\end{array}$ \\
\hline Type name & $\mathrm{x}$ & & & \\
\hline Tool class or subclass & $\mathbf{x}$ & & $\mathrm{x}$ & $\mathrm{x}$ \\
\hline Raw material & $\mathrm{x}$ & $\mathrm{x}$ & $\mathbf{x}$ & $\mathrm{x}$ \\
\hline Completeness & $\mathrm{x}$ & $\mathrm{x}$ & $\mathbf{x}$ & $\mathrm{x}$ \\
\hline Total cortex & & & $\mathrm{x}$ & \\
\hline Flake cortex & & $\mathrm{x}$ & & \\
\hline Heating & $\mathrm{x}$ & $\mathrm{x}$ & $\mathrm{x}$ & $\mathrm{x}$ \\
\hline Maximum length (mm) & $\mathrm{x}$ & & $\mathrm{x}$ & $\mathrm{x}$ \\
\hline Maximum width (mm) & & & $\mathrm{x}$ & $x$ \\
\hline Maximum thickness (mm) & $\mathrm{x}$ & & $\mathrm{x}$ & $\mathrm{x}$ \\
\hline Blade length (mm) & $\mathrm{x}$ & & & \\
\hline Blade width (mm) & $\mathrm{x}$ & & & \\
\hline Haft length (mm) & $\mathrm{x}$ & & & \\
\hline Neck width (mm) & $\mathrm{x}$ & & & \\
\hline Base width (mm) & $\mathrm{x}$ & & & \\
\hline Comments & $\mathrm{x}$ & $\mathrm{x}$ & $\mathbf{x}$ & $\mathrm{x}$ \\
\hline
\end{tabular}

database. The remainder of this section defines the various artifact classes and subclasses and the attributes that were recorded.

Various studies were conducted on samples and certain cultural materials, and some specialized technical analyses were performed by independent consultants. These include radiocarbon assays, thin sectioning and petrographic analysis of ceramics, analysis of unmodified faunal remains, and macrobotanical analysis. The methods and results of these special studies are reported in separate appendixes.

\section{Stone Artifacts}

The chipped stone collection consists of 24 artifact types. Arrow and dart points are functional groupings that denote stone artifacts probably used to tip projectiles. They are generally characterized as bifacially (sometimes unifacially) flaked specimens with a triangular to leaf-shaped blade section, a sharply pointed distal end, and sharp lateral blade edges. The distinction between arrow and dart points is one of size, with arrow points generally having a narrower blade and stem width (usually $<8 \mathrm{~mm}$ ). When possible, arrow and dart points were further classified by named types. Points too incomplete to be typed were classified as untypeable fragments. Unidentifiable projectile points are fragments that could not be classified clearly as arrow or dart points. All projectile points were assigned to types by Elton Prewitt.

Perforators are characterized as having a relatively long and tapered projecting bit that is biconvex or planoconvex in transverse cross section. They generally exhibit use-related microflaking on both faces of each edge or on alternate faces of opposite edges; polish and rounding are often evident on the blades as well. Perforator bases may be unmodified flakes, unifaces, bifaces, or projectile points reworked into perforators. As a functional group, perforators are thought to have been used primarily for drilling or poking holes through various materials. No distinction is made between fine-tipped perforatorscommonly called drills-and broad-tipped specimens called reamers.

Gouges are triangular or trapezoidal specimens with planoconvex transverse and longitudinal cross sections. They may be unifacially or bifacially flaked but have straight to concave, steeply beveled working edges; use polish and microflaking are concentrated primarily on the tool's ventral face.

Bifaces include all varieties of bifacially flaked tools not included in other classes (i.e., projectile points, perforators, or gouges). Bifaces are grouped into six subclasses: (1) early stage, (2) middle stage, (3) late stage, (4) finished, (5) beveled knife, and (6) miscellaneous. The first four subclasses represent different stages of the 
biface reduction sequence recognized by Callahan (1979), Collins (1975), Sharrock (1966), and others. Early-stage bifaces approximate Callahan's Stage 2, Collins's initial trimming, and Sharrock's Stage 1. They are distinguished by minimal shaping and considerable amounts of cortex remaining on both surfaces. The edges are irregular and exhibit no clear central plane when viewed on end. Middle-stage bifaces are comparable to Callahan's Stage 3, Collins's primary trimming, and Sharrock's Stage 2. They retain moderate amounts of cortex and may have isolated knots resulting from inadequate flake removals. The edges vary around a more distinguishable central plane. Late-stage bifaces approximate Callahan's Stage 4, Collins's primary trimming, and Sharrock's Stage 3. They are characterized by few remnants of cortex, sinuous edges centered on a longitudinal plane when viewed on end, and a well-defined outline shape. Finished bifaces are comparable to Callahan's Stage 5, Collins's secondary trimming, and Sharrock's Stage 4. They lack cortex, have straight edges, and generally have a clear ovate to triangular outline shape. Beveled knives are thin bifaces that were ovate when manufactured, but one or both ends are pointed due to resharpening of alternate blade edges. The only beveled knife is a two-beveled specimen (only one end resharpened) that is a well-thinned, large, tear-drop-shaped biface. The distal end is extremely smooth, indicative of haft wear. The miscellaneous biface subclass includes bifacially worked specimens too fragmentary or too irregular to be classified in any of the other categories. Miscellaneous bifaces may include specimens that functioned as scrapers or knives, or in other capacities.

Unifacial specimens are categorized into the following six subclasses: (1) end scrapers, (2) side scrapers, (3) end/side scrapers, (4) other scrapers, (5) miscellaneous unifaces, and (6) spokeshaves. These subclasses are recognized by the morphology and location of unifacial retouch and/or use wear relative to the flake on which the tool was made. End scrapers have significant retouch and/or use wear along their distal edges, side scrapers have one or more worked and/or worn lateral edges, and combination end/ side scrapers have characteristics of both. These scrapers, particularly end scrapers, may exhibit evidence of hafting in the form of scarring or polishing on ventral ridges or proximal lateral edges. Other scrapers are unifacially worked implements with two or more retouched working edges that do not conform to the standard morphology of the end, side, or end/side scraper subclasses (e.g. a round scraper with its entire circumference serving as a working edge). This category also includes fragments of scrapers that cannot be assigned confidently to the other subclasses. Miscellaneous unifaces are tools that do not fit into another subclass, including specimens that are irregularly shaped and/or have minimal unifacial working and retouch. Spokeshaves are small flake tools with a worked concave edge that may have functioned as a plane to shave wood off of round sticks or shafts. The notchlike indentation may have been produced bifacially or unifacially.

Cobble tools/choppers are unifacially or bifacially flaked implements made on cobbles or pebbles. Cobble tools exhibit extensive step fracturing, edge rounding, and polish indicative of heavy wear. Large cobble tools are often called choppers and were probably used as hammers for heavy battering and crushing.

Gravers/burins are flake tools with one or more carefully chipped beaklike protrusions. They probably represent specialized tools used for fine cutting and engraving. Unifacial and bifacial tools with graver tips are classified as multifunctional tools. Burins probably functioned in a manner similar to gravers (i.e., for cutting and engraving) but were made by striking off a flake so that it ran along a flake or tool edge. This technique left a very strong steep or right-angle edge where the flake was removed.

Core tools are cores (see below) that have had one or more edges subsequently modified, either intentionally prepared as a working edge or altered through use. These were likely used as scraping or battering tools. The primary distinction between core tools and cobble tools is that the former originally functioned as cores before being made into or used as a tool while the latter did not.

Multifunctional tools are artifacts that appear to have been manufactured for and used in the performance of two or more functionally distinct tasks. Multifunctional tools may include artifacts that fall into two or more of the other artifact classes (e.g., an end/side scraper with a spokeshave notch or graver beak).

Edge-modified flakes are flakes with one or more edges exhibiting minimal retouch and/or 
use vear. These expedient tools were used with little or no preparation. Edge-modified flakes include tools that some lithic analysts call utilized flakes or minimally retouched flakes.

A core is a chipped stone that has had flakes removed, and its primary function was as a source of flakes. Cores exhibit no evidence of use.

Unmodified debitage consists of flakes that exhibit no evidence of having been further modified or utilized. Unmodified flakes were classified as complete, proximal fragments, chips (medial or distal flake fragments), and chunks (angular fragments). Flakes were recorded as primary, secondary, or tertiary. Cortex is present across the entire dorsal surface of a primary flake. Secondary flakes retain some cortex, while tertiary flakes lack cortex. Raw material type was also recorded for each flake.

Ground and battered stone tools were classified into the following groups: manos, metates, mano/hammerstones, hammerstones, other ground stones, and indeterminate fragments. Manos are hand-held stones used for grinding and generally have one or two ground faces. Metates are milling slabs on which manos were used; they encompass a range of different forms and sizes. Mano/hammerstones functioned primarily as manos but also show evidence of battering along one or more edges. The precise function of hammerstones is not always clear, but most specimens are thought to represent percussion hammers used in knapping other stone tools. Other ground stones is a catchall class that may include a variety of tools such as anvils, abraders, pestles, nutting stones, and modified hematite. Indeterminate fragments are pieces of ground stone too fragmentary to identify their form or function.

Analysis of the stone artifacts also included identification of raw materials. Raw material types identified are chert, quartzite, limestone, sandstone, hematite, jasper, basalt, unknown (chertlike), and pitchstone. Specimens identified as chert consist of opaque to partially translucent cryptocrystalline or microcrystalline materials that were locally available or obviously imported from other regions. Quartzites are metamorphic rocks consisting mainly of recrystallized quartz. Most recovered quartzite specimens are characterized by finegrained crystalline structures and a reddish purple color. Various types of Cretaceous limestones (carbonate-rich, fine-grained sedimentary rocks) are the most abundant rocks found in the cultural deposits. Varieties of sandstone included fine- to coarse-textured sand grains cemented by silica and/or carbonates. Hematite nodules, iron oxide concretions in advanced stages of weathering, provide a source of red pigment when ground. Jasper is a dense, cryptocrystalline variety of quartz with iron oxide impurities that contribute to its various colors, particularly red. Specimens identified as basalt consist of a dark to medium-dark, fine-grained igneous rock whether intrusive or extrusive. Pitchstone is a volcanic glass that contains a higher percentage of water than obsidian, is usually intrusive, and has a waxy dull resinous luster. Although the color and composition differ greatly, the one sample from this study is black and includes quartz phenocrysts.

Each stone artifact was described as complete, proximal fragment, medial fragment, distal fragment, edge fragment, indeterminate fragment, nearly complete, or a barb. For incomplete specimens, no attempt was made to interpret the nature of the breakage (e.g., manufacture vs. use breaks).

The amount of cortex present on a chipped stone artifact provides evidence of the raw material source and often reveals much about the stage of manufacture. Cortex present on artifacts was recorded as 0 percent, 1-50 percent, 50-99 percent, or 100 percent. No attempt was made to describe different types of cortex.

Artifacts that exhibit evidence of low- to moderate-intensity heating, such as slight discoloration, reddening, and a glossy surface texture, may have been intentionally heat treated. In cases where artifacts were intensively burned, as evidenced by heat spalling, fracturing, or crazing, it is likely that the heating was accidental. Distinguishing between intentional and accidental heating is subjective. However, for this analysis the degree of heating characteristics was recorded as none, low, or high for all stone artifacts. The majority of chert specimens that were heated show evidence of low- to moderate-intensity heating and are thought to represent heat-treated pieces.

For most stone tools the only measurements taken were maximum length, width, and thickness. For projectile points the standard measurements taken were maximum length 
(the actual length of the point, broken or complete), blade length, blade width, haft width, neck width, base width, and maximum thickness. All measurements were taken in millimeters with digital calipers read to onetenth of a millimeter.

Two additional standard terms-recycled and reworked-were utilized for stone tools when applicable. The term recycled indicates that a tool's original form was subsequently modified to its current state. A perforator on a dart point base would be noted as a recycled dart point. A tool's edges (particularly projectile point blades) were considered reworked if the artifact's overall size and shape have been changed from its original form, but its function has not changed. For example, the fact that a projectile point has resharpened blades would be noted, but the specimen would still be classified as a projectile point. Coded artifact data were entered into a computerized database for analysis using Microsoft Access for Office 97.

\section{Ceramics}

Ceramic sherds recovered from undisturbed (Area 1) and disturbed (Area 2) contexts at $41 \mathrm{VV} 444$ are all plainwares representing a single ware type. Sherds from undisturbed contexts in Area 1 were given more attention, but all sherds were individually examined and selected attributes recorded. Visual examination included the use of low power (10x) magnification. Sherds were first grouped into six size categories: $<10 \mathrm{~mm}, 11-20 \mathrm{~mm}, 21-30 \mathrm{~mm}, 31-40 \mathrm{~mm}$, $41-50 \mathrm{~mm}$, and $>51 \mathrm{~mm}$. A series of attributes was then recorded for each sherd of sufficient size, with few attributes recorded for specimens under $10 \mathrm{~mm}$ in maximum length. Attributes recorded for larger sherds include thickness, interior and exterior surface color (using Munsell soil color chart), interior and exterior surface texture, and finish. Notations on ceramic paste, including clay matrix and temper additives, and technological features (e.g., finger impressions, coil lines or breaks, and fire clouding) also were made. Seven sherds from Area 1 were then selected for petrographic analysis. Thin sections were made by National Petrographic Services, Inc., of Houston, Texas, and submitted to Dave Robinson for analysis. Results of this analysis appear in Appendix C.

\section{Faunal Remains}

Faunal remains consist of both vertebrate and invertebrate remains. Vertebrate faunal remains were analyzed by Brian S. Shaffer and Jay Berry (see Appendix D). Depending upon their archeological context and other factors, unmodified bones are considered to represent either discarded remains of animals killed by humans or remains deposited as a result of natural processes. None of the bones in this collection exhibit evidence of intentional modification to create a tool or ornament, although some were modified incidentally or accidentally by humans (e.g., bones that exhibit spiral fractures and/or cut marks from butchering).

Invertebrate faunal remains include land snail shells and freshwater mussel shells. Snail shells, primarily various species of Rabdotus, can be ubiquitous in cultural deposits. It is likely that organic-rich detritus in habitation sites attracted the snails; consequently, the presence and abundance of snail shells were noted in excavation records and samples were collected for possible radiocarbon dating and/ or amino acid racemization studies. Sparse mussel shell valves and fragments were present and are generally thought to represent materials introduced by humans. All unmodified mussel shell valves with an umbo (whole or partial) were collected; other fragments were discarded in the field. None exhibited evidence of burning. One modified mussel shell was drilled, suggesting use as an ornament.

\section{Burned Rocks}

The burned rock category includes all nonchert rocks (primarily limestone) exhibiting such evidence of heating as thermal discoloration (e.g., reddening or blackening), angular fractures, and spalling. All thermally altered rocks were examined and quantified in the field (i.e., sorted by size and weighed) and then discarded if no other modifications were observed. One burned rock sample collected from a discrete feature was washed and visually inspected in the laboratory to assess any variety in the types of limestone. Many burned rocks were directly associated with heating/cooking features, and even nonfeature burned rocks are considered to have been heated intentionally and probably used as heatretaining stones in heating/cooking features. 


\section{Flotation Samples and} Macrobotanical Remains

Samples of macrobotanical remains, primarily charred wood and sediments containing macrobotanical remains (i.e., flotation samples), were taken from cultural deposits. These processed samples were submitted to Phil Dering, and a detailed analysis of plant remains is presented in Appendix E. 


\section{HISTORIC OVERVIEW OF SAN FELIPE SPRINGS, DEL RIO, AND VAL VERDE COUNTY, TEXAS}

Terri Myers

San Felipe Springs is one of Texas's largest springs and the key to survival in the harsh, arid environment that characterizes most of Val Verde County, Texas. The springs have drawn people for at least the past 10,000 years, and countless migratory Indian groups have stopped to camp at one of several spring heads ${ }^{1}$ that make up the San Felipe group, or along the banks of the creek that flows from the springs to the Rio Grande.

In recorded history, the springs were a wellknown trail destination. For Apache and Comanche bands, as well as Spanish, Mexican, and Anglo traders and explorers passing through this section of the Chihuahuan desert, the springs provided a welcome respite. These travelers watered horses and pack animals, replenished water supplies, and rested before pushing on to the next oasis. Among the earliest Americans to visit the springs were fortune hunters en route to the California gold fields and military surveyors who traced the boundaries of newly acquired territory in the wake of the Mexican War. For most, San Felipe Springs was a mere way station in the vast American desert. A few recorded their observations of the springs-in most appreciative terms-before moving westward.

For those seeking to build new lives on the Texan frontier, however, the springs held the possibility for permanence. San Felipe Springs provided an abundant, reliable source of water that allowed farmers and ranchers to raise crops and

\footnotetext{
${ }^{1}$ The Texas Historical Marker commemorating the springs claims that there are 7 springs, while Brune (1981) and others identify at least 10 springs in the San Felipe group.
}

livestock. Water was so plentiful, in fact, that enterprising land owners built an irrigation network from San Felipe Creek, opening more land to cultivation and attracting more settlers to the area. After the Civil War, a cavalry post was established to protect the small agricultural settlement at San Felipe Springs. Eventually businesses, railroad interests, and county government were drawn to San Felipe Del Rio, until it became the largest city between San Antonio and El Paso on the Southern Pacific Railroad.

Although ranching, retail, government, and military-related work continue to provide many jobs for Del Rio, tourism and recreation have become equally important to the local economy. Nearby Lake Amistad, completed in 1969, has created many service-related opportunities. The city is also an important gateway to Acuna, Mexico, a major tourist destination for winter visitors, and a key partner in the burgeoning maquilladora industry along the border. Despite its modern trappings, however, Del Rio remains tied to its historic origins; both the city and nearby Laughlin Air Force Base rely solely on San Felipe Springs for their water.

\section{SPANISH EXPLORATION}

According to the Texas Historical Marker locatedzat the East Springs, San Felipe Springs was named for the king of Spain. In 1675, Franciscan missionaries reportedly said a mass at the springs. By 1763, the San Felipe Siprings were well known both to Spanish militàry expeditions and Comanche Indians who raided tentative settlements below the Rio Grande in what is now Mexico. Some researchers have suggested that Spanish colonial period settlers may have lived in dugout shelters called "las sapas" along 
the creek banks leading to the Rio Grande (Jones 1976:411-415; Wilson n.d.:9), but there is little evidence to confirm this theory.

Historians have compiled a number of Spanish references to places that resemble, and events that may have occurred in the vicinity of, San Felipe Springs. While some of the Spanish (and later, Mexican) accounts probably do identify the springs, discrepancies in the records and inconsistencies in mapping, names, and physical landmarks make it difficult to positively verify such references.

A dozen or more Spanish and Mexican expeditions may have ventured into what is now Val Verde County, and several are known to have encountered the springs on San Felipe Creek. Many of these expeditions, which are summarized by Hindes (1998) and Krapf and Allday (1994), represent Spanish attempts at establishing missions and/or presidios in the Lower Pecos Region. At least two accounts mention that a mission may have been established in the vicinity of San Felipe Springs, but neither possibility has ever been substantiated. It is reported that the BosqueLarios expedition may have established a mission at San Felipe Springs during its reconnaissance of the area in 1675. In conjunction with the establishment of Presidio del Sacramento (or Presidio de San Diego de Sacramento) in 1736, it also has been speculated that a mission may have been established nearby, perhaps even at San Felipe Springs (Krapf and Allday 1994:27-29). While Krapf and Allday suggest that the presidio was just downstream from Del Rio, most researchers place its location some $32 \mathrm{~km}$ south of modern Ciudad Acuna on the San Diego River (Hindes 1998:54; Turpin 1989:283; Weddle 1976:413). No definitive archival or archeological evidence has been found to substantiate the existence of missions.

Assignment of the name San Felipe to the creek and springs may have occurred while the Spaniards were occupying the Presidio del Sacramento (Weddle 1976:413). By the time that Pedro Rabago y Teran explored this stretch of the Rio Grande in 1747, the name "Rio de San Phelipe" already was known (Hindes 1998:55; Weddle 1976:413). Except for the remote possibility that a mission existed nearby for a short time, San Felipe Springs probably saw only ephemeral use by soldiers and explorers during the Spanish and Mexican periods.

\section{U.S. MILITARY PRESENCE AND THE CHIHUAHUA TRAIL}

Some of the earliest reliable accounts of the springs stem from United States military expeditions along the border following the Mexican War (1846-1848). Another source of records comes from some of the thousands of hopeful adventurers who traveled across the largely unexplored territory of west Texas to California following the gold strike at Sutter's Mill in 1849. Trails were often improvised or altered during the course of the journey. Those who took the northern routes risked early snow, freezing weather, and the treacherous Rocky Mountains, but the advantages of taking a southerly route were offset by the possibilities of heat exhaustion and dehydration in the desert or attacks by Comanches and Apaches. One popular southern route was a branch of the Chihuahua Trail-a historic trade route into Mexico-that linked San Antonio with San Diego, California, by way of El Paso in far west Texas. Originally a trade route between far-flung Spanish/Mexican frontier outposts, activity on the Chihuahua Trail was spurred by the Gold Rush. At least one branch of the trail passed by San Felipe Springs. En route to the gold fields, naturalist Charles Wright described his camp on San Felipe Creek in July of 1849:

We are not more than a half a mile below the head of it; a small circular basin fifteen or twenty feet across, from which the creek flows in a bold rapid stream of clear limestone water. It is as unlike Maverick's Creek as can well be imagined. Hardly any water plants grow in it and very few on its margin; and from the margin of the water you ascend abruptly onto the high prairie on the one or both sides of the stream. We are told that it is only eight miles to the Rio Grande, and I am inclined to believe it . . . [Perkins 1954:60].

Although many travelers must have stopped for water along San Felipe Creek, as late as 1850 there is no mention of either American or Mexican settlement along its banks. Several official accounts, including that of William Emory of the United States Boundary Commission, note that no settlements existed along the Rio Grande 
between Fort Duncan at Eagle Pass and Presidio at Big Bend. Even as late as 1856, there were no permanent settlements on the Pecos River between Fort Clark, about 30 miles east of Del Rio, and Fort Lancaster (Perkins 1954:61). The region was isolated and arid, and agriculture was difficult at best, but it was fear of Indian attack that prevented all but the most intrepid pioneers from attempting settlement in the southwest Texas frontier in the 1850s. To encourage settlement and protect travelers through the region, the United States established a series of forts between San Antonio and El Paso, a distance of nearly 600 miles. These included Fort Bliss in El Paso (1848), Fort Clark in Brackettville (1852), Fort Lancaster at Horsehead Crossing on the Pecos River (1855), Camp Hudson on the Devils River (1857), and Fort Stockton at Comanche Springs (1859) (Pool 1975:103). According to some sources, the army also established an outpost of Fort Clark, known as Camp San Felipe at San Felipe Springs, in 1857 (Smith 1996:695). Since the springs lay approximately midway between Fort Clark and Camp Hudson, such an outpost may have helped protect the road to California, which was becoming an important military supply route. The outpost would have been abandoned along with Fort Clark-as were most Texas frontier posts-with the outbreak of the Civil War.

Most Americans who ventured into the borderlands region between Laredo and El Paso in the 1850s were military personnel, surveyors, or members of international boundary commissions. A noteworthy exception was John Twohig, an Irish immigrant, hero of the Texas Revolution, and San Antonio banker and entrepreneur. After the Mexican War a number of San Antonio lawyers and businessmen traveled with military survey expeditions in south and west Texas in search of property with development potential. John Twohig may have accompanied an expedition that took him to San Felipe Springs sometime between 1848 and 1852 (Texas. General Land Office 1854b). Twohig recognized the value of the springs and located several adjacent surveys over the springs and creek. $\mathrm{He}$ claimed both the Sostenes Carrasco Survey No. 184, which includes the main springs, and the adjacent Henry P. Brewster Survey No. 186 (Texas. General Land Office 1852, 1854b), through which a small portion of the creek passes. Twohig also obtained a third survey, the
James Mitchell Survey No. 183, through which most of San Felipe Creek passes and in which much of central Del Rio now lies, from Mitchell's heirs (Texas. General Land Office 1854a). Twohig's land acquisitions were speculative in nature. He eventually sold parts of the Brewster Survey and all of the Mitchell Survey but held the Carrasco Survey, containing the springs, until his death.

In addition to frontier and border defense, military expeditions from San Antonio helped identify trails, springs, and camp locations in the territory recently acquired in the Mexican War. San Felipe Springs was linked to San Antonio by a spur of the Chihuahua Trail that was part of the San Antonio-San Diego stage route, also known as the Jackass Mail (Pool 1975:108). The road linked the U.S. Army Eighth Military District headquarters in San Antonio to Fort Clark, about 30 miles east of San Felipe Springs, and to Camp Hudson, Fort Stockton, Fort Davis, and ultimately Fort Bliss at the far western boundary of Texas. Where the road passed through what is now Val Verde County, it was not much more than a trail. According to many Del Rio residents, the old wagon road passed a few hundred feet north of the two main springs, known as East and West Springs, skirting the northern boundary of the San Felipe golf course (Doug Newton, personal communication 1997). From there the trail proceeded to Devils River; there, the ford lay approximately where the highway bridge crosses the river today (Perkins 1954:36).

The springs were a welcome camping spot on the trail between outposts, and several military accounts survive from this period. Among the more noteworthy visitors was Lt. Edward L. Hartz, leading a caravan of camels, who camped for several days at San Felipe Springs during a topographical reconnaissance of the region around Camp Hudson in 1859. The Camel Corps, as it was known, was an army experiment to test the animal's capabilities in the American desert. Although camels were ultimately given up, they proved to have great stamina in the desert (Del Rio News-Herald 20 March 1979).

\section{EARLIEST SETTLIMIENTS AT SAN FELIPE SPRINGS: 1859-1862}

Although the line of frontier forts was established to encourage settlement in west and 
south Texas, few communities existed beyond the safety of their perimeters in the $1850 \mathrm{~s}$. In 1859 Gen. Zenas R. Bliss, en route from Fort Clark to Camp Hudson, was surprised to find American settlers at San Felipe Springs. Bliss described a man named Johnson, his wife, and two children, living along the creek below the springs "in the most extreme frontier house on the road" (Jones 1976:10; Wilson n.d.:10). It is the earliest record of Anglo settlement in the vicinity of present Del Rio. Bliss's records imply that a community had emerged on the Mexican side of the river as well, because he noted that Johnson's daughter had run away with "a Mexican who lived just across the Rio Grande" (Perkins 1954:62). Nothing further is known about this first Anglo settler at the springs. When the frontier forts were abandoned during the early years of the Civil War, there would have been no protection from raiding Indians in that area, and it is possible that Johnson and his family either fled or were killed.

Despite increased Indian attacks during the Civil War, other settlers arrived at San Felipe Springs within a few years of Bliss's discovery. Among the earliest and most influential of these pioneer settlers were James H. Taylor and his wife, Paula Losoya de Taylor, who came to the area by 1862 and built a large hacienda for protection against sporadic Indian raids. Little tangible or documentary evidence confirms this earliest settlement in the area, but accounts hint at the presence of a small community near the confluence of San Felipe Creek and the Rio Grande in the mid-nineteenth century. General Bliss's 1859 observations suggest that a Mexican settlement was present near the mouth of San Felipe Creek (Jones 1976:419; Krapf and Allday 1994:47). Family traditions recall that Taylor and his wife, who were among the first known settlers of Del Rio, first lived at Las Sapas when they arrived in the region in 1862 (Jones 1976:5). This early settlement of Las Sapas, or El Salto, was apparently little more than a semi-permanent community of branch-covered dugouts (or "las sapas," probably an anglicized version of zapa, meaning trench) carved out of the creek bank. Las Sapas predates Del Rio, and its inhabitants are reported to have been predominately of Hispanic origin. According to local accounts, once the Taylors built their house-possibly Del Rio's earliest surviving dwelling-between 1862 and 1864, the inhabitants of Las Sapas abandoned their rudimentary dwellings and came to live near the Taylor-Losoya hacienda within their walled compound (Jones 1976:3-5). This community later became known as San Felipe, and 160 people were living there by 1870 . The 1870 census (in Jones 1976:14-17) indicated that 75 percent of the inhabitants had Hispanic surnames, while only 39 persons were of Anglo ancestry.

The Taylors also are credited with building an irrigation canal-known as the "Old Ditch" or the "Old San Felipe Ditch"-from the springs. It is considered the first of the present network of canal systems. Taylor and his wife used this canal to water their sugar cane fields and livestock and to power a grist and cane mill. Nearby Fort Clark provided a reliable market for their produce and hay for the post's mules and horses (Wilson n.d.:10). The.Taylor family became the prosperous basis for future settlement at San Felipe Springs (Krapf and Allday 1994:47-48; Jones 1976:3-5).

\section{SAN FELIPE AGRICULTURAL, MANUFACTURING AND IRRIGATION COMPANY: 1869-1871}

On 12 June 1868, James H. Taylor, William C. Adams, Randolph Pafford, Donald Jackson, and John P. Grove purchased 1,476 acres of land for starting the San Felipe Agricultural, Manufacturing and Irrigation Company (Zertuche 1985:21). Local historian Louita Wilson states that the company was officially formed in 1869 , but the earliest known reference to the company's organization was found in the minutes of a shareholders meeting of the "San Felipe Agricultural Company" dated 27 April 1871 (Daughtrey and Daughtrey 1982:6; Wilson n.d.:11). The members present at the first meeting were W. C. Adams, Joseph Ney (who bought half of the shares originally belonging to Donald Jackson), Randolph Pafford, A. O. Strickland (who purchased John P. Grove's shares), and James H. Taylor. Three days later, at a second meeting on 1 May 1871, Donald Jackson was also listed as a shareholder (Daughtrey and Daughtrey 1982:6). Several of these men were associated with Fort Clark (Wilson n.d.:11). Possibly they had become familiar with the springs while stationed at the military post and speculated on their potential to develop the surrounding country. Taylor's 
success with the canal may have been a good model for future development.

Company shareholders passed several resolutions, the first of which stated that the company "would be governed by the statute regulating irrigable property." Other resolutions involved the use, repair, and maintenance of the ditches and the prohibition against free-range livestock with a fine of 50 cents for each head of livestock that damaged or crossed any cultivated land. Taylor was appointed "Ditch Commissioner" to supervise operations for a salary of $\$ 15$ per month (Daughtrey and Daughtrey 1982:6). All of the land, whether jointly or individually owned, came out of the James Mitchell Survey No. 183 (Texas. General Land Office 1854a), which included most of San Felipe Creek below the main springs. ${ }^{2}$

Minutes from the meeting on 1 May 1871 indicate that the company had already completed sufficient acequias to irrigate 1,500 acres of jointly owned land and that they intended to divide the property among themselves (Daughtrey and Daughtrey 1982:6). On 6 June 1871, a third organizational meeting was held where shareholders adopted the "Articles of Agreement" that were filed in the County Court of Uvalde on 30 June and adopted by that court 31 July 1871 (Daughtrey and Daughtrey 1982:7). ${ }^{3}$

Early minutes indicate that a dam on San Felipe Creek, just north of the Southern Pacific Railroad tracks and immediately west of its bridge, was completed by the spring of 1871 . Minutes also show that the canals making up the Madre Ditch and the San Felipe Ditch were also completed by that time. A "Map of Lands Belonging to the San Felipe \& Agricultural Co. Surveyed April \& May 1871, drawn by Chas. de Montel," identifies the Madre, San Felipe, St. Mary's, and Concepcion canals (Wilson n.d.:11).

\footnotetext{
${ }^{2}$ Details of the land transactions between Twohig and the irrigation company have not been located, but later military records for transactions involving Camp Del Rio clearly state that the post was established on the Mitchell Survey and land descended to the company from Twohig (see Baker 1996).

${ }^{3}$ San Felipe Springs was part of Uvalde County until Kinney County was formed in 1873. Val Verde County, which now contains the springs and related water works for Del Rio, was not organized until 1885.
}

When Kinney County was formed in 1873, San Felipe Springs and the irrigation company came under the regulations of that county. On 1 March 1873 the Kinney County Commissioners Court adopted the rules and regulations previously established by Uvalde County for the governing of the San Felipe Agricultural, Manufacturing and Irrigation Company, with the exception that the Ditch Commissioner, previously elected by the owners of the irrigable lands, would now be appointed by the Kinney County Court. George Enderle was so appointed (Perkins 1954:64).

Shareholders irrigated fields of corn and oats that were sold to wagon trains passing along the trade route between San Antonio, El Paso, and Chihuahua City. Wagon trains regularly camped on the site of the present Val Verde County Courthouse square to obtain supplies and water before' proceeding westward. Known then as San Felipe, the fledgling community was the last place to obtain such supplies before reaching Fort Stockton; thus, it became an important destination along the Chihuahua Trail (Perkins 1954:64). According to early settler E. S. Block, the inhabitants of San Felipe in 1874 included the shareholders of the San Felipe Agricultural, Manufacturing and Irrigation Company Co. (Randolph Pafford, John Perry, James H. Taylor, and Orlando Strickland), along with ranchmen J. Strickland, W. B. Reagan, W. B. Hudson, W. H. Pulliam, and W. R. Scriers. Other residents included a Mr. Farley, Charles Bochat, Jones Griner, and H. M. Block (Perkins 1954:64).

Although most of the property owners were Anglo farmers and entrepreneurs, some of whom were married to Hispanic women, many more Mexican American families lived in and around Del Rio in its early days. According to the 1870 census (as summarized in Federal Emergency Management Agency 1998:11-12), of the 32 families living in San Felipe, only 6 were English-speaking. The heads of these families were all "farmers," in contrast to the other 26 families headed by men with Spanish surnames whose occupations were listed as "farm laborers." Mr. Block's observations of San Felipe in 1874 excluded any mention of the Mexican Americans who lived there, perhaps because they did not own property and were not shareholders in the San Felipe Agricultural, Manufacturing and Irrigation Company. 
On 10 March 1875, the Texas legislature passed an "Act to encourage the construction of canals and ditches for navigation and irrigation" by granting state land to those who built canal systems. For every mile of a first class canal, 16 sections of land were granted, 12 sections for every mile of a second class canal, 8 for third class, and 6 for fourth class. First class canals had a uniform width of $30 \mathrm{ft}$ and a depth of $5 \mathrm{ft}$, second class canals were $15 \mathrm{ft}$ wide and $4 \mathrm{ft}$ deep, third class canals had a width of $9 \mathrm{ft}$ and depth of $3 \mathrm{ft}$, and fourth class canals were $6 \mathrm{ft}$ wide and not less than $2.5 \mathrm{ft}$ deep (Wilson n.d.:12).

That same year, shareholders of the San Felipe Agricultural, Manufacturing and Irrigation Company, including Jerome Strickland, James H. Taylor, Randolph Pafford, and John Perry (all from Kinney County), declared themselves a corporate body under legislation passed 23 April 1872. They applied for and received a 99-year charter on 15 October 1875, and filed it with A. W. DeBerry, Secretary of State. After the 99 years, terminating on 12 October 1974, the lease could be renewed for an indefinite period. This company is now the oldest continuously operating irrigation corporation in the state (San Felipe Agricultural, Manufacturing and Irrigation Company 1875).

The corporation listed its place of business as San Felipe Del Rio, as the small community was then called, in Kinney County, Texas. The company declared its object to construct, own, and operate two "certain ditches to be of the third and fourth class under the provision of the act of March 10, 1875" (San Felipe Agricultural, Manufacturing and Irrigation Company 1875). The third class ditch was known as Madre Ditch (Figure 4) and the fourth class ditch was San Felipe Ditch. The Madre Ditch was said to begin on the west bank of San Felipe Creek at a point 30 varas below the southwest line of Survey No. 185 (i.e., the northeast line of Survey No. 183), where the line crossed San Felipe Creek. Both surveys were patented to Sostenes Carrasco. Following the meanders to Stampede Creek, the total distance of the ditch was said to be ca. 5 miles (9,500 varas). San Felipe Ditch began at a point on the west bank of the creek about 2,050 varas below the initial point of Madre Ditch to the Rio Grande, a distance of 5,700 varas or 3 miles (San Felipe Agricultural, Manufacturing and Irrigation Company 1875). Since the Madre Ditch was classified as a third class canal and the San Felipe Ditch as a fourth class canal, the shareholders were granted eight sections to the mile for the Madre and six sections for the San Felipe Ditch, for a total of about 5,000 acres of land (Wilson n.d.:11). Both ditches were to have necessary lateral ditches carrying water for the purposes of "manufacturing, agricultural and irrigation purposes under the direction and management of the company." The company claimed capitol stock of $\$ 100,000$ divided into $\$ 100$ shares. It also promised to keep records in well-bound books of all company lands "heretofore transferred and that may hereafter be transferred" by the company (San Felipe Agricultural, Manufacturing and Irrigation Company 1875).

By 1876, a state inspector's report showed that the company's canals had irrigated over 3,000 acres in present-day southwestern Del Rio (Zertuche 1985:21). All of the present-day canals that make up an 18-mile system of irrigation ditches were constructed and in use by 1890 , with exception of the G. Bedell Moore Ditch, built after the turn of the century (Wilson n.d.:6). In April or May 1871, when the company was first organized, civil engineer Charles D. Montel made a survey and map of the portion of Survey No. 183 where the Pafford Mill Property was located. At least three different surveys, headed by Captain Joseph Tivy, A. Bogle, and Judge Jones, were made between 1871 and 1890 in the course of subdividing and awarding lands owned by the shareholders (Daughtrey and Daughtrey 1982:7). While there were land exchanges among shareholders, possibly to improve homesites or farm operations, all property not sold by the individual shareholders was reconveyed to the San Felipe Agricultural, Manufacturing and Irrigation Company (Daughtrey and Daughtrey 1982:7). Despite changes in individual land ownership along the canals, the earliest survey map penned by Charles De Montel depicts the irrigation network to be essentially the same as it is today. ${ }^{4}$

\footnotetext{
${ }^{4}$ Owned by the Moody Foundation of Galveston, the irrigation company still exists. It is the oldest incorporated irrigation company in Texas (Wilson n.d.:12).
} 


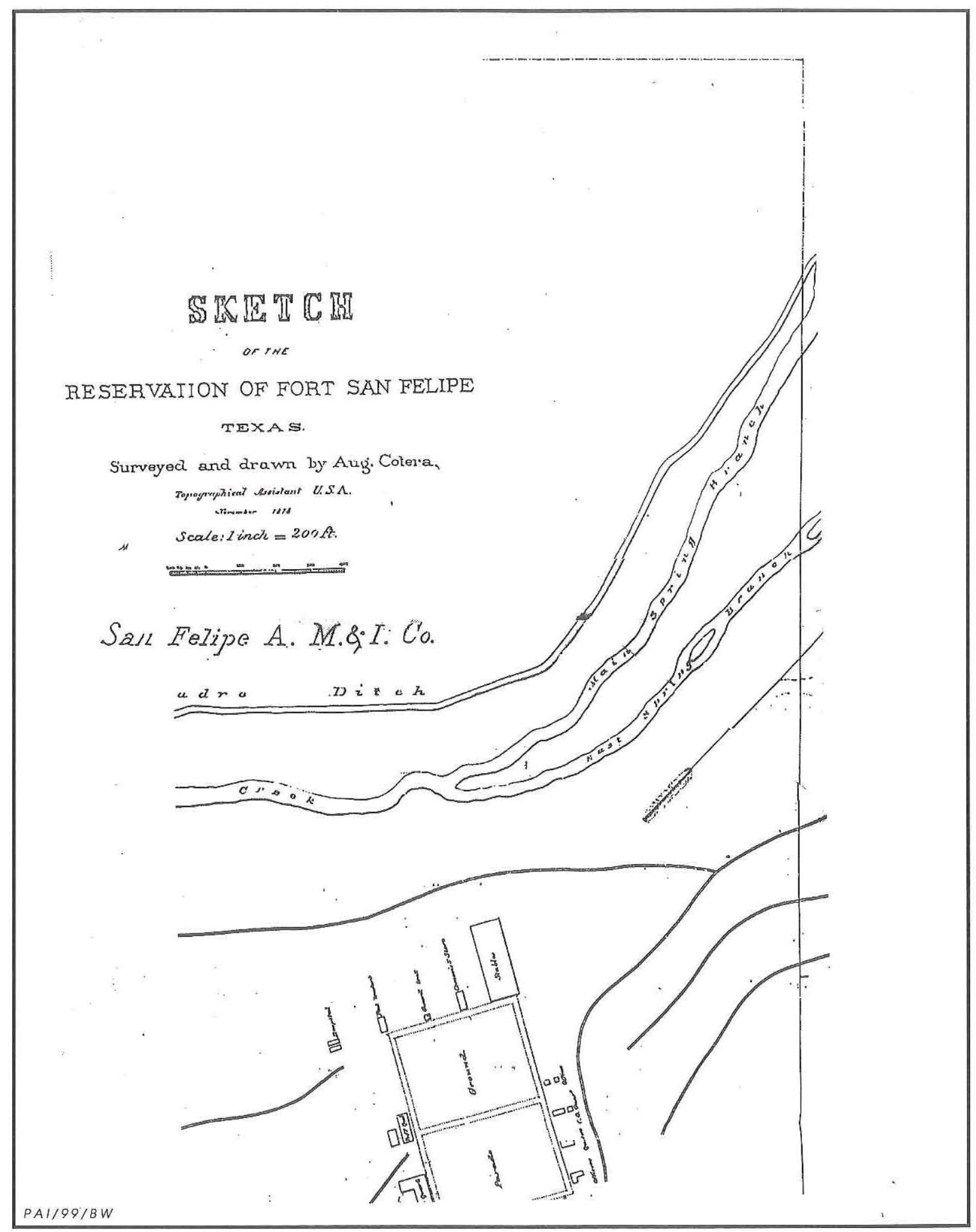

Figure 4. Historic 1878 "Sketch of the Reservation of Fort San Felipe Texas" by August Cotera (1878). Map shows relationship of Fort or Camp San Felipe to San Felipe Creek, the East Springs, the West or Main Springs, and the Madre Ditch and dam. 


\section{CAIMP SAN FELIPE: 1876-1896}

In the post-Civil War era, a line of forts was reestablished along the Texas frontier to protect travelers and settlers who remained in the region from raids by Comanches and Lipan Apaches. Fort Clark was reestablished in 1866; most military actions against Indians in what is now Val Verde County were initiated either from Fort Clark or Camp Hudson. San Felipe Springs, lying between the two outposts, was a logical site for a military encampment because of its plentiful supply of water. Discussion about reestablishing an outpost at the springs is documented as early as 1873. Gen. C. C. Augur, Headquarters Department of Texas at San Antonio, in a letter to General Mackenzie posed the question,

Would it not be well to make a ștrong camp at San Felipe for the two companies of infantry sent you, and keep a depot of supplies for the use of parties out? I think you should have a camp and depot of that kind somewhere toward the frontier, to avoid the frequent return of companies to Fort Clark [Perkins 1954:57].

Pursuant to Special Order No. 160, Department of Texas Series 1876, Camp San Felipe was established on 6 September 1876, "for the better protection of the Rio Grande frontier" (Newman 1970). Originally called the Post of San Felipe, or Fort San Felipe, the name was changed to Camp Del Rio on 18 March 1881 according to Special Order No. 9, Military Division of the Gulf at New Orleans (Figures 5 and 6). The post was officially abandoned on 8 May 1891 (Glatte 1981).

The San Felipe Agricultural, Manufacturing and Irrigation Company donated land from the Mitchell Survey for the new fort in June 1877. Possibly to encourage or assist the army's efforts to protect their families and investments, stockholders of the company authorized the donation of 200 acres to "be used and occupied and owned by the said United States as a site for a military post, Fort Depot Station and Garrison ..." (Deed Record K:286-299).

On 29 September 1877, Commanding Officer J. M. Kelley wrote the U.S. Army Adjutant General in Washington D.C. from the
"Headquarters of the Post of San Felipe, Texas.”

In compliance with your letter of the 4 th instant I have the honor to report as follows: The Post of San Felipe Texas was established on the 6th day of September 1876 per Special Order No. 160 Hdqrs Department of Texas, series 1876. The post is situated on San Felipe Creek, thirty miles west of Fort Clark Texas and one and a half miles from San Felipe Texas (North). The Rio Grande river is about four miles south of the post. The post is on a plateau about eighty feet above the level of the water. The country in the immediate vicinity of the post is rolling \& covered with mezquit [sic] trees \& Bear Grass. The Garrison consists of Company' "E" 10 Cavalry \& its officers, a post surgeon \& hospitol [sic] steward. Quarters are tents. Post office address is Del Rio, Kinney County Texas. Very respectfully, Your obedient servant J. W. Kelley Captain 10 Cavalry, Commanding Post [Kelley 1877].

Two years later the stockholders voted to add another 200 acres, "or as much thereof as might be contained in an extension of the lines of the survey of the first donation to the Eastern boundary of survey No. 183 (section 13) in Kinney County, Texas." By 1880, the amount of land deeded by the irrigation company to the U.S. military had increased to 430 acres "in the north east part of survey No. 183, section 13 , on San Felipe Creek in Kinney County, Texas, granted by the State of Texas to the heirs of James Mitchell." Irrigation Company president M. Simco appointed members John Perry, Randolph Pafford, and R.A. Farley to work with Henry T. Leggett to select and survey the donated land. Leggett was a first lieutenant of the 24th Infantry regiment acting under command of Brig. Gen. Edward O. C. Ord, then commanding the Department of Texas. August Cotera of the Department of the U.S. Army provided topographical assistance, and his name appears on the maps (see Figure 5). Field notes were approved by a Mr. Jones, County Surveyor of Kinney County (Deed Record K/2: 286-292). The John Glynn house is the only building that appears in the original land survey transferred 


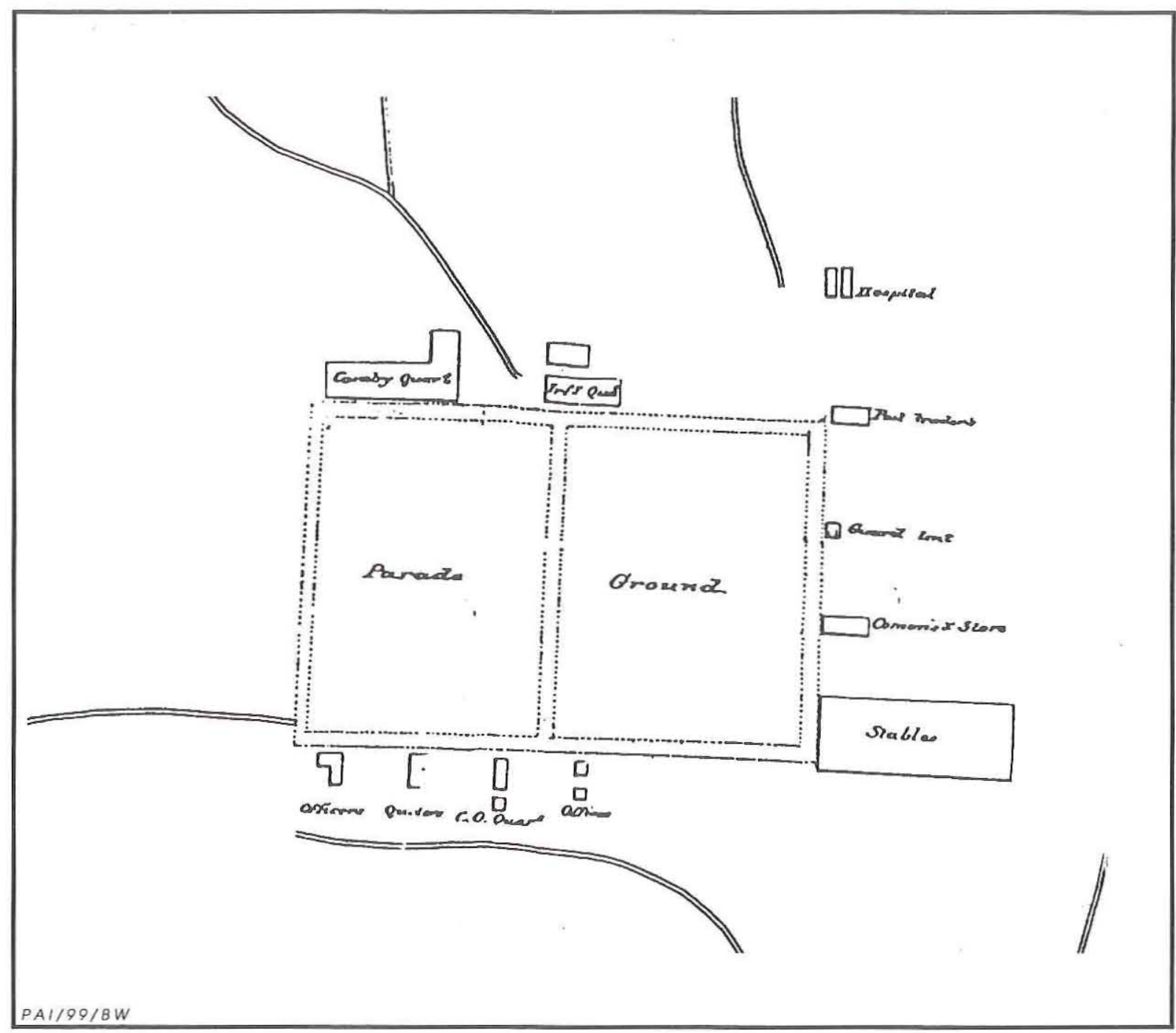

Figure 5. Close up of Fort San Felipe from 1878 "Sketch of the Reservation of Fort San Felipe Texas" by August Cotera (1878).

from the irrigation company to the army (Dignowity 1896).

The survey resulted in an adjustment of a few acres. On 28 January 1880, McDonald Simco was authorized by the irrigation company to sell 407.93 acres of land to the U.S. government for one dollar (Deed Record K/2:286-292). The strip of land lay about half a mile from the main springs, just east of San Felipe Creek and immediately south of the present railway tracks. According to the San Antonio Weekly Express, construction at the post did not begin until 1880 . The original buildings were made of lumber with thatch roofs (San Antonio Weekly Express
18 March 1880). ${ }^{5}$ In 1882, Congress appropriated $\$ 30,000$ to improve the outpost (San Antonio Daily Express 17 December 1883), and it was probably at that time that permanent facilities were built.

${ }^{5}$ One exception may have been a building identified as a bakery on a July 1896 map drawn by A. S. Dignowity (Dignowity 1896). It may have been associated with the military camp. The same building appears on a July 1905 map drawn by T. K. Pierce as “a rock house" (Pierce 1905). 


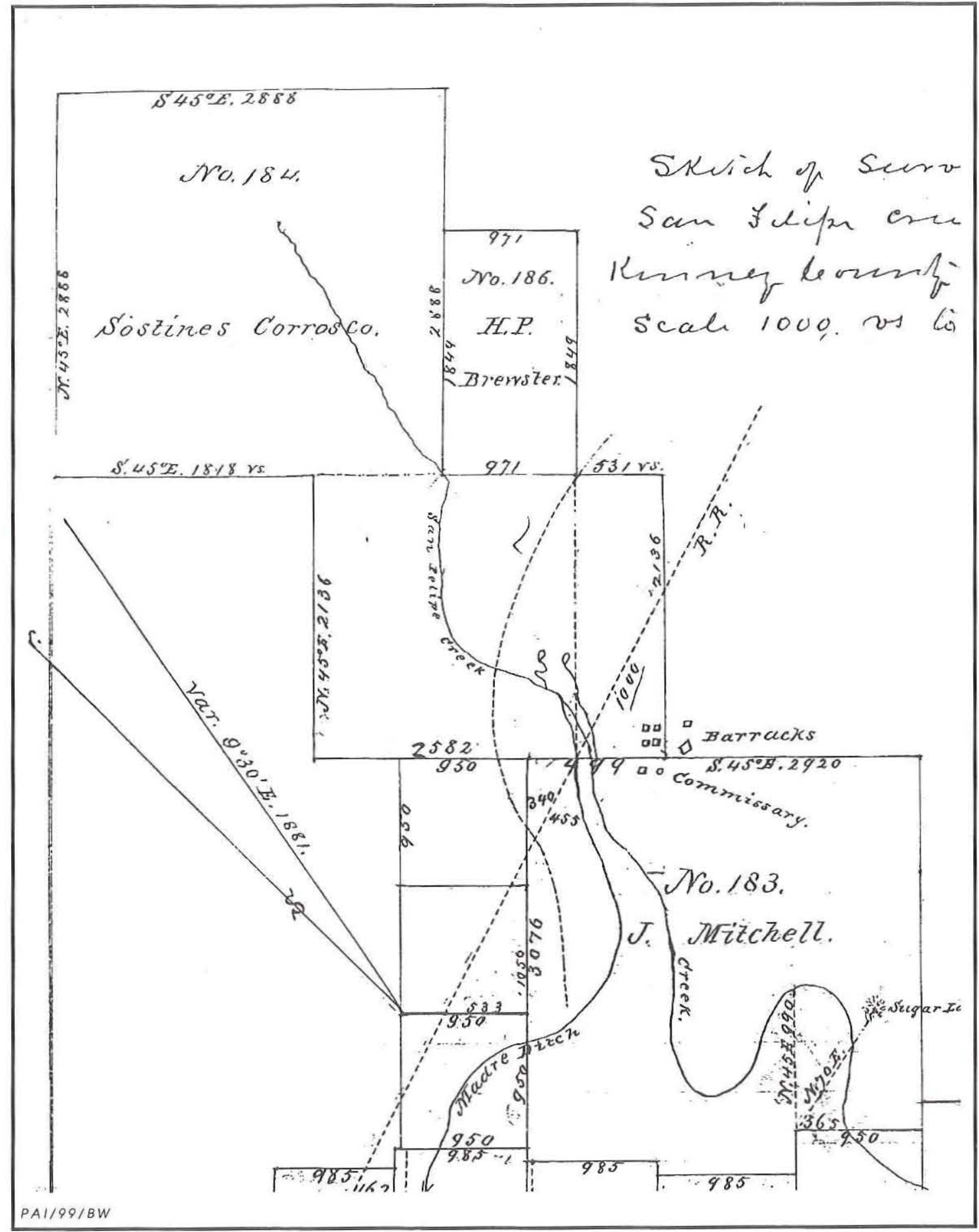

Figure 6. Historic "Sketch of Survey on San Felipe Creek, Kinney County, Texas." Survey sketch shows the San Felipe Springs, the Madre Ditch, and structures associated with Camp Del Rio. Map was filed 7 September 1885 (Deed Record 1:82). ${ }^{6}$

${ }^{6} \mathrm{All}$ deed records cited in this report are Val Verde County. 
For most of its service, Camp San Felipe was an outpost for a single company of the Tenth Cavalry, commanded by Captain Randlett in 1883-1884 (San Antonio Daily Express 17 December 1883). The Tenth Cavalry is noteworthy because it was comprised entirely of black enlisted men who, along with their sister units, the Ninth Cavalry and the 24th and 25th Infantries, were known as Buffalo Soldiers by the Indians they fought. The Ninth and Tenth Cavalries were authorized by Congress in the summer of 1866. With the single exception of Henry O. Flipper, all of the officers were white. Throughout the history of these cavalry regiments, most of the 12 companies of the Tenth Cavalry were organized at Fort Leavenworth, Kansas, where they were dispatched to provide support in various frontier operations. In 1875, the Tenth Cavalry was transferred to the Texas frontier and headquartered at Fort Concho in San Angelo. Until the mid-1880s, the Tenth Cavalry under regimental commander Col. Benjamin H. Grierson was the primary military presence in far west Texas. They manned Forts Concho, Stockton, Davis, Quitman, and Clark, as well as numerous companies, detachments, and camps, including the one at San Felipe. Partly as the result of their efforts, peace came to the Texas frontier about 1880 and troops were no longer needed at Fort Concho.

\section{COMIMUNITY OF SAN FELIPE DEL RIO}

Although relatively short-lived, the camp may have encouraged growth in the San Felipe community, which was called Del Rio by January 1883. When the camp at San Felipe was established, Indian raids still occurred in the region and communities would not have thrived far beyond the protection of a military outpost. Maj. Gen. Francis Henry French, who as a young lieutenant was detailed as the Regimental Adjutant, was posted to Fort Clark in December 1882, where he commanded the Seminole Scouts. Lieutenant French traveled frequently between Fort Clark, Camp San Felipe, and Camp Hudson. His diary, written between 1882 and 1884, offers some of the earliest observations of community life at San Felipe. The officers of the frontier posts enjoyed a lively social life, attending and hosting dinners, card games, and musicales. Whenever he passed through Del Rio, Lieutenant French was entertained by Captain Randlett at the post a short distance from the community. After dinner, the men typically rode "down town," Randlett to conduct business, and French (a bachelor) to call on the ladies. While visiting the "Misses Ffoulkes" in Del Rio, French commented that their house was "not plastered nor ceiled inside and has no floor either, but they never allude to it and so do not make a visitor nervous...." Their "misfortunes" notwithstanding, Miss Chrissie and Miss Florence had "kept up with their music" and entertained the lieutenant by playing and singing "very well." A Mr. and Mrs. Fountain and Dr. McLain joined in the evening's diversion (French 20 March 1883).

Activities such as these show that Del Rio had achieved a degree of community structure by the early 1880 s. French anticipated even greater progress with the advent of daily mail service and railroad transportation as he inspected the progress of the Southern Pacific Railroad near Mayers Spring (near present Dryden), marveling that trains were scheduled to run from San Antonio to San Francisco "in a very short time." He later noted the train's arrival in Del Rio, bringing both passengers and freight to the little town (French 4 May 1883) At the same time, vestiges of the frontier were still very much in evidence; French was cautioned to be vigilant against possible Indian attacks while riding between posts, particularly between Del Rio and Mayers Spring. When in camp, French and his Seminole Scouts relied on their ability to shoot deer or wild turkey for fresh meat. They lived in tents-sometimes improving their accommodations by building frame platforms for them-and traveled great distances on horseback (French 1883).

As the community at San Felipe Del Rio increased in population and the threat of Indian attack subsided-largely due to the success of the Tenth Cavalry - the need to maintain a permanent military camp at San Felipe Springs diminished. In 1882, the headquarters of the Tenth Cavalry was moved west to Fort Davis; 3 years later it moved again, this time to Arizona, where the skirmishes of Apache resistance were still being fought (Leckie 1996:255). Except for a small detachment sent out from Fort Clark to inventory the outpost's buildings in the summer of 1890 , no troops were stationed at Camp Del 
Rio after January 1890. On 19 May 1891, only 15 years after it was established, Camp Del Rio was officially abandoned (Glatte 1981).

On 2 July 1896, the U.S. government sold the land (409 acres) back to the San Felipe Agricultural, Manufacturing and Irrigation Company for one dollar. This deed was signed by J. G. Carlisle, Secretary of the Treasurer, filed on 30 July 1896 as the reconveyance of land to the San Felipe Agricultural, Manufacturing and Irrigation Company, and signed by Daniel S. Lamont, Secretary of War (Deed Record 6:323-325). The property was resurveyed by A. S. Dignowity in July 1896. Dignowity's map showed features of the newly abandoned fort, including a hospital, flagpole, and bakery as well as a lime house, lime kiln, an adobe house, and the John Glynn House (Val Verde County Map Record 1:41-42). Another survey of the army property conducted and filed by T. K. Pierce on 18 September 1905 showed a "rock house" at the approximate location of the former army bakery, as well as the adobe house, lime kiln, and John Glynn house shown in the 1896 survey.

\section{ARRIVAL OF THE RAILROAD AND THE FORMATION OF VAL VERDE COUNTY: 1883-1885}

The picture of Del Rio that emerges from Lieutenant French's diary is that of a very small community largely dependent on the adjacent cavalry post for its protection, commerce, health, and social life. Despite its proximity to the post and the best efforts of the irrigation company to sell agricultural lands along the canal system, San Felipe Del Rio grew very little from its inception in the mid 1860s to 1883, when French first visited the outpost. While most original residents in the area were farmers or farm laborers, the establishment of a military post undoubtedly opened a new market for development of civilian service industries to cater to the army's needs. Some civilian dwellings, such as John Glynn's house, were built near the post presumably to be close to the work there. These scattered individual houses may have provided the basis for further evolution of the San Felipe community on the east side of the creek in the 1880s. San Felipe eventually assumed the identity of the Mexican American community within Del Rio.
It was the arrival of the Galveston, Harrisburg and San Antonio Railroad in 1883 that provided the impetus for Del Rio's aggressive development in the late nineteenth and early twentieth centuries. Del Rio soon became a significant stopping point on the long rail journey between San Antonio, 154 miles to the east, and El Paso, 425 miles to the west. The impact of the railroad was quantifiable and dramatic. San Felipe Del Rio's population increased substantially, from only 50 residents in 1880 to 2,000 in 1890 , a 40 -fold increase in seven years after the railroad arrived (Overfelt 1996). The railroad and resulting population growth brought expansion to Del Rio and the beginnings of infrastructure and commerce associated with more-urban areas. Local residents started the community's first newspaper, The Del Rio Dot, in 1883 (Jones 1976:34).

While the railroad was a boon to Del Rio, it bypassed the town of Brackett (now Brackettville), the seat of newly formed Kinney County. Those attracted to the commercial opportunities associated with rail service, including some residents of Brackett, moved west to Del Rio. The increase in the town's population and the inconvenience of traveling to the county seat in Brackett led to the creation of Val Verde County, with Del Rio as its county seat, in 1885. A secondary boom ensued as the business of government became one of the town's principal occupations. Within a few short years, Del Rio had grown from a small, isolated border community dependent upon a fledgling irrigation canal system and occasional military presence to become the center of local government, a regional commercial hub, and the largest town on the railroad line between El Paso and San Antonio, a distance of nearly 600 miles.

\section{EARLY COMIMUNITY DEVELOPMENT: 1885-1896}

With the arrival of the railroads, scores of Anglo developers and settlers were attracted to the newly established Val Verde County (Figure 7). While development of the irrigation system made large-scale agriculture possible for many farmers and ranchers, the railroads linked south and west Texas with markets, goods, and services available in more-urban 


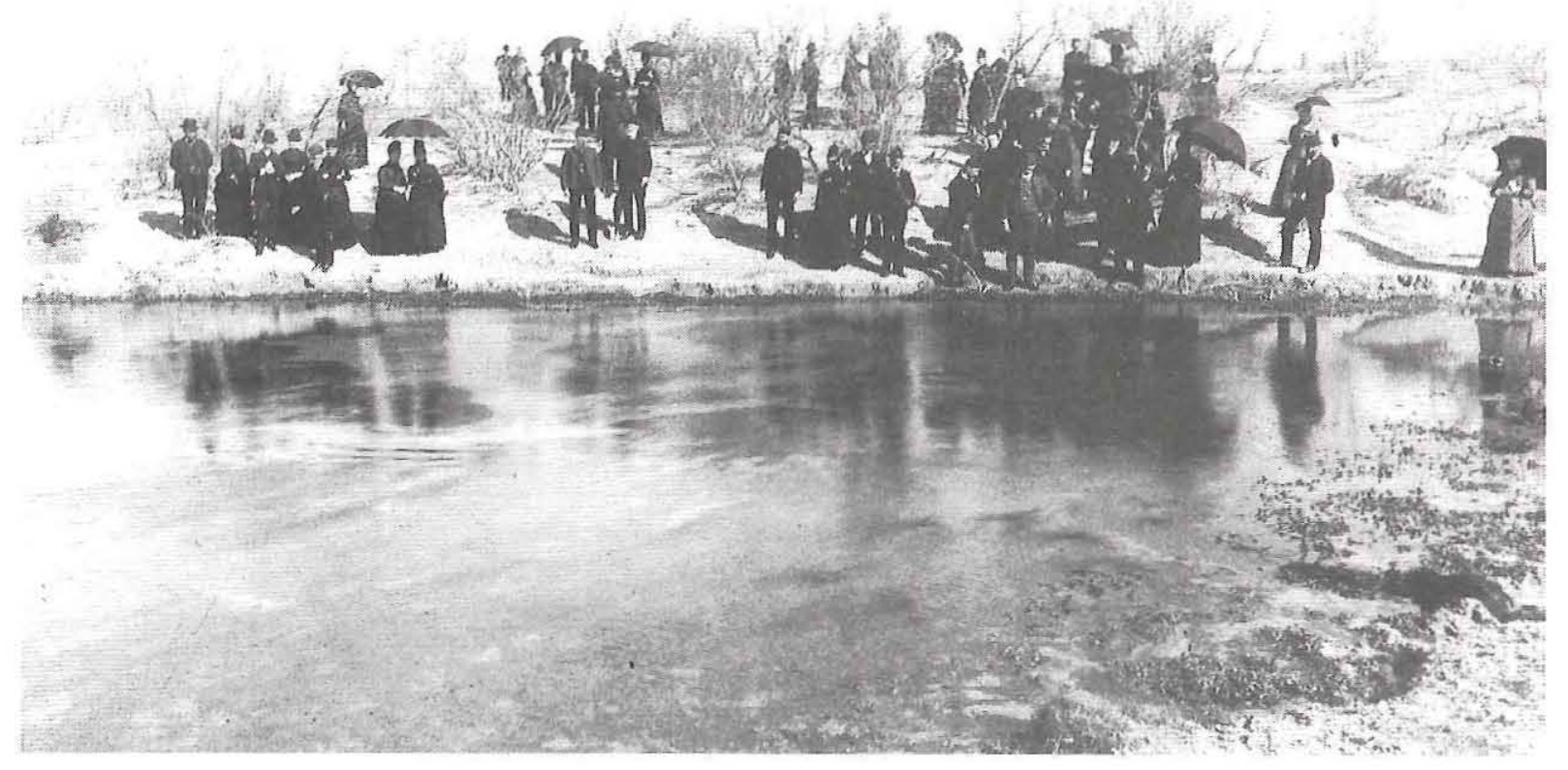

Figure 7. Historic photograph of one of the San Felipe Springs, ca. 1887, by photographer W. Snow. Photo No. 1/26-1 in Texas Scenes Photo Collection, Texas State Library and Archives, Austin, Texas. Photo caption reads "Hot springs-Del Rio, Tex." It is a Boudoir format albumen print card from Chelsea, MA.

parts of the country. New arrivals to the area came ready to invest in the local economy and brought with them the commercial and infrastructural ideas to which they were accustomed elsewhere. In 1889, the local ice plant on San Felipe Creek began to produce electricity for a limited clientele (Jones 1976:58). Daily mail service and a post office came to town as well, but the U.S. Postal Department requested that the community shorten its name to avoid confusion with the existing town of San Felipe de Austin. It was officially known as Del Rio from that time forward (Overfelt 1996:578). ${ }^{7}$ Locally, however, the name change was not

\footnotetext{
${ }^{7}$ Although the Handbook of Texas states that the name was shortened to Del Rio in response to the U.S. Postal Department's request, Captain J. W. Kelley listed the post address as "Del Rio" in correspondence as early as 1877 and the military post had officially changed its name from Camp San Felipe to Camp Del Rio by 1881 (Kelley 1877).
}

universally accepted, and alterations such as this only served to widen the growing socioeconomic and cultural gap between the Anglo and Hispanic populations of Del Rio and Val Verde County. On the west side of San Felipe Creek, an area developed largely by newly arrived Anglo businessmen, residents readily accepted the new name; the older, predominantly Hispanic community east of the creek retained the name San Felipe, at least unofficially. Although some developers tried to redefine the area as "East Del Rio" in their promotional literature, many residents continued to identify the city's east side as "San Felipe," a sobriquet that lingers to the present.

One of the earliest descriptions of the San Felipe community is from a San Antonio Weekly Express article in 1883 (in Zertouche 1985:142). The reporter described housing consisting largely of jacals "of recent construction." Despite their apparent poor living conditions, some of the area's Mexican American farmers had become landowners by that time, and several street names in the San Felipe community, including Cuellar and 
Garza, honor these early property owners ${ }^{8}$. The San Antonio Weekly Express article also noted that Paula Losoya Taylor was in the process of building "tenements" or rental properties, probably in the San Felipe area. These efforts spurred development of the community and contributed to its identification as the predominantly Mexican-American section of Del Rio, which was physically separated from the emerging railroad-influenced Anglo community.

As Del Rio became known as a commercial center, the San Felipe Agricultural, Manufacturing and Irrigation Company's efforts finally began to pay off. Although it made little progress in its first decade, by the time Del Rio was county seat the irrigation company was poised to attract a multitude of new settlers, most of whom depended on farming and ranching for their livelihoods. Good water and a functioning irrigation system were essential to attracting new farmers and ranchers. Since farming was possible only with irrigation, the canal system was heavily promoted in the real estate literature. Land developers relied almost entirely on the promotion of irrigated lands to draw new prospects to the Del Rio area. Early promotional maps of Del Rio, depicting the canals and loudly proclaiming the sale of "Irrigated Lands!," were widely circulated throughout the country as part of an effort to sell town and farm lots in the Del Rio area (Jones 1976:23).

The promotion of irrigated land in Val Verde County attracted many wealthy Anglo entrepreneurs hoping to capitalize on the emerging real estate and town development boom; land owned by local pioneer families since the antebellum period began to change hands. Upon his death in 1891, John Twohig willed his prime tract, the Sostenes Carrasco Survey No. 184, containing San Felipe Springs, to the Catholic Church. Twohig had retained ownership of the San Felipe Springs parcel since the 1850s. In 1903, it was acquired by G. Bedell Moore, a lumber entrepreneur from east Texas with residences in San Antonio and California. As an investor in the San Felipe Agricultural, Manufacturing and Irrigation Company, Moore

\footnotetext{
${ }^{8}$ Additional information on the historical development of San Felipe is available in the Federal Emergency Management Agency (1998) report.
}

had a personal interest in the value of property containing San Felipe Springs. He also stood to profit from the continued development of largescale irrigation systems in west Texas, as he owned 100,000 acres along the Rio Grande from Maverick County through Kinney County, including lands owned by the San Felipe Agricultural, Manufacturing and Irrigation Company in Val Verde County.

\section{GOAT AND CATTLE RANCHING}

At the close of the nineteenth century, Del Rio enjoyed a fairly diverse economy that included a variety of retail businesses and professional and county government-related employment. Still, farming and ranching formed the basis of the county economy. As former grazing lands in more settled parts of the state were fenced and plowed, putting an end to the open range and trail drives, cattlemen were forced to change their methods or move on. James Lowe was typical of the old-time cattle ranchers who moved west in search of open range. In 1898, he drove his herds from McMullen County to Val Verde County where there was still plenty of unfenced grazing land. His family followed a few years later, traveling in a covered wagon to Del Rio where they hoped to replicate their old life (Wilson 1985:154). Many of Del Rio's prominent ranching families came to Val Verde County about the same time, including the Whitehead family, who drove their cattle through Kimble and Sutton Counties (Jones 1976:179). As the result of this influx of farmers and ranchers, Val Verde County's rural agricultural population grew exponentially. In 1890 , the county supported only 47 farms and ranches, but by the turn of the century the area included 152 agricultural operations, comprising a total of 1.8 million acres. Around the turn of the century, the New York and Texas Land Company purchased unused railroad lands for resale and leasing to Val Verde County ranchers. Anglo ranchers interested in buying large tracts of ranch land were still coming to Del Rio; however, firms like the New York and Texas Land Company also sold smaller parcels to interest less affluent buyers. After the turn of the century there was an increase in the number of farms and ranches in Val Verde County, but there was also a general reduction in the size of individual properties, possibly a result of families 
subdividing their farms for their children. Val Verde County census returns show high percentages of foreign-born residents during this period (U.S. Bureau of the Census 1900, 1910, 1920). In 1890 , more than 38 percent of the county's residents were immigrants. The majority were born in Mexico, but Italians, Germans, and Bohemians also claimed residency. Twenty years later, in 1910, foreign-born residents $(n=3,106)$ had dropped slightly to 36 percent of the total population ( $\mathrm{n}=8,613$ ) (Smith 1996:695).

While many of the late-nineteenth- and early-twentieth-century settlers originally raised cattle, they found that the scrubby terrain was ideal for grazing sheep and goats. The coming of the railroad had a positive impact on this industry, as ranchers were able to transport their ranch products and livestock to market easily. While area farmers still raised modest truck and fruit crops, sheep and goat ranching became enormously successful. In 1900, local livestock values exceeded $\$ 1$ million, with ranchers owning 122,565 sheep, 42,000 cattle, and 15,000 goats (Smith 1996:695). Del Rio became widely known as the center of wool and mohair production, an industry that was promoted by members of the Whitehead family (prominent goat and sheep ranchers throughout the twentieth century). Del Rio became one of the state's primary twentieth-century sheep markets (Overfelt 1996:578).

\section{THE CITY OF DEL RIO}

After Camp Del Rio was abandoned in 1890 and federal troops were no longer a fixed presence in the developing community, the citizens of Del Rio found that they needed a local governmental entity to establish and maintain existing municipal laws and infrastructure. Formally established in 1875, the San Felipe Agricultural, Manufacturing and Irrigation Company was perhaps the city's earliest and most important infrastructure element. As early as 1883 , a private water company known as the Del Rio Water Company was established on the bank of San Felipe Creek (Garrett 1914), possibly just below the Tardy Dam. By 1900, the town boasted electricity and telephone service (Zertuche 1985:18). Although some historians state that local leaders began to organize a municipal government around 1890 and others support the founding of a municipality as late as
1911, minutes of a fledgling municipal government were first recorded in 1905 (Del Rio City Council Minutes 30 June 1905).

Water issues dominated the business of the Del Rio city government from its inception. Among its first official acts, the new city council granted a city franchise to the Del Rio Water Company, which had been operating under a permit issued by the county (Del Rio City Council Minutes 8 August 1905). At its second meeting, the city council unanimously accepted a proposal by Judge J. G. Griner, attorney for the Del Rio Water Company, to expand its services to a larger area, install fire plugs, and erect a water works plant (Del Rio City Council Minutes 8 August 1905). According to Griner's testimony, the city had no fire protection. Sanborn fire insurance maps drawn in 1900 summed up the city's water and fire protection: "No steam and no hand engines. No Independent Hose Carts. Water Facilities: Not Good" (Sanborn Fire Insurance Company 1900). Griner and his associates erected a new water works plant on San Felipe Creek, just north of the railroad tracks, by 1906 (Sanborn Fire Insurance Company 1917). It operated as a primary pumping plant until 1936.

As Del Rio's population grew in the early twentieth century, the city became increasingly divided along racial and ethnic lines. A new business district and residential neighborhoods on the west side of San Felipe Creek quickly became a separate, largely Anglo enclave. East of the creek lay the older, primarily Hispanic, community of San Felipe. While many of the earliest Anglo and Hispanic settlers apparently co-existed compatibly, later arrivals instituted separate schools, community centers, and recreation areas (Sanborn Fire Insurance Company 1900-1930). The new water system contributed to the city's segregation; it served only the burgeoning new west side. The community on the east side of the creek struggled with the aging and inadequate original water system.

Despite increasingly marked segregation that only became more pronounced with the Mexican Revolution in the 1910s, Del Rio's economy boomed in the first two decadess of the twentieth century. It had developed the basis for a strong local economy, with numerous retail concerns, agricultural operations, and access to the railroad. In addition to local consumption of farm and ranch products and sales to outside 
markets, farmers and ranchers profited from food they were able to sell in large quantities to Fort Clark.

\section{CAMP MIICHIIE: 1914-1924}

In 1910, the Mexican Revolution threatened to spill over into the United States borderlands of south Texas, New Mexico, and Arizona. Whether the work of bandits or revolutionaries, numerous border communities suffered raids between 1910 and 1915, a period known by Anglos as "the bandit era." All border communities were on the alert against possible attack, and some of the information was alarming. In Del Rio, The West Texas News alerted area citizens to possibilities of the Mexican Revolution spilling over into Texas (The West Texas News 29 April 1914). It was an uneasy period, especially for entrepreneurs who sought to promote and develop the border town. Raids into the United States, such as Pancho Villa's attack on Columbus, New Mexico, led anxious citizens to call for greater military protection.

Federal troops assigned to border stations extending from Brownsville near the Gulf Coast to Yuma, Arizona, maintained a strong military presence to discourage raids and protect U.S. citizens. According to official records, a semipermanent camp was established on the outskirts of Del Rio "incidental to border patrol activities during the Mexican Revolution, 191120" (United States War Office 1949:602, 908). From 1911 to 1914, Del Rio primarily provided a camping spot for occasional cavalry expeditions from Fort Clark. Local families recalled seeing soldiers camped in tents along San Felipe Creek throughout the period of the Mexican Revolution (1910-1916), and the pool below the confluence of the east and west forks of the creek was long known as the soldiers' swimming hole (Val Verde County Historical Commission files, n.d.). Military activity in Del Rio probably would have been curtailed once the border incidents diminished, if not for increased European tensions that left the world poised on the brink of war. Rumors of a possible German-Mexican alliance and fear of an invasion of the United States through a politically weakened Mexico warranted the continuation of a military presence. In Val Verde County a military encampment became a more permanent, if not autonomous, post in 1914, as World War I began.
Few records detail Del Rio's role in World War I, but it apparently remained as an auxiliary outpost of Fort Clark, with cantonment for one regiment of cavalry, for the duration of the war (United States War Office 1949: 602, 908). Many sources are unclear on this point, but the World War I encampment was located upstream from the old Camp San Felipe/Camp Del Rio, on land held by the G. Bedell Moore estate (Glatte 1981). Most of the post was a tent encampment (Figure 8) between Bedell Road on the west and San Felipe Creek on the east, extending from the railroad tracks on the south to the present hospital grounds (Doug Newton, personal communication 1997). First known as Camp Del Rio, the post was dubbed Camp Michie, for Robert E. Lee Michie, after 1916 ( Del Rio News-Herald 15 May 1972:B-1; Doug Newton, personal communication 1997). This must have been an unofficial name, as government records refer to the outpost as Camp Del Rio.

Although used as a cavalry outpost as early as 1914, the earliest formalized agreement between the government and the property owner, the G. Bedell Moore Estate ${ }^{9}$, dates to 1919. A completion report written by Maj. W. S. Hibbard for a "cantonment for one Regiment of Cavalry, Camp Del Rio," clearly states that the camp was occupied temporarily by cavalry regiment for about two months, and by two infantry companies in 16 August 1918 (Hibbard 1919). Deed records show that the Del Rio Chamber of Commerce acquired a 400-acre parcel from Mrs. Elizabeth Moore for the minor G. Bedell Moore for $\$ 8,000$ in 1919 . The property was then deeded to the U.S. government for use as a military post on 26 April 1919 (Deed Record 41:278).

By February 1920, 30 percent of the personnel stationed at Camp Michie were ready to be discharged and new recruits were arriving daily to take their place (West Texas News 27 February 1920:1). In 1921, a portion of the Twelfth Cavalry was stationed at Camp Michie. The camp was officially disbanded on 30 June 1921 (Jones 1976:420). However, the property was

${ }^{9} \mathrm{G}$. Bedell Moore, the property owner, died in 1907. His wife, Elizabeth Moore, served as guardian for his estate on behalf of their minor son, also named G. Bedell Moore. 


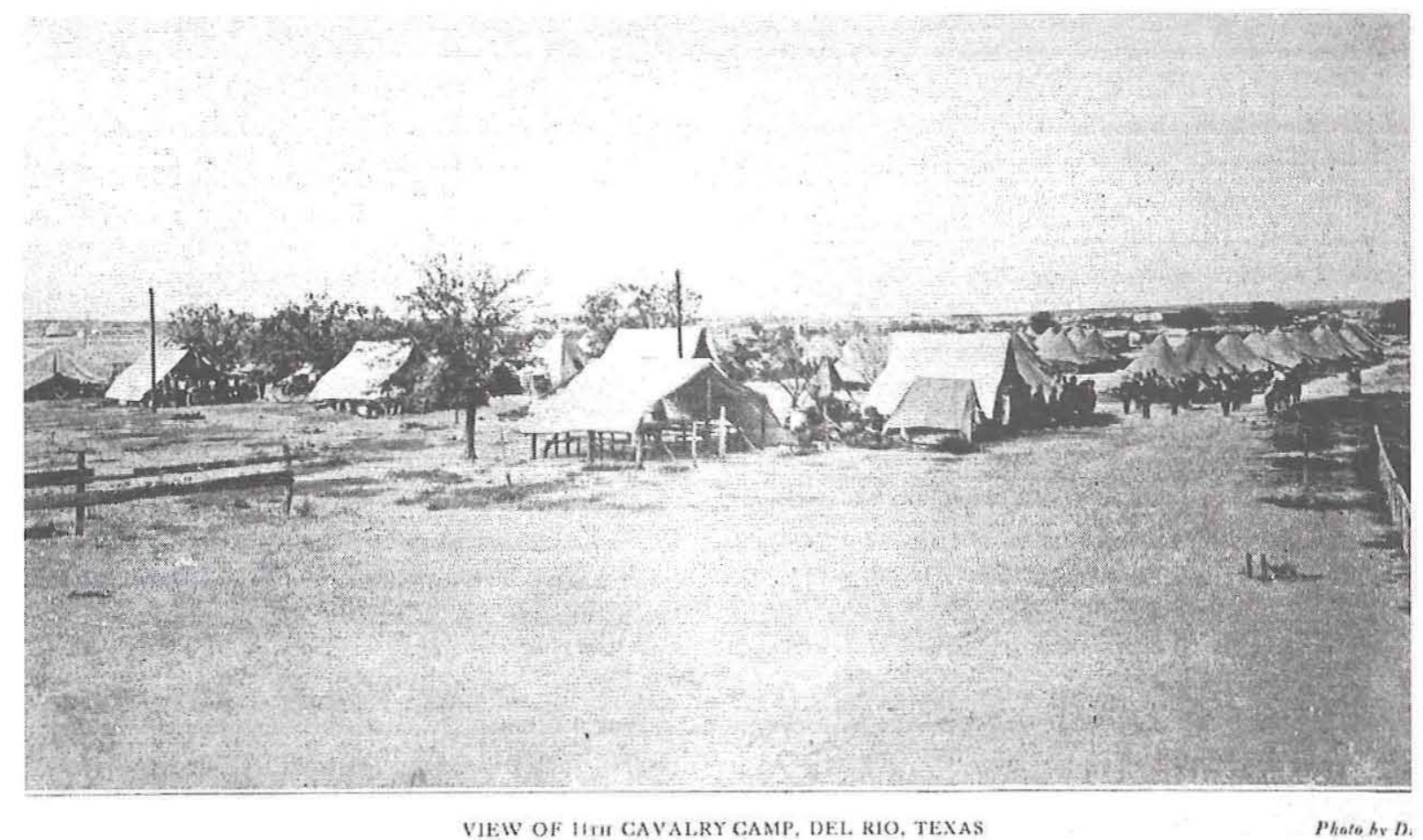

Figure 8. "View of 14th Calvary Camp, Del Rio, Texas." Photograph by Disc ca. 1917-1918. From undated pamphlet entitled "Souvenir of Fourteenth Calvary in Camp at Del Rio, Texas" in the Whitehead Museum Files, Del Rio.

not released by the federal government until 1 November 1924, when it was returned to the original owner. After the post was abandoned, the land was deeded back to the Moore estate for the original sale price of $\$ 8,000$ (Deed Record 58:222). The Moore estate in turn deeded the property, which included both East and West Springs, to the City of Del Rio under the condition that the city provide water to the new country club for $\$ 1.00$ per year (Doug Newton, personal communication 1997). ${ }^{10}$

One noteworthy building associated with the camp was the combined officers' club and quarters near the southeast boundary of the camp, north of the railroad tracks and west of San

\footnotetext{
${ }^{10}$ According to Doug Newton, the four people who owned the property including the springs had sold their land to G. Bedell Moore. Moore apparently leased some of his land to the army and the army deeded it back to Moore in 1924.
}

Felipe Creek. Built in 1919, it was used only a short time before being leased to the San Felipe Country Club as a clubhouse about 1921 . When the government reconveyed the property to Moore in 1924, the building known as "the Old Officers' Club" was specifically excluded from the transaction since it had been sold to the San Felipe Country Club and lay on grounds leased to the club, executed by the Acting Secretary of War on 31 July 1923 (Deed Record 58:223).

\section{POST-WORLD WAR I}

Following World War I and the end of the so-called bandit era on the border, Del Rio exhibited many signs of prosperity characteristic in booming towns throughout the U.S. during the 1920s. At the start of the decade, Del Rio's population was estimated at 12,706, a 48 percent increase from 1910 , when only 8,613 residents were counted (Stafford 1925:17). Many soldiers stationed at Fort Clark and Camp Michie married local women and remained in 
the area after the war. Del Rio continued to attract more farmers, ranchers, and business people eager to profit in the developing region in the postwar period. City leaders avidly promoted Del Rio to out-of-town investors and entrepreneurs through brochures and magazine advertisements distributed throughout the country. Many successful businessmen, like William Abbey of San Antonio, moved to Del Rio and contributed to the area's growth and development during this period. As a result, the city expanded beyond its original corporate limits. With the increase of a business and professional class came the area's first country club and golf course. A stone building known as the "Old Officers' Club" was deeded to the Chamber of Commerce for use as a country club by the Acting Secretary of War in 1919. Adjacent land within the G. Bedell Moore Estate, including both the West and East Springs, was acquired for a golf course, built in 1921.

Del Rio leaders began to consider the city's potential as a destination for travel and tourism, especially after the construction of the international bridge to Acuña in 1929 made Del Rio an official gateway to Mexico (Jones 1976:228). The advent of the automobile, coupled with improved highways and increased leisure time, encouraged the concept of pleasure travel; Del Rio boosters scrambled to attract their share of the new tourist economy (Figure 9). Forward Del Rio, a promotional brochure printed in the $1920 \mathrm{~s}$, lauded the great climate and amenities of the city, high among them the golf course. It stated that there was "no good reason" why Del Rio's particular attractions, including the yearround golf course "should not make the town spring into fame as a winter resort" (Stafford 1925:16). With the beautiful San Felipe Springs and Creek providing its water hazards, the golf course became a major attraction for business clientele.

\section{GREAT DEPRESSION}

Although the economic disaster of the Great Depression halted many large-scale private development schemes, several federal works projects were accomplished in Del Rio during the 1930s. Local Works Progress Administration (WPA) projects were aimed at stopping the spread of typhoid, cholera, and malaria, and addressed many other overlooked health and poverty issues in Del Rio. WPA projects and other federally funded civic projects helped to decrease poverty in Del Rio between 1930 and 1940. During the Great Depression, Del Rio's single largest capital improvement project was the installation of a new water plant, sewer system, and water mains. Funds for this project were made available contingent upon the integration of Del Rio's Anglo and Hispanic water systems. Segregation remained firmly entrenched after the bandit era, and the separate water systems were only one example of the unequal treatment Hispanics continued to receive after World War I.

With works projects improving the infrastructure and a new bridge facilitating travel to Mexico, Del Rio's leaders and citizens continued to promote tourism in the area. More people were attracted to Del Rio after Texas began highway development projects in the south and west. State highway crews built U.S. Highway 90 through Del Rio between 1930 and 1932. After the state highway system was in place, Del Rio remained as important as it had been during the railroad boom years, a major stop between San Antonio and El Paso. Local residents, including members of well-established ranching families, made efforts to adjust to Del Rio's changing economy and profit from the tourist trade. Tourist camps and motor courts sprang up along the highways that ran through the town. Jasper "Jap" Lowe, a World War I veteran, started a tourist court called Lowe's Tourist Home on the main highway through Del Rio. Lowe's Tourist Home provided sleeping accommodations, a cafe, a store, and a filling station for travelers in Del Rio (Wilson 1985:154). Other tourist courts, including one lying immediately adjacent to the golf course on the west, sprang up along U.S. Highway 90 (Doug Newton, personal communication 1997).

\section{WORLD WAR II AND RECENT DEVELOPMENTS}

After the United States entered World War II in 1941, the wartime economy, with its huge demand for soldiers, manufactured goods, and agricultural products, helped to end the Great Depression. The military return to the Del Rio area in the early 1940s stimulated the Val Verde County economy. In 1942, Laughlin Army Air Field was established six miles east of Del 


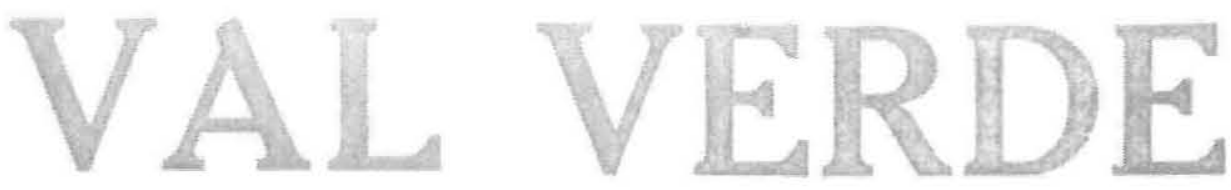

\section{On The Sunny Rio Grande}

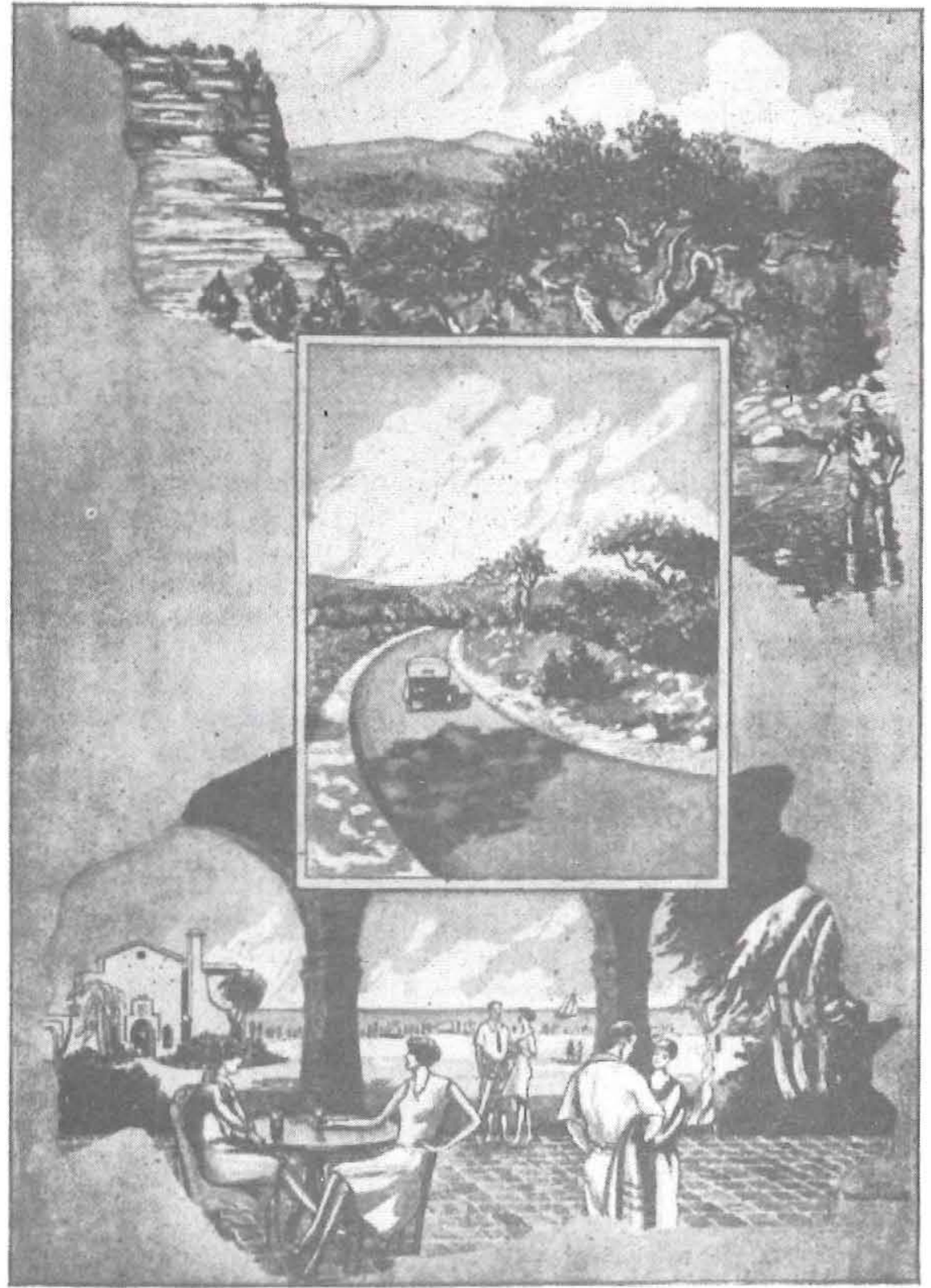

On The Federal Highway No, 90 The Scenic Route of Texas

Figure 9. Cover illustration for a 1928 article reprint promotional pamphlet entitled Val Verde on the Sunny Rio Grande: On the Federal Highway No. 90, The Scenic Route of Texas (Argus Publishing Co., Inc. 1928). 
Rio as a training base for pilots of Martin B-26 bombers (Zertuche 1985:18). The installation was named for Lt. Jack Laughlin, Del Rio's first casualty of the war. Laughlin was killed when his B-17 crashed in Java in January 1942 (Leatherwood 1996:104). Army contractors employed area residents in construction jobs to build the base, giving previously unskilled laborers an opportunity to work in a nonagricultural field. The war and the presence of Laughlin Army Air Field gave local residents the opportunity to enlist or work in defense-related industries that opened up other employment possibilities for them. Service in World War II took many residents away from Del Rio and brought many new people to the area. The base was closed in 1945 after it was no longer needed for the war effort, and the federal government leased the land to local ranchers for sheep and goat grazing, still Val Verde County's prime agricultural concern.

Although little real estate activity occurred during the war due to constraints on civilian construction, one noteworthy transaction did take place. J. E. White, who had earlier purchased a large portion of the Sostenes Carrasco Survey ${ }^{11}$ from G. Bedell Moore Jr., sold the property to W. L. Moody Jr. Moody, a developer from Galveston, promptly sold the land to Silver Lake Ranches, Inc. This company built a large housing development on the Carrasco Survey during the postwar years. W. L. Moody Jr. retained his interest in the San Felipe Agricultural, Manufacturing and Irrigation Company, however. Although he died in 1954, the Moody family trust fund is still in possession of the majority of stock in the company (Jones 1976:475).

After Japanese surrender in 1945, Del Rio's postwar economy boomed. The City invested in

${ }^{11} \mathrm{G}$. Bedell Moore died in 1907, leaving his land to his wife and infant son. When he came of age in 1929, G. Bedell Moore Jr., received all of the land, including acreage in Val Verde County containing San Felipe Springs. He promptly sold most of the property in Kinney and Val Verde Counties, some acreage in Maverick County, and all of the family's stock in the San Felipe Agricultural, Manufacturing and Irrigation Company to J. E. White of Del Rio (Jones 1976:475). White's holdings did not include the golf course and country club. new roads and utilities for new housing developments. While most of Del Rio's traditional farming and ranching families remained in Val Verde County after the war, the city attracted a large number of new residents. Many veterans who had served at Laughlin Army Air Field stayed in Del Rio permanently. This was a common phenomenon all over the country during the immediate postwar years. While population growth in Del Rio was slow in the 1920s through the 1940s, it increased dramatically during the 1950 s. Between 1950 and 1960, Val Verde County's population increased by almost 50 percent (Smith 1996:695).

In response to population increase, the city assumed greater infrastructural responsibilities. Prior to 1950, Del Rio had leased the portion of the Carrasco Survey containing San Felipe Springs. The city later installed pumps in East Springs and pumped water to the Bedell tanks for temporary storage. It eventually purchased the land containing the main San Felipe Springs (Jones 1976:475).

Del Rio population and economy increased again when Laughlin Army Air Field was reactivated in 1952 for service in the Cold War. The base's first mission was to train F-84 fighter pilots. However, in 1957 it was turned over to Strategic Air Command as a training base for 4080th Reconnaissance Wing, a highly secret U-2 unit. Laughlin Air Force Base is credited with obtaining the first pictures of the Soviet missile buildup in Cuba in October 1962. In 1963, Strategic Air Command transferred control of the base to Air Training Command as an undergraduate pilot training base, and it has continued in that capacity (Jones 1976:223; Zertuche 1985:9, 18).

During the late 1960s, Del Rio benefited from a joint U.S.-IMexican project that funded the construction of Amistad Dam, resulting in the creation of Lake Amistad, ${ }^{12}$ a major recreation attraction on the border. Between 1965 and 1969, construction crews built the dam 12 miles northwest of Del Rio and Acuña to control the Rio Grande, Pecos, and Devils Rivers.

\footnotetext{
${ }^{12}$ Lake Amistad was originally called Diablo Dam and Reservoir.
} 
When it was completed, the dam created one of the largest artificial lakes in the country, with 800 miles of shoreline. The reservoir inundated Devils Lake and Lake Walk, both created by dams erected in the 1920s for hydroelectric power generation and recreation. Lake Amistad was built for the purposes of flood control, conservation, irrigation, power, and recreation (Smith 1996:695). The dam project brought national attention to Del Rio when President Dwight D. Eisenhower met with Mexican President Adolf Lopez in 1960 to formalize the initial agreement for construction of the dam. President Lyndon B. Johnson joined Mexican President Diaz Ordaz on the bridge between Del Rio and Acuña in 1966 as a goodwill gesture commemorating future U.S.-Mexican relations.
In 1969, Ordaz and President Richard M. Nixon dedicated the dam and inaugurated the Port of Mexico facilities on the Acuña side (Zertuche 1985:9, 18).

Since its creation, Lake Amistad has encouraged more real estate development and tourism in the Del Rio area. The development of water resources in Val Verde County has transformed the City of Del Rio from a small nineteenth-century desert settlement dependent on frontier military posts for protection into a prosperous city with an independent local government, access to several types of transportation, an effective system of water utilities, and a broad economic base with farming, ranching, retail, tourist trade, recreation, service, civic, and defense-related employment for its citizens. 



\section{DESCRIPTIONS AND ASSESSMIENTS OF HISTORIC PROPERTIES}

Terri Myers

Historic cultural resources in the project area fall into three principal categories: those associated with the Lowe Ranch, those associated with the San Felipe Country Club, and those associated with the San Felipe golf course. Historic properties associated with the city waterworks system consist of pumping stations located on the golf course and the Bedell water storage tanks on a 1-acre parcel of land completely surrounded by the Lowe Ranch.

This chapter concentrates on the extant resources within the project area boundaries and offers a brief land history of two adjacent tracts. One tract contains the golf course and the other Lowe Ranch. The common land history is followed by specific property histories, physical descriptions, and National Register assessments of individual cultural resources.

\section{THE SOSTENES CARRASCO SURVEY NO. 184}

\section{Land History of the San Felipe Springs Area}

Both sites included in the project area (i.e., 41VV444 and 41VV1820) and all cultural resources examined in this effort are located within the Sostenes Carrasco Survey No. 184 (Figure 10), a parcel containing $13,500,000$ square varas (approximately 2,390 acres) of land. The property was surveyed on 30 April 1848 by J. S. McDonald, District Surveyor for Bexar District. McDonald's field notes indicate that the survey was made for John Twohig, a San Antonio banker and the assignee of Sostenes Carrasco (Texas. General Land Office 1854b). McDonald's map shows that at least one of the springs making up San Felipe Springs falls within Survey No. 184. In addition to the Carrasco Survey, Twohig also acquired the adjacent Henry P. Brewster Survey No. 186 (Texas. General Land Office 1852) as Brewster's assignee, as well as the adjoining James Mitchell Survey No. 183 (Texas. General Land Office 1854a), which was conveyed to him by Mitchell's heir (Deed Record 8:371). By obtaining these three surveys, Twohig owned the springs, San Felipe Creek, and much of what is now central Del Rio. He conveyed one equal, undivided half of each of the San Felipe tracts to A. Toutaut, also of Bexar County for $\$ 2,000$ on 13 November 1854 (Deed Record 2:227).

Although he sold portions of the Brewster and Mitchell Surveys during his lifetime, Twohig held the Carrasco Survey containing the springs site until his death in October 1891. According to his will (written 11 April 1890), the balance of his property, including the Sostenes Carrasco Survey, was left to the Right Reverend John C. Neraz, Catholic Bishop of San Antonio, or his successor, with the stipulation that it was to be used and disposed of for charitable purposes (Deed Record 36:336). In 1903, Neraz's successor, the Right Reverend John A. Torres, Bishop of the Diocese of San Antonio, conveyed the "lower part" of Survey No. 184, "a parcel of land situated on San Felipe Creek and embracing the large springs of said creek above the town of Del Rio," to G. Bedell Moore of Bexar County for $\$ 9,095.62$. The "upper part" had already been conveyed to J. K. Burr in 1900 (Deed Record 11:81).

\section{San Felipe Country Club and Golf Course}

The "lower part" of Survey No. 184 remained in the Bedell estate until 1919. G. Bedell Moore 


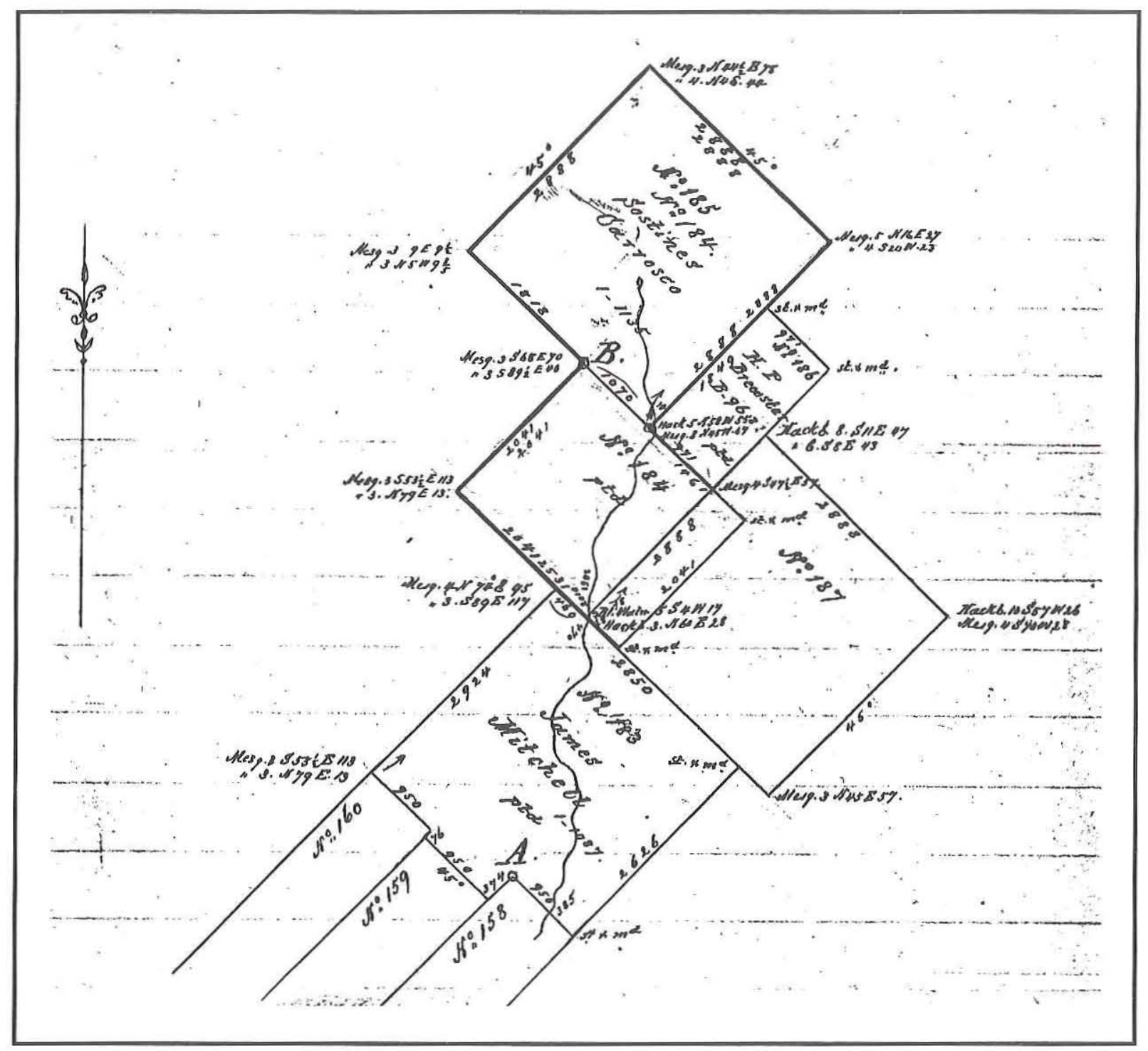

Figure 10. Certification survey map from 1852 showing the Sostines (or Sostenes) Carrasco Surveys No. 184 and No. 185 (Texas General Land Office 1854b).

died in 1907, and his wife, Elizabeth Moore, served as guardian for their minor son, also named G. Bedell Moore. On 28 February 1919, the Moore estate leased a small portion of the survey, "lying between the East and West prong of the San Felipe Creek north of the GH\&SA Railroad Company right-of-way that includes part but not all of the pump house and adjoins the G. Bedell Moore Estate," (Deed Record 43:402) to the Del Rio Water Company. This was the site of the old pump house built ca. 1906 just north of the railroad bridge. It is likely that the company had leased the property since 1906 when the pump house was built, and the 1919 lease was merely a renewal of the existing agreement.

Later that year, on 26 April 1919, Elizabeth Moore (on behalf of the minor G. Bedell Moore) sold 400 acres of the property, part of the "Springs Pasture," to the United States for use as an army post or camp. The Del Rio Chamber of Commerce made the $\$ 8,000$ purchase for the government. The deed stipulated that no wells could be drilled on the property and that the 
property would revert to the estate if the grantee abandoned the post (Deed Record 41:278). The land lay to the west of the pump house, between the west prong of San Felipe Creek and what is now Bedell Avenue. It became the site of Camp Michie, primarily a tent cavalry outpost connected to Fort Clark during World War I and for several years afterward. Five years after the initial transfer of the land to the military, on 1 November 1924, the government sold the property back to G. Bedell Moore with the following limitations:

that the building known as the Old Officers' Club which building is now the property of the San Felipe Country Club of Del Rio, Texas and is located on ground leased to the San Felipe Country Club by lease executed by the Acting Secretary of War on the 31st day of July 1923. Also no right conveyed to any building and or improvements sold to various purchasers by the Government at the public auction held at Camp Michie on October 31, 1923, and now remaining on the land hereby conveyed. By D. E. Nolan, Acting Secretary of War, United States of America [Deed Record 58:223].

From this deed it is apparent that the U.S. army built Camp Michie on the "lower part" of Survey No. 184, and that the former officers' club was already in use when the property was deeded back to the Moore heirs.

During the army's occupancy of Camp Michie, the Moore estate negotiated the sale of approximately 100 acres of land to William Abbey for a country club and golf course. The transaction took place in 1920 or 1921, but no deed records have been found to verify the terms of the sale. Abbey reportedly spent $\$ 40,000$ of his own money to develop the nine-hole golf course (Del Rio Evening News, Historical Prosperity Edition 1937, Section 6:1). The tract was adjacent to Camp Michie, lying west of the cavalry post and embracing three of the famous San Felipe Springs.

\section{Lowe Ranch}

The earliest occupation of the Lowe Ranch dates to 1924, when Herman Jasper "Jap" Lowe and his wife Braddie purchased the land from Del Rio-area ranchers W. E and W. F. Whitehead. The 1,035-acre Lowe Ranch parcel was part of the "upper section" of Survey No. 184 that had been conveyed to J.A. Burr in 1900 by the Catholic Church. Disposition of the parcel between 1900 and 1906 is unknown, but it somehow passed to the New York and Texas Land Company, one of the largest privately financed land companies operating in Texas in the last quarter of the nineteenth century. The land company formed when it obtained all of the land given to the International-Great Northern (I\&GN) Railroad Company, including millions of acres in west Texas, by the state. Much of the land acquired in west Texas was unsuitable for agriculture, and its managers leased vast tracts of brush land to ranchers for grazing sheep and cattle (Evans 1996:1007). On 16 December 1906, the New York and Texas Land Company sold more than 9,700 acres of Del Rio-area land to Val Verde County ranchers W. E. and W. F. Whitehead. Most of the land was former I\&GN Railroad property, but included in the transaction were $1,495.65$ acres of Survey No. 184 and ca. 206 acres of the adjacent Brewster Survey No. 186 (Deed Record 57:216).

At the time of the Whitehead purchase, the property was under lease to G. Bedell Moore (who owned the adjacent springs tract) until 9 April 1908 (Deed Record 57:216). It was just one of many Del Rio-area properties acquired by this well-known goat and sheep ranching family in the early part of the twentieth century. Subsequent deed records refer to fence lines, indicating that the Whiteheads may have grazed livestock on the land. However, they did not live on the property and are not known to have built any structures.

On 2 June 1924, the Whitehead brothers sold 1,035 acres of the property-all from Survey No. 184-to Jasper “Jap" Lowe and his wife, Braddie Garner Lowe. The property extended from what is now Bedell Avenue on the west "to the water's edge on the West bank of San Felipe Creek" (Deed Record 57:216). The Lowes built a house and numerous outbuildings on their ranch between 1924 and 1955, when Jap Lowe died.

On 29 September 1926, the Lowes sold a 1acre parcel out of the center of the ranch to the City of Del Rio. This small tract, intended to contain municipal water storage tanks, lay on an elevated site close to the Lowe house. At the 
time of the sale, the Lowes granted the city a 60 -ft-long strip of land extending from the south line of Lowe's Addition to 13th Street, later known as Bedell Avenue (Deed Record 62:348350 ). This strip is a dirt road sometimes called Braddie Lane that connects the 1-acre parcel with Bedell Avenue.

The city still owns the 1-acre tank parcel, but the bulk of the Lowe estate, including the ranch, passed to Louita Wilson, a niece of Mrs. Lowe, in 1978 (Del Rio News-Herald 2 June 1983; Wilson 1985:154). The house site and 120 acres of land were recently sold to another Lowe relative, Leah Wagner, of San Antonio. The original Lowe Ranch house was demolished in 1997 and a new house was built on part of the original site later that year (Lee Lincoln, personal communication 1997).

\section{SAN FELIPE COUNTRY CLUB AND GOLF COURSE}

\section{History}

William Moore Abbey is generally credited with bringing the necessary components together to create Del Rio's golf course and country club. Abbey came to Del Rio from Houston on business with the Great Southern Life Insurance Company about 1917 . He reportedly was so taken with the town and its potential for development that he packed up his family and moved to Del Rio, where he bought the Roach-McLymont Company, a local department store. A natural promoter, Abbey touted his store as "the largest department store on the border between San Antonio and El Paso" (Stafford 1925:16).

Del Rio lacked an important amenity for Abbey, however-it did not have a golf course. Abbey was an avid golfer and belonged to the Houston Country Club where Willie McGuire served as pro (Ball 1994). He missed the sport and sought to create a passable course in the tiny town of Del Rio, not only for his own pleasure but as an attraction to bring more residents to the area. In 1920, golf was a relatively recent pastime in Texas, but courses had been built in Austin, Houston, and San Antonio, and the game was catching on as the recreation of choice for the more-affluent business and professional classes.

According to family members, Abbey first tried to enlist the support of the army at Fort
Clark to build his golf course, but those efforts failed to materialize (Ball 1994). He doggedly pursued other means to obtain a country club and golf course for his community, and in 1921, he negotiated with the G. Bedell Moore heirs to purchase approximately 100 acres, including the famous San Felipe Springs, from the Moore estate. ${ }^{13}$

\section{Origins of the San Felipe Country Club}

On 12 July 1921, Abbey and two other Del Rio businessmen, B. G. Stafford and C. C. Belcher, filed a charter to form a private corporation. This corporation, the San Felipe Country Club, was created "to support and maintain a Country Club for golf, tennis and other innocent sports." The duration of the corporation was to be 50 years from the date filed with the Secretary of State. The club consisted of 100 charter members, 11 of whom (including Abbey, Stafford, and Belcher) served as its Board of Directors. W. H. Lundberg was employed as the golf instructor and grounds keeper (Del Rio Evening News Historical Prosperity Edition 1937, Section 6:1). All of the early directors were residents of Del Rio or the surrounding ranches, including most of the city's professional and business class.

The first clubhouse was the former officers' quarters and club at Camp Michie (Figure 11); the joint officers' quarters and clubhouse had been constructed about 1919 or 1920 and was one of the only permanent facilities built for the post. Built under the direction of Colonel Rice during his command of cavalry regiment at Camp Michie, the building was used only a short time before the camp began to disband at the

\footnotetext{
${ }^{13}$ Abbey may have been related to the Moores; some sources, including the promotional magazine Forward Del Rio (1925), stated that Mrs. G. Bedell Moore donated the land for the country club (Stafford 1925:16). It is more plausible that she would donate such prime real estate to a relative rather than an acquaintance. However, Mrs. Moore more likely donated the land to the city for a waterworks plant, as she had been approached by city representatives for that purpose. The city would have then granted the country club a 99-year lease of the property.
} 


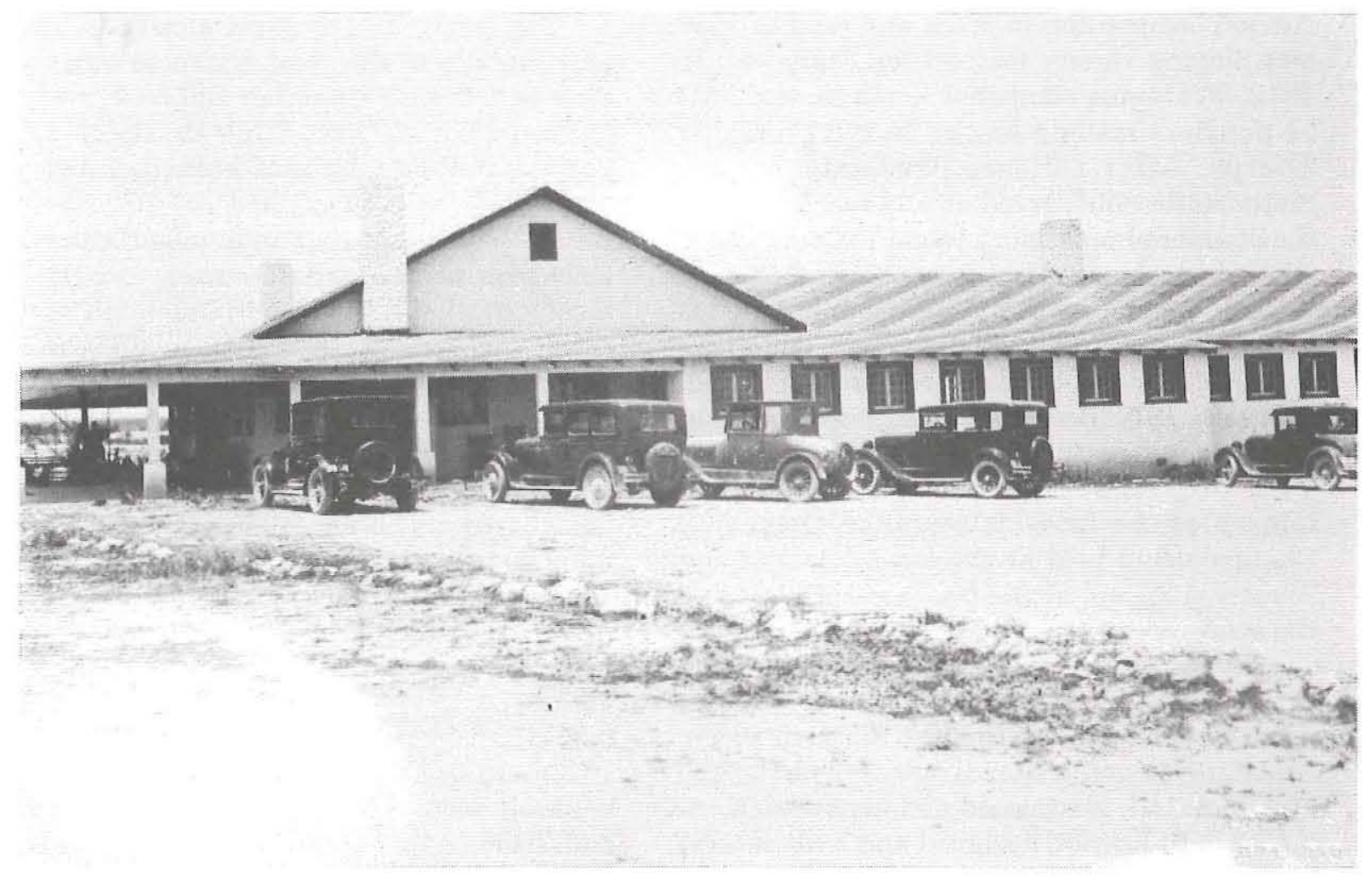

Figure 11. Former Officers' Club of Camp Del Rio/Camp Michie and first clubhouse for the San Felipe Country Club, ca. 1924. Photograph from the Val Verde County Historical Commission, vertical files.

end of World War I. The clubhouse stood empty before it was leased to the San Felipe County Club, which was in the process of building a golf course on the adjacent property in 1921.

Country club members spent several thousand dollars refitting and refurbishing the leased building for use as a clubhouse. When plans were made to abandon Camp Michie entirely, William Abbey entered into negotiations with the government, hoping to buy the building outright. In August 1923, the War Department transferred the title of the former officers' club to the San Felipe Country Club. Camp Michie was probably completely abandoned by the time the transfer took place, as Captain C. W. Legge of Fort Clark represented the government's interests in relinquishing the title (Val Verde County Herald 17 August 1923:1).

\section{The Golf Course}

Simultaneous with his efforts to establish a country club, Abbey pursued his dream of building a golf course. He reportedly spent $\$ 40,000$ of his own money to develop the ninehole course (Del Rio Evening News Historical Prosperity Edition 1937, Section 6:1). In 1921, Abbey secured the services of John Bredemus, a civil engineer, to design the course around San Felipe Springs (Doug Newton, personal communication 1997). Although popular promotional literature lauded Bredemus as "an expert" (Stafford 1925:16), the San Felipe golf course was the first one he designed. It launched Bredemus's career as a golf course architect who was ultimately responsible for designing many early-twentieth-century courses in Texas and Mexico.

Born in Flint, Michigan, in 1884 to Luxembourg immigrants, John Bredemus attended school in South Bend, Indiana. He attended Dartmouth College before switching to Princeton to finish a degree in civil engineering in 1912. At school Bredemus distinguished himself as an athlete, winning the American Athletic Union (AAU) National All- 
Around competition in track and field in 1908 and playing varsity football for Princeton. In 1912, Bredemus competed again in the AAU Nationals, finishing second to the great Jim Thorpe. After college, Bredemus taught mathematics and served as athletic director at the Stamford Preparatory School in Connecticut, where he took up golf for competition. Bitten by the golf bug, he spent his summers honing his golf skills at Van Courtlandt Park, America's first public course, built in the Bronx in the mid1890s. By 1914, Bredemus was competing as an amateur in tournaments in and around New York City. That summer he distinguished himself at the first Metropolitan Open Golf Championship held at the Scarsdale golf and country club, and within two years of taking up the sport, he turned professional.

Bredemus may have received his training in golf course design during the summer of 1915 , when he disappeared from the amateur scene. According to golf writer Frances Trimble, the architect C. B. Macdonald and his partner, engineer Seth Raynor, designed and built several courses in the Northeast, notably the Lido Club on Long Beach, Long Island, that summer. Trimble has speculated that Bredemus may have gained his initial experience working for Raynor and Macdonald. Her assumptions are based on the remarkable resemblance of the Lido Course to Bredemus's subsequent design of Offat's Bayou Park on Galveston Island, and on the fact that Bredemus declared his professional status following a 1916 U.S. Golf Association recommendation that "golf architects be put under the ban of professionalism" (Trimble 1991:13). In any event, Bredemus was declared both a golf architect and a professional golfer by 1916.

With the end of World War I and the beginning of a new era of prosperity, interest in golf increased tremendously in the United States. There was a demand for more tournaments and more courses, and many professionals headed south during the winter months when the northern clubs were closed for the season, increasing the demand for new clubs and courses in the south. John Bredemus moved from the East Coast to Texas at this time; there he played a pivotal role in the design and construction of the state's early-twentieth-century golf courses and helped to organize the first Texas Open Golf Tournament (King and Trimble 1996:204).
The game of golf grew slowly in Texas, probably due to the great distances separating amateurs from one another and from the large golf centers in the East. While the states of New York and Massachusetts each had 150 golf courses by 1900 , Texas had only 5 courses at the turn of the century. San Antonio, Dallas, and Galveston had the earliest courses, with the first legally chartered golf club in Galveston in 1898 (King and Trimble 1996:204). In 1899, Austin built the state's first municipal course, the Hancock golf course (Alan Marburger, personal communication 1998). Interest in the game gathered momentum in Texas after the turn of the century. The establishment of amateur organizations and state tournaments and the construction of public courses such as San Antonio's Brackenridge Park golf course (1916) helped to popularize the game among Texans, and more courses wère built to accommodate new enthusiasts. In addition, oil strikes in the 1910 s and 1920 s prompted newly rich barons to bankroll private clubs with golf courses (King and Trimble 1996:204). This, in turn, spurred the development of exclusive suburban additions in their midst. Real estate developers across the state commonly promoted their subdivisions with attractions such as golf courses, parks, and man-made lakes.

All of these factors contributed to the state's increased interest in golf and probably led to John Bredemus's move to Texas in 1919. Bredemus came to San Antonio to teach mathematics at a high school where he later became principal. He quickly became a regular at Brackenridge Park, the city's public golf course. He probably met or was reacquainted with Del Rio businessman William Moore Abbey at Brackenridge, where Abbey played whenever he was in town (there is some evidence that the two might have known each other at Princeton). Abbey persuaded Bredemus to try his hand at building a golf course around the beautiful natural springs in Del Rio (Cornish and Whitten 1993:213).

The small border town of Del Rio was an unlikely candidate for one of the state's earliest courses. When the game was introduced in Del Rio, it was a novelty primarily found in cities large enough to support a leisure class. Most golf courses were associated with lush green grass and surrounding woodlands; however, Del Rio had the advantages of a year-round climate 
for golfing and the beautiful San Felipe Springs. The two principal springs feeding into San Felipe Creek, known as East and West Springs, bubbled to the surface within the boundaries of the course, creating little tributaries to San Felipe Creek. The natural springs and the rivulets they spawned served as the course's eight water hazards (Doug Newton, personal communication 1997).

No records have been found of Abbey's arrangement with Bredemus, but several eyewitness and published accounts document the construction of the golf course. Bredemus reportedly worked on site "with an army of laborers" for four or five months to lay out the course (Stafford 1925). Del Rio residents Doug Newton and Bud McKinney recall that Bredemus worked from "sunup to sundown" with an African-American man and several Hispanic helpers. McKinney was impressed with Bredemus's response to the challenge of turning the rocky land into golf greens. He remembered, "He gathered all the manure he could find from along the fences at the old cavalry post. That and river sand formed fairways and was piled up in hills and smoothed with scrapers (fresnos) for greens." According to McKinney, Bredemus also brought dynamite from Fort Clark to terrace areas that were too difficult for fresnos, using the fill to build the bases for the greens (Trimble 1991:14).

Local residents were curious about the work since most knew little about the game. Sixteenyear-old Doug Newton was riding his bicycle in the vicinity of the East Springs in 1921 when he saw a black man with a fresno and mule digging a ditch and mounding the dirt up at what is now the Number 8 green. Newton asked the man what he was doing and the man replied he was building something called a golf course. Young Newton decided he needed to investigate further. He played his first game on the San Felipe course when it opened in 1922 and became a life-long golfer (Doug Newton, personal communication 1997).

The golf course was an immediate success, due to William Abbey's promotion as much as Bredemus's design. Before he left Del Rio, Bredemus helped Abbey stage an exhibition match to officially open the course. They paid golf pros Jock Huchinson and Jim Barnes, who were en route to San Antonio on a nationwide tour, $\$ 500$ "to get off the train and show the locals how it was done." They played Bredemus and San Antonio Country Club pro, Tom Lally, in the exhibition (Trimble 1991:14).

Golf historians agree that the San Felipe course established Bredemus's reputation as a golf course architect. He went on to design courses and country club landscapes throughout Texas, and old Professional Golf Association (PGA) records show that " $80 \%$ of the early Texas courses" were Bredemus layouts (Trimble 1991:15). Among his more significant courses were Colonial Country Club (Fort Worth, 1936), Offat's Bayou (Galveston, 1932), Brae Burn (Houston, 1927), Hillcrest (San Antonio, 1926), and a major renovation of Cedar Crest (Dallas, 1927) in preparation for the National PGA Tournament in 1927. In Mexico, Bredemus was responsible for building beautiful courses in Acapulco, Guadalajara, and Monterrey, and expanding the course in Mexico City (Cornish and Whitten 1993:213; Trimble 1991:15).

In addition to his work as a course designer, Bredemus's contributions to golf in Texas include cofounding the Texas PGA in 1922 and proposing a Texas Open as part of a winter schedule of professional golf events. The winter golf tour through Texas and Louisiana became the forerunner of the PGA Tour, and the Texas Open became the PGA Tour's oldest continuous event. Bredemus died while expanding the course at Big Spring, Texas, in 1946, and he was posthumously inducted into the Texas Golf Hall of Fame in 1991 (Cornish and Whitten 1993:213; Trimble 1991:15).

The finished golf course (Figures 12 and 13) was described as "A very sporty course, and with its beautiful fairways, greens and shrubbery makes a very lovely park" (Del Rio Evening News Historical Prosperity Edition 1937, Section 6:1). The game quickly caught on and became an established pastime for Del Rio's professional and business class. Lawyers, bankers, doctors, and the larger merchants in town were the principal players. By 1924, Del Rio golfers were playing in tournaments and, in fact, William Campbell Abbey won the Princeton golf trophy (West Texas News 24 October 1924). Joe. Hendry, a native of Scotland, was the first golf pro and greens keeper at San Felipe Country Club; he held the position for about 40 years (Figure 14). $\mathrm{He}$ and his wife, Mary, came to Del Rio in 1922 (Del Rio News-Herald 5 June 1992). 
Turing the Great Depression; the country club organization fell on hard times. In 1934, the W. K. Ewing Company foreclosed on the San Felipe Country Club, including the eight acres of land on which the clubhouse and tennis courts

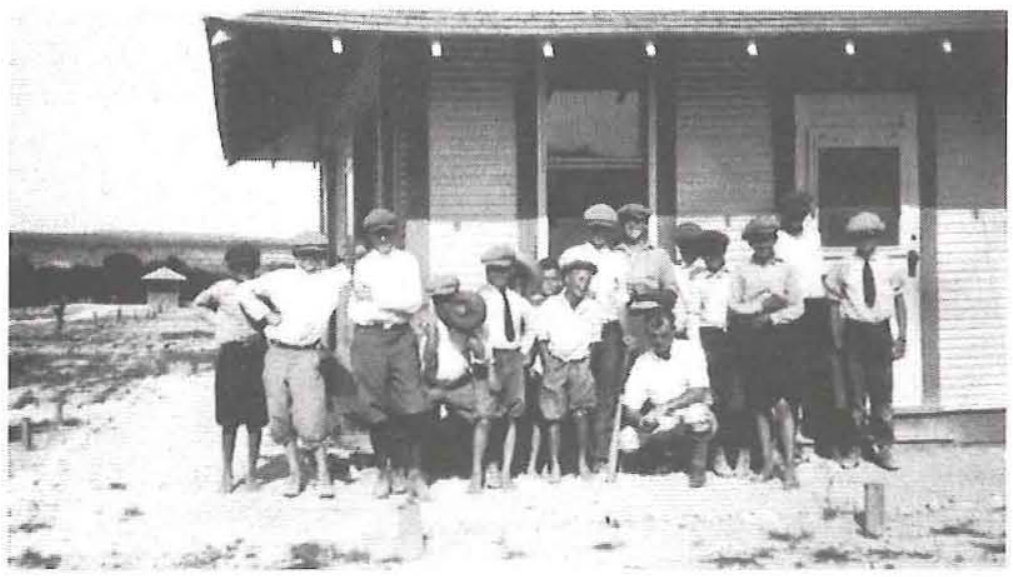

Figure 12. Caddies in front of the pro shop at the San Felipe golf course, ca. 1920s. Reproduced from photograph in the Doug Newton collection. stood. For a while only the golf club continued to operate (Val Verde County Historical Commission, vertical files). The golfers ran the course from about 1933 until 1947 (Doug Newton, personal communication 1997). However, on 25 January 1935, W. P. Wallace Jr., R. M. Crosby, and T. M. Miller chartered a new corporation called the Del Rio Country Club, an organization formed as a social club (Del Rio Country Club 1935). Thus two different clubs existed: the Del Rio Country Club, a social organization; and San Felipe Country Club, solely a golf club (Doug Newton, personal communication 1997). By 1938 the two organizations were firmly established, with separate directors for each. The Del Rio Country Club was headed by president William P. Wallace, an attorney and vice president of the First National

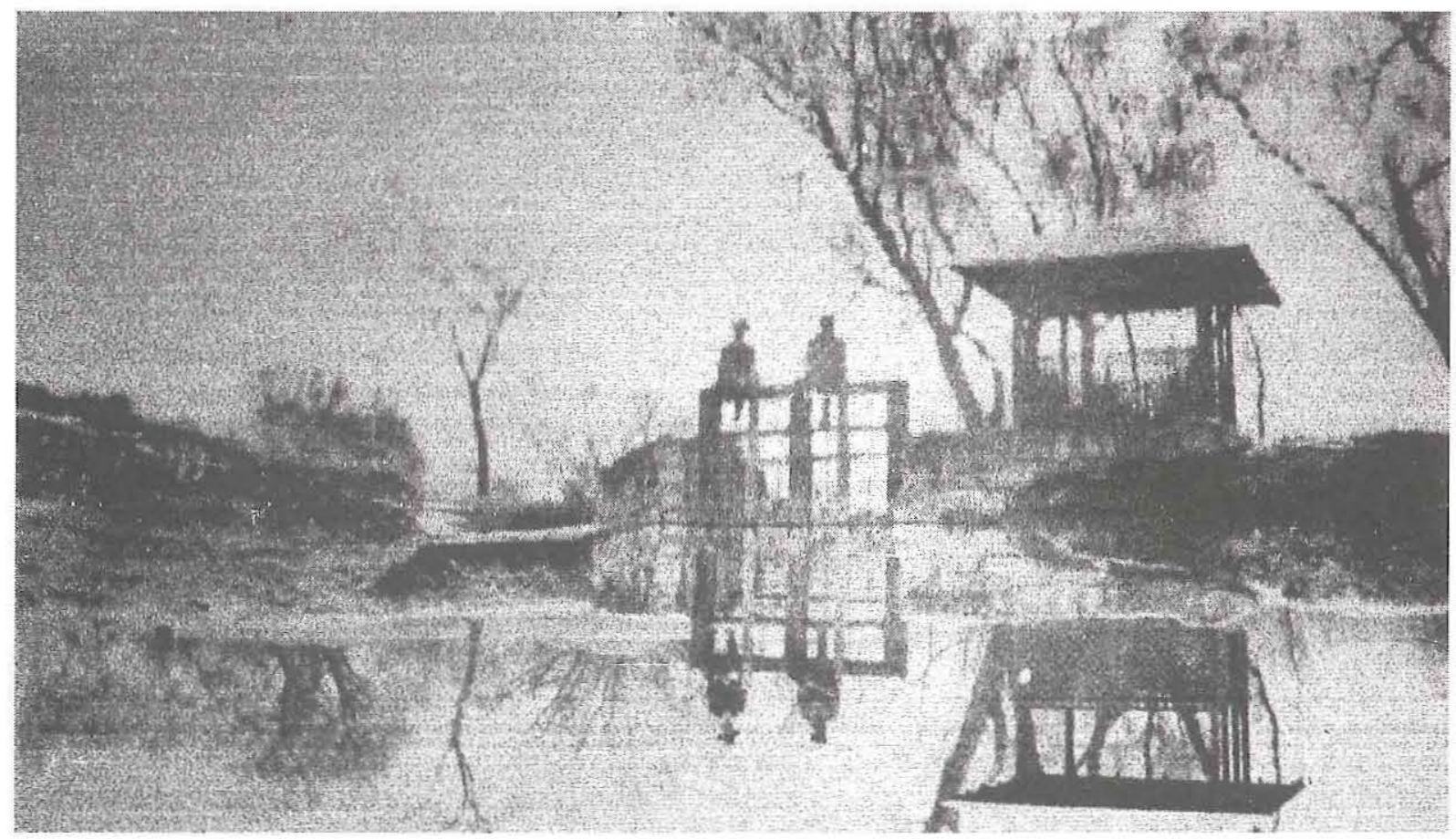

Figure 13. Kiosk on the San Felipe golf course, ca. 1920s. Photograph label indicates that this kiosk was near the "Old \#5" tee, which suggests that it was located near the East Springs. Photograph from the Vel Verde County Historical Commission, vertical files. 


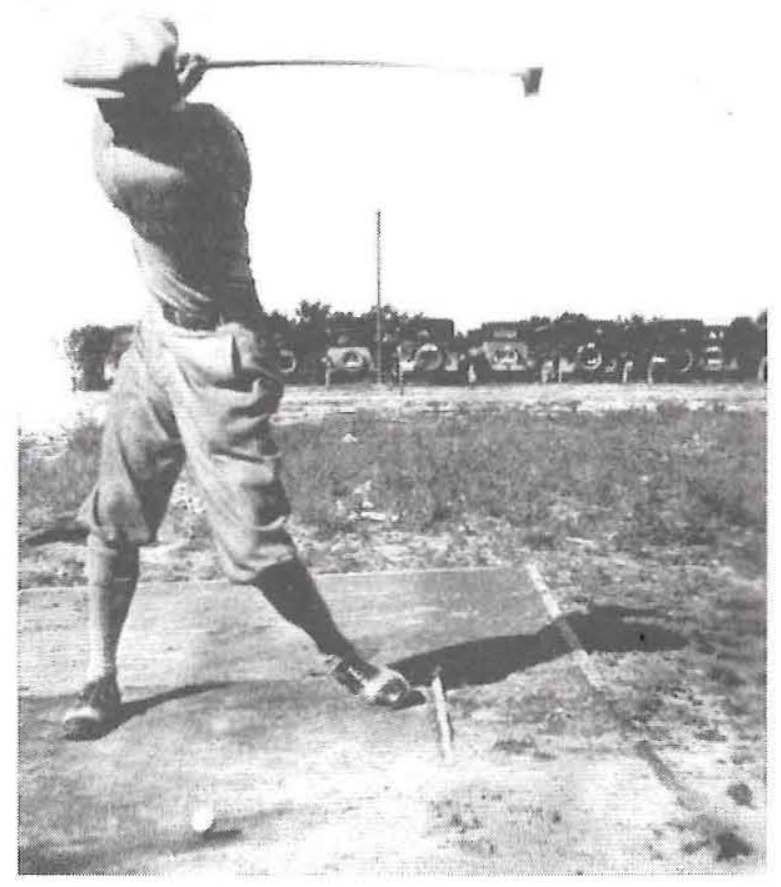

Figure 14. San Felipe Country Club golf pro Joe Hendry, ca. 1924-1925. Reproduced from photograph in the Doug Newton collection.

Loan Company. The San Felipe Country Clubthe golf club-was led by president Russell $\mathrm{H}$. Hurd, the local manager of the Texaco Gas Distributing Company (Del Rio City Directory 1938). The two clubs overlapped somewhat in membership, all being the professional and business elite of Del Rio.

\section{Postwar Developments}

In 1947, Claude Hudspeth Jr., a wealthy rancher on the Devils River, said he would give $\$ 10,000$ toward the construction of a new clubhouse if Del Rio Country Club members matched the money. They did, and construction began in 1947 (Doug Newton, personal communication 1997). The new clubhouse replaced a large elevated water tower that had stored spring water for the railroad ( Del Rio News-Herald 5 August 1976). A swimming pool and tennis courts were built on the country club grounds by 1953 (Del Rio Water Utilities Commission Minutes 1953:59).

Despite construction of the new clubhouse, the social and golf club organizations remained separate. The Del Rio Country Club membership continued to use the former officers' club for various activities until about 1962. After that, it lay vacant for several years before it burned prior to 1972 (Del Rio News-Herald 28 December 1972; Doug Newton, personal communication 1997).

In 1966, the clubhouse began the first of several renovation and enlargement projects. In 1975, architect David Bradley of San Antonio undertook alterations and several additions to the building. These were followed by other improvements overseen by Gutierrez \& Associates of Del Rio (San Felipe Country Club Historical Files and Architectural Plans). The clubhouse has continuously evolved beyond its original 1947 appearance and retains little of its original design and architectural integrity.

On 2 April 1966, the separate Del Rio and San Felipe Country Clubs merged into a single organization, the San Felipe Country Club. The articles of incorporation and bylaws of the San Felipe Country Club survived the merger, but the new Board of Directors was comprised of 5 members from the Del Rio Country Club and 5 from the San Felipe Country Club, with an eleventh member to be chosen by the other 10 directors (San Felipe Country Club 1966). The organization remains essentially unchanged since the merger.

Today the club has about 300 members. Doug Newton continues to enjoy the game of golf there at the age of 93. According to Mr. Newton, the nine-hole course is considered a tricky one, but it is known especially for its natural beauty, with the creeks formed by San Felipe Springs serving as water hazards on all but three of the holes. San Felipe Country Club has been the center of social life for the professional and business class families of Del Rio from its construction in 1921 to the present (Doug Newton, personal communication 1997).

\section{Descriptions and National Register Assessments}

Two unrelated properties lie within the golf course-the East and West Springs pumping stations of the City of Del Rio 
waterworks. These features are discussed later in this chapter.

The San Felipe golf course is a nine-hole, par-three golf course built around three of the largest springs in the San Felipe Springs group (Figure 15). Designed by golf course architect John Bredemus in 1921, it is remarkable for its crystal-clear water hazards formed by springfed ponds and the creeks that flow from them. Native and introduced trees and riparian vegetation flank the natural waterways and contribute to the graceful composition of the course. Concrete, asphalt, and tamped sand walkways lead golfers in a generally clockwise circuit that crosses several prongs of the creek before looping back to the clubhouse. Small arched bridges allow golfers to ford the meanders of the creek as they pursue the course, and kiosks provide sun shelter at the more exposed tees. Each hole features a slightly different landscape motif, ranging from oak-shaded tees and lush fairways to native mesquite and desert sand punctuated with prickly pear. Water lilies and thick stands of carrizo, a native cane, grow along portions of the creek. Astone pond enclosure and irrigation head gate near the No. 3 green and remnants of the Bedell Ditch, an early-twentieth-century acequia originally stretching between East and West Springs, are among the earliest built features on the site and may predate construction of the golf course.

Bredemus altered the original desert terrain by using dynamite to carve terraces from the hard limestone and caliche slopes of the creek beds. A team of laborers then shaped and smoothed the ragged contours with mule-drawn fresnos (scoops). The pulverized stone was used as fill to create level bases for the greens and tees, which Bredemus then covered in horse manure collected from the adjacent abandoned cavalry post to provide a medium for growing grass. The layout and contours of the course remain unchanged from their original construction. Bredemus's emphasis on native landscaping has been followed to a large degree, particularly in the drier northern section where the course grades almost imperceptibly into the desert.

Alterations to the original design include the addition of trees, substitution of metal bridges for

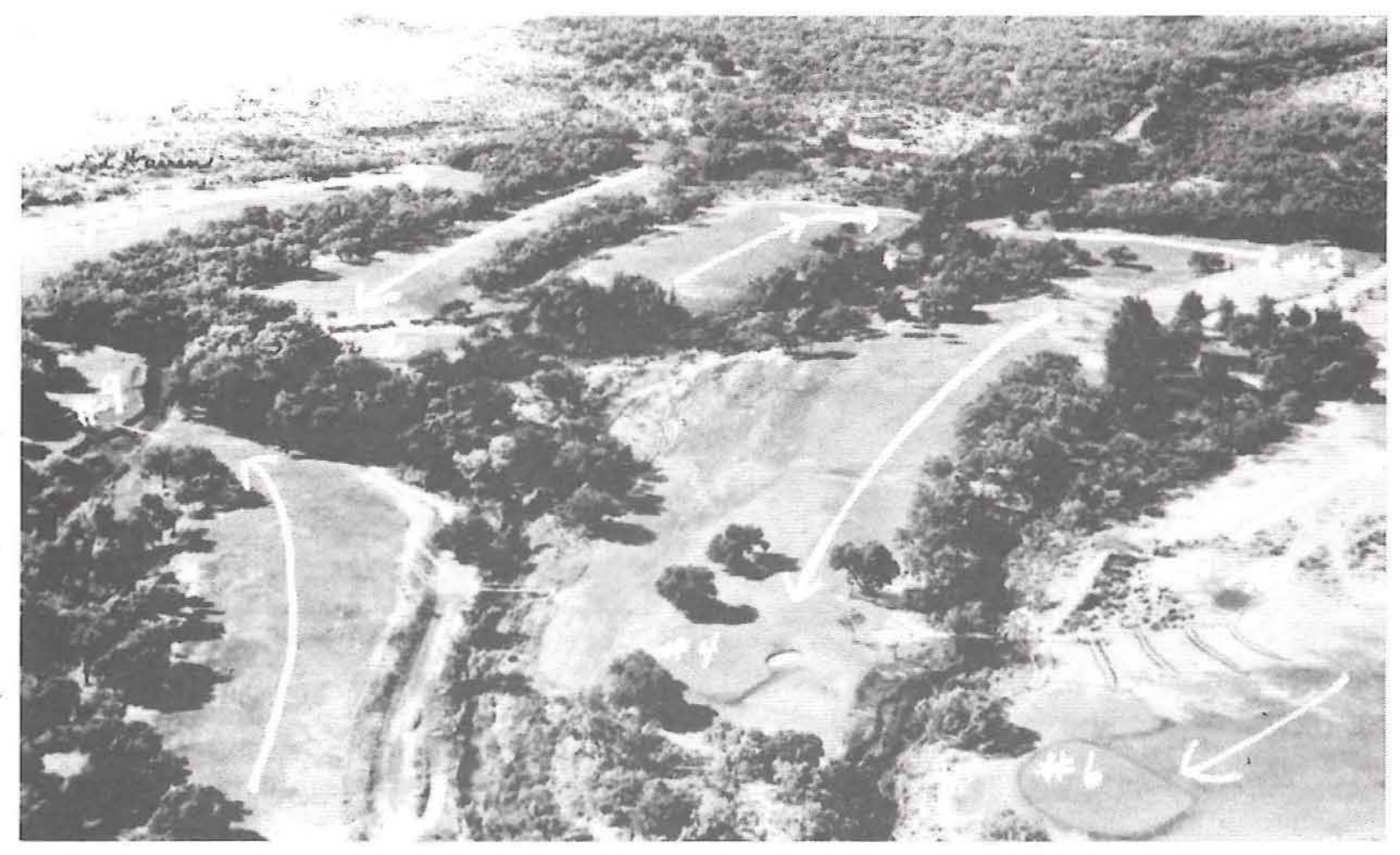

Figure 15. "Air View of Golf Course, Del Rio, Texas" by R. L. Warren, ca. 1948. Reproduced from an aerial view photograph in the Doug Newton collection. 
the original wooden ones, replacement of gravel paths with concrete and asphalt walkways, and replacement of several early pyramidal-roof, frame-and-lattice-work kiosks (see Figure 13). Until World War II, the only trees on the course were the native mesquite and ceniza. Paul Krussenberger, a local resident, collected willow, cottonwood, and pecan trees from along the Val Verde irrigation canals and planted them throughout the golf course. These are now mature trees that, along with the native trees and plants that line the natural waterways, constitute the major arboreal vegetation on the course. An occasional palm tree may date from this period as well. Originally the course had Bermudagrass; now, it has a mixed tiff green with Bermudagrass still predominating the northern section above the springs (Doug Newton, personal communication 1997). The single change in the waterway occurred when Lake Amistad was created. What once was a seasonal stream lying between the East and West Springs has become a permanent one under hydrostatic pressure from the giant reservoir.

The San Felipe golf course appears to be eligible for listing in the National Register of Historic Places (NRHP) under Criteria $\mathrm{A}$ and $\mathrm{C}$ as a historic landscape at the local, and possibly state, level of significance. It was the first of many Texas courses designed by John Bredemus, who is considered to be Texas's first golf course architect ${ }^{14}$ and one of the pioneer promoters of the game in the state. The golf course retains its original layout and early landscape features to a remarkable degree; incorporating the natural creeks stemming from San Felipe Springs and the native vegetation of its desert and creekside landscape, the course is an exemplary model of the prevailing golf course design trends of the early twentieth century. The San Felipe golf course also played a significant role in Del Rio real estate and land promotion in the 1920s and 1930s.

In January 1998, these assessments were presented to the National Register Division of the Texas Historical Commission (THC). It was recommended that since any new construction within the golf course has the potential to

\footnotetext{
${ }^{14}$ Other Texas courses predate Del Rio's San Felipe course, but they were not architect-designed according to golf historian Frances Trimble (1991).
}

negatively impact its eligibility, the design of such construction should be reviewed by the State Historic Preservation Officer to ensure compatibility with the historic landscape. After reviewing the preliminary report, THC staff concurred with this assessment.

The present clubhouse of the San Felipe Country Club was constructed in 1947 and altered significantly over the years through numerous additions and remodeling. It does not retain its original design, orientation, materials, feeling, or any other significant elements that might make it NRHP eligible.

A swimming pool, tennis courts, and picnic grounds with fixed tables and seats also occupy the country club grounds. The pool and tennis courts were built in 1952. To the east of the country club lies an enclosure surrounded by a chain link fence containing. a number of long, low, rectangular frame golf'cart sheds. The first one was built about 1956 and others have been added over the years. A pro shop, built ca. 1980, is located off the front parking lot between the clubhouse and the No. 1 tee. Built primarily of concrete block, it replaced an earlier frame pro shop that may have been part of old Camp Michie. None of the auxiliary buildings and features associated with the country club meet the age requirement for listing in the National Register. Furthermore, the attendant features have all been modified since their construction so that none retain their original integrity.

\section{LOWE RANCH}

\section{History}

Herman Jasper "Jap" Lowe was the son of James W. and Alice Chapman Lowe, who moved their family in a covered wagon from McMullen County to Del Rio about 1900. James Lowe was a cattle rancher, but his family lived in the city. Jap Lowe attended local schools and joined the military at the beginning of World War I. He was commissioned a second lieutenant in the Signal Corps, the forerunner of the Army Air Corps, and qualified as a pilot in 1918 . When he returned to Del Rio after the war, Lowe started a series of businesses with the slogan "I Buy Anything and Sell Everything." He married Braddie Garner, a local teacher and school principal, in 1921, and they worked together in Lowe's various enterprises for the rest of their lives. In 1923, 
they opened Lowe's Tourist Home near the intersections of Texas, E. Broadway, and E. Ogden streets-on what was then State Highway 3 (the Eagle Pass Road)—near the El Paso-San Antonio Road. When it opened, the tourist court was the only one of its kind between San Antonio and El Paso. The Lowes added cabins, a neighborhood store, cafe, and service station to the complex. The place became a mecca for motorists traveling across the Chihuahuan desert from the 1920s through the 1950s (Zertuche 1985:154).

Shortly after they started the tourist court, the couple bought a 1,035-acre parcel of land bordering the city's far northeast limits from ranchers Will and Walter Whitehead. According to Mrs. Lowe's niece, Louita Wilson, Jap Lowe was "a driver, messenger, secretary, friend and confidante" for the Whiteheads (Del Rio News-Herald 2 June 1983:14), and Val Verde County deed records show numerous transactions between the Lowes and Whiteheads. Jap and Braddie Lowe built a house on this parcel around 1925. Sitting high on a hill overlooking Del Rio in the midst of the desert landscape, the property became known as the Lowe Ranch. Lowe was not really a rancher, however. In the 1940s, his letterhead indicated that he owned and operated the tourist home, filling station, grocery, fountain and lunch room, and at the same time he was a lamb buyer, wool and mohair buyer, wholesale Shell distributor, and Allstate Tire dealer (Del Rio News-Herald 2 June 1983:14). Lowe used the ranch to warehouse animals that he bought in lots for later resale or trade. He kept chicken coops, corrals, and other animal pens on the ranch to hold whatever animals he might happen to have at the moment (Roebuck Daughtrey, personal communication 1997). The Lowes lived at the ranch but operated their various businesses from their headquarters at the Tourist Home.

On 29 September 1926, soon after the Lowes built their ranch house, they sold a 1-acre parcel on the highest point of the ranch to the City of Del Rio for $\$ 1,000$ (Deed Record 62:348-350). The city wanted to pump excess water from the pumping station, then located just north of the railroad tracks on San Felipe Creek, to two million-gallon concrete reservoirs to be built on the site. Del Rio was experiencing a population boom and the city needed to have adequate water to serve the community. A 60 -ft-long strip extending from the south line of Lowe's Addition to 13th Street was sold to the city in the same transaction for a road from the city streets through the Lowe property to the 1-acre tract. In addition, the Lowes conveyed a perpetual easement to lay and maintain water mains necessary for the water system. The Lowes agreed to take care of all overflow water in the overflow pipe at the north line of the 1acre tract. Del Rio agreed to install and maintain a standard fire plug at a point $400 \mathrm{ft}$ from the 1-acre tract, and at the same time a water main was placed across the lands to connect an existing 4-inch water main on the Lowes' property to the main line to provide them with water. The city also agreed to fence the second tract with "42 inch Page sheep fence with two barb wire on top" (Deed Record 62:348-350).

One of Jap Lowe's brothers built a small frame house on Braddie Lane between the ranch house and present Bedell Avenue, but it is no longer standing. The Lowes lived at the ranch until Jap Lowe's de'ath in 1955. After her husband's death, Braddie lived at least part of the time at the Tourist Home. She continued to run the family businesses, which had begun to slow down after World War II. Traffic died down after the highway was rerouted away from the store and other motels and tourist camps were built. In 1952, the construction of the Avenue F overpass cut the business off from through traffic. The cafe closed in the early $1950 \mathrm{~s}$, but the store and filling station operated until the 1970s. Braddie Lowe died in 1978 (Del Rio NewsHerald 2 June 1983:14). The Lowes had several nieces and nephews but no children. Louita Wilson became the administrator of the Lowe estate in 1972, while Braddie was still alive ( $\mathrm{Del}$ Rio News-Herald 25 October 1972:1). Ms. Wilson was active in historic preservation activities and served as the Val Verde Historical Society chairman for a number of years.

The Lowe Ranch property recently sold to a San Antonio buyer. The old house was demolished in 1997, and a new house was built on part of the original site later that year (Lee Lincoln, personal communication 1997). Part of the Lowe's Tourist Home complex stands vacant at the corner of E. Ogden and Texas Streets near the junction of U.S. Highways 90 and 277.

\section{Description and National Register Assessment}

The Lowe Ranch is recorded as one of two historic components at site 41VV1820, with the 
Bedell tanks being the other. The components are in close proximity and overlap to a minor extent. The Lowe Ranch is the southern of the two components. Both are located on a prominent hilltop in the northeastern portion of Del Rio, west of and overlooking San Felipe Creek about 1 mile northwest of the East and West Springs. The Bedell tanks are discussed below.

The Lowe Ranch was not occupied or actively utilized until the mid-1920s, when Herman "Jap" Lowe and his wife, Braddie Garner Lowe, built a house, outbuildings, fences, and animal pens on the property. It was occupied until ca. 1978, after which the structures were abandoned and fell into disrepair. At present, the ranch component consists primarily of abandoned structures and copious twentiethcentury refuse. The original Lowe Ranch house, which is depicted on the 1972 USGS topographic quadrangle map, was torn down in 1.997 and replaced by a new brick house on the same site. Several other ranch-related structures are still standing in various states of ruin.

The largest of the standing structures is located halfway between the new house constructed in 1997 and the Bedell tanks complex. This structure probably functioned as a dwelling at one time and was equipped with electricity and indoor plumbing. However, the large rough timbers used for interior framing suggest that it was converted from a barn or similar ranch structure. The house is a single-story frame structure with two floor levels built at different times. The original section is set on a substantial poured concrete slab foundation. Exterior walls are frame, with board and batten sheathing. An additional room, also of frame construction, was added to the northern end of the original building. The floor of this addition is higher than the floor of the original building and is supported by piers. Abandoned for some time, the building is deteriorating rapidly and large sections of the wooden roof and walls have collapsed.

All other surviving structures are located to the west of this building on the opposite side of a dirt road that bisects the site. Other structures include a frame privy with a concrete chamber, a wood-post and wire fence, an animal pen, a cattle loading chute, and a chicken coop. Copious twentieth-century refuse is scattered throughout the area. Large appliances and equipment (e.g., a freezer and metal air ducts), insulated cans possibly used as milk containers, and a large quantity of milled lumber are examples of this refuse. The domestic artifact scatter (ceramics, glass, etc.) is sparse, and the soil is extremely shallow, suggesting little possibility for subsurface deposits.

Existing cultural resources at the Lowe Ranch will not be affected by the proposed water treatment plant project. In any case, though the site was continuously occupied for more than half a century, it no longer retains sufficient historic or architectural integrity to be considered eligible for National Register listing. The Lowe family did not graze livestock on the property, and sheds and corrals existed merely to hold animals prior to shipping. Therefore, such resources served secondary roles on the "ranch"; the primary purpose of the site was as a country house for the owners. Since the original house has been torn down and other related structures are in various stages of ruin, the site no longer conveys its primary historic purpose. In addition, the site has no potential to yield important information through archeological investigation. It is recommended that the Lowe Ranch be considered ineligible for listing in the NRHP.

\section{DEL RIO WATERWORKS}

\section{History}

The abundant water at San Felipe Springs attracted countless nomadic people-Indian groups; Spanish, Mexican, and American explorers; and military personnel-before the first permanent settlement in historic times occurred near the springs. After the Mexican War put the springs under U.S. jurisdiction, they became an important water stop on the westward trail for travelers, surveyors, and military expeditions. The springs prompted the establishment of the first U.S. military outpost in the vicinity of present Del Rio about $1857 .{ }^{15}$ This outpost

\footnotetext{
${ }^{15}$ Fort Clark was established on 15 June 1852 about 30 miles east of Del Rio. Many secondary sources relate that an outpost of Fort Clark was established on San Felipe Creek, in the vicinity of present Del Rio, about 1857 (Jones 1976:420). However, no official records have been found to verify that claim.
} 
served as a link in the chain of frontier forts to protect travelers and encourage settlement in the newly acquired western territories.

Gen. Zenas Bliss observed the first known American settlers, members of the Johnson family, living near the springs in 1859 (Jones 1976:419). Nothing further is known about this family, but by the end of the Civil War an American named James Taylor and his wife had built a fortified hacienda on the banks of San Felipe Creek. They chose the spot for the water and were instrumental in building an irrigation network from the creek by 1869 . Their efforts formed the basis of the San Felipe Agricultural, Manufacturing and Irrigation Company, Texas's oldest irrigation corporation, and their success attracted other settlers to the area (Jones 1976:5).

By 1876, the army at Fort Clark established an outpost known as Camp San Felipe along the creek, about a mile upstream from the TaylorLosoya hacienda. Renamed Camp Del Rio in the 1880 s, the cavalry post was more permanent than its predecessor, a fact that contributed to the survival of the nearby civilian community (Jones 1976:430-431). Connected and sustained by San Felipe Creek, a community spread out along its banks between the hacienda and cavalry post. The census counted only 50 people living at Del Rio in 1880. That situation changed when the railroad arrived in 1883, precipitating a major population increase and community development.

\section{Del Rio Water Company}

The earliest settlers lived within walking distance of the springs or creek, or along the irrigation network. Both the military outpost and the adjacent community lay within the James Mitchell Survey No. 183, which included most of San Felipe Creek from just below the main springs to the Rio Grande. Men called barrilenos collected water from the springs or the stream and carried it to customers in wheeled barrels. When the railroad brought hundreds of new residents and scores of businesses to San Felipe del Rio, a more sophisticated water delivery system was needed. Private developers established the Del Rio Water Company in 1883, shortly after the railroad made its appearance. The company filed incorporation papers the following year, predating the creation of a municipality at Del Rio by more than two decades (Garrett 1914).
Little is known about the company's operation before the city was incorporated and began to record its business. The stated purpose of the company was to furnish water to the people of Del Rio solely for domestic purposes. Operating under a permit granted by the Val Verde County Commissioner's Court (after it was established in 1885), the company did not engage in any irrigation activities and did not own canals or ditches (Del Rio City Commission Minutes 1905:1:22; Garrett 1914). It is not clear what services the company provided in its early years; according to Sanborn Fire Insurance maps, the city of Del Rio did not have a waterworks plant until 1906. A notation on the 1900 edition of the Sanborn Del Rio maps states simply, "Water Facilities: Not Good." In 1905, Sanborn investigators indicated that the city, with a population of about 2,000 , had no fire protection other than' a bucket brigade and a single hook and ladder truck, but planned a waterworks "soon." From these notes, it appears that the Del Rio Water Company did not install a pumping plant or have water mains until 1906, after W. B. Garrett and Ed De Montel had acquired the company (in 1905) and the population had increased to nearly 5,000 (Sanborn Fire Insurance Company 1900, 1905, 1909). Other information, however, indicates that the Del Rio Water Company had a rudimentary system that was completely overhauled and upgraded in 1906.

\section{MUNICIPAL FRANCHISE}

When the city was incorporated in $1905^{16}$, utilities (e.g., Electric Light \& Ice Plant and the Del Rio Water Company) that had been operating under county permit sought legal status under the new municipal government to continue serving the community. Shortly after the first city commission met on 30 June 1905, Judge J. G. Griner, the attorney for the Del Rio Water Company, submitted a proposition to the council requesting a franchise. The company needed the city's permission to use the streets to lay off

\footnotetext{
${ }^{16}$ The New Handbook of Texas states that Del Rio incorporated 15 November 1911 (Overfelt 1996:578), but City of Del Rio Commission minutes date as early as 30 June 1905.
} 
water mains for fire protection to "the business and residence interests of the city and to supply a large number of other inhabitants of the city now without water for drinking and other purposes" (Del Rio City Commission Minutes 1905:1:22). In exchange for a proposed 30-year franchise, Griner promised that the company would maintain the system, mains, pipes, and laterals of the waterworks plant and its system. The company proposed to install new water mains 4-8 inches in diameter, to install new fire plugs throughout the city for the cost of materials, to furnish water for fires, to furnish water to the public for domestic purposes, and to repair damage to the streets caused by laying or operating its mains and laterals. The new city commission unanimously passed Griner's proposal (Del Rio City Commission Minutes 1905:1:22).

\section{DEL RIO WATERWORKS PUMPING STATION}

By the following year, the Del Rio Water Company had a brick building immediately north of the Galveston, Harrisburg and San Antonio Railroad tracks, about a mile and a quarter northeast of the courthouse (Sanborn Fire Insurance Company 1917). The pumping equipment was installed in 1906, but it is not known whether the company constructed their building or if the building predated the water pumping plant. In old photographs the pump house, which was demolished in 1977, looks more like a domestic property than an industrial one. It was a large rectangular building with a tin hipped roof and five 4/4 double-hung windows on each side. Anearly full-width frame porch covered the west entrance (Del Rio NewsHerald 28 February 1985; Sanborn Fire Insurance Company 1917-1930). The porch and windows in particular lend a domestic feeling to the building, characterizing it as a dwelling of some type rather than a utilitarian structure. Its size and proximity to old Camp San Felipe, and later Camp Michie, and its similarity to the officers' barracks that later served as the country clubhouse, suggest that it may have been associated with the military post, possibly a former barracks.

The building was outfitted with pumps and the floor was covered with concrete. By 1914, when the city population numbered $6,000-7,000$, the Del Rio Water Company boasted a system with 14,500 ft of 8-inch cast iron water mains, 20,000 ft of 4-inch cast iron pipe, 40,000 ft of 2inch galvanized pipe, and about $6,000 \mathrm{ft}$ of 1.5 inch pipe. It had approximately 20 double hydrants (Sanborn Fire Insurance Company 1917). It had 650 subscribers, with 400 water meters installed throughout the city. There was a standpipe next to the pump house, and extra water was pumped to a 200,000-gallon steel water tower near the intersection of Broadway and Fifth Streets. In 1914, the company petitioned the Texas Board of Water Engineers for the construction of a second 200,000-gallon reservoir to be located next to the pumping plant prong of San Felipe Creek (Garrett 1914). The petition was granted and a second water tank was installed near the pump house.

The waterworks plant used a combination of gravity and direct pressure. The source of its supply was a 20 -ft-diameter, 38 -ft-deep well at the pump house, also filled by seepage from the creek. The pump house contained one centrifugal pump with a capacity of 850 gallons per minute driven by a Fairbanks-Morse 80 -hp oil engine and one centrifugal pump with a capacity of 650 gallons per minute driven by a Fairbanks-Morse 60 -hp oil engine. The Del Rio Water Company owned a 200,000-gallon steel water tank elevated $65 \mathrm{ft}$ on a steel tower at the corner of Main and Greenwood Streets, where the base of the tower was about $50 \mathrm{ft}$ above the ground. Gravity pressure in the business section of town was about 50 pounds with direct pressure in case of fire. The company operated constantly during a six month period that included the summer months, while it ran only in the daytime the remainder of the year. One man was on duty during operating hours (Sanborn Fire Insurance Company 1917).

\section{East Del Rio/East Side Water Company}

In addition to its pumping plant along the railroad tracks, the Del Rio Water Company also owned a 4-acre parcel of land downstream from the pump house that straddled San. Felipe Creek, immediately below the Tardy Dam (Roberts 1914). The parcel appears on the map submitted to the Board of Water Engineers, and both Garrett's petition and the map indicate that it was part of the holdings of the Del Rio Water 
Company. This is unusual because two years later (1916) the 4acre site became the location of a second, unrelated water company known as the East Del Rio or San Felipe Water Company. This company formed to serve the primarily Hispanic community on the east side of San Felipe Creek (Sanborn Fire Insurance Company 1917). It is not known if the Del Rio Water Company sold or leased the site to this second company. ${ }^{17}$

City commission minutes confirm that W. $\mathrm{H}$. McKinney, of Kinney County, asked the city for permission to establish a second water company to serve the community east of San Felipe Creek in 1912. McKinney testified that a large portion of the city lying east of the San Felipe creek had no water service, and proposed to build and maintain a system to serve that community and any new additions to the city of Del Rio for a period of 15 years. He also asked to establish an irrigation system. He agreed to sell the pumping plant, water tank, and principle main to the city at any time it wished to purchase them. With council's approval, Mayor George McMullan signed an amended proposal that limited McKinney's operation to 10 years (Del Rio City Commission Minutes 1912:1:73).

McKinney's motivation may have come from his interest in developing that portion of town. Around the time he requested the franchise for the East Del Rio Water Company, he also platted an addition to the city of Del Rio, McKinney's Addition. It lay to the south of San Felipe Heights, an addition that adjoined the eastern

\footnotetext{
${ }^{17}$ It may be that the 4-acre tract of land next to the Tardy Dam was the site of the earliest waterworks, and in 1905 when Garrett and his business partner, Ed De Montel, purchased the Del Rio Water Company, they moved from the earlier site to the railroad track site. Documentation seems to indicate that there were storage tanks and pumping equipment in the vicinity of the 4-acre tract before 1905; that area would have been much closer to the original community and close to the electric light and ice plant, as well. Another piece of evidence is that all of the East Del Rio Water Company's water lines until the 1920 s were wooden pipes. A new system most likely would have installed metal water mains. Thus, the Del Rio Water Company may have sold the old works to W. H. McKinney, who put it back into operation in 1916.
}

section of the old town and the area south of San Felipe Creek. McKinney's Addition was more or less a southern extension of San Felipe Heights, with 19th Street as the northernmost boundary. Within the 13-block addition, 19th Street was known as McKinney Street (Sanborn Fire Insurance Company 1917).

McKinney either purchased or leased the waterworks equipment on a parcel of land owned by the Del Rio Water Company, just downstream from the Tardy Dam. Shortly after the city granted McKinney's request for a separate waterworks, the franchise was acquired by the East Side Water Company, led by president W. E. Weathersbee. The city retained its option to purchase the company but extended the period to 10 years from its acquisition by the East Side Water Company, effective 14 September 1915, rather than 10 years from McKinney's original approval in 1912 (D'el Rio City Commission Minutes 1915). Weathersbee petitioned the city to allow him to build a larger pumping station, larger mains and laterals, and more efficient equipment, citing increased demand for water and better fire protection (Del Rio City Clerk Files, Petition 12 August 1915).

The East Side Water Company began operating in 1916. The pump house was a one-story frame building with a metal roof and shed on the south (or east) bank of San Felipe Creek. It was located about half a mile north of Brown's Plaza, a central meeting place for Del Rio's Hispanic community on the east side of town, and about a half mile downstream from the Del Rio waterworks plant at the railroad tracks. A reservoir for the East Side waterworks lay about a mile southeast of the plant, on McLymont Avenue beyond the southern limits of the city and immediately south of McKinney's Addition (Sanborn Fire Insurance Company 1917).

The waterworks used both gravity and a direct pressure system, with a 12 -ft-diameter and 20-ft-deep well at the pump house filled by seepage from San Felipe Creek. The pump house contained one 8-inch Smith-Vaile Triplex pump driven by a Krueger-Atlas 35 -hp fuel distillate engine. A 500,000-gallon concrete reservoir stored excess water at a location $6,300 \mathrm{ft}$ southeast of the pump house and elevated $130 \mathrm{ft}$ above the level of the pump house. The system produced gravity pressure of about 55 pounds with direct pressure in case of fire. It included 6,400 ft of 8-inch, 4,385 ft of 6-inch, 
and 1,326 ft of 4 -inch wooden water mains and 8 double hydrants (Sanborn Fire Insurance Company 1917). The concrete reservoir is still extant (Jesse Velasquez, personal communication 1997).

\section{City Involvement}

After World War I the City of Del Rio began to consider purchasing the Del Rio Water Company. W. B. Garrett, president of the water company, submitted a proposition to sell to the city on 24 March 1919. He offered three different proposals for a fair valuation of the property, requesting that a "practical waterworks man and not so-called constructing engineers" make the property appraisal. He offered to sell the plant, its equipment, pipelines, and water tower for between $\$ 82,500$ and $\$ 85,000$ (Del Rio City Clerk Files, correspondence 24 March 1919). The Alamo Iron Works appraised the water plant, without the land, at $\$ 113,238$ (Del Rio City Clerk Files, M. W. Holmgreen correspondence 4 June 1919). The 4-acre parcel on which the East Side Water Company operated was valued separately at $\$ 6,000$, but was excepted from the deal since the East Side company still operated from the site. The Del Rio Water Company conducted its own appraisal and valued the company at $\$ 113,926.50$, also not including the real estate (Del Rio City Clerk Files, W. B. Garrett correspondence n.d.).

At the same time the city was engaged in negotiations for the sale of the water company, it approached Elizabeth (Mrs. G. Bedell) Moore of San Antonio with a plan to sell or lease the springs to the city for an improved water system. She agreed that the city deserved a good water system, but said she had not been inclined to allow the private Del Rio Water Company to pump directly from the springs and then charge the citizens of Del Rio for water that the company received free or mostly free. She did approve of the city doing such work, and asked Judge J. J. Foster of Del Rio to present the matter to the citizens of Del Rio on her behalf (Del Rio City Clerk Files, Moore correspondence 17 April 1919).

By 8 March 1920, the sale of the company had been completed and Mayor C. O. Fokes, acting on behalf of the City of Del Rio, requested that the city petition the county court for permission to run a water pipe from the plant to the East Springs (Del Rio, City Clerk Files, correspondence 8 March 1920). Until this time, water had been pumped from the stream and not directly from the spring head. Frank S. Taylor, a consulting engineer from Austin, designed a 25 -ft reinforced concrete flume to run from the spring to a clay pipe to the pumping plant on the railroad frontage (Del Rio City Clerk Files, correspondence 3 May 1920). Sanborn maps show that a 20 -inch water pipe was installed to run water from the East Springs to the plant by 1924 (Sanborn Fire Insurance Company 1924).

Once the city acquired the waterworks, it began improving and enlarging its system to keep up with the demand for water. Almost as soon as it took over responsibility for the system, the city began what would be a continuous process of maintenance, repair, replacement, and expansion of waterworks facilities. In fact, waterworks and road improvements projects consumed the largest portion of the city commission's time and funding priorities until after World War II, when a separate water board was established to free the city commission to address other business. As an example, one of the largest, most expensive city projects in 1922 involved a $\$ 32,500$ waterworks improvement plan (Del Rio City Commission Minutes 1922:2:23). In 1921, the city set water rates for users for the first time to help defray costs. The charge for the first 5,000 gallons was $\$ 1.50$ (Del Rio City Commission Minutes 1921:2:1).

The city pump house remained at the railroad crossing location for another 15 years. In 1924, at the height of the postwar development boom in Del Rio, the city still had two separate water companies, the city-owned Del Rio Water Company and the smaller, privately owned East Side Water Company. The city company estimated its consumption at 700,000-gallons per day and contained about 25 miles of water mains of various sizes and 47 double and triple hydrants. The East Side company had only 3.5 miles of wooden water mains and only 6 double hydrants; its daily consumption was unreported (Sanborn Fire Insurance Company 1924).

In 1924, the city commission voted to repeal the 1915 ordinance granting the East Side Water Company its 10-year franchise to operate waterworks. The move anticipated the city's plan to purchase the system, but it allowed the private company to continue its operations in 
the meantime, with the city setting user rates (Del Rio City Commission Minutes 1924:1:113).

In 1928, the city embarked upon its largest waterworks improvement project to date. The commission authorized the issuance of scrip warrants not to exceed $\$ 125,000$ to fund the project. It also levied a tax to create a fund for payment of the scrip (Del Rio City Commission Minutes 1926 and 1928:2:293). Improvements included purchasing new equipment for the city pumping station and building two concrete water reservoirs on land leased from Jap Lowe.

\section{BEDELL WATER TANKS}

Improvements and repairs of the city waterworks throughout the 1920s included repair of the pump plant building, repair and installation of new water mains, and installation of new equipment (Del Rio City Clerk Files). One important project entailed the construction of two large concrete storage tanks in 1929 on property leased from Jap Lowe (Figure 16). Prior to construction of the water storage reservoirs (now known as the Bedell tanks for their location off Bedell Avenue), the Del Rio Water Company had a 250,000-gallon water tower on Main Street as well as a smaller storage tank adjacent to the pumping plant (Sanborn Fire Insurance Company 1924).

The first two concrete water towers at the Lowe Ranch were built in 1929 under an agreement between the city and the R. C. Shane \& Company of San Antonio. Shane and Del Rio Mayor John Y. Long signed a contract on 15 April 1929 to erect concrete water storage tanks for the sum of $\$ 42,600$. Shane posted a bond of $\$ 10,650$ insured by the American Indemnity Company to produce two concrete reservoirs "free from leaks for a period of one year." Construction was to be completed within 120 working days after the execution of the contract (Del Rio City Clerk Files). Construction began immediately, with crews of laborers pouring cement into the wooden molds that formed the base of the circular tank. The forms were then placed on top of the solidified concrete bottom layer and the process was repeated about eight times until a concrete cylinder was formed (Roebuck Daughtrey, personal communication 1997). Sanborn maps show both of the tanks complete by 1930 . According to descriptions by the Sanborn surveyors, the tanks lay $7,271 \mathrm{ft}$ from the old pump house, which was then located on the creek immediately north of the railroad bridge.

According to a 1937 newspaper article, each tank was said to be $80 \mathrm{ft}$ in diameter and $32 \mathrm{ft}$ high, and had a capacity of 1,229 [sic] gallons of water (Del Rio Evening News Historical Prosperity Edition 1937, Section 2:6). While the tank dimensions are correct, the stated capacity is an error; Sanborn Fire Insurance Company maps (1930) show the reservoirs each had a capacity of $1,129,000$ gallons, and current capacity figures shown on project engineering maps approximate 1,000,000 gallons (Malcolm Pirnie 1997). A third, larger water storage tank constructed in 1963 (see below) increased the storage capacity at the Bedell tank complex to around 4,000,000 gallons.

The newspaper article mentioned above further noted that the tanks were "practically air

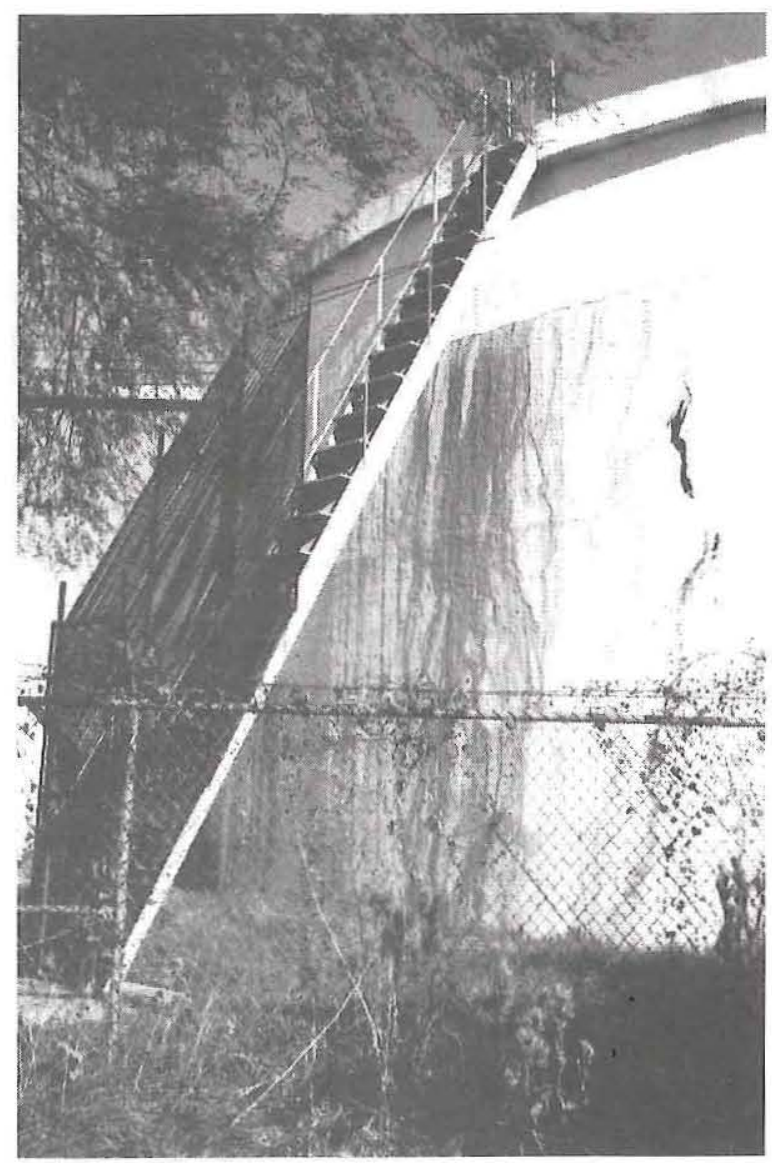

Figure 16. View north-northwest of the west side of the eastern Bedell tank, 1997. 
tight and have five vents each; four on the sides and one on the top. Each vent is covered with extremely fine copper wire that prevents trash from entering them." To keep the tanks sanitary, they were cleaned four times per year by hydraulic pumps that forced water into the reservoir to scour with 125 pounds of pressure. Men's boots were sterilized in chlorine before they entered the tank (Del Rio Evening News Historical Prosperity Edition 1937, Section 2:6).

\section{TYPHOID THREAT: 1932}

Despite the noted safeguards, several health concerns were raised about Del Rio's water supply in the early 1930 s, leading to major changes in the city's pumping and delivery systems and ultimately resulting in the consolidation of the two water companies and the relocation of the pumping plant to the headwaters of East Springs.

At its meeting on 17 May 1932, the city commission discussed a letter received from C. R. Morrill, superintendent of the Texas \& New Orleans Railway Company. The letter, dated 4 May 1932, concerned the "filthy condition of land surrounding the water tanks" on the Jap Lowe property (Del Rio City Commission Minutes 1932:2:491). Lowe maintained numerous holding pens for chickens, goats, sheep, and cattle on his ranch land surrounding the city's water storage tanks. Morrill stated that he spoke with Lowe about buying the land, but that Lowe wanted a "fancy price" for it. The city commission decided that the best thing to do was to make Lowe move the nuisance; he agreed on the condition that the city pay the expense. The issue was tabled for further discussion at the May 26 meeting (Del Rio City Commission Minutes 1932:2:491).

At the following meeting, Dr. George $\mathrm{H}$. Garrett, city health officer, testified that the city's water was unsafe for several reasons, including the possibility of animal waste contamination at the tank farm and the location of the pumping plant. The council discussed a letter written by Dr. Garrett stating that although there was no danger of a typhoid fever epidemic stemming from the city's water supply, analysis from the state chemist showed that the water (in the storage tanks) was not fit for human consumption and neither was the water taken directly out of the springs. The news alarmed city officials, particularly since Del Rio had always promoted its clean, abundant spring water as an attraction to potential residents and investors. Garrett was instructed not to divulge information about the condition of the water, but to report directly to the council and let it publish such information, if it was determined to be warranted. The council also asked Garrett to respond to Morrill's letter and advise him of the steps the city was taking to remedy the water quality situation (Del Rio City Commission Minutes 1932:2:492).

Instructions to Garrett about reporting only to the council on city matters came about because the doctor had sent a copy of his report to the local newspaper, which published it before its receipt by the city. Garrett incurred the wrath of the mayor, and several days after the council meeting in which he was instructed to write to Morrill, Mayor John Y. Long fired the health officer. On 12 July, the council reinstated Dr. Garrett over Long's objections (Del Rio City Commission Minutes 1932:2:499). Long again fired Garrett and ultimately the council appointed someone else at its meeting on September 13 (Del Rio City Commission Minutes 1932:2:505).

At the September meeting, Jap Lowe appeared in person to submit his bid to remove his outbuildings and pens from the present location to some place agreeable with the city. Lowe's estimate was an outrageous price$\$ 12,010$ - and the city said it would have an estimate made at their expense and take the matter up later (Del Rio City Commission Minutes 1932:2:505). Early the following year, during the depths of the Great Depression, the city commission authorized the mayor to make Jap Lowe an offer of $\$ 250$ for the purchase of the land surrounding the city reservoirs (Del Rio City Commission Minutes 1933:3:1). However, no further action was taken in the matter until after Jap Lowe's death, nearly 20 years later.

\section{Consolidation of the Separate Water Systems}

During the Depression, the city embarked on a series of water and sewer improvements with the assistance of the Works Progress Administration (WPA) and the Public Works Administration (PWA). It was during this time that the current East Springs pump house was 
built on the grounds of the San Felipe golf course (Figure 17). The old pump house near the railroad tracks was deeded to the Women's Clubs of Del Rio. Simultaneously, Del Rio consolidated its separate water systems into a single citywide system.

As late as 1930, the East Side Water Company had continued to use 8-inch wooden pipes to carry water to its customers. The East Side pump station was small and had a small, partially open shed, a one-room office, and a buried fuel oil tank. It operated continuously and had electric lights, and the single pump was powered by a crude oil engine (Sanborn Fire Insurance Company 1930); they also had a separate 500,000 -gallon storage tank south of the pumping station.

The city may have been compelled to purchase the old East Side waterworks as part of an agreement with the U.S. government to receive PWA funds to improve its overall water system. In order to procure the government loan, the city had to clear all liens against the company (Del Rio City Commission Minutes 1934:3:125). On 1 November 1933 Homer B. Jones, on behalf of the East Side Water Company, sold the company to the City of Del Rio for $\$ 3,740.69$ to be made in 14 installments. The deal included all property, equipment, pipes, franchises, and rights (Del Rio City Commission Minutes 1934:3:122). At the same time, the city assumed the company's debt to Mrs. Lula D. Garner in the amount of $\$ 12,365.54$, secured as a Vendor's Lien retained in a deed from the East Side Water Company to H. B. Jones (Deed Record 57:483-486). The city then faced the challenge of consolidating the two separate, unequal systems into a modern, integrated whole.

About six months after purchasing the East Del Rio Water Company, the city entered into a contract with the U.S. government for the "construction of extensions to water distribution system to serve the Mexican zone of the city which is now being served by an obsolete private company." The contract indicated that the city planned to upgrade and integrate the two systems under PWA Docket No. 3174. Total cost of the project was not to exceed $\$ 77,000$, with the purchase of $\$ 62,000$ in aggregate bonds (Del Rio City Commission Minutes 1934:3:62).

Some of the wooden mains used by the East Side Water Company may have dated to the earliest years of the town's original water company (established in the mid-1880s). The city commission minutes, in which the city assumed the old company's debt to Mrs. Garner, describe the condition of the newly acquired system as:

... that portion of the City Waterworks system of the City of Del Rio, known as the East Side Water Works, servicing that portion of the City of Del Rio now known as San Felipe ... has all deteriorated to such an extent that the water mains are all leaky and it is impossible to procure adequate pressure and sufficient water to satisfy that portion of the City and all parties interested in said water system are desirous of seeing the improvements made ... [Del Rio City Commission Minutes 1934:3:125].

On 9 November 1934, the city commission met in special session to open bids for the construction of improvements to the waterworks system. Eight companies presented bids for general contracting, ranging from $\$ 67,977$ to $\$ 83,354$. After lengthy discussion the commission voted to reject a portion of the bids because all contractors used machinery in filling and surfacing the streets once the pipe lines were installed. It was the city's desire to have that work done by hand labor:

... Del Rio is situated along the Border of Texas and Mexico and a very large portion of its population consists of very poor people, most of whom are unemployed and it is the desire of the City Commission, if possible to furnish as much labor for [them] as possible to aid them; in living during the present Winter ... [Del Rio City Commission Minutes 1934:3:157].

The commission unanimously agreed to forego the savings and efficiency of machine labor in order to put as many of the city's unemployed to work as possible. The bids were refigured as a result, with the award going to F. C. Youmans of Houston for $\$ 72,112.27$. All plans and work were subject to the approval of the PWA, whose representative, A. Benevento, was present at the special meeting (Del Rio City Commission Minutes 1934:3:157). 


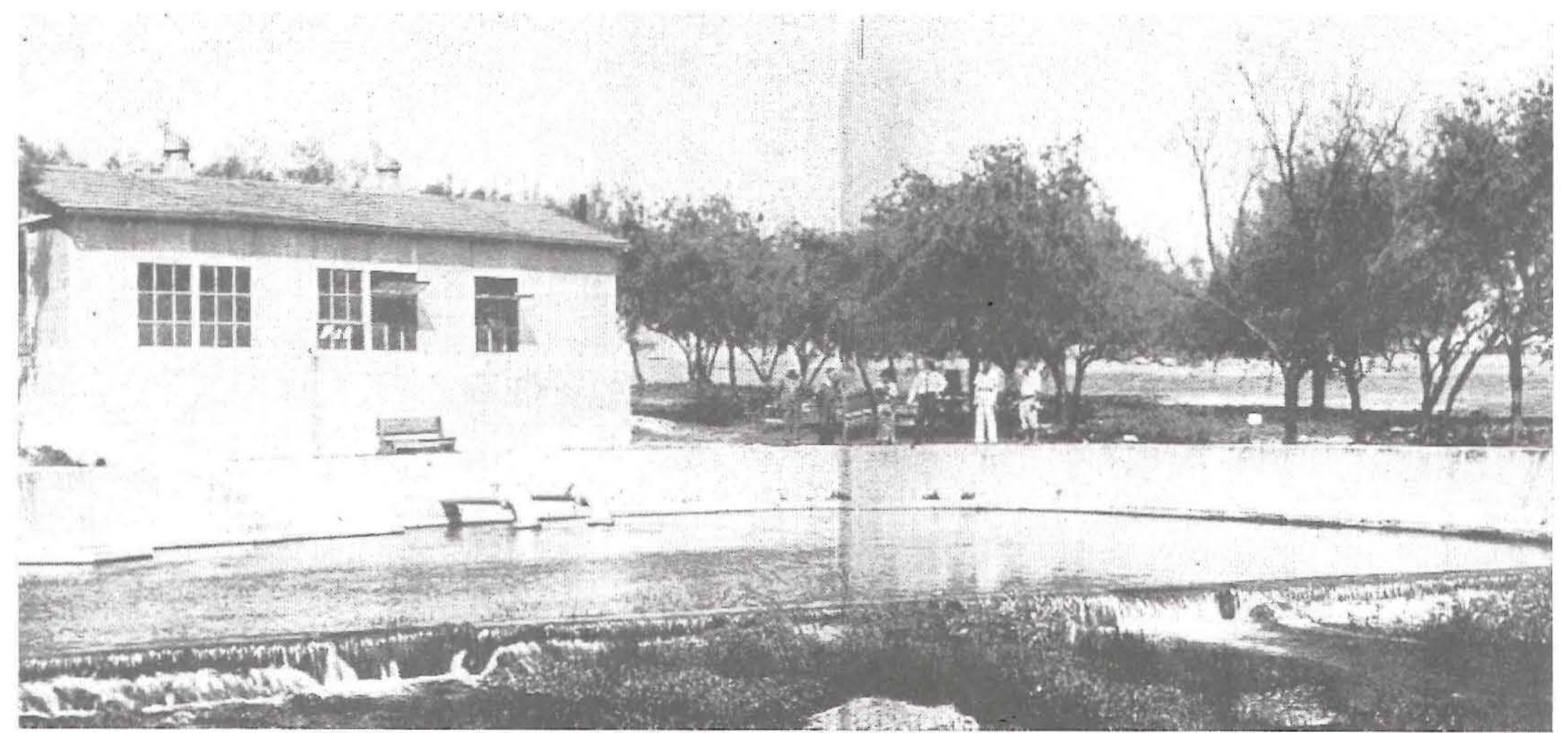

Figure 17. View northeast of the East Springs pump house and pond, ca. 1938. Photograph by Lippe in the Del Rio City Directory (1938). 


\section{A New Waterworks: 1935}

Once the new pipeline construction was under way, the city embarked upon two related projects-a bridge over San Felipe Creek and a new waterworks plant at the mouth of East Springs. In February 1935, C. A. Cripe of San Antonio was hired to design and build a steel and concrete bridge over San Felipe Creek for \$9,660 (Del Rio City Commission Minutes 1935:3:194). In April 1935, the city selected Paul Blevins of Del Rio as engineer and E. P. Arneson of San Antonio as consulting engineer in the design and supervision of the construction and improvement of a waterworks system $^{18}$ (Del Rio City Commission Minutes 1935:3:204A-I). Later in April 1935, the city contracted with Central Power and Light to purchase electric service for operation of the electric pumping equipment at the headwaters of the east ${ }^{19}$ fork of San Felipe Creek-approximately 2,000 ft upstream from the Southern Pacific railway crossing over San Felipe Creek (Del Rio City Commission Minutes 1935:3:235). This was the first public record of the city's decision to move the pumping station from the railroad right-of-way to the headwaters of the East Springs.

After advertising in the Del Rio Evening News on 10 and 17 May 1935, the city entered into an agreement with C. A. Cripe to build a new waterworks plant and authorized the issuance of $\$ 20,000$ in City of Del Rio Waterworks Warrants (Del Rio City Commission Minutes 1935:3:261). Cripe agreed to furnish and install two motor-driven centrifugal pumps, salvage $3,486 \mathrm{ft}$ of 12 -inch water main, relay $2,919 \mathrm{ft}$ of pipe in a new location, and construct a building to house the pumps at the following unit prices:

\footnotetext{
${ }^{18}$ City minutes do not clarify many details of the project, but it was somehow related to an overall water system enhancement project under PWA Docket No. 3174.

${ }^{19}$ Minutes incorrectly state that the city's water came from the west fork and from the West Springs. Either these references were incorrectly recorded by the city clerk or the city originally intended the station to be built at the West Springs and later reversed its decision.
}

\begin{tabular}{lr} 
2 Motor Driven Centrifugal Pumps & $\$ 5,350$ \\
Installation of same & $\$ 1,750$ \\
Building for same & $\$ 1,837$ \\
Suction pipe and hardware & $\$ 2,175$ \\
Salvaging 3,486 ft 12" pipe & $\$ 3,740$ \\
Relaying 2,900 ft same & $\$ 3,100$ \\
Lead fittings and supplies & $\$ 2,048$ \\
\hline Total & $\$ 20,000$
\end{tabular}

All work would be done under the direct supervision of the city commission and would employ only local laborers (Del Rio City Commission Minutes 1935:3:262).

While city commission minutes regarding construction of a new pump house fail to note the completion of the pump house, an undated newspaper article written in 1937 states that the present East Springs pump house was built in 1935 (Del Rio Evenïng News Historical Prosperity Edition 1937, Section 2:6). This is verified by other business that affected the old pump house; in 1936, the city agreed to let the Del Rio Federation of Women's Clubs lease "the old pump-house" for club use beginning 1 June 1936, for the sum of one dollar per year. Mrs. Paul J. Poag, president of the Federation of Women's Clubs of Del Rio, acting on behalf of the organization, agreed to make repairs to the roof and otherwise "beautify" the grounds in exchange for the generous lease agreement. The Del Rio Federation of Women's Clubs served as a meeting place for the different women's civic groups. It was also available for receptions, recitals, and other occasions. Gift showers for the federation were held, and crockery, glassware, and utensils were purchased and stocked for use at luncheons and dinners. The city had a large garden club that gave monthly luncheons in the building $^{20}$ (Del Rio News-Herald 28 February 1985:8A).

Thus, the new pump house must have been in place at the East Springs by May 1936. The system's intake pipes were placed in the "heart of the largest spring," which flows at about

\footnotetext{
${ }^{20}$ After a 1976 fire damaged the building, the city demolished it in 1977. Local preservationists and state officials with the THC lodged protests after the fact.
} 
$30,00 \mathrm{C}$ gallons per minute. The pumps were $6 \mathrm{ft}$ under water and carried water to the pumping plant. There, separators extracted all the sand and solids from the water before it flowed into the pump pit, where it came into contact with a current of air in constant circulation. The water was pumped from there to the two concrete storage tanks through a 12 -inch-diameter cast iron pipe under a pressure of 125 pounds to the square inch. The water was tested monthly ( Del Rio Evening News Historical Prosperity Edition 1937, Section 2:6).

The city was proud of its new water system, which was prominently featured in a Chamber of Commerce brochure and in a twopage photo layout in the 1938 Del Rio City Directory. According to the directory, San Felipe Springs was "The Nucleus Upon Which the Town Was Founded." Yielding 72,000 gallons of water per minute, the springs were declared to be more than sufficient for the city's population, and their purity was "unquestionable." The water was so pure it needed no chemical treatment and was free from all chemical contaminations, and in fact the water "never sees the light of day from the time it leaves the springs until it is drawn from the faucets for human consumption." In addition to supplying the city with pure water for commercial and domestic purposes, the water system irrigated several thousand acres of fertile land from the overflow (Del Rio City Directory 1938). It was widely believed that the water was high in iron content, and children used that as an argument against eating spinach (Del Rio Evening News Historical Prosperity Edition 1937, Section 2:6).

\section{Post World War II to Present Day}

After construction of the new pumping station in 1935, most of the city's work involved general upkeep and the extension of new water lines to keep up with increased development, and demand. However, following World War II, the city experienced another period of growth and development and because water consumed so much of its time and attention, the city commission established a separate Water Utilities Commission. The first commission, comprised of five members, met on 1 December 1949. Charged with advising the city on contracts, improvements, and disbursements made from the sale of City of Del Rio waterworks and sewer system revenue bonds, Series 1949, the commission also made recommendations on rate charges for water customers. It had the power to approve payments for buildings, tools, equipment, and land associated with the waterworks and sewer system and to provide for their maintenance and repair (Del Rio Water Utilities Commission Minutes 1949:1:7-10).

Beginning in 1949, the city turned its attention to the construction of a new sewage plant, a project that occupied the utilities commission for several years (Del Rio Water Utilities Commission Minutes 1949:1:17). In the early 1950 s, greater emphasis was placed on ensuring that the water supply was free from contamination. To this end, the city hired a certified water plant operator, J. A. Meadows, to be superintendent of water operations. All unlicensed employees of the pumping station were required to pass a' competency exam. Staff at the water plant at that time included a plant pumper, a utility clerk, and meter mechanics. The main office was located off site, at 515 Pecan Street (Del Rio Water Utilities Commission Minutes 1952:1:47).

In addition to increased personnel competency, the city embarked on several projects to upgrade equipment and protect its water source. Upon advice from the water superintendent, the commission established a procedure to add adequate amounts of chlorine on a continuous basis to the spring water prior to discharge into the distribution system. In 1952, the commission decided to raise the concrete curbing around the spring to an elevation "equal to that of the top of the concrete of the pump station" and to repair the existing curbing to prevent possible entrance of the backwater from San Felipe Creek and to keep surface water from entering the spring enclosure. Plans for the improvements were submitted to the State Health Department for approval by 15 September 1952 (Del Rio Water Utilities Commission Minutes 1952:1:47).

The State Health Department approved plans for the proposed construction at San Felipe Springs on 11 November 1952. Work began in April 1953 under the supervision of Henry Green (Del Rio Water Utilities Commission. Minutes 1953:1:56). All State Health Department-mandated work was completed by 11 August 1953 (Del Rio Water Utilities Commission Minutes 1953:1:60). Shortly afterward, the commission approved the purchase and installation of a new 
200-hp Fairbanks-Morse pump for $\$ 6,968$ to provide more-adequate water supply by the following summer (Del Rio Water Utilities Commission Minutes 13 October 1953:1:62).

Jap Lowe continued to be cantankerous in his dealings with the city. In 1952, the city tried unsuccessfully to get Lowe to fill in some sinkholes on his property. City commission minutes indicate that Lowe was reluctant to allow the city access to the property to repair the situation. A note in the utilities commission minutes alludes to difficulties in dealing with Lowe:

Provided the utilities commission can obtain permission from the owners, the sink holes on the Jap Lowe property will be filled and plans for this work will also be submitted to the State Health Dept. by Sept. 15, 1952. In the event the Utilities Com. cannot consummate a peaceful negotiation for this work, condemnation proceedings will be instituted in order to obtain sufficient land for this purpose [Del Rio Water Utilities Commission Minutes 1952:1:50].

Lowe's death later that month precluded condemnation proceedings. Mrs. Lowe proved more willing to negotiate, and a contract was drawn up for the work on 30 January 1953 (Del Rio Water Utilities Commission Minutes 1953:1:73).

In June 1954, the commission purchased 2,000 ft of 12-inch water main for Del Rio to loop into the present water system and supply water to Laughlin Air Force Base. Marshall Smith of the Alamo Iron Works presented the low bid of $\$ 4.27$ per foot and was awarded the contract (Del Rio Water Utilities Commission Minutes 1954:1:73). The water lines were completed by the end of the year, and the commission accepted a contract to pump water to the air base in January 1955 (Del Rio Water Utilities Commission Minutes 1955:1:81).

Early in 1955, the commission approved a plan to make improvements and additions to the pump house. The eastern extension of the pump house may have been added at that time. The contract was awarded to H. T. Green for low bid of $\$ 2,175$, but no details on the exact nature of the work were provided in the minutes (Del Rio Water Utilities Commission Minutes 1955:1:81).
Other minor changes occurred. In June 1955, for instance, Allen Pearson represented the San Felipe golf course before the commission to request a gate at the entrance leading to San Felipe Springs and adjoining the golf course property. The commission agreed to install a gate and to unlock it each morning. The golf club would close it at night and would erect appropriate signs informing the public when the property would be open and closed (Del Rio Water Utilities Commission Minutes 1955:1:88).

As the city water system incurred greater demand in the mid-1950s with the increase in population and the additional drain by Laughlin Air Force Base, the commission began to hear more complaints of low pressure from their customers. Customer complaints became common in 1954 and 1955, and the commission tried to alleviate the situation somewhat by adding a new 12-inch water line from Bedell Avenue to Avenue E at 11th Street (Del Rio Water Utilities Commission Minutes 1955:1:93). The following summer, Lieutenant Holt of Laughlin Air Force Base met with the commission to discuss the base's expanded building program, which would put even greater demands on the water system (Del Rio Water Utilities Commission Minutes 1956:1:102).

By 1957, so much new equipment had been installed at the pump house that the commission increased insurance coverage on contents of the pumping station from $\$ 8,000$ to $\$ 16,000$. (Del Rio Water Utilities Commission Minutes 1957:1:109). In 1958, the annual operating budget was approximately $\$ 30,000$ (Del Rio Water Utilities Commission Minutes 1958:1:122), but this figure was for salaries and regular operations and not new equipment, which continued to be a priority for the city.

Low water pressure, increased demand from Laughlin's expansion program and new residents, and periodic dry spells continued to tax the water system throughout the 1950s and 1960s. In February 1962, the water superintendent presented a comparative survey of the average monthly flow of San Felipe Springs for the preceding two years. The news was not good. The flow from the East Springs had diminished, and the superintendent advised the commission to take immediate steps to meet future demand. The commission unanimously agreed to drill for alternate water sources (Del Rio Water Utilities Commission Minutes 1963:1:182). The following 
month, the commission authorized engineer Jack Daniels to drill an exploratory 8-inch test on the golf course as a preliminary step before drilling a new well (Del Rio Water Utilities Commission Minutes 1963:1:183). In conjunction with Daniels's efforts, the commission paid Captain Lessard and Robert H. Rust \$25 each for exploratory diving in the West Springs (Del Rio Water Utilities Commission Minutes 1963:1:184).

In May of 1963 the Zachry Company drilled a number of small holes over the West Springs, and as a result of his findings, the commission authorized the company to complete the drilling and take steps to have a pump installed at the site (Del Rio Water Utilities Commission Minutes 1963:1:185). A pump costing approximately $\$ 9,000$ and a chlorinator valued at about $\$ 800$ were purchased for use at the West Springs (Del Rio Water Utilities Commission Minutes 1963:1:188), and in October, city engineer Mr. Cross drew up plans and specifications to run a 24 -inch line to the storage tanks and plans for a third storage tank with a two-milliongallon capacity (Del Rio Water Utilities Commission Minutes 1963:1:194). Finally, in December, the water superintendent completed the new pumping station by having the West Springs walled in to conserve that water source (Del Rio Water Utilities Commission Minutes 1963:1:198).

Despite completion of the new West Springs pumping station, the commission continued to identify new sources of water as population increased in the early 1960s. In December 1963, the city authorized the water superintendent to drill pilot holes in the vicinity of the West Springs to obtain information on the possibility of installing another pump (Del Rio Water Utilities Commission Minutes 1963:1:198).

By the close of December 1963, the City of Del Rio waterworks existed essentially as it appears today. Both pumping stations at the East and West Springs on the San Felipe golf course were in place, as was the third concrete water tank on the former Lowe Ranch.

The utilities commission continued to seek new and improved water sources in the years that followed. In 1964 the city hired William F. Gideon and Associates to conduct a ground water survey that would include an analysis of present and past San Felipe Creek flow and probable variations to be expected, as well as the probable yield of wells in the vicinity of the springs, and recommendations with respect to areas and procedures for possible test drilling. In addition, Gideon was to study and analyze data on the Trinity Sands and the GeorgetownEdwards Formations, inventory wells and compile records, and then recommend sources of water for the city, all at a cost of approximately $\$ 8,000$ (Del Rio Water Utilities Commission Minutes 1964:1:200). Thus began a series of water surveys and analyses that would continue for the next 30 years. However, no major changes to the system were made until the construction of two new buildings in 1994 to house chlorine and fluorine operations at the East Springs site.

\section{Descriptions and National Register Assessments}

The Del Rio Water Company, forerunner of the present city waterworks, began in 1906 on the east branch of the creek; a separate water system farther downstream served the largely Mexican-American community of San Felipe until 1935, when the two companies were consolidated into a combined system at the present East Springs location on the grounds of the San Felipe golf course. Funded by a PWA grant, the consolidated water system included a pump house building and retaining pond at the mouth of the East Springs, as well as two concrete reservoirs (now known as the Bedell tanks) built in 1929. The city leased the former pump house to the Del Rio Federation of Women's Clubs but maintained an auxiliary pumping station at the site until 1978, when the building was razed and the equipment removed. In 1963, the city augmented its pumping capability by installing a second pumping station at the West Springs, also on the San Felipe golf course. That same year, the city built a third concrete reservoir at the Bedell tanks site.

The two pumping stations and three storage tanks are the primary above-ground facilities associated with the waterworks. All will be affected by the construction of the new water treatment plant and related facilities.

\section{Architectural Descriptions of Contributing Features}

Historic components of the waterworks include the ca. 1935 East Springs pump house 
and pond enciosure and the 1929 concrete water storage reservoirs known as the Bedell tanks. Noncontributing elements of the system include the West Springs pump house and a two-milliongallon storage tank, both built in 1963, and other nonhistoric buildings and structures at both the East Springs and Bedell tanks sites.

\section{EAST SPRINGS PUMP HOUSE AND POND ENCLOSURE}

The East Springs pumping plant and current pond enclosure ${ }^{21}$ were originally built in 1935 , but both have been altered since their construction (Figure 18). Pipes and pumps have been continually upgraded and replaced, and the pond enclosure was raised several feet in 1952.

${ }^{21}$ Historic photographs show that'the East Springs pond was defined by a low rock wall as early as the 1920 s.
The east end of the pump house was expanded ca. 1955 to facilitate the addition of more pumps to provide water to Laughlin Air Force Base.

No original or as-built drawings have been located for the pump house, but an early photograph in the 1938 Del Rio City Directory clearly shows the building's salient architectural characteristics. The original 1935 portion is a one-story, side-gable frame building with sheet metal sheathing and a corrugated metal roof. Its primary access is on the north elevation through a single door with $2 / 2$ fixed-lite windows. The door opens directly into the equipment room. A narrow, at-grade platform circumscribes three sides of the room above a concrete-lined open pit containing the pumping equipment. A low chain link fence along the platform prevents people from falling into the pit. A second door on the north elevation does not appear to be in use. The west side of the building opens to the equipment room through a pair of sliding metal doors, each with fixed

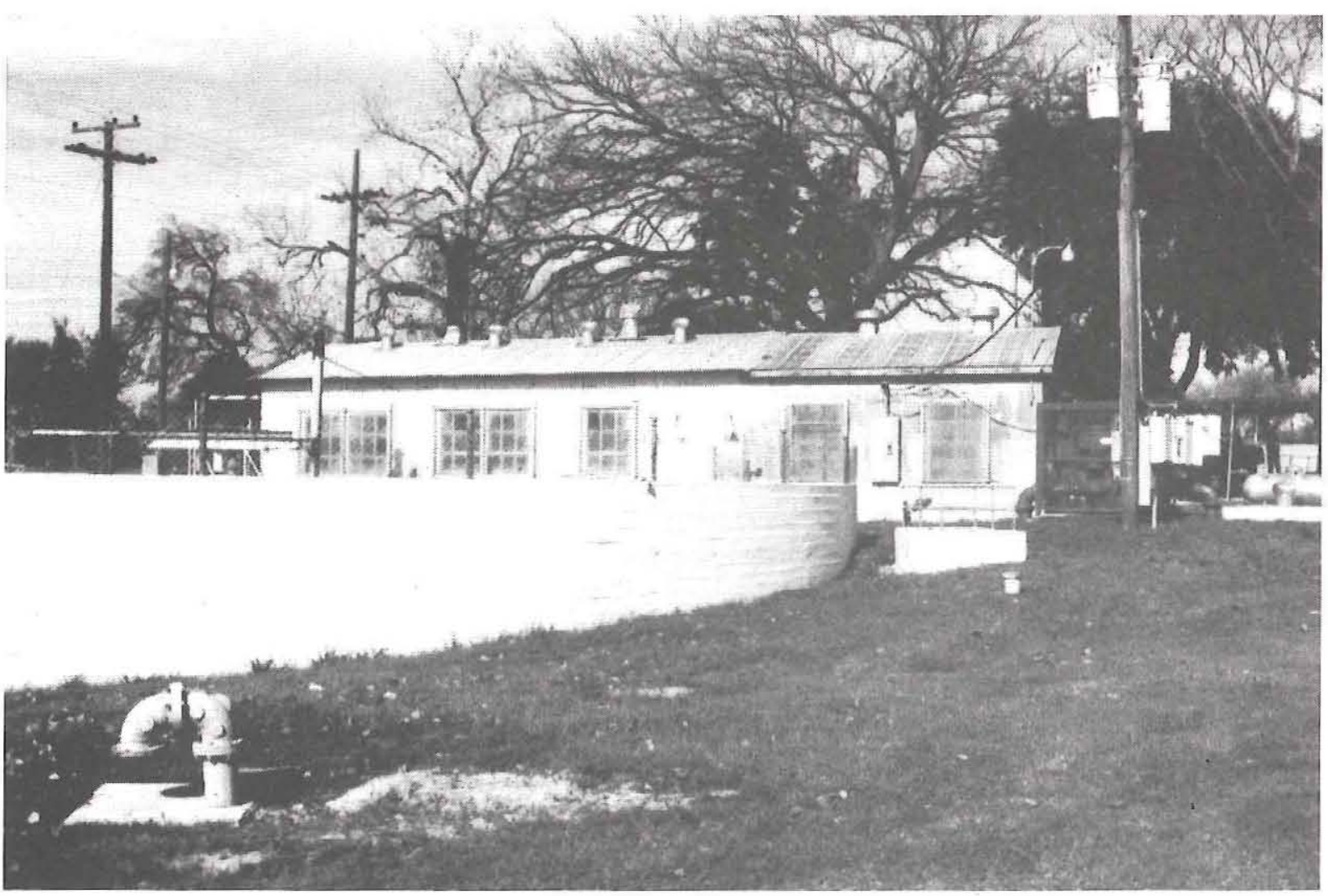

Figure 18. View north-northwest of the East Springs pump house and pond enclosure, 1997. Photograph shows the eastern addition to the pump house and the elevated pond enclosure wall. 
six-lite windows configured in a $3 / 3$ pattern. Judging from the ca. 1938 photograph, the doors and windows in the this section appear to be original. The roof, which appears to have been covered with composition shingles in the early photograph, has been replaced by corrugated metal. The building's most distinctive feature is its fenestration, consisting of two sets of paired, 9-lite projecting (awning) windows and a single 9-lite projecting (awning) window, each presented in a $3 / 3 / 3$ configuration. The top and bottom rows of the windows are fixed lites, while the center rows are hopper windows. These windows are located on the south facade of the building overlooking the spring's pond enclosure.

About 1955, a two-bay extension was added to the east end of the building. It follows the form of the original building in roof pitch and building width, but is sheathed with corrugated metal. Its windows are of different dimensions and lite configurations than the original section. The addition contains two single windows, each with 8 lites in a 2/2/2/2 configuration. Fenestration echoes the original design in that the top and bottom lites are fixed, while the center rows are movable hopper windows. The addition's east elevation contains two window openings. The northernmost window on this elevation is covered by a metal screen affixed to the building, while the southernmost window is open to the elements. Both the original pump house and the addition are set on concrete block foundations. Several other small buildings occupy the site.

The other major historic feature at the site is the retention pond and concrete block retaining wall. Sometime after the turn of the twentieth century, the East Springs pond was defined by a low wall of stacked caliche and native rocks. Prior to construction of the pump house in 1935, a low retaining wall about $4 \mathrm{ft}$ high was built around two-thirds of the pond, forming a horseshoe-shaped enclosure. The southern third of the wall was left open, and overflow water passed into San Felipe Creek. About 1952, the pond was completely enclosed and the wall raised to a height of ca. 10 feet (see Figure 18). A chain link fence capped with barbed wire tops the retaining wall. It has been changed very little from that time to the present. Overflow continues to pass into the creek, but the retention pond is no longer accessible to the public except for viewing from above. A concrete sidewalk extends around the western side of the wall to the creek, where a park bench is set in concrete facing the creek.

\section{BEDELL TANKS}

The water storage reservoirs known as the Bedell tanks are an integral part of Del Rio's historic waterworks system. At an elevation of 1090-1100 ft msl, the 1-acre square tank complex lies about $7,200 \mathrm{ft}$ northwest of the East Springs pumping plant. The tank complex is enclosed by a chain link fence and accessed by a dirt road extending from Bedell Avenue. It comprises the northern component of site 41VV1820 and lies immediately adjacent to remains of the Lowe Ranch.

Three large cylindrical concrete water storage tanks dominate the tract; two were built in 1929 , before the current pump house was constructed, and a third was built in 1963, the year that a second pumping station was erected at West Springs. In addition to the tanks, the site contains several associated outbuildings and auxiliary structures currently used by the city.

The two smaller tanks constructed in 1929 each measure $80 \mathrm{ft}$ in diameter and are about $30 \mathrm{ft}$ tall (see Figure 16). For purposes of this report, they are identified as the western and eastern Bedell tanks and as Bedell Resource $\# 1$ and \#2, respectively. The tanks were built by pouring concrete into a cylindrical form and allowing the layer to partially harden. Once the bottom layer hardened sufficiently but not completely, a second tier was added on top of the first. This process was continued until the layers reached the desired height (Roebuck Daughtrey, personal communication 1997). A thin wash of cement stucco covers the exterior of the tanks and narrow concrete caps extend about 6 inches from their rims. The two smaller tanks are linked by an overhead metal bridge attached to the rims. Each has a storage capacity of ca. one million gallons. Water leaks occur along cracks in the seams of both tanks. Thousands of gallons of water are lost each day in a steady stream that flows into the San Felipe Creek valley to the east.

The largest of the three tanks, constructed in 1963, measures ca. $110 \mathrm{ft}$ in diameter and is about $30 \mathrm{ft}$ tall, with a holding capacity of nearly two million gallons. This tank, identified as the northern Bedell tank or Bedell Resource \#3, appears to have been constructed with concrete 
blocks rather than poured concrete. Unlike the smaller tanks, it is not capped along the rim.

Also within the enclosure are smaller, more recent components, such as two corrugated tin structures that house pipes and water monitoring equipment. A fourth and much smaller concrete water tank is located a few meters north of the 1-acre fenced enclosure. It is about $10 \mathrm{ft}$ tall and $20-30 \mathrm{ft}$ in diameter and, unlike the large storage tanks, is uncovered. This tank was probably constructed by Jap Lowe sometime after 1929 to store the overflow water from the Bedell tanks.

\section{National Register Assessments}

The City of Del Rio waterworks system is deemed eligible for listing in the National Register of Historic Places. Some parts of the system do not meet the age recommendation for National Register listing and are thus noncontributing elements of the historic property. The East Springs pump house and pond enclosure are eligible for listing in the National Register under Criterion A, for their historic associations. They do not retain sufficient integrity, nor do they constitute unique or exceptional architectural or engineering significance to be eligible under Criterion C.

The West Springs pumping plant is a relatively new facility built in 1963. It consists of a concrete pad with a chain link fence enclosing a small cinder block building and two exterior electric pumps. The West Springs plant does not meet the recommended 50-year age threshhold, and does not possess exceptional significance as defined by Criterion Consideration G, for listing in the NRHP.

Only the two 1929 Bedell water storage tanks have reached the recommended 50-year age threshhold for inclusion in the National Register. They retain their original appearance, materials, and function to a large degree, and they are eligible for listing on the National Register as contributing features of the city's waterworks system. 


\section{GEOARCHEOLOGICAL INVESTIGATIONS AT THE SAN FELIPE SPRINGS SITE, 41 VV444}

Douglas K. Boyd and Karl W. Kibler

Geoarcheological investigations conducted at 41 VV444 from September to December of 1997 generated much geological and archeological data useful for understanding prehistoric occupations at San Felipe Springs. Field investigations consisted of excavating 37 backhoe trenches, 11 shovel tests, and 53 test units in three phases of work (Table 5).

\section{WORI ACCOMIPISHIED}

\section{Phase I}

The original engineering plan proposed by Malcolm Pirnie called for replacement of existing pump facilities and construction of a series of buried water pipelines in the San Felipe Creek valley. New pumping stations were planned for the East and West Springs, and east-west pipelines were proposed to carry water between the East and West Springs and between the springs and the water treatment plant, including an overflow line from the treatment plant back to the East Springs. A buried pipeline would take

Table 5. Summary of subsurface testing at 41VV444

\begin{tabular}{llccc}
\hline Phase & Area & $\begin{array}{c}\text { Backhoe } \\
\text { Trenches }\end{array}$ & $\begin{array}{c}\text { Shovel } \\
\text { Tests }\end{array}$ & $\begin{array}{c}\text { Test } \\
\text { Units }\end{array}$ \\
\hline Phase I & All & 26 & 11 & - \\
Phase IIA & Area 1 & 3 & - & 7 \\
& Area 2 & 3 & - & 9 \\
& Area 7 & 5 & - & 2 \\
Phase IIB & Area 1 & - & - & 35 \\
\hline Totals & & 37 & 11 & 53 \\
\hline
\end{tabular}

treated water from the treatment plant back to the East Springs, where it would head north for about $700 \mathrm{ft}$, make a right-angle turn, and head west across San Felipe Creek at the northern end of the site. The proposed northern pipeline route was eventually dropped from consideration, and the locations and widths of other proposed pipeline rights-of-way were later altered (see Phase IIA below); however, Phase I testing was done in areas proposed for construction under the original design. An intensive search for buried cultural deposits was made near the springs and following the proposed pipeline corridors. Twenty-six backhoe trenches and 11 shovel tests were excavated during Phase I (Figure 19; Tables 6 and 7).

For the sake of clarity, areas where Phase I subsurface testing was done are designated 16 . Five backhoe trenches and four shovel tests were excavated in Area 1, the alluvial terrace $\left(\mathrm{T}_{1}\right)$ between the East Springs and San Felipe Creek. Backhoe Trench 5 was dug near the creek on a lower bench formed by erosional beveling, while the other trenches were excavated on the higher $\mathrm{T}_{1}$ surface. In situ cultural materials were encountered in Backhoe Trenches 3 and 4 . Shovel Test 1 was excavated adjacent to Backhoe Trench 3, which had the greatest concentration of materials. Shovel Tests 2-4 were excavated $10 \mathrm{~m}$ from the trench to the north, east, and south. Prehistoric artifacts were recovered in all four shovel tests to a depth of $50 \mathrm{~cm}$, and deposits appeared to be intact. Examination of Backhoe Trench 3 showed cultural deposits as deep as $80 \mathrm{~cm}$ below the surface.

Six backhoe trenches and four shovel tests were excavated on the $T_{1}$ surface in Area 2, located west of San Felipe Creek in 
Figure 19. Location of proposed construction areas and Phase I backhoe trenches and shovel tests at 41 VV444. 
Table 5. Summary of Phase I backhoe trenches at 41VV444

\begin{tabular}{|c|c|c|c|}
\hline Area & $\begin{array}{l}\text { Backhoe } \\
\text { Trench }\end{array}$ & Dimensions & Results \\
\hline \multirow{5}{*}{1} & 1 & $2.2 \times 0.7 \times 0.8 \mathrm{~m}$ & hit bedrock at $55 \mathrm{~cm}$ \\
\hline & 2 & $2.2 \times 0.7 \times 0.7 \mathrm{~m}$ & hit bedrock at $40 \mathrm{~cm}$ \\
\hline & 3 & $2.8 \times 0.7 \times 1.72 \mathrm{~m}$ & burned rocks, debitage, and charcoal observed in situ at $20-44 \mathrm{~cm}$ \\
\hline & 4 & $2.9 \times 0.75 \times 1.3 \mathrm{~m}$ & burned rocks in fill, burned rock observed in situ at $20 \mathrm{~cm}$ \\
\hline & 5 & $5.0 \times 0.7 \times 1.8 \mathrm{~m}$ & water table hit at $150 \mathrm{~cm}$ \\
\hline \multirow[b]{4}{*}{2} & 6 & $3.0 \times 0.7 \times 1.6 \mathrm{~m}$ & water table hit at $120 \mathrm{~cm}$ \\
\hline & 7 & $2.2 \times 0.7 \times 1.4 \mathrm{~m}$ & - \\
\hline & 8 & $4.5 \times 0.7 \times 1.35 \mathrm{~m}$ & - \\
\hline & 9 & $1.0 \times 0.7 \times 0.4 \mathrm{~m}$ & $\begin{array}{l}\text { burned rocks observed but sediments are disturbed by old pipeline } \\
\text { excavation }\end{array}$ \\
\hline \multirow[t]{2}{*}{. } & 10 & $2.1 \times 0.7 \times 1.3 \mathrm{~m}$ & burned rocks, debitage, and charcoal observed in situ at $0-50 \mathrm{~cm}$ \\
\hline & 11 & $2.1 \times 0.7 \times 1.0 \mathrm{~m}$ & - \\
\hline \multirow{5}{*}{3} & 12 & $2.4 \mathrm{x} 0.7 \mathrm{x} 0.74 \mathrm{~m}$ & - \\
\hline & 13 & $2.1 \times 0.7 \times 1.04 \mathrm{~m}$ & - \\
\hline & 14 & $4.0 \times 0.7 \times 2.1 \mathrm{~m}$ & $\begin{array}{l}\text { burned rocks and flakes observed in situ at } 0-80 \mathrm{~cm} \text {; probable } \\
\text { buried burned rock mound }\end{array}$ \\
\hline & 15 & $2.3 \times 0.7 \times 1.1 \mathrm{~m}$ & burned rocks observed in fill \\
\hline & 16 & $2.2 \times 0.7 \times 0.96 \mathrm{~m}$ & $-\cdot$ \\
\hline \multirow{2}{*}{4} & 17 & $1.7 \times 0.7 \times 0.28 \mathrm{~m}$ & sediments disturbed by excavation of buried utility line \\
\hline & 18 & $1.0 \times 0.7 \times 0.15 \mathrm{~m}$ & hit bedrock at $10 \mathrm{~cm}$ \\
\hline \multirow{7}{*}{5} & 19 & $2.1 \times 0.7 \times 1.07 \mathrm{~m}$ & - \\
\hline & 20 & $1.8 \times 0.7 \times 0.95 \mathrm{~m}$ & $\begin{array}{l}\text { sediments at } 0-27 \mathrm{~cm} \text { are artificial fill, a flake and burned rocks } \\
\text { observed at } 27-67 \mathrm{~cm}\end{array}$ \\
\hline & 21 & $2.1 \times 0.7 \times 0.88 \mathrm{~m}$ & - \\
\hline & 22 & $1.7 \times 0.7 \times 0.38 \mathrm{~m}$ & - \\
\hline & 23 & $1.8 \times 0.7 \times 0.46 \mathrm{~m}$ & burned rocks observed in situ at $32-46 \mathrm{~cm}$ \\
\hline & 24 & $2.0 \times 1.7 \times 1.5 \mathrm{~m}$ & - \\
\hline & 25 & $2.0 \times 0.7 \times 1.3 \mathrm{~m}$ & artificial fill to $55 \mathrm{~cm}$; bottom of trench at $130 \mathrm{~cm}$ is near water table \\
\hline 6 & 26 & $2.4 \times 0.7 \times 1.5 \mathrm{~m}$ & sediments to $60 \mathrm{~cm}$ may be artificial fill \\
\hline
\end{tabular}

the vicinity of the West Springs. This terrace is equivalent to the $\mathrm{T}_{1}$ terrace in Area 1. Cultural materials were encountered in Backhoe Trenches 9 and 10 and were recovered in all four shovel tests. Deposits in Backhoe Trench 9 and Shovel Tests 5 and 8 appeared to be disturbed, but the cultural materials in Backhoe Trench 10 and Shovel Test 6 seemed to be intact.

Area 3 , the east-west pipeline segment at the northern end of the site, was tested with five backhoe trenches and one shovel test. Backhoe Trench 12 was located on a lower $\mathrm{T}_{1}$ bench formed by erosional beveling along San Felipe Creek, but no cultural materials were found. Backhoe Trench 13 was excavated on the sloping edge of the $T_{1}$ and crosscut the higher surface and the eroded lower bench. No cultural materials were found. The other three trenches were located on the higher $\mathrm{T}_{1}$ surface (a northern portion of the $T_{1}$ in Area 1), but cultural materials were observed only in two. A few scattered burned rocks were noted in the fill of Backhoe Trench 15, while Backhoe Trench 14, excavated on a slight circular rise, exposed a buried burned rock mound. This mound, located at the far northern end of the golf course, may have been flattened and smeared when the area was leveled for planting grass, but most of the cultural deposits exposed in Backhoe Trench 14 appeared to be intact. Shovel Test 11, excavated $10 \mathrm{~m}$ east of the eastern end of Backhoe Trench 14, revealed intact midden deposits and cultural materials to at least $60 \mathrm{~cm}$ below the surface. Additional materials (i.e., flakes, burned rocks, and mussel shells) were observed in a large (1.5x2 m), 50-cm-deep pothole about $12 \mathrm{~m}$ 
Table 7. Summary of Phase I shovel tests at 41VV444*

\begin{tabular}{|c|c|c|c|}
\hline Area & $\begin{array}{c}\text { Shovel } \\
\text { Test }\end{array}$ & Location & Depth and Results \\
\hline 1 & $\begin{array}{l}2 \\
3 \\
4\end{array}$ & $\begin{array}{l}\text { adjacent to Backhoe Trench } 3 \\
10 \mathrm{~m} \text { north of Backhoe Trench } 3 \\
10 \mathrm{~m} \text { east of Backhoe Trench } 3 \\
10 \mathrm{~m} \text { south of Backhoe Trench } 3\end{array}$ & $\begin{array}{l}50 \mathrm{~cm} \text {; burned rocks and flakes recovered at } 0-50 \mathrm{~cm} \\
50 \mathrm{~cm} \text {; pull tab recovered at } 0-20 \mathrm{~cm} \text {; burned rocks } \\
\text { and flakes recovered at } 20-50 \mathrm{~cm} \\
50 \mathrm{~cm} \text {; burned rocks and flakes recovered at } 0-40 \mathrm{~cm} \\
50 \mathrm{~cm} \text {; nail recovered at } 0-20 \mathrm{~cm} \text {; burned rocks and } \\
\text { flakes recovered at } 0-40 \mathrm{~cm}\end{array}$ \\
\hline 2 & $\begin{array}{l}6 \\
7 \\
8\end{array}$ & $\begin{array}{l}2 \mathrm{~m} \text { north of Backhoe Trench } 8 \\
\text { adjacent to Backhoe Trench } 10 \\
15 \text { m east of Backhoe Trench } 10 \\
10 \text { m southeast of Backhoe } \\
\text { Trench } 8\end{array}$ & $\begin{array}{l}50 \mathrm{~cm} \text {; burned rocks recovered at } 0-20 \mathrm{~cm} \text {, deposits } \\
\text { possibly disturbed } \\
50 \mathrm{~cm} \text {; burned rocks, flakes, and charcoal recovered } \\
\text { at } 0-50 \mathrm{~cm} \\
40 \mathrm{~cm} \text {; burned rocks and flakes recovered at } 0-40 \mathrm{~cm} \\
40 \mathrm{~cm} \text {; disturbed/artificial fill at } 0-40 \mathrm{~cm}\end{array}$ \\
\hline 3 & 11 & 10 m east of Backhoe Trench 14 & $\begin{array}{l}60 \mathrm{~cm} \text {; burned rocks, flakes, and a biface recovered at } \\
0-60 \mathrm{~cm} \text {; probable continuation of burned rock } \\
\text { mound observed in Backhoe Trench } 14\end{array}$ \\
\hline 5 & 10 & $\begin{array}{l}\text { adjacent to Backhoe Trench } 20 \\
\text { adjacent to Backhoe Trench } 25\end{array}$ & $\begin{array}{l}65 \mathrm{~cm} \text {; disturbed/artificial fill at } 0-25 \mathrm{~cm} \text {; burned } \\
\text { rocks and flakes recovered at } 25-65 \mathrm{~cm} \\
95 \mathrm{~cm} \text {; disturbed/artificial fill at } 0-55 \mathrm{~cm} \text {; burned } \\
\text { rocks recovered at } 55-75 \mathrm{~cm}\end{array}$ \\
\hline
\end{tabular}

north of Backhoe Trench 14. This pothole indicates that the buried deposits extend north of the mowed golf course into the heavily vegetated area. No evidence of vandalism was observed within the golf course.

Area 4 is the north slope of a bedrock knoll along the north-south proposed pipeline segment. It was tested with Backhoe Trenches 17 and 18 , but no cultural materials were observed. Backhoe Trench 17 was terminated at $28 \mathrm{~cm}$ when buried sprinkler control lines were encountered. Backhoe Trench 18 exposed limestone bedrock at $10 \mathrm{~cm}$. No trenches were dug in Area 4 on the southern slope of the knoll (i.e., south of Backhoe Trench 18) because exposed weathered limestone fragments indicated that bedrock is shallow in this area.

Area 5, located east of the East Springs, was tested with seven backhoe trenches and two shovel tests. Selecting locations for trenching was difficult because of the many buried water and utility lines in the area. Disturbed sediments were observed in Backhoe Trenches 20 and 25, and cultural materials were observed only in Backhoe Trenches 20 and 23. Shovel Test 9, excavated adjacent to Backhoe Trench
20 , yielded burned rocks and flakes at $25-65 \mathrm{~cm}$. Shovel Test 10, excavated adjacent to Backhoe Trench 25, yielded burned rocks at $55-75 \mathrm{~cm}$.

Area 6, at the northwest corner of the site, was tested with a single backhoe trench. Backhoe Trench 26 yielded no evidence of buried cultural occupations, and evidence of disturbance was observed to $95 \mathrm{~cm}$ below the surface.

Forty eight artifacts were collected from the surface $(n=2)$ or recovered from shovel tests $(\mathrm{n}=46)$ during Phase I (see Appendix F, Tables 40 and 45). The two surface-collected specimens are dart points identified as a Castroville and a Shumla. The other specimens consist of 45 unmodified flakes and a finished biface.

All Phase I excavations were backfilled at the conclusion of the work. At this time, the engineering design was modified. The northern pipeline route, which was to take treated water from the East Springs north and then west toward the storage tanks, was altered. The treated water pipeline was rerouted to run eastwest across the San Felipe Creek valley and parallel to the other water lines between the treatment plant and the East and West Springs. From the West Springs, the new plan called for 
a single line to continue across the western portion of the creek valley until it left the site area. After consultation with the Department of Antiquities Protection of the Texas Historical Commission, three areas at 41VV444 were slated for testing. The decisions were based on Phase I findings and the new pipeline construction design.

\section{Phase IIIA}

Phase IIA was a testing phase to obtain samples of cultural materials and define buried cultural zones in three separate areas where construction-related impacts would occur (Figure 20). Testing focused on the proposed pipeline rights-of-way. The modified engineering design included three parallel water lines from the water treatment plant to the East Springs pumping facility, two parallel lines from'the East Springs to the West Springs, and a single line west of the West Springs. Eleven new backhoe trenches were excavated, previously excavated Backhoe Trench 3 was reopened and expanded, and 18 test units were hand excavated (Table 8). Cultural materials recovered from these excavations are summarized in Appendix F.

Area 1 is the alluvial terrace between the East Springs and San Felipe Creek. It crosses part of the 6th fairway of the golf course. Phase I work revealed a concentration of buried cultural remains in the vicinity of Backhoe Trenches 3 and 4. Backhoe Trench 3 was reopened and expanded slightly, and three new backhoe trenches (Backhoe Trenches 27-29) were dug nearby (Figure 21). Each of these trenches was excavated along the center line of one of the three proposed water pipelines. Based on the cultural materials observed in these trenches, seven test units were hand excavated (Test Units 1-4 and 6-8) to sample the buried deposits. Excavation revealed the presence of buried cultural zones from the surface to a depth of more than $80 \mathrm{~cm}$. The east-west extent of the buried deposits in this area is limited because the terrace is beveled to the east by erosion and/ or landscaping associated with construction of the golf course. The terrace surface also drops sharply to the west of Backhoe Trenches 28 and 29 . The north-south extent of buried deposits in this terrace is unknown because testing was limited to the pipeline corridor. However, the presence of similar deposits located over $200 \mathrm{~m}$ to the north (in Backhoe Trench 14) suggests that the entire terrace may contain buried cultural materials. Additional, more-intensive testing was done in Area 1 during Phase IIB (see below).

Area 2 is the alluvial terrace between San Felipe Creek and the West Springs; it crosses the 5th fairway of the golf course. This terrace is a depositional equivalent to the Area 1 terrace, and the surfaces of these two terraces are at a comparable elevation. Backhoe Trenches 30-32 and Test Units 9,10 , and 12-18 were dug in this area during Phase IIA (Figure 22). All of the test units produced some cultural materials (see Appendix F, Table 43), but considerable disturbance was noted in the upper $40-50 \mathrm{~cm}$ of fill in most. In many places a capping layer of artificial fill containing cultural materials had been brought in. It is likely that the upper fill throughout Area 2 represents borrow laid down when the golf course was constructed. This artifact-rich fill contained ceramic sherds $(n=8)$ like those found in Area 1. This fill was probably brought a short distance $(<100 \mathrm{~m})$, so the disturbed deposits may represent cultural occupations that originated in the immediate vicinity. The eastern edge of this terrace, which slopes toward San Felipe Creek, may have been artificially beveled when the golf course was constructed. It is possible that this artificial fill was bladed up along the creek edge to raise the terrace near Area 2.

A few flakes were recovered from undisturbed lower sediments (Levels 5-8 in Area 2), but no definable occupation zones were identified. A portion of an intact, rock-lined hearth was found in Backhoe Trench 31, and approximately a third to a half of this feature was excavated in Test Units 9 and 13. This hearth is a circular concentration of burned limestone cobbles measuring $90 \mathrm{~cm}$ in maximum length and ca. $100 \mathrm{~cm}$ in diameter. It was encountered from 20 to $40 \mathrm{~cm}$ below the surface, immediately below the layer of artificial fill. A perforator made on a Conejo dart point was found just outside of and at the same elevation as this feature. However, this artifact may be from the artificial fill rather than directly associated with the hearth.

Besides the perforator/point and the ceramic sherds, the other diagnostic from Area 2 is an Early Barbed dart point found in the backdirt from Backhoe Trench 31 . This point may have been brought in with the artificial fill. The blades 


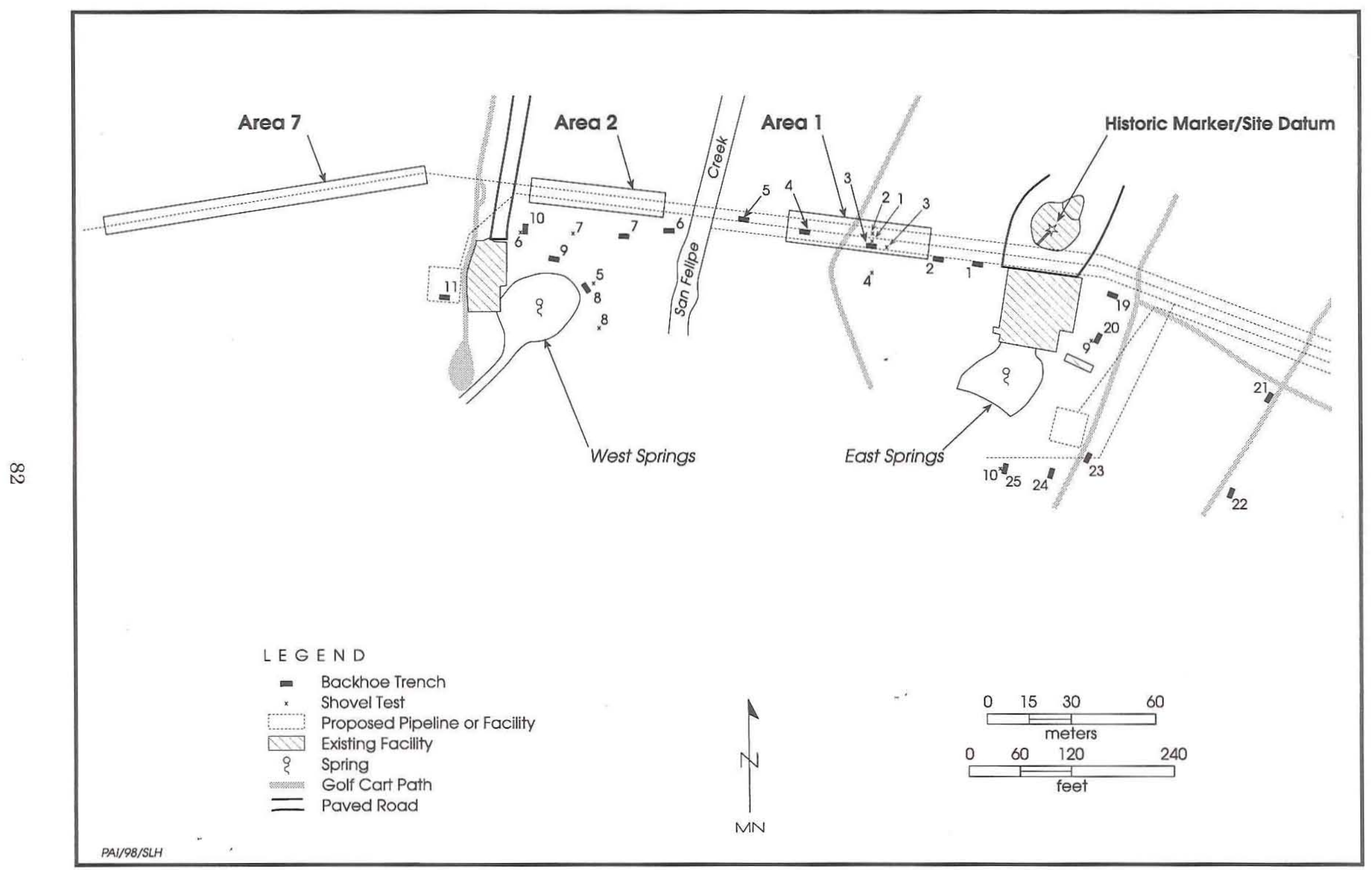

Figure 20. Modified engineering plan, Phase I excavations, and key archeological areas for Phase II investigations at 41 VV444. 
Table 8. Summary of Phase 11A excavations at 41VV444

\begin{tabular}{|c|c|c|c|}
\hline \multicolumn{4}{|c|}{ Backhoe Trenches } \\
\hline Area & Backhoe Trench & Dimensions & Results \\
\hline \multirow{4}{*}{1} & $3^{*}$ & $5.0 \times 0.7 \times 1.4 \mathrm{~m}$ & cultural materials observed at $40-50 \mathrm{~cm}$ \\
\hline & 27 & $5.0 \times 0.6 \times 1.1 \mathrm{~m}$ & cultural materials observed at $0-35 \mathrm{~cm}$ \\
\hline & 28 & $7.0 \times 0.6 \times 1.1 \mathrm{~m}$ & cultural materials observed at $0-40 \mathrm{~cm}$ and $70 \mathrm{~cm}$ \\
\hline & 29 & $6.5 \times 0.6 \times 1.0 \mathrm{~m}$ & cultural materials observed at $80 \mathrm{~cm}$ \\
\hline \multirow{3}{*}{2} & 30 & $6.0 \times 0.6 \times 1.1 \mathrm{~m}$ & one burned rock observed at $75 \mathrm{~cm}$ \\
\hline & 31 & $13.5 \times 0.6 \times 0.9 \mathrm{~m}$ & cultural materials observed at $0-50 \mathrm{~cm}$; in situ \\
\hline & 32 & $7.0 \times 0.6 \times 1.2 \mathrm{~m}$ & $\begin{array}{l}\text { hearth at } 20-40 \mathrm{~cm} \text {; isolated flake at } 70 \mathrm{~cm} \\
\text { no cultural materials observed }\end{array}$ \\
\hline & 33 & $5.0 \times 0.6 \times 1.2 \mathrm{~m}$ & no cultural materials observed \\
\hline & 34 & $5.0 \times 0.6 \times 1.2 \mathrm{~m}$ & one burned rock observed at $110 \mathrm{~cm}$ \\
\hline \multirow[t]{3}{*}{7} & 35 & $8.0 \times 0.6 \times 1.5 \mathrm{~m}$ & one burned rock observed at $25 \mathrm{~cm}$ \\
\hline & 36 & $5.5 \times 0.6 \times 1.2 \mathrm{~m}$ & no cultural materials observed \\
\hline & 37 & $8.0 \times 0.8 \times 1.5 \mathrm{~m}$ & no cultural materials observed \\
\hline \multicolumn{4}{|c|}{ Test Units } \\
\hline Area & Test Unit & Dimensions, & Location \\
\hline \multirow{7}{*}{1} & 1 & $1.4 \times 1.0 \times 1.3 \mathrm{~m}$ & adjacent to Backhoe Trench 3 \\
\hline & 2 & $1.0 \times 0.5 \times 1.1 \mathrm{~m}$ & adjacent to Backhoe Trench 29 \\
\hline & 3 & $1.4 \times 1.0 \times 1.0 \mathrm{~m}$ & adjacent to Backhoe Trench 27 \\
\hline & 4 & $1.0 \times 1.0 \times 1.0 \mathrm{~m}$ & adjacent to Backhoe Trench 28 \\
\hline & 6 & $1.0 \times 1.0 \times 1.0 \mathrm{~m}$ & isolated \\
\hline & 7 & $1.0 \times 1.0 \times 0.9 \mathrm{~m}$ & isolated \\
\hline & 8 & $1.0 \times 1.0 \times 1.02 \mathrm{~m}$ & isolated \\
\hline \multirow{9}{*}{2} & 9 & $1.0 \times 1.0 \times 0.61 \mathrm{~m}$ & adjacent to Backhoe Trench 31 \\
\hline & 10 & $1.0 \times 1.0 \times 0.8 \mathrm{~m}$ & adjacent to Backhoe Trench 31 \\
\hline & 12 & $1.0 \times 1.0 \times 0.85 \mathrm{~m}$ & isolated \\
\hline & 13 & $1.0 \times 1.0 \times 0.43 \mathrm{~m}$ & adjacent to Backhoe Trench 31 \\
\hline & 14 & $1.0 \times 1.0 \times 0.5 \mathrm{~m}$ & isolated \\
\hline & 15 & $1.0 \times 1.0 \times 0.45 \mathrm{~m}$ & isolated \\
\hline & 16 & $1.0 \times 1.0 \times 0.38 \mathrm{~m}$ & isolated \\
\hline & 17 & $1.0 \times 1.0 \times 0.49 \mathrm{~m}$ & isolated \\
\hline & 18 & $1.0 \times 1.0 \times 0.46 \mathrm{~m}$ & isolated \\
\hline \multirow{2}{*}{7} & $5 * *$ & $1.0 \times 1.0 \times 1.3 \mathrm{~m}$ & adjacent to Backhoe Trench 34 \\
\hline & 11 & $1.0 \times 0.5 \times 0.8 \mathrm{~m}(1.30)$ & adjacent to Backhoe Trench 34 \\
\hline \multicolumn{4}{|c|}{$\begin{array}{l}\text { * Backhoe Trench } 3 \text { was dug during Phase I but reexcavated and expanded during Phase IIA } \\
\text { ** Test Unit } 5 \text { excavation began at } 70 \mathrm{~cm} \text { and extended to } 130 \mathrm{~cm} \text {. The upper } 70 \mathrm{~cm} \text { was removed by } \\
\text { backhoe. }\end{array}$} \\
\hline
\end{tabular}

of this dart point have been heavily reworked. The cultural materials recovered/observed in the artificial fill in Area 2 probably represent a cultural component comparable to the upper $50 \mathrm{~cm}$ of cultural occupations (i.e., Zone A) in Area 1.

Area 7 is the alluvial terrace west of the West Springs, crossing the 4th fairway of the golf course. Five backhoe trenches (Backhoe Trenches 33-37) and two test units (Test Units 5 and 11) were excavated along the proposed pipeline route (Figure 23). Single isolated burned rocks were observed in Backhoe Trenches 34 and 35, but no cultural materials were observed in the other three trenches. Since the burned rock in Backhoe Trench 34 was found in situ at $110 \mathrm{~cm}$, Test Unit 5 was excavated adjacent to the trench to sample these deep deposits. Scattered burned rocks and a moderate concentration of flakes $(n=28)$ were found at 70-120 cm (see Appendix F, Table 44). 


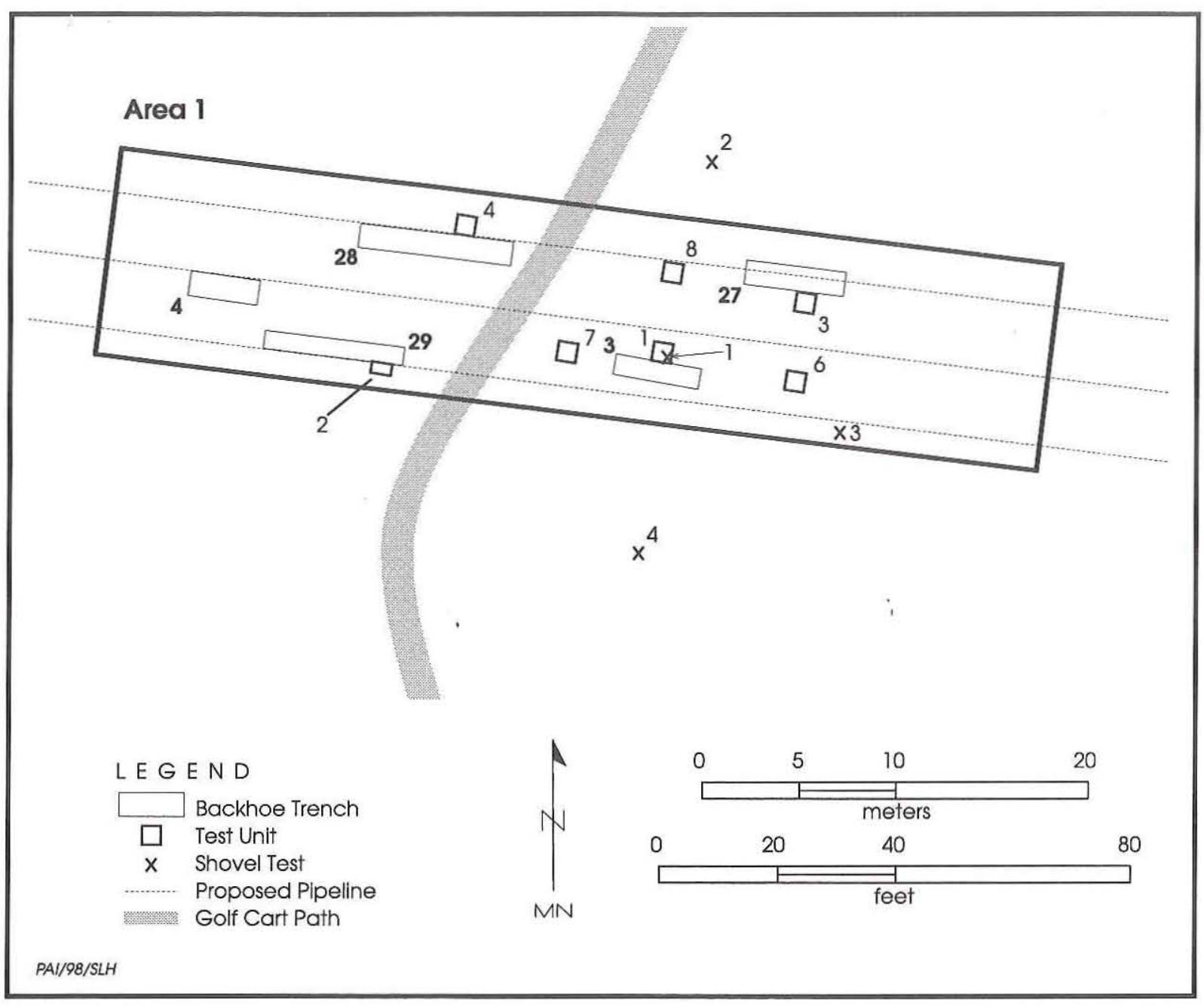

Figure 21. Phase I and IIA test excavations in Area 1, 41VV444.

The burned rocks were most concentrated at $90-110 \mathrm{~cm}$, while the flakes were most concentrated $(n=25)$ at $100-110 \mathrm{~cm}$. Test Unit 11 was excavated adjacent to Test Unit 5 to discern whether the burned rocks might be associated with an intact feature. The upper $70 \mathrm{~cm}$ of sediment was removed by the backhoe and the unit was hand excavated from 70 to $130 \mathrm{~cm}$. Additional scattered burned rocks were found at the same depths as in Test Unit 5, but no intact feature was encountered. No flakes were recovered from this unit.

The Department of Antiquities Protection at the Texas Historical Commission was consulted at the conclusion of Phase IIA testing. Additional work was recommended in Area 1, where stratified cultural zones yielding interpretable materials and containing intact features and organic remains had been encountered. The area of potential effect was small relative to portions of the site where comparable deposits might be expected. Consequently, it was determined that hand excavation of a small block of units would provide an adequate sample of cultural remains from the deposits that were to be impacted and would yield sufficient data for interpreting the prehistoric occupations. Area 1 was slated for the excavation of 30 additional 1x1-m units to an average depth of approximately $100 \mathrm{~cm}\left(\right.$ ca. $\left.30 \mathrm{~m}^{3}\right)$.

Cultural materials encountered in Area 2 were found to be extensively disturbed. Although 


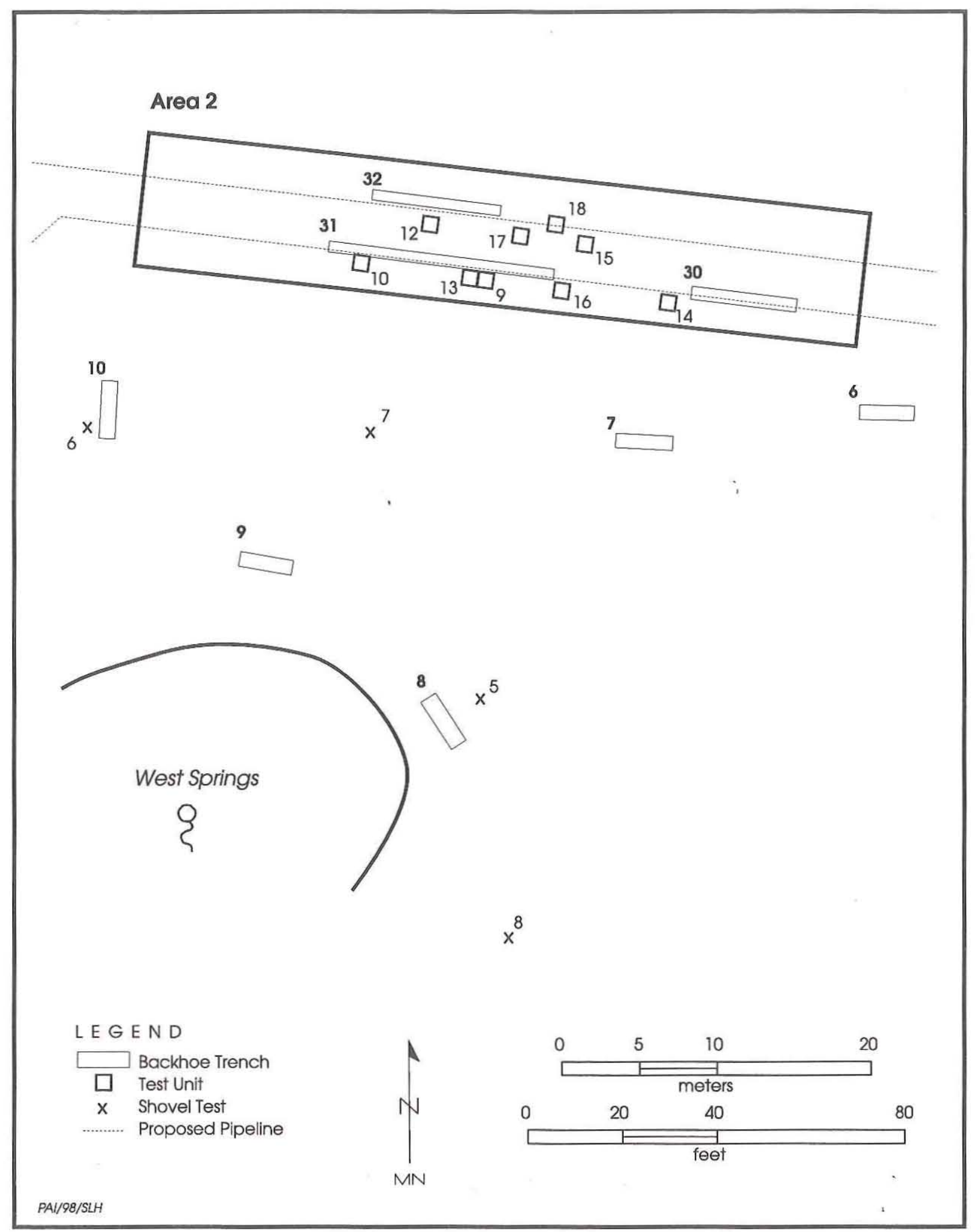

Figure 22. Phase I and IIA test excavations in Area 2, 41VV444. 


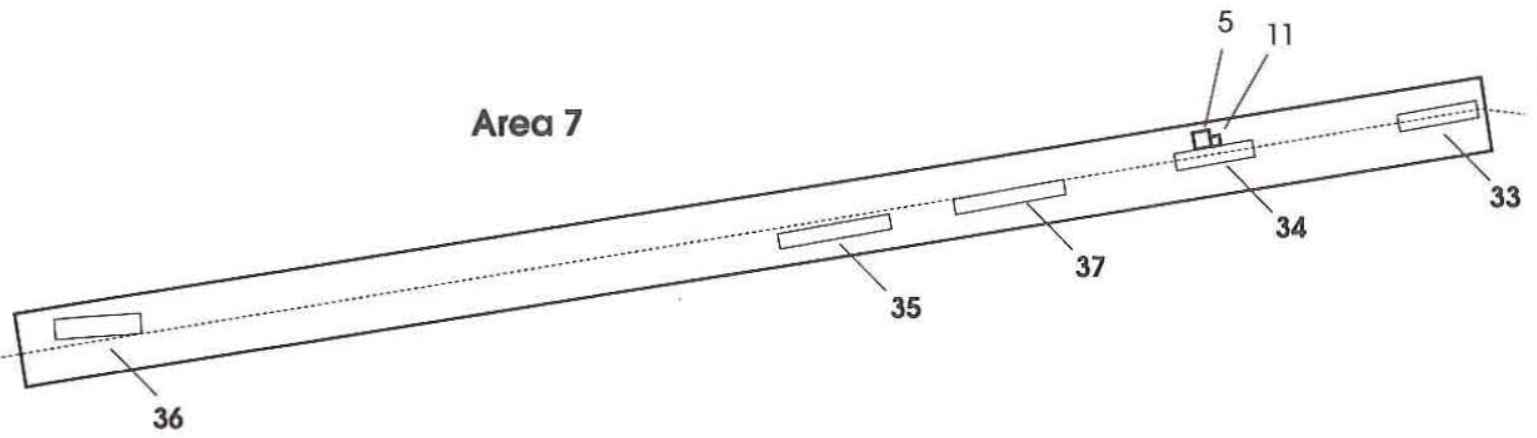

LEGEN D

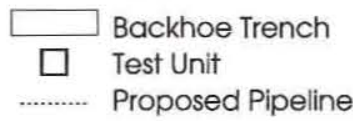

PAI/98/SLH

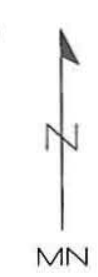

$\mathrm{MN}$

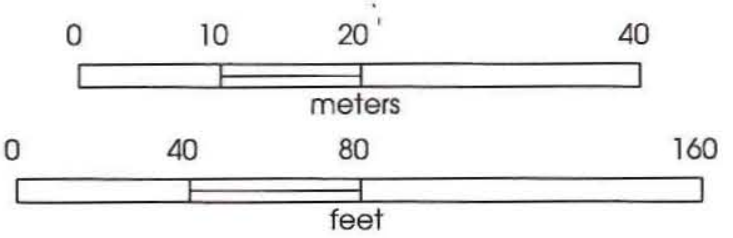

Figure 23. Phase IIA test excavations in Area 7, 41VV444,

intact deposits are likely to be present nearby but outside the proposed pipeline corridor, no further work was scheduled for Area 2.

Area 7 testing revealed that buried cultural materials are present; however, no preserved organic remains (e.g., charcoal) were encountered. The relatively low density scatter of cultural materials likely represents an intact buried cultural component, but obtaining an interpretable sample of materials would require a large block excavation. Such an effort was deemed unwarranted because the deeply buried deposits would only be impacted by the excavation of a single pipeline trench. No further work was slated for Area 7. At the conclusion of Phase IIA fieldwork, Areas 2 and 3 were backfilled.

\section{Phase IIIB}

Phase IIB consisted of intensive testing in Area 1 only. The plan called for an additional 30 test units, but 35 units were actually dug, bringing the number of hand-excavated units in Area 1 to 42 (Figure 24). At the conclusion of the Phase IIB fieldwork, 53 test units had been excavated in all areas of the site (Table 9). Excavated sediment totaled $43 \mathrm{~m}^{3}$, most of which (85 percent, $36.4 \mathrm{~m}^{3}$ ) was removed from Area 1 . For ease of analysis, the test units were renumbered as excavation units; these new unit designations are used for the rest of the report. Appendix $\mathrm{F}$ lists provenience data for artifacts recovered from all phases of work at 41VV444.

\section{SEDIMENTS AND STRATIGRAPHY OF THE SAN FELIPE CREIEIK VALLEY}

San Felipe Creek heads northeast of Del Rio and drains ca. $130 \mathrm{~km}^{2}$ before it reaches the Rio Grande. Relief throughout the drainage basin ranges from 265 to $400 \mathrm{~m} \mathrm{msl}$. The creek incises 


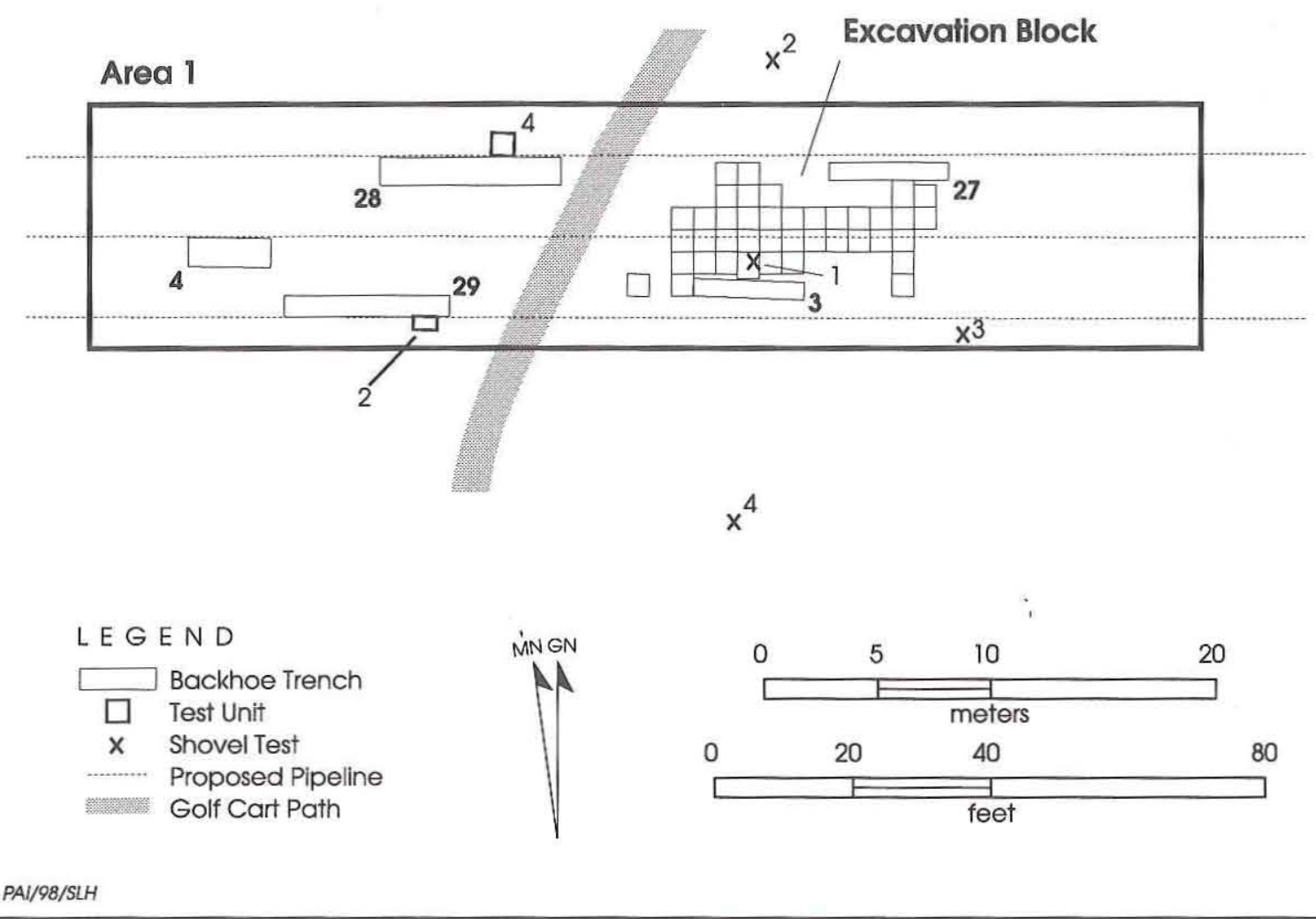

Figure 24. Phase I, IIA, and IIB excavations in Area 1, 41VV444.

Upper Cretaceous limestones, shales, and siltstones; calcareous and gypsiferous clays of the Eagle Ford Group, Buda Formation, and Del Rio Clay; and Lower Cretaceous Salmon Peak Formation limestones that contain abundant chert masses (Bureau of Economic Geology 1977). Tertiary Uvalde Gravels mantle the divides (Salmon Peak Formation) between San Felipe Creek and its tributaries. The gradient of the channel is $5.4 \mathrm{~m} / \mathrm{km}$ and its sinuosity is 1.2. Downstream portions of San Felipe Creek are a perennial stream fed by several springs, including the 10 vents of San Felipe Springs, the fourth largest in Texas (Brune 1981:452). Abandoned, sediment-filled spring vents were encountered in the project area in some of the geotechnical borings made by FugroMcClelland, Inc. (1997) (Figures 25 and 26). In the vicinity of San Felipe Springs and site $41 \mathrm{VV} 444$, the stream channel is straight and the gradient is low $(3 \mathrm{~m} / \mathrm{km})$.
One constructional surface $\left(\mathrm{T}_{1}\right.$ terrace) is present within the valley near 41VV444. The terrace surface lies 3.0 to $3.5 \mathrm{~m}$ above the San Felipe channel and extends across the entire valley. The margins of the terrace are beveled, sloping toward the creek channel. Geotechnical borings reveal that the fill below the $\mathrm{T}_{1}$ surface is 2 to $3 \mathrm{~m}$ thick. Backhoe trench exposures show that the fill consists of a basal gravelly alluvium and overlying fine-grained alluvium. These alluvial deposits interfinger with gravelly colluvial deposits that drape portions of the valley margins.

Colluvial deposits were observed in Backhoe Trenches 19 and 36, on the eastern and western margins of the valley, respectively. Colluvial sediments constitute the basal deposits (Zones 3-4, 72-156 cm) in Backhoe Trench 19 and rest on the Salmon Peak limestone. The deposits are characterized by light yellowish brown gravelly silty clays and gravelly silt 
Table 9. Summary of all hand-excavated units at 41VV444

\begin{tabular}{|c|c|c|c|c|c|}
\hline $\begin{array}{c}\text { Original } \\
\text { Test } \\
\text { Unit } \\
\end{array}$ & $\begin{array}{c}\text { Excavation } \\
\text { Unit }\end{array}$ & $\begin{array}{l}\text { Unit } \\
\text { Size* }\end{array}$ & $\begin{array}{l}\text { Depth of } \\
\text { Excavation } \\
\text { (cm) }\end{array}$ & $\begin{array}{c}\text { Excavated } \\
\text { Volume }\left(\mathrm{m}^{3}\right)\end{array}$ & Comments \\
\hline \multicolumn{6}{|l|}{ AREA 1} \\
\hline 38 & 1 & - & 72 & 0.72 & \\
\hline 8 & 2 & - & 102 & 1.02 & \\
\hline 39 & 3 & - & 70 & 0.70 & \\
\hline 22 & 4 & - & 72 & 0.72 & \\
\hline 37 & 5 & - & 85 & 0.85 & \\
\hline 3 & 6 & $1.0 \times 1.4 \mathrm{~m}$ & 100 & 1.40 & \\
\hline 42 & 7 & - & 95 & 0.95 & \\
\hline 52 & 8 & - & 69 & 0.69 & \\
\hline 48 & 9 & - & 66 & 0.66 & \\
\hline 40 & 10 & - & 66 & 0.66 & \\
\hline 23 & 11 & - & 90 & 0.90 & \\
\hline 25 & 12 & - & 90 & 0.90 & \\
\hline 26 & 13 & - & 96 & 0.96 & ; \\
\hline 27 & 14 & - & 99 & 0.99 & \\
\hline 28 & 15 & - & 91 & 0.91 & \\
\hline 29 & 16 & - & 88 & 0.88 & \\
\hline 30 & 17 & - & 98 & 0.98 & \\
\hline 19 & 18 & - & 94 & 0.94 & \\
\hline 43 & 19 & - & 84 & 0.84 & \\
\hline 51 & 20 & - & 66 & 0.66 & \\
\hline 45 & 21 & - & 64 & 0.64 & \\
\hline 41 & 22 & - & 86 & 0.86 & \\
\hline 24 & 23 & - & 96 & 0.96 & \\
\hline 31 & 24 & - & 86 & 0.86 & \\
\hline 32 & 25 & - & 93 & 0.93 & \\
\hline 33 & 26 & - & 93 & 0.93 & \\
\hline 34 & 27 & - & 89 & 0.89 & \\
\hline 35 & 28 & - & 87 & 0.87 & \\
\hline $\begin{array}{l}36 \\
20\end{array}$ & 29 & - & 85 & $\begin{array}{l}0.85 \\
0.90\end{array}$ & \\
\hline & & . & & & \\
\hline $\begin{array}{l}50 \\
46\end{array}$ & $\begin{array}{l}31 \\
32\end{array}$ & - & $\begin{array}{l}60 \\
65\end{array}$ & $\begin{array}{l}0.60 \\
0.65\end{array}$ & \\
\hline 47 & 33 & - & 66 & $\begin{array}{l}0.65 \\
0.66\end{array}$ & \\
\hline 1 & 34 & $1.0 \times 1.4 \mathrm{~m}$ & 130 & 1.82 & \\
\hline 44 & 35 & - & 93 & 0.93 & \\
\hline 49 & 36 & - & 90 & 0.90 & \\
\hline 21 & 37 & - & 66 & 0.66 & \\
\hline 7 & 38 & - & 93 & 0.93 & \\
\hline 53 & 39 & - & 63 & 0.63 & \\
\hline 6 & 40 & - & 105 & 1.05 & . \\
\hline 4 & 41 & - & 100 & 1.00 & $10 \mathrm{~cm}$ of artificial fill, not screened \\
\hline 2 & 42 & $1.0 \times 0.5 \mathrm{~m}$ & 110 & 0.55 & \\
\hline Subtotal & & & & 36.40 & \\
\hline
\end{tabular}


Table 9 continued

\begin{tabular}{|c|c|c|c|c|c|}
\hline $\begin{array}{c}\text { Original } \\
\text { Test } \\
\text { Unit } \\
\end{array}$ & $\begin{array}{c}\text { Excavation } \\
\text { Unit } \\
\end{array}$ & $\begin{array}{l}\text { Unit } \\
\text { Size* }\end{array}$ & $\begin{array}{l}\text { Depth of } \\
\text { Excavation } \\
\text { (cm) }\end{array}$ & $\begin{array}{c}\text { Excavated } \\
\text { Volume }\left(\mathrm{m}^{3}\right)\end{array}$ & Comments \\
\hline \multicolumn{6}{|l|}{ AREA 2} \\
\hline 18 & 43 & - & 46 & 0.46 & $30 \mathrm{~cm}$ of artificial fill, not screened \\
\hline 12 & 44 & - & 85 & 0.85 & \\
\hline 17 & 45 & - & 49 & 0.49 & $33 \mathrm{~cm}$ of artificial fill, not screened \\
\hline 15 & 46 & - & 45 & 0.45 & $15 \mathrm{~cm}$ of artificial fill, not screened \\
\hline 10 & 47 & - & 80 & 0.80 & \\
\hline 13 & 48 & - & 43 & 0.43 & $43 \mathrm{~cm}$ of artificial fill \\
\hline 9 & 49 & - & 61 & 0.61 & $41 \mathrm{~cm}$ of artificial fill \\
\hline 16 & 50 & - & 38 & 0.38 & $23 \mathrm{~cm}$ of artificial fill, not screened \\
\hline 14 & 51 & - & 50 & 0.50 & \\
\hline Subtotal & & & & 4.97 & \\
\hline \multicolumn{6}{|l|}{ AREA 7} \\
\hline 5 & 52 & - & 130 & 1.30 & \\
\hline 11 & 53 & $1.0 \times 0.5 \mathrm{~m}$ & . $\quad 70$ & 0.35 & $\begin{array}{l}\text { excludes } 60 \mathrm{~cm} \text { removed by } \\
\text { backhoe }\end{array}$ \\
\hline Subtotal & & & & 1.65 & \\
\hline Totals & & & & 43.02 & \\
\hline
\end{tabular}

loams. These deposits are probably late to middle Holocene in age, as they interfinger with alluvial deposits of similar age. The overlying alluvium is no older than late Holocene based on the degree of soil development (A-B soil profile). Colluvial deposits observed in Backhoe Trench 36 are $114 \mathrm{~cm}$ thick and rest on the Salmon Peak limestone. Sediments consist of very pale brown, yellowish brown, and brown silt loams and silty clays. Matrix-supported gravels increase in frequency with depth in the profile of Backhoe Trench 36, suggesting that the gradient of the valley margin has decreased over time. Based on the degree of soil development (A-B-C profile) observed in the profile of this trench, these deposits are late Holocene in age.

The valley alluvium below the $T_{1}$ surface appears to consist of two fills, a basal gravel and an overlying fine-grained alluvium. The basal gravel is at least $1 \mathrm{~m}$ thick based on geotechnical borings and was observed in Backhoe Trench 29 and Excavation Unit 34. The gravels are poorly sorted, rounded limestone clasts that become slightly cemented with depth. The age of the basal gravels is uncertain, but their slightly cemented nature and the fact that many of the limestone gravels are very soft and powdery (in an advanced stage of weathering) suggest great antiquity. This gravel deposit is probably late Pleistocene to early Holocene in age.

Overlying fine-grained alluvial sediments were observed across the valley in all trenches except Backhoe Trench 36 and in all excavation units. These sediments encapsulate the archeological materials. Based on exposures in Backhoe Trenches 29 and 33 and Excavation Unit 34, these fine-grained sediments are at least 1.5 and up to $2.0 \mathrm{~m}$ thick. The sediments are typically dark gray, dark grayish brown, brown, pale brown, yellowish brown, and light yellowish brown loams, clay loams, silty clay loams, and silty clays. Dispersed gravels are common in the backhoe trench and excavation unit profiles close to San Felipe Creek. These gravels tend to grade laterally in size, becoming smaller (from predominately pebble- to granule-sized clasts) and less abundant away from the creek. Accumulation of these sediments and aggradation of the $T_{1}$ surface began by 3,300 years ago, based on a conventional radiocarbon age obtained on a bulk sediment sample from just above the 


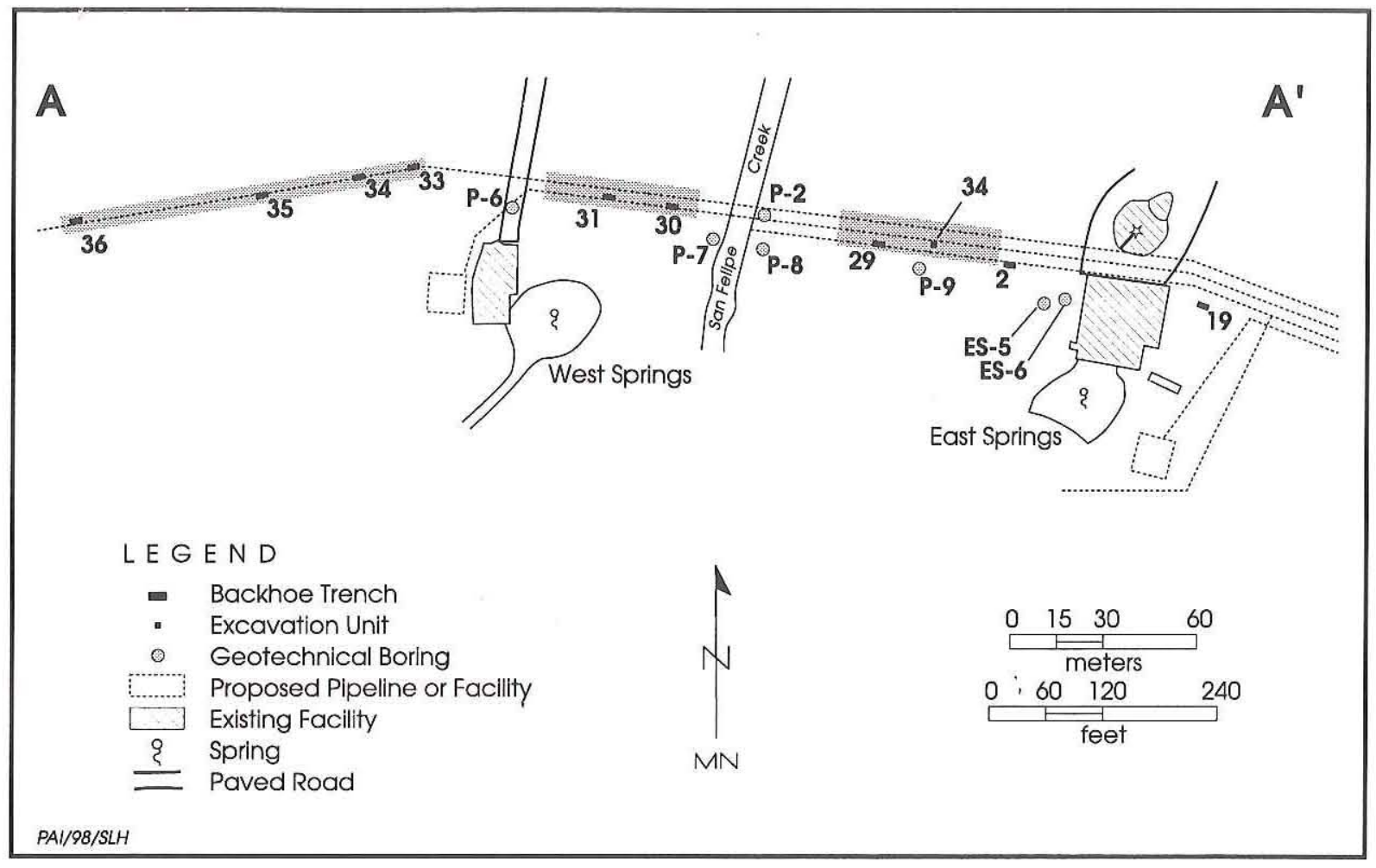

Figure 25. Map showing locations of selected backhoe trenches, excavation units, and geotechnical bore holes in the vicinity of 41 VV 444 .

basal gravels. Soils of the Reynosa series have formed on these deposits (Golden et al. 1982). These soils are classified as Fluventic Ustochrepts-inceptisols with ochric epipedons (surface horizon is light in color and contains little organic matter) and ustic moisture regime (moisture is limited but present at a time suitable for plant growth)_formed on fluvial sediments (Soil Survey Staff 1996). Profiles typically display A-B-B2-C or A-Bw-Bw2-C horizons. Evidence of bioturbation from insects is great throughout the soil matrix.

The deposition of the upper fine-grained alluvial unit of the $T_{1}$ terrace in this portion of the valley is unusual in that channel fill facies and evidence of lateral accretion and migration of the channel are absent from the backhoe trench profiles. The $T_{1}$ surface that extends across the valley is relatively flat, with the only relief being the recent alterations made by construction of the golf course. The absence of meander scars on the $\mathrm{T}_{1}$ surface and cutbanks along the channel suggest that the San Felipe channel has been stable throughout much of the late Holocene and that most of the upper alluvial unit and development of the $\mathrm{T}_{1}$ floodplain formed by vertical accretion due to overbank sedimentation. This type of floodplain development can be explained in part by the stable bed-aggrading banks (SBAB) model of Brown (1987, 1997:2326) and Brown and Keough (1992). This model was constructed to explain the evolution of layered floodplains (late Pleistocene basal gravels and surficial fine-grained alluvium) in lowgradient and low-sinuosity channels in the Midlands, United Kingdom.

The segment of San Felipe Creek in the project area has similar characteristics-a relatively low gradient and sinuosity and finegrained overbank facies overlying gravel deposits. Brown and Keough (1992:441) argue that these characteristics develop in part due to an increase in the supply of fine-grained sediment and an imbalance between channel bed and floodplain aggradation rates. This results in high bank development through increased vertical accretion, relative channel incision, a reduction in relative floodplain relief 


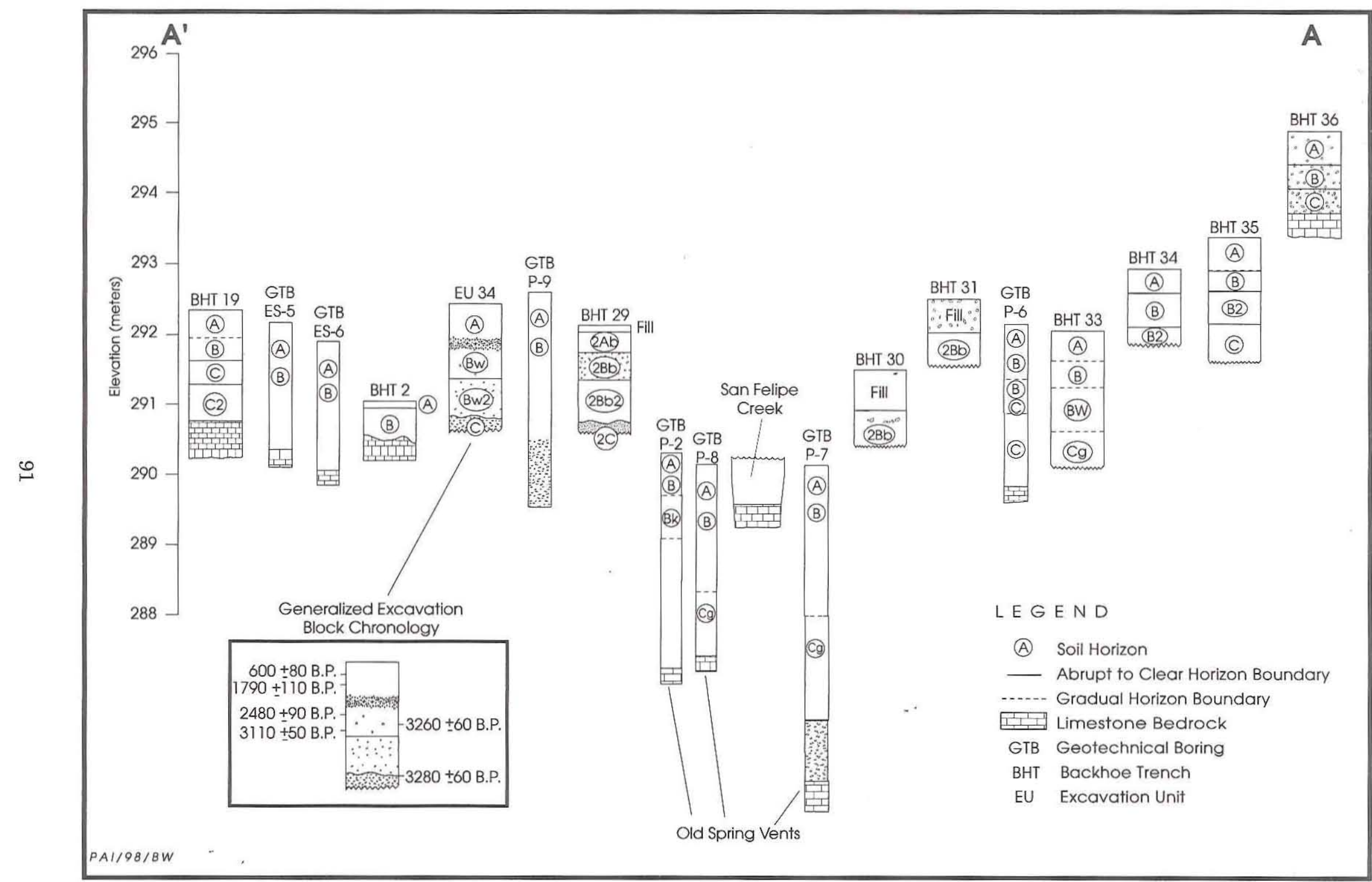

Figure 26. San Felipe Creek valley cross section depicting backhoe trench, excavation unit, and geotechnical bore hole profiles. 
and channel width-to-depth ratios, and an increase in the proportion of muddy overbank sediments. Bank resistance and a reduction in channel migration follow as a result of the development of high banks of cohesive finegrained (silts and clays) sediments (Brown and Keough 1992:435).

An increase in the availability and deposition of fine-grained sediment reflects a change from a supply-limited system to a transport-limited system, which Brown and Keough (1992:443) suggest is induced by climatic or anthropogenic changes (e.g., clear cutting for agricultural fields). In the case of San Felipe Creek, it may not be as much a matter of fine-grained sediment availability or supply as a shift to a hydrologic regime that permitted the deposition and storage of finegrained alluvium rather than its erosion and transport out of the valley. Regardless, evidence at San Felipe Springs suggests that'a shift in hydrologic conditions occurred by ca. 3,280 B.P. Prior to this time, San Felipe Creek was probably a gravelly bed load type stream with a braided channel pattern. Such characteristics are more typical of high-gradient streams with flashy discharges brought on by infrequent but high-intensity rainfall during prolonged periods of more xeric conditions. Such conditions probably prevented the deposition of finegrained alluvium prior to 3280 B.P. and stripped the San Felipe Creek valley of much of its earlier alluvium. The catalyst for this shift in depositional regimes may have been climatic change.

Palynological, microfaunal, isotopic, and stratigraphic data all concur that a period prior to ca. 3280 B.P. was drier across most of Texas (e.g., Bryant and Holloway 1985; Holliday 1989, 1995; Nordt et al. 1994; Toomey et al. 1993). Typically referred to as the Altithermal (Antevs 1955), this period of prolonged xeric conditions encompassed much of the early to middle Holocene and ended by ca. 5000-4500 B.P. Altithermal conditions may have had an effect on discharge at San Felipe Springs since the post-3280 B.P. hydrologic regime is more typical of a nonflashy, low-energy, perennial stream. Such conditions are probably the result of, or at least enhanced by, a greater discharge at San Felipe Springs. The hydrologic change in San Felipe Creek clearly occurred prior to 3280 B.P.; however, more precise chronological resolution and temporal correlation with other paleoenvironmental data linking the event to the waning of the Altithermal cannot be made at this time due to the small number of radiocarbon ages and stratigraphic profiles observed in this study.

Vertical accretion of fine-grained sediments commenced around 3280 B.P., and all of the cultural deposits investigated during this project accumulated after that time. Deposition was relatively rapid, promoting stratigraphic separation of the earlier cultural components at 41VV444. Radiocarbon ages and compressed upper cultural components suggest that aggradation of the $\mathrm{T}_{1}$ terrace slowed after ca. $1500-1000$ B.P. as the terrace surface aggraded to a level that could not be inundated by floodwaters on a regular basis. It was probably at this time that the terrace margins were beveled, as erosional processes (slopewash) outpaced deposition.

\section{SUMMIRY OF DEPOSITIONAL HISTORY AND PREHISTORIC OCCUPATIONS}

Radiocarbon ages, cultural materials, and stratigraphic and pedologic data suggest that a large portion of the Holocene alluvial record is missing from the San Felipe valley in the vicinity of 41 VV 444. Prior to the earliest occupations at the site, San Felipe Creek was a gravelly, braided system. Arid Altithermal conditions and lower spring discharge promoted flashy rainfall discharges and erosion of alluvial deposits containing earlier sites and components (Paleoindian through Middle Archaic). The waning of Altithermal conditions fostered a shift in the hydrologic regime of San Felipe Creek, promoting the development of a floodplain through vertical accretion of finegrained sediments across the valley. The construction of erosion-resistant, high channel banks resulted in the relative incision and limited lateral movement of San Felipe Creek. As a result, Late Archaic and Late Prehistoric archeological remains were encapsulated and preserved in silty floodplain facies after ca. 3000 B.P. Vertical accretion of the floodplain continued but slowed by ca. $1500-1000$ B.P., as evidenced by radiocarbon ages and compressed archeological assemblages. 


\section{BLOCK EXACAVATIONS IN AREA 1, 41VV444}

Gemma Mehalchick and Douglas K. Boyd

\section{SUMIMARY OF EXCAVATIONS}

The intensive excavations in Area 1 at the San Felipe Springs site consisted of 5 backhoe trenches, 4 shovel tests, and 42 excavation units. One isolated and 39 contiguous excavation units were located east of the golf cart path on the highest portion of the terrace, with the terrace surface to the east and west beveled by natural erosion and/or human alteration (Figure 27). These 40 units constitute the block excavation that is the subject of the remainder of this report. Features and cultural materials encountered are described in this chapter and are interpreted in Chapter 8. The cultural features and materials encountered elsewhere at 41VV444 are discussed in Chapter 6.

The ground in the vicinity of the excavation block slopes gradually from the northwest to the east-southeast. Surface elevation for each unit was obtained using an electronic total station and tied to a primary datum point with a known elevation above mean sea level. Surface elevations in the northwest corner of the block excavation (i.e., at Excavation Units 1-5, 11, and 12) are highest, at 292.52-292.50 m, while those in the east end of the block (i.e., Excavation Units 7, 18, 19, 29, and 30) are lowest, at 292.35-292.30 m (Table 10).

Units were excavated to depths ranging from 60 to $110 \mathrm{~cm}$ below the surface; the average depth was $86 \mathrm{~cm}$. Excavations were done in arbitrary 10-cm levels tied to the primary datum (Figure 28). A total of $36.4 \mathrm{~m}^{3}$ of fill was hand excavated from the 40 units (see Table 9).

\section{SEDIMENTS AND STRATIGRAPHY}

The archeological materials recovered from the block excavation were encapsulated in the late Holocene alluvial unit (see Chapter 6). A summary of the soil stratigraphy and sedimentological data of this alluvial unit is presented in Figure 29.

The alluvial sediments consist of loams and clay loams with varying amounts of dispersed granule- to pebble-sized gravels. Discrete gravel beds or lenses were not present in the profiles due to the high degree of bioturbation, primarily insect burrowing. The loamy deposits rest on gravelly alluvium and are ca. $170 \mathrm{~cm}$ thick. Deposition of these sediments commenced by 3,280 B.P. The floodplain surface rapidly aggraded until ca. $1500-1000$ B.P. based on the compressed nature of the later archeological assemblages at the site and their associated radiocarbon ages. At this point, the terrace obtained a height that could not be inundated on a regular basis and was topped only by the highest of floods. The paleoflood record suggests that one or more floods between ca. 2700 and 1700 B.P. were of high magnitude, as abundant granulesized gravels were observed in the profiles of the excavation block (at 291.95-291.85 m). This zone of pea-sized gravels corresponds to a decrease in artifact densities separating Cultural Zone B from Cultural Zone C.

The soil imprint on these sediments consists of an A-Bw-Bw2 profile. The A horizon is a dark gray to dark grayish brown loam with moderate granular structure and a few dispersed gravels. The $\mathrm{Bw}$ horizon is a brown clay loam with moderate subangular blocky structure and few to common dispersed gravels. The Bw2 horizon, observed only in the profile of Excavation Unit 34 , is a brown clay loam with moderate subangular blocky structure. Dispersed gravels are present and increase in frequency down profile. 


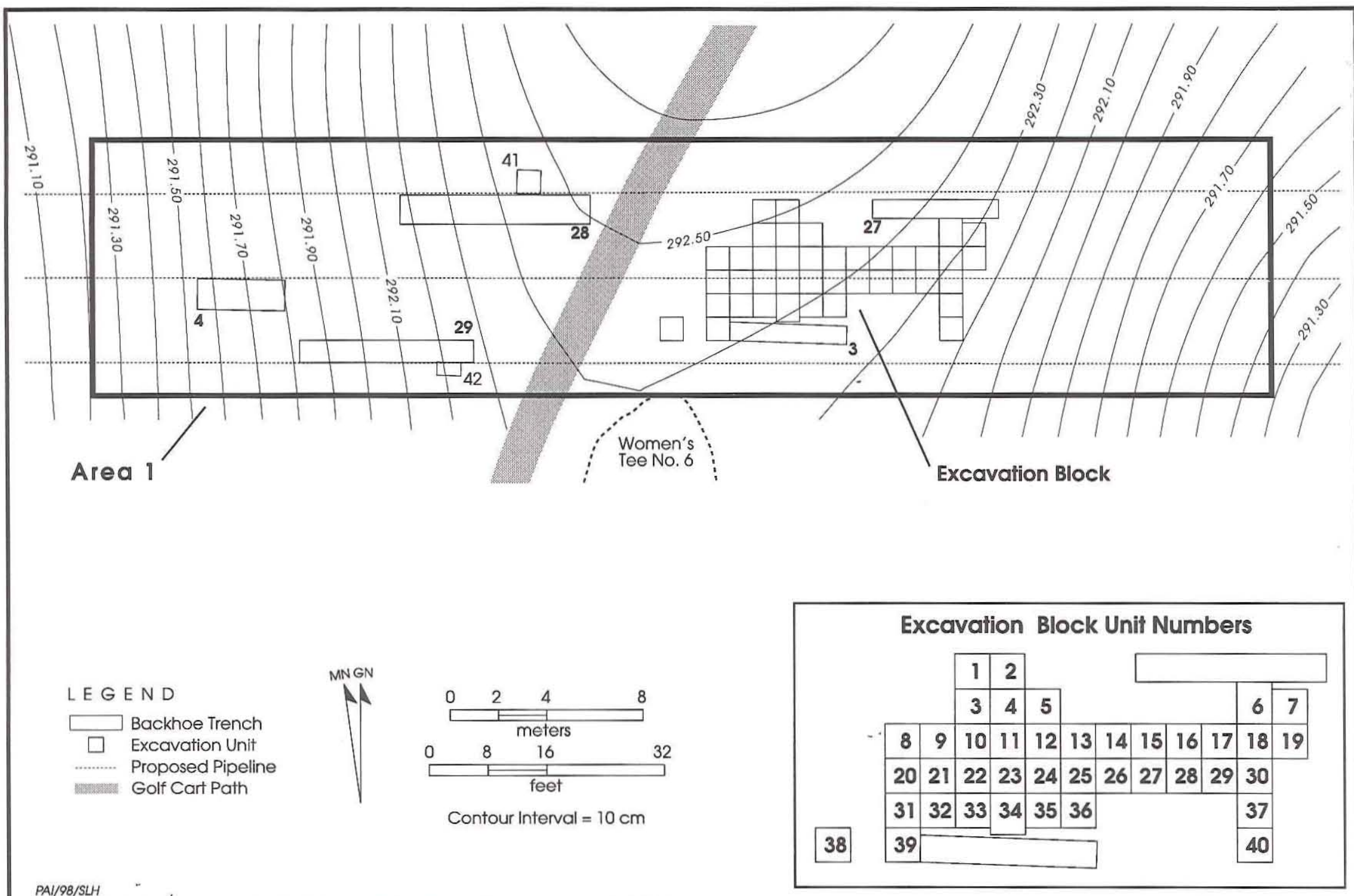

Figure 27. Topographic plan view of excavations in Area 1, 41 VV444. 
Table 10. Elevation data for excavation block umits in Area 1, 41VV444

\begin{tabular}{|c|c|c|}
\hline $\begin{array}{c}\text { Excavation } \\
\text { Unit }\end{array}$ & $\begin{array}{c}\text { Starting } \\
\text { Elevation (m) }\end{array}$ & $\begin{array}{c}\text { Ending } \\
\text { Elevation (m) }\end{array}$ \\
\hline 1 & 292.52 & 291.80 \\
\hline 2 & 292.52 & 291.50 \\
\hline 3 & 292.50 & 291.80 \\
\hline 4 & 292.52 & 291.80 \\
\hline 5 & 292.50 & 291.65 \\
\hline 6 & 292.38 & 291.38 \\
\hline 7 & 292.35 & 291.40 \\
\hline 8 & 292.49 & 291.80 \\
\hline 9 & 292.46 & 291.80 \\
\hline 10 & 292.46 & 291.80 \\
\hline 11 & 292.50 & 291.60 \\
\hline 12 & 292.50 & 291.60 \\
\hline 13 & 292.46 & 291.50 \\
\hline 14 & 292.39 & 291.40 \\
\hline 15 & 292.41 & 291.50 \\
\hline 16 & 292.38 & 291.50 \\
\hline 17 & 292.38 & 291.40 \\
\hline 18 & 292.34 & 291.40 \\
\hline 19 & 292.34 & 291.50 \\
\hline 20 & 292.46 & 291.80 \\
\hline 21 & 292.44 & 291.80 \\
\hline 22 & 292.46 & 291.60 \\
\hline 23 & 292.46 & 291.50 \\
\hline 24 & 292.46 & 291.60 \\
\hline 25 & 292.43 & 291.50 \\
\hline 26 & 292.43 & 291.50 \\
\hline 27 & 292.39 & 291.50 \\
\hline 28 & 292.37 & 291.50 \\
\hline 29 & 292.35 & 291.50 \\
\hline 30 & 292.30 & 291.40 \\
\hline 31 & 292.40 & 291.80 \\
\hline 32 & 292.45 & 291.80 \\
\hline 33 & 292.46 & 291.80 \\
\hline 34 & 292.45 & 291.15 \\
\hline 35 & 292.43 & 291.50 \\
\hline 36 & 292.40 & 291.50 \\
\hline 37 & 292.26 & 291.60 \\
\hline 38 & 292.43 & 291.50 \\
\hline 39 & 292.43 & 291.80 \\
\hline 40 & 292.25 & 291.20 \\
\hline
\end{tabular}

\section{DEFINITION OF CULTURAL ZONES AND FEATURE DESCRIPTIONS}

Stratigraphically separable cultural zones were recognized as the excavation block was in progress. Although the fine-grained alluvial sediments are relatively uniform throughout the stratigraphic profile in the Area 1 block, it was obvious that materials and features could be separated into at least two, and possibly three or more, stratigraphic zones (see Figure 28). Field observations regarding cultural/stratigraphic zones are outlined below.

The upper $32 \mathrm{~cm}$ of the deposit, from 292.52 to $292.20 \mathrm{~m}$, was designated Cultural Zone A. Diagnostic artifacts recovered from this zone consist mostly of ceramic sherds and arrow points, particularly Cliffton and Perdiz points.

From 292.20 to 291.90 m, Cultural Zone B is represented by Shumla points and a dense accumulation of burned rocks across the eastern half of the excavation block. Occasional arrow points and sherds were present at this depth, but these artifacts are believed to be vertically displaced by bioturbation.

A decrease in the density of cultural materials was evident from 291.90 to $291.80 \mathrm{~m}$. Designated Cultural Zone $\mathrm{B} / \mathrm{C}$, this $10-\mathrm{cm}$ level is viewed as a transition zone rather than a true cultural zone.

Cultural Zone $\mathrm{C}$ was defined by excavations from 291.80 to $291.40 \mathrm{~m}$, although most of the materials in this zone were recovered at 291.80 $291.50 \mathrm{~m}$. Zone C consists of another extensive layer of burned rocks and a discrete pit feature in the eastern portion of the block, in addition to a flint knapping dump area in the western half of the block. Although other pit features were intrusive into the burned rock layer in this zone, their origins and relative ages were unclear at the time. Only seven units were excavated from 291.50 to $291.40 \mathrm{~m}$. Though included in Zone C, this 10-cm level produced less than $3 \mathrm{~kg}$ of burned rocks and only four flakes.

Two units were excavated below $291.40 \mathrm{~m}$, but only three flakes were recovered from these deeper levels. The excavations below $291.40 \mathrm{~m}-$ to a maximum depth of $291.15 \mathrm{~m}$ in Excavation Unit 34-are collapsed under the heading of Cultural Zone D. Due to limited sampling and the paucity of artifacts, this zone is not discussed further below.

Seven cultural features were encountered (including the burned rock layers in Cultural Zones $\mathrm{B}$ and $\mathrm{C}$, which are not given feature numbers), and charcoal radiocarbon dates were obtained from six of them (Table 11). Three radiocarbon dates on nonfeature charcoal and sediment provide additional chronometric evidence. Most of the dates show stratigraphic 


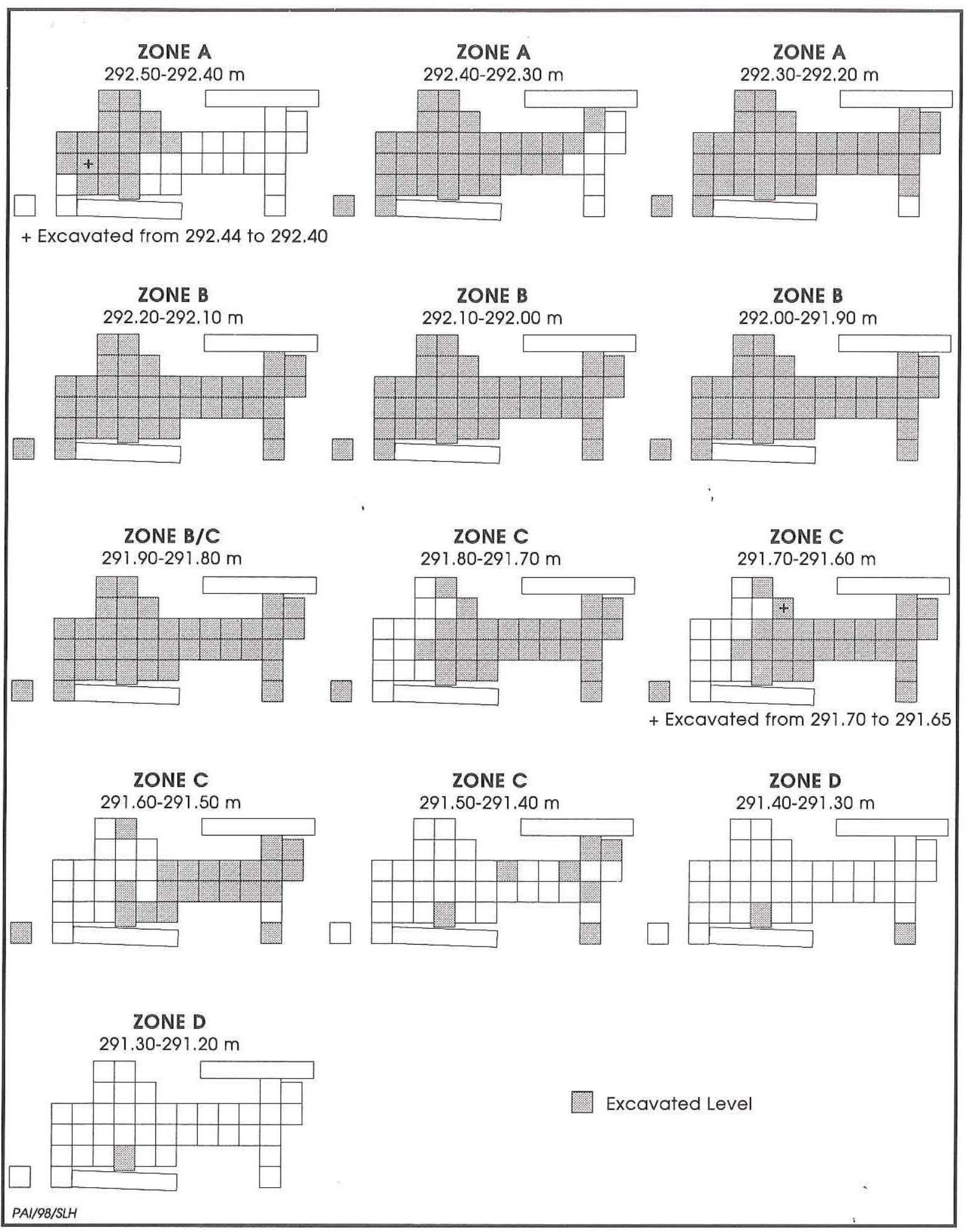

Figure 28. Excavated levels in the Area 1 excavation block, $41 \mathrm{VV} 444$. 


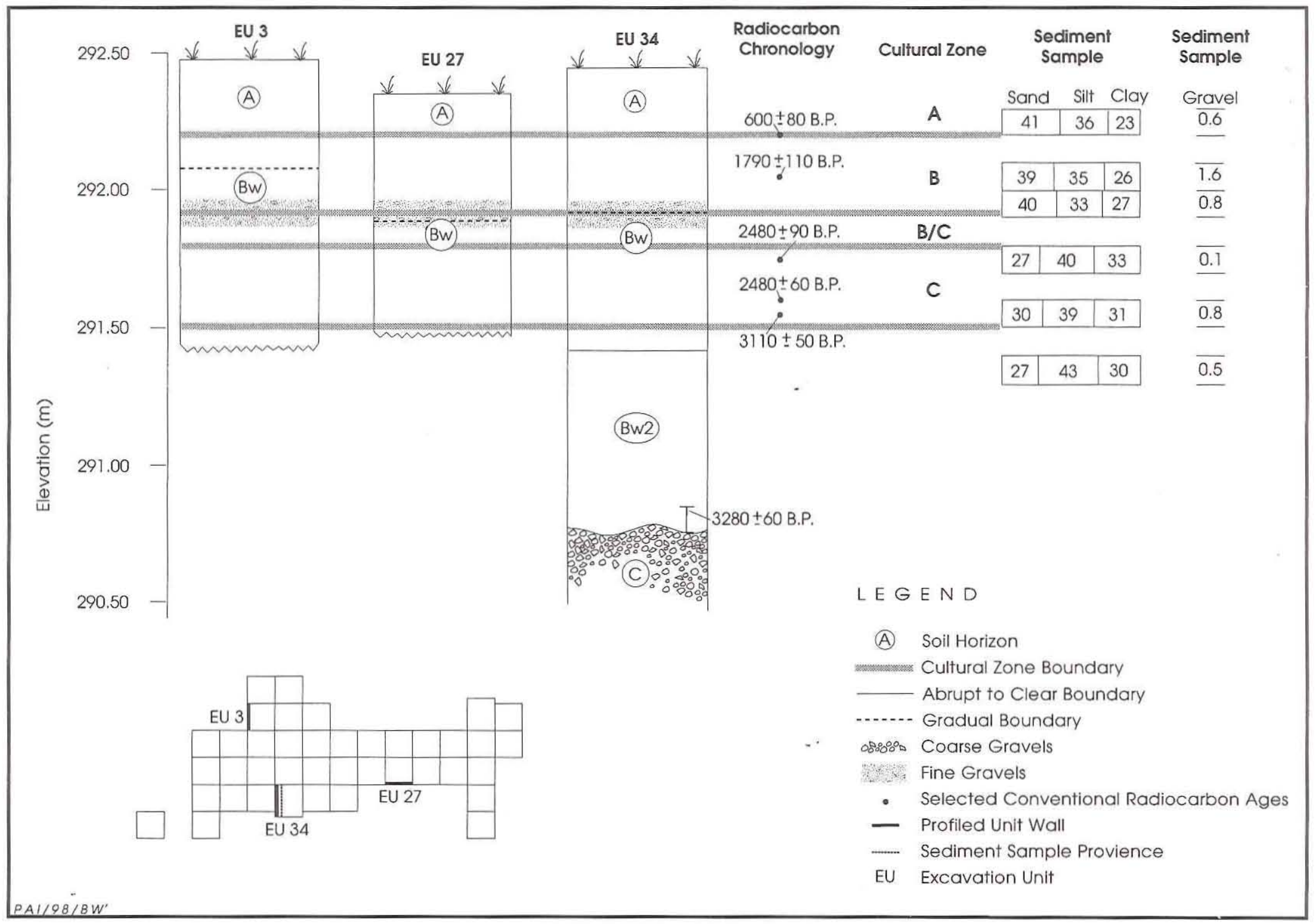

Figure 29. Soil stratigraphic profiles from Excavation Units 3, 27, and 34, along with particle-size data and radiocarbon chronology. 
Table 11. Summary of radiocarbon dates and investigated features from Area 1, 41VV444.

\begin{tabular}{|c|c|c|c|}
\hline Cultural Zone & Context & Excavation Units & $\begin{array}{c}\text { Calibrated } \\
\text { Radiocarbon Date } \\
\text { (1-Sigma Range)* }\end{array}$ \\
\hline Zone A/B Contact & Nonfeature $(292.20 \mathrm{~m})$ & 24 & A.D. $1295-1420$ \\
\hline Zone B & Zone B burned rock layer (292.20-291.90 m) & $\begin{array}{r}6,7,13-19,25- \\
30,36,37,40\end{array}$ & A.D. $110-395$ \\
\hline Zone B & Feature 3, burned rock-filled pit & $6,7,18,19$ & $790-405$ в.С. \\
\hline Zone B & Feature 5, soil stain & 6 & 375-190 в.С. \\
\hline Zone B & Feature 12 , burned rock-filled pit & 7,19 & $385-200$ в.C. \\
\hline Zone B/C & Nonfeature (291.84 m) & 24 & A.D. $1420-1450$ \\
\hline Zone C & Zone C burned rock layer (291.80-291.40) & $\begin{array}{c}6,7,13-19,25- \\
30,37,40\end{array}$ & 1420-1305 в.С. \\
\hline Zone C & Feature 11, burned rock-filled pit & $16,17,28,29$ & 1605-1440 в.C. \\
\hline Zone C & Feature 13 , knapping debris concentration & 13 & none \\
\hline Below Zone D & Nonfeature (290.85-290.75 m) & 34 & $1620-1490$ в.С. ${ }^{* *}$ \\
\hline
\end{tabular}

consistency, although a few are seemingly out of sequence.

\section{Cultural Zone A: 292.52-292.20 m}

Cultural Zone A deposits are beveled due to natural erosion and/or by landscaping during construction of the golf course. It is between 25 and $30 \mathrm{~cm}$ thick in the western half of the block but considerably thinner to the east. In Excavation Unit 40 at the southeast corner of the block, Zone A was completely lacking. For analysis purposes, it was subdivided into the following zones/ levels: A1, 292.52-292.40 m; A2, 292.40$292.30 \mathrm{~m}$; and A3, 292.30-292.20 m.
Cultural Zone A generated $99.9 \mathrm{~kg}$ of burned rocks scattered throughout the units, but only two units produced more than $4 \mathrm{~kg}$. Artifacts were common throughout the deposit. The apparent tendency for artifacts to be concentrated in the western portion of the block reflects the thinning and disappearance of Zone A to the east (Figure 30 ).

Intrusive recent and historic items were encountered sporadically in the upper $10-20 \mathrm{~cm}$ of deposits, but a few small items were noted as deep as $30 \mathrm{~cm}$ below the ground surface. No discrete features were encountered in Cultural Zone A. Charcoal collected from the base of the Zone A at $292.20 \mathrm{~m}$ in Excavation Unit 24 was

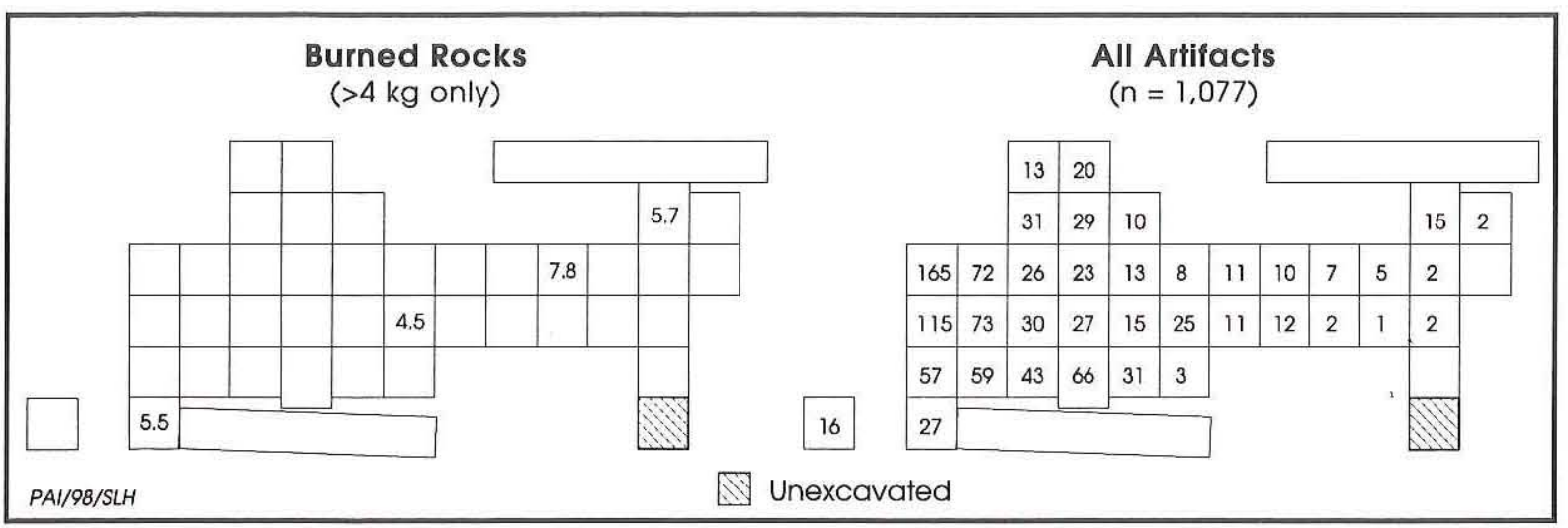

Figure 30. Horizontal distribution of burned rocks and artifacts in Cultural Zone A. 
identified as huisache and yielded a radiocarbon age of $600 \pm 80$ B.P. (see Appendix B).

\section{Cultural Zone B: 292.20-291.90 m}

Each excavation unit includes the $30-\mathrm{cm}$ thick deposit designated Cultural Zone B and subdivided into the following zones/levels: B1, 292.20-292.10 m; B2, 292.10-292.00 m; and B3, $292.00-291.90 \mathrm{~m}$. Since contiguous units were not always excavated simultaneously and dense accumulations of burned rocks could not always be spatially correlated in the field, various feature numbers were assigned to the massive rock layer encountered in different units. During analysis, these feature designations were dropped, and the accumulation of burned rocks in the eastern half of the block was designated the Cultural Zone B burned rock layer. This layer was present in 18 excavation units and had maximum excavated dimensions of $7 \mathrm{~m}$ east-west by $5 \mathrm{~m}$ north-south (Figure 31 ). These units contained 87 percent $(\mathrm{n}=774.5 \mathrm{~kg})$ of the total burned rock weight $(\mathrm{n}=888.85 \mathrm{~kg}$ ) for the entire cultural zone, excluding pit features. This averages $43 \mathrm{~kg}$ per unit within the layer versus $5.2 \mathrm{~kg}$ per unit in the surrounding matrix.

Almost half of the total burned rock weight from nonfeature contexts in Cultural Zone B occurred from 292.10 to $292.00 \mathrm{~m}$ (Figure 32). Collected from the middle of the burned rock layer at $292.04 \mathrm{~m}$ in Excavation Unit 14, a sample of charred mesquite wood yielded a radiocarbon age of $1790 \pm 110$ B.P. Flotation samples also yielded charred guayacan and indeterminate wood, in addition to a charred walnut fragment. Although comparable numbers of artifacts were recovered within and outside the burned rock layer, a peak in artifact density (primarily unmodified debitage) occurs in three contiguous units at the southwest margin of the block where negligible amounts of burned rocks occur (see Figure 31).

In addition, three' discrete features (Features 3,5 , and 12) were encountered within the burned rock layer in the northeast portion of the block. These are discussed in detail below.

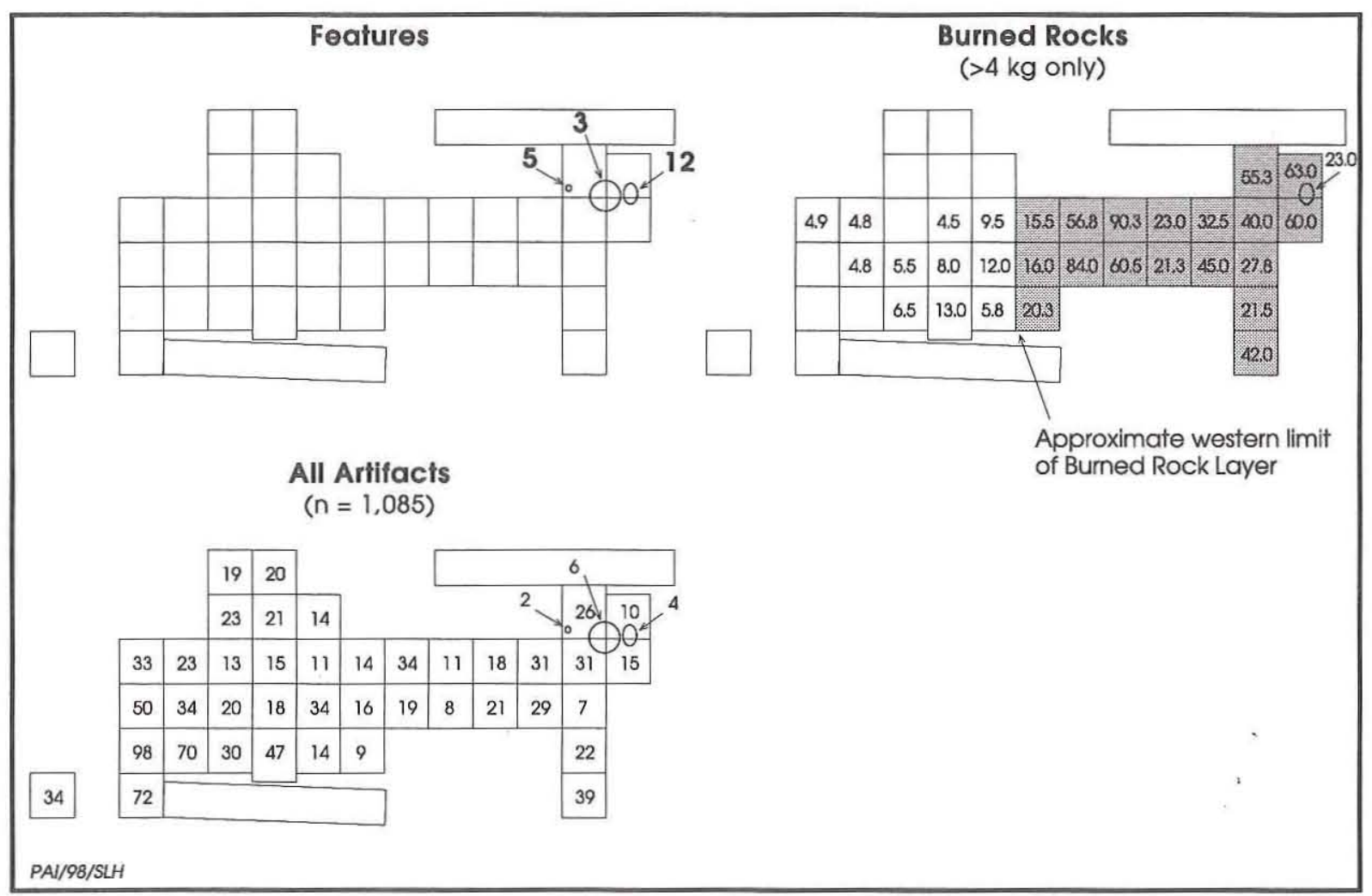

Figure 31. Horizontal distribution of features, burned rocks, and artifacts in Cultural Zone B. 


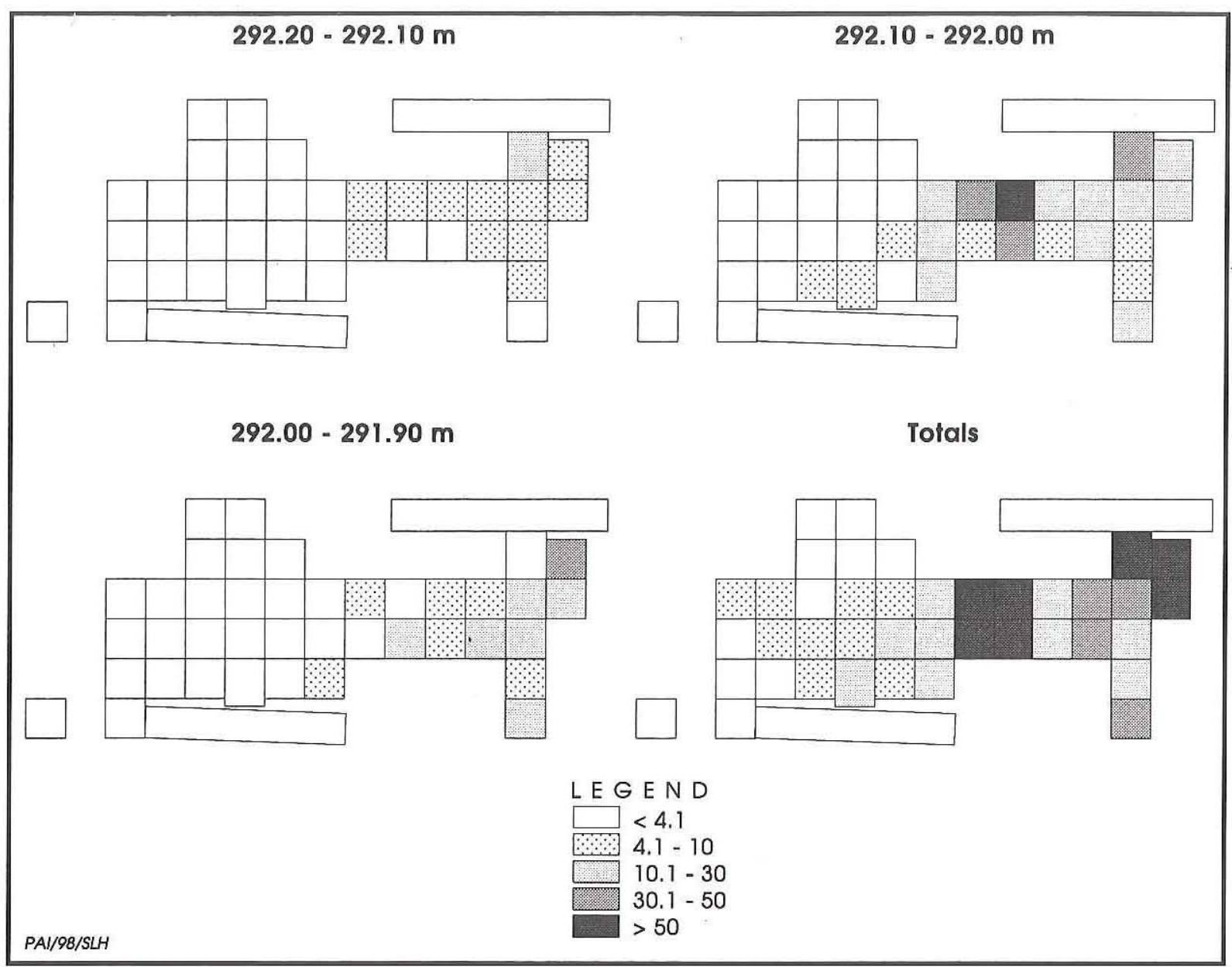

Figure 32. Distribution of burned rocks in Cultural Zone B by level.

\section{Feature 3}

Feature 3, a rock-filled pit, was present in Excavation Units 6, 7, 18, and 19. When first encountered in the southeast corner of Excavation Unit 6, the feature was a discrete, dense cluster of burned rocks and organicstained sediment at $291.85 \mathrm{~m}$ (Figure 33). After Excavation Unit 6 was completed, Feature 3 was still visible in the east and south walls. The south wall profile revealed an animal burrow near the base of the pit that continued an additional $20 \mathrm{~cm}$ to the bottom, and partially across the floor of, Excavation Unit 6.

In Excavation Unit 18 immediately south of Excavation Unit 6, the feature was again initially identified as a burned rock cluster. In this unit, the top of the feature occurred at a slightly higher elevation, $291.90 \mathrm{~m}$. Contiguous
Units 7 and 19 to the east revealed only a narrow portion of Feature 3 that did not contain significant numbers of burned rocks. The feature here was primarily recognized by the presence of a mottled, organic-enriched matrix from 291.85 to $291.82 \mathrm{~m}$. In addition, an amorphous area of dark soil containing charcoal flecks and scattered burned rocks abutted Feature 3 in Excavation Unit 7 from 291.90 to $291.70 \mathrm{~m}$.

At ca. $291.70 \mathrm{~m}$ it became clear that this irregular soil stain resulted from bioturbation. Long, linear animal burrows extended across a larger portion of the unit. In addition, burrowing disturbance was obvious at the base of Feature 3 in Excavation Units 7 and 19. This disturbance extended to $291.40 \mathrm{~m}$ and appeared to bisect another pit feature (see Feature 12 below).

Upon complete excavation, Feature 3 existed from 291.90 to $291.56 \mathrm{~m}$ in four excavation units. 


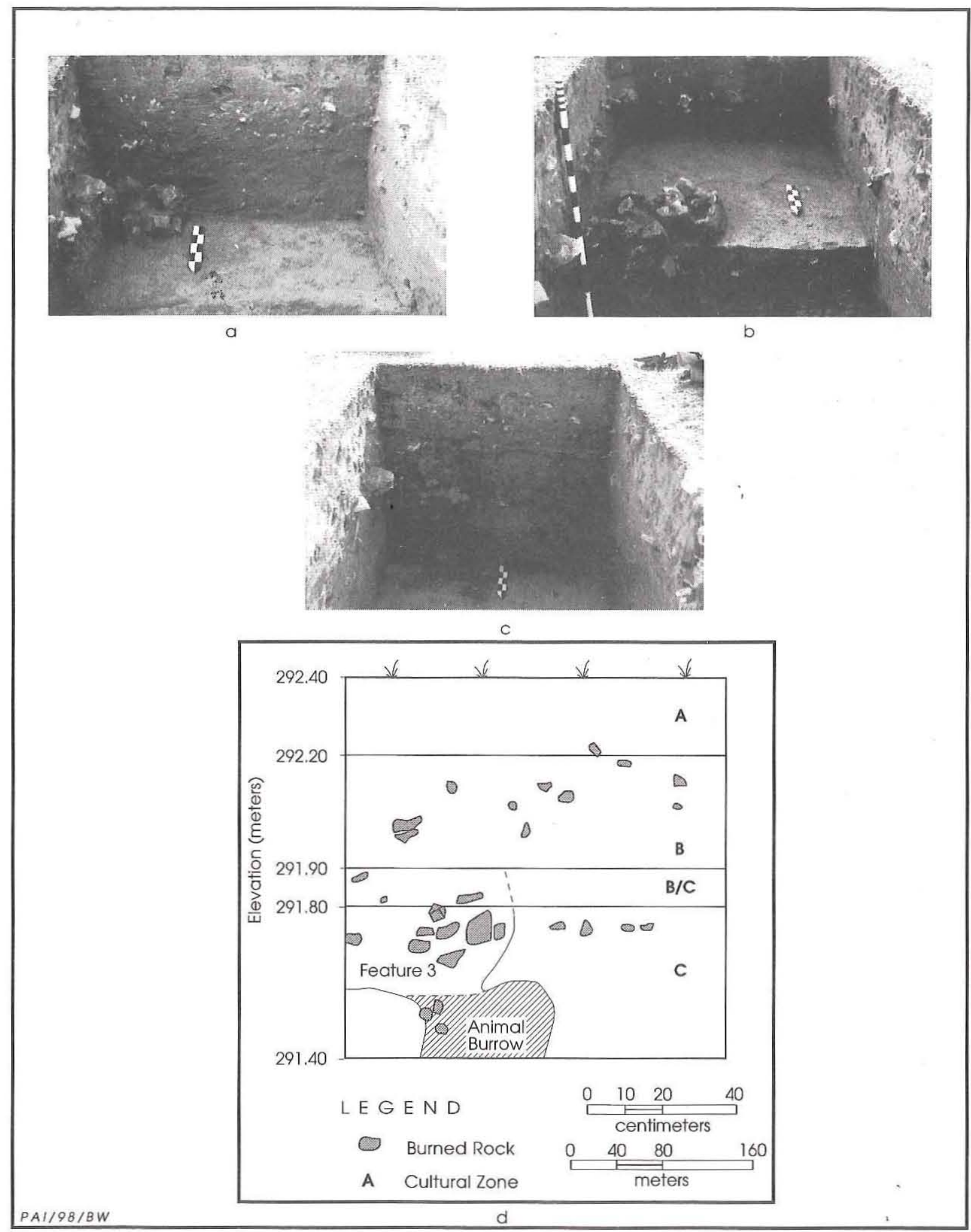

Figure 33. Feature 3 in Cultural Zone B. (a) Excavation Unit 6 at 291.85 m; (b) Unit 18 at 291.90-291.80 m; (c) south wall of Unit 6 at $292.40-291.40 \mathrm{~m}$; (d) profile drawing of south wall of Unit 6 at $292.40-291.40 \mathrm{~m}$. 
Based on the extent of the darker stained matrix, it had maximum dimensions of $117 \mathrm{~cm}$ northsouth by $62 \mathrm{~cm}$ east-west and was $34 \mathrm{~cm}$ thick. The dense cluster of burned rocks that was primarily restricted to Excavation Units 6 and 18 at $291.90-291.61 \mathrm{~m}$ measured $62 \mathrm{~cm}$ northsouth by $45 \mathrm{~cm}$ east-west. These two units contained 177 (75 percent) of the 237 burned rocks in the feature, accounting for approximately 85 percent of the total burned rock weight $(22.95 \mathrm{~kg})$. Almost 99 percent of the burned rocks were less than $10 \mathrm{~cm}$ in size, with the majority consisting of angular to subangular pieces. The feature fill contained six flakes. Charcoal collected at $291.76 \mathrm{~m}$ yielded a radiocarbon age of $2480 \pm 90$ B.P. Flotation samples contained charred mesquite wood. Although Feature 3 intrudes approximately $25 \mathrm{~cm}$ into Cultural Zone $\mathrm{C}$, this pit feature originated near the base of Cultural Zone B and is associated with the Zone B occupations.

\section{Feature 5}

Located approximately $40 \mathrm{~cm}$ west of Feature 3, Feature 5 was confined to the southwest quadrant of Excavation Unit 6 from 291.58 to $291.50 \mathrm{~m}$ (Figure $34 \mathrm{a}$ ). In plan view, the feature appeared as a somewhat ovate, dark soil stain, but the cross section revealed an irregular profile with a shallow basin-shaped depression. An ant nest and worm casts observed in the matrix of this small pit feature are evidence of minor bioturbation; however, Feature 5 does not appear to be the product of serious rodent disturbances such as observed in the bottom of nearby Feature 3. Maximum dimensions for Feature 5 are $30 \times 25 \times 8 \mathrm{~cm}$. The feature fill produced four highly fragmented burned rocks $(0.1 \mathrm{~kg})$ and two flakes. A charcoal sample from 291.58 to $291.56 \mathrm{~m}$ yielded a radiocarbon age of $2220 \pm 50$ B.P. Although found completely within Cultural Zone C, this assay suggests that the feature is intrusive and originated at an elevation above $291.58 \mathrm{~m}$, most likely in Cultural Zone B. One feature fill flotation sample yielded no carbonized remains.

\section{Feature 12}

Feature 12 is a disturbed rock-filled pit found in Excavation Units 7 and 19 at 291.60$291.40 \mathrm{~m}$. Its maximum dimensions are
$60 \times 43 \times 20 \mathrm{~cm}$. Animal burrows extended in several directions from the central portion of the feature, which consists of jumbled burned rocks and charcoal-stained soil (Figure 35). Feature 12 is a few centimeters east of Feature 3 (see above), and the disturbance partially connects the two features. The perimeter of Feature 12 was defined by organic-stained sediment with an irregular outline, and a shallow basin was apparent in cross section. Bioturbated sediment was still present at the base of the feature. Although 31 burned rocks $(3.5 \mathrm{~kg}$ ) were noted in the feature fill, they did not constitute a discrete cluster as did the rocks in Feature 3. None were greater than $10 \mathrm{~cm}$ in size, and except for one broken cobble, all were angular fragments. The feature matrix contained three flakes and one fragment of a quartzite mano/hammerstone. The mano/hammerstone was found in situ at $291.43 \mathrm{~m}$ and refits with two other fragments recovered from two separate units in the Zone B burned rock layer (see Cultural Materials). Flotation samples contained charred hackberry wood but were dominated by mesquite. Charcoal collected at $291.44 \mathrm{~m}$ yielded a radiocarbon age of $2250 \pm 60$ B.P. Although Feature 12 was primarily contained within Cultural Zone C, stratigraphic evidence, the associated radiocarbon assay, and refitted ground stone fragments all indicate that the pit feature originated in Zone B.

\section{Cultural Zone B/C: 291.90-291.80 m}

This 10-cm transition zone was encountered in all 40 excavation units. A dramatic decrease in the density of cultural materials was apparent. Artifact counts per unit ranged from none to a maximum of 16 (Figure 36 ). No dense quantities of burned rocks or discrete features were present. Isolated fragments of charcoal collected at $291.84 \mathrm{~m}$ in Excavation Unit 24 yielded a radiocarbon age of $480 \pm 50$ B.P.

\section{Cultural Zone C: 291.80-291.40 m}

Twenty-eight of the 40 units were excavated through 40-cm-thick Cultural Zone $\mathrm{C}$, which for analysis purposes was subdivided into the following zones/levels: C1, 291.80-291.70 m; C2, 291.70-291.60 m; C3, 291.60-291.50 m; and C4, $291.50-291.40 \mathrm{~m}$. The effects of bioturbation were apparent in Excavation Unit 34, where two 

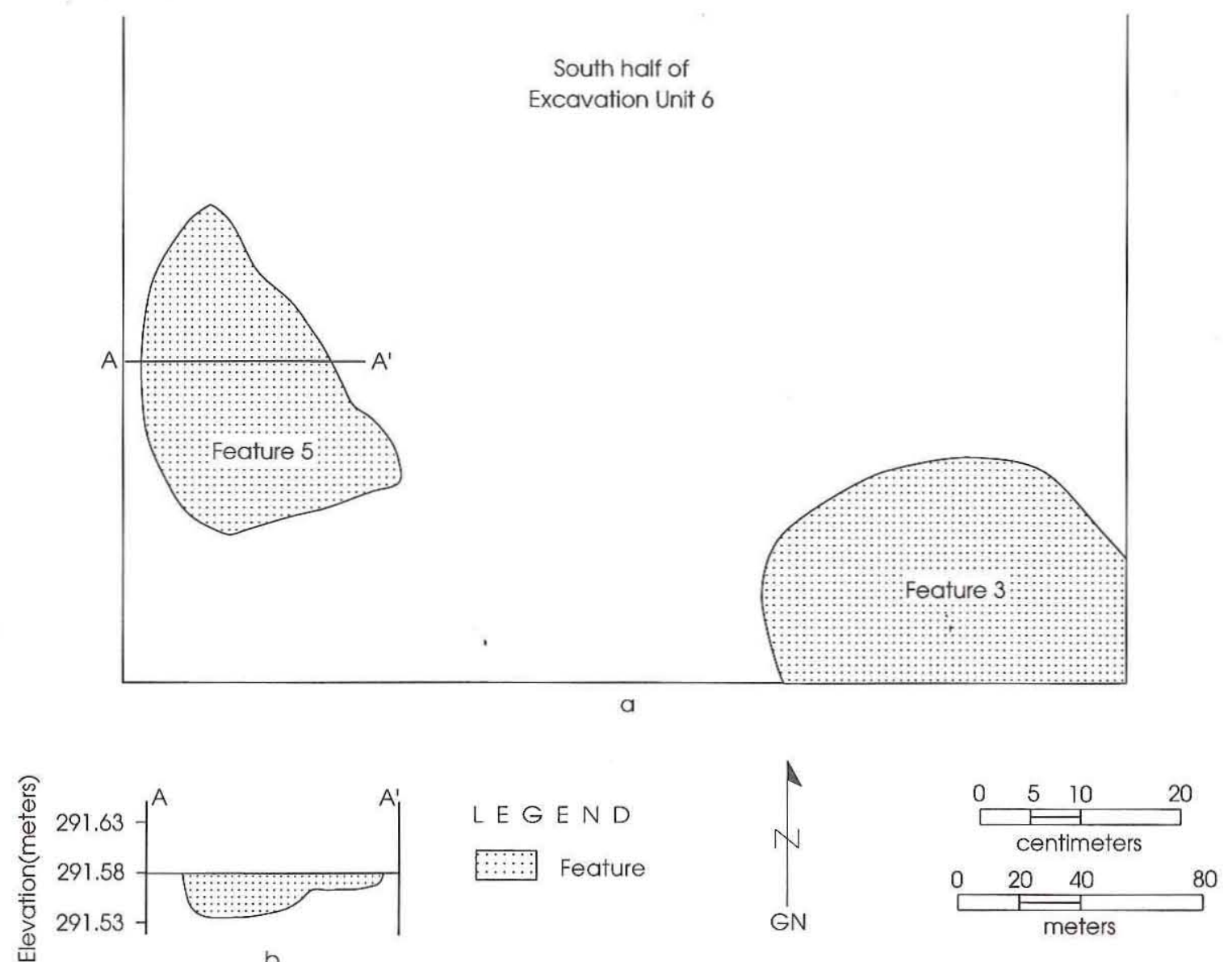

b

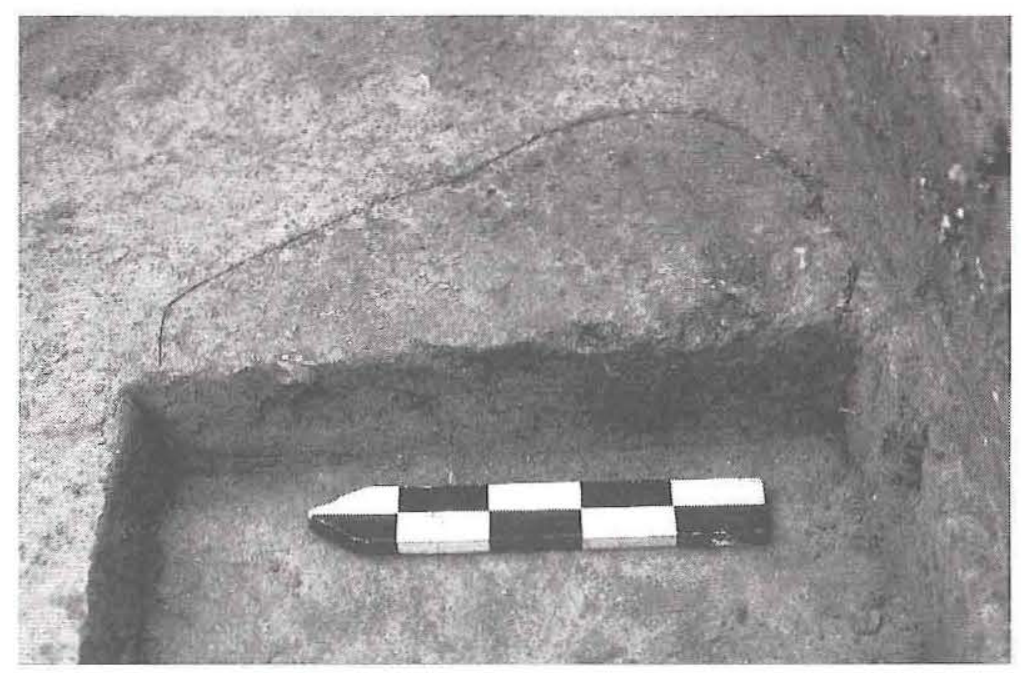

C

Figure 34. Feature 5 in Cultural Zone B. (a) Plan view of Features 3 and 5 at $291.56 \mathrm{~m}$ in Excavation Unit 6; (b) profile of Feature 5 looking south; (c) photograph showing profile and south half of Feature 5 in plan view. 


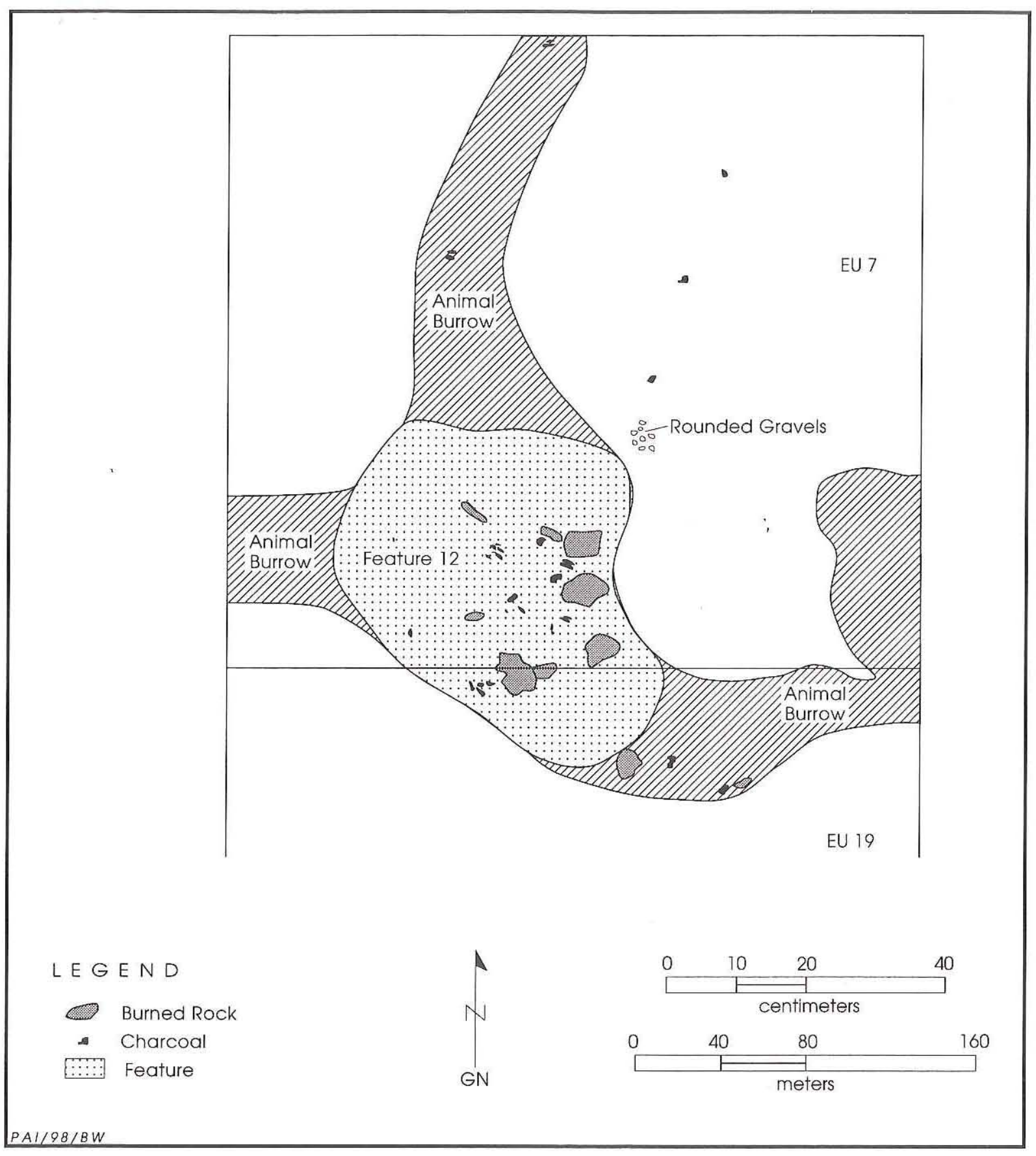

Figure 35. Plan view of Feature 12 in Cultural Zone B at $291.50 \mathrm{~m}$ in Excavation Units 7 and 19.

glass buttons were found in an animal burrow at 291.80-291.70 m. As in Cultural Zone B, a dense burned rock accumulation occurred in the eastern half of the block throughout Cultural Zone C (Figure 37). During excavation, this accumulation was designated Features 9 and 10, but these labels were dropped during analysis. The entire accumulation was reclassified as the Cultural Zone C burned rock layer. Although similar to the massive rock layer in Cultural Zone $\mathrm{B}$, this lower layer included a large distinct pit (see Feature 11 below). The burned 


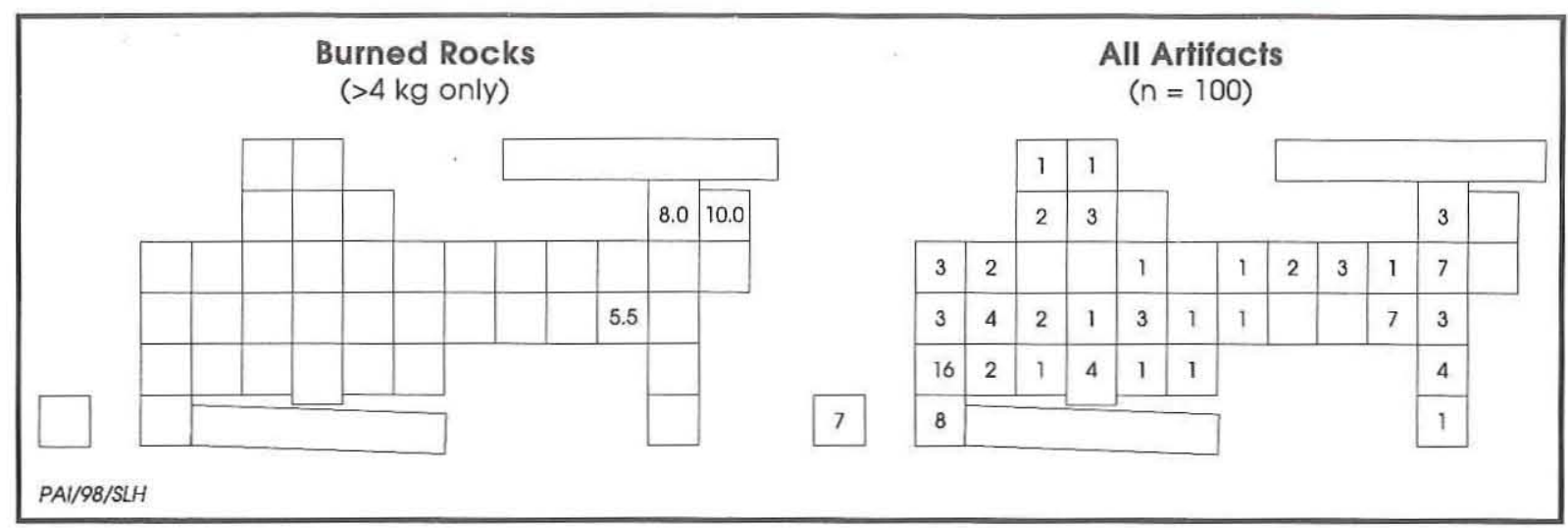

Figure 36. Horizontal distribution of burned rocks and artifacts in Cultural Zone B/C.

rocks appear to occur in a concentric ring around the pit, with lesser amounts adjacent to the pit and higher densities 1-2 $\mathrm{m}$ away from the feature's perimeter. Burned rock frequencies decrease slightly at a distance of $3 \mathrm{~m}$.

Excluding Feature 11, Cultural Zone C yielded $187 \mathrm{~kg}$ of burned rocks, with $178.85 \mathrm{~kg}$ (96 percent) coming from the burned rock layer in the easternmost 17 excavation units. Added to the entire Zone $\mathrm{C}$ burned rock weight, Feature 11 yielded one-quarter of the total, i.e., 61 of $248 \mathrm{~kg}$.

Encountered along the western edge of the burned rock layer, Feature 13 is a knapping debris concentration marked by a peak in the density of unmodified debitage (see Figure 37). Charcoal recovered near the base of the burned rock layer, at $291.55 \mathrm{~m}$ in Excavation Unit 26, yielded a radiocarbon age of $3110 \pm 50$ B.P. One of three flotation samples submitted for macrobotanical analysis contained charred huisache wood.

\section{Feature 11}

Contained solely in Cultural Zone C, Feature 11 is a rock-filled pit encountered at 291.71-291.50 m. Found in Excavation Units 16, 17,28 , and 29 , approximately 80 percent of the feature was contained in Units 16 and 17 (Figures 38 and 39). Based on the extent of the burned rocks, the feature was roughly circular and approximately $135 \mathrm{~cm}$ in diameter. However, some sparse charcoal flecking was noted 10 to $20 \mathrm{~cm}$ beyond this perimeter. The feature consists of one to two layers of burned rocks exhibiting moderate imbrication. Of the 447 burned rocks $(61 \mathrm{~kg})$, none were greater than $15 \mathrm{~cm}$ in size, and 96 percent were under $10 \mathrm{~cm}$. The overwhelming majority were angular and subrounded pieces, but a small number consisted of complete cobbles or rounded fragments. Several rocks were fractured in situ, and chunks of oxidized soil were noted. A shallow basin-shaped bottom was apparent both in cross section and plan view. The only disturbance observed, two rodent burrows beneath the bottom burned rocks in Excavation Unit 17, extended across the entire unit. All but one of the burned rocks in the feature were local limestones. The odd specimen was a piece of shattered basalt. No artifacts were recovered from the feature fill.

Charcoal collected at $291.60 \mathrm{~m}$ was identified as huisache wood and yielded a radiocarbon age of $3260 \pm 60$ B.P. All of the feature fill was taken as flotation samples. Macrobotanical analysis identified charred wood of huisache, guyacan, and green condalia and an indeterminate root fragment.

\section{Feature 13}

A discrete concentration of chipped lithic artifacts encountered at 291.77-291.74 m near the center of Excavation Unit 13 was designated Feature 13. The concentration was partially excavated before it was recognized as a feature, so the exact size and configuration of the original cluster is not known. Once the feature was recognized, however, the associated artifacts already removed were easily identified. There 


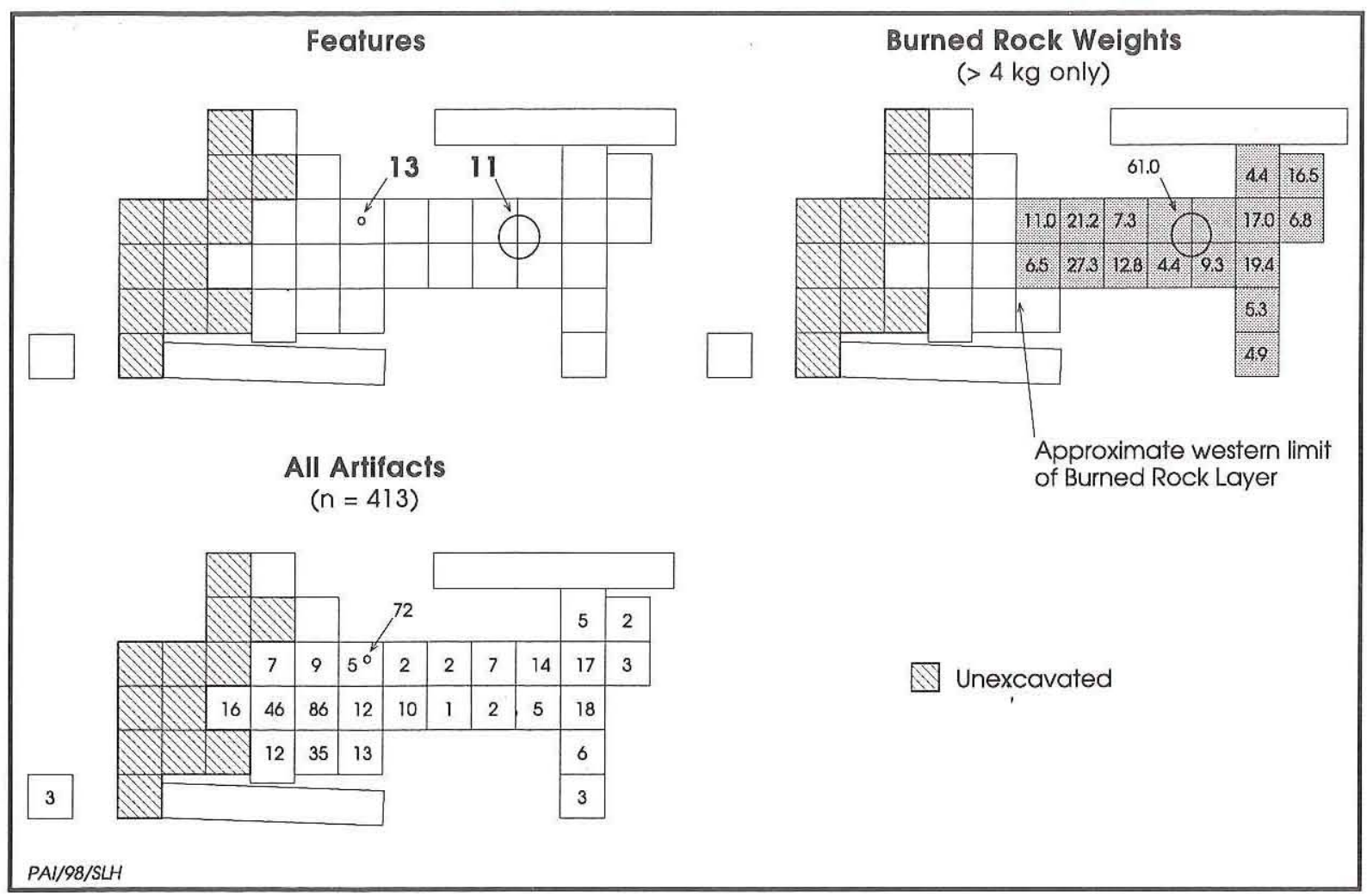

Figure 37. Horizontal distribution of features, burned rocks, and artifacts in Cultural Zone C.

is little doubt that the feature consisted of at least 72 lithic artifacts found in a roughly circular area about $25-30 \mathrm{~cm}$ in diameter and $5-10 \mathrm{~cm}$ in depth. About half of the specimens were found in situ in a tight cluster (Figure 40), and the others came from the same immediate vicinity. Most of the in situ specimens were lying flat or slightly on angle, but two flakes were vertical. No sediment staining was observed in or around the cluster of artifacts. No evidence of disturbance was noted in the in situ portion of the feature, but an animal burrow running from the south edge of the unit to near the center of the unit was observed at the same approximate elevation. It is possible that the upper portion of the feature had been disturbed slightly.

The 72 artifacts from Feature 13 consist of 2 complete Zone C middle-stage bifaces, 1 finished biface fragment, 1 graver made on a flake, 3 edge-modified flakes, and 65 unmodified flakes. These specimens are of two different types of cherts and may have originated from two different cores (Table 12). Both chert types are presumed to represent locally

Table 12. Summary of lithic artifacts from Feature 13 in Cultural

\begin{tabular}{lccc}
\hline Artifact Type & Chert Type 1 & Chert Type 2* & Totals \\
\hline Middle-stage biface & $1(1)$ & $1(1)$ & 2 \\
Finished biface & $1(1)$ & 0 & 1 \\
fragment & $1(1)$ & 0 & 1 \\
Graver & $2(2)$ & $1(1)$ & 3 \\
Edge-modified flake & $\underline{30(24)}$ & $\underline{35(33)}$ & $\underline{65}$ \\
Unmodified flake & $35(29)$ & $37(35)$ & 72 \\
Totals &
\end{tabular}

Note: Numbers in parentheses represent the number of specimens exhibiting evidence of thermal alteration.

*One flake of Type 2 chert was recovered from the same level as Feature 13 but in an adjacent excavation unit; it is not directly associated with the feature but refits to the middle-stage biface. 


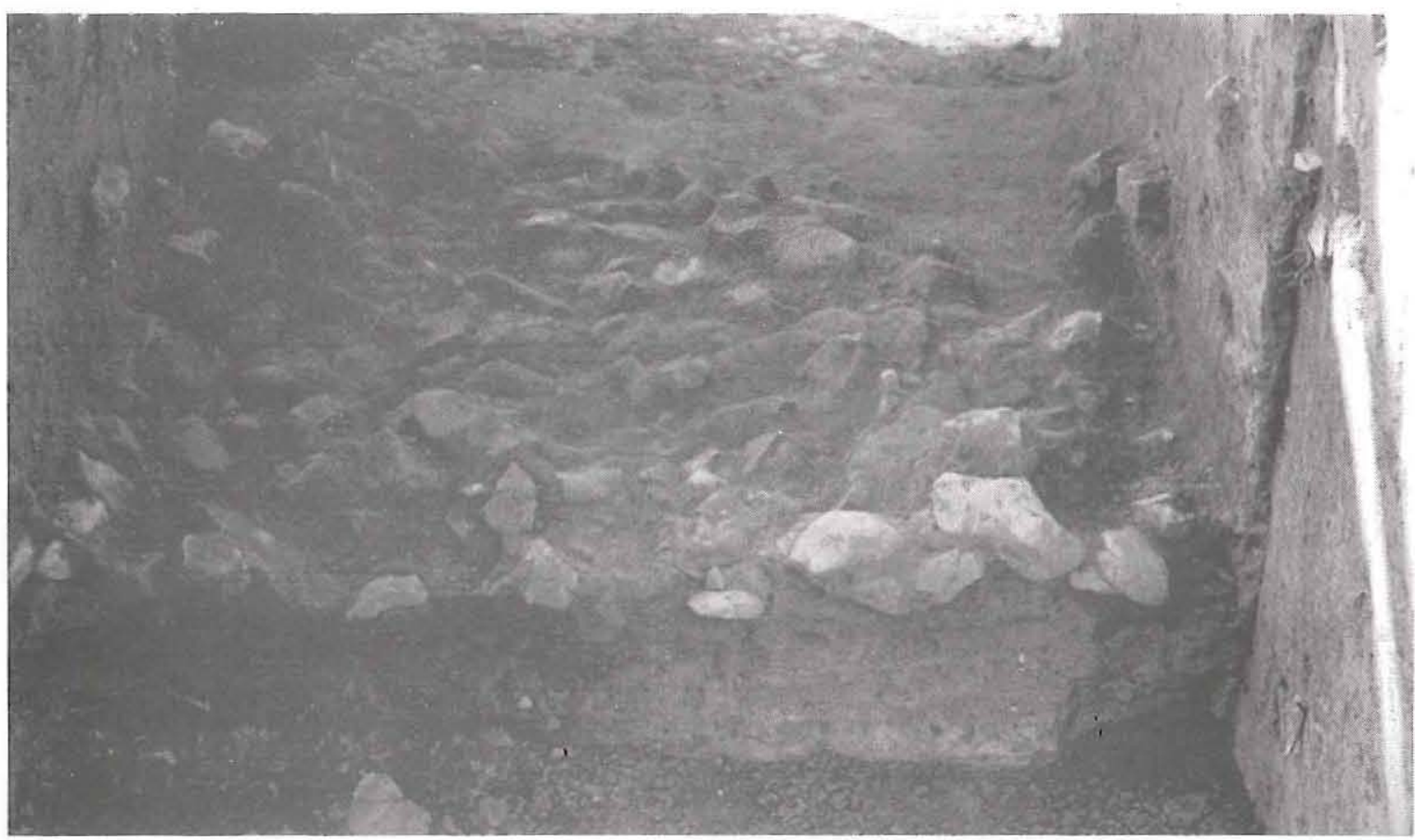

a

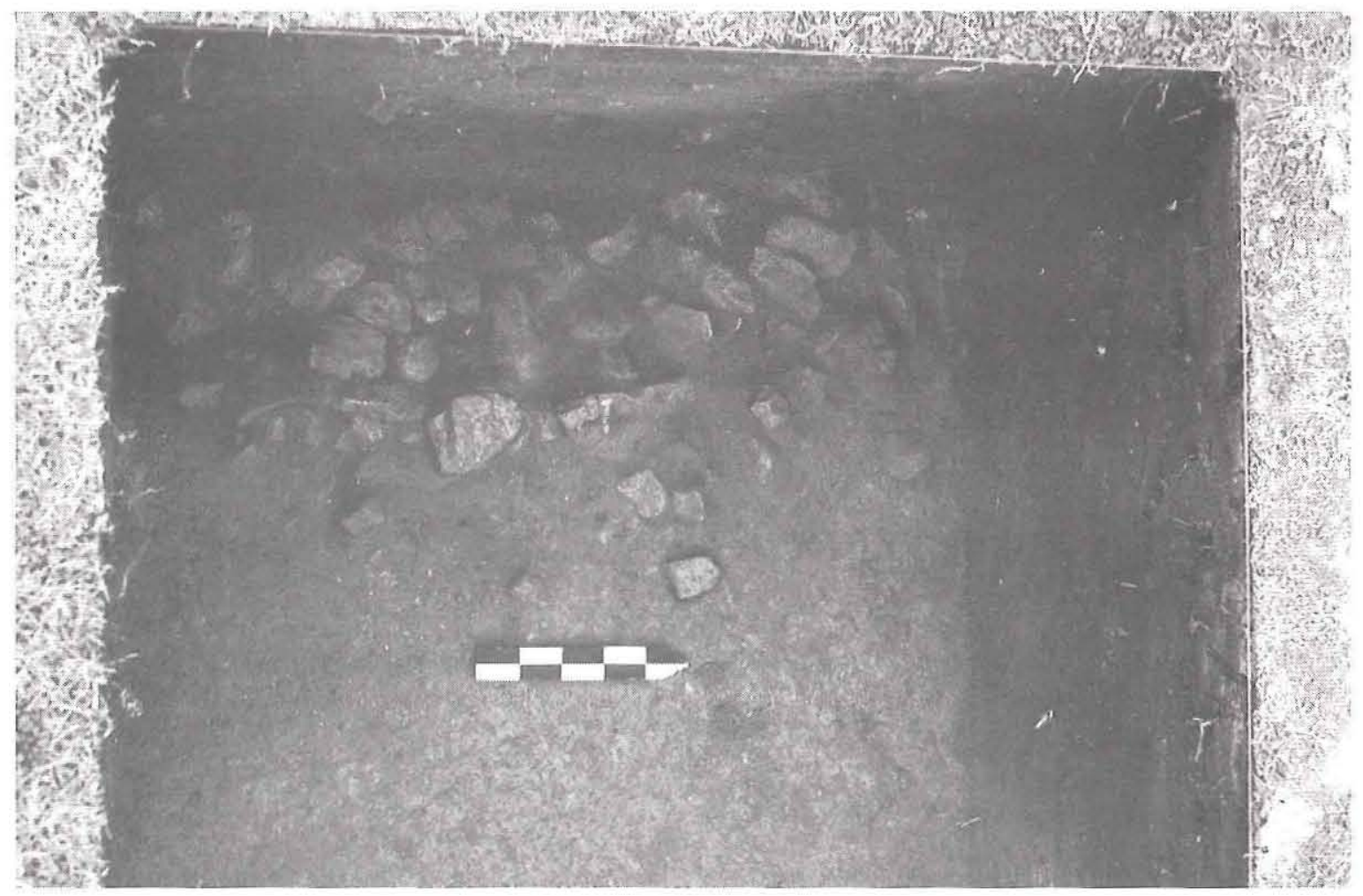

b

Figure 38. Photographs of Feature 11 in Cultural Zone C. (a) Plan view at $291.60 \mathrm{~m}$ in Excavation Unit 16; (b) plan view at $291.60 \mathrm{~m}$ in Excavation Unit 17. 
$L E G E N D$
Burned Rock

- Shattered Basalt

$$
\text { EU } 16
$$$$
\text { OV }
$$

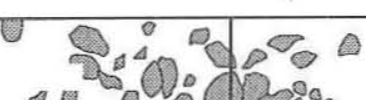
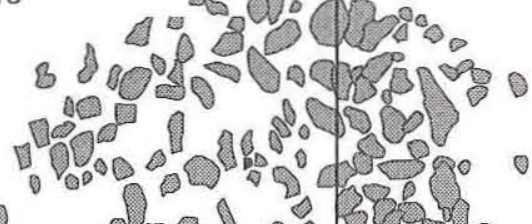

0

1
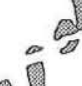
(1)

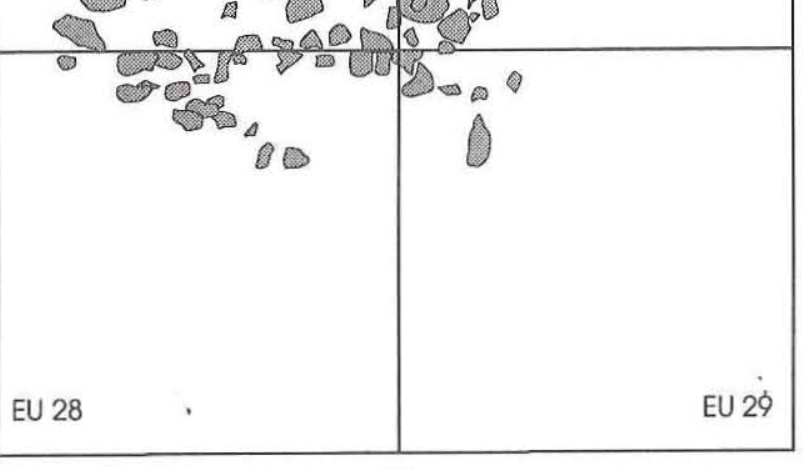

a

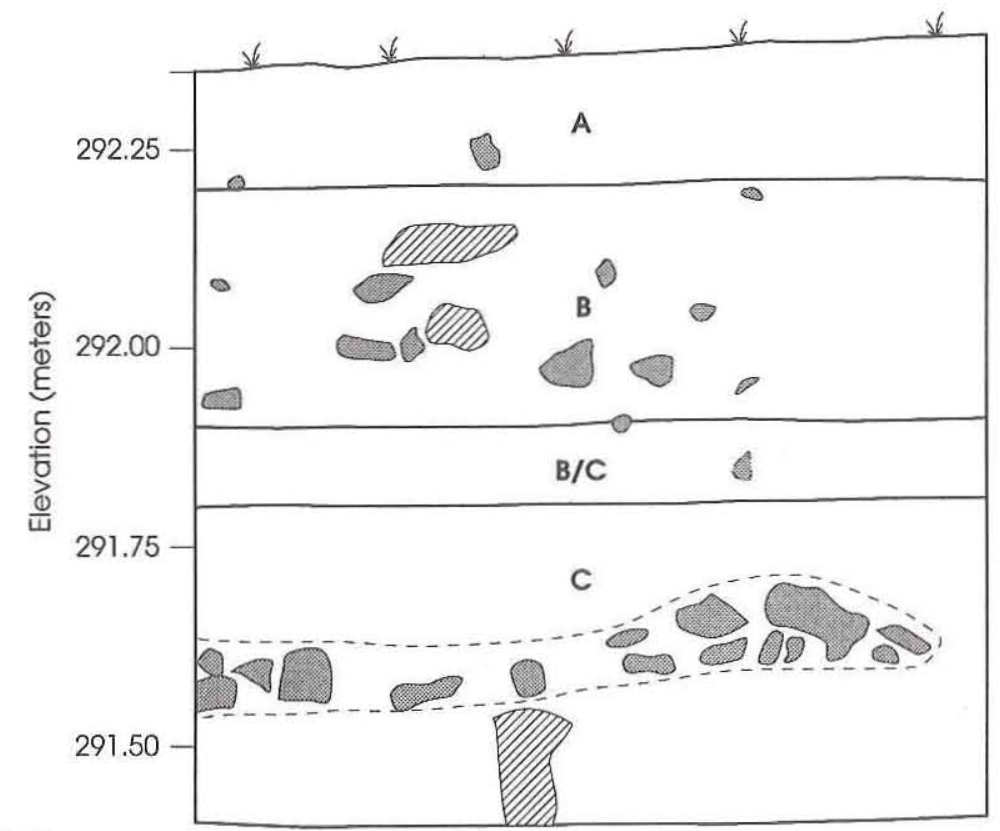

$L E G E N D$

b
EU 17

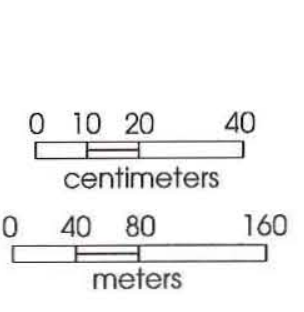

$\frac{40 \quad 80 \quad 160}{\square+1}$

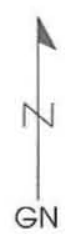

$+2$ 


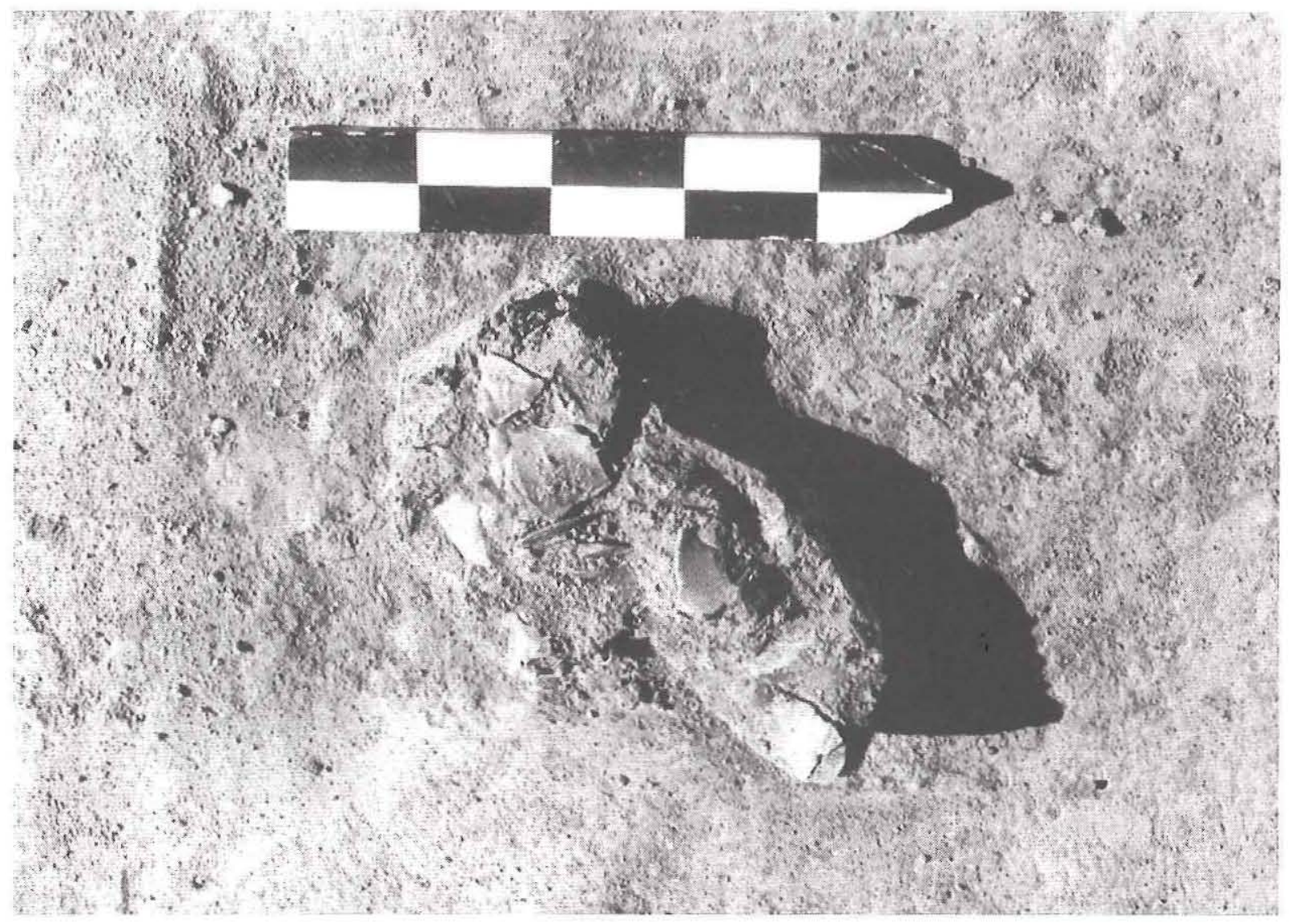

Figure 40. Photograph of in situ lithic artifacts in lower portion of Feature 13 in Cultural Zone C.

available materials found in the Uvalde gravels along the margins of San Felipe Creek. Several of the artifacts refit onto the two complete middle-stage bifaces, which are simply bifacial cores. In addition, at least one other unmodified flake recovered from the same level but not directly associated with Feature 13 refits to one of the bifaces.

Chert Type 1 is fine-grained and light brownish gray (10YR 6/2) to gray (10YR 5/1) in color with common small to medium-sized very pale brown (10YR 7/3) mottles. Several specimens exhibit remnants of a thin white cortex that is smooth and heavily abraded. The cortex indicates that the specimens are from a streamrolled cobble or cobbles.

Thirty-five specimens from Feature 13 are classified as Chert Type 1, and 83 percent of these appear to have been thermally altered (see Table 12). Of these, an unmodified flake and the flake graver refit onto the middle-stage biface (which is actually two fragments that fit together along a heat-fractured contact). All four of these refit specimens (Figure 41a, b) are thermally altered, and it is clear that the biface was heat treated prior to the removal of the two flakes. The biface was subsequently broken, apparently post depositionally. The 29 other unmodified flakes and 2 modified flakes may have been from the same core, but they do not refit. The finished biface fragment appears to be an edge from a thin oval biface. It has an irregular bump along the finished edge, and the specimen may have been broken during manufacture. It is possible that the finished biface was made on a flake that came from the same core.

Chert Type 2 is fine-grained and varies between brown (7.5YR 5/3) and gray (10YR 5/1) in color, with abundant small light gray (10YR $7 / 2$ ) mottles that are coarser than the main chert body. Several specimens exhibit remnants of a thin brown and white cortex that is smooth and 


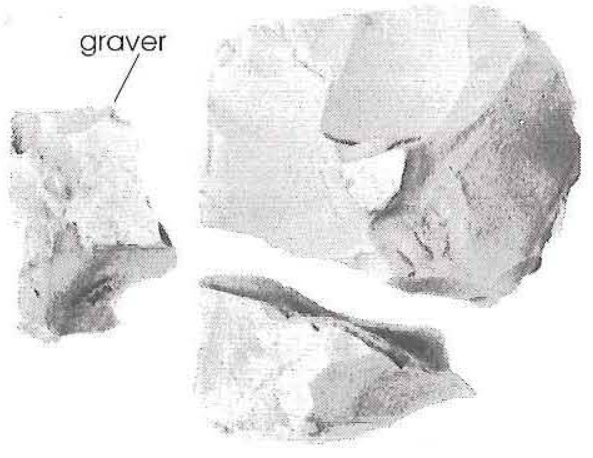

(a) Exploded View

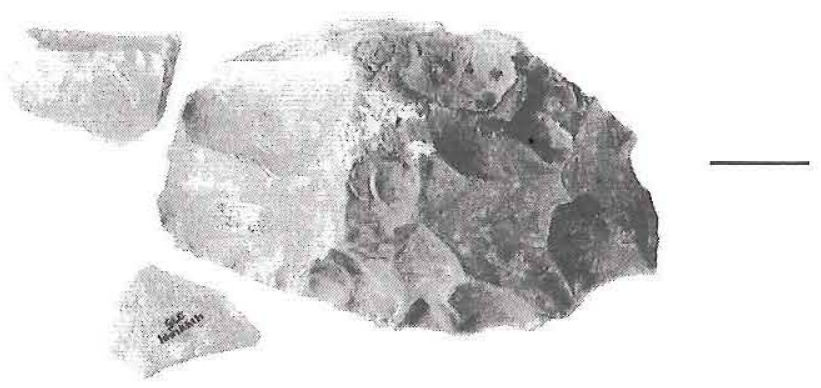

(c) Exploded View

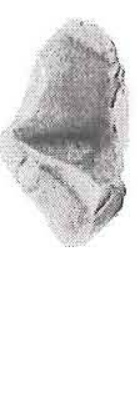

(b) Refit View

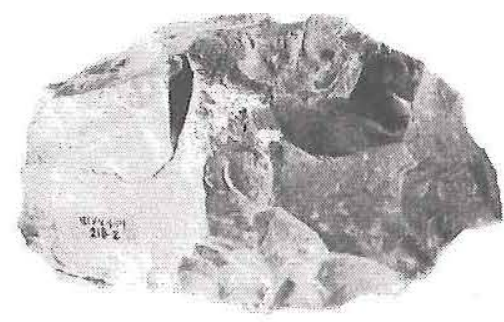

(d) Refit View

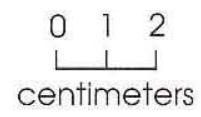

Figure 41. Refit lithic artifacts from Feature 13. (a-b) Middle-stage biface (two fragments), unmodified flake, and graver, Type 1 chert; (c-d) middle-stage biface and unmodified flake from Feature 13, along with an unmodified flake from nonfeature context, Type 2 chert.

heavily abraded. The cortex indicates that the specimens are from a stream-rolled cobble or cobbles.

In all, 37 specimens from Feature 13 are classified as Chert Type 2, and 95 percent of them appear to have been thermally altered (see Table 12). One of the unmodified flakes refits onto the middle-stage biface, along with a flake found in an adjacent unit at the same approximate elevation as Feature 13 (Figure 41c, d). It is possible that the other nonfeature flake and all of the Type 2 chert specimens in Feature 13 originated from the same core.

Feature 13 appears to represent a flint knapper's dump or cache for four reasons: (1) the cluster of in situ artifacts is so tight; (2) all of the flakes are of two easily distinguishable chert types; (3) almost all of the materials are thermally altered, probably due to heat treatment; and (4) the specimens seem to represent flakes and tools in various stages of manufacture, with several of the specimens refitting onto two bifacial cores. It is not known whether the cluster represents lithic materials that were discarded or a cache of lithic materials stashed for future use. The latter interpretation is more likely since many of the flakes are large enough to be made into small tools and the middle-stage bifaces are large enough to have still served as cores or been 
made into tools. The feature may represent artifacts once held in a perishable container (e.g., basket or hide pouch), although no staining indicating a container was observed. Although Feature 13 is not dated directly, its in situ occurrence in Cultural Zone $\mathrm{C}$ indicates that it is at least 3,000 years old.

\section{CULTURAL MATERIALS}

Cultural materials recovered from the Area 1 excavation block include chipped stone artifacts $(\mathrm{n}=2,554)$, ground and battered stone artifacts $(n=8)$, ceramics $(n=115)$, and a modified mussel shell. Other cultural materials consist of unmodified mussel shells ( $\mathrm{n}=13$ ), bones $(\mathrm{n}=177)$, land snail shells (unquantified), and burned rocks (total weight $=1,317.6 \mathrm{~kg}$ ).

\section{Chipped Stone Artifacts .}

The chipped stone artifact class is comprised of 2,335 pieces of unmodified debitage (91 percent), 207 chipped stone tools (8 percent), and 12 cores ( $<1$ percent). Although these artifacts represent seven material types, the vast majority (97 percent) are of locally available chert, followed by basalt ( 3 percent). Projectile points were assigned to type groups by Elton Prewitt using published typological data (e.g., Sorrow 1968; Suhm and Jelks 1962; Turner and Hester 1993).

\section{Arrow Points}

Twenty-three chert arrow points were recovered from nonfeature contexts in Cultural Zones A and B (Table 13). Two Perdiz points

Table 13. Arrow point types by cultural zone

\begin{tabular}{lccc}
\hline Point Type & $\begin{array}{c}\text { Cultural } \\
\text { Zone A }\end{array}$ & $\begin{array}{c}\text { Cultural } \\
\text { Zone B }\end{array}$ & Totals \\
\hline Bonham & 2 & - & 2 \\
Cliffton & 4 & - & 4 \\
Cuney & 1 & - & 1 \\
Perdiz & 4 & 2 & 6 \\
Scallorn & 1 & - & 1 \\
Probable & 1 & - & 1 \\
Perdiz & 7 & 1 & 8 \\
Untypeable & 20 & 3 & 23 \\
\hline Totals & 20 & & \\
\hline
\end{tabular}

and an untypeable point were found in Zone B and may represent downward displacement; the rest came from Zone A. Typed specimens consist of 2 Bonham, 4 Cliffton, 1 Cuney, 6 Perdiz, and 1 Scallorn. The remainder consist of 1 probable Perdiz and 8 untypeable points. Five specimens are complete or nearly complete, and 18 are fragmentary. Metric data for each arrow point, including a refitted piece, are listed in Table 14.

\section{BONHAM}

The two Bonham points consist of one nearly complete, partially serrated specimen and one proximal fragment (Figure 42). The stems are generally straight with rounded bases, and the barbs are flared.

\section{CLIFFTON}

Of the four Cliffton points, one is complete, one is nearly complete, and two are proximal fragments (see Figure 42). Each has a contracting stem with a pointed base and short barbs. Three exhibit moderately wide necks $(8.4-11.2 \mathrm{~mm})$, and all except the nearly complete specimen are chipped primarily on one face.

\section{CUNEY}

The one Cuney point is a proximal fragment with a notched base (see Figure 42).

\section{PERDIZ}

The six Perdiz points consist of one complete specimen, one nearly complete point, and four proximal fragments (Figure 43). Each point has a contracting stem with a pointed base and short barbs. The neck widths $(4.8-9.3 \mathrm{~mm})$ and blade lengths (18.6-40.3 mm) vary considerably. The complete and nearly complete points are bifacially flaked (Figure 43, upper row). Found in Cultural Zone B, the nearly complete specimen occurred in the same excavation unit and level as a Shumla dart point.

The four proximal fragments are unifacial. A distal fragment classified as an untypeable arrow point (see below) was recovered in Excavation Unit 31 near the base of Cultural Zone A. It refits with a proximal 
Table 14. Arrow point metric data*

\begin{tabular}{|c|c|c|c|c|c|c|c|c|c|}
\hline Point Type & $\begin{array}{l}\text { Zone/ } \\
\text { Level }\end{array}$ & Completeness & $\begin{array}{l}\text { Maximum } \\
\text { Length }\end{array}$ & $\begin{array}{c}\text { Blade } \\
\text { Length }\end{array}$ & $\begin{array}{l}\text { Blade } \\
\text { Width }\end{array}$ & $\begin{array}{c}\text { Haft } \\
\text { Length }\end{array}$ & $\begin{array}{c}\text { Neck } \\
\text { Width } \\
\end{array}$ & $\begin{array}{c}\text { Base } \\
\text { Width }\end{array}$ & $\begin{array}{l}\text { Maximum } \\
\text { Thickness }\end{array}$ \\
\hline \multicolumn{10}{|c|}{ CULTURAL ZONE A } \\
\hline Bonham & A2 & nearly complete & 27.7 & - & 19.1 & 7.6 & 5.2 & 5.4 & 3.0 \\
\hline Bonham & A3 & proximal fragment & 21.2 & - & 22.5 & 8.0 & 6.3 & 5.2 & 2.3 \\
\hline Clifton $^{1}$ & A2 & proximal fragment & 24.7 & - & - & 7.9 & 11.2 & 1.3 & 3.7 \\
\hline Clifton & $\mathrm{A} 2$ & nearly complete & 36.6 & 32.4 & 16.8 & - & 8.8 & - & 4.4 \\
\hline Clifton $^{1}$ & $\mathrm{~A} 2$ & proximal fragment & 26.8 & - & - & 7.0 & 8.4 & 2.2 & 3.7 \\
\hline Clifton $^{1}$ & A2 & complete & 32.0 & 26.2 & 17.0 & 5.8 & 5.5 & 1.9 & 2.2 \\
\hline Cuney & A3 & proximal fragment & 12.9 & - & - & 6.6 & 6.8 & - & 2.4 \\
\hline Perdiz ${ }^{1}$ & $\mathrm{~A} 2$ & proximal fragment & 27.6 & - & - & 11.2 & 8.5 & 1.2 & 2.5 \\
\hline Perdiz $^{1}$ & A2 & proximal fragment & 23.0 & - & - & 6.6 & 7.4 & 1.4 & 3.3 \\
\hline Perdiz & A2 & complete & 47.8 & 40.3 & 12.9 & 7.5 & 6.1 & 2.5 & 3.0 \\
\hline Perdiz ${ }^{1}$ & A2 & proximal fragment & 33.2 & - & 23.1 & 9.9 & 9.3 & 2.4 & 2.8 \\
\hline probable Perdiz & A2 & medial fragment & 26.1 & - & $-\cdot$ & - & 6.7 & - & 2.8 \\
\hline Scallorn & A3 & proximal fragment & 20.6 & - & 13.3 & 6.4 & 4.8 & 6.1 & 3.4 \\
\hline untypeable & A2 & distal fragment & 22.5 & - & - & - & - & - & 2.9 \\
\hline untypeable & A3 & edge fragment & 17.1 & - & - & - & - & - & 2.0 \\
\hline untypeable & A3 & distal fragment & 19.6 & - & - & - & - & - & 1.4 \\
\hline untypeable & A3 & distal fragment & 31.5 & - & - & - & - & - & 2.1 \\
\hline untypeable & A3 & distal fragment & 29.7 & 24.6 & 17.8 & - & 6.0 & - & 3.2 \\
\hline untypeable & A3 & distal fragment & 25.0 & 22.1 & - & - & 5.5 & - & 2.0 \\
\hline untypeable $^{2}$ & A3 & distal fragment & 34.1 & - & - & - & - & - & 2.3 \\
\hline \multicolumn{10}{|c|}{ CULTURAL ZONE B } \\
\hline Perdiz ${ }^{1,2}$ & B2 & proximal fragment & 26.6 & - & 24.2 & 10.1 & 8.7 & 1.7 & 2.3 \\
\hline Perdiz & B2 & nearly complete & 26.8 & 18.6 & - & 8.2 & 4.8 & - & 2.1 \\
\hline untypeable & B2 & distal fragment & 13.6 & - & - & - & - & - & 3.0 \\
\hline
\end{tabular}

*All measurements are in millimeters

Primarily unifacial

${ }^{2}$ These two fragments refit to form a complete Perdiz point measuring $44.5 \mathrm{~mm}$ in maximum length, $34.4 \mathrm{~mm}$ in blade length, $24.2 \mathrm{~mm}$ in blade width, $10.1 \mathrm{~mm}$ in haft length, $8.7 \mathrm{~mm}$ in neck width, $1.7 \mathrm{~mm}$ in base width, and $2.3 \mathrm{~mm}$ in maximum thickness. 


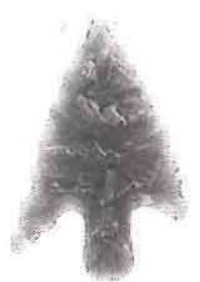

Bonham

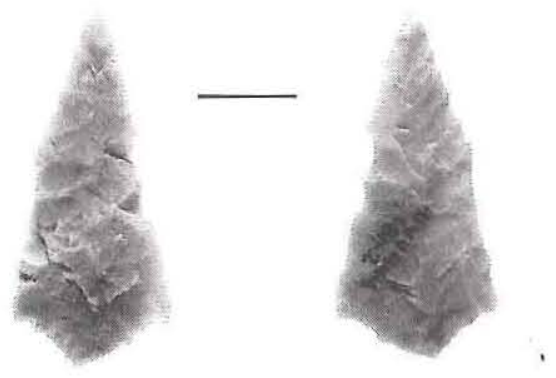

Cliffton

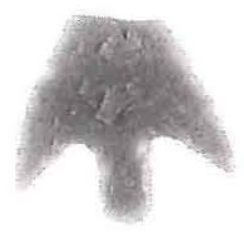

Bonham
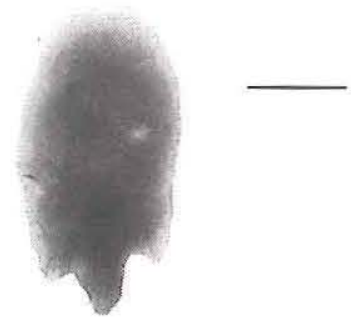

Cliffton

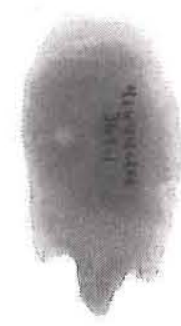

Cliffton
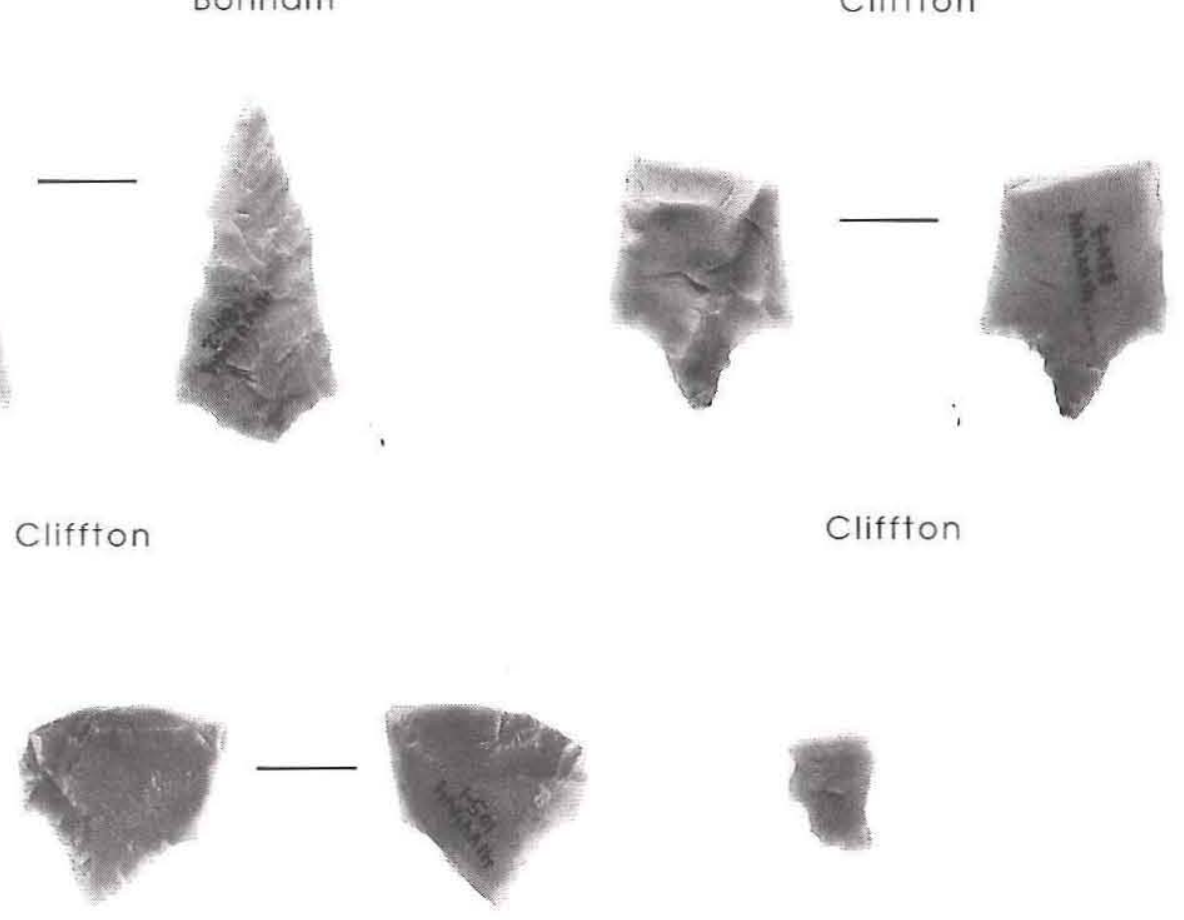

Cliffton

Cuney

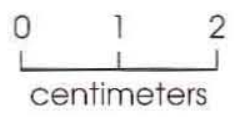

Figure 42. Arrow Points

fragment of a Perdiz point found in Excavation Unit 39 near the middle of Zone B (see Figure 43 , lower right). Although recovered in adjacent excavation units, these two pieces were vertically separated by $20 \mathrm{~cm}$.

\section{PROBABLE PERDIZ}

The probable Perdiz point is a medial fragment that includes a snapped, contracting stem (Figure 44). The lateral edges are partially serrated, and the barbs are long.

\section{SCALLORN}

This serrated proximal fragment has a slightly expanding stem and a straight base (Figure 44). Approximately two-thirds of the surface is patinated.

\section{UNTYPEABLE ARROW POINTS}

One edge and seven distal fragments are untypeable arrow points. One distal fragment refits with a proximal section of a Perdiz point. 

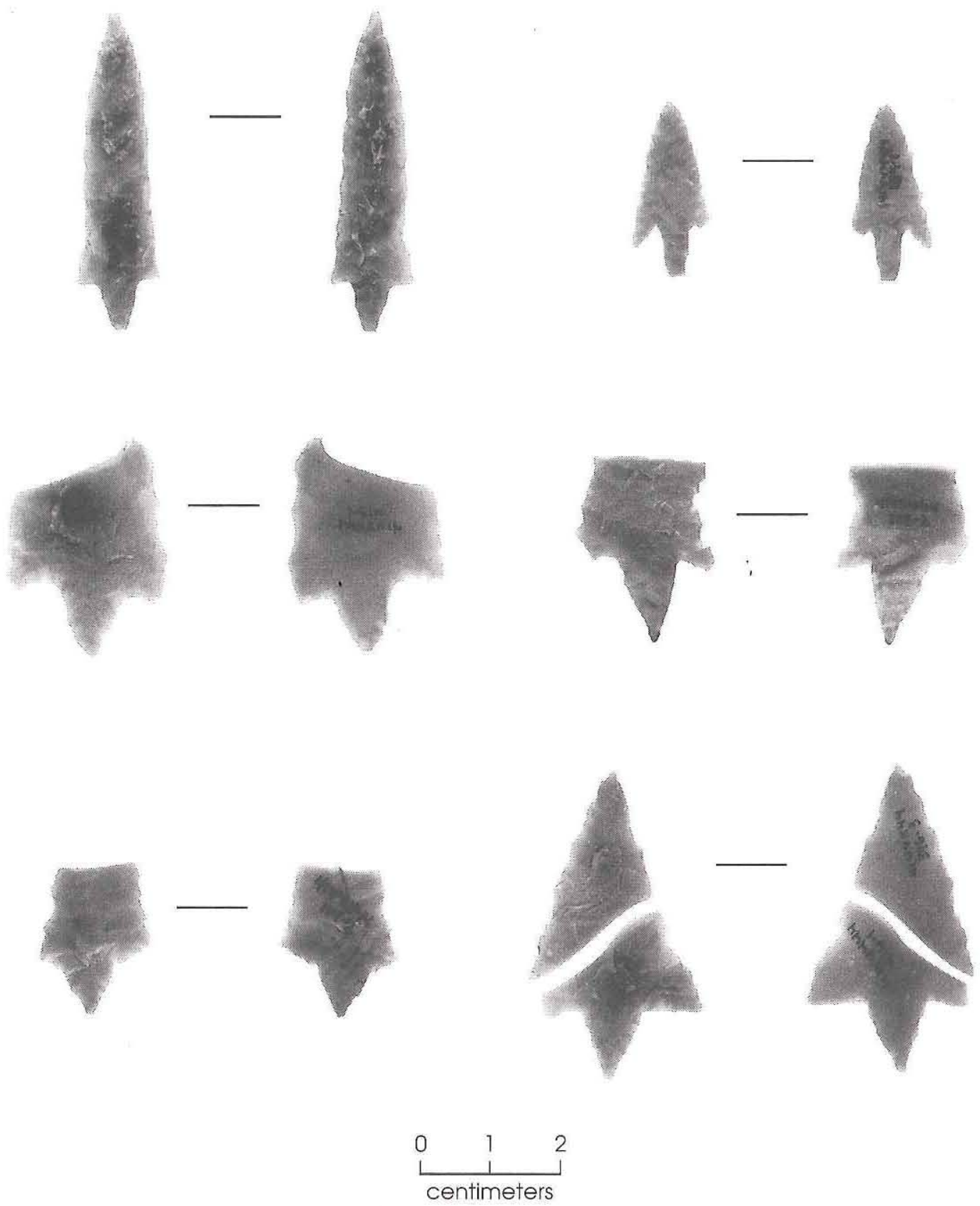

Figure 43. Perdiz arrow points.

\section{Dart Points}

Twenty-two chert dart points were recovered from Cultural Zones $A(n=6,27$ percent), $B(n=12,55$ percent), $B / C(n=1,5$ percent $)$, and $C(n=3,14$ percent) (Table 15). In contrast to most of the arrow points, the dart points have neck widths greater than $10 \mathrm{~mm}$. The 13 dart points with measurable neck widths (59 percent) range from 13.2 to $22.4 \mathrm{~mm}$. Metric data for each dart point, including one refitted piece, are recorded in Table 16.

Thirteen specimens are assigned to named types as follows: 1 Bulverde, 2 Ensor, 1 Paisano, 


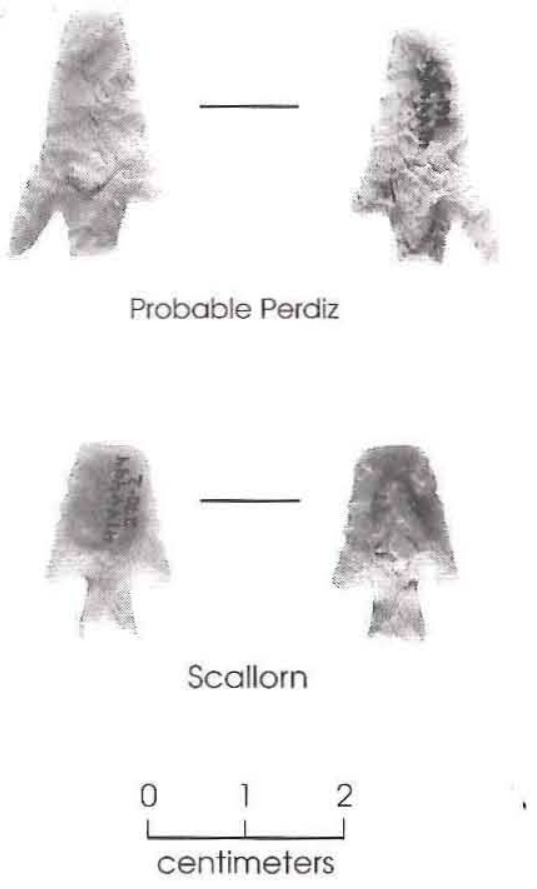

Figure 44. Arrow points.

Table 15. Dart point types by cultural zone

\begin{tabular}{lccccc}
\hline Point Type & $\begin{array}{c}\text { Cultural } \\
\text { Zone A }\end{array}$ & $\begin{array}{c}\text { Cultural } \\
\text { Zone B }\end{array}$ & $\begin{array}{c}\text { Cultural } \\
\text { Zone B/C }\end{array}$ & $\begin{array}{c}\text { Cultural } \\
\text { Zone C }\end{array}$ & Totals \\
\hline Bulverde & - & - & - & 1 & 1 \\
Ensor & 2 & - & - & - & 2 \\
Paisano & 1 & - & - & - & 1 \\
Pandale & - & 1 & - & - & 1 \\
Shumla & - & 7 & 1 & - & 8 \\
Untypeable & 3 & 4 & - & 1 & 8 \\
Untyped & - & - & - & 1 & 1 \\
\hline Totals & 6 & 12 & 1 & 3 & 22 \\
\hline
\end{tabular}

\section{ENSOR} respectively.

\section{PAISANO} Figure 45).

\section{PANDALE}

contracting stem with a concave base (Figure 45). The neck width of $22.4 \mathrm{~mm}$ is the broadest of all the measurable dart points.

The two Ensor points consist of one complete artifact and one distal fragment (see Figure 45). Both were recovered from Cultural Zone A. The blade lengths and neck widths range from 25.4 to $32.8 \mathrm{~mm}$ and 15.1 to $15.4 \mathrm{~mm}$,

Found in Cultural Zone A, the Paisano point is a proximal fragment that is relatively thick $(8.5 \mathrm{~mm}$ ) and has a shallow basal concavity (see

This nearly complete point from Cultural Zone B is crudely manufactured and heavily patinated (see Figure 45). The haft length and neck width are 16.4 and $14.1 \mathrm{~mm}$, respectively.

\section{SHUMLA}

Shumla is the most common dart point type. One complete point, one nearly complete point, and five proximal fragments were recovered from Cultural Zone B. One proximal fragment

1 Pandale, and 8 Shumla. The other 9 specimens are 8 untypeable points and 1 untyped point. Five dart points are complete or nearly complete, and 17 are fragmentary. Although the typed dart points span the Early through Late Archaic periods, several specimens (particularly in Cultural Zones A and B) probably represent items collected for reuse or are vertically displaced artifacts.

\section{BULVERDE}

This complete specimen from Cultural Zone $\mathrm{C}$ has short pronounced barbs and a slightly occurred in Cultural Zone B/C. The complete point is short (maximum length of $38.6 \mathrm{~mm}$ ) and has been reworked (Figure 46, upper left). A deep step fracture is present on one surface. Having a maximum length of $50.3 \mathrm{~mm}$, the nearly complete point is well made and has straight lateral edges and prominent barbs (see Figure 46, upper center). Other attributes include deep basal notches, long curving barbs, and a slightly rounded base. Three of the six proximal fragments consist solely of stems having straight to slightly rounded bases. Most of the barbs on the remaining three 
Table 16. Dart point metric data*

\begin{tabular}{|c|c|c|c|c|c|c|c|c|c|}
\hline Point Type & $\begin{array}{l}\text { Zone/ } \\
\text { Level } \\
\end{array}$ & Completeness & $\begin{array}{l}\text { Maximum } \\
\text { Length }\end{array}$ & $\begin{array}{l}\text { Blade } \\
\text { Length }\end{array}$ & $\begin{array}{l}\text { Blade } \\
\text { Width } \\
\end{array}$ & $\begin{array}{c}\text { Haft } \\
\text { Width }\end{array}$ & $\begin{array}{l}\text { Neck } \\
\text { Width } \\
\end{array}$ & $\begin{array}{c}\text { Base } \\
\text { Width }\end{array}$ & $\begin{array}{c}\text { Maxiumum } \\
\text { Thickness }\end{array}$ \\
\hline \multicolumn{10}{|c|}{ CULTURAL ZONE A } \\
\hline Ensor & A3 & complete & 44.5 & 32.8 & 20.4 & 11.7 & 15.1 & 21.0 & 5.9 \\
\hline Ensor & $\mathrm{A} 2$ & distal fragment & 34.5 & 25.4 & 19.4 & - & 15.4 & - & 5.8 \\
\hline Paisano & A3 & proximal fragment & 33.4 & - & 19.6 & 9.2 & 14.6 & - & 8.5 \\
\hline untypeable $^{1}$ & A3 & medial fragment & 20.9 & - & - & - & - & - & 6.9 \\
\hline untypeable & A3 & proximal fragment & 26.4 & - & - & - & 15.2 & - & 5.8 \\
\hline untypeable ${ }^{1}$ & A3 & medial fragment & 17.0 & - & - & - & - & - & 4.8 \\
\hline \multicolumn{10}{|c|}{ CULTURAL ZONE B } \\
\hline Pandale & B1 & nearly complete & 56.6 & - & 18.5 & 16.4 & 14.1 & 14.3 & 6.8 \\
\hline Shumla & B3 & proximal fragment & 39.4 & - & - & 7.8 & 14.4 & 15.1 & 5.1 \\
\hline Shumla & B1 & nearly complete & 50.3 & 38.1 & 39.2 & - $\quad 11.1$ & 13.2 & 14.4 & 5.3 \\
\hline Shumla & B1 & proximal fragment & 32.8 & - & - & 10.4 & 17.4 & 17.7 & 5.3 \\
\hline Shumla & B1 & complete & 38.6 & 29.8 & 22.0 & 8.8 & 14.5 & 13.8 & 6.7 \\
\hline Shumla & B1 & proximal fragment & 11.6 & - & - & - & - & 16.9 & 3.7 \\
\hline Shumla & B3 & proximal fragment & 13.0 & - & - & - & - & 13.0 & 3.4 \\
\hline Shumla & B2 & proximal fragment & 24.0 & - & - & - & 13.3 & 10.8 & 4.6 \\
\hline untypeable & B1 & proximal fragment & 13.6 & - & - & - & - & 12.5 & 5.4 \\
\hline untypeable & $\mathrm{B} 2$ & distal fragment & 43.5 & 36.4 & 30.6 & - & - & - & 3.4 \\
\hline untypeable & $\mathrm{B} 2 / \mathrm{B} 3$ & distal fragment & 25.6 & - & - & - & - & - & 3.5 \\
\hline untypeable & B2 & proximal fragment & 12.2 & - & - & - & 14.3 & 12.3 & 5.9 \\
\hline \multicolumn{10}{|c|}{ CULTURAL ZONE B/C } \\
\hline Shumla & $\mathrm{B} / \mathrm{C}$ & proximal fragment & 8.6 & - & - & - & - & 10.2 & 3.9 \\
\hline \multicolumn{10}{|c|}{ CULTURAL ZONE C } \\
\hline Bulverde & $\mathrm{C} 1$ & complete & 59.8 & 41.7 & 35.8 & 18.1 & 22.4 & 18.8 & 7.3 \\
\hline untypeable & $\mathrm{C} 2$ & barb & 17.3 & - & - & - & - & - & 2.7 \\
\hline untyped & C3 & proximal fragment & 29.4 & - & 36.0 & - & 18.2 & - & 6.2 \\
\hline
\end{tabular}

\footnotetext{
*All measurements are in millimeters

${ }^{1}$ These two fragments refit to form an untypeable point (medial fragment) that measures 35.3 mm in maximum length and 6.9 mm in maximum
} thickness. 


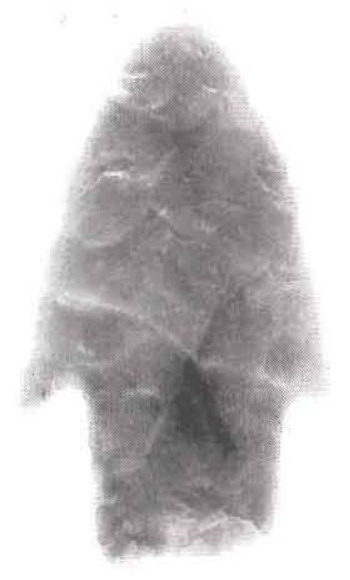

Bulverde

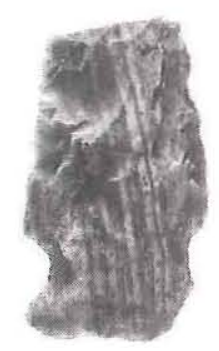

Paisano

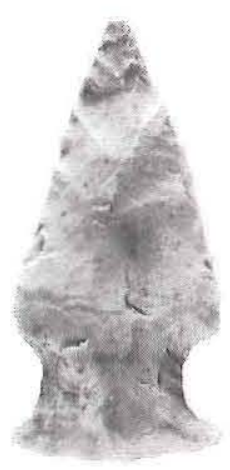

Ensor

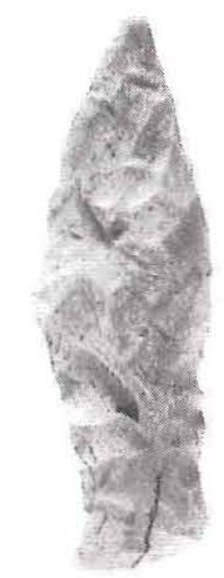

Pandale

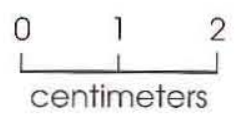

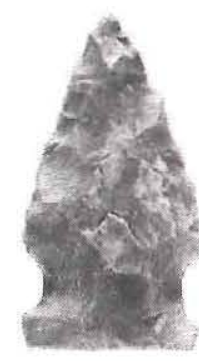

Ensor

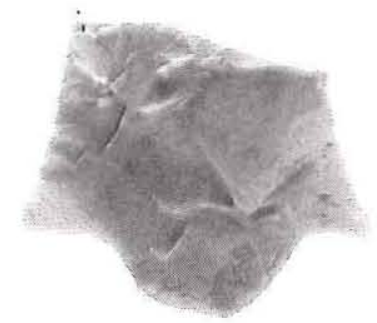

Untyped

Figure 45. Dart points.

proximal fragments are snapped, but one specimen retains a long, curving barb. The stems are straight to contracting, and the bases are straight to slightly rounded. The specimens with long curving barbs are similar to the younger of two styles of Shumla points recovered at Arenosa Shelter (Dibble 1997:35, 72-73). This type occurred towards the end of the Late Archaic period. Due to similar flaking patterns on the bases of the eight Shumla points, all appear to represent this younger variant.

\section{UNTYPEABLE AND UNTYPED DART POINTS}

Eight untypeable dart points and one untyped point were recovered from Cultural Zones A, B, and C. The untypeable items consist of one barb, three proximal fragments, two medial fragments, and two distal fragments. The proximal specimens consist of two stems and one fragment with a snapped base. The medial fragments refit; although found at the same elevation in Zone A, the pieces were in different 

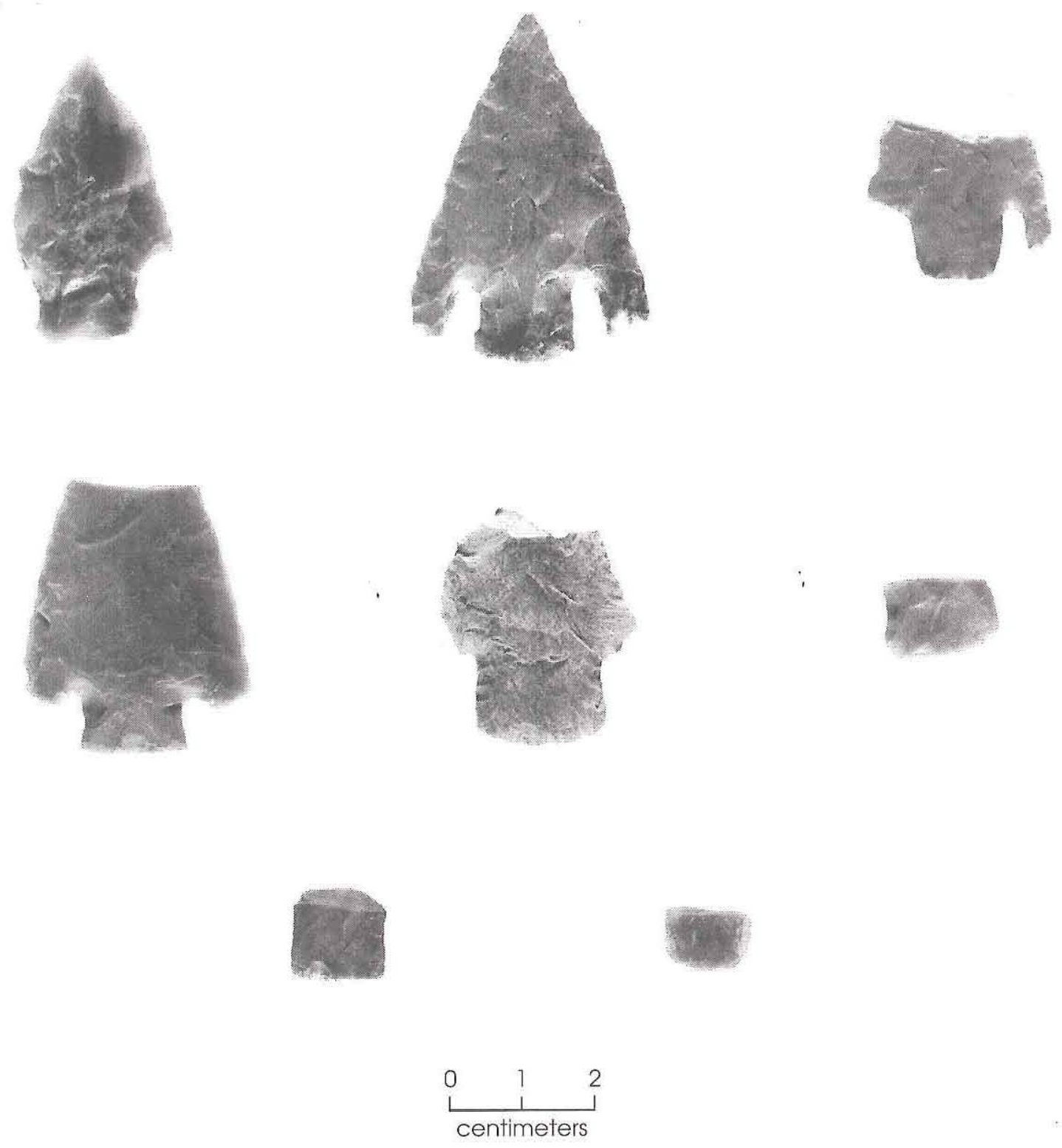

Figure 46. Shumla dart points.

excavation units spaced ca. $1 \mathrm{~m}$ apart. Both distal fragments appear well made and are thin (3.4-3.5 mm).

The untyped point is the lower portion of a snapped stem (see Figure 45). It is similar to the Almagre type (possible Langtry preforms; Turner and Hester 1993:69-70) or the Langtry variant of the Arenosa type (Bement 1991:5164). It has weak shoulders and a contracting stem. The lower section of its lateral edges are slightly curved. This artifact was found in Zone C.

\section{Unidentifiable Projectile Points}

This subclass includes one barb (Cultural Zone A) and one distal specimen (Cultural Zone B). Both are made of chert but are so fragmentary that they could not be assigned to the arrow or dart point category with any confidence.

\section{Bifaces}

Classified into six categories, the 50 bifaces 
consist of 3 early stage ( 6 percent), 15 middle stage ( 30 percent), 8 late stage ( 16 percent), 7 finished (14 percent), 1 beveled knife ( 2 percent), and 16 miscellaneous bifaces (32 percent). Table 17 summarizes the biface types by cultural zone. The three chert early-stage bifaces are complete specimens that retain cortex primarily on the dorsal surface (Figure 47). They are 57.6-77.6 $\mathrm{mm}$ long, 51.6-64 mm wide, and 17.4-25.4 mm thick.

The middle-stage bifaces (see Figure 47) consist of 12 complete specimens, 1 nearly complete specimen, and 2 distal fragments. The complete specimens are $37.7-97.3 \mathrm{~mm}$ long, 11.1-83.2 $\mathrm{mm}$ wide, and 7.1-29.8 $\mathrm{mm}$ thick. Most are circular or ovate in shape; one is manufactured from basalt and the remainder are chert. Two were recovered from Feature 13. Both of these are complete, but one was heat fractured into two pieces. One graver, two flakes from the feature fill, and one flake from nonfeature matrix in a nearby unit refit onto these two middle-stage bifaces.

The late-stage chert bifaces consist of one complete specimen, one nearly complete biface, and one distal and five proximal fragments (see Figure 47). The complete specimen is subtriangular in outline and measures $47.1 \times 30.5 \times 6.0 \mathrm{~mm}$. The nearly complete, triangular artifact is $75.1 \mathrm{~mm}$ long, $43.9 \mathrm{~mm}$ wide, and $11.2 \mathrm{~mm}$ thick (see Figure 47, lower left). The five proximal fragments have rounded bases and are $21.9-60.6 \mathrm{~mm}$ long, 35.8-70.7 $\mathrm{mm}$ wide, and 7.1-17.2 mm thick. Some exhibit deep step fractures, usually near an inclusion or adjacent to bulbous areas that could not be reduced further.

One complete specimen and one proximal, one medial, one distal, and three edge fragments make up the finished bifaces. All are chert. None were typed, but most display excellent knapping ability. The thickness of these bifaces is between 2.1 and $5.9 \mathrm{~mm}$. The complete specimen, from Cultural Zone B, is a small triangular biface that probably represents a point preform (Figure 48). It measures $41.4 \mathrm{~mm}$ long, $26.3 \mathrm{~mm}$ wide, and $4.5 \mathrm{~mm}$ thick. Recovered from Zone $\mathrm{C}$, the proximal fragment is $100.4 \mathrm{~mm}$ long, $47.3 \mathrm{~mm}$ wide, and $5 \mathrm{~mm}$ thick (see Figure 48). Although generally rectangular in outline, one corner is rounded. The lateral edge to this rounded corner is slightly curved, has been moderately pressure flaked, and exhibits use wear. Pressure flake scars are visible the entire length of the opposite lateral edge, which is straight.

Found in situ in the middle of Cultural Zone B (Excavation Unit 33), a two-beveled knife made of dark reddish brown (2.5YR $3 / 3$ ) jasper is complete and teardrop shaped (see Figure 48). This material is distinctive and unusual; it may be available in the Uvalde gravels in the Lake Amistad area (Joe Labadie, personal communication 1997). This knife measures $103.8 \mathrm{~mm}$ long, $39.4 \mathrm{~mm}$ wide, and $7.8 \mathrm{~mm}$ thick. The beveling occurs on alternate edges but is more dominant on one face, probably from resharpening. The opposite lateral edge exhibits use wear. The edges along the base are extremely smooth and rounded, probably resulting from haft wear.

The 16 miscellaneous bifaces consist of fragments that could not be assigned to one of the specific subclasses. All are made of chert.

\section{Unifaces}

The 25 unifaces, all of chert, were categorized as end scrapers ( $\mathrm{n}=3,12$ percent), a side scraper ( $n=1,4$ percent), end/side scrapers $(n=4,16$ percent), other scrapers $(n=2$, 8 percent), and miscellaneous unifaces $(\mathrm{n}=15$, 60 percent). Twenty ( 80 percent) were recovered from Zone A, and the remainder occurred in the upper $10 \mathrm{~cm}$ of Cultural Zone B (Table 18). The end scrapers consist of three large distal fragments with worked edges (Figure 49). The complete side scraper has dimensions of $60.5 \times 31.6 \times 12.4 \mathrm{~mm}$ and a 


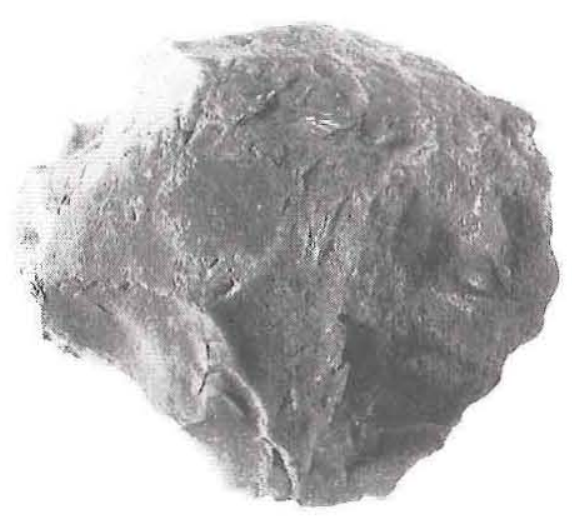

Early Stage

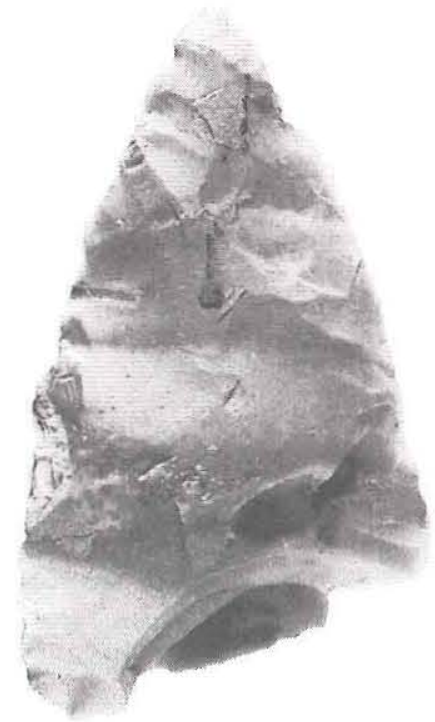

Late Stage

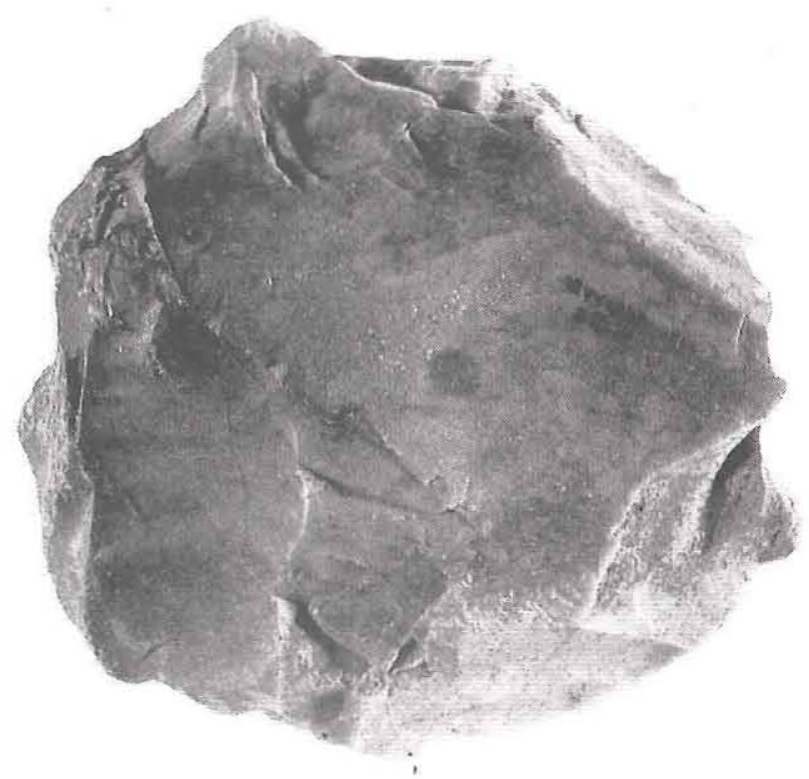

Middle Stage

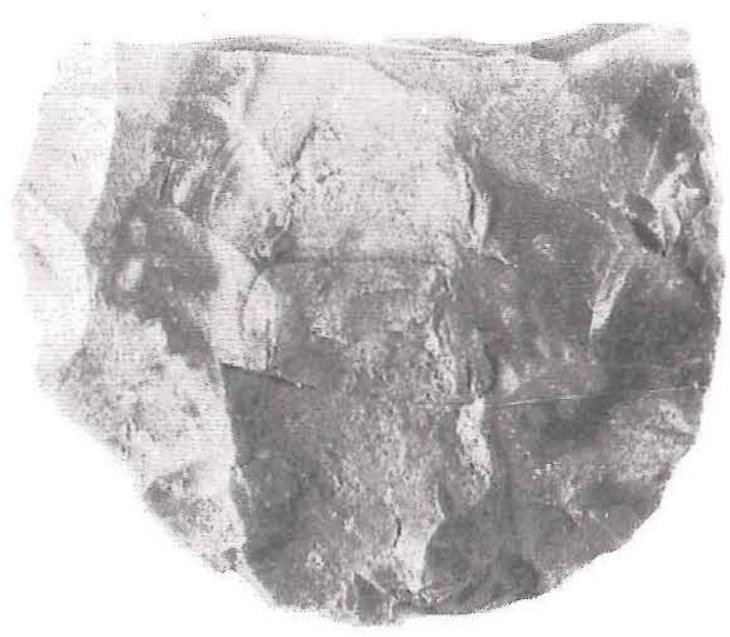

Late Stage

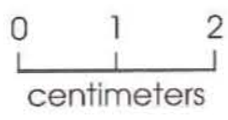

Figure 47. Bifaces. 

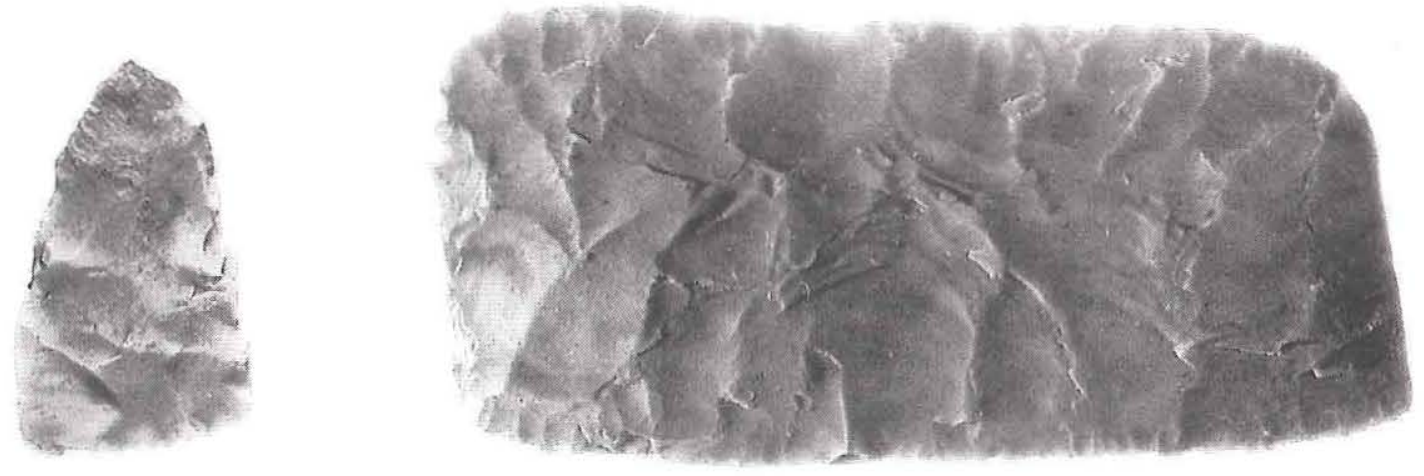

Finished, Triangular

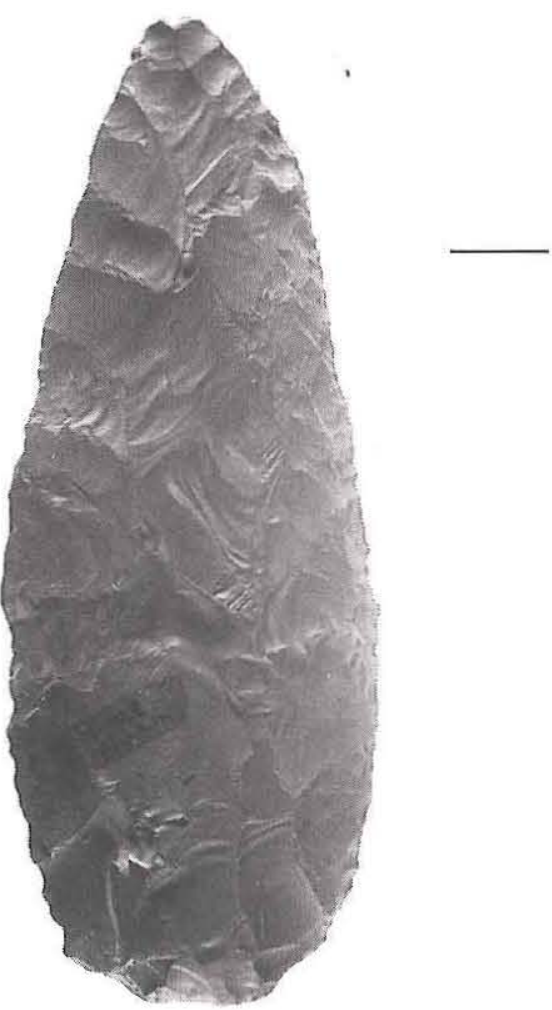

Finished, Rectangular

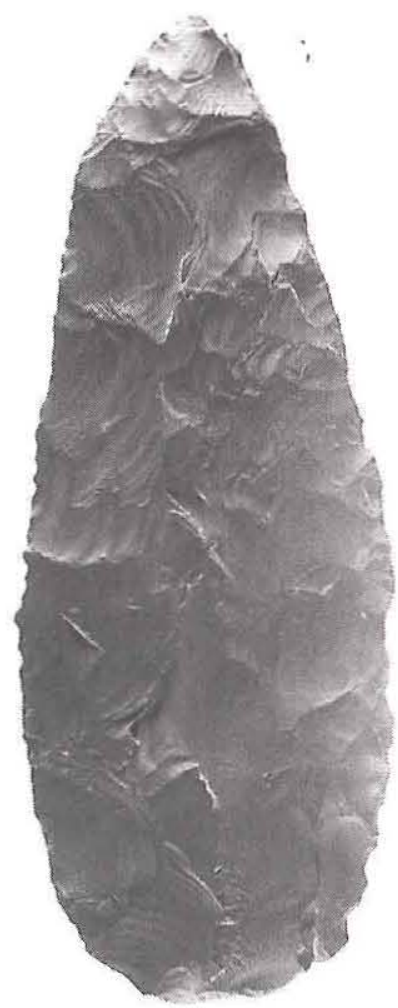

Beveled Knife

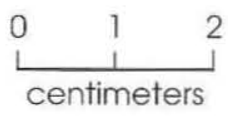

Figure 48. Bifaces. 
Tabla 18. Uniface types by culltural zone

\begin{tabular}{lccc}
\hline Uniface Type & $\begin{array}{c}\text { Cultural } \\
\text { Zone A }\end{array}$ & $\begin{array}{l}\text { Cultural } \\
\text { Zone B }\end{array}$ & Totals \\
\hline End scraper & 2 & 1 & 3 \\
Side scraper & 1 & - & 1 \\
End/side scraper & 3 & 1 & 4 \\
Other scraper & 2 & - & 2 \\
Miscellaneous & 12 & 3 & 15 \\
uniface & 20 & 5 & 25 \\
\hline Totals & & & \\
\hline
\end{tabular}

single worked edge (see Figure 49). Three complete specimens and one distal fragment are end/side scrapers. These have steeply beveled distal working edges and are planoconvex in cross section (see Figure 49). Two specimens exhibit haft and use wear. They are typical of "plains style," "keeled," "snub-nosed," or "dorso" end scrapers and are a defining characteristic of Toyah culture and many other Late Prehistoric bison hunting groups (e.g., Bement and Turpin 1987; Wedel 1970). The complete specimens are 50.1-61.4 mm long, 39.1-44 $\mathrm{mm}$ wide, and 9.6-15.7 $\mathrm{mm}$ thick. The two other scrapers are edge fragments too small to indicate the location of the working edge(s).

The 15 miscellaneous unifaces exhibit intentionally trimmed edges but cannot be assigned to one of the other subclasses. One proximal fragment and one edge fragment refit. These were recovered from the same excavation unit but at differing elevations, indicating at least $10 \mathrm{~cm}$ vertical separation.

Three other miscellaneous uniface fragments and a multifunctional tool (see below) refit to form a nearly complete unifacial tool (i.e., a side scraper), but the various fragments exhibit evidence of subsequent reworking and reuse (Figure 50). The fragments were found in two adjacent excavation units within $20 \mathrm{~cm}$ in Zone A. The tool began as an elongated flake (perhaps a blade flake) with extensive unifacial working on the dorsal face (with over 75 percent cortex remaining) along one lateral edge and minimal working of the ventral face along the opposite lateral edge. The original tool was $81 \mathrm{~mm}$ long and $40 \mathrm{~mm}$ wide. It was then broken (apparently a pressure snap) into three pieces and the dorsal side of the proximal fragment was chipped along the snapped edge. One small wedge-shaped medial fragment exhibits no evidence of having been reworked. The distal fragment was reworked along the snapped edge, with a spokeshave notch being added. This latter fragment is classified as a multifunctional tool (spokeshave/miscellaneous uniface, see below). The proximal fragment subsequently snapped again; a small wedge-shaped piece was broken off. Aflake scar on the snapped edge of the larger proximal fragment indicates that it sustained some damage or was reworked after the wedge-shaped piece was broken off. The complex use life of this specimen indicates that reworking and reuse of broken tools was common. The smaller wedge-shaped fragments were apparently too small to serve other functions, but the larger fragments were considered useful raw material.

\section{Spokeshaves}

Found in Cultural Zone A, the unifacially worked chert spokeshaves consist of one complete specimen and one distal fragment (see Figure 50).

\section{Cobble Tools/Choppers}

One chert and two basalt cobble tools/choppers are complete. Bifacial flaking on these artifacts produced slightly sinuous to sinuous edges, and each retains cortex on a thick proximal end that provides a smooth, sometimes rounded, surface. One cobble tool/chopper from Cultural Zone A is subtriangular, manufactured of chert, and retains less than 25 percent cortex. It measures $94.1 \mathrm{~mm}$ long, $86.6 \mathrm{~mm}$ wide, and $49.4 \mathrm{~mm}$ thick. The battered edges are slightly rounded, suggesting that this fine-grained material does not maintain worked edges as well as the harder, coarse-grained basalt.

Recovered from Cultural Zone B, one basalt specimen $(88.4 \times 75.5 \times 49 \mathrm{~mm})$ is circular and retains less than 50 percent cortex (Figure 51, upper). This artifact has flake scars and battered edges that are well rounded.

Found in Cultural Zone C, one ovate basalt specimen measures $88.1 \times 60.9 \times 38.1 \mathrm{~mm}$ (Figure 51 , lower). It has more than 50 percent cortex and exhibits some use striations. The battered edges and a few flake scars are rounded and slightly polished. The damage and wear patterns suggest that this tool had multiple uses. 


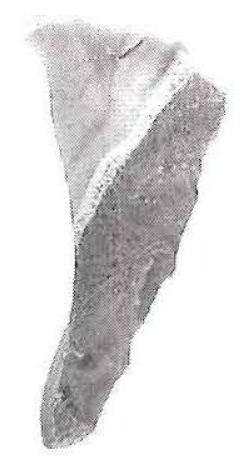

End Scraper
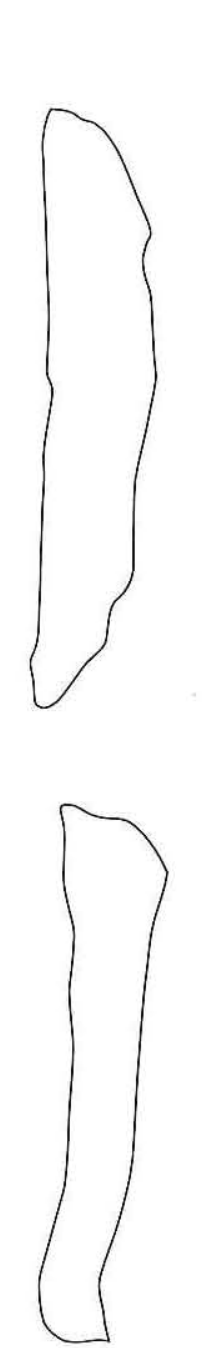
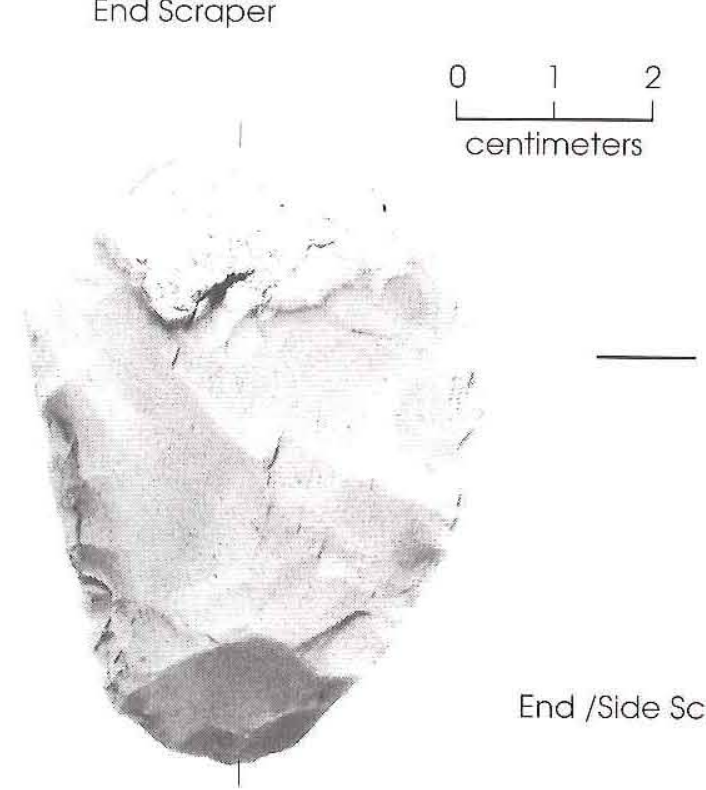

End /Side Scraper

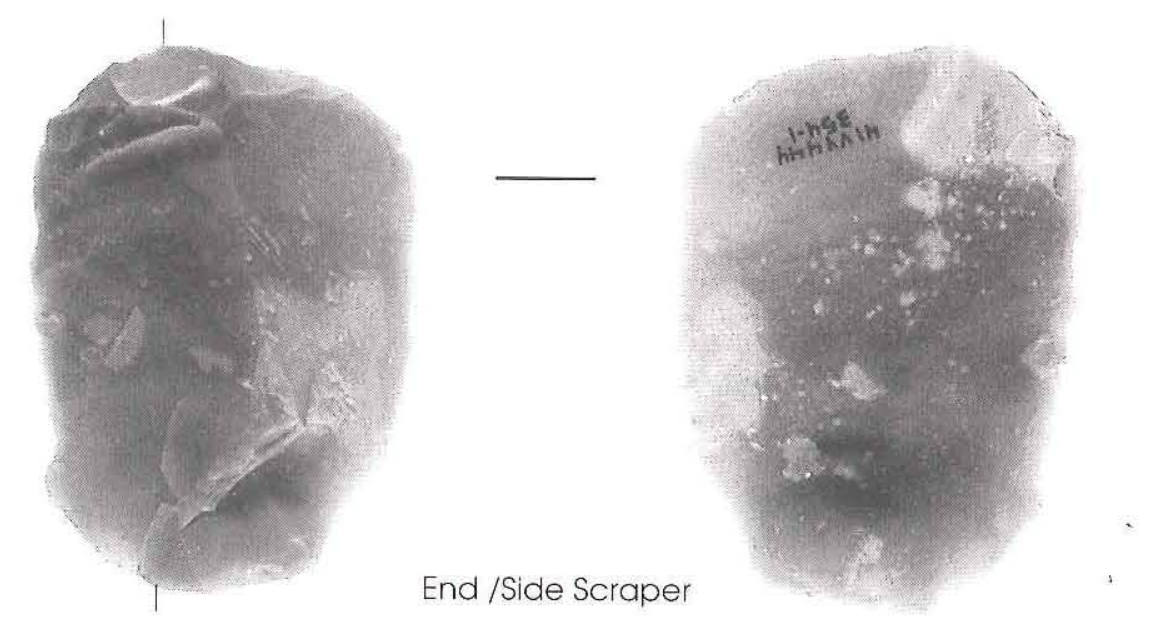

Figure 49. End, side, and end/side scrapers.

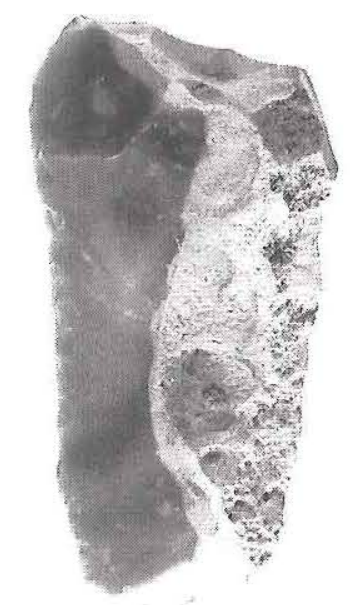

Side Scraper

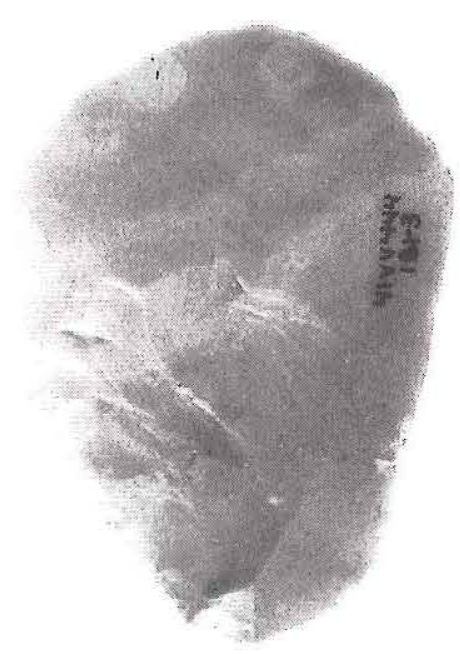



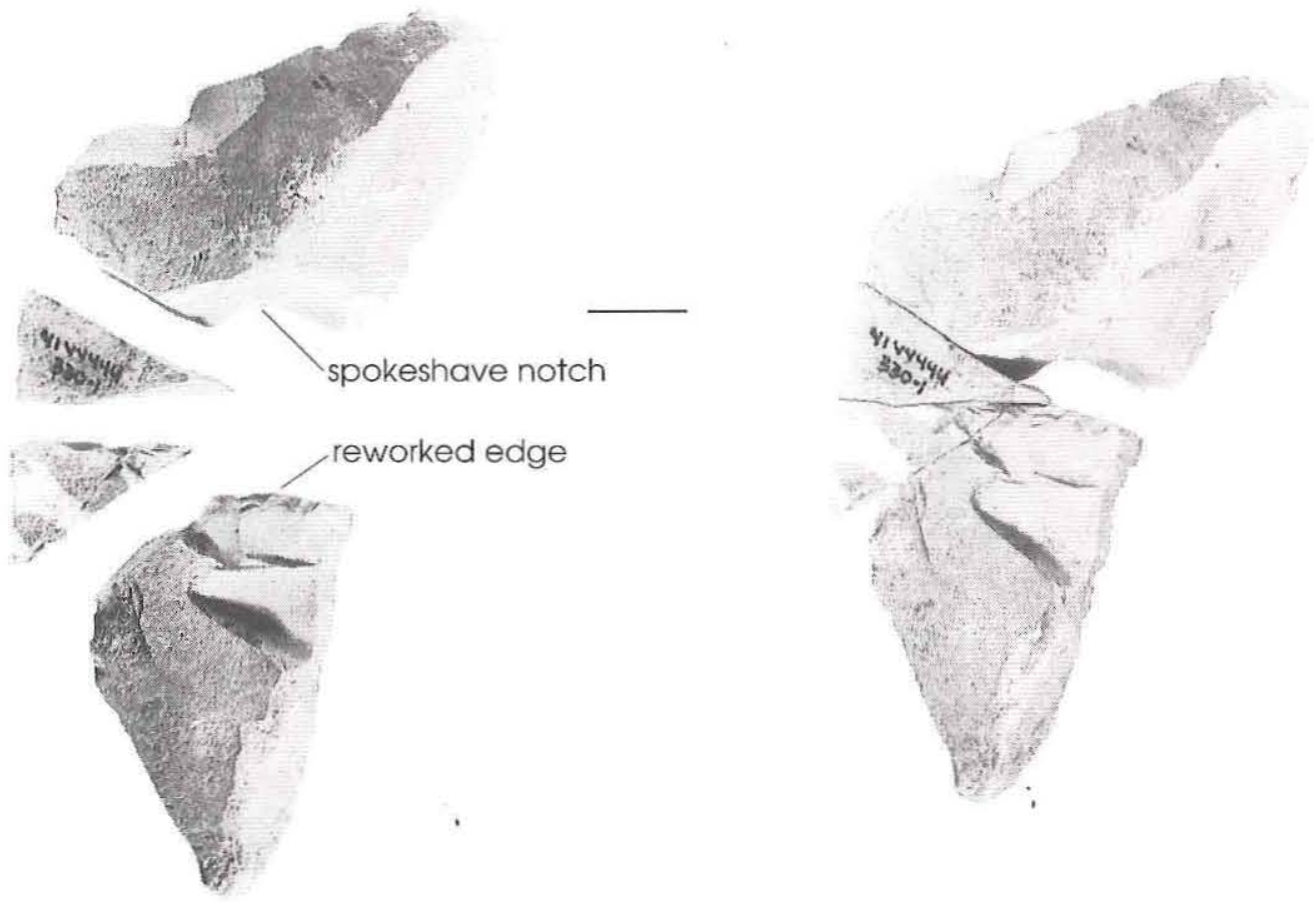

Miscellaneous Uniface, Exploded View

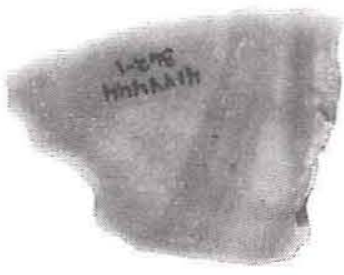

Spokeshave

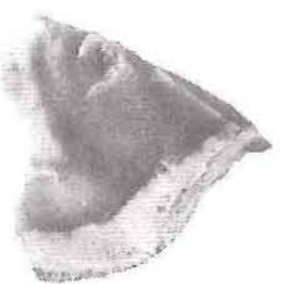

Spokeshave

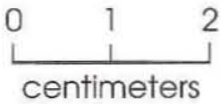

Miscellaneous Uniface, Refit View

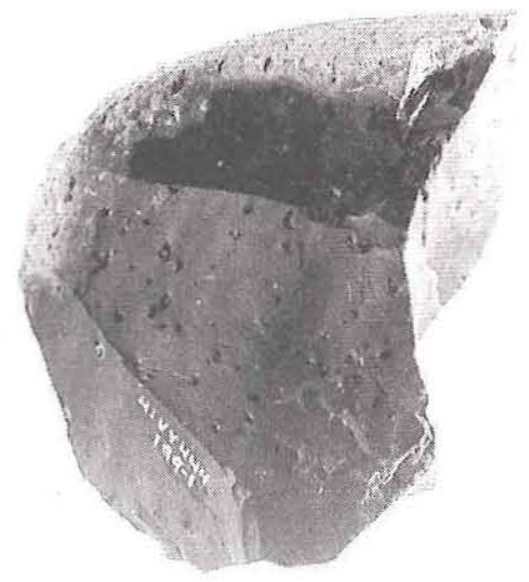

Core

Figure 50. Miscellaneous uniface, spokeshaves, and core.

\section{Gravers/Burins}

This complete artifact was made on a chert flake removed from a middle-stage biface. Both artifacts were recovered from Feature 13 in Cultural Zone $\mathrm{C}$, and the graver flake refits onto the biface (see Figure $41 \mathrm{a}, \mathrm{b}$ ).

\section{Core Tools}

A single complete core tool from Cultural Zone $\mathrm{C}$ is an exhausted chert core with one battered and crushed edge. Its measures $52 \mathrm{~mm}$ long, $39.2 \mathrm{~mm}$ wide, and $21 \mathrm{~mm}$ thick. 

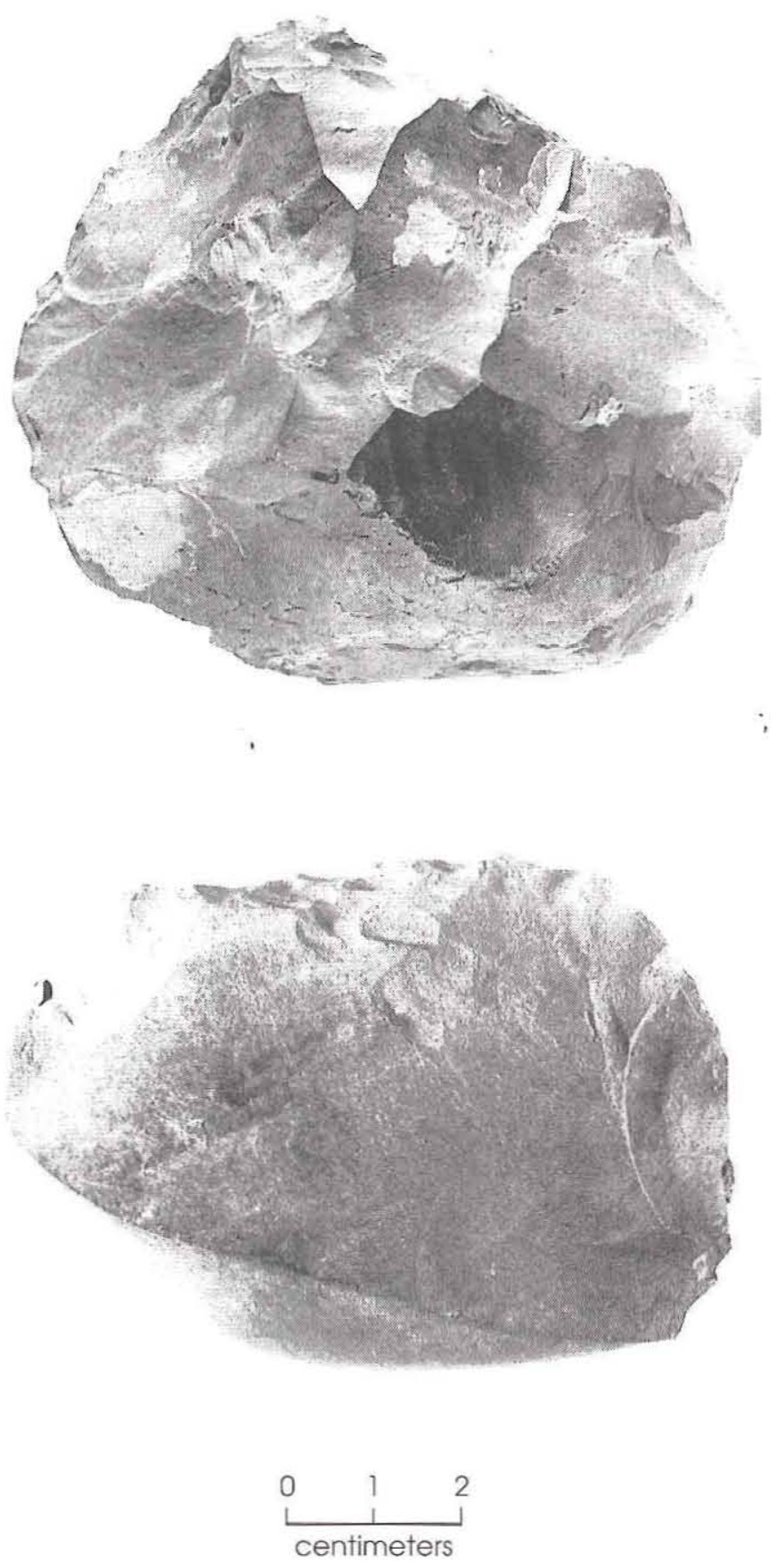

Figure 51. Cobble tools/choppers.

\section{Multifunctional Tools}

These nine specimens are tools that appear to have had at least two distinct functions. Two are complete, one is nearly complete, one is a proximal fragment, and five are distal frag- ments. The inferred functions of each and associated cultural zones are listed in Table 19. One spokeshave/ miscellaneous uniface is a distal fragment that refits with three fragments of a miscellaneous uniface (see Figure 50). 
Table 19. Multifunctional tools by cultural zone

\begin{tabular}{lccc}
\hline Tool Function & $\begin{array}{c}\text { Cultural } \\
\text { Zone A }\end{array}$ & $\begin{array}{c}\text { Cultural } \\
\text { Zone B }\end{array}$ & Totals \\
\hline Edge-modified flake/graver & - & 3 & 3 \\
Edge-modified flake/perforator & - & 1 & 1 \\
Graver/miscellaneous biface & 1 & - & 1 \\
Graver/miscellaneous uniface & 2 & - & 2 \\
$\begin{array}{l}\text { Spokeshave/miscellaneous } \\
\text { uniface }\end{array}$ & $1^{*}$ & 1 & 2 \\
\hline Totals & 4 & 5 & 9 \\
\hline *This specimen refits with other unifacial tool fragments. \\
\hline
\end{tabular}

the amount of dorsal cortex, each flake was classified as primary, secondary, or tertiary (Table 20). Chert $(n=2,260,97$ percent) is the dominant material type, followed by basalt $(n=65,3$ percent) and jasper ( $\mathrm{n}=4,<1$ percent).

\section{Ground and Battered Stone Artifacts}

Eight ground or battered stone artifacts consist of one

\section{Edge-Modified Flakes}

This subclass makes up 33 percent of the 207 chipped stone tools. The 69 edge-modified flakes consist of 27 complete specimens (39 percent) and 18 proximal ( 26 percent), 7 medial ( 10 percent), 9 distal (13 percent), 6 edge ( 9 percent), and 2 indeterminate ( 3 percent) fragments. Cultural Zones A ( $\mathrm{n}=31)$ and B $(\mathrm{n}=28)$ contained 86 percent of these artifacts. Two and eight edgemodified flakes were found in Cultural Zones B/C and $\mathrm{C}$, respectively. One specimen is made of basalt and the remainder are chert.

\section{Cores}

Twelve cores were recovered from Cultural Zones $A(n=3,25$ percent), $B(n=8,67$ percent), and $\mathrm{C}(\mathrm{n}=1,8$ percent). One specimen completely lacks cortex, 10 retain $1-50$ percent cortex, and 1 has 50-99 percent of its surface covered with cortex. Ten are made of chert, 1 is basalt, and 1 is pitchstone. The pitchstone core is black (7.5YR $2 / 0$ ) with small black and gray (7.5YR 6/0) inclusions (see Figure 50). It is an unusual material; its stream cobble cortex suggests that it is from the Uvalde gravels. One chert core displays patterned battering, indicating that it is a recycled hammerstone.

\section{Unmodified Debitage}

The most common stone artifact type is unmodified debitage $(\mathrm{n}=2,335)$. It consists of 1,215 complete specimens (52 percent), 345 proximal fragments (15 percent), 747 chips (32 percent), and 28 chunks ( 1 percent). Based on
Table 20. Summary of unmodified debitage

\begin{tabular}{ccccc}
\hline Cultural & & & & \\
Zone & Primary & Secondary & Tertiary & Total \\
\hline A & 9 & 115 & 748 & 872 \\
B & 15 & 133 & 829 & 977 \\
B/C & 1 & 16 & 76 & 93 \\
C & 2 & 50 & 338 & 390 \\
D & - & 1 & 2 & 3 \\
Total & 27 & 315 & 1,993 & 2,335 \\
\hline
\end{tabular}



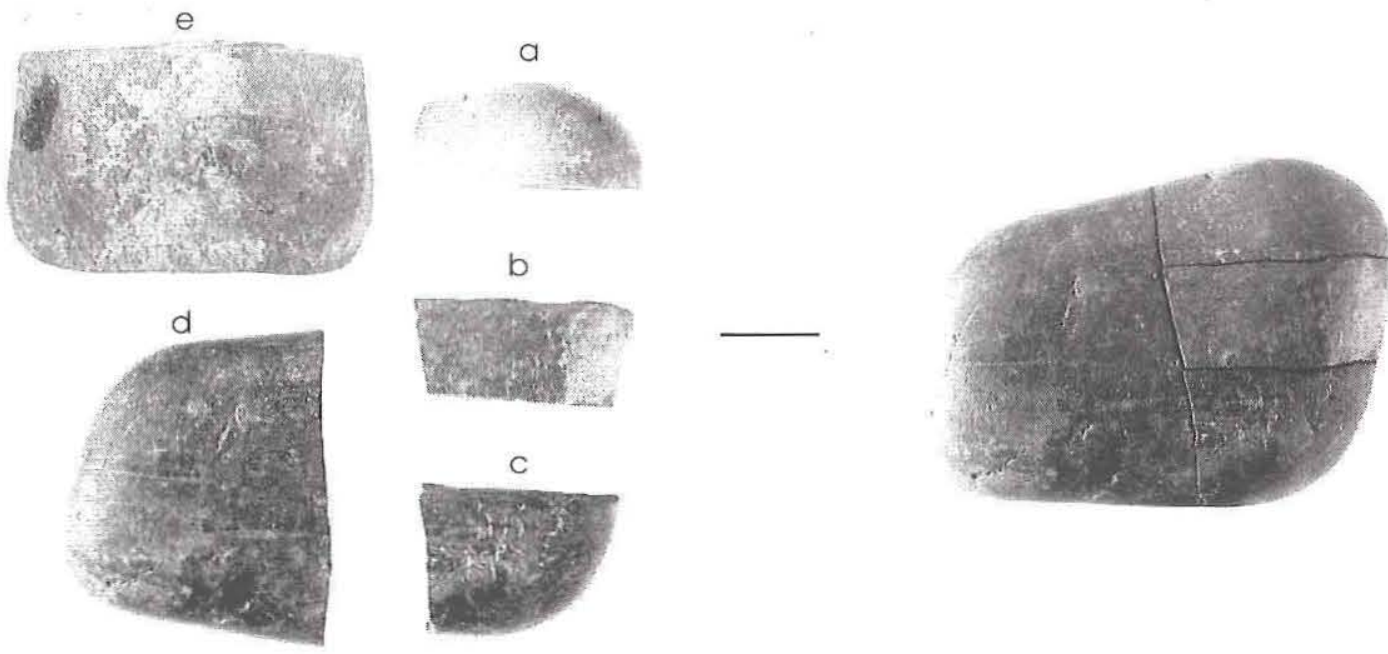

\section{Mano/Hammerstone, Exploded View}
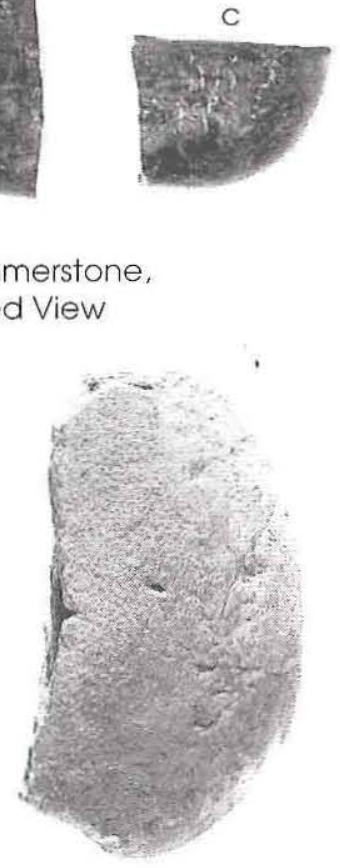

Mano/Hammerstone, Refit View

Mano

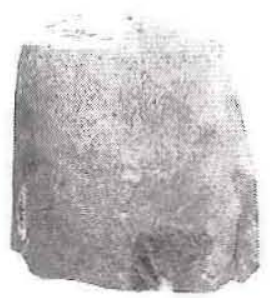

Slickstone

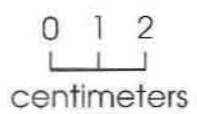

Figure 52. Ground and battered stone tools. Note that fragment e of the mano/hammerstone refits behind fragments $\mathrm{c}$ and $\mathrm{d}$, but pieces are missing from behind fragments $\mathrm{a}, \mathrm{b}$, and part of $\mathrm{d}$.

excavated. This third piece was recovered from a portion of Feature 12, which probably originated in Zone B but was intrusive through Zone $\mathrm{B} / \mathrm{C}$ and into Zone $\mathrm{C}$. It is from a third excavation unit 2-3 $\mathrm{m}$ from the other two, and was found in situ $50-70 \mathrm{~cm}$ below the other two pieces. Approximately two-thirds of the entire cobble are present when the fragments are refitted. All edges and surfaces are rounded and/or smooth, striations are visible, and two opposite edges exhibit battering.
Recovered from Cultural Zone B, the other ground stone tool is one end of a coarse-grained limestone cobble. It is $60.9 \mathrm{~mm}$ long, $54 \mathrm{~mm}$ wide, and $41.2 \mathrm{~mm}$ thick. Although a few flake scars are apparent on the end, the unflaked portion is rounded, extremely smooth, and polished (see Figure 52). Two opposite lateral edges are heavily modified. One rounded and polished edge is discolored by black mottling. Striations parallel this edge the entire length of the artifact. The opposite edge exhibits similar 
modification but is also battered and not as noticeably discolored. Morphologically, this artifact is comparable to the "slickstones" or latestage hide processing tools described by Ahr (1998). He notes that polishing and striations are evident on these stones, and some are pecked, battered, and/or have flaked ends.

\section{Ceramics}

The ceramic assemblage from the Area 1 excavation block consists of 115 sherds of bonetempered plainware ${ }^{22}$ (Table 21). The sherds

${ }^{22}$ The nine sherds recovered from Area 2 are virtually identical but are from a disturbed context.

Table 21. Summary of sherds by size and cultural zone

\begin{tabular}{lcccr}
\hline Size Class & $\begin{array}{c}\text { Cultural } \\
\text { Zone A }\end{array}$ & $\begin{array}{l}\text { Cultural } \\
\text { Zone B }\end{array}$ & $\begin{array}{l}\text { Cultural } \\
\text { Zone B/C }\end{array}$ & Total \\
\hline 5-10 mm & 19 & 1 & 1 & 21 \\
11-20 mm & 49 & 4 & 1 & 54 \\
21-30 mm & 25 & 7 & - & 32 \\
$31-40 \mathrm{~mm}$ & 7 & - & - & 7 \\
41-50 mm & - & - & - & 0 \\
51-60 mm & 1 & - & - & 1 \\
\hline Totals & 101 & 12 & 2 & 115 \\
\hline
\end{tabular}

Table 22. Interior and exterior surface colors of selected sherds

\begin{tabular}{llcc}
\hline & Munsell & \multicolumn{2}{c}{ Number or Sherds } \\
Color & Designation & Interior & Exterior \\
\hline Reddish brown & 2.5 YR 5/4 & 1 & 0 \\
Red & $2.5 Y R$ 5/6 & 0 & 1 \\
Light reddish brown & 2.5 YR 6/4 & 0 & 1 \\
Light red & $2.5 Y R$ 6/6 & 0 & 4 \\
Yellowish red & 5YR 5/6 & 1 & 2 \\
Light reddish brown & 5YR 6/4 & 1 & 2 \\
Reddish yellow & 5YR 6/6 & 11 & 6 \\
Reddish yellow & 5YR 7/6 & 1 & 1 \\
Black & $7.5 Y R ~ 2 / 0 *$ & 1 & 1 \\
Light brown & $7.5 Y R ~ 6 / 4$ & 1 & 9 \\
Reddish yellow & $7.5 Y R$ 6/6 & 17 & 16 \\
Pinkish gray & $7.5 Y R ~ 7 / 2$ & 0 & 1 \\
Pink & $7.5 Y R ~ 7 / 4$ & 1 & 0 \\
Light gray & 10YR 7/2 & 1 & 0 \\
Very pale brown & 10YR 7/4 & 0 & 1 \\
\hline Total & & \\
\hline *Smudged or sooted after vessel was broken & \\
\hline
\end{tabular}

are generally small, most under $30 \mathrm{~mm}$ in maximum dimension ( $\mathrm{n}=107,93$ percent). They range from as small as $5 \mathrm{~mm}$ to one sherd measuring $51 \times 31 \mathrm{~mm}$. Most were recovered from Zone $A$ ( $\mathrm{n}=101,88$ percent) and only 14 were recovered from lower deposits. There seems to be some size sorting evident in the vertical distribution. All eight of the sherds larger than $31 \mathrm{~mm}$ were found in Zone A. The fact that all sherds from Zones B and B/C are less than $30 \mathrm{~mm}$ suggests that they may have been transported down-profile into these lower zones by natural processes.

A sample of 50 of the larger sherds (i.e., those over ca. $15 \mathrm{~mm}$ ) with intact interior and/or exterior surfaces was analyzed and categorized by color ( $\mathrm{n}=81,70$ percent). These sherds are predominantly reddish yellow in interior $(n=29$, 81 percent of 36 interior surfaces) and exterior $(n=23,51$ percent of 45 exterior surfaces) color, although a range of colors is represented (Table 22). Many of the sherds have a darker core, often a dark center stripe or darkening along the interior or exterior edge. One rim sherd is black, and only four body sherds are unusual in color (pinkish gray, pink, light gray, and very pale brown). These colors are probably due to fire clouding during vessel firing. True surface colors are evident more often on the exterior surfaces, while interiors are more frequently eroded and scarred. The higher incidence of inter-ior surface damage may be due to use, perhaps stirring damage in cooking vessels. Almost all of the sherds exhibit some degree of weathering, but undamaged exterior surfaces tend to be very smooth or burnished. Conversely, interior surfaces are only occasionally smooth and seldom appear burnished. Parallel striations are often present, and both the interior and exterior surfaces undulate along coil lines. A few sherds appear to be broken along coil lines, and occasional circular impressions, presumably finger marks made while thinning vessel walls, are 
evident. After examining a sample of the sherds, Regge Wiseman (personal communication 1999) observed that some sherd interiors also exhibit fingernail indentations that probably resulted from pinching the vessel wall between the end of the thumb and the index finger during final thinning. Sherd thickness varies from 3.3 to $7.3 \mathrm{~mm}$, averaging $4.9 \mathrm{~mm}$ for the 77 sherds complete and large enough to measure with confidence. The standard deviation for the 77 measured sherds is 0.63 , meaning 63 percent of the specimens are between 4.3 and $5.5 \mathrm{~mm}$ thick. At least four of the larger specimens (over $30 \mathrm{~mm}$ in maximum dimension) vary in thickness by more than a $1 \mathrm{~mm}$ within the individual sherd, and one sherd ranges from 4.6 to $6.0 \mathrm{~mm}$ in thickness. The sherd surfaces are extremely soft, being about 3-4 on Moh's scale of hardness.

Only two small rim sherds were recovered, so little is known about vessel form (Figure 53). The thinner rim sherd is about $16 \times 16 \mathrm{~mm}$, with a maximum length of $22.4 \mathrm{~mm}$. It is an inverted rim with straight sides and a rounded lip. It came from a carelessly constructed vessel; its thickness is inconsistent for such a small sherd. At $2 \mathrm{~mm}$ down from the lip the sherd ranges from 2.6 to $3.1 \mathrm{~mm}$ thick, and the thickness ranges from 2.7 to $3.5 \mathrm{~mm}$ at $15 \mathrm{~mm}$ down from the lip. The thicker rim sherd, which measures about $17 \times 18 \mathrm{~mm}$ with a maximum length of $20.2 \mathrm{~mm}$, represents a better-made vessel. It is consistent in thickness, being $4.8 \mathrm{~mm}$ thick at $2 \mathrm{~mm}$ down from the lip and $7.2 \mathrm{~mm}$ thick at $15 \mathrm{~mm}$ down from the lip. It is not possible to differentiate its interior and exterior sides with certainty, but curvature is sufficient to suggest that it is an inverted rim. This portion of the rim has

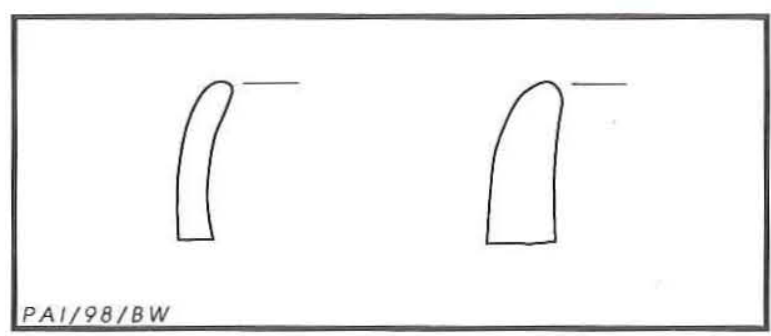

Figure 53. Plainware rim sherd profiles. straight sides and a rounded lip with its tip flattened (the flattened edge is approximately $1.5 \mathrm{~mm}$ wide).

The two rim sherds undoubtedly come from two different vessels, but neither is large enough or distinctive enough to estimate vessel form. The thinner rim sherd is from a smaller vessel than the thicker rim, which represents a vessel with a large mouth diameter. Regarding colors, the thinner rim is typical, being yellowish red (5YR 5/6 interior) to reddish yellow (7.5YR $6 / 6$ exterior) with a slightly darker core. The larger rim is black throughout, apparently having been smudged or sooted after the vessel was broken. It is likely that additional vessels are represented in the sample of body sherds, but it is not possible to estimate the minimum number.

The sample of 115 sherds from the Area 1 excavation block is homogenous in terms of ceramic paste composition. Examination using low power magnification reveals that the sherds are characterized by a fine sandy paste with common small $(<0.5 \mathrm{~mm})$ subrounded to subangular clear, white, or black grains that are apparently part of the clay component. Also common are small to large ( $<0.5 \mathrm{~mm}$ to $2.0 \mathrm{~mm}$ ) angular bone fragments added as a tempering agent. Occasional bone fragments are larger than $2 \mathrm{~mm}$, and one sliver measures $3.4 \mathrm{~mm}$ in length. All bone fragments appear to be heated, and they range in color from unusually white (i.e., calcined) to gray or black.

The sherds described here are essentially the same as bone-tempered sherds found at other sites in south and central Texas. Prehistoric ceramics are rare in Val Verde County, but similar sherds have been found at other nearby sites. Eight sherds were found at the Devil's Mouth site between 1958 and 1967 (Johnson 1961:279, 1964:73; Sorrow 1968:42), and 12 were found at the Javelina Bluff site in 1966 (McClurkan 1968:8). Previous researchers have called this type of bone-tempered ware Leon Plain (Suhm and Jelks 1962:95-96), or Doss Redware (Kelley 1947:123) when it has a distinctive red wash or slip. It is generally acknowledged that these types are poorly defined and are found across a vast portion of central and south Texas (e.g., Hester and Hill 1971:198-200; Johnson 1994:209-210). In Val Verde County, bone-tempered pottery has been attributed to 
the Toyah and Infierno phases (Turpin and Robinson 1998). The San Felipe pottery appears to represent crudely made utilitarian vessels that are typical of bone-tempered ceramics from classic Toyah phase sites. Johnson (1994:207, 285) suggests that Toyah potters were not particularly skilled and were interested primarily in making serviceable containers.

Petrographic analysis of thin sections of seven sherds is reported in Appendix C. This study suggests that the pottery from San Felipe Springs is very homogeneous and was probably made locally.

\section{Burned Rocks}

A total of $1,317.6 \mathrm{~kg}$ of burned limestone was encountered in the four cultural zones. Zone A yielded $99.9 \mathrm{~kg}$ but contained no apparent features. Zone B contained a total of $915.4 \mathrm{~kg}$ of burned rocks; $774.5 \mathrm{~kg}$ (84.6 percent) comprised the extensive layer of burned rocks in the easternmost 18 excavation units. Burned rocks associated with discrete pit features in the eastern half of the excavation block account for $26.5 \mathrm{~kg}$ ( 3 percent) of the total, while scattered burned rocks in the western half of the unit comprise the remaining $114.4 \mathrm{~kg}$ (12.5 percent). Cultural Zone B/C produced only $54.3 \mathrm{~kg}$. Of the $248 \mathrm{~kg}$ of burned rocks from Zone C, $178.85 \mathrm{~kg}$ (96 percent) comprised the burned rock layer in the eastern half of the block. In addition, Feature 11 produced $61 \mathrm{~kg}$ ( 25 percent).

All burned rocks were limestone, the most ubiquitous local material. From one excavation unit, all burned rocks from approximately half of Feature 11 were collected as a comparative sample. Once cleaned, a visual analysis revealed that the rocks consisted entirely of locally available limestone.

\section{Faunal Remains}

\section{Mussel Shells}

All mussel shell valves and fragments with umbos were collected and analyzed for completeness, evidence of heating, and possible cultural modification. During excavation, mussel shell fragments were examined for modification and subsequently discarded if none was present.

The excavations yielded one modified umbo fragment (from Excavation Unit 8), nine unmodified umbo fragments, and four unmodified partial valves. Most of the unmodified shells ( $\mathrm{n}=9,69$ percent) occurred in Cultural Zone $\mathrm{C}$ (Table 23); all but one were recovered from the layer of burned rocks. Thirteen specimens were identified as Lampsilis teres or probable L. teres (Howells et al. 1996), and one was not identifiable. The modified umbo fragment (left valve) was recovered from Cultural Zone B (Figure 54). A drill hole, approximately $2 \mathrm{~mm}$ in diameter, is apparent along the broken edge of the shell. It was drilled from the interior surface near the center of the shell.

Table 23. Summary of mussel shells

\begin{tabular}{cccc}
\hline $\begin{array}{c}\text { Cultural } \\
\text { Zone }\end{array}$ & Modified & Unmodified & Totals \\
\hline A & - & 1 & 1 \\
B & 1 & 2 & 3 \\
B/C & - & 1 & 1 \\
C & - & 9 & 9 \\
Totals & 1 & 13 & 14 \\
\hline
\end{tabular}

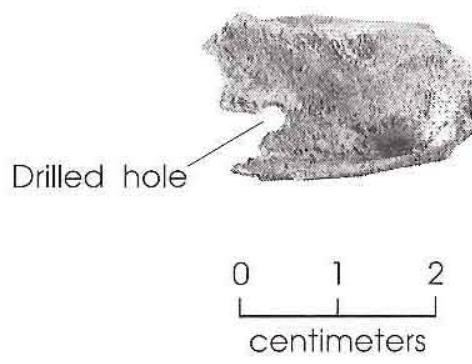

Figure 54. Modified mussel shell.

\section{Bones}

A total of 177 unmodified bones was recovered from the four cultural zones; no modified bones were present (Table 24). Most ( $\mathrm{n}=121$, 68 percent) came from Cultural Zone B. Due to poor preservation and fragmentation, none could be identified below the family level. Approximately 94 percent $(n=166)$ of the assemblage consists of vertebrates and mammals. Most of the mammal remains $(n=74,42$ percent) were identified as medium/large and are probably from deer-sized animals. Two specimens identified as 
Table 24. Summary of vertebrate remains

\begin{tabular}{lccccc}
\hline & Cultural & Cultural & Cultural & \multicolumn{2}{c}{ Cultural } \\
Taxon & Zone A & Zone B & Zone B/C & Zone C & Totals \\
\hline Artiodactyla & 1 & - & - & - & 1 \\
Artiodactyla (medium) & - & 5 & - & 3 & 8 \\
Canidae & - & - & 1 & - & 1 \\
Colubridae & 1 & - & - & - & 1 \\
Mammalia (small/medium) & - & 1 & - & - & 1 \\
Mammalia (medium/large) & 17 & 47 & 9 & - & 74 \\
Mammalia (large/very large) & - & 1 & - & - & 1 \\
Mammalia (very large) & - & - & 1 & - & 89 \\
Vertebrata & 20 & 67 & 2 & 13 & 177 \\
\hline Bone Totals & 39 & 121 & 13 & 4 \\
\hline Spirally-Fractured Bones & 15 & 24 & 5 & - & 4 \\
Burned Bones & 1 & 2 & 1 & - & 4 \\
\hline
\end{tabular}

large/very large and very large mammals may be from animals the size of elk or bison. One canine tooth and eight medium-sized ungulate bones (deer/pronghornsized) were also identified. Approximately one-quarter of the assemblage consists of spirally fractured bones. The vertebrate remains are discussed in more detail in Appendix D.

\section{Snail Shells}

The only species of land snail recovered from the excavation block was Rabdotus; they were abundant throughout the deposits. A sample was collected from each level and from feature contexts. None were modified, and no special analyses or attempt to quantify the shells were undertaken.

\section{Macrobotanical Remains}

Twenty-eight flotation samples from Cultural Zones B and C were submitted for macrobotanical analysis (see Appendix E). Twelve from feature contexts and five from the two burned rock layers ( $\mathrm{n}=17,61$ percent) yielded charred plant remains, primarily wood charcoal. In addition, three charcoal samples (one each from Cultural Zones A, B, and C) were submitted for wood identification. Although honey mesquite dominates the identified carbonized remains, green condalia, guayan, hackberry, and huisache are also present. One indeterminate root and a littleleaf walnut nut fragment are the only nonwood macroplant remains. The analysis concluded that a mesquite-huisache woodland bordered San Felipe Creek. 



\section{ANALYSIS OF CULTURAL OCCUPATIONS IN AREA 1, 41VV444}

Gemma Mehalchick

\section{CHRONOLOGY}

The results of radiocarbon dating and the vertical distributions of the diagnostic artifacts corroborate and define the stratigraphic separation of the excavation block into four'distinct cultural zones. The burned rock layers in Cultural Zones $\mathrm{B}$ and $\mathrm{C}$, and also the radiocarbondated burned rock features, are all in the eastern half of the excavation block. A generalized (i.e., collapsed) profile of the block excavation shows vertical relationships between the cultural zones, radiocarbon dates, and features (Figure 55). The four cultural zones defined in Area 1 yielded 2,675 artifacts (Table 25) and five discrete features (i.e., Features 3, 5, 11, 12 , and 13) in addition to two massive burned rock layers.

A calibrated radiocarbon date of A.D. 12951420 at the base of Cultural Zone A indicates that the upper $30 \mathrm{~cm}$ of deposit dates primarily to the latter part of the Late Prehistoric period. Although dart points and early-style arrow points (i.e., corner notched and/or stemmed) are intermixed in Zone A, the assemblage is dominated by Cliffton and Perdiz points, plainware potsherds, and scrapers. These artifacts represent many repeated occupations at San Felipe Springs, with most of the materials appearing to be residue left by Toyah peoples. Although the chronology of this zone is not well defined because almost no datable materials were recovered, the grossly estimated age of the Zone A deposits corresponds with confirmed ages of Toyah occupations in south and central Texas.

Radiocarbon dates from feature and nonfeature contexts suggest that Cultural Zone B predates A.D. 1295 and postdates 800 B.C. Geomorphic evidence indicates that this surface aggraded slowly, resulting in compressed components. Although the most common dart points from this zone are Shumlas, a few later diagnostic artifacts (e.g., ceramics, a beveled knife, and arrow points) also were found in the upper $15-20 \mathrm{~cm}$ of Zone B in the western onethird of the block. Intermixing is evidenced by the fact that two separate arrow point fragments recovered from Cultural Zones A and B refit into a single Perdiz point. Radiocarbon dates from the middle and top of Zone B denote occupations between ca. A.D. 110 and 1295 . These findings indicate that bioturbation and human activities associated with the Toyah occupations, in addition to slow aggradation of sediments, have contributed significantly to the mixing of Late Prehistoric and Late Archaic cultural deposits in the upper portion of Zone B.

Radiocarbon dates associated with Zone B came from near the middle of the burned rock layer and from three pit features that apparently originated in Zone B but were intrusive into the underlying zones. These dates indicate occupations from approximately 790 B.C. to A.D. 395. The only diagnostic points found in the lower half of Zone B in the western half of the block are Shumla points. A few ceramic sherds also were found there and in the underlying transitional Zone $\mathrm{B} / \mathrm{C}$, but the extremely small sherd sizes and low frequency suggest that they represent items that migrated downward due to bioturbation. Most evidence indicates that the lower deposits in Cultural Zone B are Late Archaic in age.

A radiocarbon date of A.D. 1420-1450 was obtained on isolated charcoal from the middle of Zone $\mathrm{B} / \mathrm{C}$. This date is the youngest from the entire block, and its contextual integrity is questionable because it is out of stratigraphic 


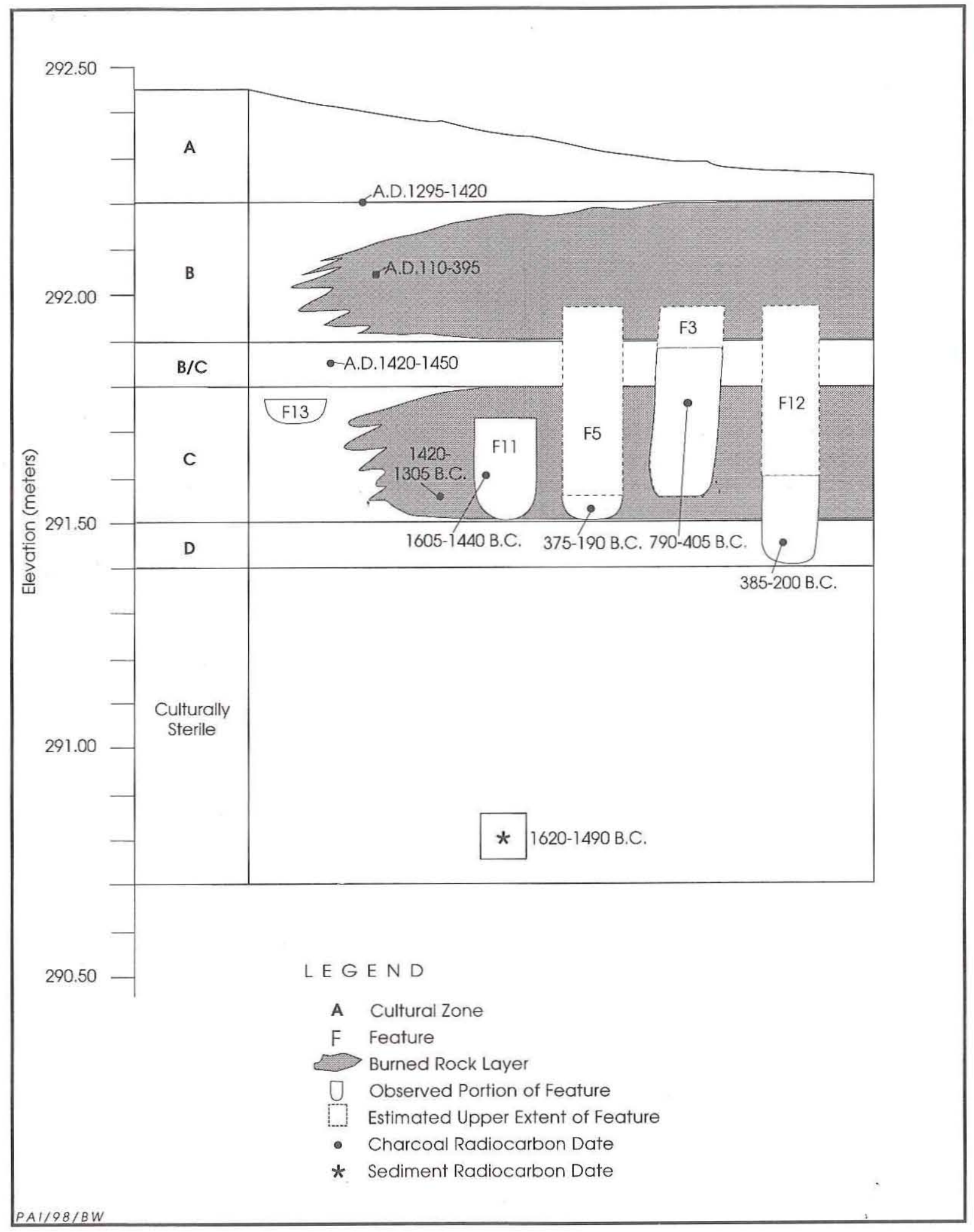

Figure 55. Generalized stratigraphic profile of the excavation block in Area 1, 41 VV444. 
Table 25. Summary of artifacts types by cultural zones and features, Area 1, 41VV444

\begin{tabular}{|c|c|c|c|c|c|c|c|c|c|}
\hline Artifact Type & $\begin{array}{c}\text { Cultural } \\
\text { Zone A } \\
\end{array}$ & General Zone B & \multicolumn{3}{|c|}{ Cultural Zone B } & $\begin{array}{c}\text { Cultural } \\
\text { Zone B/C }\end{array}$ & \multicolumn{2}{|c|}{ Cultural Zone $\mathrm{C}$} & Totals \\
\hline Unidentifiable projectile point & 1 & 1 & 0 & 0 & 0 & 0 & 0 & 0 & 2 \\
\hline Arrow point & 20 & 3 & 0 & 0 & 0 & 0 & 0 & 0 & 23 \\
\hline Dart point & 6 & 12 & 0 & 0 & 0 & 1 & 3 & 0 & 22 \\
\hline Early-stage biface & 1 & 2 & 0 & 0 & 0 & 0 & 0 & 0 & 3 \\
\hline Middle-stage biface & 2 & 10 & 0 & 0 & 0 & 1 & 0 & 2 & 15 \\
\hline Late-stage biface & 2 & 6 & 0 & 0 & 0 & 0 & 0 & 0 & 8 \\
\hline Finished biface & 2 & 3 & 0 & 0 & 0 & 0 & 1 & 1 & 7 \\
\hline Beveled knife & 0 & 1 & 0 & 0 & 0 & 0 & 0 & 0 & 1 \\
\hline Miscellaneous biface & 9 & 4 & 0 & 0 & 0 & 1 & 2 & 0 & 16 \\
\hline End scraper & 2 & 1 & 0 & 0 & 0 & 0 & 0 & 0 & 3 \\
\hline Side scraper & 1 & 0 & 0 & 0 & 0 & 0 & 0 & 0 & 1 \\
\hline End/side scraper & 3 & 1 & 0 & 0 & 0 & 0 & 0 & 0 & 4 \\
\hline Other scraper & 2 & 0 & 0 & 0 & 0 & 0 & 0 & 0 & 2 \\
\hline Miscellaneous uniface & 12 & 3 & 0 & 0 & 0 & 0 & 0 & 0 & 15 \\
\hline Spokeshave & 2 & 0 & 0 & 0 & 0 & 0 & 0 & 0 & 2 \\
\hline Cobble tool/chopper & 1 & 1 & 0 & 0 & 0 & 0 & 1 & 0 & 3 \\
\hline Graver/burin & 0 & 0 & 0 & 0 & 0 & 0 & 0 & 1 & 1 \\
\hline Core tool & 0 & 0 & 0 & 0 & 0 & 0 & 1 & 0 & 1 \\
\hline Multifunctional tool & 4 & 5 & 0 & 0 & 0 & 0 & 0 & 0 & 9 \\
\hline Edge-modified flake & 31 & 28 & 0 & 0 & 0 & 2 & 5 & 3 & 69 \\
\hline Core & 3 & 8 & 0 & 0 & 0 & 0 & 1 & 0 & 12 \\
\hline Unmodified debitage & 872 & 966 & 6 & 2 & 3 & 93 & 325 & 65 & $2,332^{*}$ \\
\hline Mano & 0 & 1 & 0 & 0 & 0 & 0 & 0 & 0 & 1 \\
\hline Indeterminate fragment & 0 & 1 & 0 & 0 & 0 & 0 & 0 & 0 & 1 \\
\hline Mano/hammerstone & 0 & 2 & 0 & 0 & 1 & 0 & 2 & 0 & 5 \\
\hline Other ground stone & 0 & 1 & 0 & 0 & 0 & 0 & 0 & 0 & 1 \\
\hline Sherd & 101 & 12 & 0 & 0 & 0 & 2 & 0 & 0 & 115 \\
\hline Modified shell & 0 & 1 & 0 & 0 & 0 & 0 & 0 & 0 & 1 \\
\hline Totals & 1,077 & 1,073 & 6 & 2 & 4 & 100 & 341 & 72 & $2,675^{*}$ \\
\hline
\end{tabular}


sequence. In all likelihood, the dated charcoal was vertically displaced, having originated somewhere in Zone A and filtered down profile due to bioturbation. Based on radiocarbon dates for Cultural Zones B and C, Zone B/C dates to approximately 1300 to 800 B.C. This transition zone is characterized by a relatively low frequency of cultural materials, denoting lessintensive occupations. Coinciding with the decreased artifact density, the Zone B/C sediments contain abundant small gravels that denote a high magnitude flood(s). Such wet conditions would not have been conducive to occupations on the terrace.

Charcoal dates from the burned rock layer and an intact rock-filled pit in Cultural Zone C reveal utilization of the area between ca. 1605 and 1305 B.C. Rapid deposition of fine-grained alluvium buried this early occupation. Although subsequent bioturbation disturbed this cultural deposit to some extent, no evidence of the younger occupations was encountered in Zone C.

Zone D contains no significant cultural materials and is not discussed further here. Approximately $70 \mathrm{~cm}$ below the base of Cultural Zone C, a bulk sediment sample collected from just above the basal gravels (in Excavation Unit 34 ) yielded a radiocarbon date of $1620-1490$ B.C., indicating that the fine-grained sediments containing occupational debris began to accrete approximately 3,500 years ago (or earlier since radiocarbon dates on sediments are often too young). Sediments must have accumulated rapidly at first, but the accretion apparently slowed down by the time cultural occupations began.

\section{SUMIMARY OF CULTURAL ZONES}

\section{Zone A}

Post dating A.D. 1300, Cultural Zone A yielded evidence of Late Prehistoric occupations attributable to the Toyah phase (Figures 56 and 57). Although 39 of 40 units contained this cultural zone, cultural materials were concentrated in the westernmost third of the block where the thicker deposit was located. The presence of some intrusive modern artifacts shows that construction of the golf course and other historic activities have contributed to disturbance of these deposits. It is also possible that construction of the golf course removed some of Zone A from the eastern portion of the block, since the eastward beveling of the terrace surface appears to be artificial.

Zone A contained no cultural features and produced only sparse burned rocks when compared with Zones B and C. Ten of the 15 projectile points identifiable to type are classified as Bonham ( $n=2)$, Cliffton ( $=4)$, and Perdiz $(n=4)$ and denote a Toyah component. The other points are classified as Cuney, Ensor, Paisano, probable Perdiz, and Scallorn (1 each). Other diagnostic artifacts commonly associated with Toyah occupations include bone-tempered plainware ceramic sherds $(n=101)$, formal scrapers $(n=8)$, and miscellaneous unifaces $(\mathrm{n}=12)$. Other chipped stone tools include bifaces, spokeshaves, multifunctional tools (gravers/unifaces, a graver/biface, and a spokeshave/ uniface), edge-modified flakes, cores, and a chopper.

Unmodified debitage was densest in units along the western edge of the block. These flakes, and a core from this area, suggest that lithic reduction was a primary activity. Edge-modified flakes also were common in the western portion of the block, but it is uncertain what activities these expedient tools represent. Two small pieces of hematite were recovered, but neither exhibits modification.

The limited faunal assemblage $(n=39)$ is almost evenly divided between vertebrate fragments and medium/large mammals. The latter probably represent deer-sized animals. Slightly less than half of these bones are spirally fractured, possibly representing breakage for marrow extraction. One unit near the north end of the block produced almost 40 percent of the bone inventory. A single mussel umbo and several fragments suggest that aquatic resources were exploited. The radiocarbon-dated charcoal sample from the base of Zone A was identified as huisache wood (see Appendix A).

The Toyah component indicates that the springs were a major attraction to people during the end of the Late Prehistoric period. The absence of features and a general lack of horizontal patterning of cultural materials limit the interpretation of discrete activity areas, but this reflects poor sampling rather than an absence of various types of activities. Relative to the overall size of this large site, this small sample reflects only limited activities and is much too small to see any meaningful horizontal patterns 


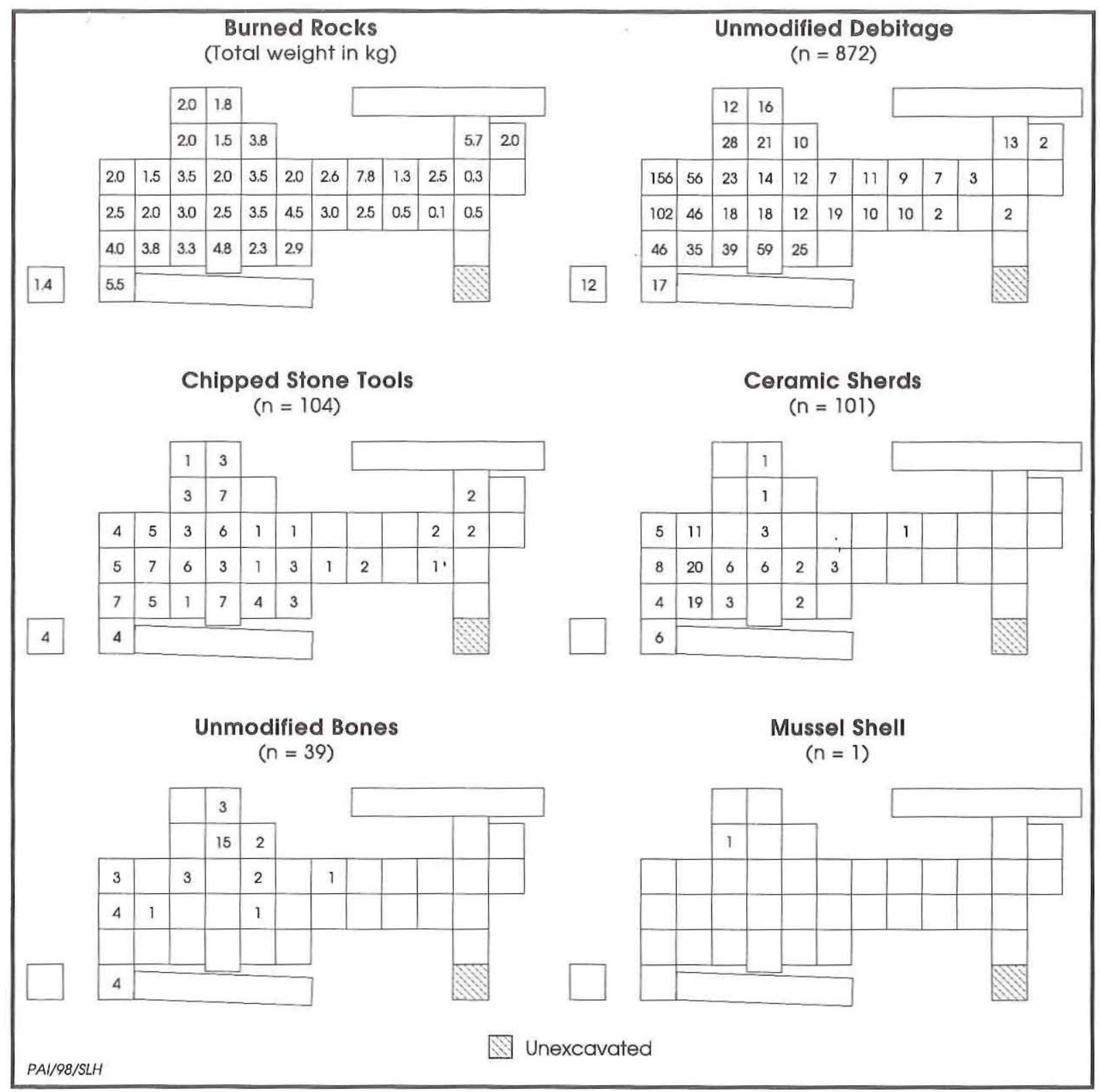

Figure 56. Horizontal distribution of burned rocks, stone artifacts, ceramics, and faunal remains in Cultural Zone A.

in artifact distribution. Projectile points, formal scrapers, bifaces, edge-modified flakes, and possibly the chopper indicate hunting and processing of deer-sized animals. Spokeshaves and gravers may denote cutting and/or engraving of wood, bone, and other materials.

The bone-tempered plainware sherds from the excavation block constitute the largest assemblage of ceramics found at any site in the Lower Pecos region (see Appendix C). This high sherd density suggests that cooking and/or storage of foods in ceramic vessels was a common occurrence. The 101 sherds from Zone A make up 88 percent of the total ceramic assemblage from Area $1(n=115)$. The sherds recovered from Zones $\mathrm{B}$ and $\mathrm{B} / \mathrm{C}$ are generally smaller pieces and are presumed to have originated in Zone A. The assemblage suggests that San Felipe Springs served as a major base camp for Toyah peoples. 


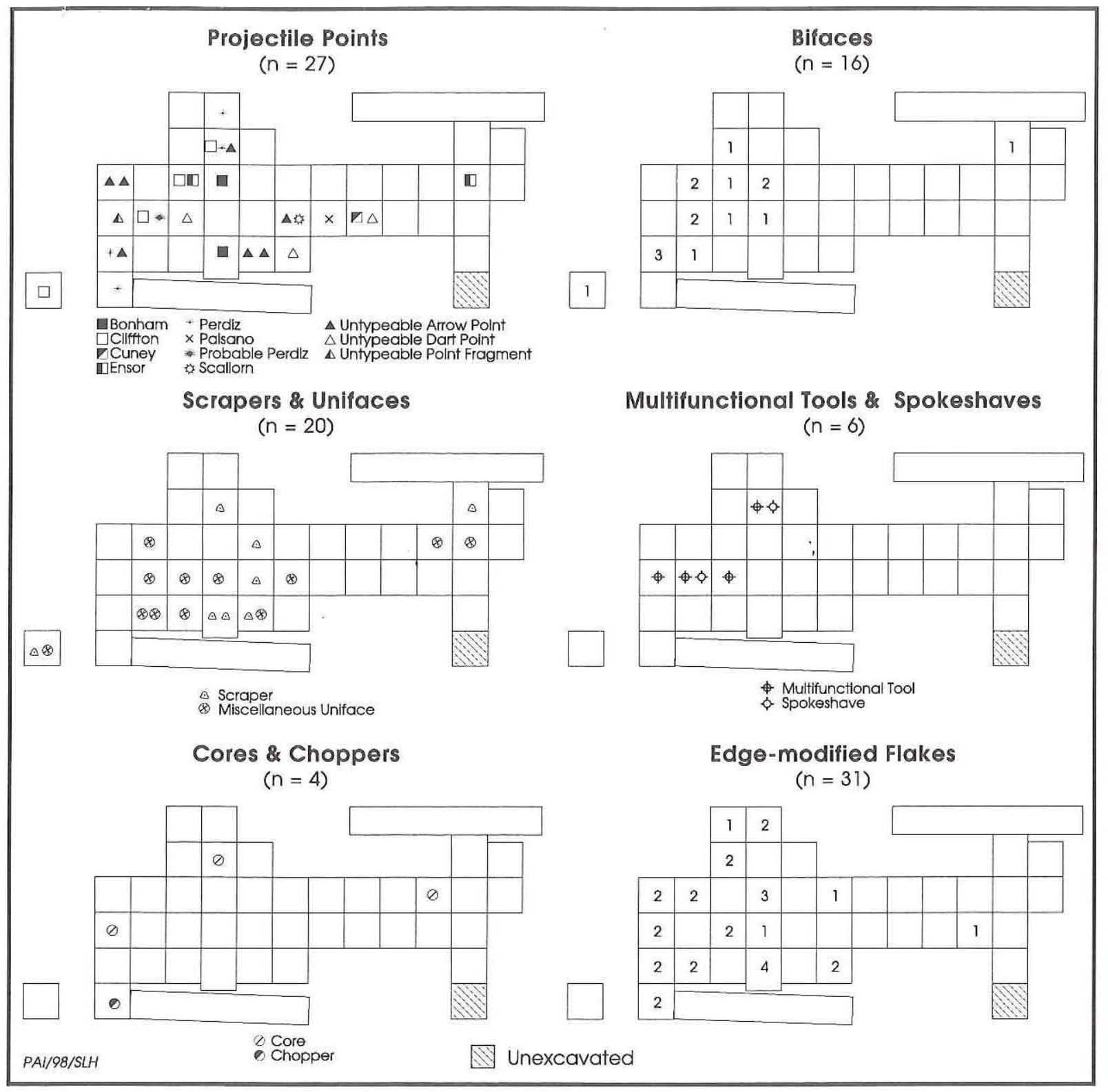

Figure 57. Horizontal distribution of various types of chipped stone tools in Cultural Zone A.

\section{Zone B}

Radiocarbon dates for Cultural Zone B denote repeated occupations during the terminal Late Archaic period and into the Late Prehistoric period. In the upper portion of the deposit, these occupations cannot be separated vertically with any confidence due to bioturbation by animals and humans. Cultural materials from both periods are mixed in the upper half of Zone B. In addition to the massive burned rock layer that covers the eastern half of the block, Zone B yielded a variety of artifacts (Figures 58 and 59). Among these are Perdiz and Shumla points, a beveled knife, a few ceramic sherds, and a ground stone tool interpreted as a "slickstone" used in hide processing. In general, comparable amounts of chipped, ground, and battered stone artifacts were found inside and outside the burned rock layer. However, the deposits in the western third of the excavation block, outside the 


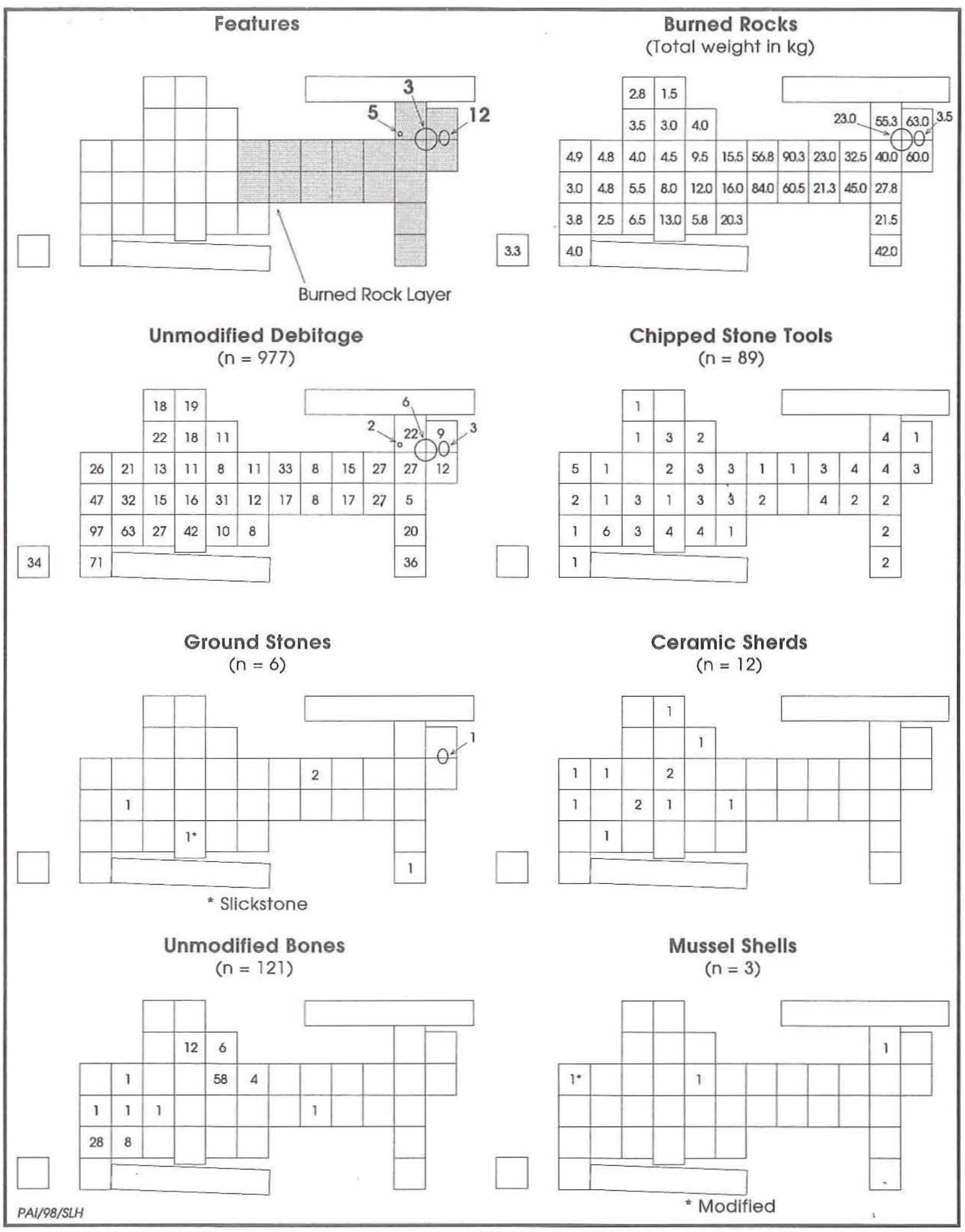

Figure 58. Horizontal distribution of features, burned rocks, stone artifacts, ceramics, and faunal remains in Cultural Zone B. 


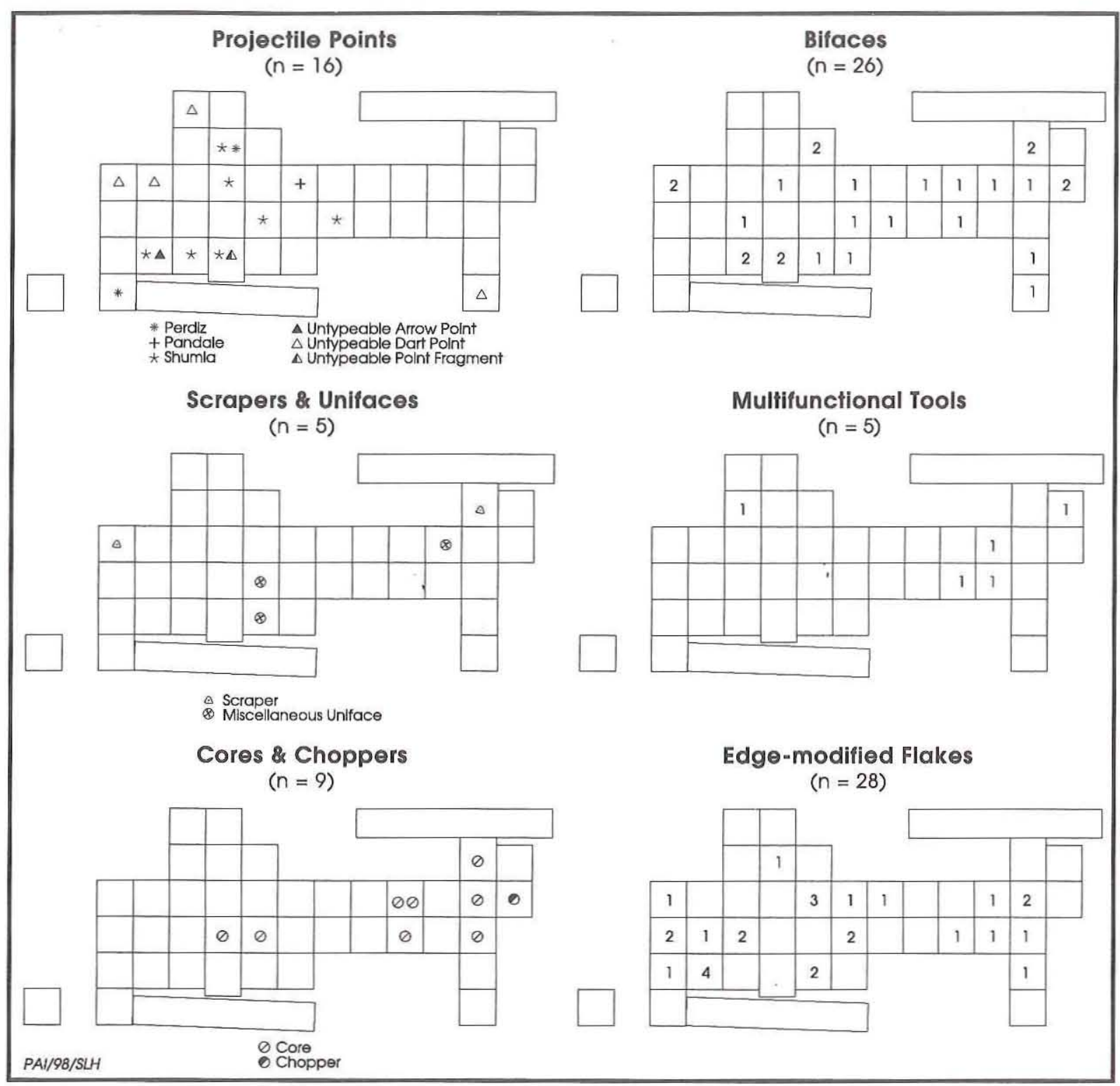

Figure 59. Horizontal distribution of various types of chipped stone tools in Cultural Zone B.

burned rock layer, appear to be more mixed than the deposits in the rock layer. This does not imply, however, that the burned rock layer was not reused or did not continue to accrete during the Late Prehistoric period; there is not enough chronological evidence to know when the burned rocks began to accumulate, how long the accumulation continued, or when it ceased.

Although many types of artifacts are scattered randomly across the block, a few types, including projectile points and ceramics, appear to be spatially separated from the burned rock layer. The frequency of unmodified debitage generally increases away from the burned rock layer, and the highest concentrations of flakes correspond to generally low concentrations of burned rocks. This evidence suggests that certain activities, especially chipped stone tool manufacture and maintenance, were done near but not on the burned rock pile.

The Zone B faunal remains also are clustered in the western half of the block. They indicate hunting and processing of deer-sized game and possibly bison (although this 
identification is tenuous, based on the presence of one large/very large mammal bone). Almost half of the bones were found in a single unit. Less than one-quarter of the bones exhibit spiral fractures. The recovery of one modified and two unmodified mussel shells indicates that bivalves were used for ornamentation and possibly as food. The presence of a mano and mano/ hammerstone fragments may be indicative of plant processing.

Chronometric data for the lower portion of Zone B indicate occupations during the latter half of the Late Archaic period, from ca. 790 B.C. to A.D. 395. These dates are associated with the burned rock layer and pit features that appear to have originated near the base of this layer. Excluding the pit features, the burned rock layer consists of $774.5 \mathrm{~kg}$ of burned rocks and constitutes approximately 87 percent of the entire burned rock weight $(888.85 \mathrm{~kg})$ from Cultural Zone B. When the burned rocks from Features $3(22.95 \mathrm{~kg})$ and $5(3.5 \mathrm{~kg})$ are included, the total weight of burned rocks in or associated with Zone B is $915.4 \mathrm{~kg}$. The densest accumulation occurs from 292.10 to $292.00 \mathrm{~m}$ and accounts for 45 percent $(400.5 \mathrm{~kg})$ of the nonfeature burned rock weight. In addition to unmodified debitage, artifacts associated with the burned rock layer include bifaces, cores, edge-modified flakes, and multifunctional tools (edge-modified flakes/gravers, an edge-modified flake/perforator, and a spokeshave/uniface). Identified macrobotanical remains associated with the burned rock layer include charred wood of honey mesquite and guayan and one fragment of a littleleaf walnut.

Features 3, 5, and 12 are located within a $1.5 \times 2-m$ area in the northeast corner of the block. All three are interpreted as pit features that originated in Zone B but were dug into Zone C. A calibrated radiocarbon date of 790-405 B.C. was obtained for Feature 3, whereas the dates for Features 5 and 12 overlap between 385 and 190 B.C. Each feature produced sparse debitage and varying amounts of burned rocks. Feature 3 is two to three times larger than the other two features and contained the greatest amount of burned rocks $(22.95 \mathrm{~kg})$. The other two features contained only minor amounts of burned rocks: $0.1 \mathrm{~kg}$ for Feature 5 and $3.5 \mathrm{~kg}$ for Feature 12 . Feature 3 appears to represent the remnant of a baking pit, filled in with rocks and dark organic-stained sediment. Features 5 and 12 are more disturbed but may also represent remnants of baking pits.

Although each of these pit features extended into Zone $\mathrm{C}$, their precise origins are difficult to ascertain. The features appear to have originated somewhere in the Zone B burned rock layer, but the top of each pit was not identified. The charcoal-stained sediments and haphazard jumbles of burned rocks made it impossible to recognize the edges of the pits or any old ground surface within the Zone B rock layer. It is likely that the Zone B burned rock layer represents an accumulation of rocks discarded during repeated uses of baking pits.

Stone tools reconstructed from burned rock fragments provide direct evidence for recycling of artifacts and reuse of pit features. A quartzite mano/hammerstone fragment found at $291.43 \mathrm{~m}$ in Feature 12 refits with two other fragments found at $292.10-291.90 \mathrm{~m}$ in the burned rock layer in two different units. When refit, these three fragments form a nearly complete mano/hammerstone and demonstrate that worn out and/or broken tools were reused as hearth stones.

Feature 5 did not yield carbonized plant remains, but Features 3 and 12 contained honey mesquite wood. Feature 12 also yielded a small amount of hackberry wood. These probably denote woods used as fuel. Macrobotanical remains also indicate that mesquite beans, hackberries, and walnuts were available as food resources. Ecologically diagnostic xylem analysis (EDXA) on mesquite wood from the burned rock layer and Feature 3 indicates that the mesquites in this area were drought adapted (see Appendix E). Although the sample is too small to support interpretations of climatic change, the analysis results indicate that EDXA on archeological remains is potentially useful as a regional paleoenvironmental indicator.

There is no apparent horizontal patterning in the Zone B artifact distribution relative to the pit features. Similar numbers and types of artifacts were found adjacent to these features and scattered across the remainder of the Zone B burned rock layer. However, the burned rocks within the massive Zone B layer do exhibit a pattern that reflects cultural activities. The amount of burned rocks immediately surrounding the pit features is high. While the combined weight of burned rocks from Features 3,5 , and 12 is only about $27 \mathrm{~kg}$, there are between 40 
and $63 \mathrm{~kg}$ of burned rocks in each of the four units containing these features. As suggested above, this pattern seems to denote a relationship between the locations of the pit features and high densities of burned rocks in the rock layer. If this theory holds true, one or more pit features should be present in the vicinity of Excavation Units $14,15,26$, and 27, where between 56 and $90 \mathrm{~kg}$ of burned rocks were present in each unit. Perhaps a pit feature(s) was present in one of these units but was unrecognized. Alternatively and more likely, a pit feature(s) may be present in an adjacent but unexcavated unit.

\section{Zone B/C}

Cultural Zone $\mathrm{B} / \mathrm{C}$ is interpreted as a transitional zone rather than a discrete cultural occupation. Bracketing dates place this zone roughly between 1300 and 800 B.C. This zone is characterized by sparse burned rocks, lithic debitage, artifacts, and faunal remains (Figure 60). A Shumla point and two potsherds are the only temporally diagnostic artifacts, and these are not thought to be contemporaneous. The potsherds, both of which are $20 \mathrm{~mm}$ in maximum length, probably reflect bioturbation. Coincidental with the paucity of cultural materials are abundant pea gravels that indicate high energy flooding.

\section{Zone C}

Though animal burrowing was apparent, no artifacts found in Cultural Zone $\mathrm{C}$ are obviously out of place or seem to have originated from the upper zones. Geomorphic evidence indicates that the Zone $\mathrm{C}$ sediments aggraded fairly rapidly, and the occupational debris in this zone seems to represent a stratigraphically discrete component. Two calibrated radiocarbon dates reveal that these occupations occurred around 16051305 B.C., toward the end of the Middle Archaic period.

As in Zone B, a massive burned rock layer covers the eastern half of the block (Figure 61). This lower burned rock layer is in the same approximate horizontal location as the Zone B burned rock layer above it, a fact that may not be purely coincidental. Although both burned rock accumulations are about the same thickness (ca. $30 \mathrm{~cm}$ ) and extend across almost as many units in the eastern half of the block, the Zone B rock layer is approximately four times as dense as the one in Zone C (i.e., $774.5 \mathrm{~kg}$ for Zone B vs. $168.75 \mathrm{~kg}$ for Zone C). The limited size of the excavation block prevented any meaningful dissection of the Zone $\mathrm{C}$ rock layer to discern cultural patterns. However, it is notable that the overall weight of burned rocks is approximately the same in each of the three levels within Zone C.

One rock-filled pit, Feature 11, was wholly contained within Cultural Zone C. This large feature consists of $61 \mathrm{~kg}$ of burned rocks in a basin-shaped pit, but no artifacts are directly associated. It is interpreted as the bottom portion of a baking pit that originated from within Zone C. Identified macrobotanical remains include charred wood of guayan, acacia, and green condalia, and a charred fragment of an indeterminate root. Mesquite wood is noticeably absent in the Feature 11 sample. Burned rock densities in the matrix surrounding the feature are minuscule, while the burned rock weight per level is significantly higher 1-2 m away to the east and west. Beyond this, the density of burned rocks decreases with distance away from the feature. The large accumulations of rocks nearest the pit feature may represent debris discarded from this pit (and possibly others nearby in unexcavated units). The accumulation of rocks also may have served as a stockpile, with larger rocks intended for reuse in baking pits.

Diagnostic artifacts from the rock layer include one Bulverde and one untyped dart point (Figure 62). The untyped point is probably an Almagre or Arenosa point; both types are contempo-raneous with, and may be variants of, Langtry points. A third but untypeable dart point was found in the western part of the block. Other artifacts from Zone C include a core, a core tool, a chopper, bifaces, a graver, two fragments of the same mano/hammerstone, and moderate amounts of unmodified debitage $(n=390)$. The most common tool type is the edge-modified flake $(\mathrm{n}=8)$; unmodified mussel shells $(\mathrm{n}=9)$ also are common. This small sample (derived from only 28 excavation units sampling Zone $\mathrm{C}$ ) only allows for minimal interpretation of the occupations. Mussels may have been utilized as a food resource, but the paucity of bones may be a factor of poor preservation. The only macro-botanical remains identified in the Zone $\mathrm{C}$ burned rock layer are fragments of charred acacia wood. 


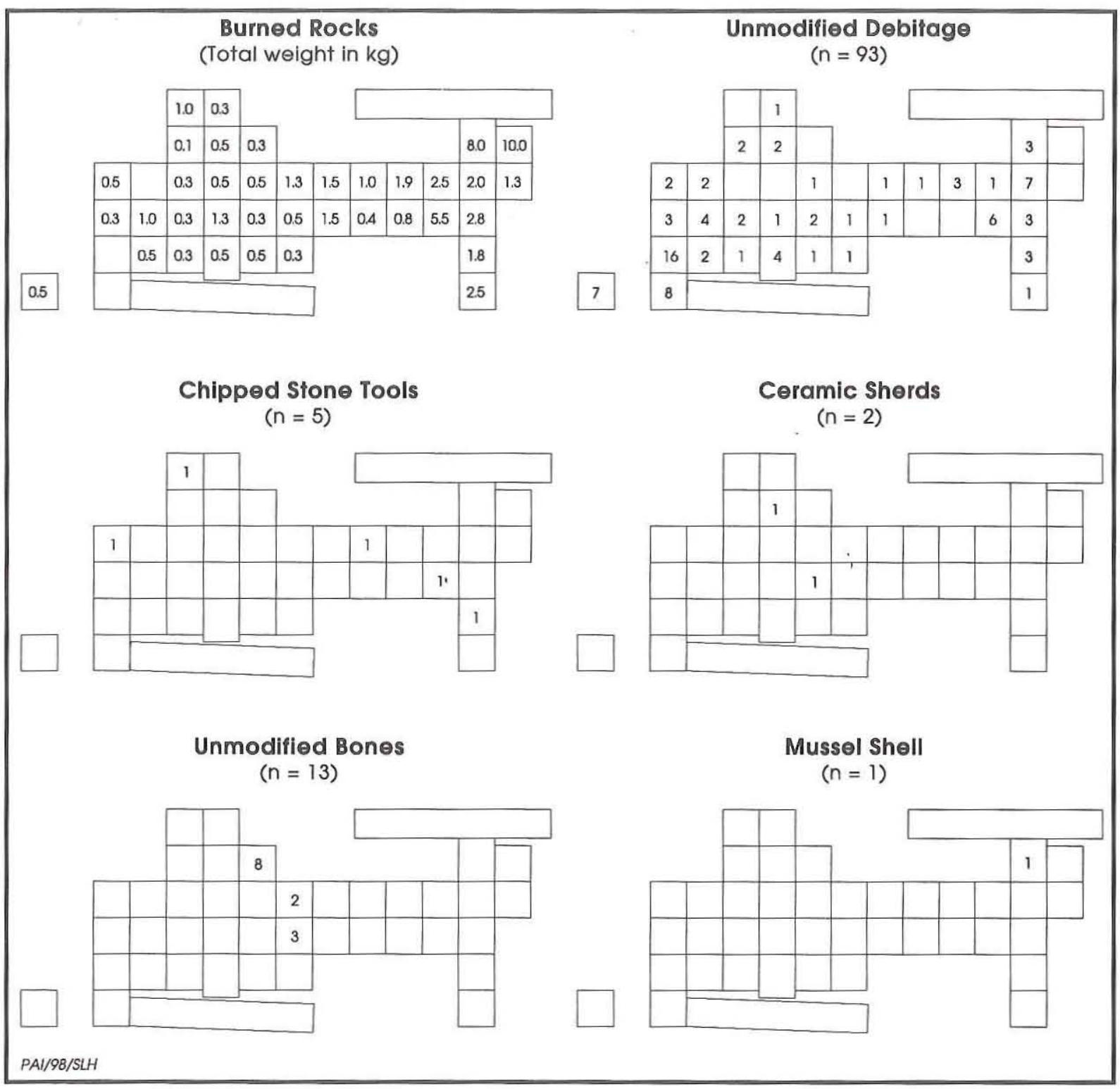

Figure 60. Horizontal distribution of cultural materials in Cultural Zone B/C.

Just beyond the western edge of the Zone $\mathrm{C}$ burned rock layer, a concentration of chipped lithic tools and flakes was encountered. Designated Feature 13, this 25-cm-diameter cluster of artifacts consists of 2 complete middle-stage bifaces, 1 finished biface fragment, 1 graver, 3 edge- modified flakes, and 65 pieces of debitage. Some of the artifacts were dislocated before the feature was recognized, but most specimens found in situ were lying flat or at a slight angle. All items are from only two types of chert and may have originated from two different cores. Several modified and unmodified flakes refit onto both of the middlestage bifaces, and an additional flake from outside the feature in an adjacent unit also refit onto one of these bifaces. This cluster of lithic artifacts was very discrete, and only 4 flakes were recovered from the surrounding nonfeature matrix in the same unit. The feature is interpreted as either a dump of lithic knapping debris or, more likely, a cache of lithic debris, since many of the flakes and tools are large enough to still be useful. Because the lithic 


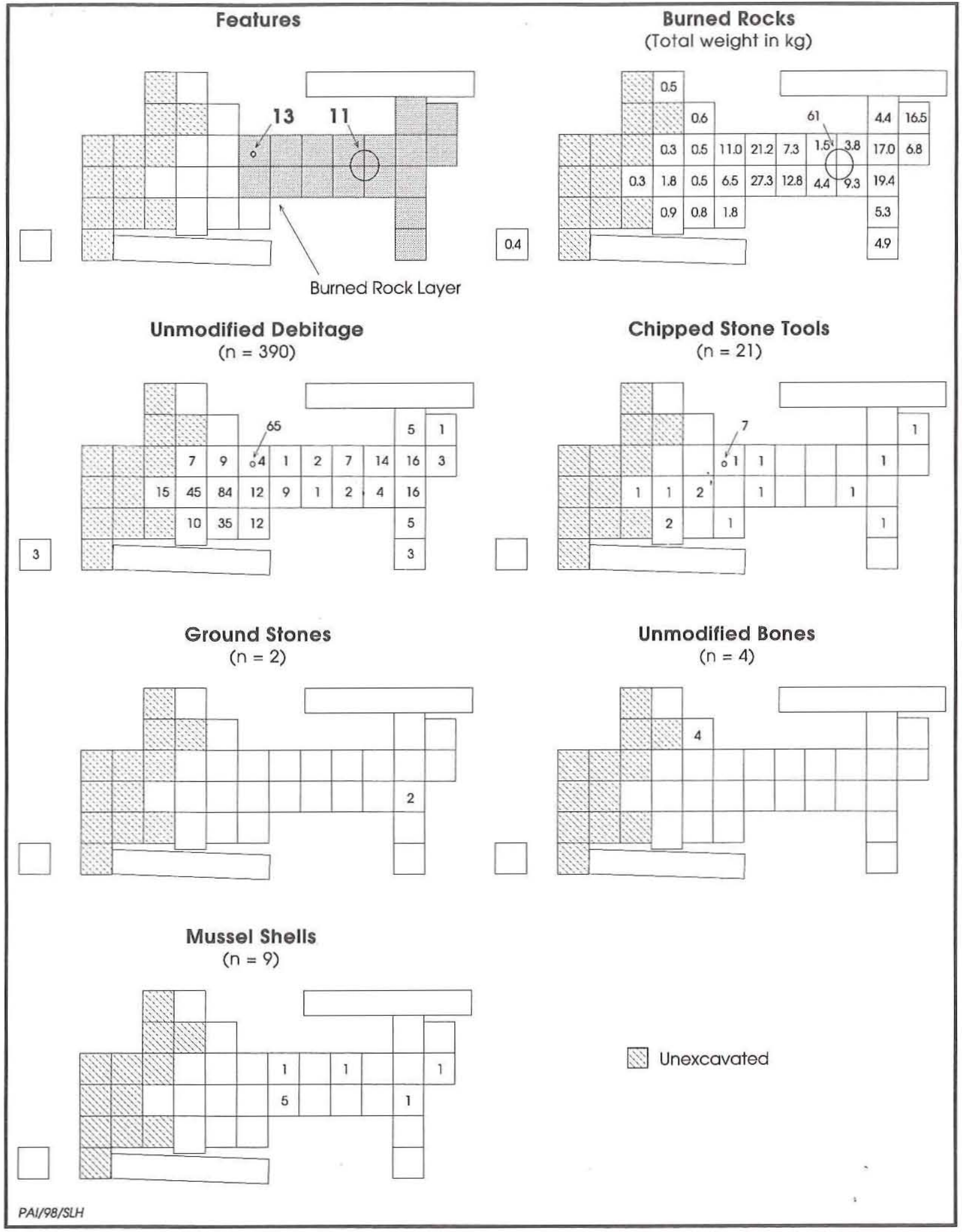

Figure 61. Horizontal distribution of features, burned rocks, stone artifacts, ceramics, ground stones, and faunal remains in Cultural Zone C. 


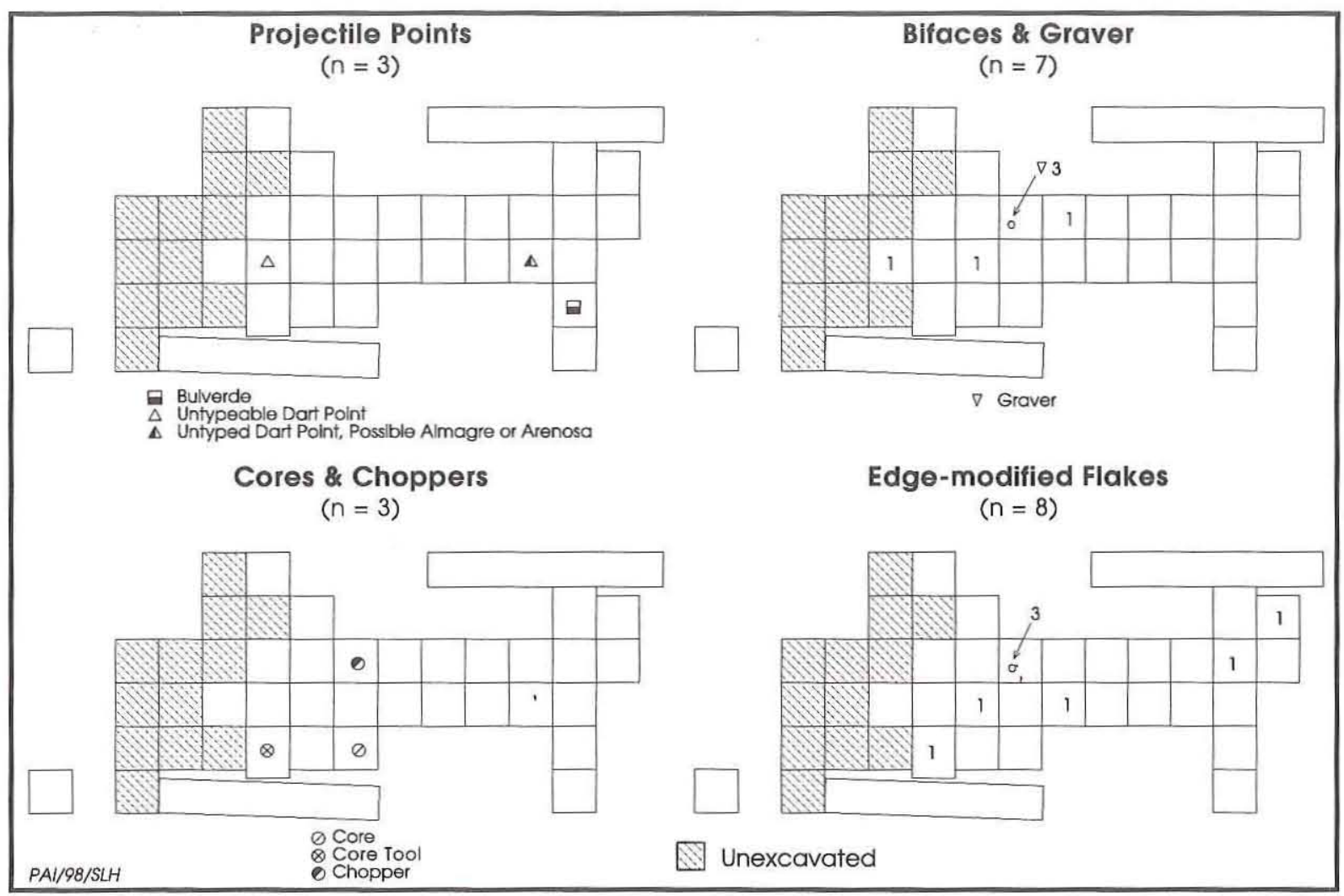

Figure 62. Horizontal distribution of various types of chipped stone tools in Cultural Zone C.

cluster was so small and confined, it is possible that the cache was left inside a perishable container such as a basket or hide pouch, although no evidence of this has survived.

\section{COMPARATIVE ANALYSIS OF CULTURAL ZONES}

A comparison of the numbers and densities of artifacts, approximate chronologies, and rates of deposition for each of the four cultural zones provides some insights into the occupations at San Felipe Springs (Table 26). The chronology is admittedly crude, based on far fewer absolute dates than ideal, but it is internally consistent given the dates, diagnostic artifacts, and stratigraphic evidence available. However, the age of the Zone B/C deposits, the transitional zone between the Late Archaic occupations and the overlying Toyah phase occupations, is especially uncertain.

When the artifact densities are compared with the rates of deposition, as in Figure 63, relative intensities of occupation through time are indicated. Cultural Zones A and B exhibit similarly high artifact densities but very different rates of deposition. It is difficult to determine exactly when the rate of deposition increased, but the slow rate that characterizes Zone B may have shifted to the moderately high rate seen in Zone A around A.D. 1300. Regardless of precisely when it happened, these data indicate intensive and repeated habitation on the Holocene alluvial terrace of San Felipe Creek from the end of the Late Archaic through the Late Prehistoric period, with the slow rate of deposition for Zone B leading to compressed cultural components during the Late Archaic period. The 1,085 artifacts in Zone B were deposited over a long period of time, perhaps as much as 2,100 years (a rate of 52 artifacts per century). In contrast, the 1,077 Zone A artifacts were deposited during about 300 years (at a rate of 359 artifacts per century). Consequently, the Zone A Toyah assemblage is a relatively discrete sample. 
Table 26. Comparisons between the cultural zones in Area 1, 41VV444.

\begin{tabular}{lrrrr}
\hline & Zone A & Zone B & Zone B/C & Zone C \\
\hline Artifacts recovered & 1,077 & 1,085 & 100 & 413 \\
Number of 10-cm levels excavated & 84 & 120 & 40 & 84 \\
Artifact density per 10-cm level & 12.8 & 9.0 & 2.5 & 4.9 \\
Estimated chronology & A.D. 1300-1600 & 800 B.C.-A.D. 1300 & $1300-800$ B.C. & $1600-1300$ B.C. \\
Thickness of deposits (cm) & 30 & 30 & 10 & 40 \\
Rate of deposition (cm/100 years) & 10.0 & 1.4 & 2.0 & 13.3 \\
\hline
\end{tabular}

An obvious stratigraphic break is represented by Zone B/C, which has a very low artifact density. While the rate of deposition appears to have been very slow (nearly equal to that of Zone B), this is based on little chronometric data, and other evidence hints at a high rate of deposition. The presence of peasized gravels suggests a short periop of high magnitude flooding, and the extremely low artifact density suggests that occupations were limited during that time. This would be expected if the area were prone to flooding or if the deposit really represents a single depositional event. There is no geomorphic unconformity hinting at erosional stripping of deposits at this time.

Although the artifact density for Cultural Zone $\mathrm{C}$ is approximately a third to a half of

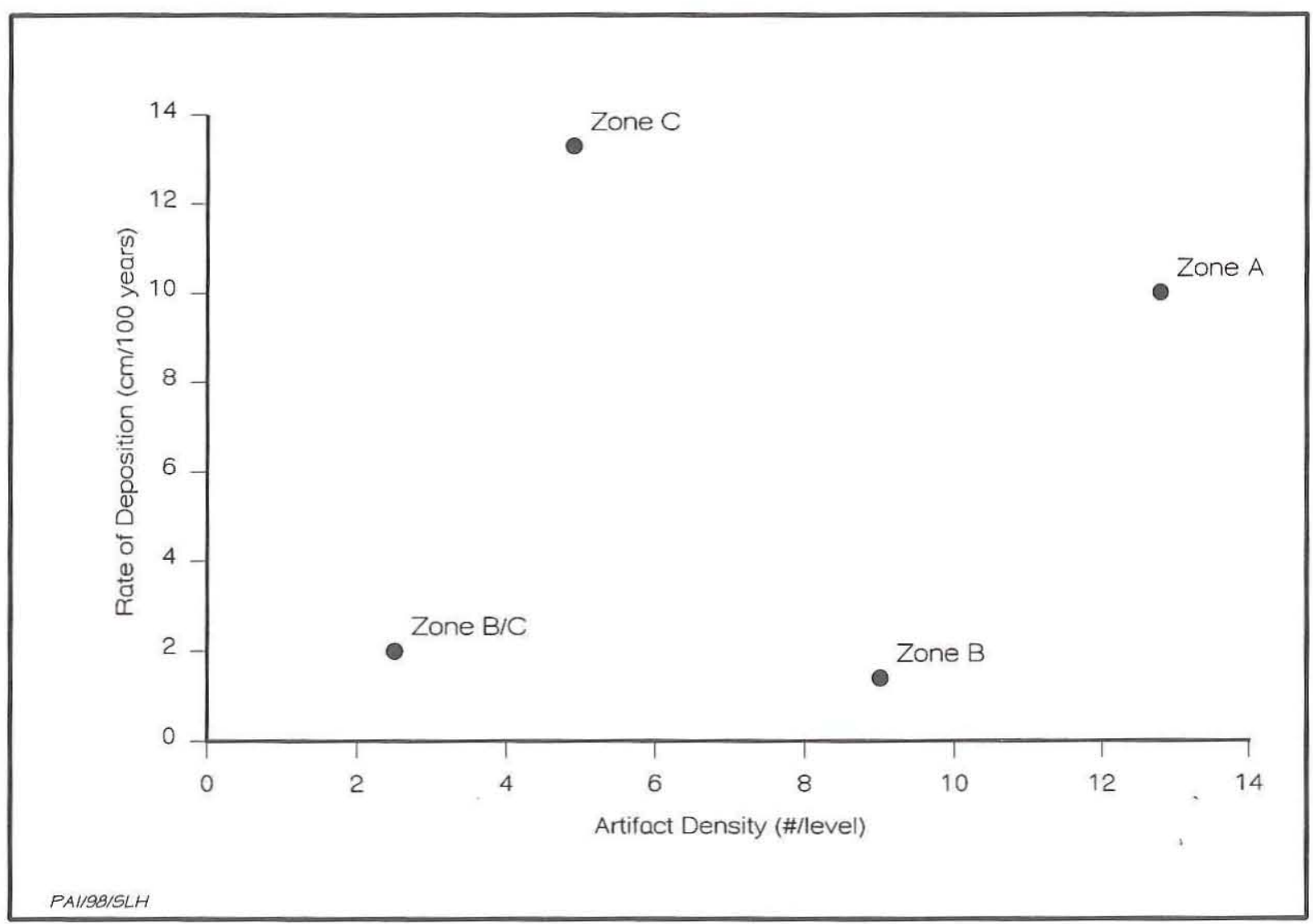

Figure 63. Comparison of stone artifact densities vs. rates of deposition for the cultural zones in Area 1, 41VV444. 
Zones $f_{\star}$ and $\mathrm{B}$, Zone $\mathrm{C}$ is stratigraphically discrete and its geomorphic context is good. The terrace deposits aggraded rapidly, encompassing this Middle Archaic component (i.e., the San Felipe subperiod of the Middle Archaic; see Turpin 1995:Table 1). The total artifact sample is small, but it appears to be temporally discrete.

Large accumulations of burned rocks and internal pit features mark the Late and Middle Archaic components in Zones B and C (see Figures 58 and 61). Burned rock quantities vary both horizontally and vertically within the burned rock layers. It has been suggested that the internal features, some of which are interpreted as baking pits, are functionally related to the large burned rock accumulations. However, it was impossible to precisely differentiate the tops of the pit features from the rock layers, particularly in Cultural Zone B. Despite these uncertainties, it appears that the Zone $\mathrm{B}$ and Zone $\mathrm{C}$ burned rock layers represent accumulations of rocks burned during repeated cooking episodes. It is likely that much of the burned rock in these middens represents discarded debris related to cooking in earth ovens or baking pits, as described by Black et al. (1997). However, it is not suggested that these middens accumulated only through pit baking activities. There is no way to know how much (if any) of the burned rock represents debris discarded from surface hearths, stone boiling, or other activities. As noted by Black et al. (1997:307-314), midden structure will be revealed only by carefully excavating areas much larger than were excavated at San Felipe Springs. 



\section{WATER IN THE DESERT: PREHISTORIC OCCUPATIONS AT SAN FELIPE SPRINGS}

Gemma Mehalchick and Douglas K. Boyd

9

The archeological data generated by the recent investigations at the San Felipe Springs site (41VV444) constitute one of the largest samples of excavated and dated cultural materials and features from an open habitation site in Val Verde County. Little substantive work has been done at open sites in the vicinity of Amistad Reservoir since the 1960s, and this new evidence has many implications for understanding prehistoric occupations in this region. The site's unique environmental setting and geographic location make it an important locality for understanding the activities and interactions of peoples inhabiting a critical ecological transition zone.

\section{THE BALCONES ESCARPMENT ENVIRONMENTAL ZONE}

San Felipe Springs is the westernmost of a series of major spring localities along the Balcones escarpment (also called the Balcones fault zone), a major geologic and topographic feature that marks the southern and eastern boundaries of the area most commonly called central Texas. To the south, the escarpment separates the Edwards Plateau from the South Texas Plains, and to the east it separates the Edwards Plateau from the Blackland Prairie. It forms an arc extending from Del Rio in the southwest through the San Antonio and Austin areas and northward past Waco. Emanating from this prominent geologic fault zone are some of the largest and most historically significant springs in Texas (Figure 64, Table 27). In his landmark studies of springs throughout the state, Brune $(1975,1981)$ noted that the geologic structure of the Balcones fault zone is responsible for a large number of springs, including most of Texas's larger springs. He states that along the fault zone, "displacement of the rocks by faulting has brought the Austin chalk and Taylor Marl into contact with the southeastern edge of the Edwards limestone underground reservoir, forming an impervious dam. The water, under artesian pressure, is forced to escape upward along the fault planes" (Brune 1981:15).

Artesian sources along the Balcones escarpment include not only many well known large springs, such as San Antonio and Barton Springs, but also hundreds of smaller undocumented springs. Springs flowing from ancient faults are so common within the Balcones escarpment that one does not have to travel far to find a dependable water supply. Even in the wetter areas along the eastern portion of the escarpment, where annual precipitation averages about 30 inches (at San Antonio, Austin, and Waco), springs were important and predictable sources of water. Springs were even more critical for survival along the western end of the escarpment, where annual precipitation is as low as 18 inches at Del Rio (Bomar 1983:Figure 28, Table C2). During extended drought periods (Paulson et al. 1991:518-520), large springs and major rivers were the only dependable water supplies as smaller springs and seeps and lowerorder tributaries dried up.

The ubiquity of archeological remains at major escarpment spring localities testifies to the importance of the resources they provided. It is likely that all of the well-known springs contain abundant archeological remains, denoting frequent and intensive prehistoric occupations; however, only a few of these localities have been systematically investigated or reported. Shiner (1983) notes that Paleoindian points in 


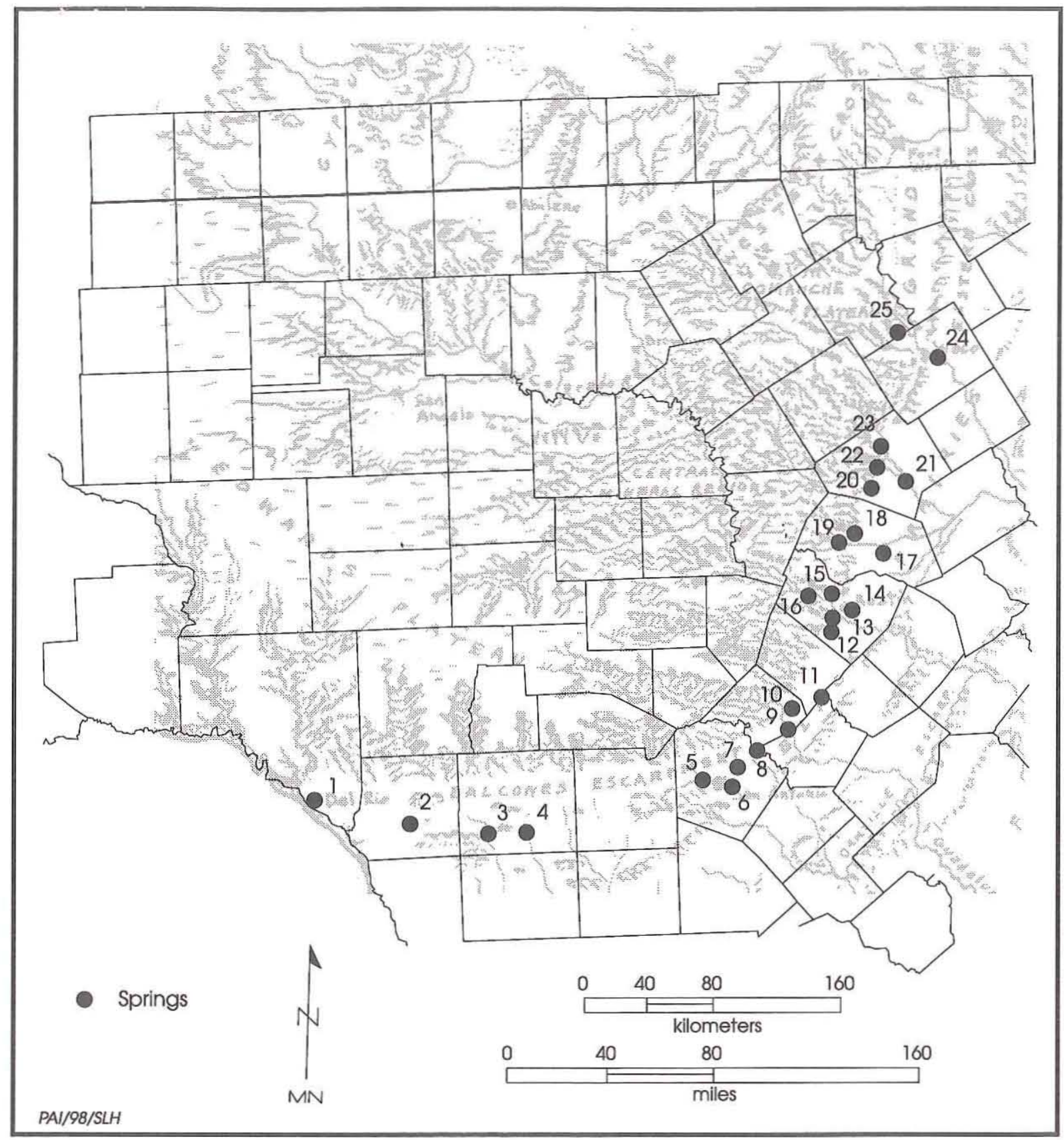

Figure 64. Map of the Balcones escarpment and fault zone (from Raisz 1957) showing locations of major and historical springs (from Brune 1975:Figures 2 and 58). See Table 27 for the key to spring identifications.

central Texas are concentrated at major spring localities, most of which are along the Balcones escarpment. Other archeological work demonstrates that intensive occupations dating to all periods are present at these large springs. Examples of archeological investigations at or near major Balcones escarpment springs include:
San Marcos or Spring Lake (Cargill and Brown 1997; Garber and Orloff 1984; Shiner 1983), Landa Park near Comal Springs (Arnn 1997a, 1997b, 1997c, 1997d), and Zilker Park near Barton Springs (Ricklis et al. 1991).

Not only is San Felipe Springs the westernmost in a series of major springs and 
Table 27. Major and historical springs emerging from the Edwards Aquifer along the Balcones Fault Zone

\begin{tabular}{ccll}
\hline Figure 64 Key & Brune's (1975) Map Key & Name of Springs & County \\
\hline 1 & KK 10 & San Felipe* & Val Verde \\
2 & KK 13 & Las Moras* & Kinney \\
3 & LL 10 & Soldier's Camp & Uvalde \\
4 & LL 11 & Leona Springs, Group 1 & Uvalde \\
5 & LL 33 & San Pedro* & Bexar \\
6 & LL 32 & San Antonio* & Bexar \\
7 & LL 31 & Salado Creek* & Bexar \\
8 & LL 30 & Selma* & Bexar \\
9 & LL 29 & Comal* & Comal \\
10 & LL 28 & Hueco* & Comal \\
11 & MM 1 & San Marcos* & Hays \\
12 & FF 8 & Barton* & Travis \\
13 & FF 7 & Cold* & Travis \\
14 & FF 6 & Seiders* & Travis \\
15 & FF 5 & Power House* & Travis \\
16 & FF 4 & Mormon* & Travis \\
17 & FF 3 & Manske Branch* & Williamson \\
18 & FF 2 & Berr** & Williamson \\
19 & FF 12 & Knight & Williamson \\
20 & FF 1 & Salado* & Bell \\
21 & FF 18 & Fort Little River* & Bell \\
22 & FF 17 & Childers* & Bell \\
23 & Y 6 & Leon* & Bell \\
24 & Y 2 & Waco* & McLennan \\
25 & Y 1 & El Flechazo (Love at First Sight) & Bosque \\
\hline
\end{tabular}

*Specifically listed by Brune (1975) as springs emerging from the Balcones Fault Zone.

located at the junction of several major ecological zones, it also may have been located along a major prehistoric trade route that ran from east to west between central/south Texas and the Lower Pecos. It is probably not a coincidence that the modern transportation routes from Dallas to San Antonio (Interstate 35) and San Antonio to Del Rio (U.S. Highway 90) run along the Balcones escarpment. These modern roads developed from historic trails that took advantage of the topography and water resources; indeed, many historic roads followed along part or all of the escarpment zone (Brune 1975:Figure 2; 1981 supplemental maps). It is likely that these historic routes followed existing Indian trails that evolved during prehistoric times; travel along the Balcones escarpment undoubtedly was easier than traversing directly across many parts of the dissected Edwards Plateau and Hill Country. Given its unique location, it is no wonder San Felipe Springs contains evidence of intensive prehistoric use.

\section{SUMMARY OF PREHISTORIC OCCUPATIONS AT SAN FELIPE SPRINGS}

Archeological testing reported herein provides evidence of intensive and repeated occupations at San Felipe Springs during the past 3,300 years. In the excavations, no older alluvial fills were recognized or tested. It is presumed that the examined San Felipe Creek terraces are relatively young and that older alluvial deposits were stripped away or are deeply buried in areas that have yet to be recognized. Thus, there is a geomorphic bias represented in the tested portions of 41VV444 and probably the rest of the site. It is likely that prehistoric peoples used the springs intensively for many thousands of years but that most of the older Paleoindian and Early and Middle Archaic deposits have been removed from this section of the San Felipe Creek valley by erosion. 
Archeological investigations in Area 1 of 41VV444 defined three main stratified prehistoric components. Cultural Zone A is interpreted as a Late Prehistoric component postdating A.D. 1300; it is distinguished primarily by Cliffton and Perdiz points, ceramics, and formal scrapers, and is defined as a Toyah phase occupation. However, Zone A does not appear to be a pure Toyah component, as other point styles hint at occupations by non-Toyah groups. No features were encountered in Zone A, but cultural materials suggest intensive occupations. A larger excavation block in Area 1 or excavations elsewhere in this large site would likely yield features and additional artifactual evidence of Toyah occupations.

Within the 41VV444 stratigraphic sequence, the upper part of Cultural Zone B is the most difficult to evaluate because of the compressed multicomponent nature of the cultural deposits. The lower half of Zone B definitely correlates to the Late Archaic period, however, and it appears to represent occupational debris associated with peoples who made Shumla points. The Zone B artifact assemblage is dominated by expedient tools and artifacts associated with lithic reduction activities, and the burned rock layer and pit features denote intensive cooking activities in earth ovens. Mesquite was the principal firewood, and it is likely that locally available desert plants were processed and baked in rockfilled pits. Dry mesquite certainly would have been one of the preferred fuels in the Lower Pecos for pit cooking (Phil Dering, personal communication 1998). Specialized botanical analysis of the charred mesquite samples (see Appendix D) suggests that the trees grew under extremely arid conditions. This could indicate xeric environmental conditions, but the sample is too small to be sure.

The lower component, designated Cultural Zone C, represents Middle Archaic occupations. It consists of an extensive burned rock layer, a basinshaped rocklined feature, and a discrete knapper's cache (or lithic debris dump). Excluding the stone tools and flakes contained in the cache, most of the cultural debris is edgemodified flakes and unmodified mussel shells. The former denote an expedient technology that may be related to plant processing. Of the three dart points recovered from Zone $\mathrm{C}$, a Bulverde is the only identified type. As in Zone B, the pit feature and rock layer in Zone $\mathrm{C}$ are thought to represent a baking pit and rocks discarded from such pit-cooking activities.

The absence of charred mesquite wood in the burned rock layer and pit feature is interesting. The lack of mesquite in Zone $\mathrm{C}$ may indicate that this wood was intentionally avoided, perhaps in favor of fuels that produced a highheat, shortterm fire. Alternatively, if mesquite were the preferred fuel for such cooking activities, its absence might indicate that mesquite wood was not readily available at that time, perhaps because it was overharvested in the vicinity of the site during a period of intense occupation. Unfortunately, the sample size is too small to support any definitive conclusions.

\section{SAN FELIPE SPRINGS IN REGIONAL PERSPECTIVE}

The three components identified in the San Felipe Springs excavations are intriguing from a regional perspective. The Zone A Toyah occupations are situated at the southwestern margin of the classic Toyah culture area of central and south Texas (Johnson 1994:Figure 105), but the cultural evidence also has many interesting similarities with Infierno phase occupations in the Lower Pecos. The Late Archaic Zone B occupations, characterized by Shumla dart points, represent a rare example of such occupations in an open campsite. The Middle Archaic Zone C is known only through a limited sample, but the cultural evidence is important nonetheless. These remains are attributed to the San Felipe subperiod and represent occupations that may be contemporaneous with the appearance of Pecos River-style rock art.

\section{Late Prehistoric/Protohistoric Occupations in the Lower Pecos}

The Infierno and Toyah phases represent archeological constructs that presumably identify two different groups of peoples. Dibble (1978) first identified the Infierno subperiod (or phase) based on findings at 41VV446, Infierno Camp (see Turpin 1982). The artifact assemblage from this site consists of plain brownware ceramics, steeply beveled (or dorso) end scrapers, four-beveled knives, and small, triangular, stemmed arrow points (Turpin 1982, 1995). The site contains over 100 stone circles representing small structures. This evidence suggests that the location was a 
Plains Indian camp site. Based primarily on the fact that the pottery from Infierno Camp is similar to pottery found at other sites in the Lower Pecos region and northern Mexico and at the Apache mission of Mission San Lorenzo de la Santa Cruz (Tunnell and Newcomb 1969), the Infierno phase is believed to be Protohistoric in age. The age estimate for the Infierno phase is A.D. 1500-1780, but there are no absolute dates for any site attributed to it (Turpin 1991, 1995; Turpin and Robinson 1998; Table 28).

Turpin and Robinson (1998) note that only 12 ceramic-bearing sites have been found in the Lower Pecos region and that all are located in southeastern Val Verde County; they attribute these sites to the Infierno phase. The total number of sherds from these sites (excluding San Felipe Springs) is less than 100 , and all but 3 are bone-tempered plainware. The 3 odd specimens are decorated sherds of a single type found in two rockshelters. Macroscopic and petrographic analysis conducted on the plainware ceramics from five of the Val Verde County sites (along with other comparative samples including historic sherds from Mission San Lorenzo in Real County) reveal that the primary aplastic material is bone that was intentionally added as a tempering agent. Fragments of crushed

Table 28. Chronology of the Lower Pecos region

\begin{tabular}{|c|c|c|}
\hline Period/Subperiod & $\begin{array}{l}\text { Radiocarbon } \\
\text { Years B.P. }\end{array}$ & $\begin{array}{c}\text { Radiocarbon } \\
\text { Calendar Dates }\end{array}$ \\
\hline $\begin{array}{c}\text { Paleoindian } \\
\text { Aurora } \\
\text { Bonfire } \\
\end{array}$ & $\begin{array}{r}14,500-11,900 \\
10,700-9,800 \\
\end{array}$ & $\begin{array}{r}12,550-9950 \text { в.C. } \\
8750-7850 \text { в.C. }\end{array}$ \\
\hline $\begin{array}{l}\text { Late Paleoindian } \\
\text { Oriente }\end{array}$ & $9,400-8,800$ & $7450-6850$ в.с. \\
\hline $\begin{array}{l}\text { Early Archaic } \\
\text { Viejo }\end{array}$ & $8,900-5,500$ & 6950-3550 B.C. \\
\hline $\begin{array}{c}\text { Middle Archaic } \\
\text { Eagle Nest } \\
\text { San Felipe }\end{array}$ & $\begin{array}{l}5,500-4,100 \\
4,100-3,200\end{array}$ & $\begin{array}{l}3550-2150 \text { в.C. } \\
2150-1250 \text { в.C. }\end{array}$ \\
\hline $\begin{array}{l}\text { Late Archaic } \\
\text { Cibola } \\
\text { Flanders } \\
\text { Blue Hills }\end{array}$ & $\begin{array}{r}3,150-2,300 \\
2,300-? \\
2,300-1,300 \\
\end{array}$ & $\begin{array}{r}1200-350 \text { B.C. } \\
350 \text { B.C. }-? \\
350 \text { B.C. }- \text { A.D. } 650\end{array}$ \\
\hline $\begin{array}{l}\text { Late Prehistoric- } \\
\text { Protohistoric } \\
\text { Flecha } \\
\text { Infierno }\end{array}$ & $\begin{array}{r}1,320-450 \\
450-170\end{array}$ & $\begin{array}{r}\text { A.D. } 630-1500 \\
\text { A.D. } 1500-1780\end{array}$ \\
\hline
\end{tabular}

calcium carbonate, or limestone, are common and appear to represent natural inclusions in the clay. While all of the sample sherds share many characteristics, minor differences in the types and quantities of limestone and other minor constituents seem to indicate local production (i.e., use of local clays) in several different manufacturing sites.

A sample of ceramic sherds from San Felipe Springs was subjected to comparable macroscopic and petrographic analyses by Robinson (see Appendix C). The results of this study mirror the results of Turpin and Robinson (1998). Minor variability in the composition of the San Felipe ceramics reflects expected variability between a few different local production sites. When petrographic data for the San Felipe Springs sample are compared with the data from Infierno phase sites, the homogeneity is striking. The minor variations are attributed to use of different locally available resources within a vast region characterized by only minor geologic differences.

Results of these petrographic studies indicate that the Infierno phase plainwares are essentially identical (with only minor variations due to local production) to the bone-tempered pottery manufactured by Toyah peoples across south and central Texas. Such pottery was originally called Leon Plain (Suhm and Jelks 1962:95-96) or Doss Red Ware (Kelley 1947:123), but Johnson (1994) redefined these ceramics as Classic Toyah ware and states that it is "distinctive and sometimes crude plain-ware pottery that is altogether utilitarian." Studies indicate that the bone-tempered plainware tradition became widespread around A.D. 1300 and continued into the Protohistoric period, possibly through the 1700 s.

Another similarity in the tool kit attributed to the Infierno phase and the Zone A artifact assemblage from San Felipe Springs is the presence of steeply beveled end and end/side scrapers. A defining characteristic of the Classic Toyah phase, these formal scrapers functioned as hide processing tools and are commonly associated with bisonhunting cultures (Johnson 1994). Microscopic use wear analysis of virtually identical dorso end scrapers from various sites in the Lower Pecos region indicates that most of these tools were utilized in 
plant processing and exhibit limited haft wear (Bement and Turpin 1987). Thus, it appears that these hafted scrapers were multipurpose tools rather than strictly hide-scraping tools, perhaps as an adaptation to the desert environment.

Perdiz points and preforms (typed as Cliffton points) are common in the Toyah occupations at San Felipe Springs and are diagnostic artifacts of Toyah occupations at many other sites in central and south Texas (e.g., Black 1986; Creel 1990; Highley 1986). Other arrow point types from various Toyah components suggest that reuse of other peoples' arrow points may have occurred or that there was variability in the stone arrow tips used by Toyah culture peoples. Diversity in point styles also could indicate contact and/or cooperation with other populations. Arrow points from Infierno phase sites have not been assigned to types but are generally described as small stemmed arrow points typically made on blades (Prewitt, personal communication 1998). Prewitt's (1995) study of projectile point distributions shows that substantial numbers of Perdiz points (50+) have been found in 25 counties, including Val Verde. Most of the Perdizproducing sites referenced in Prewitt's study are located within Amistad Reservoir and along the Rio Grande. The Devil's Mouth site (Johnson 1964; Sorrow 1968) alone produced approximately 25 Perdiz points. A comparison of archeological data for all the known ceramic-bearing sites in Val Verde County shows that five also yielded Perdiz and other arrow points, while one site contained only Perdiz points (Table 29). Five of these six sites are located on cr just above terraces of the Devils River and the Rio Grande, while San Felipe Springs is situated farther to the east.

Although no two- or four-beveled knives were recovered from the Toyah component at San Felipe Springs, these diagnostic stone tools (the latter being more common except along the south Texas coastal plain) are hallmarks of the Classic Toyah (Johnson 1994:103) and Infierno phases (Turpin 1995:552). These tools, also called Plains or Harahey Knives, are commonly associated with bison bones and are well documented archeologically as bison-skinning knives (Turner and Hester 1993).

At Infierno Camp in Seminole Canyon State Historical Park, over 100 stone circles are identified as diagnostic features of the Infierno phase. Each is formed by six or eight pairs of limestone blocks that probably were pole supports for huts or tipi-like structures (Turpin 1982:109). Seven similar sites were located in the vicinity of Infierno Camp. Interestingly, three of these yielded Perdiz points. In 1986, stone circles were discovered at the Tonto site (Turpin and Bement 1989), in proximity to the Live Oak Hole rockshelter where certain pictographs are presumed to date after A.D. 1700. The excavation of one stone circle yielded inconclusive evidence as to the age of the feature. Although spatially discrete activity areas have been identified on carefully excavated living surfaces (Johnson 1994:263-265), no known Toyah component has yet yielded conclusive evidence of structural remains. This is most likely a factor of sampling and the difficulty in

Table 29. Comparison of Val Verde county sites yielding Late Prehistoric/Protohistoric artifacts

\begin{tabular}{|c|c|c|c|c|}
\hline \multicolumn{2}{|c|}{ Site Number and Name } & $\begin{array}{c}\text { Bone-tempered } \\
\text { Plainware Ceramics }\end{array}$ & $\begin{array}{l}\text { Perdiz } \\
\text { Points } \\
\end{array}$ & $\begin{array}{c}\text { Other Arrow } \\
\text { Points }\end{array}$ \\
\hline 41VV11 & Javelina Bluff & $\mathrm{X}$ & $\mathrm{X}$ & $\mathrm{X}$ \\
\hline $41 \mathrm{VV} 82$ & Coontail Spin Rockshelter & $\mathrm{X}$ & & \\
\hline 41VV188 & Devil's Mouth & $\mathrm{X}$ & $\mathrm{X}$ & $\mathrm{X}$ \\
\hline 41VV365 & Black Cave Camp & $\mathrm{X}$ & & \\
\hline 41VV424 & Baker's Crossing & $\mathrm{X}$ & $\mathrm{X}$ & $\mathrm{X}$ \\
\hline 41VV444 & San Felipe Springs & $\mathrm{X}$ & $\mathrm{X}$ & $\mathrm{X}$ \\
\hline 41VV446 & Infierno Camp & $\mathrm{X}$ & & $\mathrm{X}$ \\
\hline 41VV662 & Brite Terrace & $\mathrm{X}$ & & + \\
\hline 41VV828 & Tonto Site (Live Oak Hole Complex) & $\mathrm{X}$ & & $\mathrm{X}$ \\
\hline $41 V V 869$ & Dolan Creek Terrace & $\mathrm{X}$ & & $\mathrm{X}$ \\
\hline 41VV1723 & - & $\mathrm{X}$ & $\mathrm{X}$ & $\mathrm{X}$ \\
\hline 41VV1724 & - & $\mathrm{X}$ & $\mathrm{X}$ & \\
\hline
\end{tabular}


recognizing what may be ephemeral structural remains in alluvial settings.

The most significant problem when correlating site components to the Infierno phase is chronometric. Most of these sites are located on deflated surfaces where the contextual integrity of diagnostic materials is questionable and the likelihood of recovering dateable remains is low. In addition, no European-derived historic artifacts have been found at these sites (Turpin 1995). Hence, the age assessment for Infierno, ca. A.D. 1500 to 1780 , is largely speculative. Johnson's (1994:241-287) detailed study of the Buckhollow site establishes a more precise chronology for Toyah culture. He estimates that it ranges from A.D. 1300 to 1650 . Clearly, there is some degree of temporal overlap between Toyah and Infierno if these age assessments are correct.

In general, the representative tool kits of the Infierno and Toyah phases appear analogous, with arrow points, scrapers, and beveled knives being common in both. Many central and south Texas Toyah sites contain substantial amounts of bison bone, yielding information about hunting, butchering, and processing activities. These remains and the associated artifact assemblages demonstrate that Toyah people relied on and followed the bison herds, but the extent to which Toyah peoples in the Lower Pecos hunted bison is not well documented archeologically. A pit feature at 41VV87, the Perry Calk site, was lined with rocks, agave, sotol, oak, croton, and a tanned bison hide (Collins 1969; Turpin 1987). The stratigraphic location of this feature indicated that it was the latest event at the site, probably occurring in the latter part of the Late Prehistoric (A.D. 1000-1600) or early Historic (post A.D. 1600) period (Collins 1969:1-11). Although not directly associated with the pit, diagnostic arrow points from the site were typed as Cliffton, Perdiz, and Perdiz-like.

None of the sparse faunal remains from San Felipe Springs were definitively identified as bison, although some of the medium/large mammal bone fragments from Zone A could be bison. Like many other open campsites in the Lower Pecos, the faunal assemblage at San Felipe may be biased due to poor preservation and small sample size. Ethnohistoric documentation indicates that bison hunting did occur in and near the Lower Pecos region as early as A.D. 1582 and continued to approximately 1850 (Turpin 1987:424-426). A few pictographs portraying bison appear to postdate the eighteenth century and may be attributed to Plains aborigines (Turpin 1987, 1989). This evidence suggests that conditions in the Lower Pecos were attractive to bison during Protohistoric and historic times.

In summary, investigations of stratigraphically discrete Late Prehistoric and/or Protohistoric components at sites in the Lower Pecos region are rare. Only three open terrace sites-Devil's Mouth (Johnson 1964; Sorrow 1968), Javelina Bluff (McClurkan 1968), and San Felipe Springs-have produced interpretable artifact assemblages attributable to the Toyah culture. The dating of the San Felipe Springs component corroborates Johnson's (1994) assessment of A.D. 1300 for the onset of the Toyah phase. The density of Toyah debris at San Felipe indicates repeated occupations, but the full duration of these occupation episodes is not known. The appeal of the springs and the riparian flora and fauna along San Felipe Creek suggests that repeated occupations probably extended well into Protohistoric times.

The Toyah remains at San Felipe Springs and other sites in Amistad Reservoir and near the Devils River provide evidence for intensive utilization of this area by Toyah culture peoples. Though Johnson's (1994:Figure 105) map of Classic Toyah and Toyah "shared area" suggests a dearth of Toyah materials near the mouth of the Pecos River, this perception is probably incorrect. No exhaustive attempt was made to search site file records for evidence of Toyah occupations along the Pecos River, but a literature search revealed that at least one such site exists. Located on an upland overlooking the Pecos River about $10 \mathrm{~km}$ upstream from its confluence with the Rio Grande, 41VV597 contains rock features, including two mounds and possible stone cairns and alignments, in addition to beveled end scrapers, "thumb-nail" scrapers, and Ensor and Perdiz points (Turpin and Eling 1983). Cultural materials from 41VV597, similar to other Toyah assemblages along the Devils River and its tributaries, suggest that Toyah people did inhabit much of the Lower Pecos region. Figure 65 illustrates Johnson's (1994:243) map of the Toyah culture "shared area," which is modified to include all of the Lower Pecos region.

Current archeological data indicate that large open camp sites such as Devil's Mouth and San Felipe Springs contain substantial Toyah 


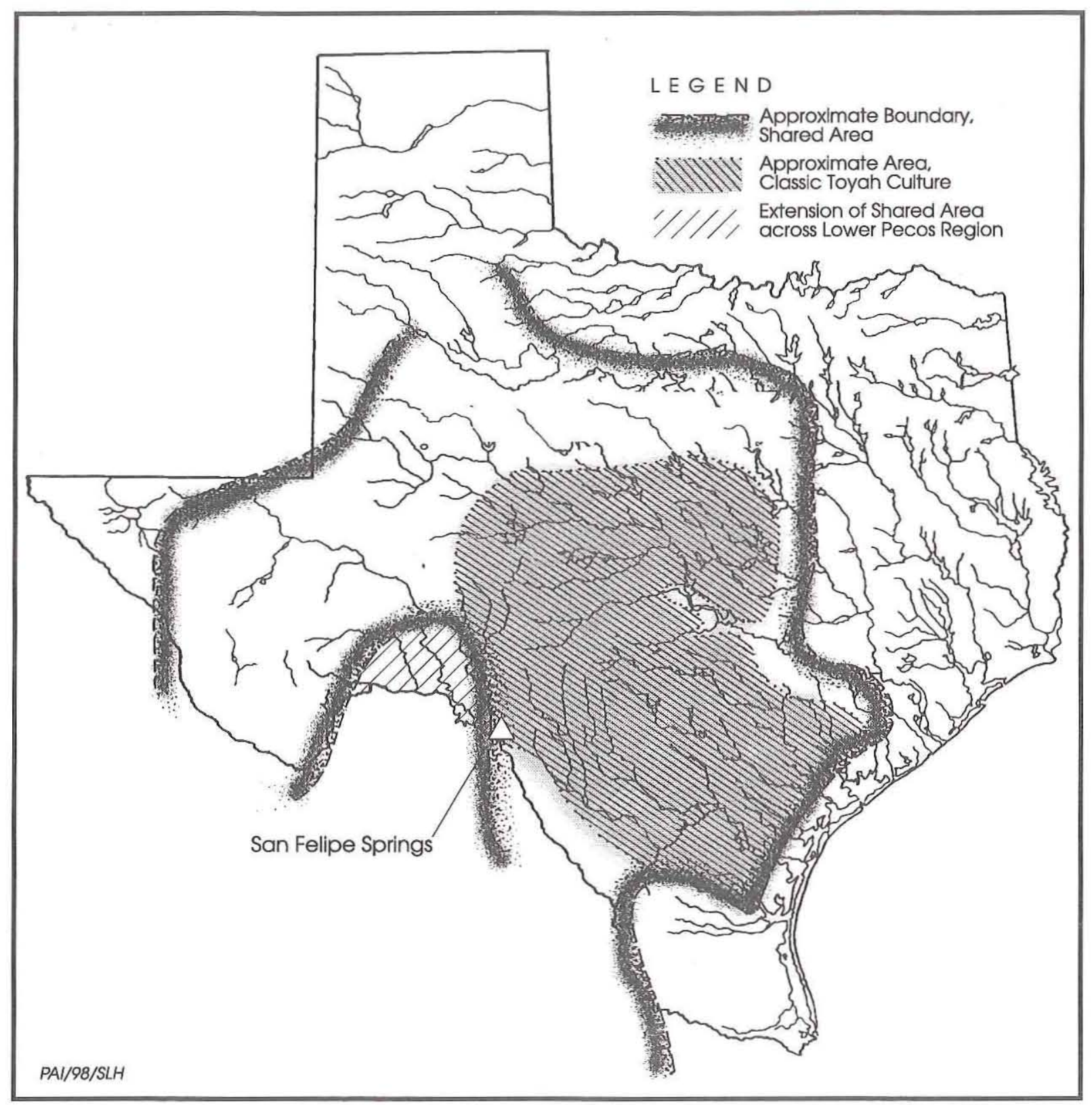

Figure 65. Map depicting extent of Classic Toyah and shared Toyah cultures (after Johnson 1994:Figure 105).

phase occupations on the western margin of the Classic Toyah area. Because Toyah occupations in the Amistad area overlap geographically and temporally with Infierno phase occupations, the relationship between these two archeological manifestations becomes an important consideration. If the Toyah and Infierno cultures were contemporaneous during the Protohistoric period (ca. A.D. 1500-1700), what do they really repre- sent? The differences between Toyah and Infierno seem to boil down to two things-Perdiz points are diagnostic of the Toyah phase but not thought to be associated with Infierno, while stone circles are documented for Infierno but not for Toyah. The absence of stone circles or other structures for the Toyah culture is probably little more than an archeological sampling (and perhaps methodological) problem. It is likely that 
evidence of structures at Toyah sites has not been recognized or systematically searched for.

The evidence is far from conclusive, but there are two equally plausible explanations. The Infierno phase may represent a distinctive but intrusive Protohistoric Plains culture sharing many lifestyle and material culture characteristics with the Toyah phase, or it may be little more than a continuum or late (after A.D. 1500) variant of Toyah in the Lower Pecos. In any case, intensive investigations of more sites will be needed to resolve such issues.

\section{Late Archaic Occupations in the Lower Pecos}

Most of the Late Archaic period in the Lower Pecos, from 1050 B.C. to A.D. 950, is well documented from numerous rockshelter excavations (i.e., Alexander 1974; Dibble 1997; Dibble and Lorrain 1968; Lord 1984; Parsons 1965; Ross 1965; Sorrow 1968; Turpin 1990a). Turpin (1991, 1995) provides an overview of this period and divides it into three subperiods, each characterized by different attributes. At San Felipe Springs, the upper part of the Late Archaic component (i.e., upper Zone B) is compressed and bioturbated, as evidenced by intermixed Late Prehistoric artifacts and abundant occupational debris that accumulated on a slowly aggrading surface. However, the underlying deposits (lower Zone B) are characterized by stratigraphically discrete occupational debris correlating to the Flanders subperiod (see Table 28). The diagnostic artifact for this subperiod is the Shumla point, yet this is the most poorly dated temporal unit in the entire Lower Pecos regional chronology (Turpin 1994:549). Shumla points recovered from Cueva de la Zona, a rockshelter in northern Mexico, are well dated to between 1150 and 100 B.C., with a peak in frequency occurring at approximately 350 B.C. Shumla points have been recovered from numerous sites in Texas, but their chronology is less precise in many cases.

At Arenosa Shelter, Dibble (1997) noted that a later variety of Shumla points were found with Marcos and Frio points. The chronology for the strata yielding these diagnostic artifacts is dubious since not all of the dates are in correct stratigraphic sequence (Turpin 1991:32-33). Shumla-like, Langtry, and Val Verde points occurred in deeper sediments dating from 2115 to
1427 B.C. (Turpin 1991:30). Portions of these lower strata were affected by running water and may contain redeposited cultural materials (Dibble 1997:29). Nevertheless, the earlier Shumla-like points are morphologically distinct from the later Shumlas; the former are generally larger and lack curving barbs.

Three previously excavated campsites in the Lower Pecos produced Shumla points. At Nopal Terrace (Sorrow 1968), Shumla points were associated with other Middle and Late Archaic points, butted knives, other knives, bone beads, and unmodified ocher in a dense burned rock zone (i.e., Stratum VII). The upper part this zone produced Montell and Shumla points dating to 1154-915 B.C. (Sorrow 1968:30; Turpin 1991:31). The butted knives, or fist axes, are associated only with the upper part of this zone. They exhibit use wear, polish, and/or smoothing on their bifacially worked, distal ends. These working edges are too thin for heavy chopping and probably were used for cutting meat or soft plants (Turner and Hester 1993:243). Their rounded proximal ends retain cortex, indicating that these tools were probably hand-held. Turner and Hester (1993) assign butted knives to the Late Archaic period, ca. 650-300 B.C.

In the lower portion of the Stratum VII burned rock accumulations, Shumlas were found with Almagre, Langtry, and Marshall-like points, but no radiocarbon dates are associated. Still deeper, the Stratum VIII alluvium contained mostly classic Shumla points in the upper half, while Shumla-like points were predominant in the lower half. Like the Shumla points from Arenosa Shelter, these specimens indicate that the smaller Shumlas with curving barbs were later in time.

Shumla points from the Devil's Mouth site consist of three variants, but Johnson (1964) does not assign temporal significance to them and they cooccur with a wide variety of Early and predomi-nantly Middle and Late Archaic dart points. The stratigraphic evidence suggests that the Shumla points correspond to the latter two periods and do not date to the Early Archaic. The assemblage at Devil's Mouth includes knives, scrapers, cores, ground stones, fist axes, and painted and scratched pebbles. A radiocarbon date of 1439-1260 B.C. was obtained from a strata dominated by Montell points but also including Shumla points and other Middle and Late Archaic types (Turpin 1991:31). Burned 
rock midden deposits occur throughout the Late Archaic stratigraphic zones at the site.

A midden deposit at the Doss site (Nunley et al. 1965) yielded only one Shumla point among a plethora of Early and Middle Archaic points, particularly Nolan and Langtry. Fist axes occurred in these deposits, but most are of the fine, bifacially worked distal-end type. One cruder specimen is minimally modified along its distal edges. In a detailed technological study, Priour (1987) distinguished between classic and nonclassic butted knives. Distinctive characteristics of the former include a narrower blade, evidence of polish on the distal end of the majority of the specimens (the nonclassical group exhibited none), and a narrow bit angle ( $25^{\circ}$ or less on the distal end) on almost all specimens (while every nonclassic knife measured greater than $25^{\circ}$ ). These results probably indicate different specialized uses for olassic and nonclassic butted knives.

At Coontail Spin (Nunley et al. 1965), Shumla points were present with Early through Late Archaic points, primarily Langtry. Shumla points were found in relative abundance at this site; they account for 93 (22 percent) of the 420 typed dart points. The associated assemblage includes choppers, knives, scrapers, manos, hammerstones, clay figurines, unmodified ochre, bone awls and beads, fiber, and vegetal materials. About 3 miles east of Coontail Spin, another rockshelter called Mosquito Cave contained a large number of Shumla points $(\mathrm{n}=64,19$ percent). These are associated with lithics similar to the Coontail Spin lithic assemblage and were found along with Paleoindian through Late Archaic dart point types.

Three pits at San Felipe Springs originated near the base of the dense Zone B burned rock layer. The associated living surface just beyond the limits of the burned rock accumulation yielded only Shumla points. Overlapping in age, two of the pits date between 385 and 190 B.C., whereas the third is slightly older, at 790-405 B.C. These dates fall within the time frame of the Cueva de la Zona Shumla points in northern Mexico. The San Felipe dates suggest that many of the Shumla points could date to around 350 B.C., when the peak in Shumla activity occurred at Cueva de la Zona.

All of the Shumla points from San Felipe Springs are of the smaller, younger variety with pronounced curving barbs, but very little can be interpreted from the associated artifact assemblage. One cobble tool similar to nonclassic butted knives was found in this component. However, tools of this type also were found in younger and older deposits at San Felipe Springs. Mesquite was the predominant wood used as fuel in the fire pits, but littleleaf walnut also was present in a flotation sample pit. Feature morphology, a significant accumulation of burned rocks in a layer above the pits, and the use of mesquite wood as fuel suggest that these features functioned primarily as baking pits. Based on the presence of burned rock midden accumulations at the San Felipe Springs, Doss, and Devil's Mouth sites, it appears that pit baking and processing of plant foods were important activities during the late Archaic period. The extent to which these activities were prevalent during Shumla times is not well documented except at San Felipe Springs.

\section{Middle Archaic Occupations in the Lower Pecos}

The Middle Archaic period subsumes the Eagle Nest (3550-2150 B.C.) and San Felipe (2150-1250 B.C.) subperiods of the Lower Pecos chronology (see Table 28). Middle Archaic components are well defined in the stratified deposits of several rockshelters also containing Late Archaic occupations. In summarizing these subperiods, Turpin $(1991,1995)$ suggests that desertification continued throughout the Middle Archaic period. It also appears that the Middle Archaic was a time of increased flooding and dramatic flood events. This is most apparent at Arenosa Shelter (Dibble 1997; Patton and Dibble 1982), where approximately half of the strata deposited during this time represent sterile alluvium from large-scale floods. Of the 20 alluvial layers representing high magnitude floods in Arenosa Shelter, 10 were deposited during the San Felipe subperiod.

The beginning of the Eagle Nest subperiod coincides with the end of a hot, dry period marked by erosional disconformities in Arenosa Shelter and Black Cave and at the Devil's Mouth site. Arid conditions apparently continued throughout the Eagle Nest and San Felipe subperiods. Turpin (1991:29; 1995:545-548) speculates that this geomorphic evidence represents extreme aridity and flash flooding, causing widespread erosional stripping of sediments in many areas. 
Coinciding with the climatic stress, a trend toward regionalism is evident in the Lower Pecos dart point styles of the Middle Archaic. The Eagle Nest subperiod is characterized by distinctive Pandale points, whileAlmagre, Arenosa, Langtry, and Val Verde are associated with the subsequent San Felipe subperiod. All of these point styles have a limited geographic distribution and occur primarily in the Lower Pecos region (Prewitt 1995). These styles occur at periods when climatic stress may have caused some degree of cultural insularity. If so, the regionalism evident in the point styles and the geomorphic evidence suggest that drought conditions forced Lower Pecos peoples to congregate in the major river valleys during the Middle Archaic (Turpin 1991:28-30).

It is thought that the San Felipe subperiod is when the distinctive Pecos River-style pictographs appeared (Turpin 1990b:115, 1991:30, 1994:93). This artistic cave painting is thought to represent ritual activity developed in response to increasing population densities in the river valleys and concomitant increase in social complexity. Although the relationships are complex and still poorly understood, it appears that Lower Pecos peoples adapted to the encroaching desert environment by coalescing in larger groups in river valleys, intensifying their exploitation of desert plants by adopting communal collecting and processing techniques, and modifying their social structure.

San Felipe Springs contains an isolable, sealed component correlating to the San Felipe subperiod, but it is unclear how these occupations fit into the larger regional picture. At Arenosa Shelter, Langtry points dominate the San Felipe subperiod but co-occur with Almagre, Pandale, Shumla-like, and Val Verde points. Some of the sediments at Arenosa may be redeposited, with associated materials in secondary context (see the discussion of Late Archaic occupations above). Ground and pecked stones, scratched pebbles, and bone beads were recovered from intact deposits. The chronometric data reveals that these occupations date between 2138 and 1427 B.C. (Turpin 1991:30).

Other rockshelters (e.g., Conejo, Eagle Cave, and Fate Bell) primarily yielded Langtry, Pandale, and Val Verde points. These sites also indicate repeated and intensive occupation of these natural shelters during the San Felipe subperiod. The assemblages include other chipped stone tools, ground stone tools, bone artifacts, and leather. Probable hearths contain burned rocks and organic remains, and a wide variety of vegetal materials are often present, consisting mainly of drought-tolerant desert succulents such as yucca, sotol, and lechiguilla.

The stratigraphic sequence at the Devil's Mouth site (Johnson 1964) revealed a discrete midden deposit containing a "sizeable amount" of burned rocks between alternating layers of eolian sand. Interpreted as a Middle Archaic component, the dominant point types found in association were Langtry and Shumla, but other varieties of Early, Middle (including Bulverde), and Late Archaic points also were recovered. Dating toward the end of the Middle Archaic period, a steeply sloping erosional surface that truncated deeper deposits was apparent in the stratigraphic profile. This surface was capped by another midden deposit dating to the Late Archaic period.

Although not nearly as refined as at Arenosa Shelter or the Devil's Mouth site, the stratigraphy at San Felipe Springs records a flash flood event toward the end of the San Felipe subperiod. Containing dispersed gravel stringers and a pronounced decrease in the frequency of cultural materials, this flood deposit (i.e., Zone B/C) separates the upper Late Archaic component from the lower Middle Archaic component. An accumulation of burned rocks (i.e., the Zone C burned rock layer) and a large, rocklined, basin-shaped pit denote important Middle Archaic subsistence activities (similar to those represented by the Late Archaic burned rock layer in Zone B). The burned rock features appear to represent repeated cooking activities involving earth ovens or baking pits and continual discard of fired rock debris. It is assumed that these activities were related to plant processing, but there is no evidence to suggest which plants were cooked. However, one may speculate that the inhabitants had immediate access to a variety of riparian species and a diversity of upland desert plants in close proximity.

The only diagnostic artifacts from the Middle Archaic component at San Felipe Springs are a Langtry (variant) and a Bulverde point. The former type is a hallmark of the Middle Archaic period, whereas the latter is rare in the region. A Bulverde point was recovered in a mixed assemblage from the Devil's Mouth site, thus indicating that the type is present in the Amistad area, but its temporal placement is 
uncertain. The San Felipe Springs evidence is not conclusive, but the Bulverde point from Zone $\mathrm{C}$ appears to be associated with a discrete component dating to the San Felipe subperiod.

Although detailed interpretations are limited, the Middle Archaic component at 41VV444 and the corresponding geomorphic evidence corroborate other findings that indicate that the San Felipe subperiod represents a time of extreme xeric conditions and catastrophic flood events. Increasing aridity forced Lower Pecos peoples to coalesce along the main rivers and intensify exploitation of desert plants approximately 3,500-4,000 years ago, and the San Felipe Springs must have offered a haven for these desert dwellers. 


\section{REFERENCES CITED}

Ahr, Steven W.

1998 Patterns of Hide Processing Along the Texas Inner Gulf Coastal Plain: Implications of Late Prehistoric and Early Historic Trade. Paper presented at the $63^{\text {rd }}$ annual meeting of the Society for American Archeology. Seattle, Washington.

Alexander, Robert K.

1974 The Archeology of Conejo Shelter: A Study of Cultural Stability at an Archaic Rockshelter Site in Southwestern Texas. Ph.D. diss., Department of Anthropology, The University of Texas at Austin.

Antevs

1955 Geologic-Climatic Dating in the West. American Antiquity 20:317-335.

Arbingast, Stanley, Lorrin G. Kennamer, Robert H. Ryan, Alice Lo, David L. Karney, Charles P. Zlatkovich, Michael E. Bonine, and Roberta G. Steele

1973 Atlas of Texas. Bureau of Business Research, The University of Texas at Austin.

Argus Publishing Company, Inc.

1928 Val Verde on the Sunny Rio Grande: On the Federal Highway No. 90, The Scenic Route of Texas. Undated, unpaginated promotional brochure reprinted by the Argus Publishing Co., Inc. of San Antonio. Contents originally published in the Texas Argus copyright 1928. Brochure on file at Archives Division, Texas State Library, Austin.

Arnn, J. W., III

1997a Archaeological Investigations at the Landa Park Golf Course, New Braunfels, Texas. Archaeological Survey Report No. 250. Center for Archaeological Research, The University of Texas at San Antonio,

1997b Archaeological Monitoring of a Sidewalk Construction Project in Landa Park, New Braunfels, Comal County, Texas. Archaeological Survey Report No. 254. Center for Archaeological Research, The
University of Texas at San Antonio.

1997c Archaeological Monitoring of a Parking Lot Construction Project in New Braunfels, Comal County, Texas. Archaeological Survey Report No. 255. Center for Archaeological Research, The University of Texas at San Antonio.

1997d Archaeological Investigations at the Landa Park Golf Course Pro Shop, New Braunfels, Comal County, Texas. Archaeological Survey Report No. 256. Center for Archaeological Research, The University of Texas at San Antonio.

Baker, Erma

1996 John Twohig. In The New Handbook of Texas, Vol. 6, pp. 606. Texas State Historical Association, Austin.

Ball, Claudia Abbey

1994 Correspondence to Doug Newton, Del Rio, Texas, September 5, 1994. Available correspondence files of Doug Newton, Del Rio, Texas.

Bement, Leland C.

1991 The Statistical Analysis of Langtry Variants from Arenosa Shelter, Val Verde County, Texas. In Papers on Lower Pecos Prehistory, edited by Solveig A. Turpin, pp. 51-64. Studies in Archeology 8. Texas Archeological Research Laboratory, The University of Texas at Austin.

Bement, Leland C., and Solveig A. Turpin

1987 Technological Continuity and Functional Change: The Case of the Dorso End Scraper. Plains Anthropologist 32(116):191-196.

Black, Stephen L.

1986 The Clemente and Herminia Hinojosa Site, 41JW8: A Toyah Horizon Campsite in Southern Texas. Special Report No. 18. Center for Archaeological Research, The University of Texas at San Antonio. 
Black, Stephen L., Linda W. Ellis, Darrell G. Creel, and Glenn T. Goode

1997 Hot Rock Cooking on the Greater Edwards Plateau: Four Burned Rock Midden Sites in West Central Texas. Studies in Archeology 22, Texas Archeological Research Laboratory, The University of Texas at Austin and Archeological Studies Program, Report 2, Environmental Affairs Department, Texas Department of Transportation.

Blair, W. Frank

1950 The Biotic Provinces of Texas. The Texas Journal of Science 2(1):93-117.

Bomar, George W.

1983 Texas Weather. University of Texas Press, Austin.

Brown, A. G.

1987 Holocene Floodplain Sedimentation and Channel Response of the Lower River Severn, United Kingdom. Zeitschrift für Geomorphologie N.F. 31:293310.

1997 Alluvial Geoarchaeology: Floodplain Archaeology and Environmental Change. Cambridge University Press, Cambridge.

Brown and Keough

1992 Holocene Floodplain Metamorphosis in the Midlands, United Kingdom. Geomorphology 4:433445 .

Brune, Gunnar

1975 Major and Historical Springs of Texas. Report No. 189. Texas Water Development Board, Austin.

1981 The Springs of Texas, Volume I. Branch-Smith, Inc., Fort Worth, Texas.

Bryant, Vaughn M., and Richard G. Holloway

1985 A Late Quaternary Paleoenvironmental Record of Texas: An Overview of the Pollen Evidence. In Pollen Records of Late Quaternary North American Sediments, edited by Vaughn M. Bryant Jr. and Richard G. Holloway, pp. 39-70. American Association of Stratigraphic Palynologists Foundation, Dallas.

Bureau of Economic Geology

1977 Geologic Atlas of Texas, Del Rio Sheet. Bureau of Economic Geology, The University of Texas at Austin.

Burkett, R. W.

1990 Archeological Survey (Phase I) for Proposed Landfill Expansion, City of Del Rio, Val Verde County, Texas. Archeological Survey Report No. 193. Center for Archeological Research, The University of Texas at San Antonio.
Callahan, E.

1979 The Basics of Biface Knapping in the Eastern Fluted Point Tradition: A Manual for Flintknappers and Lithic Analysts. Archeology of Eastern North America 7:1-180.

Cargill, D. A., and M. Brown

1997 Archaeological Testing at Crook's Park in San Marcos, Hays County, Texas. Archaeological Survey Report, No. 263. Center for Archaeological Research, The University of Texas at San Antonio.

Collins, Michael B.

1969 Text Excavations at Amistad International Reservoir: Fall, 1967. Papers of the Texas Archeological Salvage Project, No. 16. The University of Texas at Austin.

1975 Lithic Technology as a Means of Processual Inference. In Lithic Technology: Making and Using Stone Tools, edited by Earl Swanson, pp. 14-34. World Anthropology Series. Mouton Publishers, The Hague, Paris.

Cornish, Geoffrey, and Ron Whitten

1993 The Architects of Golf. Harper Collins Publishing Company, New York.

Cotera, Auguste

1878 Sketch of the Reservation of Fort San Felipe, Texas. Available in Val Verde County Historical Commission files, Whitehead Museum, Del Rio, Texas.

Creel, Darrell

1990 Excavations at 41TG91, Tom Green County, Texas, 1978. Publications in Archaeology, Report No. 38. Texas Department of Transportation, Austin.

Daughtrey, Robuck, and Elizabeth Daughtrey

1982 First 100 years of Water and Electric Power in Val Verde County, Texas. Val Verde County Historical Commission, Del Rio, Texas.

Del Rio, City Clerk

City Clerk Files

1905 City Council Minutes

1926-1933 City Commission Minutes

1949-1964 Water Utilities Commission Minutes

Del Rio City Directory, 1938

Del Rio Country Club (Texas)

1935 Articles of Incorporation, No. 6681, January 25, 1935. Available at office of City Clerk, City of Del Rio, Texas.

Del Rio Evening News

1937 Historical Prosperity Edition. Copy available at Whitehead Museum, Del Rio, Texas. 
Del Rio News-Herald

Dering, Philip J. (editor)

1998 Archaeological Context and Land Use in the Western Rio Grande Plain: Phase II Evaluations at Eleven Sites on the Laughlin Air Force Base, Val Verde County, Texas. Technical Report No. 1. Center for Ecological Archaeology, Texas A\&M University, College Station.

Dibble, David S.

1978 The Infierno Phase: Evidence for a Late Occupation in the Lower Pecos River Region, Texas. Paper presented to the $43^{\text {rd }}$ Annual Meeting, Society for American Archeology, Tucson, Arizona.

1997 Excavations at Arenosa Shelter, 1965-1966. Report of the Texas Archeological Salvage Project, University of Texas at Austin (1967). Reprinted by the Texas Archeological Research Laboratory, The University of Texas at Austin.

Dibble, David S., and Dessamae Lorrain

1968 Bonfire Shelter: A Stratified Bison Kill Site, Val Verde County, Texas. Miscellaneous Papers No. 1, Texas Memorial Museum, Austin.

Dignowity, A. S.

1896 The San FelipeAgl., Mang., \& Irrg. Co., Del Rio, Texas, Subn. of Block J of Orig. Sur. 183, July 1896. Recorded in Val Verde County Map Records Vol. I, pp. 41-42.

Eaton, Jack D., Ronald W. Burkett, Herbert G. Uecker, and James T. Abbott

1991 Archeological Testing for a Proposed Landfill Expansion (Phase II), City of Del Rio, Val Verde County, Texas. Archaeological Survey Report No. 197. Center for Archaeological Research, The University of Texas at San Antonio.

Evans, H. Leslie

1996 New York and Texas Land Company. In The New Handbook of Texas, Vol. 4, pp. 1007. Texas State Historical Association, Austin.

Federal Emergency Management Agency

1998 Architectural/Historical Assessment for Properties in the City of Del Rio, Texas, Adversely Affected by Tropical Storm Charley and Affected in the Federal Undertaking as Part of FEMA Disaster 1239. DR-TX. Draft report submitted to the Texas Historical Commission. Prepared by the Federal Emergency Management Agency and Sorg and Associates, Washington D.C.

French, Francis Henry (Major General)

1883 Personal diary, E Company, 19th Infantry, Fort Clark, Texas. Typescript in private collection of Bill Haen, Fort Clark, Bracketville, Texas.
Fugro-McClelland (Southwest), Inc.

1997 Reconnaissance Geotechnical Study of Proposed Water Treatment Plant, Del Rio, Texas. Report submitted to Malcolm Pirnie, Inc. by FugroMcClelland (Southwest), Inc., San Antonio, Texas.

Garber, J. F., and M. D. Orloff

1984 Excavations at 41HY37: An Archaic Site on the Balcones Escarpment in San Marcos, Texas. La Tierra 11(3):31-37.

Garrett, W. B.

1914 Sworn Statement, May 23, 1914. Available at office of City Clerk, Del Rio, Texas.

Glatte, Cynthia V., and Johnnye H. Seale

n.d. "A Guide to Historic Del Rio: Queen City of the Rio Grande." Brochure for Val Verde County Historical Commission, Del Rio, Texas.

Glatte, Hayden A.

1981 Correspondence to General Services Administration, National Archives, June 30, 1981. Available in Val Verde County Historical Commission files, Whitehead Museum, Del Rio, Texas.

Golden, Michael L., Wayne J. Gabriel, and Jack W. Stevens 1982 Soil Survey of Val Verde County, Texas. United States Department of Agriculture, Soil Conservation Service, in cooperation with the Texas Agricultural Experiment Station and Val Verde County Commissioners Court.

Hester, Thomas R., and T. C. Hill

1971 An Initial Study of a Prehistoric Ceramic Tradition in Southern Texas. Plains Anthropologist 16(53): 195-203.

Hibbard, W. S.

1919 Correspondence in Completion Report, January 8, 1919. Available in Val Verde County Historical Commission files, Whitehead Museum, Del Rio, Texas.

Highley, Cheryl L.

1986 Archaeological Investigations at 41LK201, Choke Canyon Reservoir, Southern Texas. Choke Canyon Series Vol. 11. Center for Archaeological Research, The University of Texas at San Antonio.

Hindes, Kay

1998 Historic and Archival Research. In Archeological Context and Land Use in the Western Rio Grande Plains: Phase II Evaluations at Eleven Sites on the Laughlin Air Force Base, Val Verde County, Texas, edited by J. Philip Dering. Technical Report No. 1. Center for Ecological Archeology, Texas A\&M University, College Station. 
Holliday, Vance T.

1989 Middle Holocene Drought on the Southern High Plains. Quaternary Research 31:74-82.

1995 Late Quaternary Stratigraphy of the Southern High Plains. In Ancient Peoples and Landscapes, edited by Eileen Johnson, pp. 289-313. Texas Tech University, Lubbock.

Howells, Robert G., Raymond W. Neck, and Harold D. Murray

1996 Freshwater Mussels of Texas. Texas Parks and Wildlife Department, Inland Fisheries Division. Austin, Texas.

Johnson, LeRoy, Jr.

1961 The Devil's Mouth Site: A River Terrace Midden, Diablo Reservoir, Texas. Bulletin of the Texas Archeological Society 30:253-285.

1964 The Devil's Mouth Site: A Stratified Campsite at Amistad Reservoir, Val Verde County, Texas. Archeology Series No. 6. Department of Anthropology, The University of Texas at Austin.

1994 The Life and Times of Toyah-Culture Folk as Seen from the Buckhollow Encampment, Site 41MK16 of Kimble County, Texas. Office of the State Archeologist, Report No. 38. Texas Department of Transportation and the Texas Historical Commission, Austin.

Jones, Rosemary Whitehead

1976 La Hacienda: An Official Bicentennial Publication for Val Verde County-City of Del Rio. University of Oklahoma Press, Norman.

Kelley, J. Charles

1947 The Lehmann Rock Shelter: A Stratified Site of the Toyah, Uvalde, and Round Rock Foci. Bulletin of the Texas Archeological and Paleontological Society 18:115-128.

Kelley, J. W. (Captain)

1877 Correspondence, September 29, 1877. Available in Val Verde County Historical Commission Files, Whitehead Museum, Del Rio, Texas.

King, J. C., and Frances G. Trimble

1996 Golf. In The New Handbook of Texas, Vol. 3, pp. 204-205. Texas State Historical Association, Austin.

Krapf, Kellie A., and Sharlene N. Allday

1994 The Historic Period in the Lower Pecos River and Val Verde County Region. In Prehistoric and Historic Overview of the Laughlin Air Force Base Area: Del Rio, Val Verde County, and the Lower Pecos Region (10,000 B.C. to A.D. 1942), by Kellie A.
Krapf, Duane E. Peter, and Sharlene N. Allday. Special Report of Investigations No. 2. Geo-Marine, Inc., Plano, Texas.

Labadie, Joseph H.

1986 An Archeological Survey of A Proposed Water Main in Val Verde County, Texas. Archaeological Survey Report No. 158. Center for Archaeological Research, The University of Texas at San Antonio.

Leatherwood, Art

1996 Laughlin Air Force Base. In The New Handbook of Texas, Vol. 4, pp. 104. Texas State Historical Association, Austin.

Leckie, William H.

1996 Tenth United States Cavalry. In The New Handbook of Texas, Vol. 6, pp. 255. Texas State Historical Association, Austin.

Lord, Kenneth J.

1984 The Zooarcheology of Hinds Cave (41VV546). Ph.D. diss., Department of Anthropology, Texas A\&M University, College Station.

Malcolm Pirnie, Inc.

1997 Map of San Felipe Springs Water Treatment Plant Project: Existing Bedell Tanks Storage Facility, City of Del Rio, Texas.

McClurkan, Burney B.

1968 Test Excavations, Javelina Bluff, Val Verde County, Texas. Report submitted to the National Park Service by the Texas Archeological Salvage Project, The University of Texas at Austin.

McDonald, Kenyon, and Thomas R. Hester

1975 An Archaeological Survey of Areas Proposed for Modification in the Vicinity of Del Rio International Airport. Archaeological Survey Report No. 11. Center for Archaeological Research, The University of Texas at San Antonio.

Newman, Coleman C.

1970 Correspondence to Rosie Whitehead Jones, February 24, 1970. Available in Val Verde County Historical Commission vertical files, Whitehead Museum, Del Rio, Texas.

Newton, Douglas

Historical files

Photographic files

Correspondence files

Nordt, Lee C., Thomas W. Boutton, Charles T. Hallmark, and Michael R. Waters

1994 Late Quaternary Vegetation and Climate Changes in Central Texas Based on the Isotopic Composi- 
tion of Organic Carbon. Quaternary Research 41:109-120.

Nunley, John P., Lathel F. Duffield, and Edward B. Jelks

1965 Excavations at Amistad Reservoir: Miscellaneous Papers 3. Texas Archeological Salvage Project, The University of Texas at Austin.

Overfelt, Robert C.

1996 Del Rio, Texas. In The New Handbook of Texas, Vol. 2, pp. 578. Texas State Historical Association, Austin.

Parsons, Mark L.

19651963 Texas Excavations at Fate Bell Shelter, Amistad Reservoir, Val Verde County, Texas. Miscellaneous Papers 4. Texas Archeological Salvage Project, The University of Texas at Austin.

Patton, Peter C., and David S. Dibble

1982 Archeologic and Geomorphic Evidence for the Paleohydrolic Record of the Pecos River in West Texas. American Journals of Science 282:97-121. Yale University Press.

Paulson, Richard W., Edith B. Chase, Robert S. Roberts, and David W. Moody (Compilers)

1991 National Water Summary 1988-89: Hydrologic Events and Floods and Droughts. Water-Supply Paper 2375. U.S. Geological Survey, Denver.

Perkins, George O.

1954 The Early History of Val Verde County. Masters thesis, Sul Ross College, Alpine, Texas.

Pierce, T. K.

1905 Map of subdivision of U.S. Division J, San Felipe Agricultural, Manufacturing and Irrigation Company, out of original Survey No. 183. Available in Val Verde County Deed Records, Vol. 12, pp. 564.

Pool, William C.

1975 A Historical Atlas of Texas. The Encino Press, Austin.

Prewitt, Elton R., and David S. Dibble

1974 The San Felipe Creek Watershed Project, Val Verde County, Texas: An Archeological Survey. Research Report No. 40. Texas Archeological Survey, The University of Texas at Austin.

1995 Distributions of Typed Projectile Points in Texas. Bulletin of the Texas Archeological Society 66:83173.

Priour, Donald J.

1987 A Preliminary Report on the "Butted Knife" Biface Survey. La Tierra 14(2):5-18.
Raisz, Erwin

1957 Landforms of the United States. Map, 6th rev. ed., to accompany Atwood's "Physiographic Provinces of North America."

Ricklis, R. A., M. D. Blum, and M. B. Collins

1991 Archeological Testing at the Vera Daniel Site (41VT364), Zilker Park, Austin, Texas. Studies in Archeology 12. Texas Archeological Research Laboratory, The University of Texas at Austin.

Roberts, C. C.

1914 Map Showing Plant of the Del Rio Water Company, May 26, 1914. Available at office of City Clerk, City of Del Rio, Texas.

Ross, Richard E.

1965 The Archeology of Eagle Cave. Papers of the Texas Archeological Salvage Project 7. The University of Texas at Austin.:

San Antonio Daily Express

San Antonio Weekly Express

San Felipe Agricultural, Manufacturing and Irrigation Company

1875 Articles of Incorporation, October 8, 1875. Available at the office of Secretary of State, Austin.

San Felipe Country Club

Historical Files

Architectural Plans

1921 Articles of Incorporation, July 12, 1921. Available at office of City Clerk, City of Del Rio, Texas.

1966 Articles of Merger, April 2, 1966. Available at office of City Clerk, City of Del Rio, Texas.

Sanborn Fire Insurance Company

1900 Map of Del Rio, Texas

1905 Map of Del Rio, Texas

1909 Map of Del Rio, Texas

1917 Map of Del Rio, Texas

1924 Map of Del Rio, Texas

1930 Map of Del Rio, Texas

Sharrock, F. W.

1966 Prehistoric Occupation Patterns in S.W. Wyoming and Cultural Relationships with the Great Basin and Plains Cultural Areas. Anthropology Papers No. 17. Department of Anthropology, University of Utah.

Shiner, J. L.

1983 Large Springs and Early American Indians. Plains Anthropologist 28:1-7. 
Smith, Julia Cable

1996 Val Verde County. In The New Handbook of Texas, Vol. 6, pp. 694-695. Texas State Historical Association, Austin.

Soil Survey Staff

1996 Keys to Soil Taxonomy, 7th ed. United States Department of Agriculture, Natural Resources Conservation Service, Washington, D. C.

Sorrow, William M.

1968 The Devil's Mouth Site: The Third Season-1967 and Test Excavations at the Nopal Terrace Site: Val Verde County, Texas. Papers of the Texas Archeological Salvage Project, Nos. 14 and 15. Austin, Texas.

Stafford, B. G.

1925 San Felipe Golf Course is Big Asset to City of Roses. In Forward Del Rio, January 1925.

State Archeologist, Texas Historical Commission Correspondence files

National Register of Historic Places files

Steely, James Wright

1984 A Catalog of Texas Properties in the National Register of Historic Places. Texas Historical Commission, Austin.

Suhm, Dee Ann, and Edward B. Jelks

1962 Handbook of Texas Archeology: Type Descriptions. Special Publication No. 1, Texas Archeological Society, and Bulletin No. 4, Texas Memorial Museum, Austin.

Tennis, Cynthia, Marcie Renner, and Robert J. Hard (editors) 1996 Archaeological Survey of Laughlin Air Base, Val Verde, Texas. Archaeological Survey Report No. 239. Center for Archaeological Research, The University of Texas at San Antonio.

Texas. General Land Office

1852 Bexar Bounty Class file 963. Abstract 137 patented in the name of John Twohig December 18, 1852.

1854a Bexar First Class file 1087. Abstract 1295 patented to the heirs of James Mitchell September 29, 1854.

1854b Bexar First Class file 1135. Abstract 1614 patented to John Twohig, assignee of Sostenes Carrasco November 3, 1854.

Toomey III, Rickard S., Michael D. Blum, and Salvatore Valastro Jr.

1993 Late Quaternary Climates and Environments of the Edwards Plateau, Texas. Global and Planetary Change 7:299-320.

Trimble, Francis G.

n.d. John Bredemus: Texas' First Golf Course Architect. In Golfiana.
1991 "Golf on the Texas Riviera," in program of the Ben Hogan South Texas Open, February 24-March 3, 1991, North Shore Country Club, Corpus Christi, Texas. Golf Writers Association of America. Douglas Newton collection, Del Rio, Texas.

Tunnell, Curtis D., and W. W. Newcomb Jr.

1969 A Lipan Apache Mission, San Lorenzo de la Santa Cruz 1762-1771. Texas Memorial Museum Bulletin 14. The University of Texas at Austin.

Turner, Sue Ellen, and Thomas R. Hester

1993 A Field Guide to Stone Artifacts of Texas Indians. 2nd ed. Gulf Publishing Company. Houston, Texas.

Turpin, Solveig A. (editor)

1991 Papers on Lower Pecos Prehistory. Studies in Archeology 8. Texas Archeological Research Laboratory, The University of Texas at Austin.

Turpin, Solveig A.

1982 Seminole Canyon! The Art and Archeology. Research Report No. 83. Texas Archeological Survey, The University of Texas at Austin.

1987 Ethnohistoric Observations of Bison in the Lower Pecos River Region: Implications for Environmental Change. Plains Anthropologist 32(118):424 429.

1989 The Iconography of Contact: Spanish Influences on the Rock Art of the Middle Rio Grande. In Columbian Consequences, Volume I: Archaeological and Historical Perspectives on the Spanish Borderlands West, edited by D. H. Thomas, pp. 277-299. Smithsonian Institution Press, Washington, D.C.

1990a Skyline Ranch: Archeological Investigations on the Devils River. Report to the Texas Historical Commission. On file, Texas Archeological Research Laboratory, The University of Texas at Austin.

1990b Speculations on the Age and Origin of the Pecos River Style, Southwest Texas. American Indian Rock Art 16:99-122. Proceedings of the International Rock Art Conference and the 16th Annual Meeting of the American Rock Art Research Association. Published jointly by the National Park Service, American Rock Art Research Association, and the Texas Archeological Research Laboratory at the University of Texas at Austin.

1991 Time Out of Mind: The Radiocarbon Chronology of the Lower Pecos River Region. In Papers on Lower Pecos Prehistory, edited by S. A. Turpin, pp. 1-49. Studies in Archeology 8. Texas Archeological Research Laboratory, The University of Texas at Austin. 
1994

On a Wing and A Prayer: Flight Metaphors in Pecos River Art. Shamanism and Rock Art in North America. Special Publication No. 1. Rock Art Foundation, Inc., San Antonio, Texas.

1995 The Lower Pecos River Region of Texas and Northern Mexico. Bulletin of the Texas Archeological Society 66:541-560.

Turpin, Solveig A., and Leland C. Bement

1989 The Live Oak Hole Complex: Plains Indian Art and Occupation in the Lower Pecos River Region. Bulletin of the Texas Archeological Society 59:65-82.

Turpin, Solveig, and Herb Eling

1983 Site File for 41VV597. Texas Archeological Research Laboratory, The University of Texas at Austin.

Turpin, Solveig A., and David G. Robinson

1998 Infierno Phase Pottery of the Lower Pecos River Region. Bulletin of the Texas Archeological Society 69: 89-97.

Twohig, John

Personal Papers. Available at the Center for American History, The University of Texas at Austin.

United States Bureau of the Census

1900 Val Verde County, Texas.

1910 Val Verde County, Texas.

1920 Val Verde County, Texas.

United States War Office

1949 Military Reservations of the U.S. Land Forces in the World War (1917-1919). Vol. 3, part 1. Prepared in World War I group, Historical Division, Special Staff, U.S. Army. U.S. Government Printing Office, Washington.

Val Verde County

Ad Valorem Tax records
County Clerk records

Deed records

Map records

Val Verde County Herald

Val Verde County Historical Commission, Whitehead Museum (Del Rio)

Camp San Felipe files

Camp Del Rio files

Val Verde County Historical Commission files

Vertical files

Weddle, Robert S.

1976 The Vanguard. In La Hacienda: An Official Bicentennial Publication for Val Verde County - City of Del Rio, edited by Rosemary Whitehead Jones. University of Oklahoma Press, Norman.

Wedel, Waldo R.

1970 Antler Tine Scraper Handles in the Central Plains. Plains Anthropologist 15(47):36-45.

West Texas News

Wilson, Louita Dodson

n.d. "Data about San Felipe Springs Creek and the San Felipe Agricultural, Manufacturing, and Irrigation Company," and, "San Felipe Springs, Creek, and Irrigation System in Del Rio, Val Verde County, Texas." Available in Val Verde County Historical Commission files, Whitehead Museum, Del Rio, Texas.

1985 H. J. "Jap" Lowe (1983-1955). In Spirit of Val Verde, edited by Diana Sotolo Zertuche, pp. 114. Taylor Publishing Company, Dallas.

Zertuche, Diana Sotolo (editor)

1985 The Spirit of Val Verde. Taylor Publishing Company, Dallas. 



\section{APPENDIX A: Stratigraphic Descriptions for $41 \mathrm{VV} 444$}

Karl W. Kibler 


\section{AREA 1}

Backhoe Trench 2, south wall

Zone $1 \quad 0-8 \mathrm{~cm} \quad$ Dark gray (10YR 4/1) silty clay loam, firm, moderate coarse granular structure, common distinct medium mottles (10YR 5/3), clear smooth lower boundary. Late Holocene alluvium, A horizon.

Zone $2 \quad 8-47 / 60 \mathrm{~cm}$ Brown (10YR 5/3) silty clay, firm, moderate fine subangular blocky structure, few dispersed small gravels increasing in frequency with depth, abrupt wavy lower boundary. Late Holocene alluvium, B horizon.

Zone 3 47/60+ cm Lower Cretaceous Salmon Peak limestone, R horizon.

\section{Backhoe Trench 19, north wall}

Zone $1 \quad 0-41 \mathrm{~cm} \quad$ Dark grayish brown (10YR 4/2) silty clay loam, friable, moderate coarse granular structure, few pieces of culturally burned rock, gradual smooth lower boundary. Late Holocene alluvium, A horizon.

Zone $2 \quad 41-72 \mathrm{~cm} \quad$ Yellowish brown (10YR 5/4) silty clay, firm, moderate fine subangular blocky structure, few pieces of culturally burned rock, clear smooth lower boundary. Late Holocene alluvium, B horizon.

Zone 3 72-105 cm Light yellowish brown (10YR 6/4) gravelly silty clay, firm, moderate coarse granular structure, clear smooth lower boundary. Late to middle Holocene colluvium, $\mathrm{C}$ horizon.

Zone 4 105-156 cm Light yellowish brown (10YR 6/4), gravelly silt loam, friable, structureless, abrupt wavy lower boundary. Late to middle Holocene colluvium, C2 horizon.

Zone $5 \quad 156+\mathrm{cm} \quad$ Lower Cretaceous Salmon Peak limestone, R horizon.

Excavation Unit 3, west wall

Zone $1 \quad 0-38 \mathrm{~cm} \quad$ Dark gray (10YR 4/1) loam, friable, moderate coarse granular structure, few dispersed small gravels, gradual smooth lower boundary. Late Holocene alluvium, A horizon.

Zone 2 38-66+ cm Brown (10YR 5/3) clay loam, friable, moderate fine subangular blocky structure, common dispersed small gravels, few $\mathrm{CaCO}_{3}$ filaments, lower boundary not observed. Late Holocene alluvium, Bw horizon.

\section{Excavation Unit 27, south wall}

Zone $1 \quad 0-48 \mathrm{~cm}$ Dark gray (10YR 4/1) to dark grayish brown (10YR 4/2) loam, firm, moderate coarse granular structure, common pieces of culturally burned rock, few dispersed small gravels, gradual smooth lower boundary. Late Holocene alluvium, A horizon.

Zone 2 48-86+ cm Brown (10YR 5/3) clay loam, firm, moderate fine subangular blocky structure, few dispersed small gravels, lower boundary not observed. Late Holocene alluvium, Bw horizon.

\section{Excavation Unit 34, west wall}

Zone 1 0-54 cm Dark grayish brown (10YR 4/2) loam, firm, moderate coarse granular structure, common pieces of culturally burned rock, gradual smooth lower boundary. Late Holocene alluvium, A horizon. 
Zone 2 54-104 cm Brown (10YR 5/3) clay loam, firm, moderate fine subangular blocky structure, few $\mathrm{CaCO}_{3}$ filaments, clear smooth lower boundary. Late Holocene alluvium, Bw horizon.

Zone 3 104-167 cm Brown (10YR 5/3) grading to brown (7.5YR 5/3) clay loam, firm, moderate fine subangular blocky structure, few dispersed gravels that increase in frequency with depth, abrupt wavy lower boundary. Late Holocene alluvium, Bw2 horizon.

Zone $4 \quad 167+\mathrm{cm} \quad$ Brown (10YR 5/3) muddy gravel, structureless, lower boundary not observed. Late Holocene alluvium, $\mathrm{C}$ horizon.

\section{Excavation Unit 42, south wall}

Zone $1 \quad 0-10 \mathrm{~cm} \quad$ Artificial fill.

Zone $2 \quad 10-36 \mathrm{~cm}$ Dark grayish brown (10YR 4/2) loam, firm, moderate medium subangular blocky structure, clear smooth lower boundary. Late Holocene alluvium, $2 \mathrm{Ab}$ horizon.

Zone $3 \quad 36-76 \mathrm{~cm}$ Brown (10YR 5/3) gravelly sandy clay loam, firm, moderate fine subangular blocky structure, few pieces of charcoal, clear smooth lower boundary. Late Holocene alluvium, $2 \mathrm{Bb}$ horizon.

Zone 4 76-135 cm Brown (10YR 5/3) clay loam, firm, moderate coarse granular structure, few dispersed granulesized gravels, abrupt wavy lower boundary. Late Holocene alluvium, 2Bb2 horizon.

Zone 5 135-150+ $\mathrm{cm}$ Poorly sorted, rounded gravels. Holocene alluvium, $2 \mathrm{C}$ horizon.

\section{AREA 2}

\section{Backhoe Trench 30, south wall}

Zone $1 \quad 0-56 \mathrm{~cm} \quad$ Artificial fill.

Zone 2 56-104+ cm Light yellowish brown (10YR 6/4) silty clay, firm, moderate fine subangular blocky structure, few dispersed gravels, few $\mathrm{CaCO}_{3}$ filaments, lower boundary not observed. Late Holocene alluvium, $2 \mathrm{Bb}$ horizon.

\section{Backhoe Trench 31, north wall}

Zone $1 \quad 0-46 \mathrm{~cm} \quad$ Artificial fill.

Zone $246-90+\mathrm{cm}$ Yellowish brown (10YR 5/4) silty clay, firm, moderate fine subangular blocky structure, lower boundary not observed. Late Holocene alluvium, $2 \mathrm{Bb}$ horizon.

\section{Backhoe Trench 33, south wall}

Zone $10-43 \mathrm{~cm}$ Grayish brown (10YR 5/2) silty clay loam, firm, moderate fine subangular blocky structure, gradual smooth lower boundary. Late Holocene alluvium, A horizon.

Zone $243-80 \mathrm{~cm}$ Light yellowish brown (10YR 6/4) silty clay, firm, moderate fine subangular blocky structure, gradual smooth lower boundary. Late Holocene alluvium, B horizon.

Zone 3 80-142 cm Light yellowish brown (10YR 6/4) silty clay, firm, weak coarse prismatic breaking to moderate fine subangular blocky structure, gradual smooth lower boundary. Late Holocene alluvium, Bw horizon. 
Zone $4 \quad$ 142-190+cm Very pale brown (10YR 7/4) silty clay, firm, moderate fine subangular blocky structure, common distinct fine mottles (10YR 6/6), common dispersed gravels, lower boundary not observed. Late Holocene alluvium, $\mathrm{Cg}$ horizon.

\section{Backhoe Trench 34, south wall}

Zone $1 \quad 0-38 \mathrm{~cm} \quad$ Dark grayish brown (2.5Y 4/2) silty clay, firm, weak coarse granular structure, clear smooth lower boundary. Late Holocene alluvium, A horizon.

Zone $2 \quad 38-86 \mathrm{~cm} \quad$ Brown (10YR 5/3) silty clay, friable, weak fine subangular blocky structure, clear smooth lower boundary. Late Holocene alluvium, B horizon.

Zone 3 86-107+ cm Pale brown (10YR 6/3) silty clay loam, firm, moderate medium subangular blocky structure, lower boundary not observed. Late Holocene alluvium, B2 horizon.

\section{Backhoe Trench 37, north wall}

Zone $1 \quad 0-45 \mathrm{~cm}$ Dark yellowish brown (10YR 4/4) silt loam, friable, weak fine subangular blocky structure, clear smooth lower boundary. Late Holocene alluvium, A horizon.

Zone $2 \quad 45-115 \mathrm{~cm}$ Yellowish brown (10YR 5/4) silty clay, firm, weak fine subangular blocky structure, clear smooth lower boundary. Late Holocene alluvium, B horizon.

Zone 3 115-150+cm Pale brown (10YR 6/3) silty clay, firm, moderate medium subangular blocky structure, lower boundary not observed. Late Holocene alluvium, C horizon.

\section{AREA 7}

\section{Backhoe Trench 35, south wall}

Zone $1 \quad 0-45 \mathrm{~cm} \quad$ Dark gray (10YR 4/1) silty clay, firm, weak coarse granular structure, gradual smooth lower boundary. Late Holocene alluvium, A horizon.

Zone $2 \quad 45-75 \mathrm{~cm}$ Grayish brown (10YR 5/2) silty clay, firm, moderate fine subangular blocky structure, clear smooth lower boundary. Late Holocene alluvium, B horizon.

Zone 3 75-122 cm Grayish brown (10YR 5/2) silt, friable, weak fine subangular blocky structure, few $\mathrm{CaCO}_{3}$ filaments, clear smooth lower boundary. Late Holocene alluvium, B2 horizon.

Zone 4 122-175+cm Yellowish brown (10YR 5/4) silty clay loam, firm, weak medium subangular blocky structure, lower boundary not observed. Late Holocene alluvium, $\mathrm{C}$ horizon.

\section{Backhoe Trench 36, north wall}

Zone $1 \quad 0-48 \mathrm{~cm} \quad$ Brown (10YR 5/3) silt loam, firm, weak coarse granular structure, few dispersed small gravels, gradual smooth lower boundary. Late Holocene colluvium, A horizon.

Zone $2 \quad 48-81 \mathrm{~cm} \quad$ Yellowish brown (10YR 5/4) silty clay, firm, moderate fine subangular blocky structure, few dispersed small gravels, gradual smooth lower boundary. Late Holocene colluvium, B' horizon.

Zone $3 \quad 81-114 \mathrm{~cm}$ Very pale brown (10YR 7/4) silty clay, firm, moderate fine subangular blocky structure, common dispersed small gravels, abrupt wavy lower boundary. Late Holocene colluvium, $\mathrm{C}$ horizon.

Zone $4 \quad 114+\mathrm{cm} \quad$ Lower Cretaceous Salmon Peak limestone, R horizon. 



\section{APPENDIX B: Radiocarbon Dating Results from 41 VV444}

Gemma Mehalchick 
, 
Nine organic material samples from cultural and noncultural contexts from the excavation block in Area 1 at 41VV444 were radiocarbon dated by Beta Analytic, Inc., of Miami, Florida. Eight of the radiocarbon dates were on charred wood, while one was derived from organic remains in bulk sediment. Seven of the samples were dated using the accelerator mass spectrometer (AMS) method.

Table 30 presents laboratory sample numbers, dated materials, provenience designations, conventional radiocarbon ages and $\delta{ }^{13} \mathrm{C}$ values, and calibrated calendrical dates (1-sigma ranges) for these samples. Three samples also include wood identifications. The standard radiometric assays were done by Beta Analytic, while the AMS assays were done by one of Beta Analytic's collaborating laboratories, either
Woods Hole in Cambridge, Massachusetts, or Eidgenössische Technische Hochschule University (ETH) in Zürich, Switzerland. Two charcoal samples assayed by the standard radiometric method were very small and required extended counting times.

The conventional radiocarbon ages $\left(\delta^{13} \mathrm{C}\right.$ corrected ages) are reported in radiocarbon years before present (RCYBP), where present is A.D. 1950. They were calculated using the Libby ${ }^{14} \mathrm{C}$ half life of 5,568 years. The ${ }^{13} \mathrm{C} /{ }^{12} \mathrm{C}$ ratios are relative to the PDB-1 international standard, and RCYBP ages are normalized to -25 per mil. The conventional radiocarbon ages were tree-ring calibrated by Beta Analytic using the Pretoria calibration curve (Stuiver et al. 1993; Talma and Vogel 1993; Vogel et al. 1993).

\section{REIERENCES CITED}

Stuiver, Minze, Austin Long, Renee S. Kra, and James M. Devine

1993 Calibration 1993. Radiocarbon 35(1).

Talma, A. S., and J. C. Vogel

1993 A Simplified Approach to Calibrating ${ }^{14} \mathrm{C}$ Dates. Radiocarbon 35(2):317-322.
Vogel, J. C., AnneMarie Fuls, Ebbie Visser, and Bernd Becker 1993 Pretoria Calibration Curve for Short Lived Samples. Radiocarbon 35(1):73-86. 
Table 30. Summary of radiocarbon dates, Area 1 ezcavation block, 41 VV444

\begin{tabular}{|c|c|c|c|c|c|c|}
\hline Sample* & Material & Provenience & $\begin{array}{l}\text { Feature } \\
\text { Association }\end{array}$ & $\begin{array}{l}\text { Conventional Age B.P. } \\
\left(\mathrm{C}^{13} / \mathbb{C}^{12} \text { Ratio }\right)\end{array}$ & $\begin{array}{l}\text { Calibrated Calendrical Date, } \\
\text { 1-Sigma Range with (intercepts) }\end{array}$ & $\begin{array}{c}\text { Wood } \\
\text { Identification }\end{array}$ \\
\hline Beta-113884-W & sediment & EU 34, 290.85-290.75 m & none & $3280 \pm 60(-19.6)$ & 1620 (1525) 1490 в.с. & \\
\hline Beta-113885-W & charcoal & EU 6, $291.76 \mathrm{~m}$ & Feature 3 & $2480 \pm 90(-25.4)$ & $790(755,685,540) 405$ в.C. & \\
\hline Beta-113886 & charcoal $^{1}$ & EU 14, $292.04 \mathrm{~m}$ & Zone B rock layer & $1790 \pm 110(-26.1)$ & A.D. $110(245) 395$ & mesquite \\
\hline Beta-113887-W & charcoal & EU 17, $291.60 \mathrm{~m}$ & Feature 11 & $3260 \pm 60(-24.1)$ & 1605 (1515) 1440 в.с. & huisache \\
\hline Beta-113888-W & charcoal & EU 19, $291.44 \mathrm{~m}$ & Feature 12 & $2250 \pm 60(-26.0)$ & 385 (365) 200 B.C. & \\
\hline Beta-113889-W & charcoal & EU 26, $291.55 \mathrm{~m}$ & Zone $\mathrm{C}$ rock layer & $3310 \pm 50(-25.0)$ & 1420 (1395) 1305 в.с. & \\
\hline Beta-113890-W & charcoal & EU 6, 291.58-291.56 m & Feature 5 & $2220 \pm 50(-25.6)$ & $375(350,300,215) 190$ в.с. & \\
\hline Beta-116160 & charcoal $^{1}$ & EU 24, $292.20 \mathrm{~m}$ & none & $600 \pm 80(-25.6)$ & A.D. 1295 (1395) 1420 & huisache \\
\hline Beta-116161-E & charcoal & EU 24, $291.84 \mathrm{~m}$ & none & $480 \pm 50(-23.7)$ & A.D. 1420 (1435) 1450 & \\
\hline $\begin{array}{r}{ }^{*} \mathrm{AMS} \text { radiocarb } \\
\mathrm{E}=\mathrm{ETH} \text { in } 2 \\
\mathrm{~W}=\mathrm{Woods} \mathrm{H} \\
{ }^{1} \text { Small sample } \mathrm{r}\end{array}$ & $\begin{array}{l}\text { n dates ind } \\
\text { irich, Switz } \\
\text { le in Camb } \\
\text { quiring ext }\end{array}$ & $\begin{array}{l}\text { ated by: } \\
\text { land } \\
\text { dge, Massachusetts } \\
\text { ded counting time }\end{array}$ & & & & \\
\hline
\end{tabular}




\section{APPENDIX C: Petrographic Analysis of Plainware Pottery from 41VV444}

David G. Robinson, Research Fellow

Texas Archeological Research Laboratory, The University of Texas at Austin 



\section{INTRODUCTION}

In June and July, 1998, a petrographic analysis was performed on seven plainware sherds from Area 1 at the San Felipe Springs site, 41VV444, Val Verde County, Texas. Inspection revealed that the Late Prehistoric plainware sherds are similar to the well-known Toyah phase ceramics of central and south Texas (types commonly called Leon Plain and/or Doss Redware) and recently described pottery of the Infierno phase of the Lower Pecos. Regardless of spatial and cultural affinities, the studied sherds were chosen from a plainware assemblage from the Late Prehistoric deposits at the site, although a few sherds were found in lower deposits that could be terminal Archaic in age. These latter could be from earlier occupations, or they may represent postdepositional disturbance or mixing (i.e., materials moved down profile by bioturbation). Unquestionably, the Late Prehistoric deposits that yielded most of the sherds date no earlier than A.D. 1300 and perhaps as late as A.D. 1500 to 1700 (see Chapters 7 and 8 ).

Analysis was directed toward addressing specific cultural and technological questions. The most important cultural question is identifying the differences between Infierno and Toyah bonetempered plainwares. This study provided a fortuitous opportunity to conduct a direct comparison between the San Felipe sherds, presumed to be Toyah phase ceramics from the southwestern margin of the Toyah culture area, and the Infierno phase ceramics defined by Turpin and Robinson (1998) and associated with protohistoric occupations in the Lower Pecos. Because the microscopic/petrographic analysis was conducted using the same equipment and methods in both studies, interobserver methodological bias was minimized. Recent petrographic work on Toyah ceramics in central and south Texas was consulted for comparative data for similarly analyzed pottery assemblages in those regions.

Technically, six questions emerged as significant issues. First, what is the variability in the sample? Are there technical and stylistic varieties, or could all the sherds be from one vessel? Second, are there any remains of a slip on the vessel surfaces? Third, are there any other technological observations that can be made on a microscopic basis? Fourth, is the paste well sorted or poorly mixed? Fifth, what is the tempering agent vs. natural inclusions? Finally, is there any way to identify manufacturing source localities (i.e., local materials and production as opposed to regional production and distribution/trade)?

\section{SAMPLE SELECTION AND METHODOLOGY}

The ceramic assemblage from Area 1 at 41VV444 is fairly homogenous (see Chapter 7). The seven specimens selected for thin sectioning and petrographic analysis were chosen because they are from various vertical and horizontal proveniences and each sherd is fairly large (Table 31). To define megascopic attributes, each sherd was visually examined with the naked eye and under low-power magnification. Thin sections were prepared by the National Petrographic Service, Inc., of Houston, Texas. No mineral staining was added, but cover slips were affixed to the finished sections. Identification and point-counting were conducted on a Zeiss stereo petrographic microscope with a rotating and mechanical stage at the Bureau of Economic Geology, The University of Texas at Austin. The purpose of the initial microscopic work was to identify and characterize the matrix, pores, mineral and other bodies, and any incidental inclusions. After the contents of the sections were identified, point-counts were made. For the point-counting, each slide was traversed with the mechanical stage at consistent 1-mm intervals, and every species or body falling directly under the cross hairs was counted; traverses continued back and

Table 31. Provenience data for petrographic sample sherds from Area 1, 41VV444

\begin{tabular}{clc}
\hline $\begin{array}{c}\text { Sample } \\
\text { Number }\end{array}$ & Provenience & $\begin{array}{c}\text { Cultural } \\
\text { Zone/Level }\end{array}$ \\
\hline 1 & Excavation Unit 2 $(2.30-2.20 \mathrm{~m})$ & $\mathrm{A} 3$ \\
2 & Excavation Unit 2 $(2.00-1.90 \mathrm{~m})$ & $\mathrm{B} 3$ \\
3 & Excavation Unit 25 $(2.30-2.20 \mathrm{~m})$ & $\mathrm{A} 3$ \\
4 & Excavation Unit 35 $(2.43-2.30 \mathrm{~m})$ & $\mathrm{A} 2$ \\
5 & Excavation Unit 21 $(2.44-2.30 \mathrm{~m})$ & $\mathrm{A} 2$ \\
6 & Excavation Unit 32 $(2.40-2.30 \mathrm{~m})$ & $\mathrm{A} 2$ \\
7 & Excavation Unit 9 $(2.10-2.00 \mathrm{~m})$ & $\mathrm{B} 2$ \\
\hline
\end{tabular}


forth until a count of 200 was achieved. Tabulations were made at 100 counts; this was done to compare the counts of the first half of the traversed section with those of the second half. Differences between them could be a measure of the quality of sorting within the ceramic matrix and a check on the consistency of identifications entering the count. The point-count was made at $25 \mathrm{x}$ (the $2.5 \mathrm{x}$ objective times the $10 \mathrm{x}$ ocular). Bodies larger than the 1-mm interval of the traverse were not counted twice, either on subsequent points or on return transects. Rare minerals that failed to enter the point-counts were recorded as "trace." In general, the pointcount procedure followed the method of Chayes (1949). Size classification of nonplastic particles was done using the Wentworth scale. The successful outcome of the point-count permits a quantified assessment of the attributes of the collection, a body of data comparable to other regional petrographic data, and manipulation by a variety of statistical measures.

\section{RESULTS}

The seven studied ceramic specimens fit into a generic plainware grouping that includes Lower Pecos ceramics of the Infierno phase defined by Turpin and Robinson (1998) and the ubiquitous central and south Texas wares associated with the Toyah phase and often called Leon Plain (Suhm and Jelks 1962:95-96; Hester and Hill 1971) or Doss Redware (Kelley 1947:123). All of the studied specimens are heavily bone tempered, with lesser amounts of crushed limestone. Other minerals and bodies include quartz, calcite, hematite, and one particle each of dolomitic limestone and chert. Collectively, these sherds constitute an interesting sample from the San Felipe Springs site that may be compared with similar ceramic samples and petrographic data from elsewhere in the region.

Megascopic attribute descriptions of individual sherds in the 41VV444 sample are compared with other regional ceramic samples in Table 32. Petrographic data for the 41VV444 sherds and other plainware samples in the region are compared in Table 33. Each sherd in the San Felipe Springs sample is described below.

SAMPLE 1: This sherd is reddish brown (7.5YR $6 / 6$ ) with rough paste texture and a smoothed

Table 32. Summary of ceramic sherds in the $41 \mathrm{VV} 444$ petrographic sample and other Lower Pecos petrographic samples*

\begin{tabular}{|c|c|c|c|}
\hline \multirow{2}{*}{$\begin{array}{l}\text { Petrographic } \\
\text { Sample }\end{array}$} & \multicolumn{3}{|c|}{ Surface } \\
\hline & Texture & Color & Surface Finish \\
\hline \multicolumn{4}{|c|}{ 41VV444, San Felipe Springs } \\
\hline 1 & rough & 7.5YR 6/6 & smoothed \\
\hline 2 & coarse & 7.5YR 7/2 & rough \\
\hline 3 & rough & 7.5YR 6/6 & smoothed \\
\hline 4 & rough & $7.5 \mathrm{YR} 6 / 6$ & smoothed/polished \\
\hline 5 & even & $5 \mathrm{YR} 7 / 4$ & smoothed \\
\hline 6 & rough & $5 \mathrm{YR} 6 / 6$ & smoothed \\
\hline 7 & rough & 7.5YR 6/4 & smoothed \\
\hline
\end{tabular}

41VV11, Javelina Bluff (McClurkan 1968)

$\begin{array}{llll}1119 & \text { smooth } & \text { pinkish tan } & \begin{array}{l}\text { smoothed } \\ \text { smoothed/polished }\end{array}\end{array}$

41VV188, Devil's Mouth (Johnson 1961, 1964; Sorrow 1968)

751 smooth dark tan smoothed/polished

761 granular pinkish tan smoothed/polished

41VV365, Black Cave Camp (Turpin 1982)

3651 smooth pinkish tan smoothed

3652 rough pinkish tan smoothed

41VV424, Baker's Crossing (Turpin and Robinson 1998)

424 granular pinkish tan smoothed

41VV446, Infierno Camp (Turpin 1982; Turpin and Robinson 1998)

GQU-1 coarse red polished

GQU-2 coarse yellowish tan polished

*See Turpin and Robinson (1998) for descriptions and petrographic data for ceramics from sites other than 41VV444. 
Table 33. Comparison of ceramic petrographic point count data for 41 VV444 and other Lower Pecos ceramic samples*

\begin{tabular}{|c|c|c|c|c|c|c|c|c|c|c|c|c|}
\hline Site & Sample & $\begin{array}{c}\text { Clay } \\
\text { Matrix }\end{array}$ & $\begin{array}{c}\text { Pore } \\
\text { Space } \\
\end{array}$ & Quartz & Bone & Limestone & $\begin{array}{l}\text { Dolomitic } \\
\text { Limestone }\end{array}$ & Calcite & Chert & Hematite & Fe Stain & $\begin{array}{l}\text { Clay } \\
\text { Ball } \\
\end{array}$ \\
\hline 41VV444 & 1 & 53 & 6.5 & - & 36 & 4 & 1 & - & - & - & - & - \\
\hline 41VV444 & 2 & 52 & 8.5 & - & 35.5 & 1.5 & - & - & - & 3 & - & - \\
\hline 41VV444 & 3 & 49.5 & 10 & - & 37 & 2 & - & 1 & 1 & - & - & - \\
\hline 41VV444 & 4 & 53.5 & 7.5 & 1 & 30 & 5 & - & - & - & 3 & - & - \\
\hline 41VV444 & 5 & 51.5 & 9 & 2 & 34.5 & 0.5 & - & - & - & 2.5 & - & - \\
\hline 41VV444 & 6 & 49 & 11 & 2 & 32.5 & 2.5 & - & - & - & 3 & - & - \\
\hline 41VV444 & 7 & 44 & 7 & 4.5 & 36.5 & 3 & - & 0.5 & - & 4.5 & - & - \\
\hline 41VV11 & 1119 & 64.5 & 4.5 & 2.5 & 12 & 10.5 & - & - & - & - & 3 & 3 \\
\hline 41VV11 & 1131 & 53.5 & 5 & 2.5 & 30 & 5.5 & - & - & - & - & 2 & 1 \\
\hline 41VV188 & 751 & 58.5 & 3.5 & 13 & 17 & 3.5 & - & - & - & - & 4 & 0.5 \\
\hline 41VV188 & 761 & 61 & 11.5 & 5 & 18 & 1.5 & - & - & - & - & 2.5 & 0.5 \\
\hline 41VV365 & 3651 & 59.5 & 11 & 1.5 & 24 & 1.5 & - & - & - & - & 1 & 1.5 \\
\hline 41VV365 & 3652 & 58 & 7 & 1 & 30 & 2 & - & - & - & - & 2 & - \\
\hline 41VV424 & 424 & 66 & 3 & 1.5 & 21 & 4.5 & - & - & - & - & 4 & - \\
\hline 41VV446 & GQU-1 & 52.5 & 19.5 & 11.5 & 12.5 & 2.5 & - & 1 & - & - & - & - \\
\hline 41VV446 & GQU-2 & 55 & 17.5 & 17 & 8 & 2.5 & - & - & - & - & - & - \\
\hline
\end{tabular}


interior surface. The exterior surface is difficult to assess due to extensive carbonate coating. Its thickness is $5 \mathrm{~mm}$. The ceramic matrix is dense, with variable colors and relatively few voids ( 6.5 percent of the pointcount), in long jagged strips. The sections had relatively little variability of inclusions, these restricted to bone and limestone particles and a single observed subangular, very-coarsesized particle of dolomitic limestone. The section shows remnants of a very thin wash of clay on both surfaces; this wash may be clay particles floated to the surface during the finishing process.

SAMPLE 2: The sherd is pinkish gray (7.5YR $7 / 2$ ) on both surfaces and has coarse texture and rough surface finishing. The specimen is $5.3 \mathrm{~mm}$ thick. Its matrix is dense and massive, as in Sample 1, but the edges (interior and exterior surfaces) show no remnants of a slip or wash. Voids are in long jagged strips, fine rounded shapes, and strips surrounding larger particles of bone and other bodies. These voids around bodies appear to represent shrinkage of the matrix away from solid particles during the firing process. The section also has a low diversity of solid inclusions, having only bone, limestone, and hematite.

SAMPLE 3: The sherd is reddish yellow (7.5YR 6/6) on both surfaces. The paste texture is rough, yet the surfaces are smoothed, marred by unpatterned brush scoring. The specimen is $5.4 \mathrm{~mm}$ thick. The sherd interior has a carbon streak. Voids interrupting the massive, dense matrix vary from jagged strips to rounded shapes, irregular shapes, and borders around solid bodies. Bone is the most common solid body constituent; some fragments range in size from medium sand sized or slightly smaller to granule sized, but most are coarse sand sized or larger. They range in color from light olive near the surfaces to black in the center with the carbon streak, but this trend is not uniform for all bone particles. Other solid inclusions are limestone, chert, calcite, and a trace amount of quartz. There were no signs of a slip or wash.

SAMPLE 4: The specimen is reddish yellow (7.5YR 6/6) on both surfaces, although the interior has significant gray carbonate crusting. The paste texture is rough. The surfaces are smoothed, with minor incidental polishing on high points on the exterior surface. The interior surface is undulating, revealing incomplete smoothing-over of the coils. Shallow pits along the former coil edges also bespeak incomplete or casual finishing. The interior lacks a carbon streak. The sherd is $5.6 \mathrm{~mm}$ thick. The dense, massive matrix is riddled with voids in the shape of jagged strips, rounded bodies, and borders around solid particles. The voids are distinctive in that they are so small. The surfaces of the sherd (i.e., the edges of the thin section) have remnants of a slip or wash on the exterior. Solid bodies include bone, limestone, quartz grains, and rounded hematite particles.

SAIMPLE 5: The sherd is pink (5YR 7/4) on both surfaces. The paste texture is even. The exterior is smoothed, while the interior is rough and has the unpatterned brush scoring seen on Sample 3. The fragment is $4.4 \mathrm{~mm}$ thick and lacks a carbon streak. The matrix is dense and massive, interrupted by proportionally few voids in jagged strips, rounded shapes, and borders around solid inclusions. Bone is the most common aplastic component, followed by rounded hematite particles, quartz grains, and limestone particles. The quartz is notable for being fine sand sized, suggesting that it is a detrital constituent of the original clay and not a tempering agent.

SAMPLE 6: The sherd is reddish yellow (5YR $6 / 6$ ) on both surfaces. The paste texture is rough, but both the interior and exterior surfaces have been smoothed. The exterior is undulating, suggesting the former coils. The specimen is $5.5 \mathrm{~mm}$ thick and has a very slight carbon streak in its interior. The interior matrix is a dense, massive body interrupted by proportionally few voids. The voids are mostly shaped in jagged strips and borders around solid bodies; few are rounded. Solid bodies include bone, limestone, quartz grains, and small rounded particles of hematite.

SAMIPLE 7: This sherd is light brown (7.5YR 6/4) on the exterior and reddish yellow (5YR 6/6) on the interior. The paste texture is rough. Both surfaces are smoothed, but some streaks of polish were left on the exterior surface by the finishing tool. The sherd is $5.3 \mathrm{~mm}$ thick and has a very faint carbon streak in its interior. The matrix is 
dense and massive and attains a golden brown color under crossed polarizers. The thin section has proportionally very few voids, these in strips and borders around solid bodies. Bone is the dominant aplastic inclusion, followed by quartz, hematite, limestone, and calcite. The hematite ranges from very fine sand to coarse sand in size and contains particles of calcite within the body of hematite.

\section{DISCUSSION AND REGIONAL COMPARISON}

Overall variability in the San Felipe Springs petrographic sample is very low. All the thin sections are generally similar in that each: (1) contains crushed bone as the predominant aplastic inclusion; (2) has a dense, massive matrix with relatively few voids; and (3) has limestone as a common minor aplastic. With little doubt, the bone fragments represent a tempering agent that was intentionally added to the clay, while the limestone probably represents natural inclusions in the clay. Megascopically, the paste textures of the sample sherds range narrowly between coarse and rough, with only Sample 5 having an even texture. Likewise, surface finishes are generally smooth, with minor burnishing or polishing, with the exception of the rough surfaces on Sample 2. Surface colors range narrowly between the 5YR and 7.5YR hues, with generally high chroma and value readings. Thicknesses of the specimens, all of which are body sherds, vary between 4.4 and $6.2 \mathrm{~mm}$, a range of $1.8 \mathrm{~mm}$. Variability is seen in the minor minerals of the thin sections, which have almost chance occurrences of dolomitic limestone, calcite, and chert. Even so, these are predictable rocks and minerals on the prevailingly carbonate landscapes of the Edwards and Stockton plateaus. Hematite was found in low proportions in five of the seven specimens (Samples 1 and 3 being the exceptions), and its occurrence in the thin sections seems to ally more with pattern than variation. Collectively, the seven thin-sectioned sherds in the San Felipe Springs sample represent a single, fairly uniform paste group.

Remnant patches of slips were observed in the thin sections of Samples 1 and 4 . In both cases they are less than $1 \mathrm{~mm}$ thick and appear to be composed of finer particles of the matrix. This may mean that the fine particles floated up from the ceramic paste during the process of surface finishing. The remnants are the same color as the matrix and lack a reddish hue or other color that would imply the mixture of a pigment into a prepared slip.

Bone particles range widely in size, from coarse silt to granule (Wentworth scale), in every sample. Angularity of bone fragments ranges from subrounded to subangular and angular. The angularity is consistent with crushing to prepare tempering material. The wide range of particle sizes suggests that bone temper was mixed into the clay without sieving or size sorting in any fashion. In the matrix, the crushed bone material is notable for being extremely well mixed in the section, there being no discernible patterning in size or density distribution of bone particles within each thin section. It is generally observed that the ceramic pastes, with all their inclusions, are extremely well mixed. This thoroughness was probably of value to the potters and represents a deliberate, intentional step in the manufacturing process.

The color of the bone particles in the thin sections ranges from chalky white through light olive green to gray and reddish black. This color variation is commonly assumed to be from preproduction heat processing of the bone prior to grinding as temper (Reese-Taylor 1993:I-8; Reese-Taylor et al. 1994:564). Individual bone particles are darker in the interiors of sections with carbon streaks, and lighter toward the sherd surfaces. This is not the case in sections without a carbon streak. Although dark bone particles are present in these sections, they appear to be randomly mixed with particles of other colors. Furthermore, while distinctly discernible, this trend in lightness and darkness is not uniform, there being some light particles in carbon streak interiors and some very dark particles near the surfaces. This pattern supports the hypothesis that the effects of firing on the composition of bone are evident in Toyah phase ceramics (ReeseTaylor et al. 1994:564). Differences in bone particle color are most likely explained by the behavior of carbon in vessel interiors during firing. Variations in color value may be due to transit or exchange of carbon between bone particles and the clay matrix during the earthenware firing. The fact that not all bone particles in the interior achieved the same color suggests that the chemical steps in this transfer, and its directionality, may be fairly complex. 


\section{Tempering vs. Natural Inclusions}

Formal methods of distinguishing between the tempering agent in a ceramic and naturally occurring aplastic bodies are preferable to unsupported assumptions, especially if one is attempting to distinguish between sandy paste and sand temper (Reese-Taylor et al. 1994:556557). In the case of the San Felipe Springs ceramics, the temper is identified by elimination: there are no likely candidates for temper other than bone. Quartz and limestone are present, but in amounts and sizes too small to have served as temper; hematite is too soft a mineral to function as a tempering agent and also is present only in minor amounts. Furthermore, natural alluvial clay deposits are unlikely to contain crushed mammal bone in amounts exceeding 30 percent by volume. Consequently, the crushed bone must have been added to the paste and mixed well by potters. This method of temper determination is logical rather than empirical. It does, however, account for the structure of the ceramics without resting on unstated assumptions.

\section{Ceramic Sourcing}

Questions of ceramic sourcing, or identifying localities of production, rise perennially in ceramic studies. Local production implies that the resources used to make ceramics were obtained within a day's walk of the campsite where the sherds were found, and that the campsite or another nearby may have been the manufacturing locality. Hunter-gatherer ethnographies commonly describe daily round trip excursions from and returning to a campsite of 20-25 km (12-15 miles) (Lee 1968; Meggitt 1962; Robinson 1987:36-37). For this discussion, it is assumed that $25 \mathrm{~km}$ is the maximum distance for the availability of local resources. The term nonlocal is taken to mean materials available at distances farther than $25 \mathrm{~km}$.

Beyond the establishment of precise terminology, methods for inferring ceramic production localities vary widely and usually depend on the specific context and character of the ceramic assemblage. Few methods are wholly satisfying. One common-sense approach to determining the locality of production is to compare mineral bodies within the ceramics to the local and regional surface geology. This method appears to be the most useful for understanding the San Felipe Springs ceramic sample and Lower Pecos comparative materials. Diagnostic aplastic inclusions found in the ceramic matrix through petrographic analysis may be considered to be key fossils or "telltales" if their natural occurrence is spatially limited in some way. These telltale particles may be matched to local or regional geological outcrops or stream systems draining geologically distinctive areas. Through such comparisons, possible zones of resource origin and, by inference, ceramic production locales, may be identified. Local origin may be indicated when all of the nonplastic components are similar to locally available materials. Conversely, if marked differences exist between the ceramic telltales and the geology in the immediate vicinity of the site where sherds were found, then pottery production may have been nonlocal. In such cases, a wider net must be cast to find the source provenience of potential ceramic resources and determine the scale of distribution.

In the case of the San Felipe Springs ceramics, bone and limestone cannot serve as key indicators or telltales because they are ubiquitous across large areas. Bone was a major tempering additive that could be obtained anywhere, and limestones are superabundant across the vast carbonate landscapes of the Edwards and Stockton plateaus. By virtue of their abundance, stability, and durability, silicates, and especially quartz, are poor telltales. The quartz observed in the San Felipe thin sections offers no distinctive traits of origin or alteration that might give it value as a geographic source indicator.

The two grains of dolomitic limestone in Sample 1 and the hematite seen in five of the samples may serve as telltales because these materials are rare in the region. Dolomite has a more limited distribution across the region than other forms of limestone, and various iron-rich minerals found in some areas may alter through weathering to the hematitic form of iron oxide (generally $\mathrm{Fe}_{2} \mathrm{O}_{3}$ ) observed in the San Felipe thin sections. The Geological Atlas of Texas, Del Rio Sheet (Bureau of Economic Geology 1977) and its indices were examined to identify local sources of iron and dolomite. The surface geology of the San Felipe Creek drainage basin is summarized here to provide baseline comparative data in the immediate vicinity of the site. 
San Felipe Creek and the springs drain a landscape covered by outcrops of Cretaceous-age Salmon Peak limestone. The upper $23 \mathrm{~m}$ of this formation is a crossbedded limestone with abundant marine invertebrate fossils and chert masses. The creek heads in the Eagle Ford group of shales, siltstones, and limestones, the upper part of which is yellowish brown flaggy limestone with some shale. Relatively minor outcrops of Del Rio Clay and Buda limestone are crosscut by San Felipe Creek; these outcrops contain common pyrite masses. Pyrite may transform through weathering to limonite and then to hematite, and limonite may convert to hematite upon heating (e.g., ceramic firing). Dolomite also is a component of the Buda limestone. The San Felipe Creek bed contains Quaternary alluvium derived from these surface rocks. Thus, the telltales in the San Felipe thin sections (i.e., the dolomitic limestone and hematite) have potential local sources in the alluvial clay beds available along San Felipe Creek. While this does not prove where the bonetempered plainwares found at 41VV444 were made, it does indicate that they were probably made at the site or at some other localities in the San Felipe Creek valley.

To compare the San Felipe ceramics with similar samples of Lower Pecos ceramics, geologic descriptions of more-distant rock outcrops were examined for sources of iron and dolomite. The presence of iron is noted in three Cretaceous formations nearby (Bureau of Economic Geology 1977). The Olmos formation (chiefly limestone), which crops out approximately $100 \mathrm{~km}$ northwest of the San Felipe Springs, contains ferruginous concretions. The Olmos formation is local to the Lower Pecos and Devils River, where similar plainware sherds have been found in several sites (see Tables 32 and 33). The Anacacho limestone, which contains poorly described rusty bentonite beds, lies in Uvalde County approximately $100 \mathrm{~km}$ east of San Felipe Springs and is much farther from the Lower Pecos and Devils River sites. The Austin Chalk contains pyritic structures that may ultimately convert to hematite. This formation is 50 miles northwest of San Felipe Springs at its closest but is drained by the Devils River. Thus, resources derived from the Austin Chalk are likely to be present in the alluvial clays in the vicinity of Javelina Bluff (41VV11) and the Devil's Mouth Site (41VV188).
It is notable that, in contrast to the hematite in the San Felipe sherds, the bone-tempered sherds from other Val Verde County sites have iron (Fe) staining but no hematite. This may or may not be meaningful in terms of sourcing. One scenario is that the iron staining is actually derived from (i.e., a remnant of) hematite, in which case it might indicate that hematite is geographically widespread in the Lower Pecos and is not a particularly good telltale sourcing indicator. Alternatively, the iron staining may be related to other ferric sources and not to hematite at all, in which case the hematite may be a good telltale mineral in some areas. If so, it would strengthen the argument for local production at San Felipe Springs, and the compositional variability seen in sherd thin sections from other sites may also represent local production. The total absence of hematite in the sherds exhibiting iron staining suggests that the latter scenario is more likely.

Dolomite is found in bedded strata in greater or lesser quantities in the Segovia member, Fort Terrett member, and the Devils River limestone, cropping out variously no less than about 50 miles north of San Felipe Springs (Bureau of Economic Geology 1977). As mapped, the San Felipe Creek drainage system does not drain any of these geologic exposures. The Devils River drains the Devils River limestone, thus making dolomite available in the alluvial clays in the vicinity of Javelina Bluff and the Devil's Mouth sites. Petrographic analysis of ceramic thin sections from these sites identified no dolomite. The Glen Rose limestone also contains dolomite, although its nearest outcrops are some $80-100$ miles east of San Felipe in Uvalde and Edwards counties. Materials originating in the Glen Rose Formation drain southward and eastward away from San Felipe Creek, the Devils River, and the Lower Pecos proper.

This initial comparison between regional geology and telltale minerals in the bone-tempered sherds from various Val Verde County sites gives some probable evidence for local production of ceramics. The pottery at three major Toyah phase sites-San Felipe Springs, Javelina Bluff, and Devil's Mouth-seems likely to have been made locally and appears to represent Toyah phase materials. Ceramic constituents would have been available no farther than $10 \mathrm{~km}$ away and perhaps in the immediate vicinity of each of these sites. While the analyzed sherds from 
the Javelina Bluff and Devil's Mouth sites are very similar, they are distinctly different from those at the San Felipe Springs site.

It also appears likely that the plainware pottery at three Infierno phase sites-Infierno Camp, Black Cave Camp, and Baker's Crossing-may have been locally made. At Infierno Camp and Black Cave Camp (located only a few kilometers from Infierno Camp), the maximum distance to any of the observed ceramic constituents is $5 \mathrm{~km}$. Observations of the examined thin sections from these sites are suggestive of local variability. Thin sections from Infierno Camp have higher proportions of quartz than do the San Felipe Springs sherds or sherds from the other sampled sites in the region. The high proportion of quartz appears to be at the expense of the bone, which is found in relatively low frequencies, while the clay matrix typically constitutes more than half of the ceramic paste. These same thin sections are lacking in iron minerals, but both analyzed sherds from Black Cave Camp exhibit iron staining as a notable occurrence.

Thus, the San Felipe and Lower Pecos ceramics share fundamental technological similarities in the nature of the clay matrix, commitment to bone tempering, and firing techniques (effects on surface colors, paste texture, and carbon streaks). Variability is relatively minor and is best attributed to local production and minor variation in available resources.

\section{Toyah vs. Infierno Phase Bone-Tempered Pottery}

This study provides only limited data for addressing sociocultural research questions that arise when dealing with Lower Pecos ceramics. The fundamental technology of the bone-tempered earthenwares is essentially the same across a large portion of the Lower Pecos and into central and south Texas. Archeologically, some of the bone-tempered plainwares from the Lower Pecos are attributed to Toyah phase peoples who lived on the southwestern margin of their culture area between ca. A.D. 1200 and 1600. Bone-tempered pottery from other Lower Pecos sites is attributed to the Infierno phase, which appears to represent peoples living there after ca. A.D. 1500. At the petrographic level of examination, there are no distinctive or even subtle differences that reasonably may be defined as culturally meaningful between Toyah and Infierno phase pottery in the Lower Pecos. The observed compositional variability defined through petrographic analysis appears to be primarily attributable to differences in local production and accessible resources, not cultural or behavioral differences. Based on current research, it seems that a basic plainware ceramic technology was shared knowledge across a vast region, and production took place at many different campsites, with locally available materials most commonly used. In his study of Toyah phase ceramics from central Texas sites, Johnson (1994:285) notes that "it is likely that most of the pottery was locally made." This appears to be true for the Toyah and Infierno phase pottery of the Lower Pecos as well.

At this time it must be concluded that there are no discernible technological or compositional differences between the bone-tempered pottery of classic Toyah phase and the bonetempered pottery of the western Toyah and Infierno phases of the Lower Pecos proper. Ceramic analysis must ultimately play a larger role in a fuller exploration of cultural dynamics and archeological differences between the Lower Pecos and the classic Toyah culture area of central and south Texas, but the data currently available are inadequate to address these complex issues. 


\section{REFERENCES CITED}

Bureau of Economic Geology

1977 Geologic Atlas of Texas, Del Rio Sheet. Bureau of Economic Geology, The University of Texas at Austin.

Chayes, F.

1949 A Simple Point-Counter for Thin Section Analysis. American Mineralogist 34:1-11.

Hester, Thomas R., and T. C. Hill

1971 An Initial Study of a Prehistoric Ceramic Tradition in Southern Texas. Plains Anthropologist 16(53):195-203.

Johnson, LeRoy, Jr.

1961 The Devil's Mouth Site: A River Terrace Midden, Diablo Reservoir, Texas. Bulletin of the Texas Archeological Society 30:253-285.

1964 The Devil's Mouth Site: A Stratified Campsite at Amistad Reservoir, Val Verde County, Texas. Archeology Series No.6. Department of Anthropology, The University of Texas at Austin.

1994 The Life an d Times of Toyah-Culture Folk as Seen from the Buckhollow Encampment, Site 41MK16 of Kimble County, Texas. Office of the State Archeologist Report No. 38. Texas Department of Transportation and the Texas Historical Commission, Austin.

Kelley, J. Charles

1947 The Lehmann Rock Shelter: A Stratified Site of the Toyah, Uvalde, and Round Rock Foci. Bulletin of the Texas Archeological and Paleontological Society 18:115-128.

Lee, R. B.

1968 What Hunters do for a Living, or, How to Make Out on Scarce Resources. In Man the Hunter, R. B. Lee and I. DeVore, editors. Aldine-Atherton Press. Chicago.

McClurkan, Burney B.

1968 Test Excavations, Javelina Bluff, Val Verde County, Texas. Report submitted to the National Park Service by the Texas Archeological Salvage Project, The University of Texas at Austin.
Meggitt, J. M.

1962 Desert People. Angus and Robertson, Ltd. Sydney.

Reese-Taylor, K.

1993 Petrographic Studies of Ceramic Pastes. Appendix I in Cultural Resource Investigations in the O. $\mathrm{H}$. Ivie Reservoir, Concho, Coleman, and Runnels Counties, Texas, Volume IV, by A. C. Treece, C. Lintz, W. N. Trierweiler, J. M. Quigg, and K. A. Miller, pp. I-1-I11. Technical Report 346-IV. Mariah Associates, Inc.

Reese-Taylor, K., J. Hageman, and R. A. Ricklis

1994 Preliminary Paste Analyses of Ceramic Samples from the Mustang Branch Site (41HY209) and Barton Site (41HY202). In Archaic and Late Prehistoric Human Ecology in the Middle Onion Creek Valley, Hays County, Texas, Vol. 2, by R. A. Ricklis and M. B. Collins, pp. 549-568. Studies in Archeology 19. Texas Archeological Research Laboratory, The University of Texas at Austin.

Robinson, D. G.

1987 Bastrop County Historical Commission Sesquicentennial Project: Cultural Resource Investigations Along the Colorado River. Archeology Series 2. Texas Archeological Survey, The University of Texas at Austin.

Sorrow, William M.

1968 The Devil's Mouth Site: The Third Season-1967 and Test Excavations at the Nopal Terrace Site: Val Verde County, Texas. Papers of the Texas Archeological Salvage Project, Nos. 14 and 15. Austin, Texas.

Suhm, Dee Ann, and Edward B. Jelks

1962 Handbook of Texas Archeology: Type Descriptions. Special Publication No. 1, Texas Archeological Society, and Bulletin No. 4, Texas Memorial Museum, Austin.

Turpin, Solveig A.

1982 Seminole Canyon: The Art and Archeology. Research Report No. 83. Texas Archeological Survey, The University of Texas at Austin.

Turpin, Solveig A., and David G. Robinson

1998 Infierno Phase Pottery of the Lower Pecos River Region. Bulletin of the Texas Archeological Society 69:89-97. 


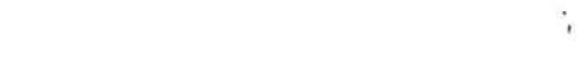




\section{APPENDIX D: Analysis of Vertebrate Faunal Remains from 41 VV444}

Brian S. Shaffer and Jay Barry Institute of Applied Sciences

University of North Texas 



\section{INTRODUCTION}

A total of 180 vertebrate specimens from 41VV444, Area 1, were analyzed. Excluding 3 bone fragments from Excavation Unit 41, all of the faunal materials were recovered from the excavation block. Each specimen was identified to the most specific taxonomic level possible. Also, each specimen's anatomical portion and condition were identified in hopes of learning about cultural activities at the site. The taphonomic conditions of weathering, burning, breakage, gnawing, cut marks, and chemical dissolution or etching were also noted. Specimens were quantified using the number of identified specimens within each taxonomic/ anatomical category (i.e., raw specimen count). Provenience and analysis data are summarized in Table 34. The minimum number of individuals quantification method was not used because no elements are duplicated.

\section{RESULTS}

Due to the condition of the assemblage, none of the specimens could be identified below the level of family (Table 35). This is primarily due to fragmentation and chemical dissolution of the specimens recovered. This indicates that the sample may be biased by differential preservation and that many faunal remains deposited prehistorically may have disappeared from the archeological record. This is especially true for elements exposed for some period of time prior to burial and for remains of small fauna.

Fifty percent $(n=90)$ of the specimens could be identified only as Vertebrata, with another 44 percent being identifiable only as Mammalia $(\mathrm{n}=79)$. Of the identified taxa, the Colubridae snake vertebra is in generally better condition than the rest of the assemblage, appearing not to have suffered from the same taphonomic factors, and hence is probably not part of the cultural assemblage. The Canidae (one tooth) and Artiodactyla remains all exhibit the same degraded patterns noted on the majority of the assemblage.

Of notable interest are the medium/large mammal remains. Most of these are probably from deer-sized animals. This corresponds with medium-sized (deer-sized) Artiodactyla, the most commonly identified taxon below the
Class level. Three additional specimens are identified as large/very large and very large mammal. Given the size of the cortical bone wall thickness, these specimens could be from animals the size of elk or bison. However, no diagnostic features are present to conclusively identify the specimens as to element, much less to a specific taxon.

Taphonomic factors identified as affecting the assemblage include weathering, breakage, burning, and chemical dissolution or etching. Only one specimen with marked weathering was identified, indicating that the assemblage was buried fairly rapidly. Another possibility is that subtle weathering is present, but the signs have been obliterated by the chemical etching noted on 177 (98 percent) of the specimens. Marked etching (heavily pitted, edges rounded, and surficial feature degraded) was noted on 148 (82 percent) specimens. Chemical dissolution probably also destroyed any evidence of cultural modification that may have been present, such as cut marks or use wear polish, along with noncultural factors such as rodent or carnivore gnawing.

Only one bone, a deer-sized artiodactyl first tarsal, is complete (excluding the snake vertebra). Angular or dry bone fractures were identified on 133 (74 percent) specimens. The breakage identified on these specimens occurred after the bones had lost collagen. Spiral or green bone fractures were identified on 46 (26 percent) specimens. This high percentage of spirally fractured bones may be due to marrow or grease processing activities, but spiral fracturing indicates only that the bones were broken while still containing collagen and does not indicate the process or agent involved (natural vs. cultural). Burning was noted on just 4 specimens. One specimen is charred (burned black) and 3 are calcined (burned white).

\section{SUMMIMARY}

Little information regarding human activities can be gleaned from the faunal sample recovered from Area 1 of the San.Felipe Springs site. Given the small sample size and degraded condition of the bones, it is likely that this assemblage is extremely biased due to poor preservation. However, the relatively high number of spirally fractured bones, and the fact that artiodactyls represent the most common 
Table 34. Faunal data from $41 \mathrm{VV} 44$

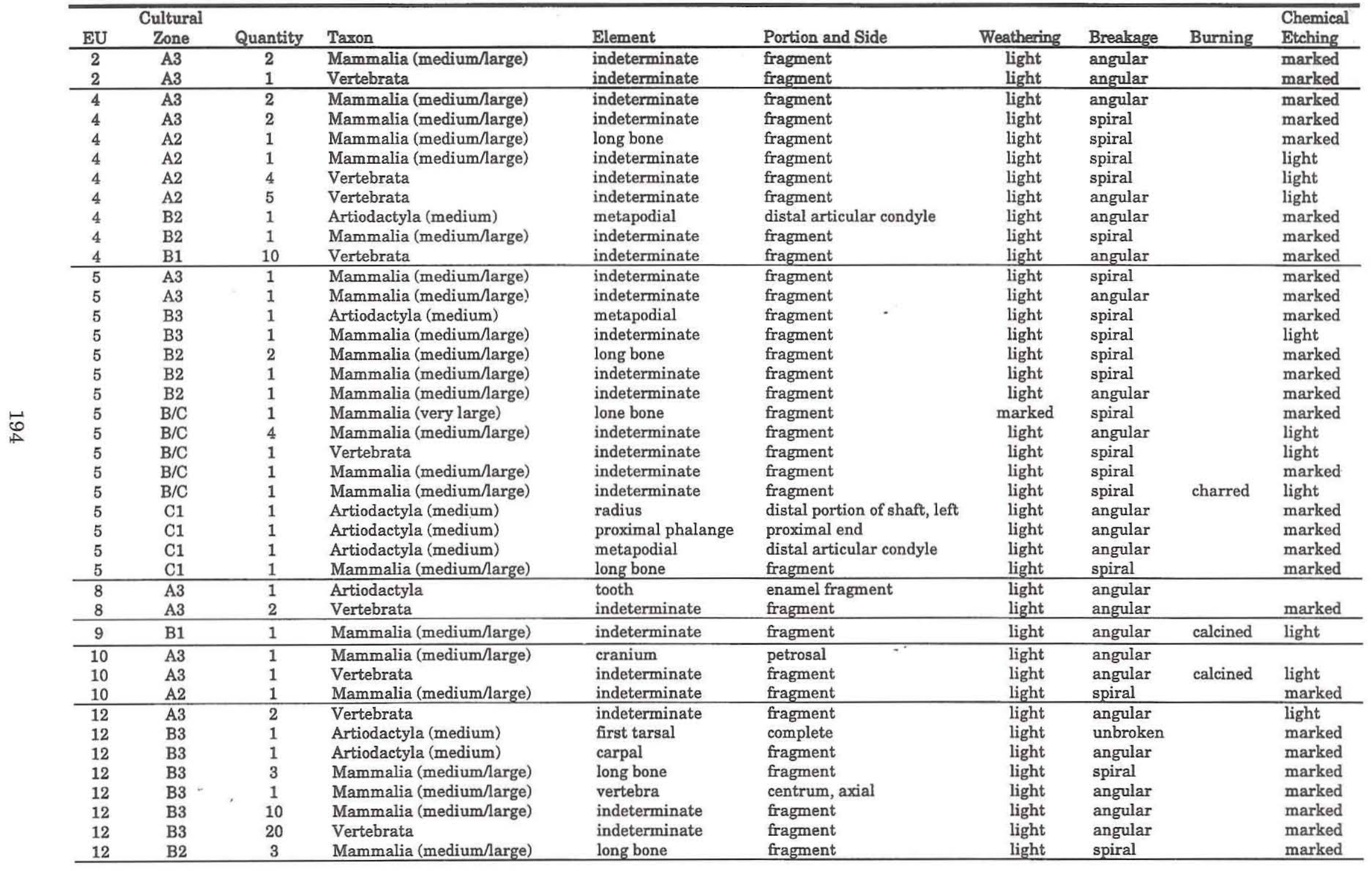


Table 34 continued

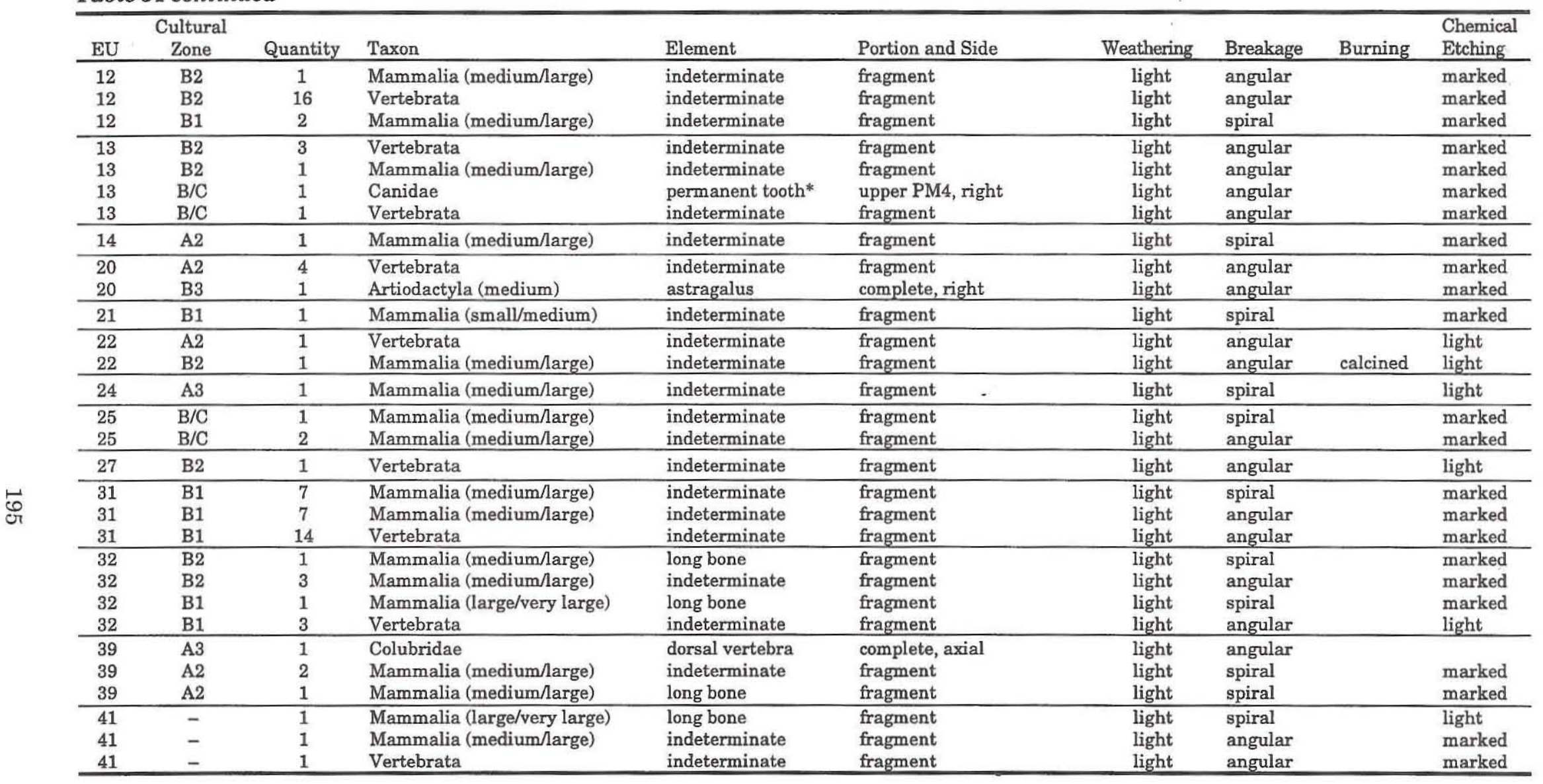


Geoarcheological and Historical Investigations at San Felipe Springs

Table 35. Taxa recovered from 41 VV444

\begin{tabular}{llr}
\hline Taxon & Common Name & Total \\
\hline Vertebrata & vertebrates & 90 \\
Colubridae & Colubrid snakes & 1 \\
Mammalia (small/medium) & rabbit/canid-sized mammals & 1 \\
Mammalia (medium/large) & canid/deer-sized mammals & 75 \\
Mammalia (large/very large) & deer/bison-sized mammals & 2 \\
Mammalia (very large) & bison-sized mammals & 1 \\
Canidae & dogs and relatives & 1 \\
Artiodactyla & even-toed ungulates & 1 \\
Artiodactyla (medium) & deer/pronghorn-sized ungulates & 8 \\
\hline Totals & & 180 \\
\hline
\end{tabular}

taxon recovered, indicate that marrow or grease processing may have occurred at the site. The lack of smaller fauna in the 41VV 444 assemblage is probably due to the chemical dissolution noted above, and is expectable in open sites in the Lower Pecos region. 


\section{APPENDIX E: Analysis of Plant Remains from $41 \mathrm{VV} 444$}

J. Phillip Dering

Center for Ecological Archeology

Texas A\&M University 


\section{INTRODUCTION}

Twenty-eight flotation samples and three macroplant samples were submitted to the Archaeobotany Laboratory of the Center for Ecological Archaeology for identification. This analysis has three objectives: to establish the density and condition of carbonized plant material present in the archeological assemblage at 41VV444; to identify the fuel woods and any plant foods; and to identify woody plants used as fuel in the region and characterize the condition of the wood (and by inference climatic conditions) using electron microscopy.

Changing climatic conditions affect the anatomy of xylem tissue in certain woods. The density, diameter, and shape of vessel elements in the wood of certain species have been shown to increase or decrease with changes in effective moisture. By establishing a database of woody plant images from archeological charcoal throughout south and southwest Texas, scientists may be able to interpret climatic change in the region during the Holocene. Wood charcoal, therefore, has the potential to become a proxy measure of climatic change. Studies of wood charcoal taxonomic frequencies and anatomical change in South Africa have been able to identify climatic trends over the last 10,000 years (Prior 1988; Prior and Price-Williams 1989:472; Scholtz 1986).

\section{METHODS}

\section{Identification}

Each wood charcoal fragment was fractured after scoring. All specimens were first examined using a Nikon dissecting scope at magnifications varying from $8 \mathrm{x}$ to $45 \mathrm{x}$. Preliminary identifications were assigned to each specimen, primarily on the basis of its transverse anatomy. Specimens that exhibited adequate diagnostic features were selected for further study. Each specimen had to possess both early and/or latewood pores and parenchyma, and more than one annual growth ring in transverse section.

Specimens of sufficient size were fractured along the transverse (cross section), radial, and tangential planes. Each specimen was mounted on a $1 \times 1-\mathrm{cm}$ aluminum cylindrical stub using Aquadag colloidal graphite. All stubs were dried in an oven at $55^{\circ} \mathrm{C}$ for 48 hours and then sputter-coated to a thickness of $20 \mathrm{~nm}$ (nanometers) with gold-palladium. Each specimen was examined in a JEOL T330A scanning electron microscope operating at $15-25 \mathrm{kv}$, with magnifications varying from $50 \mathrm{x}$ to $350 \mathrm{x}$.

Each specimen was assigned to a taxonomic category based on anatomical characteristics observed in the transverse, radial, and tangential sections of the carbonized wood. The accuracy and the taxonomic level of each identification is dependent on the size, condition, and abundance of diagnostic characters. In this small, weathered assemblage, the degree of success in identification is quite variable. Many charred wood fragments are not identifiable because the anatomical structure has been destroyed by biological or mechanical degradation. Hunter-gatherers often prefer dead wood picked from trees for use as fuel (Jelenic and van Vegten 1981). Standing dead-wood can be superior fuel wood, but it has often been affected by decompositional processes. Biological degradation, especially if caused by insects or fungi, is often noted in the charred wood of an archeological assemblage. For example, fungal mycelia that grow through the vessel elements of wood can pierce the walls of the vessel elements and the surrounding parenchymatous tissue. Wood affected by these processes often lacks structure or diagnostic elements and is placed in the indeterminate category.

When a wood charcoal specimen exhibits sufficient diagnostic features to be assigned to a specific category, most of the identifications can be made to genus. However, certain woods belonging to different taxa are difficult to distinguish. These woods are often placed in more general categories, such as plant families or wood types that include more than one species, genus, or plant family. A good example is the genus Quercus (oaks), which can be divided into the live oaks and the deciduous oaks.

In the Rio Grande Plains, a common problem in identification is the separation of genera of the legume family (Fabaceae), especially mesquite and the acacias. Several species of acacia grow within the study area along with mesquite. Mesquite, however, is a much more important fuel and food resource than acacia in the deserts of North America (e.g. Dering 1997), and it is important to separate these genera if possible. Mesquite often can be separated from the acacias if the sample is large enough and 
well preserved, with the appropriate diagnostic features exhibited by the specimen. Scanning electron microscopy increases the resolution of any visible features far beyond that achievable by light microscopy, enabling the analyst to obtain more positive identifications than would be available with a binocular stereoscope.

As noted in Table 36, there are several subtle differences between mesquite and catclaw acacia, one of the acacias anatomically very similar to mesquite. The woody trunk and stem of most trees and shrubs are composed of xylem tissue, in contrast to the bark, which is composed of phloem. Wood is the cell wall material of the xylem portion of a woody plant, and all identifications of charred wood are based on patterns observed in the various cell types of the xylem. Most identifications are based on inspection of the transverse (cross) sections of charred wood (xylem). The following brief descriptions highlight the major differences between acacia and mesquite wood.

The primary tissue types visible in transverse sections of wood xylem are rays, parenchyma, fibers, and vessels. Vessels transport water and dissolved materials from the roots to the stems of a plant. Rays transport materials laterally. Obvious differences in the transverse sections of mesquite and acacia xylem are visible in the parenchyma. In xylem, parenchyma cells retain living contents much longer than surrounding cells and usually are recognizable

Table 36. Characteristics of mature mesquite xylem compared to mature Acacia Greggii (catclaw acacia) xylem

\begin{tabular}{|c|c|}
\hline Mesquite (Prosopis glandulosa) & Catclaw acacia (Acacia greggii) \\
\hline I. Wood topography: ring-porous & I. Wood topography: ring-porous \\
\hline $\begin{array}{l}\text { II. Vessels } \\
\text { - late-wood vessel arrangement highly variable: } \\
\text { solitary to clustered in groups of two to seven, } \\
\text { some are arranged in radial pattern up to } \\
\text { seven pores } \\
\text { - spirals absent } \\
\text { - pits rounded and located in rows } \\
\text { - perforations at vessel ends are simple } \\
\text { - inclusions limited to gum in the heartwood }\end{array}$ & $\begin{array}{l}\text { II. Vessels } \\
\text { - late-wood vessel arrangement variable: solitary } \\
\text { to clustered in groups of two to three, some are } \\
\text { arranged in radial pattern, seldom more than } \\
\text { three } \\
\text { - spirals absent } \\
\text { - pits rounded and located in rows } \\
\text { - perforations at vessel ends are simple } \\
\text { - inclusions limited to gum in the heartwood }\end{array}$ \\
\hline $\begin{array}{l}\text { III. Axial parenchyma } \\
\text { - paratracheal to confluent arrangement. } \\
\text { Parenchyma cells comprise about half the } \\
\text { transverse area of the xylem. } \\
\text { - most axial parenchyma cells are fusiform cells } \\
\text { without cross walls }\end{array}$ & $\begin{array}{l}\text { III. Axial parenchyma } \\
\text { - confluent aliform paratracheal arrangement. } \\
\text { Parenchyma cells comprise much less than } \\
\text { half the transverse area of the xylem } \\
\text { - most axial parenchyma cells are fusiform cells } \\
\text { without cross walls }\end{array}$ \\
\hline $\begin{array}{l}\text { IV. Fibers } \\
\text { - Libriform fibers } \\
\text { - modifications: Most exhibit gelatinous } \\
\text { thickening } \\
\text { - constitute much less than half the transverse } \\
\text { area of the xylem }\end{array}$ & $\begin{array}{l}\text { IV. Fibers } \\
\text { - Libriform fibers } \\
\text { - modifications: Most exhibit gelatinous } \\
\text { thickening } \\
\text { - constitute more than half the transverse area } \\
\text { of the xylem }\end{array}$ \\
\hline $\begin{array}{l}\text { V. Wood rays } \\
\text { - type: simple } \\
\text { - arrangement: not storied } \\
\text { - seriation: three-four seriated (three-four cells } \\
\text { wide in tangential section) } \\
\text { - composition: homogenous, all procumbent with } \\
\text { similar shape }\end{array}$ & $\begin{array}{l}\text { V. Wood rays } \\
\text { - type: simple } \\
\text { - arrangement: not storied } \\
\text { - seriation: three-four seriated (three-four cells } \\
\text { wide in tangential section) } \\
\text { - composition: homogenous, all procumbent with } \\
\text { similar shape }\end{array}$ \\
\hline
\end{tabular}

Note: Descriptions are based on Meyer et al. (1974), Wheeler et al. (1989), and reference material. 
as slightly larger cells or as cells with thinner cell walls than the surrounding fibers. Both mesquite and acacia have paratracheal parenchyma-parenchyma located adjacent to vessels. In mesquite, the parenchyma constitutes about 50 percent of the transverse area of the xylem. The parenchyma surrounds the vessels and coalesces in thick bands among the vessels (Meyer et al. 1974). Conversely, acacia exhibits much thinner bands of parenchyma. These are best described as aliform (wing-shaped) bands that only occasionally coalesce among the vessels. The next most obvious difference between these two woody plants is the arrangement of the vessels. The vessels in mesquite often occur in groups of up to seven, whereas the vessels in catclaw acacia seldom occur in groups of more than three, and usually are solitary.

\section{Ecologically Diagnostic . Xylem Analysis (EDXA)}

This type of analysis requires a large charcoal assemblage. Thus the work for this project will contribute to this database but will not result in any conclusions regarding environmental conditions or change at 41VV444. Efforts to accumulate a database of suitable temporal depth and geographic spread by analyzing numerous samples from several archeological sites will allow the assembly of another type of proxy database that can be utilized to infer climate change in the Rio Grande Plains.

It has been demonstrated that the density and size of specific anatomical features in wood differ according to conditions of varying moisture, temperature, and elevation (Baas 1982; Carlquist 1977). Further, wood recovered from an archeological site may reflect the local abundance of certain culturally preferred woods (Shackleton and Prins 1992). These principles have been applied to wood charcoal studies at stratified archeological sites in South Africa by Scholtz (1986) and Tusenius (1989). They have developed EDXA, an approach that measures the size and abundance of multiple anatomical features visible in a transverse section of wood. The size, abundance, and distribution of several anatomical features of wood have been shown to be related to a plant's ability to withstand water stress (Carlquist 1975, 1977). Several indices have been developed based on measurements of these anatomical features. These indices provide evidence of a plant's tolerance to extreme drought or moisture (Scholtz 1986). Although several indices have been developed, the one suggested for use in the study region of the Rio Grande Plains is the vulnerability index developed by Carlquist (1977) and adapted by Sholtz (1986) and Tusenius (1989). It is based on the measurement of xylem vessel diameter and density of xylem vessels in a transverse section of wood. A woody plant species grown under drought conditions contains vessel elements that are comparatively small in diameter and are more densely packed. The same species grown under moister conditions exhibits comparatively large diameter vessel elements and fewer vessels per $\mathrm{mm}^{2}$ in a measured transverse section of the wood (Carlquist 1977; Scholtz 1986). The most expedient means to document this information is to photograph a sample of the wood from different stratigraphic levels of the site using a scanning electron microscope and then take the vessel diameter and vessel density measurements from the photograph (Scholtz 1986; Tusenius 1989). A transparent point-plotter grid is then laid over the photograph, and all anatomical elements contacting a point are counted and measured. This facilitates the methodical assessment of the charcoal piece, as the measurements begin in the upper left corner and continue across and down to the lower right corner of the photograph.

\section{RESULTS AND DISCUSSION}

\section{Identification of the Charcoal Assemblage}

Identification of carbonized macroplant samples appear in Table 37 and counts of the flotation samples are presented in Table 38. Of the 28 flotation samples submitted, 17 contained identifiable plant remains. A total of 378 charcoal fragments weighing $6.75 \mathrm{~g}$ was noted in the 252.2 liters of flotation samples. Density of all charred plant remains in the samples was 1.5 fragments/ liter. The density of seeds/fruits and other edible plant parts density was very low, at 0.008 fragments/liter.

Wood charcoal constitutes the vast majority of the assemblage. The most common wood taxon is honey mesquite, present in 8 ( 29 percent) of the 28 flotation samples. Four other taxa are present in a few samples-guayacan, 
Table 37. Identification of charcoal samples submitted for radiocarbon dating

\begin{tabular}{|c|c|c|c|c|c|}
\hline Provenience & Context & Identification & Part & Count & Weight \\
\hline EU $14(292.04 \mathrm{~m})$ & Zone B burned rock layer & $\begin{array}{l}\text { honey mesquite (Prosopis } \\
\text { glandulosa) }\end{array}$ & wood & 2 & $0.20 \mathrm{~g}$ \\
\hline EU $17(291.60 \mathrm{~m})$ & Feature 11 & huisache (Acacia farnesiana) & wood & 3 & $0.10 \mathrm{~g}$ \\
\hline EU $24(292.20 \mathrm{~m})$ & base of Zone A & huisache (Acacia farnesiana) & wood & 24 & $0.20 \mathrm{~g}$ \\
\hline
\end{tabular}

Table 38. Counts from flotation samples

\begin{tabular}{|c|c|c|c|c|c|c|}
\hline \multirow{2}{*}{$\begin{array}{l}\text { Sample } \\
\text { Number }\end{array}$} & \multicolumn{3}{|c|}{ Excavation } & \multirow[b]{2}{*}{ Plant Part } & \multirow[b]{2}{*}{ Count } & \multirow{2}{*}{ Weight (g) } \\
\hline & Context & Unit & Common Name & & & \\
\hline 4 & Feature 3 & 6 & $* *$ & - & - & - \\
\hline 6 & Feature 3 & 6 & honey mesquite & wood & 18 & 0.30 \\
\hline 12 & Feature 3 & 18 & $* *$ & - & - & - \\
\hline 13 & Feature 3 & 18 & $* *$ & - & - & - \\
\hline 14 & Feature 3 & 18 & honey mesquite & wood & 13 & 0.10 \\
\hline 28 & Feature 3 & 7 & honey mesquite & wood & 10 & 0.10 \\
\hline 29 & Feature 3 & 7 & honey mesquite & wood & 5 & 0.10 \\
\hline 30 & Feature 3 & 7 & honey mesquite & wood & 3 & 0.10 \\
\hline 7 & Feature 5 & 6 & *** & - & - & - \\
\hline 21 & Feature 11 & 17 & green condalia & wood & 1 & 0.10 \\
\hline 22 & Feature 11 & 17 & $* *$ & - & - & - \\
\hline 23 & Feature 11 & 17 & indeterminate & wood & 26 & 0.30 \\
\hline 24 & Feature 11 & 17 & huisache & wood & 24 & 0.20 \\
\hline 27 & Feature 11 & 16 & indeterminate & root & 2 & 0.20 \\
\hline 27 & Feature 11 & 16 & guayacan & wood & 3 & 0.10 \\
\hline 31 & Feature 12 & 7 & honey mesquite & wood & 121 & 0.60 \\
\hline 32 & Feature 12 & 7 & honey mesquite & wood & 26 & 0.20 \\
\hline 33 & Feature 12 & 19 & hackberry & wood & 12 & 0.10 \\
\hline 33 & Feature 12 & 19 & honey mesquite & wood & 83 & 3.70 \\
\hline 2 & Zone B & 34 & indeterminate & wood & 1 & 0.05 \\
\hline 3 & Zone B* & 6 & guayacan & wood & 1 & 0.05 \\
\hline 5 & Zone B* & 40 & $* *$ & - & - & - \\
\hline 11 & Zone B* & 18 & $* *$ & - & - & - \\
\hline 18 & Zone B* & 17 & $* *$ & - & - & - \\
\hline 19 & Zone $\mathrm{B}^{*}$ & 15 & indeterminate & wood & 3 & 0.10 \\
\hline 20 & Zone B* & 26 & $* *$ & & - & - \\
\hline 26 & Zone B* & 27 & littleleaf walnut & nut & 1 & 0.05 \\
\hline 26 & Zone B* & 27 & inderterminate & $\begin{array}{l}\text { fragment } \\
\text { wood }\end{array}$ & 3 & 0.10 \\
\hline 15 & Zone $\mathrm{C}^{*}$ & 18 & $* *$ & - & - & - \\
\hline 17 & Zone C* & 30 & $* *$ & - & - & - \\
\hline 35 & Zone $\mathrm{C}^{*}$ & 26 & huisache & wood & 22 & 0.20 \\
\hline Totals & & & & & 378 & 6.75 \\
\hline $\begin{array}{l}* \text { Collecte } \\
* * \text { No carb }\end{array}$ & $\begin{array}{l}\text { m burned } \\
\text { ed plant re }\end{array}$ & rer & & & & \\
\hline
\end{tabular}


condalia, huisache, and hackberry. One fragment of littleleaf walnut nutshell and a single fragment of storage root were noted, but the latter could not be identified.

\section{Sample Descriptions}

Feature 3. Eight flotation samples were processed from this feature. No seeds, fruits, or edible root fragments were noted. Honey mesquite wood charcoal is the only plant material identified.

Feature 5. A single flotation sample from this feature did not yield identifiable carbonized plant remains.

Feature 11. Five flotation samples were processed from this feature. One unidentified storage root fragment was noted, and three wood types-guayacan, condalia, and huisache acacia-were identified.

Feature 12. Three flotation samples were processed from this feature. A relatively large quantity of mesquite charcoal, 242 fragments weighing $4.6 \mathrm{~g}$, was recovered. The mesquite from this feature accounts for 64 percent of all the counted charred plant material from the flotation samples. Charred hackberry wood was also identified.

Non feature samples. Eleven flotation samples from general contexts were analyzed. The yield from these samples was low compared to the features. Six of these samples contained no identifiable plant remains. Sample 26 from Zone B contained a single shell fragment of littleleaf walnut, and Sample 3 from Zone B contained a single fragment of guayacan wood charcoal. Sample 35 from Zone C contained 22 fragments of huisache wood charcoal.

\section{Ecologically Diagnostic Xylem Analysis (EDXA)}

This analysis, which is preliminary and intended to contribute to a larger database, is limited to the honey mesquite charcoal. Honey mesquite has the widest distribution of any commonly occurring tree in the region. It occurs from the post oak savannah in Brazos and Grimes Counties to the Chihuahuan desert in New Mexico, northward into the Cut Plains and to the scarp of the Llano Estacado. Measurements of vessel diameters and density in the xylem of mesquite charcoal recovered from various archeological sites are presented in Table 39.

These EDXA results demonstrate clear differences in the anatomy of mesquite collected in its eastern range as compared to mesquite collected from its southwestern range in Val Verde County. For example, the diameter of xylem vessels is larger, and the density of the xylem vessels is lower in mesquite collected from Brazos County, with an average annual precipitation of approximately 39 inches. This

Table 39. EDXA measurements of reference mesquite and archeological mesquite charcoal from 41VV444 and 41ZP364.

\begin{tabular}{|c|c|c|c|}
\hline Sample Type, Location, and Number & $\begin{array}{c}\text { Mean Vessel } \\
\text { Diameter }(\mathrm{mm})\end{array}$ & $\begin{array}{l}\text { Vessel Density } \\
\left(\text { vessels } / \mathrm{mm}^{2} \text { ) }\right.\end{array}$ & $\begin{array}{l}\text { Vulnerability Index } \\
\text { (MVESD/NVES)* }\end{array}$ \\
\hline Reference, Brazos County (\#207) & 0.09 & 11.1 & 0.0081 \\
\hline Reference, Val Verde County (\#207) & 0.048 & 27 & 0.0018 \\
\hline 41VV444 (Flotation Sample 30) & 0.060 & 24 & 0.0025 \\
\hline 41VV444 (Flotation Sample 30) & 0.052 & 23 & 0.0023 \\
\hline 41VV444 (Flotation Sample 30) & 0.055 & 27 & 0.0020 \\
\hline 41VV444 (Flotation Sample 30) & 0.057 & 24 & 0.0024 \\
\hline 41VV444 (EU 14, Charcoal Sample) & 0.037 & 33 & 0.0011 \\
\hline $41 Z$ P364 $(155-1)^{* *}$ & 0.064 & 18.2 & 0.0035 \\
\hline $41 \mathrm{ZP} 364(409-3)^{* *}$ & 0.061 & 17.8 & 0.0034 \\
\hline $41 Z \mathrm{ZP} 64(447)^{* *}$ & 0.049 & 21 & 0.0023 \\
\hline $41 Z$ P364 (448)** & 0.045 & 23 & 0.0020 \\
\hline $41 \mathrm{ZP} 364(449)^{* *}$ & 0.058 & 21 & 0.0028 \\
\hline
\end{tabular}


results in a much higher vulnerability index, indicating that the eastern mesquite has adapted to a moister precipitation regime. Conversely, the Val Verde County and Zapata County mesquite wood fragments exhibit much smaller diameter vessels that occur in a much higher density, generating a lower vulnerability index and indicating a plant much better adapted to drought (Carlquist 1975, 1977; Scholtz 1986). The sample from Zone B of Excavation Unit 14 at 41VV444 has the smallest index of any of the mesquite thus far examined.

Although the sample size is too small to yield definitive results, the analysis does suggest that EDXA may work. Mesquite may seem an unlikely subject because it has a reputation for being able to tap into ground water, but recent research suggests that it is sensitive to fluctuations in precipitation (Archer 1990, 1995; Steve Archer, personal communication 1998)..The perception that mesquite does not react to changing climatic conditions, or that it does not respond to fluctuations in precipitation, is a demonstrated misconception. Further work is planned on living populations of mesquite in Brazos, Jim Wells, El Paso, and Val Verde Counties. The examination of more wood charcoal from archeological sites in the Rio Grande Plains will add temporal depth to the database. What should emerge is a reasonably reliable proxy measure for climatic change that will complement other such paleoenvironmental indicators available in the region.

\section{SUMIMARY}

Twenty-eight flotation samples and three macroplant samples were identified and analyzed by means of light microscopy and scanning electron microscopy. Because two of the most abundant woody plant groups in the Rio Grande Plains are mesquite (Prosopis spp.) and the acacias (Acacia spp.), a method for separating mesquite and closely related acacia wood was detailed. Identifications of fuel wood include guayacan, huisache, condalia, and mesquite. A small fragment of littleleaf walnut was noted from a nonfeature context in Zone B, and an unidentifiable storage root fragment was identified from Feature 11. The identifications noted that mesquite was a preferred fuel wood in Features 3 and 12. Feature 11 contained a mix of huisache and condalia wood and an unidentifiable hardwood. The identifications suggest a riparian woodland of mesquite and huisache bordering San Felipe Creek, similar to shrubby woodlands along nearby San Pedro Creek and Sacatosa Creek in Val Verde County.

Ecologically Diagnostic Xylem Analysis (EDXA) was introduced to begin the construction of a database for the assessment of climatic change in the region via the examination of wood charcoal. The work is preliminary, but the analysis of both reference material and archeological material demonstrates that the method is promising. Reference mesquite collected from Brazos County, an area with 39 inches average annual rainfall, and Val Verde County, an area with 17 inches average annual rainfall, was examined. The vulnerability index was calculated for each and was found to be twice as high for the material collected from the moister precipitation regime. Five charcoal fragments, one from Zone B and four from Feature 3 , were analyzed, from which it was determined that the vulnerability index could be calculated for the archeological material. Results suggest that changes in the wood anatomy of mesquite may have occurred at 41 VV444, but this cannot be ascertained until the elasticity of modern mesquite anatomy is studied more thoroughly and the causes of these changes are determined.

Two conclusions may be drawn from this study. First, mesquite and its resources, both wood and fruit, were available during the occupation at 41VV444. Second, changes in mesquite wood anatomy in the archaeological record can be detected. If the anatomical changes reflect changes in effective moisture, then EDXA of mesquite wood may provide a useful proxy indicator of climatic change in the region. It is encouraging for the implementation of EDXA that mesquite wood is proving to be very common at open sites across the Rio Grande Plains and the Lower Pecos region. 


\section{REFERENCES}

Archer, Steve

1990 Development and Stability of Grass/Woody Mosaics in a Subtropical Savanna Parkland, Texas, U.S.A. Journal of Biogeography 17:453-462.

1995 Tree-grass Dynamics in a Prosopis-Thornscrub Savannah Parkland: Reconstructing the Past and Predicting the Future. Ecoscience 2(1):84-99.

Baas, P.

1982 Systematic, Phylogenetic, and Ecological Wood Anatomy-History and Perspectives. In New Perspectives in Wood Anatomy, edited by P. Baas, pp. 23-58. Martinus Nijhoff: The Hague.

Carlquist, S.

1975 Ecological Strategies of Xylem Evolution. University of California Press, Berkeley.

1977 Ecological Factors in Wood Evolution: A Floristic Approach. American Journal of Botany 64:887896.

Dering, Phil

1997 In Search of the Lost Legume: Identifying and Plugging Data Gaps in the Paleodiet of Archaic Period Hunter-Gatherers Living at the Edge of the Southern Plains. Paper Presented at the 68th Annual Meeting of the Texas Archaeological Society, November 1, 1997.

1998 Carbonized Plant Remains from 41ZP364: Identification and Analysis Using Scanning Electron Microscopy. Unpublished manuscript submitted to TRC-Mariah Associates, Inc., Austin, Texas.

Jelenic, N. E., and J. A. van Vegten

1981 A Pain in the Neck: The Firewood Situation in South-Western Kgatlen, Botswana. NIR Research Note 5.: Gabrone, Botswana.
Meyer, R. E., H. L. Morton, R. H. Haas, E. D. Robison, and T. E. Riley

1974 Morphology and Anatomy of Honey Mesquite. Technical Bulletin No. 1423. Agricultural Research Service, U.S. Department of Agriculture, Washington, D.C.

Prior, Julia

1988 Methods Used in Charcoal Analysis and the Relationship Between Woods Used in Archaeological Times and the Present Fuelwod Crisis. In, Scanning Electron Microscopy in Archaeology, edited by Sandra L. Olsen, pp. 187-202. BAR International Series 452. Oxford, England.

Prior, Julia, and D. Price-Williams

1989 Investigation of Climatic Change in the Holocene Epoch Using Archaeological Charcoal from Swaziland, Southern Africa. Journal of Archaeological Science 12:457-475.

Scholtz, Anton

1986 Palynological and Paleobotanical Studies in the Southern Cape. Masters thesis. University of Stellenbosch.

Shackleton, C. M., and F. Prins

1992 Charcoal Analysis and the "Principle of Least Effort". Journal of Archaeological Science 19:631-637.

Tusenius, Madelon

1989 Charcoal Analytical Studies in the North-Eastern Cape, South Africa. South African Archaeological Society Goodwin Series 6:77-83.

Wheeler, E. A., P. Baas, and P. E. Gasson

1989 IAWA List of Microsocopic Features for Hardwood Identification. International Association of Wood Anatomists at the Rijksherbarium. Leiden, The Netherlands. 



\section{APPENDIX F: Provenience of Artifacts Recovered from 411 VV444}



Table 40. Summary of all prehistoric artifacts recovered from 41 VV444

\begin{tabular}{lrrrr}
\hline & Stone & & \multicolumn{2}{c}{ Modified } \\
Location & Artifacts & Ceramics & Shell & Totals \\
\hline Area 1 Excavation Block (Units 1-40) & 2,562 & 115 & 1 & 2,678 \\
Area 1 Nonexcavation Block (Units 41-42) & 22 & - & - & 22 \\
Area 2 Excavation Units (Units 43-51) & 151 & 8 & - & 159 \\
Area 7 Excavation Unit (Unit 52) & 31 & - & - & 31 \\
Shovel Tests & 46 & - & - & 46 \\
Surface & 2 & - & - & 2 \\
Backhoe Trenches & 2 & 1 & - & 3 \\
\hline Totals & 2,816 & 124 & 1 & 2,941 \\
\hline
\end{tabular}




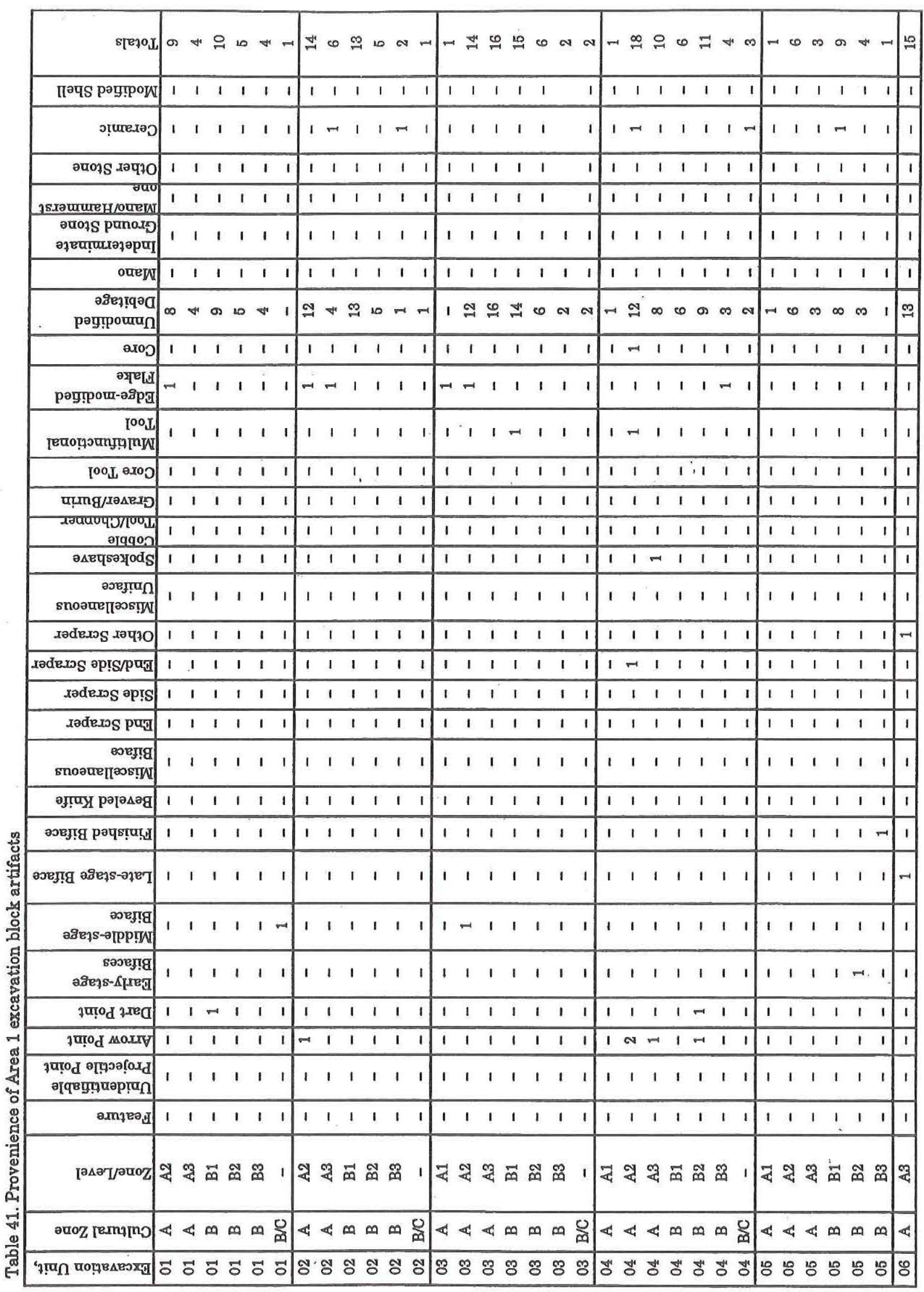




\begin{tabular}{|c|c|c|c|c|c|c|c|c|c|c|c|c|c|c|c|c|c|c|c|c|c|c|c|c|c|c|c|c|c|c|c|c|c|}
\hline 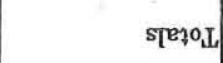 & - & $\stackrel{N}{\sim}$ & r & - & $\sim$ & $m$ & 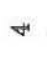 & -1 & N & $\infty$ & 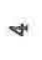 & $\rightarrow$ & $N$ & $m$ & N & a & $\mathscr{M}$ & న & $\stackrel{ \pm}{-1}$ & ㄱ & $r c$ & $\infty$ & 국 & $\vec{\infty}$ & $r$ & $\infty$ & $\infty \sim$ & $\infty$ & 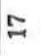 & a & $N$ & $* \propto$ & $\stackrel{m}{\sim}$ \\
\hline IIәपS pәу!роW & 1 & 1 & 1 & 1 & 1 & 1 & 1 & 1 & 1 & 1 & 1 & 1 & 1 & 1 & 1 & 1 & 1 & 1 & 1 & 1 & - & 1 & 1 & 1 & 1 & 1 & 11 & 1 & 1 & 1 & 1 & 11 & 1 \\
\hline วุ̣uาxอว & 1 & 1 & 1 & 1 & 1 & 1 & 1 & 1 & 1 & 1 & 1 & 1 & 1 & 1 & 1 & 1 & o & $\infty$ & 1 & - & 1 & 1 & $\Rightarrow$ & 1 & 1 & $r$ & 11 & 1 & 1 & 1 & 1 & 11 & $\omega$ \\
\hline әх0)ड хәपวО & 1 & 1 & 1 & 1 & 1 & 1 & 1 & 1 & 1 & 1 & 1 & 1 & 1 & 1 & 1 & 1 & 1 & 1 & 1 & 1 & 1 & 1 & 1 & 1 & 1 & 1 & 11 & 1 & 1 & 1 & 1 & $\begin{array}{ll}1 & 1\end{array}$ & 1 \\
\hline 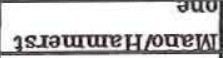 & 1 & 1 & 1 & 1 & 1 & 1 & 1 & 1 & 1 & 1 & 1 & 1 & 1 & 1 & 1 & 1 & 1 & 1 & 1 & 1 & 1 & 1 & 1 & 1 & 1 & 1 & 11 & 1 & 1 & 1 & 1 & $\begin{array}{ll}1 & 1\end{array}$ & 1 \\
\hline 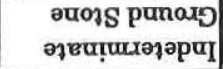 & 1 & 1 & 1 & 1 & 1 & 1 & 1 & 1 & 1 & 1 & 1 & 1 & 1 & 1 & 1 & 1 & 1 & 1 & 1 & 1 & 1 & 1 & 1 & 1 & 1 & 1 & 11 & 1 & 1 & 1 & 1 & 11 & 1 \\
\hline ouEW & 1 & 1 & 1 & 1 & 1 & 1 & 1 & 1 & 1 & 1 & 1 & 1 & 1 & 1 & 1 & 1 & 1 & 1 & 1 & 1 & 1 & 1 & 1 & 1 & 1 & 1 & 11 & 1 & 1 & 1 & 1 & $\begin{array}{ll}1 & 1\end{array}$ & 1 \\
\hline 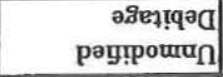 & 0 & 0 & $N$ & 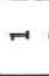 & $N$ & $\infty$ & 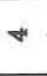 & -1 & o & $N$ & $\nabla$ & $r$ & N & $r$ & $\mathbf{N}$ & -1 & $\infty$ & $\stackrel{\infty}{\sigma}$ & ศ & $\infty$ & $0 \circ$ & & & $\vec{\infty}$ & $r$ & $\omega$ & $\infty \sim$ & & 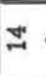 & a & $r$ & $\forall N$ & 1 \\
\hline $2 x 00$ & 1 & $\pi$ & 1 & 1 & 1 & 1 & 1 & 1 & 1 & 1 & 1 & 1 & 1 & 1 & 1 & 1 & 1 & 1 & 1 & 1 & 1 & 1 & 1 & 1 & 1 & 1 & 11 & 1 & 1 & 1 & 1 & $\begin{array}{ll}1 & 1\end{array}$ & 1 \\
\hline 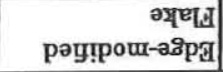 & 1 & 1 & 1 & 1 & 1 & 1 & 1 & 1 & .1 & 1 & 1 & 1 & 1 & 1 & 1 & $\rightarrow$ & $\infty$ & 1 & 1 & $\rightarrow$ & 1 & 1 & N & 1 & 1 & 1 & 11 & 1 & 1 & 1 & 1 & $\begin{array}{ll}1 & 1\end{array}$ & N \\
\hline 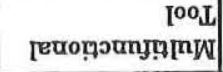 & 1 & 1 & 1 & 1 & 1 & I & 1 & 1 & 1 & -1 & 1 & 1 & 1 & 1 & 1 & 1 & I & 1 & 1 & 1 & 1 & 1 & 1 & 1 & 1 & 1 & 11 & 1 & 1 & 1 & 1 & $\begin{array}{ll}1 & 1\end{array}$ & 1 \\
\hline [00工, 2x00] & 1 & 1 & 1 & 1 & 1 & 1 & 1 & 1 & 1 & 1 & 1 & 1 & 1 & 1 & 1 & 1 & 1 & 1 & 1 & 1 & 1 & 1 & 1 & 1 & $; t$ & 1 & 11 & 1 & 1 & 1 & 1 & $\begin{array}{ll}1 & 1\end{array}$ & 1 \\
\hline 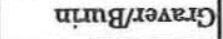 & 1 & 1 & 1 & 1 & 1 & 1 & 1 & 1 & 1 & 1 & 1 & 1 & 1 & 1 & 1 & 1 & 1 & 1 & 1 & 1 & 1 & 1 & 1 & 1 & 1 & 1 & 11 & 1 & 1 & 1 & 1 & $\begin{array}{ll}1 & 1\end{array}$ & 1 \\
\hline 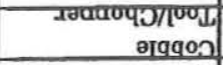 & 1 & 1 & 1 & 1 & I & I & I & 1 & 1 & 1 & 1 & 1 & 1 & 1 & I & 1 & 1 & 1 & 1 & 1 & 1 & 1 & 1 & 1 & 1 & 1 & 11 & 1 & 1 & 1 & 1 & $\begin{array}{ll}1 & 1\end{array}$ & 1 \\
\hline 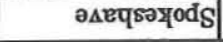 & 1 & 1 & 1 & 1 & I & 1 & 1 & 1 & 1 & 1 & 1 & 1 & 1 & 1 & 1 & 1 & 1 & 1 & 1 & 1 & 1 & 1 & 1 & 1 & 1 & 1 & 11 & 1 & 1 & 1 & 1 & 11 & 1 \\
\hline 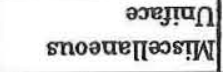 & 1 & 1 & 1 & 1 & 1 & 1 & 1 & 1 & 1 & 1 & 1 & 1 & 1 & 1 & 1 & 1 & 1 & 1 & 1 & 1 & 1 & 1 & -1 & 1 & 1 & 1 & 11 & 1 & 1 & 1 & 1 & $\begin{array}{ll}1 & 1\end{array}$ & 1 \\
\hline xәdexs дәपэО & 1 & 1 & 1 & 1 & 1 & 1 & 1 & 1 & 1 & 1 & 1 & 1 & 1 & 1 & 1 & 1 & 1 & 1 & 1 & 1 & 1 & 1 & 1 & 1 & 1 & 1 & 11 & 1 & 1 & 1 & 1 & 11 & 1 \\
\hline xəđexas өp!S/puप्त्र & 1 & 1 & 1 & 1 & 1 & 1 & 1 & 1 & 1 & 1 & 1 & 1 & 1 & 1 & 1 & 1 & 1 & 1 & $\rightarrow$ & 1 & 1 & 1 & 1 & 1 & 1 & 1 & 11 & 1 & 1 & 1 & 1 & 11 & 1 \\
\hline xadexs әp!s & 1 & 1 & 1 & 1 & 1 & 1 & 1 & 1 & 1 & 1 & 1 & 1 & 1 & 1 & I & 1 & 1 & 1 & I & 1 & 1 & 1 & 1 & 1 & 1 & 1 & 11 & 1 & 1 & 1 & 1 & 11 & 1 \\
\hline xәdexगs pप्ष & -1 & 1 & 1 & 1 & 1 & 1 & 1 & 1 & 1 & 1 & 1 & 1 & 1 & 1 & 1 & 1 & 1 & 1 & 1 & 1 & 1 & 1 & 1 & 1 & 1 & 1 & 11 & 1 & 1 & 1 & 1 & $\begin{array}{ll}1 & 1\end{array}$ & 1 \\
\hline 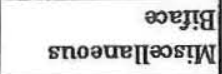 & 1 & $\rightarrow$ & 1 & 1 & 1 & 1 & 1 & 1 & 1 & 1 & 1 & 1 & 1 & 1 & 1 & 1 & 1 & 1 & 1 & 1 & 1 & 1 & $\infty$ & 1 & 1 & 1 & 11 & 1 & -1 & 1 & 1 & 11 & -1 \\
\hline 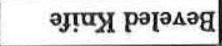 & 1 & 1 & 1 & 1 & 1 & 1 & 1 & 1 & 1 & 1 & 1 & 1 & 1 & 1 & 1 & 1 & 1 & 1 & 1 & 1 & 1 & & 1 & 1 & 1 & 1 & 11 & 1 & 1 & 1 & 1 & 11 & 1 \\
\hline 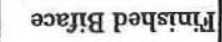 & 1 & 1 & 1 & 1 & 1 & 1 & 1 & 1 & 1 & 1 & 1 & 1 & 1 & 1 & 1 & 1 & 1 & 1 & 1 & 1 & 1 & 1 & 1 & 1 & 1 & 1 & 11 & 1 & 1 & 1 & 1 & 11 & -1 \\
\hline 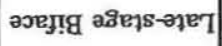 & 1 & $r$ & 1 & 1 & 1 & 1 & 1 & 1 & 1 & 1 & 1 & 1 & 1 & 1 & 1 & 1 & 1 & 1 & 1 & 1 & 1 & & 1 & 1 & 1 & 1 & 11 & 1 & 1 & 1 & 1 & 11 & 1 \\
\hline 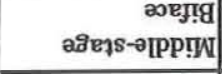 & 1 & 1 & 1 & 1 & 1 & 1 & 1 & 1 & I & 1 & 1 & 1 & 1 & 1 & 1 & 1 & 1 & 1 & $\rightarrow$ & $\rightarrow$ & 1 & I & 1 & 1 & 1 & 1 & 11 & I & 1 & 1 & 1 & 11 & 1 \\
\hline 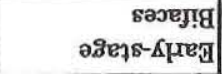 & 1 & 1 & 1 & 1 & 1 & 1 & 1 & 1 & 1 & 1 & 1 & 1 & 1 & 1 & 1 & 1 & 1 & 1 & 1 & 1 & 1 & 1 & 1 & 1 & 1 & 1 & 11 & 1 & 1 & 1 & 1 & 1.1. & 1 \\
\hline эụ़d भred & 1 & 1 & 1 & 1 & 1 & 1 & 1 & 1 & 1 & 1 & 1 & 1 & 1 & 1 & 1 & 1 & 1 & 1 & 1 & -1 & 1 & -1 & 1 & 1 & 1 & - & 11 & 1 & $\rightarrow$ & 1 & 1 & 11 & 1 \\
\hline jụ़ d Maury & 1 & 1 & 1 & 1 & 1 & 1 & 1 & 1 & 1 & 1 & 1 & 1 & 1 & 1 & 1 & 1 & -1 & -1 & 1 & 1 & 1 & 1 & 1 & 1 & 1 & 1 & 11 & 1 & $\rightarrow$ & 1 & 1 & 11 & 1 \\
\hline 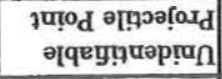 & 1 & 1 & 1 & I & 1 & 1 & 1 & 1 & I & 1 & 1 & 1 & 1 & 1 & I & 1 & 1 & 1 & 1 & 1 & 1 & 1 & 1 & 1 & I & 1 & 11 & & 1 & 1 & 1 & 11 & 1 \\
\hline 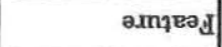 & o & $\alpha$ & 1 & $\infty$ & 10 & 1 & 1 & 1 & 1 & 1 & $N$ & 1 & 1 & $\stackrel{\sim}{\sim}$ & $\infty$ & 1 & 1 & 1 & 1 & 1 & 1 & 1 & & 1 & 1 & 1 & 11 & । & 1 & 1 & 1 & 11 & 1 \\
\hline 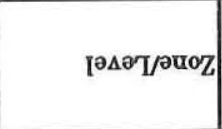 & $\ddot{m}$ & ๓ิ & ๓̊ & 1 & 1 & 1 & 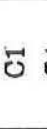 & ठี่ & $\ddot{4}$ & $\vec{m}$ & 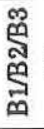 & ๓ี & ๓ & 1 & 1 & ঠ๋ & ชै & æृ & $\vec{\oplus}$ & ๓ิ & $\mathscr{m}$ & 1 & 4 & क्ष & 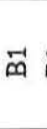 & ๓ี ๕ & m 1 & & ชุ & $\dddot{m}$ & $\ddot{\infty}$ & ๓゙ ๓ุ & $\frac{9}{4}$ \\
\hline әuoZ [थाn][ก] & $m$ & $m$ & $m$ & $m$ & $m$ & एँ & 0 & 0 & 4 & $m$ & & m & 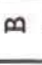 & $\infty$ & $m$ & 0 & 4 & $\varangle$ & $m$ & m & $m \frac{c}{2}$ & & & 4 & $m$ & $m$ & ๓ & & 4 & 4 & $m$ & $m \infty$ & $<$ \\
\hline ‘ & $\varnothing$ & $\dddot{\circ}$ & 8 & $\mathscr{8}$ & $\mathscr{8}$ & $\mathscr{0}$ & $\mathscr{0}$ & 8 & 5 & 5 & 5 & 5 & 5 & 5 & 5 & 5 & 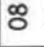 & : & 옹 & ஜ & : & 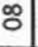 & 용 & 8 & 8 & 8 & 웅 응 & 8 & & 으 & $ㅇ$ & 으 으 & $=$ \\
\hline
\end{tabular}




\begin{tabular}{|c|c|c|c|c|c|c|c|c|c|c|c|c|c|c|c|c|c|c|c|c|c|c|c|c|c|c|c|c|c|c|c|c|c|}
\hline or & & & है & & 宓 & 苾 & & if & & $\stackrel{\vec{A}}{ }$ & & $\vec{\omega}$ & $\vec{\omega}$ & & $\vec{\omega}$ & & c & $\vec{\omega}$ & & in & N & & $\vec{N}$ & & $\mathbb{N}$ & & & & 涪 & ま & $\vec{\theta} \bullet$ & $\stackrel{\bullet}{\bullet}$ & Brcavation Unit, \\
\hline 四 & & & $\infty$ & $>$ & o & & & $\infty$ & & $>$ & & 0 & & 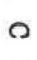 & $\omega$ & $\theta$ & $\varpi$ & $>$ & & $\Omega$ & & & $\varpi$ & 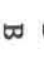 & $\infty$ & & $\rightarrow>$ & & 0 & $\infty$ & $\infty$ & & Cultural Zone \\
\hline 1 & 怘 & & 幽 & & $£$ & & & 䍐 & 四 & E & & 1 & \& & 오 & ஜ્ఱ & প్య & & E & & กิ & 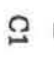 & । & 四 & 㤈 & 四 & $\rightleftarrows$ & $R$ & & న & 愢 䍐 & 정 & $\rightleftarrows$ & Zone/Level \\
\hline I & 1 & $\infty$ & $\infty$ & & 0 & 1 & 1 & $\infty$ & 1 & 1 & 1 & $\vec{\omega}$ & $\omega$ & $\omega$ & 1 & $\infty$ & 1 & 1 & 1 & 1 & 1 & 1 & 1 & 1 & 1 & 1 & 11 & & 1 & 11 & 1 & & Feature \\
\hline 1 & 1 & & 1 & 1 & 1 & 1 & 1 & 1 & 1 & 1 & 1 & 1 & 1 & 1 & 1 & 1 & 1 & 1 & 1 & 1 & 1 & 1 & 1 & 1 & 11 & 1 & 11 & & 1 & 11 & 1 & & $\begin{array}{l}\text { Unidentifiable } \\
\text { Projectile Point }\end{array}$ \\
\hline 1 & 1 & 1 & 1 & 1 & 1 & 1 & 1 & 1 & 1 & 1 & 1 & 1 & 1 & 1 & 1 & 1 & 1 & 1 & 1 & 1. & 1 & 1 & 1 & 1 & 11 & 1 & 11 & & 1 & 11 & 1 & $\mapsto$ & Arrow Point \\
\hline 1 & 1 & & 1 & 1 & 1 & 1 & 1 & 1 & 1 & 1 & 1 & 1 & 1 & 1 & 1 & 1 & $\sim$ & 1 & 1 & 1 & 1 & 1 & 1 & 1 & 11 & 1 & 11 & & 1 & $\rightarrow 1$ & 1 & 1 & Dart Point \\
\hline 1 & 1 & & 1 & 1 & 1 & 1 & 1 & 1 & 1 & 1 & 1 & 1 & 1 & 1 & 1 & 1 & 1 & 1 & 1 & 1 & 1 & 1 & 1 & 1 & 11 & 1 & 11 & & & 11 & 1 & & \begin{tabular}{|l} 
Early-stage \\
Bifaces
\end{tabular} \\
\hline 1 & 1 & 1 & 1 & 1 & 1 & 1 & 1 & 1 & 1 & 1 & 1 & No & 1 & 1 & 1 & 1 & 1 & 1 & 1 & 1 & 1 & 1 & 1 & 1 & 11 & 1 & 11 & & & 11 & 1 & 1 & $\begin{array}{l}\text { Middle-stage } \\
\text { Biface }\end{array}$ \\
\hline 1 & 1 & r & 1 & 1 & 1 & 1 & 1 & 1 & 1 & 1 & 1 & 1 & 1 & 1 & 1 & 1 & $\mapsto$ & 1 & 1 & 1 & 1 & 1 & 1 & 1 & 11 & 1 & 11 & & 1 & 11 & 1 & & Late-stage Biface \\
\hline 1 & 1 & 1 & 1 & 1 & 1 & 1 & 1 & 1 & 1 & 1 & 1 & 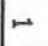 & 1 & 1 & 1 & 1 & 1 & 1 & 1 & 1 & 11 & । & 1 & 1 & 11 & 1 & 11 & & 1 & 11 & 1 & & Finished Biface \\
\hline 1 & 1 & 1 & 1 & 1 & 1 & 1 & 1 & 1 & 1 & 1 & 1 & 1 & 1 & 1 & 1 & 1 & 1 & 1 & 1 & 1 & 11 & 1 & 1 & 1 & 11 & 1 & 11 & & 1 & 11 & 1 & 1 & Beveled Knife \\
\hline 1 & 1 & 1 & 1 & 1 & 1 & 1 & 1 & 1 & 1 & 1 & 1 & 1 & 1 & 1 & 1 & 1 & 1 & 1 & & 1 & 11 & 1 & 1 & 1 & 11 & 1 & 11 & & 1 & 11 & 1 & 1 & $\begin{array}{l}\text { Miscellaneous } \\
\text { Biface }\end{array}$ \\
\hline 1 & 1 & 1 & 1 & 1 & 1 & 1 & 1 & 1 & 1 & 1 & 1 & 1 & 1 & 1 & 1 & 1 & 1 & 1 & 1 & 1 & 11 & 1 & 11 & 1 & 11 & 1 & $\sim 1$ & & 1 & 11 & 1 & 1 & End Scraper \\
\hline 1 & 1 & 1 & 1 & 1 & 1 & 1 & 1 & 1 & 1 & 1 & 1 & 1 & 1 & 1 & 1 & 1 & 1 & 11 & 1 & 1 & 11 & 1 & 1 & 1 & 11 & 1 & 11 & & 1 & 11 & 1 & 1 & Side Scraper \\
\hline 1 & 1 & 1 & 1 & 1 & 1 & 1 & 1 & 1 & 1 & 1 & 1 & 1 & 1 & 1 & 1 & 1 & 1 & 11 & 1. & 1 & 11 & 1 & 1 & 1 & 11 & 1 & 11 & & 1 & 11 & 1 & 1 & End/Side Scraper \\
\hline 1 & 1 & 1 & 1 & 1 & 1 & 1 & 1 & 1 & 1 & 1 & 1 & 1 & 1 & 1 & 1 & 1 & 1 & 11 & 1 & 1 & 11 & I & 11 & 1 & 11 & 1 & 11 & & 1 & 11 & 1 & 1 & Other Scraper \\
\hline 1 & 1 & 1 & 1 & 1 & 1 & 1 & 1 & 1 & 1 & 1 & 1 & 1 & 1 & 1 & 1 & 1 & 1 & 11 & & 1 & 11 & 1 & 11 & 1 & 11 & 1 & 11 & & 11 & 11 & 1 & 1 & $\begin{array}{l}\text { Miscellaneous } \\
\text { Uniface }\end{array}$ \\
\hline 1 & 1 & 1 & 1 & 1 & 1 & 1 & 1 & 1 & 1 & 1 & 1 & 1 & 1 & 1 & 1 & 1 & 1 & 11 & 1 & 1 & 11 & I & 11 & 1 & 11 & 1 & 11 & & 11 & 11 & 1 & 1 & Spokeshave \\
\hline 1 & 1 & 1 & 1 & 1 & 1 & 1 & 1 & 1 & 1 & 1 & 1 & 1 & $\sim$ & 1 & 1 & 1 & 1 & 11 & & 1 & 11 & 11 & 11 & 1 & 11 & 1 & 11 & & 11 & 11 & 1 & 1 & Cobble \\
\hline 1 & 1 & 1 & 1 & 1 & 1 & 1 & 1 & 1 & 1 & 1 & 1 & $\mapsto$ & 1 & 1 & 1 & 1 & 1 & 11 & 1 & 1 & 11 & 11 & 11 & I & 11 & I & 11 & & 11 & 11 & 1 & 1 & Graver/Burin \\
\hline 1 & 1 & 1 & 1 & 1 & 1 & 1 & 1 & 1 & $1:$ & 1 & 1 & 1 & 1 & 1 & 1 & 1 & 1 & 11 & 1 & 1 & 11 & 11 & $1 \mathrm{i}$ & i & 11 & 1 & 11 & & 11 & 11 & 1 & 1 & Core Tool \\
\hline 1 & 1 & 1 & 1 & 1 & 1 & 1 & 1 & 1 & 1 & 1 & 1 & 1 & 1 & 1 & 1 & 1 & I & 11 & & 1 & 11 & & 11 & 11 & 11 & & 11 & & 11 & 11 & 1 & 1 & $\begin{array}{l}\text { Multifunctional } \\
\text { Tool }\end{array}$ \\
\hline$\mapsto$ & 1 & 1 & 1 & 1 & 1 & 1 & 1 & $\rightarrow$ & 1 & 1 & 1 & $\omega$ & 1 & 1 & 1 & $\omega$ & 1 & $\sim 1$ & & 1 & 11 & 11 & & ה & $\mapsto \quad$ I & & 11 & & & 11 & 1 & $\sim$ & $\begin{array}{l}\text { Edge-modified } \\
\text { Flake }\end{array}$ \\
\hline 1 & 1 & 1 & 1 & 1 & 1 & 1 & 1 & 1 & I & 1 & & 1 & 1 & 1 & 1 & 1 & 1 & 11 & & 1 & 11 & 11 & 11 & 11 & 11 & I & 11 & 1 & 11 & 11 & 1 & 1 & Core \\
\hline$\vec{\Delta}$ & N & or & $\mapsto$ & 0 & - & - & or & జ & $\infty$ & 0 & & \& & $\sim$ & $\omega$ & No & N. & $\checkmark$ & or $N$ & & $\omega$ & o - & - 0 & or a & $\infty 1$ & 1 & & $\omega 0$ & & & $\omega$ & 4 & $\checkmark$ & $\begin{array}{l}\text { Unmodified } \\
\text { Debitage }\end{array}$ \\
\hline 1 & 1 & $\mapsto$ & 1 & 1 & 1 & 1 & 1 & 1 & 1 & 1 & 1 & 1 & 1 & 1 & 1 & 1 & 1 & 11 & & 1 & 11 & 1 & 11 & 11 & 11 & 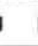 & 11 & I & 11 & 11 & 1 & 1 & Mano \\
\hline 1 & 1 & 1 & 1 & 1 & 1 & 1 & 1 & 1 & 1 & 1 & & 1 & 1 & 1 & 1 & 1 & 1 & 11 & & 1 & 1 & 1 & 11 & 11 & 11 & I & 11 & 1 & 11 & 11 & 1 & & $\begin{array}{l}\text { Indeterminate } \\
\text { Ground Stone }\end{array}$ \\
\hline 1 & 1 & - & 1 & 1 & 1 & 1 & 1 & 1 & 1 & 1 & 1 & 1 & 1 & 1 & 1 & 1 & 1 & 11 & & 1 & 11 & 1 & 11 & 11 & 11 & & 11 & 1 & 11 & 11 & 1 & 1 & linano/Hammerst \\
\hline 1 & 1 & 1 & 1 & 1 & 1 & 1 & 1 & 1 & 1 & 1 & 1 & 1 & 1 & 1 & 1 & 1 & 1 & 11 & 1 & 1 & 11 & I & 1 & 1 & 11 & 1 & 11 & 1 & 1 & 11 & 1 & 1 & Other Stone \\
\hline & 1 & 1 & 1 & $\omega$ & 1 & 1 & 1 & 1 & 1 & 1 & 1 & 1 & 1 & 1 & 1 & 1 & 1 & 11 & 1 & 1 & 11 & I & 1 & 1 & 11 & & 11 & 1 & $1 N$ & ו ט & 1 & - & Ceramic \\
\hline I & 1 & 1 & 1 & 1 & 1 & 1 & 1 & 1 & 1 & 1 & 1 & 1 & 1 & 1 & 1 & 11 & 1 & 11 & 1 & 1 & 11 & 1 & 1 & 1 & 11 & 1 & 11 & । & 11 & 1 & 1 & 1 & Modified Shell \\
\hline & & 。 & $\leftarrow$ & & & 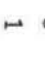 & 。 & $\stackrel{\sim}{N}$ & $\infty$ & $\omega$ & & సે & n & $\omega$ & N C & $\omega$ & $\omega$ & $a n$ & & $\omega$ & ar & 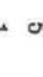 & o & 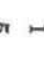 & A & 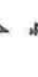 & A 0 & & $\triangle A$ & $A \infty$ & $\infty$ & & Tot \\
\hline
\end{tabular}




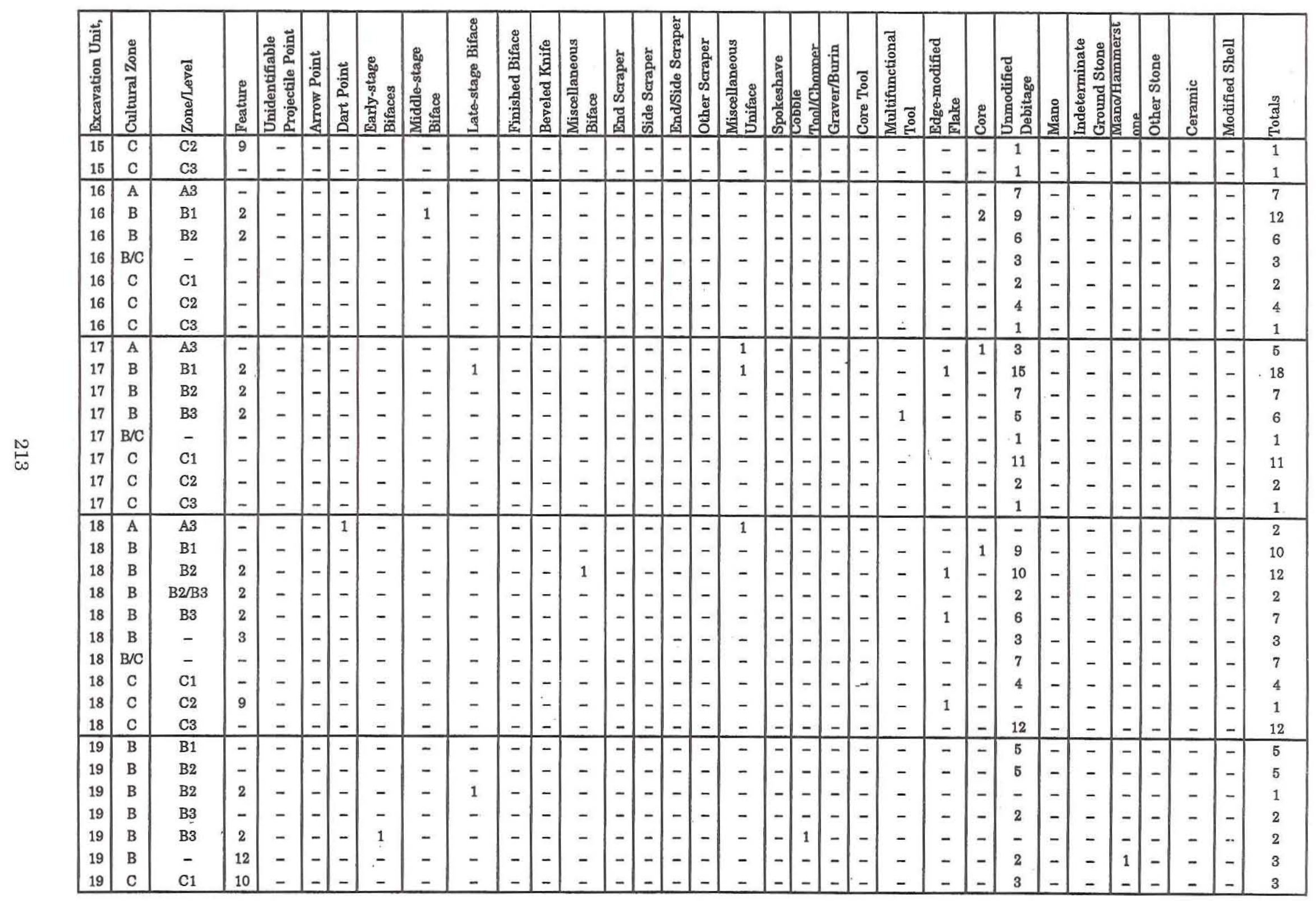




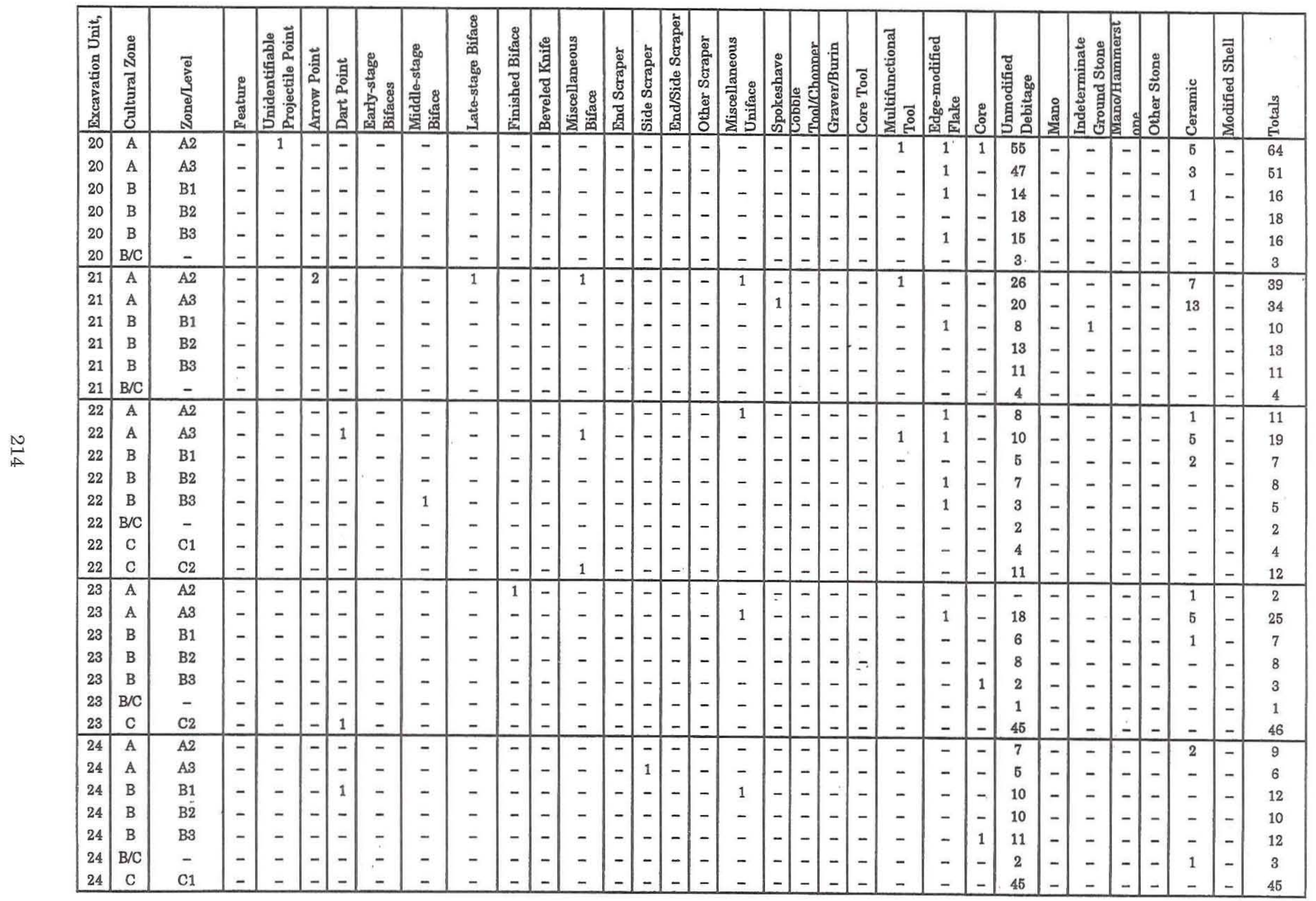




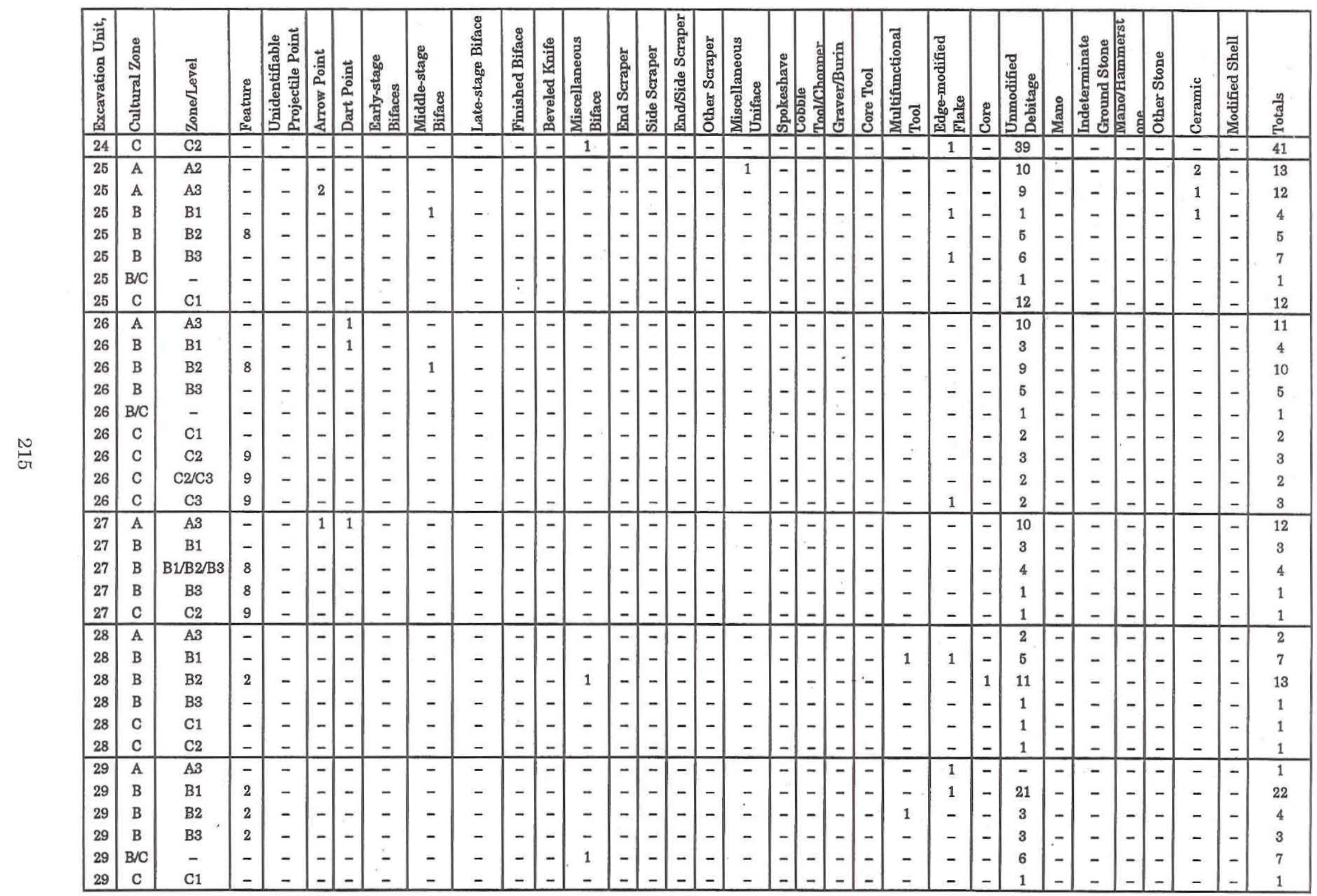




\begin{tabular}{|c|c|c|c|c|c|c|c|c|c|c|c|c|c|c|c|c|c|c|c|c|c|c|}
\hline 긴ㄷㄴ & $\infty-1$ & $\infty$ & $10-1$ & -1 & $\infty$ 는 & $\theta-\infty$ & & ๘ొ & $\cong$ & $\stackrel{\infty}{\sim}$ & 89 & ஜே & $\stackrel{\circ}{\sim}$ & 고 고 & $y$ & Ð & $r \approx$ ? & $\approx-1$ & ๑ ஓ প & $\stackrel{\infty}{\sim}$ & $\stackrel{\infty}{\sim}$ & $F-1$ \\
\hline IIәपs pәy!pow & $\begin{array}{ll}1 & 1 \\
\end{array}$ & 1 & 11 & 11 & 11 & $\begin{array}{lll}1 & 1 & 1\end{array}$ & & 11 & 1 & 11 & $1 \quad 1$ & 11 & 1 & 11 & 11 & 11 & 11 & $\begin{array}{ll}1 & 1\end{array}$ & 11 & 1 & 11 & 11 \\
\hline эт̣urex & $\begin{array}{ll}1 & 1\end{array}$ & 1 & 11 & 1 & 11 & $\begin{array}{lll}1 & 1 & 1\end{array}$ & & $1+$ & 1 & 11 & $\begin{array}{ll}1 & 1\end{array}$ & $\infty=$ & $r$ & 11 & $\begin{array}{ll}1 & 1\end{array}$ & Ir $\alpha$ & 11 & $\begin{array}{ll}1 & 1\end{array}$ & 11 & 1 & 11 & 11 \\
\hline әप0эS хәчэ० & $\begin{array}{ll}1 & 1 \\
\end{array}$ & I & 11 & 1 & 11 & $\begin{array}{lll}1 & 1 & 1\end{array}$ & & 11 & 1 & 11 & $\begin{array}{ll}1 & 1\end{array}$ & 11 & 1 & 11 & $\begin{array}{ll}1 & 1\end{array}$ & 11 & 11 & $\begin{array}{ll}1 & 1\end{array}$ & 11 & 1 & $\rightarrow$ & 1 \\
\hline sourureH/ourai & $\begin{array}{ll}1 & 1\end{array}$ & 1 & 11 & 1 & $1-$ & $\begin{array}{rll}-1 & -1\end{array}$ & & 11 & 1 & 11 & $\begin{array}{ll}1 & 1\end{array}$ & 11 & 1 & 11 & $\begin{array}{ll}1 & 1\end{array}$ & 11 & 11 & 11 & 11 & 1 & 11 & 11 \\
\hline 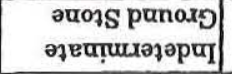 & $\begin{array}{ll}1 & 1\end{array} \mid$ & 1 & 11 & 1 & 11 & $\begin{array}{lll}1 & 1 & 1\end{array}$ & & 11 & 1 & 11 & $\begin{array}{ll}1 & 1\end{array}$ & 11 & 1 & 11 & $\begin{array}{ll}1 & 1\end{array}$ & 11 & 11 & $\begin{array}{ll}1 & 1\end{array}$ & $\begin{array}{ll}1 & 1\end{array}$ & 1 & 11 & $\begin{array}{ll}1 & 1\end{array}$ \\
\hline ourew & $\begin{array}{ll}1 & 1\end{array}$ & 1 & 11 & 1 & 11 & $\begin{array}{lll}1 & 1 & 1\end{array}$ & & 11 & 1 & 11 & $\begin{array}{ll}1 & 1\end{array}$ & 11 & 1 & 11 & 1.1 & 11 & 11 & $\begin{array}{ll}1 & 1\end{array}$ & 11 & 1 & 11 & 11 \\
\hline $\begin{array}{r}\text { әระ)!ด्व } \\
\text { pag!pouru }\end{array}$ & $\infty$ & N & $* 1$ & -1 & $\infty む$ & $\neq-1$ & & సี สี & $\approx$ & $\simeq \approx$ & $: 0$ & ำ & $\stackrel{-1}{2}$ & $\Rightarrow$ \% & 召 $\mathrm{N}$ & $\stackrel{\sim}{\sim}$ & 0 으 : & $=-1$ & ब ले & 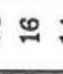 & $\approx \mp$ & $=-1$ \\
\hline $0 \times 00$ & $\begin{array}{ll}1 & 1\end{array}$ & 1 & $1-$ & 1 & 11 & 111 & & 11 & 1 & 11 & $\begin{array}{ll}1 & 1\end{array}$ & 11 & 1 & 11 & $\begin{array}{ll}1 & 1\end{array}$ & 11 & 11 & $\begin{array}{ll}1 & 1\end{array}$ & 11 & 1 & 11 & 11 \\
\hline 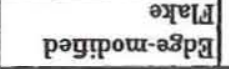 & $\begin{array}{ll}1 & 1\end{array}$ & 1. & $\Rightarrow 1$ & 1 & 11 & 111 & & 10 & 1 & $\rightarrow 1$ & $\begin{array}{ll}1 & 1\end{array}$ & $\infty 1$ & $N$ & 10 & $\begin{array}{ll}* & 1\end{array}$ & 11 & 11 & 11 & $1 N$ & N & 11 & $\begin{array}{ll}1 & 1\end{array}$ \\
\hline 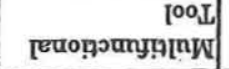 & $\begin{array}{ll}1 & 1\end{array}$ & 1 & 11 & 1 & 11 & 11 & & 11 & 1 & 11 & & 11 & 1 & 11 & $\begin{array}{ll}1 & 1\end{array}$ & 11 & 11 & $1 \quad 1$ & 11 & 1 & 11 & $\begin{array}{ll}1 & 1\end{array}$ \\
\hline [OOL axoJ] & $\begin{array}{ll}1 & 1\end{array} \mid$ & 1 & 11 & 1 & 11 & 11 & & 11 & 1 & 11 & 11 & 11 & 1 & 11 & $\begin{array}{ll}1 & 1\end{array}$ & 11 & 111 & $\begin{array}{ll}1 & 1\end{array}$ & 11 & 1 & 11 & $\begin{array}{ll}1 & 1\end{array}$ \\
\hline 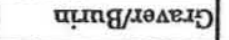 & $\begin{array}{ll}1 & 1\end{array} \mid$ & 1 & 11 & 1 & 11 & $\begin{array}{ll}1 & 1\end{array}$ & & 11 & 1 & 11 & $\begin{array}{ll}1 & 1\end{array}$ & 11 & 1 & 11 & $\begin{array}{ll}1 & 1\end{array}$ & 11 & 11 & 11 & 11 & 1 & 11 & $\begin{array}{ll}1 & 1\end{array}$ \\
\hline 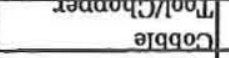 & 11 & 1 & 11 & 1 & 11 & 11 & & 11 & 1 & 11 & 11 & 11 & 1 & 11 & $\begin{array}{ll}1 & 1\end{array}$ & 11 & 11 & 11 & 11 & 1 & 11 & \\
\hline 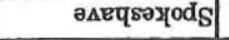 & $\begin{array}{ll}1 & 1\end{array}$ & 1 & 11 & 1 & 11 & $\begin{array}{ll}1 & 1\end{array}$ & & 11 & 1 & 11 & $\begin{array}{ll}1 & 1 \\
\end{array}$ & 11 & 1 & 11 & $1 \quad 1$ & 11 & 11 & $\begin{array}{ll}1 & 1\end{array}$ & 11 & 1 & 11 & 11 \\
\hline 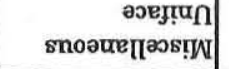 & $\begin{array}{ll}1 & 1\end{array}$ & 1 & 11 & 1 & 11 & $\begin{array}{ll}1 & 1\end{array}$ & & 11 & 1 & 11 & 11 & $-1-1$ & 1 & 11 & $\begin{array}{ll}1 & 1\end{array}$ & $1-$ & 11 & $\begin{array}{ll}1 & 1\end{array}$ & 11 & 1 & 11 & 11 \\
\hline प10 & 11 & 1 & 11 & 1 & 11 & 11 & & 11 & 1 & 11 & 11 & 11 & 1 & 11 & $\begin{array}{ll}1 & 1 \\
\end{array}$ & 11 & 11 & $\begin{array}{ll}1 & 1\end{array}$ & 11 & 1 & 11 & 11 \\
\hline s/pug & $\begin{array}{ll}1 & 1 \\
\end{array}$ & 1 & 11 & 1 & 11 & $\begin{array}{ll}1 & 1 \\
\end{array}$ & & 11 & 1 & 11 & 11 & 11 & 1 & 11 & $\begin{array}{ll}1 & 1 \\
\end{array}$ & 11 & 11 & $\begin{array}{ll}1 & 1 \\
\end{array}$ & $1-1$ & 1 & 11 & $1 \quad 1$ \\
\hline xade & $\begin{array}{ll}1 & 1 \\
\end{array}$ & 1 & 11 & 1 & 11 & $\begin{array}{ll}11 \\
\end{array}$ & & 11 & 1 & 11 & 1 & 11 & 1 & 11 & $\begin{array}{ll}1 & 1 \\
\end{array}$ & 11 & 11 & $\begin{array}{ll}1 & 1 \\
\end{array}$ & 11 & 1 & 11 & 11 \\
\hline xəderrs pur & $\begin{array}{ll}1 & 1 \\
\end{array}$ & 1 & 11 & 1 & 11 & 11 & & 11 & 1 & 11 & 1 & 11 & 1 & 11 & $\begin{array}{ll}1 & 1 \\
\end{array}$ & 11 & 11 & $\begin{array}{ll}1 & 1 \\
\end{array}$ & $1-$ & 1 & 11 & 11 \\
\hline 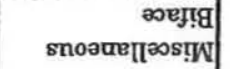 & $\begin{array}{ll}1 & 1\end{array}$ & 1 & 11 & 1 & 11 & $\begin{array}{ll}1 & 1\end{array}$ & & $1 \mathrm{~N}$ & 1 & 11 & 1 & 11 & 1 & 11 & $\begin{array}{ll}1 & 1\end{array}$ & 11 & $11=$ & -1 & 11 & 1 & 11 & 11 \\
\hline$\Delta$ ag & $\begin{array}{ll}1 & 1\end{array}$ & 1 & 11 & 1 & 11 & $\begin{array}{ll}1 & 1\end{array}$ & & 11 & 1 & 11 & 1 & 11 & 1 & 11 & $\begin{array}{ll}1 & 1\end{array}$ & 11 & $1-$ & $\begin{array}{ll}1 & 1\end{array}$ & 11 & 1 & 11 & 11 \\
\hline 20हा! & $\begin{array}{ll}1 & 1\end{array}$ & 1 & 11 & 1 & 11 & 11 & & 11 & 1 & 11 & 1 & 11 & 1 & 11 & $\begin{array}{ll}1 & 1\end{array}$ & 11 & 11 & $\begin{array}{ll}1 & 1\end{array}$ & 11 & 1 & $\rightarrow 1$ & 11 \\
\hline 787 & $\begin{array}{ll}1 & 1\end{array}$ & 1 & 11 & 1 & 11 & 11 & & 11 & 1 & 11 & 1 & 11 & 1 & 11 & $\begin{array}{ll}1 & 1\end{array}$ & 11 & 11 & $\begin{array}{ll}1 & 1\end{array}$ & 11 & 1 & 11 & $\begin{array}{ll}1 & 1\end{array}$ \\
\hline 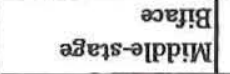 & $\begin{array}{ll}1 & 1\end{array}$ & 1 & 11 & 1 & 11 & 11 & & 11 & 1 & 11 & 1 & $1 \pi$ & 1 & 11 & $\begin{array}{ll}1 & 1\end{array}$ & $\begin{array}{ll}1 & 1\end{array}$ & 11 & $\begin{array}{ll}1 & 1\end{array}$ & 11 & 1 & 11 & 11 \\
\hline 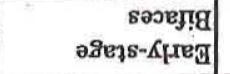 & $\begin{array}{ll}1 & 1\end{array}$ & 1 & 11 & 1 & 11 & 11 & - & $-1 \quad 1$ & 1 & 11 & 1 & 11 & 1 & 11 & $\begin{array}{ll}1 & 1\end{array}$ & 11 & 11 & $\begin{array}{ll}1 & 1\end{array}$ & 11 & 1 & 11 & 11 \\
\hline $201 \mathrm{l}^{\circ} \mathrm{drea}$ & $\begin{array}{ll}1 & -1\end{array}$ & 1 & 11 & 1 & 11 & 11 & 1 & 11 & 1 & 11 & 1 & 11 & 1 & $1-1$ & -1 & 11 & -1 & 11 & 11 & 1 & -1 & 11 \\
\hline 2u!od Masxy & $\begin{array}{ll}1 & 1 \\
\end{array}$ & 1 & 11 & 1 & 11 & 11 & - & $\rightarrow r$ & 1 & 11 & 1 & 11 & 1. & -1 & 11 & 11 & 11 & $\begin{array}{ll}1 & 1 \\
\end{array}$ & $1-$ & 1 & 11 & 11 \\
\hline 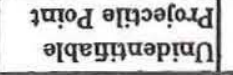 & $\begin{array}{ll}1 & 1\end{array} \mid$ & 1 & 11 & 1 & 11 & 11 & 1 & 11 & 1 & 11 & 1 & 11 & 1 & 11 & 11 & 11 & 11 & 11 & 11 & 1 & -1 & 11 \\
\hline axnzeəal & $\begin{array}{ll}1 & 1\end{array} \mid$ & 1 & $1 N$ & 1 & 1 우 & 11 & & 11 & 1 & 11 & 1 & 11 & 1 & 11 & 1 & 11 & 11 & 11 & $\begin{array}{ll}1 & 1\end{array}$ & 1 & 1 & $1-1$ \\
\hline $\mathrm{aO}$ & రี రొ & $m_{4}^{2}$ & 离 兽 & $\mathscr{m}$ & 15 & ชี ชี & & प्व & $\vec{m}$ & 山 & 1 & वै & 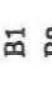 & ભี ణ & 1 & वै ₹ & 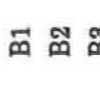 & $\begin{array}{ll}\mathscr{m} & 1 \\
& \end{array}$ & द व & क & $\ddot{m}$ ณ & 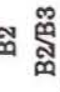 \\
\hline [n] & 00 & 40 & $\infty$ & $m$ & M 0 & 00 & & $4<x$ & $\infty$ & $m \infty$ & $\frac{O}{m}$ & $4<$ & $\infty$ & m & ํํㅁ & $4<$ & $\infty$ 舟 & $\infty$ 总 & $4<$ & 4 & $m \infty$ & $\infty m$ \\
\hline M & ลุ ล & 5 & ిల ద్ల & ஓ & ঃ్ల ঃ్ & 요 요 & & $\vec{~}$ & & $\infty$ & के & న్లి ల్ & స్ల : & శ్ల స్ స & ભั & ஜొ ஜ & ஜ ஜ : & ஜ ஜ & లే లే & ले & है ब & 00 \\
\hline
\end{tabular}




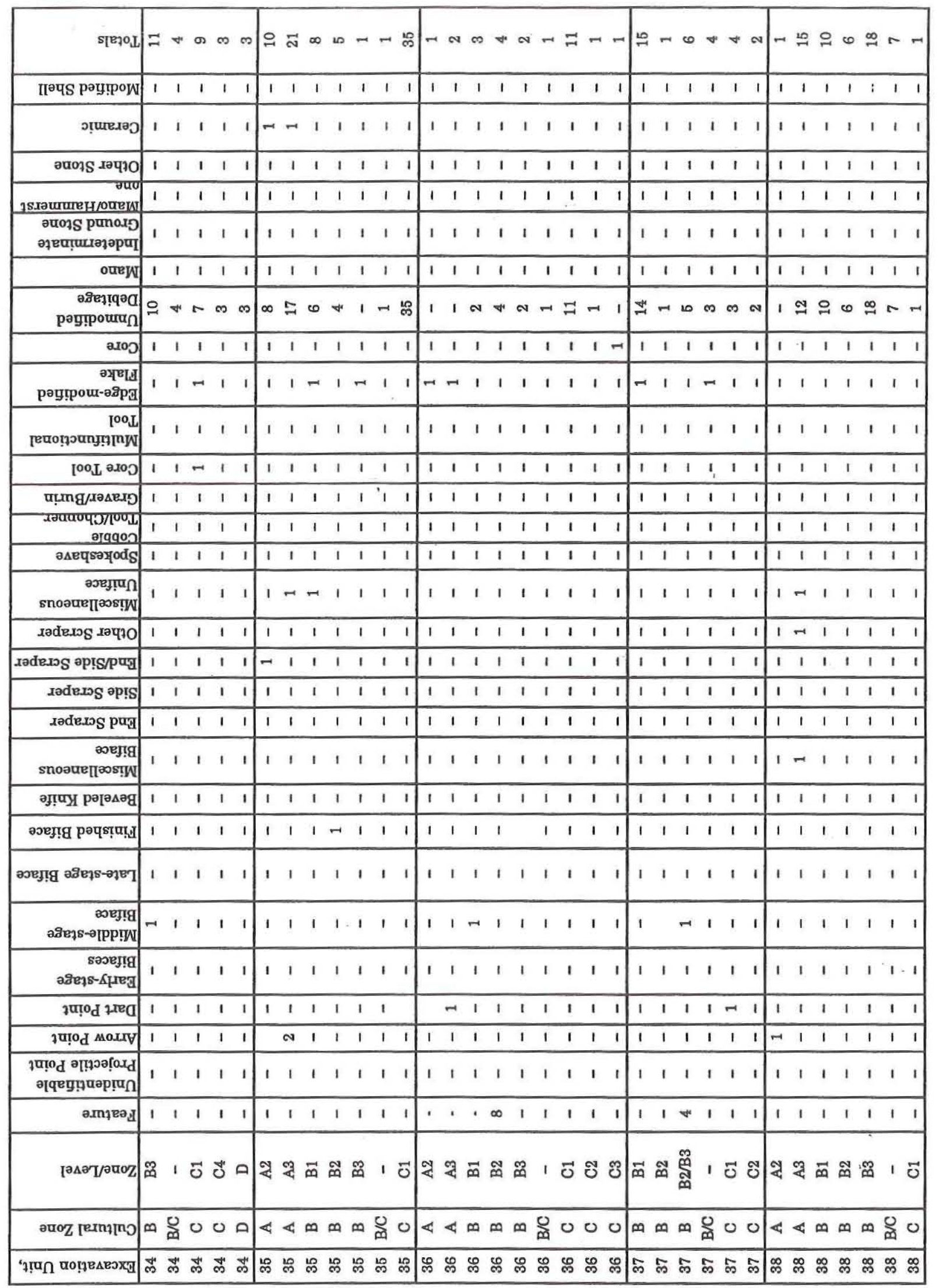




\begin{tabular}{|c|c|c|c|c|c|c|c|c|c|c|c|c|c|}
\hline \multirow{4}{*}{ 客 } & \multirow{2}{*}{ है } & \multicolumn{4}{|c|}{5 告 点 它 } & \multicolumn{6}{|c|}{ ఝ } & & \multirow{2}{*}{$\begin{array}{l}\text { Excavation Unit, } \\
\text { Cultural Zone }\end{array}$} \\
\hline & & 罖 & $\varpi$ & $\infty \infty$ & & 苋 & $\infty$ & $\infty$ & $\infty$ & $p p$ & & 이 & \\
\hline & $\Omega$ & 1 & $\mathbb{W}_{\mathbb{W}}^{\mathbb{W}}$ & 四 品 & & 1 & 䍐 & 四 & $\underset{\omega}{\mathbb{W}}$ & 芯 & ß & Sิ & Zone/Level \\
\hline & 1 & 1 & 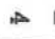 & 11 & & 1 & 1 & 1 & 1 & 11 & 1 & 1 & Feature \\
\hline$N$ & 1 & 1 & 1 & 11 & 1 & 1 & 1 & 1 & 1 & 11 & & 1 & $\begin{array}{l}\text { Unidentifiable } \\
\text { Projectile Point }\end{array}$ \\
\hline న్ & 1 & 1 & 1 & 11 & & 1 & 1 & $\mapsto$ & 1 & $1 \mapsto$ & $\mapsto$ & 1 & Arrow Point \\
\hline N & 1 & 1 & $\mapsto$ & 11 & & 1 & 1 & 1 & 1 & 11 & 1 & 1 & Dart Point \\
\hline$\omega$ & 1 & 1 & 1 & 11 & 1 & 1 & 1 & 1 & 1 & 11 & 1 & 1 & $\begin{array}{l}\text { Early-stage } \\
\text { Bifaces }\end{array}$ \\
\hline$\ddot{\theta}$ & 1 & 1 & 1 & 11 & & 1 & 1 & 1 & 1 & 11 & 1 & 1 & $\begin{array}{l}\text { Middle-stage } \\
\text { Biface }\end{array}$ \\
\hline$\infty$ & 1 & 1 & 1 & $\sim 1$ & 1 & 1 & 1 & 1 & 1 & 11 & I & 1 & Late-stage Biface \\
\hline 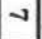 & 1 & 1 & 1 & 11 & & 1 & 1 & 1 & 1 & 11 & 1 & 1 & Finished Biface \\
\hline 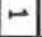 & 1 & 1 & 1 & 11 & 1 & 1 & 1 & 1 & I & 11 & 1 & 1 & Beveled Knife \\
\hline के & 1 & 1 & 1 & 11 & 1 & 1 & 1 & 1 & 1 & 11 & 1 & 1 & $\begin{array}{l}\text { Miscellaneous } \\
\text { Biface }\end{array}$ \\
\hline$\omega$ & 1 & 1 & 1 & 11 & 1 & 1 & 1 & 1 & 1 & 11 & 1 & $1 \cdot$ & End Scraper \\
\hline 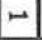 & 1 & 1 & 1 & 11 & 1 & 1 & 1 & 1 & 1 & 11 & 1 & 1 & Side Scraper \\
\hline is & 1 & 1 & 1 & 11 & 1 & 1 & 1 & 1 & 1 & 11 & 1 & 1 & End/Side Scraper \\
\hline N & 1 & 1 & 1 & 11 & I & 1 & 1 & 1 & 1 & 11 & 1 & 1 & Other Scraper \\
\hline$\ddot{0 r}$ & 1 & 1 & 1 & 11 & 1 & 1 & 1 & 1 & 1 & 11 & 1 & 1 & $\begin{array}{l}\text { Miscellaneous } \\
\text { Uniface }\end{array}$ \\
\hline$N$ & 1 & 1 & 1 & 11 & 1 & 1 & 1 & 1 & 1 & 11 & 1 & 1 & Spokeshave \\
\hline$\infty$ & 1 & 1 & 1 & 11 & 1 & 1 & 1 & 1 & 1 & $\mapsto 1$ & 1 & 1 & $\begin{array}{l}\text { Cobble } \\
\text { Tonl/Chonner }\end{array}$ \\
\hline$\sim$ & 1 & 1 & 1 & 11 & 1 & 1 & 1 & 1 & 1 & 11 & 1 & 1 & Graver/Burin \\
\hline$\infty$ & 1 & 1 & $i$ & 11 & 1 & 1 & 1 & 1 & 1 & 11 & 1 & 1 & Core Tool \\
\hline$\infty$ & 1 & 1 & 1 & 11 & 1 & 1 & 1 & 1 & 1 & 11 & I & 1 & $\begin{array}{l}\text { Multifunctional } \\
\text { Tool }\end{array}$ \\
\hline ஜ & 1 & 1 & 1 & 11 & 1 & 1 & 1 & 1 & 1 & $N 1$ & 1 & 1 & $\begin{array}{l}\text { Edge-modified } \\
\text { Flake }\end{array}$ \\
\hline$\vec{N}$ & 1 & 1 & 1 & 11 & & 1 & 1 & 1 & 1 & 11 & 1 & 1 & Core \\
\hline $\begin{array}{l}N \\
\mathscr{E} \\
\mathbb{E} \\
\text { rn } \\
\end{array}$ & $\omega$ & $\mapsto$ & N & $\infty$ or & $r$ & $\infty$ & ఝ్ఱ & $\stackrel{\bullet}{\sim}$ & $\overrightarrow{e r}$ & $\vec{\omega} \oplus$ & 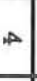 & $N$ & $\begin{array}{l}\text { Unmodified } \\
\text { Debitage }\end{array}$ \\
\hline$\infty$ & 1 & 1 & 1 & 11 & 1 & 1 & 1 & 1 & 1 & 11 & 1 & 1 & Mano \\
\hline$\mapsto$ & 1 & 1 & 11 & 11 & 1 & 1 & 1 & 1 & 1 & 11 & 1 & 1 & $\begin{array}{l}\text { Indeterminate } \\
\text { Ground Stone }\end{array}$ \\
\hline or & 1 & 1 & $\sim 1$ & 11 & & 1 & 1 & 1 & 1 & 11 & 1 & 1 & $\begin{array}{l}\text { IVandHammerst } \\
\text { one }\end{array}$ \\
\hline$\omega$ & 1 & 1 & 11 & 11 & & 1 & 1 & 1 & 1 & 11 & 1 & 1 & Other Stone \\
\hline$\stackrel{\overrightarrow{0}}{\circ}$ & 1 & 1 & 11 & 11 & I & 1 & 1 & 1 & 1 & - o & ar & 1 & Ceramic \\
\hline$\bullet$ & 1 & 1 & 11 & 11 & 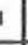 & 1 & 1 & 1 & 1 & 11 & 1 & 1 & Modified Shell \\
\hline 裪 & $\omega$ & $\mapsto$ & N & $\omega$ or & & $\infty$ & ర్రు & $\vec{\infty}$ & $\overrightarrow{~ o r: ~}$ & $\overrightarrow{2}$ & $\overrightarrow{0}$ & $N$ & Totals \\
\hline
\end{tabular}


Appendix F: Provenience of Artifacts

Table 42. Provenience of Area 1 nonexcavation block artifacts

\begin{tabular}{ccccccc}
\hline $\begin{array}{c}\text { Excavation } \\
\text { Unit }\end{array}$ & Level & Spokeshave & $\begin{array}{c}\text { Edge-modified } \\
\text { Flake }\end{array}$ & Core & $\begin{array}{c}\text { Unmodified } \\
\text { Debitage }\end{array}$ & Totals \\
\hline 41 & 7 & - & - & - & 3 & 3 \\
41 & 8 & - & - & - & 5 & 5 \\
41 & 9 & - & - & - & 1 & 1 \\
42 & 6 & - & 1 & - & 1 & 2 \\
42 & 7 & - & - & - & 1 & 1 \\
42 & 8 & 1 & - & - & 1 & 6 \\
42 & 9 & - & - & - & 3 & 3 \\
42 & 10 & - & - & 1 & 19 & 22 \\
\hline Totals & & 1 & 1 & & & \\
\hline
\end{tabular}


Table 43. Provenience of Area 2 artifacts

\begin{tabular}{|c|c|c|c|c|c|c|c|c|c|c|c|c|c|c|}
\hline $\begin{array}{c}\text { Excavation } \\
\text { Unit }\end{array}$ & Level & $\begin{array}{l}\text { Dart } \\
\text { Points }\end{array}$ & Perforators & $\begin{array}{l}\text { Middle- } \\
\text { stage } \\
\text { Biface }\end{array}$ & $\begin{array}{l}\text { Late- } \\
\text { stage } \\
\text { Biface }\end{array}$ & $\begin{array}{c}\text { Other } \\
\text { Scraper }\end{array}$ & $\begin{array}{c}\text { Misc. } \\
\text { Unifaces }\end{array}$ & $\begin{array}{c}\text { Graver/ } \\
\text { Burin }\end{array}$ & $\begin{array}{c}\text { Multi- } \\
\text { functional } \\
\text { Tool }\end{array}$ & $\begin{array}{c}\text { Edge- } \\
\text { modified } \\
\text { Flake }\end{array}$ & Core & $\begin{array}{l}\text { Unmodified } \\
\text { Debitage }\end{array}$ & Ceramic & Totals \\
\hline 43 & 4 & - & - & - & 1 & - & - & - & - & - & - & 1 & - & 2 \\
\hline 44 & 1 & - & - & - & - & - & - & - & 1 & 1 & - & 7 & - & 9 \\
\hline 44 & 2 & - & - & - & - & - & - & - & - & - & 1 & 5 & 1 & 7 \\
\hline 44 & 3 & 1 & - & - & 1 & - & - & - & - & 1 & - & 9 & - & 12 \\
\hline 44 & 4 & - & - & - & - & - & - & - & - & - & - & 3 & - & 3 \\
\hline 44 & 5 & 1 & - & - & - & - & - & - & - & - & - & 8 & - & 9 \\
\hline 44 & 6 & - & - & - & - & - & - & - & - & - & - & 1 & - & 1 \\
\hline 45 & 4 & - & - & - & - & - & - & - & - & - & - & 1 & - & 1 \\
\hline 46 & 4 & - & - & - & - & - & - & - & - & - & - & 1 & - & 1 \\
\hline 47 & 2 & - & - & - & - & - & - & - & 1 & - & - & 17 & - & 18 \\
\hline 47 & 3 & - & - & - & - & - & - & - & - & - & - & 3 & - & 3 \\
\hline 47 & 4 & - & - & - & - & - & 1 & - & - & - & - & 2 & - & 3 \\
\hline 47 & 5 & - & - & - & - & - & - & - & - & - & - & 6 & - & 6 \\
\hline 47 & 8 & - & - & - & - & - & - & - & -. & - & - & 1 & - & 1 \\
\hline 48 & 1 & - & - & - & - & - & - & 1 & - & - & - & 2 & - & 3 \\
\hline 48 & 2 & - & 1 & - & - & - & - & - & - & 1 & - & 14 & 1 & 17 \\
\hline 48 & 3 & - & - & 1 & - & - & - & - & - & - & - & 10 & - & 11 \\
\hline 49 & 2 & - & - & 1 & - & 1 & 1 & - & - & 2 & - & 16 & 5 & 26 \\
\hline 49 & 3 & - & - & - & - & - & - & - & - & - & - & 12 & 1 & 13 \\
\hline 49 & 4 & - & 1 & - & - & - & - & - & - & - & - & 2 & - & 3 \\
\hline 49 & 5 & - & - & - & - & - & - & - & - & - & - & 1 & - & 1 \\
\hline 51 & 2 & - & - & - & - & - & - & - & - & 1 & - & 8 & - & 9 \\
\hline Totals & & 2 & 2 & 2 & 2 & 1 & 2 & 1 & 2 & 6 & 1 & 130 & 8 & 159 \\
\hline
\end{tabular}


Table 44. Provenience of Area 7 artifacts

\begin{tabular}{ccccc}
\hline Excavation Unit & Level & Edge-modified Flake & Unmodified Debitage & Totals \\
\hline 52 & 2 & 1 & - & 1 \\
52 & 9 & - & 2 & 2 \\
52 & 10 & - & 1 & 1 \\
52 & 11 & - & 25 & 25 \\
52 & 12 & - & 2 & 2 \\
\hline Totals & & 1 & 30 & 31 \\
\hline
\end{tabular}

Table 45. Provenience of artifacts from shovel tests, backhoe trenches, and surface contexts*

\begin{tabular}{|c|c|c|c|c|c|c|}
\hline Provenience & Dart Points & $\begin{array}{c}\text { Finished } \\
\text { Biface }\end{array}$ & $\begin{array}{c}\text { Unmodified } \\
\text { Debitage }\end{array}$ & Mano & Ceramic & Totals \\
\hline Shovel Test 9 & - & - & 3 & - & - & 3 \\
\hline Area 1, Backhoe Trench 27 & - & - & - & 1 & - & 1 \\
\hline Area 1, Surface & $1^{1}$ & - & - & 1 & - & 1 \\
\hline Area 1, Surface & $1^{2}$ & - & - & - & - & 1 \\
\hline Area 1, Shovel Test 1 & - & - & 9 & - & - & 9 \\
\hline Area 1, Shovel Test 2 & - & - & 3 & - & - & 3 \\
\hline Area 1, Shovel Test 3 & - & - & 3 & - & - & 3 \\
\hline Area 1, Shovel Test 4 & - & - & 1 & - & - & 1 \\
\hline Area 2, Backhoe Trench 31 & $1^{3}$ & - & - & - & - & 1 \\
\hline Area 2, Backhoe Trench 32 & - & - & - & - & 1 & 1 \\
\hline Area 2, Shovel Test 6 & - & - & 3 & - & - & 3 \\
\hline Area 2, Shovel Test 7 & - & - & 1 & - & - & 1 \\
\hline Area 7, Shovel Test 11 & - & 1 & 22 & - & - & 23 \\
\hline Totals & 3 & 1 & 45 & 1 & 1 & 51 \\
\hline \multicolumn{7}{|c|}{$\begin{array}{l}\text { *The specimens from backhoe trenches were recovered during Phase IIA; all specimens from surface } \\
\text { contexts or shovel tests were recovered during Phase I. } \\
{ }^{1} \text { Castroville } \\
{ }^{2} \text { Shumla } \\
{ }^{3} \text { Early Barbed }\end{array}$} \\
\hline
\end{tabular}




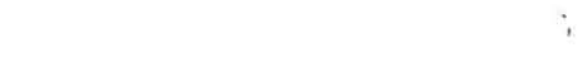


